\title{
Wykorzystanie podejścia memoriałowego i kasowego w ocenie operacyjnego bezpieczeństwa finansowego przedsiębiorstw sektora TSL
}


盗 


\section{Lidia Karbownik}

\section{Wykorzystanie podejścia memoriałowego i kasowego w ocenie operacyjnego bezpieczeństwa finansowego przedsiębiorstw sektora TSL}


Lidia Karbownik - Uniwersytet Łódzki, Wydział Ekonomiczno-Socjologiczny Instytut Ekonomik Stosowanych i Informatyki, Katedra Analizy i Strategii Przedsiębiorstwa 90-214 Łódź, ul. Rewolucji 1905 r. nr 41

\author{
RECENZENT \\ Magdalena Jerzemowska \\ REDAKCJA TECHNICZNA, SKŁAD I ŁAMANIE \\ Monika Wolska
}

PROJEKT OKŁADKI

Stämpfli Polska Sp. z o.o.

Zdjęcie na okładce: (C) shutterstock.com

Wydanie niniejszego opracowania zostało sfinansowane

przez Ministerstwo Nauki i Szkolnictwa Wyższego z dotacji dla młodych naukowców

Wydrukowano z gotowych materiałów dostarczonych do Wydawnictwa UŁ

przez Wydział Ekonomiczno-Socjologiczny

(C) Copyright by Uniwersytet Łódzki, Łódź 2014

Wydane przez Wydawnictwo Uniwersytetu Łódzkiego

Wydanie I. W.06784.14.0.M

ISBN 978-83-7969-458-7 (wersja papierowa)

ISBN 978-83-7969-525-6 (wersja elektroniczna)
Wydawnictwo Uniwersytetu Łódzkiego
90-131 Łódź, ul. Lindleya 8
www.wydawnictwo.uni.lodz.pl
e-mail: ksiegarnia@uni.lodz.pl
tel. (42) 66558 63, faks (42) 6655862





\section{Notka informacyjna}

W monografii przedstawiona została autorska koncepcja dwuwymiarowej oceny operacyjnego bezpieczeństwa finansowego przedsiębiorstwa oraz wyniki oryginalnych i zarazem pierwszych obszernych rezultatów analiz nad oceną tego zjawiska wśród spółek sektora TSL (Transport, Spedycja, Logistyka). Ocena ta nie ogranicza się tylko do wykorzystania w niej podejścia memoriałowego, lecz zawiera również rezultaty analizy „kasowych” wyników finansowej działalności jednostek gospodarczych.

Podjęte zamierzenie uzasadnione było potrzebą wypełnienia luki badawczej istniejącej w studiach teoretycznych i empirycznych poświęconych zdolności przedsiębiorstwa do uzyskania oraz utrzymania finansowych warunków kontynuacji jego działalności gospodarczej.

Opracowanie adresowane jest do szerokiego grona praktyków zarządzania finansami przedsiębiorstw (w tym w szczególności z sektora TSL) oraz nauczycieli akademickich i studentów, dla których identyfikacja i ocena zdolności przedsiębiorstwa do uzyskania oraz utrzymania finansowych warunków kontynuacji jego działalności gospodarczej stanowi fascynujący przedmiot podejmowanych i realizowanych decyzji kierowniczych, prowadzonych badań oraz dyskursów naukowych. 


\section{SPIS TREŚCI}

Wprowadzenie

Rozdział 1. Istota i ocena operacyjnego bezpieczeństwa finansowego przedsiębiorstwa: problemy teoretyczno-metodyczne

1.1. Pojęcie, kryteria i miary operacyjnego bezpieczeństwa finansowego przedsiębiorstwa

1.2. Przesłanki stosowania memoriałowego i kasowego podejścia w ocenie operacyjnego bezpieczeństwa finansowego przedsiębiorstwa

1.2.1. Przesłanki stosowania memoriałowego podejścia w ocenie operacyjnego bezpieczeństwa finansowego przedsiębiorstwa

1.2.2. Przesłanki stosowania kasowego podejścia w ocenie operacyjnego bezpieczeństwa finansowego przedsiębiorstwa

1.2.3. Przesłanki jednoczesnego stosowania memoriałowego i kasowego podejścia w ocenie operacyjnego bezpieczeństwa finansowego przedsiębiorstwa

1.3. Dylematy wyboru oraz konstrukcji memoriałowych i kasowych mierników oceny operacyjnego bezpieczeństwa finansowego przedsiębiorstwa

Rozdział 2. Obszary działania i mierniki oceny operacyjnego bezpieczeństwa finansowego przedsiębiorstw sektora TSL

2.1. Podmioty i podstawy metodyczne oceny operacyjnego bezpieczeństwa finansowego przedsiębiorstw sektora TSL

2.2. Wybrane memoriałowe i kasowe mierniki oceny operacyjnego bezpieczeństwa finansowego przedsiębiorstw sektora TSL

2.3. Pomiar i ocena zróżnicowania zakresu działalności gospodarczej przedsiębiorstw sektora TSL

Rozdział 3. Analiza empiryczna spreadu oraz zależności między miernikami oceny operacyjnego bezpieczeństwa finansowego spółek sektora TSL

3.1. Analiza empiryczna spreadu memoriałowych i kasowych mierników oceny operacyjnego bezpieczeństwa finansowego spółek sektora TSL

3.2. Analiza zależności między memoriałowymi a kasowymi miernikami oceny operacyjnego bezpieczeństwa finansowego przedsiębiorstw sektora TSL

3.3. Analiza zależności między memoriałowymi i kasowymi miernikami oceny operacyjnego bezpieczeństwa finansowego a poziomem dywersyfikacji działalności gospodarczej spółek sektora TSL 
Rozdział 4. Ocena operacyjnego bezpieczeństwa finansowego przedsiębiorstw sektora TSL

4.1. Koniunktura gospodarcza a poziom operacyjnego bezpieczeństwa finansowego spółek sektora TSL

4.2. Analiza porównawcza struktury skupień przedsiębiorstw sektora TSL o zbliżonym poziomie operacyjnego bezpieczeństwa finansowego

4.3. Analiza zależności między syntetycznym miernikiem oceny operacyjnego bezpieczeństwa finansowego a poziomem dywersyfikacji działalności gospodarczej spółek sektora TSL

Rozdział 5. Zastosowanie memoriałowych oraz kasowych mierników w prognozowaniu operacyjnego zagrożenia finansowego przedsiębiorstw sektora TSL

5.1. Zakres badań empirycznych

5.2. Ocena zdolności predykcyjnej wybranych modeli dyskryminacyjnych w prognozowaniu operacyjnego zagrożenia finansowego przedsiębiorstw sektora TSL

5.3. Ocena zdolności predykcyjnych wybranych zmiennych diagnostycznych operacyjnego zagrożenia finansowego dla przedsiębiorstw sektora TSL

5.3.1. Ocena zdolności predykcyjnych mierników na rok przed upadłością przedsiębiorstw

5.3.2. Ocena zdolności predykcyjnych mierników na dwa lata przed upadłością przedsiębiorstw

5.3.3. Ocena zdolności predykcyjnych mierników na trzy lata przed upadłością przedsiębiorstw

5.4. Prognozowanie operacyjnego zagrożenia finansowego przedsiębiorstw sektora TSL przy wykorzystaniu memoriałowych i kasowych mierników oceny

5.4.1. Prognozowanie operacyjnego zagrożenia finansowego na rok przed upadłością przedsiębiorstw sektora TSL

5.4.2. Prognozowanie operacyjnego zagrożenia finansowego na dwa lata przed upadłością przedsiębiorstw sektora TSL

5.4.3. Prognozowanie operacyjnego zagrożenia finansowego na trzy lata przed upadłością przedsiębiorstw sektora TSL

Zakończenie

Bibliografia

Spis tabel

Spis schematów

Spis wykresów 


\section{WPROWADZENIE}

Prowadzenie działalności gospodarczej zawsze wiąże się z koniecznością podejmowania, realizacji i kontroli decyzji w warunkach niepewności oraz ograniczonej możliwości wpływu przedsiębiorstwa na efekty swego funkcjonowania i rozwoju. Jest ono zorientowane na realizację wielu różnorodnych celów, wymagających nie tylko ciągłego diagnozowania i analizowania efektów minionych oraz aktualnych procesów pozyskiwania, gromadzenia i wykorzystywania kapitału, lecz także nakładających na przedsiębiorstwa obowiązek prognozowania zdarzeń i efektów przyszłej działalności.

Wobec ogólnego wzrostu ryzyka funkcjonowania podmiotów gospodarczych na rynku, odczuwalnych i bardzo trudnych do ograniczenia oraz usunięcia skutków kryzysu gospodarczego, licznych upadłości i likwidacji przedsiębiorstw, z jakimi spotykamy się na świecie oraz ciągłego braku pewności dostatecznego finansowego zabezpieczenia ich działalności gospodarczej, istnieje potrzeba utworzenia wiarygodnych oraz skutecznych metod i narzędzi analiz. Uwarunkowane są one w szczególności jakością danych pochodzących głównie $\mathrm{z}$ systemu rachunkowości, a zatem także od stosowanych $\mathrm{w}$ danym podmiocie zasad rachunkowości.

Często można spotkać się z opinią ograniczonej przydatności memoriałowych mierników oceny przy określaniu rzeczywistej kondycji finansowej przedsiębiorstw i/lub przewidywaniu potencjalnych zagrożeń dla kontynuacji działania i rozwoju. $Z$ tego powodu mierniki oceny utworzone w oparciu o dane finansowe wygenerowane jedynie przy uwzględnieniu zasady memoriałowej, powinny być uzupełniane o kasowe mierniki oceny badanego zjawiska. Wykorzystanie danych ze sprawozdania z przepływów pieniężnych daje bowiem możliwość prowadzenia szerszych analiz oraz uwzględnienia różnych wymiarów tej oceny, co w wysokim stopniu pozwala rozpoznać niebezpieczeństwo finansowe oraz podjąć działania zapobiegające zagrożeniu funkcjonowania przedsiębiorstw.

Jednym $\mathrm{z}$ istotnych celów podmiotu gospodarczego jest zapewnienie bezpieczeństwa finansowego realizacji zadań produkcyjnych i/lub usługowych, marketingowych, kadrowych itp. Można przyjąć, że posiadanie bezpieczeństwa finansowego przez przedsiębiorstwo jest podstawowym warunkiem kontynuacji i rozwoju jego działalności. Operacyjne bezpieczeństwo finansowe jest podsys- 
temem systemu bezpieczeństwa finansowego przedsiębiorstwa, stwarzającym możliwości kontynuacji działania tego podmiotu gospodarczego.

Podstawowym celem monografii jest przedstawienie autorskiej koncepcji dwuwymiarowej oceny operacyjnego bezpieczeństwa finansowego przedsiębiorstwa oraz wyników badań naukowych nad oceną tego zjawiska wśród spółek sektora TSL. Ocena ta nie ogranicza się tylko do wykorzystania w niej podejścia memoriałowego, lecz zawiera również rezultaty analizy „kasowych” wyników finansowej działalności jednostek gospodarczych.

Ocena dotychczasowej i przyszłej sytuacji finansowej przedsiębiorstwa nie powinna ograniczać się do wykorzystania tylko podejścia memoriałowego. Może być ono daleko niewystarczające do sformułowania kompleksowej oraz obiektywnej oceny działalności podmiotu gospodarczego z jednoczesnym pozbawieniem przedsiębiorstwa możliwości pełniejszego poznania wszystkich procesów oraz zdarzeń wpływających na jego obecne i przyszłe funkcjonowanie. $\mathrm{Z}$ tego względu w monografii przyjęto zasadę łączenia podejścia memoriałowego i kasowego zarówno w ocenie ex post, jak i ocenie ex ante operacyjnego bezpieczeństwa finansowego przedsiębiorstwa.

Zasygnalizowany cel posiada zatem charakter dualny. $\mathrm{Z}$ jednej bowiem strony zmierza do stworzenia modelu oceny operacyjnego bezpieczeństwa przedsiębiorstw, z drugiej zaś wskazuje na pragmatyczny jej charakter, wyrażający się w dostarczeniu rozwiązań metodycznych tej analizy, mogących służyć kształtowaniu warunków kontynuacji działania jednostek gospodarczych.

Dla realizacji celu opracowania sformułowana została teza stwierdzająca, że konieczność kreowania oraz zapewniania finansowych warunków kontynuacji działalności gospodarczej determinuje potrzebe jednoczesnego oraz kompleksowego wykorzystania podejścia memoriałowego i kasowego w ocenie operacyjnego bezpieczeństwa finansowego przedsiębiorstwa.

Teza ta została zoperacjonalizowana za pomocą sześciu hipotez głównych i siedemnastu hipotez pomocniczych, którym towarzyszą również pytania badawcze (zob. zał. 1). Pierwsza z tych hipotez jest stwierdzeniem odnoszącym się do badań teoretycznych. Pozostałe hipotezy główne oraz pomocnicze wiążą się $\mathrm{z}$ kolei z badaniami empirycznymi, tj. diagnostyką i analizą ex post operacyjnego bezpieczeństwa finansowego (cztery główne hipotezy oraz dwanaście subhipotez i dwanaście pytań badawczych) oraz do prognozowania zagrożenia bezpieczeństwa finansowego przedsiębiorstwa (jedna główna hipoteza, uzupełniona czterema subhipotezami i czterema pytaniami badawczymi).

W teoretycznym obszarze zapowiedzianych dokonań znajduje się następująca hipoteza badawcza stanowiąca, iż $w$ literaturze przedmiotu nie zostało jednoznacznie sformułowane pojęcie operacyjnego bezpieczeństwa finansowego przedsiębiorstwa. Nie zostały tym samym określone determinanty efektywnej i skutecznej kontynuacji działalności gospodarczej przez tego rodzaju jednostki gospodarczej. 
Badania empiryczne przeprowadzone zostały w przedsiębiorstwach sektora TSL (Transport, Spedycja, Logistyka).

Duże zróżnicowanie wartości zmiennych diagnostycznych w całym badanym okresie oraz między różnymi rodzajami działalności gospodarczej przedsiębiorstw sektora TSL stały się kluczową determinantą zmiany poziomu optymalnego operacyjnego bezpieczeństwa finansowego.

Hipoteza druga stwierdza przeto, że $w$ spótkach sektora TSL obserwuje się znaczqce zróżnicowanie poziomu mierników oceny operacyjnego bezpieczeństwa finansowego przedsiębiorstw sektora TSL.

Specyfika grupowania pozycji $\mathrm{w}$ rachunku zysków i strat nie pozwala na jednoznaczne przyporządkowanie przepływów pieniężnych powstałych $\mathrm{z}$ tytułu ogółu pozycji danej grupy do tego samego rodzaju działalności. Powstawanie różnicy między memoriałowymi a kasowymi miernikami oceny operacyjnego bezpieczeństwa finansowego jawi się zatem jako sytuacja typowa i uzasadniona odmiennymi podejściami.

Hipoteza trzecia zawiera zatem stwierdzenie, iż memoriatowe $i$ kasowe mierniki oceny operacyjnego bezpieczeństwa finansowego wykazuja znaczne różnice w spótkach sektora TSL.

Niski poziom związku korelacyjnego między memoriałowymi i kasowymi miernikami operacyjnego bezpieczeństwa finansowego przedsiębiorstwa może wskazywać na pogorszenie się sytuacji finansowej podmiotu gospodarczego.

W hipotezie czwartej przyjęto, że wśród spótek sektora TSL ma miejsce znaczne zróżnicowanie charakteru i sity zwiazku pomiędzy podstawowymi miernikami kształtujacymi operacyjne bezpieczeństwo finansowe przedsiębiorstw. Jeśli to zróżnicowanie posiada trwały charakter może ono wpływać negatywnie na kontynuację działalności gospodarczej.

Posiadane względnie stabilnego poziomu operacyjnego bezpieczeństwa finansowego sprzyja wzmocnieniu warunków kontynuacji działania przedsiębiorstwa.

Hipoteza piąta wyraża przypuszczenie, że $w$ spótkach sektora TSL obserwuje się znaczace zróżnicowanie poziomu operacyjnego bezpieczeństwa finansowego przedsiębiorstw.

Wczesne rozpoznanie symptomów zagrożenia finansowego stwarza możliwość przeciwdziałania niepożądanym procesom pogorszenia warunków finansowych kontynuacji działania przedsiębiorstwa.

Hipoteza szósta zawiera stwierdzenie, iż uwzględnienie mierników kasowych $w$ prognozowaniu zagrożenia finansowego przedsiębiorstw sektora TSL może poprawić zdolność predykcyjna wykorzystywanych metod wielowymiarowej analizy danych.

Opracowanie posiada charakter monografii naukowej, składającej się z wprowadzenia, pięciu rozdziałów, zakończenia, bibliografii, spisów schematów, tabel oraz wykresów. 
Rozdział pierwszy, zatytułowany: Istota i ocena operacyjnego bezpieczeństwa finansowego przedsiębiorstwa: problemy teoretyczno-metodyczne, zawiera propozycje określenia pojęcia operacyjnego bezpieczeństwa finansowego przedsiębiorstwa, analizę przesłanek stosowania memoriałowego i kasowego podejścia $\mathrm{w}$ ocenie operacyjnego bezpieczeństwa finansowego podmiotu gospodarczego oraz rozważania nad dylematami wyboru oraz konstrukcji memoriałowych i kasowych mierników oceny tego rodzaju bezpieczeństwa.

Rozdział drugi monografii, pt.: Obszary działania i mierniki oceny operacyjnego bezpieczeństwa finansowego przedsiębiorstw sektora TSL, koncentruje się na przedstawieniu poziomu i charakteru wybranych zmiennych opisujących zdolność badanych spółek do uzyskania oraz utrzymania dobrego standingu finansowego, rynkowego, produkcyjnego i kadrowego. Zawarta w tej części pracy analiza mierników oceny operacyjnego bezpieczeństwa finansowego została ograniczona do kilkunastu wyselekcjonowanych zmiennych diagnostycznych z obszaru finansowego i produktowego (usługowego), z uwagi na występujące liczne bariery w pozyskaniu danych liczbowych i ich powiązanie z hipotezą drugą niniejszej monografii.

Rozdział trzeci opracowania, nt.: Analiza empiryczna spreadu oraz zależności między miernikami oceny operacyjnego bezpieczeństwa finansowego spótek sektora TSL, zawiera wyniki analizy spreadu memoriałowych oraz kasowych mierników oceny badanego zjawiska w obszarze finansowym, jak i analizy zależności pomiędzy zmiennymi diagnostycznymi kształtującymi operacyjne bezpieczeństwo finansowe spółek sektora TSL. Badania te zostały przeprowadzone w celu weryfikacji empirycznej hipotezy trzeciej i czwartej.

Rozdział czwarty pracy, zatytułowany: Ocena operacyjnego bezpieczeństwa finansowego przedsiębiorstw sektora TSL, wskazuje na potrzebę poszukiwania takich metod oceny badanego zjawiska, które w wysokim stopniu pozwolą rozpoznać niebezpieczeństwo finansowe oraz podjąć działania zapobiegające rozwojowi tego rodzaju zagrożenia w funkcjonowaniu przedsiębiorstw sektora TSL w Polsce. W sukurs przychodzi szereg innych, obok tradycyjnej analizy wskaźnikowej, metod badania kondycji finansowej przedsiębiorstw. Są nimi chociażby metody wielowymiarowej analizy danych, analiza skupień, drzewa klasyfikacyjne czy też porządkowanie liniowe. Ich wykorzystanie zmierzało do zweryfikowania hipotezy piątej.

Rozdział piąty, nazwany: Zastosowanie memoriałowych oraz kasowych mierników w prognozowaniu operacyjnego zagrożenia finansowego przedsiębiorstw sektora TSL, jest związany z weryfikacją hipotezy szóstej. W tej części monografii zbadana została zdolność predykcyjna wybranych modeli zagrożenia upadłością. Zawarta została ponadto próba oszacowania modelu dyskryminacyjnego, tworzącego metodyczne warunki wzrostu zdolności predykcyjnej operacyjnego zagrożenia finansowego przedsiębiorstw sektora TSL. 
W zakończeniu niniejszego opracowania zawarte zostały zasadnicze spostrzeżenia i wnioski płynące z rozważań teoretycznych oraz wyników badań empirycznych przeprowadzonych w celu weryfikacji postawionych hipotez.

Pracę uzupełniają bibliografia, schematy, tabele i wykresy.

Prezentowane opracowanie opiera się na studiach literatury przedmiotu i badaniach empirycznych przeprowadzonych $w$ przedsiębiorstwach sektora TSL. Podjęte zamierzenie uzasadnione było potrzebą wypełnienia luki badawczej istniejącej w studiach teoretycznych i empirycznych poświęconych zdolności przedsiębiorstwa do uzyskania oraz utrzymania finansowych warunków kontynuacji jego działalności gospodarczej. Ma ono charakter wzbogacający w relacji do innych opracowań. Przedstawia bowiem nową wizję i obszary analizy operacyjnego bezpieczeństwa finansowego przedsiębiorstwa, jednocześnie nie negując wartości dotychczasowego dorobku naukowego innych autorów prezentowanego w literaturze przedmiotu.

Przeprowadzone badania empiryczne należą do oryginalnych i zarazem pierwszych obszernych rezultatów analiz nad operacyjnym bezpieczeństwem finansowym przedsiębiorstw sektora TSL. Zawierają one dane liczbowe dotyczące rezultatów działania spółek z tego sektora w latach 2004-2012, zlokalizowanych $w$ obrębie warszawskiego KRS. Podmioty te składały jednostkowe sprawozdania finansowe (w tym sprawozdanie z przepływów pieniężnych) przez cały okres poddany analizie, zaś dzień bilansowy przypadał na koniec badanego okresu, tj. zamykał się każdego 31 grudnia danego roku.

Uzupełniającą, w celu dokonania analizy dyskryminacyjnej, próbę badawczą stanowiły spółki sektora TSL, wobec których w latach 2004-2012 wydane zostało sądowe postanowienie o ogłoszeniu upadłości, a ich dokumentacja (w tym sprawozdanie z przepływów pieniężnych za okres trzech lat przed datą ogłoszenia upadłości) znajdowała się w Krajowym Rejestrze Sądowym w Warszawie (KRS).

Zebrane przez autorkę monografii, a następnie przetworzone i wykorzystane podstawowe dane pochodzą $\mathrm{z}$ danych KRS w Warszawie, bazy danych Info Veriti Polska Sp. z o.o., portali finansowych (m. in.: Bankier.pl, Money.pl), Elektronicznego Systemu Przekazywania Informacji (ESPI), Głównego Urzędu Statystycznego w Warszawie, Centralnego Ośrodka Informacji Gospodarczej Sp. z o.o. oraz czasopisma „EuroLogistics”.

W pracy wykorzystano bogaty arsenał metod i technik badawczych. Zasadniczymi ilościowymi metodami empirycznej weryfikacji postawionych w monografii hipotez badawczych są - obok analizy podstawowych statystyk opisowych i korelacji analizowanych mierników - testy istotności różnic dla wielu prób zależnych i niezależnych, panel EGLS oraz metody wielowymiarowej analizy danych. Należy wskazać, iż zastosowane zostały zarówno techniki analizy porównawczej w czasie, jak i w przestrzeni (wewnątrzsektorowa analiza), zaś nie- 
zbędne obliczenia wykonane zostały w programach Microsoft Excel, Statistica 10, Taksonomia numeryczna, SPSS Statistics (wersja 22) oraz EViews 7.

Wydanie niniejszego opracowania zostało sfinansowane przez Ministerstwo Nauki i Szkolnictwa Wyższego z dotacji dla młodych naukowców. Jest ono adresowane do szerokiego grona praktyków zarządzania finansami przedsiębiorstw (w tym w szczególności z sektora TSL) oraz nauczycieli akademickich i studentów, dla których identyfikacja i ocena zdolności przedsiębiorstwa do uzyskania oraz utrzymania finansowych warunków kontynuacji jego działalności gospodarczej stanowi fascynujący przedmiot podejmowanych oraz realizowanych decyzji kierowniczych i prowadzonych badań czy też dyskursów naukowych.

Prezentowana monografia jest rezultatem niezwykle inspirującej współpracy naukowej z Profesorem Janem Durajem oraz Koleżanek i Kolegów z Katedry Analizy i Strategii Przedsiębiorstwa Uniwersytetu Łódzkiego. Na ostateczny kształt monografii wpłynęły również niezmiernie cenne i konstruktywne uwagi oraz sugestie wniesione przez Panią Profesor Magdalenę Jerzemowską z Uniwersytetu Gdańskiego, Panią Profesor Monikę Marcinkowską z Uniwersytetu Łódzkiego i Pana Profesora Wiktora Gabrusewicza z Uniwersytetu Ekonomicznego w Poznaniu.

Oddzielne podziękowania składam moim Najbliższym za ogromną wyrozumiałość i okazaną pomoc.

Korzystając z licznych porad, sugestii i uwag sama jednak biorę odpowiedzialność za przedstawione w monografii treści, wykorzystane metody badań empirycznych oraz wnioski z nich płynące.

Lidia Karbownik 


\section{Rozdział 1}

\section{ISTOTA I OCENA OPERACYJNEGO BEZPIECZEŃSTWA FINANSOWEGO PRZEDSIĘBIORSTWA PROBLEMY TEORETYCZNO-METODYCZNE}

\subsection{Pojęcie, kryteria i miary operacyjnego bezpieczeństwa finansowego przedsiębiorstwa}

Podjęcie próby zdefiniowania operacyjnego bezpieczeństwa finansowego przedsiębiorstwa nakłada wymóg wcześniejszego określenia pojęcia bezpieczeństwa finansowego. Operacyjne bezpieczeństwo finansowe przedsiębiorstwa jest bowiem pewnym rodzajem bezpieczeństwa finansowego jednostki gospodarczej. Można przyjąć, że na bezpieczeństwo finansowe przedsiębiorstwa składa się strategiczne bezpieczeństwo finansowe i operacyjne bezpieczeństwo finansowe. Nie jest to jednakże „składanka” wymienionych rodzajów finansowego bezpieczeństwa przedsiębiorstwa. $\mathrm{Z}$ istoty finansowego bezpieczeństwa przedsiębiorstwa wynika komplementarny i zarazem bezpośredni charakter związków zachodzących między operacyjnym oraz strategicznym bezpieczeństwem finansowym przedsiębiorstwa. Samo zaś bezpieczeństwo finansowe jest najważniejszym komponentem bezpieczeństwa ekonomicznego i głównym fundamentem szeroko rozumianego bezpieczeństwa narodowego, powiązanym przede wszystkim z dyscypliną naukową finanse, jak również ekonomią, nauką o zarządzaniu, nauką o bezpieczeństwie, matematyką czy psychologią - w wymiarze ekonomicznym ${ }^{1}$.

Termin „bezpieczeństwo” jest niezmiernie często używany i adresowany do wielu różnorodnych problemów ludzkiej działalności, zjawisk przyrodniczych, zdrowia, sytuacji politycznych i społecznych itp. Generalnie biorąc, można przyjąć, iż bezpieczeństwo utożsamiane jest najczęściej z stanem niezagrożenia (zob. tab. 1.1), będąc jego negacją.

${ }^{1}$ K. R aczkowski, Bezpieczeństwo finansowe, [w:] J. Płaczek (red.), Ekonomika bezpieczeństwa państwa w zarysie, Difin, Warszawa 2014, s. 323. 
Tabela 1.1. Słownikowe pojęcie bezpieczeństwa

\begin{tabular}{|c|c|}
\hline Terminologia & Definicja \\
\hline \multirow{4}{*}{ 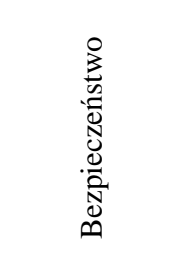 } & stan niezagrożenia, spokoju, pewności, \\
\hline & $\begin{array}{l}\text { stan psychiczny lub prawny, w którym jednostka ma poczucie } \\
\text { pewności, oparcie w drugiej osobie lub w sprawnie działającym } \\
\text { systemie prawnym, przeciwieństwo zagrożenia, }\end{array}$ \\
\hline & stan niezagrożenia, spokoju, \\
\hline & niezagrożenie, nienaruszalność, zabezpieczenie. \\
\hline
\end{tabular}

Źródło: opracowanie własne na podstawie: H. Zgółkowa (red.), Praktyczny stownik wspótczesnej polszczyzny, t. 4, Wydawnictwo „KURPISZ”, Poznań 1995, s. 128; B. Dun aj (red.), Słownik współczesnego języka polskiego, t. A-E, Wydawnictwo WILGA, Kraków 2000, s. 82; E. S o b o l, Stownik języka polskiego, Wydawnictwo Naukowe PWN, Warszawa 2005, s. 46; Stownik polszczyzny XVI wieku, t. II, Wrocław-Warszawa-Kraków 1967, s. 67.

Wyższemu poziomowi zagrożenia odpowiada niższy poziom bezpieczeństwa (zob. wykres 1.1), co można zapisać za pomocą funkcji²:

$$
\operatorname{Sec}=f(T h r)
$$

przy założeniu, iż

$$
\lim _{T h r \rightarrow \infty} f(T h r)=O \Rightarrow \lim _{T h r \rightarrow \infty} \operatorname{Sec}=O
$$

${ }^{2}$ Szczególnym przypadkiem funkcji wymiernej jest funkcja postaci: $f(T h x)=a / T h r$.

W języku angielskim termin „bezpieczeństwo” występuje w dwóch postaciach, jako security oraz safety. Często terminy te można uznać za synonimy, jednakże pierwszy z nich jest powszechniej stosowany wobec większych organizacji, zasobów czy poziomów zarządzania, [za:] K. R a c z k o w ski, K. Ż u krowska, M. Żuber (red.), Interdyscyplinarność nauk o bezpieczeństwie, Difin, Warszawa 2013, s. 62-63.

W literaturze przedmiotu pod pojęciem financial security rozumie się „,bezpieczeństwo finansowe”. Zob. В. О. Аре ф’єв, Кониептуальні Підходи Щодо Управління Фінансовою Безпекою Підприємства На Стратегічному I Тактичному Рівнях, „Економіка. Економіка підприємства, Бізнесінформ” 2011, № 12, s. 74-76 [V. O. A r e fi e v, Conceptual Approaches to Enterprise Financial Security Management at Strategic and Tactical Levels, http://www.businessinform.net/thematic-search/?theme=economy-of-enterprise\&lang=en (dostęp: 14.01.2013)];

A. Ch u p is, K. Ka s h e n k o, Financial Security of Agricultural Enterprises, [w:] M. W a sile w ski (red.), Ekonomika i organizacja gospodarki żywnościowej, „Zeszyty Naukowe SGGW w Warszawie nr 96", Warszawa 2012, s. 5-16.

Jednakże pod tym pojęciem rozumie się również ,finansowe papiery wartościowe”, w tym m. in. akcje i obligacje. Zob. R. C. Higgins, Analysis for Financial Management, 5th ed., McGraw-Hill Companies, Boston 1998, s. 149.

${ }^{3}$ Jeśli w przedziale $(a ; \infty)$ granica dla zmiennej Thr przy Thr wzrastającym (dążącym) do $\infty$ jest równa „zeru”, to Sec przy Thr wzrastającym (dążącym) do $\infty$ maleje do „zera”. 
gdzie $f(T h r)$ oznacza funkcję wymierną, która jest określona w przedziale $(a ; \infty)$ przy a $>0$, dziedziną tej funkcji jest zbiór $\mathbf{R}^{+}$, a zbiorem wartości funkcji (przeciwdziedziną) jest dowolna dodatnia wartość rzeczywista za wyjątkiem liczby $0^{4}$. Dla a $>0$ w przedziale $(0 ; \infty)$ jest funkcją ciągłą i malejącą.

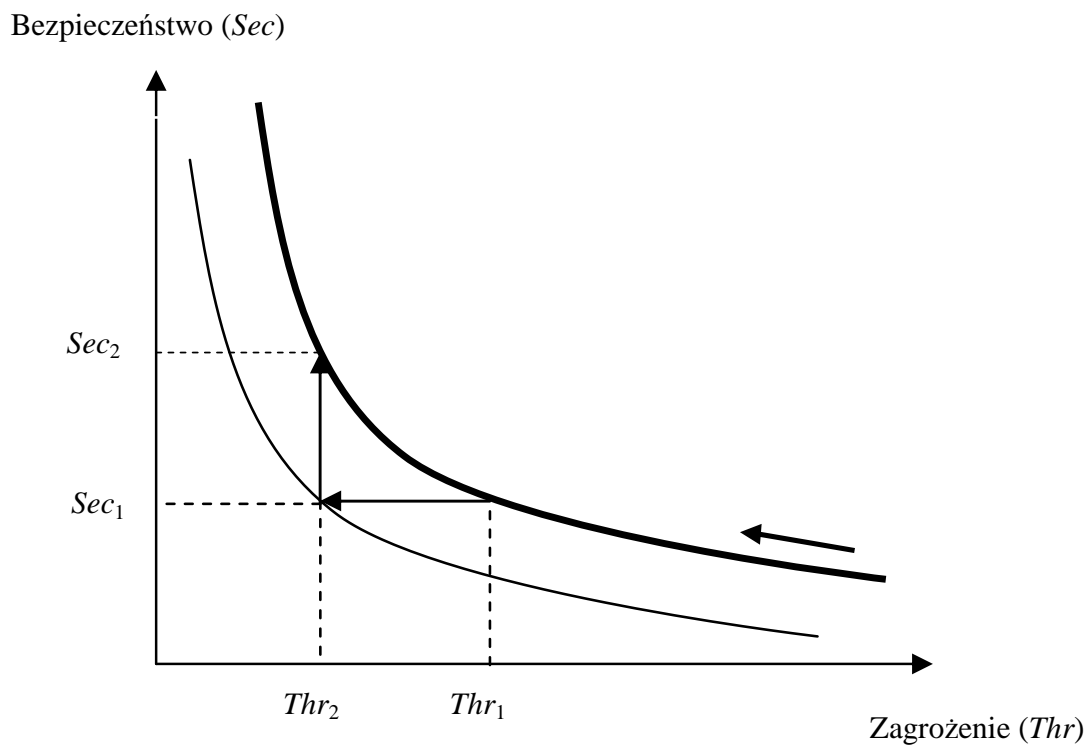

Wykres 1.1. Bezpieczeństwo a zagrożenie

Źródło: opracowanie własne.

Spadek zagrożenia ${ }^{5}$ z poziomu $T h r_{1}$ do $T h r_{2}$ przyczynia się do wzrostu bezpieczeństwa funkcjonowania danego podmiotu gospodarczego z poziomu $\operatorname{Sec}_{1}$ do $\mathrm{Sec}_{2}$. Należy przy tym jednakże wskazać, iż przy niskim stopniu zagrożenia - jego początkowy wzrost - przyczynia się do znacznie wyższego spadku bezpieczeństwa danej jednostki gospodarczej. Z kolei - przy wysokim stopniu zagrożenia - jego dalszy znaczny wzrost nie powoduje relatywnie większego tempa zmniejszenia bezpieczeństwa przedsiębiorstwa.

\footnotetext{
${ }^{4}$ Asymptotami tej funkcji są: $T h x=0$ oraz $S e c=0$.

${ }^{5}$ Podstawowym zadaniem przedsiębiorstwa jest określenie (zdefiniowanie), reagowanie, eliminacja lub łagodzenie zagrożeń, które mogą powodować zmniejszenie poziomu bezpieczeństwa finansowego tego podmiotu gospodarczego. Por. Т.Б. Кузенко, К. А. Усенко, Управление Финансовой Безопасностью Предприятия В Соответствии С Принципами Ее Обеспечения, „Економіка, Фінансова Стійкість I Безпека, Бізнесінформ” 2011, № 2(1), s. 136-138 [T. B. Ku ze n k o, K. A. U s e n k o, Management of Financial Security of Enterprise in Accordance with the Principles of its Control, http://www.business-inform.net/annotatedcatalogue/?year=2011\&abstract=2011_02_1\&lang=en (dostęp:14.01.2013)].
} 
Generalnie biorąc, można powiedzieć, że przez bezpieczeństwo można rozumieć stan i/lub proces, który(e) daje(ą) określonej jednostce poczucie spokoju i pewności istnienia oraz gwarancję ich zachowania i szanse na rozwój. Pojęcie to można odnieść także do finansowego bezpieczeństwa przedsiębiorstwa.

Polska i obcojęzyczna literatura przedmiotu ${ }^{6}$ wskazuje, że:

a) występują dość zróżnicowane pojęcia bezpieczeństwa finansowego przedsiębiorstwa (zob. tab. 1.2),

b) nie zostało wyróżnione i tym samym nie zostało zdefiniowane pojęcie operacyjnego bezpieczeństwa finansowego przedsiębiorstwa.

$\mathrm{W}$ tab. 1.2 przedstawione są różne poglądy przedstawicieli świata akademickiego na temat bezpieczeństwa finansowego. Dla przykładu D. Wędzki wskazuje, iż bezpieczeństwo finansowe podmiotu gospodarczego maleje, gdy poziom nadwyżki majątku zabezpieczającego spłatę wymagalnych zobowiązań maleje $^{7}$. Zdaniem B. O. Apeф'єв podniesienie poziomu bezpieczeństwa finansowego przedsiębiorstwa można zagwarantować m. in. poprzez optymizację produkcji (usług) przedsiębiorstwa ${ }^{8}$, inwestycje, podniesienie poziomu konkurencyjności produkcji (usług), czy też podjęcie agresywnych działań marketingowych ${ }^{9}$. A. Chupis i K. Kashenko stwierdzają zaś, iż bezpieczeństwo finanso-

${ }^{6} \mathrm{~W}$ latach $60 . \mathrm{XX}$ w. w literaturze przedmiotu pojawiła się definicja bezpieczeństwa finansowego. Definicja ta dotyczyła bezpieczeństwa finansowego rodziny, poprzez które rozumiano pewność posiadania przez nią zasobów niezbędnych do realizacji jej przyszłych potrzeb finansowych. Zob. Family financial security, North Central Regional Research Publication nr 131, Special Report 36, Iowa State University of Science and Technology, Iowa 1964, s. 8.

Zdaniem zaś Т. Б. Кузенко oraz О. П. Полтинина początkowo terminu „,bezpieczeństwo finansowe" używano w stosunku do państwa, jako jednego z zasadniczych elementów bezpieczeństwa ekonomicznego. Jednak z czasem oddzielnym przedmiotem badań naukowych stało się bezpieczeństwo finansowe przedsiębiorstwa. Zob. Т. Б. Кузенко, О. П. Полтинина, Конкретизаиия Угроз Финансовой Безопасности Предприятия, „Економіка Фінансова Стійкість І Безпека, Бізнесінформ” 2011, № 2(1), s. 131-133 [T. В. K u ze n k o, O. P. Polti nina, Concretization of Threats of Financial Security of Enterprise, www.business-inform.net (dostęp: 14.01.2013)].

D. W ędzki, Strategie ptynności finansowej przedsiębiorstwa, Oficyna Ekonomiczna, Kraków 2003, s. 34-36.

${ }^{8}$ Usługa, wszelka działalność lub korzyść, którą jedna ze stron może zaoferować drugiej, z zasady jest niematerialna oraz nie prowadzi do uzyskania jakiejkolwiek własności. Produkt to wszystko to, co można zaoferować na rynku w celu zwrócenia uwagi, nabycia, użytkowania i/lub konsumpcji, co jest w stanie zaspokoić potrzebę lub pragnienie, tj. przedmiot, usługa, osoba, miejsce, organizacja, idea. Zob. P. Kotler, G. Armstrong, J. S aunders, V. Wong, Marketing. Podręcznik europejski, PWE, Warszawa 2002, s. 41.

Zgodnie z art. 3 ust. 19 ustawy o rachunkowości, w ramach rzeczowych aktywów obrotowych wyróżnić można wytworzone lub przetworzone przez jednostkę produkty gotowe (wyroby i usługi), [za:] Ustawa z dnia 29 września 1994 r. o rachunkowości, DzU 1994, nr 121, poz. 591 z późn. $\mathrm{zm}$.

Przychody ze sprzedaży usług nie są wyodrębnione w rachunku zysków i strat, ponieważ są ujęte łącznie ze sprzedażą produktów, [za:] K. Czubakowska, W. Gabrusewicz, E. Now a k, Przychody, koszty, wynik finansowy przedsiębiorstwa, PWE, Warszawa 2009, s. 50.

${ }^{9}$ B. O. A p е ф' є в, op. cit. (dostęp: 14.01.2013). 
we przedsiębiorstwa jest złożoną koncepcją, zakładającą efektywne wykorzystanie zasobów finansowych, stworzenie perspektyw rozwoju gospodarczego i pozytywnej oceny atrakcyjności inwestycyjnej danego przedsiębiorstwa ${ }^{10}$.

Przyjęcie bezpieczeństwa finansowego jako zmiennej zależnej od zagrożenia finansowego ${ }^{11}$ wiąże się $\mathrm{z}$ problemem istnienia struktury relacyjnej o złożonym i zmieniającym się charakterze ze względu na to, że sytuacja finansowa przedsiębiorstwa odzwierciedla dotychczasowe i dyskontuje wszystkie przyszłe efekty, procesy i warunki jego działania.

Finansowe bezpieczeństwo podmiotu gospodarczego może być przeto zdefiniowane jako ogół warunków finansowych zapewniających przedsiębiorstwu efektywną i skuteczną kontynuację działalności oraz szanse na rozwój ${ }^{12}$.

${ }^{10}$ Por. A. Chupis, K. Ka shen ko,op. cit., s. 15.

Rozwój przedsiębiorstwa należy do najbardziej złożonych, obiektywnych zjawisk i procesów, wynikających ze zmienności różnorodnej materii oraz istniejącego stanu rzeczy. Jest on długotrwałym procesem zmian ilościowych i jakościowych, prowadzących do zróżnicowania oraz wzbogacenia elementów składowych przedsiębiorstwa i zachodzących między nimi stosunków, [za:] J. Duraj, Analiza rozwoju przedsiębiorstwa, [w:] L. B ednarski, R. B orowiecki, J. Duraj, E. Kurtys, T. Waśniewski, B. Wersty, Analiza ekonomiczna przedsiębiorstwa, Wydawnictwo Akademii Ekonomicznej im. Oskara Langego we Wrocławiu, Wrocław 1996, s. 354.

${ }^{11}$ Spadek zagrożenia finansowego powoduje wzrost bezpieczeństwa finansowego danego podmiotu gospodarczego.

D. Hen sher i S. Jo n e s wyróżnili następujące stany zagrożenia finansowego:

0: przedsiębiorstwa nieupadłe,

1: przedsiębiorstwa niewydolne* finansowo - te przedsiębiorstwa zdefiniowano jako spełniające jeden z warunków:

a) niespłacanie zadłużenia,

b) nieuiszczanie opłat listingowych na rzecz Australian Stock Exchange,

c) podnoszenie kapitału wyłącznie z powodu konieczności generowania środków na finansowanie bieżącej działalności,

d) restrukturyzacja długu z powodu zmniejszonej zdolności do jego spłaty;

2: przedsiębiorstwa zagrożone finansowo - są to te przedsiębiorstwa usunięte $\mathrm{z}$ Australian Stock Exchange, które były przedmiotem transakcji fuzji lub przejęcia;

3: przedsiębiorstwa, które złożyły wniosek o upadłość, w którego następstwie wyznaczono syndyków upadłości.

Zob. D. Hen sher, S. Jon es, Mixed logit and error component models of corporate insolvency and bankruptcy risk, [w:] D. He n sher, S. Jon e s (ed.), Advances in credit risk modelling and corporate bankruptcy prediction, Cambridge University Press, Cambridge 2008, s. 59; M. Gru szczyński, Empiryczne finanse przedsiębiorstw. Mikroekonomia finansowa, Difin SA \& Marek Gruszczyński, Warszawa 2012, s. 136.

* „Niewydolny” (w odniesieniu do organizmu lub jego narządów) - tj. częściowo lub całkowicie niezdolny do skutecznego funkcjonowania; nieradzący sobie z czymś lub niesprawnie działający. Zob. J. B ralc zy k (red.), Stownik 100 tysięcy potrzebnych słów, Wydawnictwo Naukowe PWN, Warszawa 2005, s. 462.

„Niewydolny” - tj. taki, który nie nadąża za wzrostem potrzeb, nie zaspokaja ich (bliskoznaczne: niewystarczający, niedostosowany, ograniczony; antonimy: wydolny, zdolny, zdatny). Zob. H. Zgółkow a (red.), Praktyczny stownik wspótczesnej polszczyzny, t. 24, Wydawnictwo „KURPISZ”, Poznań 1995, s. 198.

${ }^{12}$ Por. L. Karbow ni k, Kasowe i memoriałowe mierniki oceny bezpieczeństwa finansowego przedsiębiorstwa, [w:] J. D u raj (red.), Instrumenty i sposoby zarzadzania kapitatem przedsiębior- 
Nie jest to określenie wykluczające wcześniej zredagowane przez L. Karbownik następujące pojęcie bezpieczeństwa finansowego: „Przez bezpieczeństwo finansowe przedsiębiorstwa należy rozmieć finansową gwarancję istnienia i rozwoju przedsiębiorstwa, która powstaje w wyniku codziennych wieloletnich starań przedsiębiorstwa o zapewnienie dobrej kondycji finansowej" (zob. tab. 1.2) ${ }^{13}$. Można bowiem przyjąć, że ta może posiadać zgeneralizowany charakter $\mathrm{z}$ uwagi na zawarcie w niej paradygmatu osiągnięcia finansowej gwarancji istnienia i rozwoju przedsiębiorstwa.

Operacyjne bezpieczeństwo finansowe przedsiębiorstwa jest to ogół finansowych warunków efektywnej i skutecznej kontynuacji działalności przedsiębiorstwa, zdolnych do wykreowania oraz utrzymania dobrego standingu finansowego, rynkowego, produkcyjnego i kadrowego. Przez standing przedsiębiorstwa można rozumieć jego zdolność dostosowawczą do zmiennego otoczenia dzięki umiejętności łączenia, koordynacji i harmonizacji zróżnicowanej działalności finansowej, marketingowej, produkcyjnej i rozwoju kapitału ludzkiego.

stwa, „Acta Universitatis Lodziensis”, Folia Oeconomica 267, Wydawnictwo Uniwersytetu Łódzkiego, Łódź 2012, s. 79-80.

Zgodnie z art. 5 ust. 2 ustawy o rachunkowości przy stosowaniu zasad (polityki) rachunkowości przyjmuje się założenie, że jednostka będzie kontynuowała - w dającej się przewidzieć przyszłości - działalność w niezmienionym istotnie zakresie, bez postawienia jej w stan likwidacji lub upadłości, chyba że jest to niezgodne ze stanem faktycznym lub prawnym. Ustalając zdolność jednostki do kontynuowania działalności, kierownik jednostki uwzględnia wszystkie informacje dostępne na dzień sporządzenia sprawozdania finansowego, dotyczące dającej się przewidzieć przyszłości, obejmującej okres nie krótszy niż jeden rok od dnia bilansowego, [za:] Ustawa z dnia 29 września 1994 r..., op. cit.

${ }^{13}$ L. Karbownik, Pojęcie i obszary kreowania oraz zapewniania bezpieczeństwa finansowego przedsiębiorstwa, [w:] J. D u r aj (red.), Instrumenty i sposoby zarzadzania kapitatem przedsiębiorstwa, „Acta Universitatis Lodziensis”, Folia Oeconomica 267, Wydawnictwo Uniwersytetu Łódzkiego, Łódź 2012, s. 66.

Kondycja finansowa oznacza sytuację, pozycję finansową przedsiębiorstwa, będącą rezultatem podejmowanych przez ten podmiot decyzji gospodarczych i związanych z tym jego perspektyw przyszłościowych, [za:] E. S i e mi ń sk a, Metody pomiaru i oceny kondycji finansowej przedsiębiorstwa, TNOiK - Stowarzyszenie Wyższej Użyteczności DOM ORGANIZATORA, Toruń 2002, s. 31.

Pojęcia „kondycja” i „,sytuacja finansowa” w literaturze przedmiotu stosowane są zamiennie, w tym m. in. przez: L. B ednarski, T. W a śn ie w ski (red.), Analiza finansowa w zarzadzaniu przedsiębiorstwem, t. 1, Fundacja Rozwoju Rachunkowości w Polsce, Warszawa 1996, s. 315-316; M. S i e r pińs ka, D. W ę d zki, Zarządzanie płynnościa finansowa w przedsiębiorstwie, Wydawnictwo Naukowe PWN, Warszawa 1997, s. 35-36; T. Waśnie w ski, W. Sk oczylas, Syntetyczna ocena wyników oraz sytuacji finansowej przedsiębiorstwa, „Rachunkowość” 1998, nr 4, s. 199-211; E. U rb ań c zy k, Metody ilościowe w analizie finansowej przedsiębiorstwa, Uniwersytet Szczeciński, Szczecin 1998, s. 139-142 i 264-266; M. Sier pińska, T. J a chna, Ocena przedsiębiorstwa wedtug standardów światowych, Wydawnictwo Naukowe PWN, Warszawa 2004, s. 9-10, 15-16 i 144-221; B. P o m y kal s k a, P. P o m y kals ki, Analiza finansowa przedsiębiorstwa, Wydawnictwo Naukowe PWN, Warszawa 2007, s. 66-67. 
Tabela 1.2. Definicje bezpieczeństwa finansowego (przegląd literatury)

\begin{tabular}{|c|c|c|}
\hline $\begin{array}{c}\text { Autor/Autorzy } \\
\text { (Rok publikacji) }\end{array}$ & Definicja/Opis & Podmiot \\
\hline 1 & 2 & 3 \\
\hline $\begin{array}{l}\text { D. Wędzki } \\
(2003)\end{array}$ & $\begin{array}{l}\text { Bezpieczeństwo finansowe maleje, gdy poziom nadwyżki } \\
\text { majątku zabezpieczającego spłatę wymagalnych zobowiązań } \\
\text { maleje. }\end{array}$ & przedsiębiorstwo \\
\hline $\begin{array}{l}\text { J. Franc- } \\
\text {-Dąbrowska } \\
(2006)\end{array}$ & $\begin{array}{l}\text { Bezpieczeństwo finansowe należy rozumieć jako zdolność } \\
\text { zachowania płynności finansowej oraz wysoką sprawność } \\
\text { działania. }\end{array}$ & przedsiębiorstwo \\
\hline $\begin{array}{l}\text { A. Jurkowska- } \\
\text {-Zeidler } \\
(2008)\end{array}$ & $\begin{array}{l}\text { Bezpieczeństwo finansowe stanowi element szeroko rozu- } \\
\text { mianego bezpieczeństwa ekonomicznego, ponieważ to wła- } \\
\text { śnie zagrożenia związane z funkcjonowaniem rynku finanso- } \\
\text { wego powodują zakłócenia w funkcjonowaniu całej gospo- } \\
\text { darki, powodując tym samym największe zagrożenie dla } \\
\text { bezpieczeństwa ekonomicznego państwa. }\end{array}$ & państwo \\
\hline $\begin{array}{l}\text { M. Capiga, } \\
\text { W. Gradoń, } \\
\text { G. Szustak } \\
\quad(2010)\end{array}$ & $\begin{array}{l}\text { Bezpieczeństwo finansowe utożsamiane jest bezpieczeń- } \\
\text { stwem rynku finansowego, tj. czterema wzajemnie powiąza- } \\
\text { nymi ze sobą jego wymiarami: bezpieczeństwa transakcji } \\
\text { finansowych, bezpieczeństwa segmentów rynku finansowego, } \\
\text { bezpieczeństwa klienta rynku finansowego i bezpieczeństwa } \\
\text { instytucji finansowych. Ten ostatni rodzaj bezpieczeństwa, } \\
\text { tj. bezpieczeństwo instytucji finansowych, oznacza ich nieza- } \\
\text { kłócone funkcjonowanie, przejawiające się przede wszystkim } \\
\text { w dobrej kondycji finansowej i utrzymywaniu ryzyka działa- } \\
\text { nia w tzw. bezpiecznych granicach. Sytuacja ta stwarza moż- } \\
\text { liwość szybkiego reagowania na pojawiające się zagrożenia. } \\
\text { Bezpieczeństwo instytucji finansowych jest nierozerwalnie } \\
\text { związane z ryzykiem, dlatego zarządzanie nimi to również } \\
\text { zarządzanie różnymi rodzajami ryzyka. }\end{array}$ & rynek finansowy \\
\hline $\begin{array}{c}\text { Л. А. } \\
\text { Запорожцева } \\
(2011)\end{array}$ & $\begin{array}{l}\text { Bezpieczeństwo finansowe przedsiębiorstwa to „stabilne” } \\
\text { zabezpieczenie produkcyjno-finansowej działalności gospo- } \\
\text { darczej od realnych i potencjalnych wewnętrznych oraz ze- } \\
\text { wnętrznych zagrożeń w celu zapewniania stabilnego jego } \\
\text { rozwoju (...). }\end{array}$ & przedsiębiorstwo \\
\hline $\begin{array}{c}\text { В. О. Ареф'єв } \\
\text { (2011) }\end{array}$ & $\begin{array}{l}\text { Podniesienie poziomu bezpieczeństwa finansowego przedsię- } \\
\text { biorstwa można zagwarantować przez optymizację produkcji } \\
\text { (usług) przedsiębiorstwa, inwestycje, podniesienie poziomu } \\
\text { konkurencyjności produkcji (usług), czy też poprzez zabez- } \\
\text { pieczenie niezależności przedsiębiorstwa od zmian koniunk- } \\
\text { tury na rynku dzięki zewnętrznej elastyczności i podjęciu } \\
\text { agresywnych działań marketingowych. }\end{array}$ & przedsiębiorstwo \\
\hline $\begin{array}{l}\text { A. Chupis, } \\
\text { K. Kashenko } \\
\text { (2012) }\end{array}$ & $\begin{array}{l}\text { Bezpieczeństwo finansowe przedsiębiorstw rolnych jest } \\
\text { złożoną koncepcją, zapewniającą zapobieganie negatywnemu } \\
\text { wpływowi czynników związanych z zagrożeniami wewnętrz- } \\
\text { nymi i zewnętrznymi. Zakłada ona również efektywne wyko- } \\
\text { rzystanie zasobów finansowych, stworzenie perspektyw } \\
\text { rozwoju gospodarczego i pozytywnej oceny atrakcyjności } \\
\text { inwestycyjnej danego przedsiębiorstwa. }\end{array}$ & przedsiębiorstwo \\
\hline
\end{tabular}


Tabela 1.2 (cd.)

\begin{tabular}{|c|c|c|}
\hline 1 & 2 & 3 \\
\hline $\begin{array}{l}\text { I . Ładysz } \\
\text { (2012) }\end{array}$ & $\begin{array}{l}\text { Bezpieczeństwo finansowe miasta oraz możliwość realizacji } \\
\text { przez miasto funkcji metropolitalnych zależy od wielkości do- } \\
\text { chodów, skali wydatków, a także źródeł finansowania licznych } \\
\text { inwestycji. Ważnym wskaźnikiem charakteryzującym bezpie- } \\
\text { czeństwo finansowe Wrocławia jest relacja deficytu budżetu do } \\
\text { dochodów budżetowych, która nie powinna przekraczać poziomu } \\
\text { wynikającego z Ustawy z dnia } 27 \text { sierpnia } 2009 \text { r. o finansach } \\
\text { publicznych. Należy pamiętać, że w warunkach polskich ban- } \\
\text { kructwo w sensie prawnym jakiegokolwiek miasta nie jest moż- } \\
\text { liwe, możliwa jest jedynie (lub aż) utrata płynności finansowej. } \\
\text { Jednakże przyczyną utraty płynności finansowej przez jednostki } \\
\text { samorządu terytorialnego z reguły nie są nadmierne kredyty } \\
\text { inwestycyjne, lecz słabo kontrolowane wydatki bieżące. }\end{array}$ & $\begin{array}{l}\text { jednostka } \\
\text { samorządu } \\
\text { terytorialnego }\end{array}$ \\
\hline $\begin{array}{l}\text { L. Karbownik } \\
\qquad(2012)\end{array}$ & $\begin{array}{l}\text { Przez bezpieczeństwo finansowe przedsiębiorstwa należy roz- } \\
\text { mieć finansową gwarancję istnienia i rozwoju przedsiębiorstwa, } \\
\text { która powstaje w wyniku codziennych wieloletnich starań przed- } \\
\text { siębiorstwa o zapewnienie dobrej kondycji finansowej. }\end{array}$ & przedsiębiorstwo \\
\hline $\begin{array}{l}\text { A. N. Duraj } \\
(2013)\end{array}$ & $\begin{array}{l}\text { Bezpieczeństwo finansowe przedsiębiorstwa można wyrazić jako } \\
\text { proces i/lub ogół warunków pozyskania, gromadzenia i wykorzy- } \\
\text { stywania środków finansowych zapewniający kontynuację dzia- } \\
\text { łalności przedsiębiorstwa oraz finansowe warunki jego rozwoju. }\end{array}$ & przedsiębiorstwo \\
\hline $\begin{array}{l}\text { K. Raczkowski } \\
\text { (2013) }\end{array}$ & $\begin{array}{l}\text { Bezpieczeństwo finansowe to proces stałego ograniczania } \\
\text { i eliminacji ryzyka pieniężnego w celu takiego zabezpieczenia } \\
\text { adekwartności kapitałowej, która będzie dostosowana do profilu } \\
\text { ryzyka i preferencji danego podmiotu lub jednostki. }\end{array}$ & - \\
\hline
\end{tabular}

Źródło: opracowanie własne na postawie: D. W ędzki, Strategie plynności finansowej przedsiębiorstwa, Oficyna ekonomiczna, Kraków 2003, s. 34-36; J. Fr a n c-Dą b o w s k a, Bezpieczeństwo finansowe a efektywność zaangażowanych kapitałów własnych, Roczniki Nauk Rolniczych, seria G, t. 93, z. 1, Warszawa 2006, s. 121; A. Jurk ow sk a-Ze idle r, Bezpieczeństwo rynku finansowego w świetle prawa Unii Europejskiej, Wolters Kluwer Polska Sp. z o.o., Warszawa 2008, s. 166-171; M. Capiga, W. Gradoń, G. Szu stak, Sieć bezpieczeństwa finansowego, CeDeWu Sp. z o.o., Warszawa 2010, s. 12-13; Л. А. Запорожцева, Финансовая Безопасность Предприятия При Переходе На МСФО, „Проблемы. Мнения. Решения, Международный Бухгалтерский Учет”, сентябрь 2011, № 36(186), s. 46-47 [L. A. Zaporozhtseva, Financial safety of the enterprise at transition on IFRS, „International Accounting”, September 2011, No. 36(186), s. 46-47); В. О. А р е ф' є в, Конщептуальні Підходи Щодо Управління Фінансовою Безпекою Підприємства На Стратегічному I Тактичному Рівнях, „Економіка. Економіка підприємства, Бізнесінформ” 2011, № 12, s. 74-76 [V. O. A refi i v, Conceptual Approaches to Enterprise Financial Security Management at Strategic and Tactical Levels, http://www.business-inform.net/thematic-search /?theme=economy-of-enterprise\&lang=en (dostęp: 14.01.2013)]; A. Chupis, K. Kashenk o, Financial Security of Agricultural Enterprises, [w:] M. W a s i l e w s ki (red.), Ekonomika i organizacja gospodarki żywnościowej, „Zeszyty Naukowe SGGW w Warszawie nr 96”, Warszawa 2012, s. 15; I. Ła d y s z, Wybrane aspekty zarządzania bezpieczeństwem finansowym $i$ zadtużeniem miasta Wroctawia, [w:] Rocznik Bezpieczeństwa Międzynarodowego, Wydawnictwo Naukowe Dolnośląskiej Szkoły Wyższej, Wrocław 2012, s. 18, 21 i 23; L. Karbownik, Pojęcie i obszary kreowania oraz zapewniania bezpieczeństwa finansowego przedsiębiorstwa, [w:] J. D u r a j (red.), Instrumenty i sposoby zarzadzania kapitałem przedsiębiorstwa, „Acta Universitatis Lodziensis”, Folia Oeconomica 267, Wydawnictwo Uniwersytetu Łódzkiego, Łódź 2012, s. 66; A. N. D u r a j, Wieloczynnikowa koncepcja modelu bezpieczeństwa finansowego przedsiębiorstwa, [w:] J. D u r a j, A. S a j nóg (red.), Ekonomiczne i pozaekonomiczne czynniki zarządzania wartościa przedsiębiorstwa, Wydawnictwo Uniwersytetu Łódzkiego, Łódź 2013, s. 65; K. R a c zk ow sk i, Bezpieczeństwo finansowe, [w:] J. Pła c ze k (red.), Ekonomika bezpieczeństwa państwa w zarysie, Difin, Warszawa 2014, s. 301-302. 
Zawarte w wykazie definicji bezpieczeństwa finansowego poglądy M. Capigi, W. Gradonia oraz G. Szustaka (zob. tab. 1.2), odnoszące się do bezpieczeństwa rynku finansowego, pozwalają dostrzec złożony charakter tej kategorii finansowej oraz wyeksponować różne rodzaje związków zachodzących w obrębie danego podmiotu. Jest ono związane m. in. z niezakłóconym funkcjonowaniem i zarządzaniem różnymi rodzajami ryzyka. Na poziomie przedsiębiorstwa ryzyko to dotyczy wszystkich sfer i obszarów jego działalności. Stąd też operacyjne bezpieczeństwo finansowe przedsiębiorstwa, widziane przez pryzmat realizacji efektywnej i skutecznej kontynuacji działalności podmiotu gospodarczego, zdolnej do wykreowania i utrzymania dobrego standingu finansowego, zawiera w sobie paradygmat konieczności łączenia działalności produkcyjnej, marketingowej oraz kadrowej z działalnością finansową i uznania tej ostatniej za wiodącą.

Operacyjne bezpieczeństwo finansowe przedsiębiorstwa może być traktowane jako stan i/lub proces. W pierwszym przypadku odnosi się głównie do istniejącej sytuacji finansowej podmiotu gospodarczego, która może być rozpatrywana w statycznych porównaniach przestrzennych, z określonym benchmarkiem oraz czasowych. W podejściu procesowym przedmiotem rozważań są zmiany wielkości i charakteru różnorodnych determinant kontynuacji działania podmiotu gospodarczego, mające miejsce w określonej przestrzeni czasowej. W tym ujęciu uwaga badacza powinna zostać skierowana na określenie (zdefiniowanie) zmiany (wzrostu, spadku) ilości oraz siły oddziaływania zagrożeń na finansowe warunki efektywnej i skutecznej kontynuacji działalności, które mogą powodować zmianę (pogorszenie, polepszenie) ${ }^{14} \mathrm{w} / \mathrm{w}$ standingu finansowego, rynkowego, produkcyjnego i kadrowego przedsiębiorstwa.

Należy wskazać, iż informacje finansowe są niezbędne do podejmowania decyzji we wszystkich sferach zarządzania przedsiębiorstwem. Odgrywają one kluczową rolę w planowaniu, organizowaniu, motywowaniu, kontrolowaniu. $\mathrm{W}$ marketingu, informacje finansowe są wykorzystywane w procesie podejmowania decyzji, w formułowaniu i realizacji strategii marketingowych. Podstawową kwestią jest jednakże potrzeba wyodrębnienia podstawowych informacji finansowych, które powinny zostać wzięte pod uwagę w podejmowaniu decyzji marketingowych w takich sferach jak: polityka produktu, cena, promocja, dystrybucja, badania marketingowe i obsługa posprzedażna ${ }^{15}$. Te sfery działalności marketingowej stanowią interaktywny obszar finansowo-marketingowego zarządzania bezpieczeństwem finansowym przedsiębiorstwa.

${ }^{14}$ L. Karbownik, Zróżnicowanie poziomu operacyjnego bezpieczeństwa finansowego przedsiębiorstw sektora TSL, [w:] J. Duraj (red.), Instrumenty kształtowania dochodowości i rentowności przedsiębiorstwa, „Acta Universitatis Lodziensis”, Folia Oeconomica 278, Wydawnictwo Uniwersytetu Łódzkiego, Łódź 2013, s. 223.

${ }^{15} \mathrm{C}$. Ko chalski, The finance-marketing interface, [w:] W. Frąckowiak, C. Kochalski, Modern Managerial Finance. New trends and research areas, Poznań Uniwersity of Economic Press, Poznań 2010, s. 37. 
Wskazanie na standing produkcyjny jako jedną z determinant i efektów bezpieczeństwa finansowego przedsiębiorstwa nabiera w swej intencji charakter imperatywu zespolenia działalności produkcyjnej $\mathrm{z}$ działalnością finansową, które zmierza do efektywnego wykorzystania istniejących zdolności produkcyjnych ${ }^{16}$ oraz wzrostu ekonomicznej wartości dodanej. Natomiast wyróżniona zmienna, określana jako rozwój kapitału ludzkiego, odnosi się do kształtowania relacji między wynikami finansowymi a zasobem wiedzy, umiejętności, zdolności, kwalifikacji, postaw, motywacji oraz zdrowia, o określonej wartości, będącym źródłem przyszłych zarobków czy satysfakcji ${ }^{17}$.

W wykazanej literaturze przedmiotu wielokrotnie uwydatnianym obszarem kreowania i zapewniania bezpieczeństwa finansowego przedsiębiorstwa jest płynność finansowa (zob. tab. 1.3). Brak płynności lub nadpłynność finansowa mogą wprost lub pośrednio prowadzić do eliminacji przedsiębiorstwa z procesu gospodarczego $^{18}$.

Niezależnie od oceny bieżącej zdolności płatniczej przedsiębiorstwa, celowa jest także analiza perspektywicznych możliwości spłaty jej zobowiązań długoterminowych, zaciągniętych na cele inwestycyjno-modernizacyjne, tj. wypłacalności finansowej ${ }^{19}$. Ten obszar kreowania i zapewniania bezpieczeństwa finansowego przedsiębiorstwa należy uznać za niezbędny nie tylko dla kontynua-

${ }^{16}$ Nie w pełni docenionym, jak i wykorzystanym źródłem poprawy efektywności jest dla przykładu produktywność.

Produktywność definiowana jest generalnie jako miara efektywności przedsiębiorstwa, określana relacją wyników produkcyjnych do nakładów wykorzystywanych w celu ich osiągnięcia, [za:] M. P a pi e rn i k-Woj d e ra, Produktywność jako źródto poprawy rentowności przedsiębiorstwa, [w:] A. S tabryła (red.), Strategie wzrostu produktywności firmy, Wydawnictwo Akademii Ekonomicznej w Krakowie, Kraków 2000, s. 466.

W związku z charakterystycznymi cechami usług trudno jest zmierzyć ich produktywność $\mathrm{z}$ taką samą precyzją, jaka istnieje w sektorze produkcyjnym, choć dla przykładu usług transportowych - wkład (tj. godziny przepracowane przez kierowcę) oraz wynik ( $\mathrm{tj}$. tony na kilometry), jak i związek między nimi daje jasny wymiar produktywności. Zob. P. Mudie, A. Cottam, Ustugi. Zarzadzanie i marketing, Wydawnictwo Naukowe PWN, Warszawa 1998, s. 258.

Należy zauważyć, iż odniesienie produkcji tylko do jednego czynnika jest dużym uproszczeniem, gdyż przypisuje mu efekty, które powstają przy współgraniu różnych czynników. Wobec tego dla zmierzenia jednoczesnego wpływu wszystkich czynników wprowadzono wieloczynnikową produktywność, [za:] G. Ju szczak-Szu macher, Makroekonometryczna analiza procesu produkcyjnego, Wydawnictwo Uniwersytetu Łódzkiego, Łódź 1996, s. 33.

17 K. Szopik-Depczyńska, W. Korzeniewicz, Kapitat ludzki w modelu wartości przedsiębiorstwa, „Studia i Prace Wydziału Nauk Ekonomicznych i Zarządzania nr 24”, Uniwersytet Szczeciński, Szczecin 2011, s. 180, http://www.wneiz.pl/nauka_wneiz/sip/sip24-2011/SiP24-12.pdf (dostęp: 26.05.2013).

${ }^{18}$ T. W a śn i e w ski, W. S k o c zy las, Teoria i praktyka analizy finansowej $w$ przedsiębiorstwie, Fundacja Rozwoju Rachunkowości w Polsce, Warszawa 2002, s. 431.

${ }_{19}$ M. Zuba, Wptyw poziomu wartości majątku na bezpieczeństwo finansowe wybranych spótdzielni mleczarskich w Polsce, Roczniki Naukowe Stowarzyszenia Ekonomistów Rolnictwa i Agrobiznesu, t. XIII, z. 1, Warszawa-Poznań-Wrocław 2011, s. 485; M. Sierpińska, T. J a chn a, op. cit., s. 89. 
cji działania przedsiębiorstwa, lecz także do jego rozwoju i wzrostu wartości rynkowej ${ }^{20}$.

Zdaniem J. Franc-Dąbrowskiej, analiza płynności finansowej nie stanowi całkowitego odzwierciedlenia bezpieczeństwa finansowego, a ważne jej uzupełnienie tworzy analiza sprawności gospodarowania ${ }^{21}$.

Tabela 1.3. Obszary kreowania i zapewniania bezpieczeństwa finansowego (przegląd literatury)*

\begin{tabular}{|c|c|c|c|c|c|c|c|}
\hline $\begin{array}{l}\text { Obszary oceny } \\
\text { bezpieczeństwa finanso- } \\
\text { wego przedsiębiorstwa }\end{array}$ & 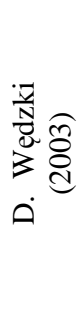 & 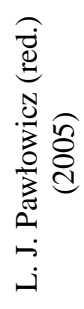 & 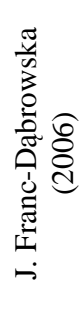 & 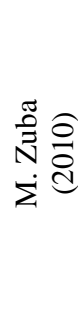 & 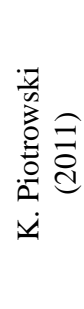 & 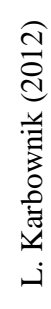 & 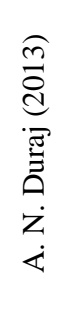 \\
\hline \multicolumn{8}{|l|}{ Płynność finansowa } \\
\hline \multicolumn{8}{|l|}{ Wypłacalność finansowa } \\
\hline \multicolumn{8}{|l|}{ Sprawność gospodarowania } \\
\hline \multicolumn{8}{|l|}{$\begin{array}{l}\text { Sprzedaż produktów (usług), } \\
\text { towarów i materiałów }\end{array}$} \\
\hline \multicolumn{8}{|l|}{ Rentowność } \\
\hline \multicolumn{8}{|l|}{ Rezerwy finansowe } \\
\hline Inwestycje & & & & & & & \\
\hline
\end{tabular}

* Kolorem zaznaczone zostały obszary oceny bezpieczeństwa finansowego wskazywane przez poszczególnych Autorów.

Źródło: opracowanie własne na podstawie: J. Franc-Dąbrowska, op. cit., s. 121; L. Pawłowicz (red.), Ekonomika przedsiębiorstw: zagadnienia wybrane, ODDK Gdańsk, Gdańsk 2005, s. 42; K. Piotrowski, Bezpieczeństwo finansowe w branży TSL, „Transport i Spedycja" 2011, nr 4, s. 52-54; D. W ę d zki, Strategie..., op. cit., s. 35-36; M. Zu b a, Wptyw zatrudnienia na rentowność $i$ bezpieczeństwo finansowe wybranych spótdzielni mleczarskich w Polsce, [w:] H. M. Szoege (red.), Problemy Rolnictwa Światowego, „Zeszyty Naukowe SGGW w Warszawie", Wydawnictwo SGGW, Warszawa 2010, s. 117; L. Karb ow ni k, Pojęcie i obszary kreowania..., op. cit., s. 68-77; L. K a r b o w n i k, Kasowe i memoriatowe mierniki oceny bezpieczeństwa finansowego przedsiębiorstwa, [w:] J. D u raj (red.), Instrumenty i sposoby zarzadzania kapitatem przedsiębiorstwa, „Acta Universitatis Lodziensis”, Folia Oeconomica 267, Wydawnictwo Uniwersytetu Łódzkiego, Łódź 2012, s. 88; A. N. D u raj, Wieloczynnikowa koncepcja..., op. cit., s. 66-68.

${ }^{20}$ A. N. Duraj, Wykorzystanie rezerw finansowych $w$ ocenie wyptacalności przedsiębiorstwa, [w:] J. Duraj (red.), Problemy wspótczesnej analizy ekonomicznej przedsiębiorstwa, Wydawnictwo Uniwersytetu Łódzkiego, Łódź 2007, s. 219 i 221.

${ }^{21} \mathrm{~J}$. Fran c-Dąb row s ka, Bezpieczeństwo finansowe a efektywność zaangażowania kapitatów własnych, Roczniki Nauk Rolniczych, seria G, t. 93, z. 1, Warszawa 2006, s. 125. 
A. N. Duraj wskazuje, iż rezerwy stanowią istotny czynnik wywierający wpływ na przetrwanie i rozwój przedsiębiorstwa przez kształtowanie jego wiarygodności kredytowej, rentowności, płynności i zdolności do pozyskania kapitałów zewnętrznych. Ich tworzenie stanowi wyraz przestrzegania przez daną jednostkę gospodarczą zasady memoriału, zasady ostrożności, czy też zasady kontynuacji działania oraz współmierności przychodów i kosztów ${ }^{22}$. Są one również instrumentem kształtowania struktury kapitału, a ich zakres (wynikający z prawa bilansowego) wywiera nie tylko istotny wpływ na ocenę sytuacji finansowo-majątkowej jednostki gospodarczej, ale także na tworzenie obrazu podmiotu gospodarczego troskliwie wypełniającego swoje powinności wobec interesariuszy ${ }^{23}$.

Na bezpieczeństwo finansowe przedsiębiorstwa oddziałują - obok płynności finansowej i wypłacalności - odpowiednia rentowność, właściwy podział osiągniętego zysku netto, ale także przychody netto ze sprzedaży produktów (usług), towarów i materiałów ${ }^{24}$. To właśnie sprzedaż uznana została przez A. N. Duraj za ośrodek generowania nadwyżki finansowej przedsiębiorstwa oraz warunek osiągania i utrzymania płynności finansowej, jak i wypłacalności ${ }^{25}$.

W polskiej i zagranicznej literaturze przedmiotu prezentowane są różnorodne mierniki pomiaru bezpieczeństwa finansowego przedsiębiorstwa. Stosownie do prezentowanych poglądów, zdecydowana większość z nich dotyczy pomiaru płynności finansowej oraz wypłacalności. Л. А. Запорожцева - obok współczynnika $^{26}$ bieżącej płynności finansowej - nie wskazała współczynnika przyspieszonej i natychmiastowej płynności, jak i cyklu zapasów w dniach, cyklu należności w dniach, cyklu zobowiązań w dniach oraz cyklu kapitału obrotowe$\mathrm{go}^{27}$. Uwydatniła jednakże potrzebę badania współczynników rotacji należności i zobowiązań krótkoterminowych (zob. tab.1.4).

${ }^{22}$ A. N. Duraj, Rezerwy w sprawozdaniach finansowych przedsiębiorstwa, [w:] J. Du raj (red.), Prace z zakresu ekonomiki i zarzadzania przedsiębiorstwem, ,Acta Universitatis Lodziensis”, Folia Oeconomica 171, Wydawnictwo Uniwersytetu Łódzkiego, Łódź 2004, s. 24-27.

${ }^{23}$ A. N. Du raj, Gwarancyjna funkcja rezerw finansowych przedsiębiorstwa, [w:] J. D u raj (red.), Prace z zakresu ekonomiki i zarzadzania przedsiębiorstwem, „Acta Universitatis Lodziensis", Folia Oeconomica 200, Wydawnictwo Uniwersytetu Łódzkiego, Łódź 2006, s. 43.

${ }^{24}$ L. Karbownik, Pojęcie i obszary kreowania..., op. cit., s. 76.

${ }^{25}$ A. N. D u raj, Wieloczynnikowa koncepcja modelu bezpieczeństwa finansowego przedsiębiorstwa, [w:] J. D u raj, A. S a j nóg (red.), Ekonomiczne i pozaekonomiczne czynniki zarządzania wartościa przedsiębiorstwa, Wydawnictwo Uniwersytetu Łódzkiego, Łódź 2013, s. 66.

${ }^{26}$ Wskaźniki finansowe w literaturze są utożsamiane z współczynnikami, a zatem w dalszej części opracowania pojęcia te będą stosowane zamiennie.

Budowa formuły oparta na wzorach podanych, [w:] J. Du raj, Analiza decyzyjna w przedsiębiorstwie, Polskie Towarzystwo Ekonomiczne w Zielonej Górze, Zielona Góra 1992, s. 76.

${ }^{27}$ Należy wskazać, iż wartość poznawcza kapitału obrotowego netto odpowiada funkcjom spełnionym przez wskaźnik bieżącej płynności finansowej, [za:] W. Gabrusewicz, Analiza finansowa w audycie sprawozdań finansowych, [w:] W. Gabru s e wicz (red.), Audyt sprawozdań finansowych, PWE, Warszawa 2010, s. 117. 
Tabela 1.4. Kryteria i mierniki oceny bezpieczeństwa finansowego przedsiębiorstwa w literaturze przedmiotu*

\begin{tabular}{|c|c|c|c|c|c|c|c|c|}
\hline \multirow[b]{2}{*}{$\begin{array}{l}\text { Kryteria oceny } \\
\text { bezpieczeństwa } \\
\text { finansowego } \\
\text { przedsiębiorstwa }\end{array}$} & \multirow{2}{*}{\multicolumn{2}{|c|}{$\begin{array}{l}\text { Mierniki oceny bezpieczeństwa finansowego } \\
\text { przedsiębiorstwa }\end{array}$}} & \multicolumn{6}{|c|}{ Autor (Rok publikacji) } \\
\hline & & & 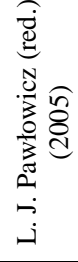 & 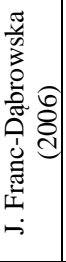 & 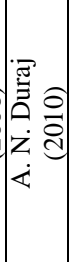 & 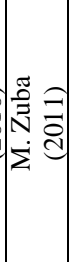 & 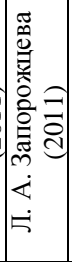 & 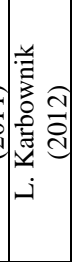 \\
\hline 1 & 2 & 3 & 4 & 5 & 6 & 7 & 8 & 9 \\
\hline \multirow{3}{*}{ Sprzedaż } & $\begin{array}{l}\text { Przychody netto ze } \\
\text { sprzedaży produktów } \\
\text { (usług), towarów } \\
\text { i materiałów }\end{array}$ & $S$ & & & & & & \\
\hline & $\begin{array}{l}\text { Wskaźnik dynamiki } \\
\text { przychodów netto ze } \\
\text { sprzedaży }\end{array}$ & $S_{t} / S_{t-1}$ & & & & & & \\
\hline & $\begin{array}{l}\text { Wpływy gotówkowe } \\
\text { z działalności } \\
\text { operacyjnej }\end{array}$ & $O C R$ & & & & & & \\
\hline \multirow{11}{*}{$\begin{array}{l}\text { Płynność } \\
\text { finansowa }\end{array}$} & $\begin{array}{l}\text { Współczynnik } \\
\text { bieżącej płynności } \\
\text { finansowej }\end{array}$ & $C A / C L$ & & & & & & \\
\hline & $\begin{array}{c}\text { Współczynnik } \\
\text { przyspieszonej } \\
\text { płynności finansowej }\end{array}$ & $(C A-I n-S D E) / C L$ & & & & & & \\
\hline & $\begin{array}{c}\text { Współczynnik } \\
\text { szybkiej (wysokiej) } \\
\text { płynności finansowej }\end{array}$ & $(C A-I n) / C L$ & & & & & & \\
\hline & $\begin{array}{c}\text { Współczynnik } \\
\text { natychmiastowej } \\
\text { płynności finansowej }\end{array}$ & $C / C L$ & & & & & & \\
\hline & $\begin{array}{c}\text { Wystarczalność } \\
\text { gotówkowa środków } \\
\text { na rachunkach }\end{array}$ & $C_{1} /(W * 30 / 360)$ & & & & & & \\
\hline & $\begin{array}{c}\text { Współczynnik } \\
\text { gotówkowej } \\
\text { płynności finansowej }\end{array}$ & $O C F / C L$ & & & & & & \\
\hline & $\begin{array}{l}\text { Cykl zapasów } \\
\text { w dniach }\end{array}$ & In $* 365 / S$ & & & & & & \\
\hline & $\begin{array}{l}\text { Cykl należności } \\
\text { w dniach }\end{array}$ & $S A R * 365 / S$ & & & & & & \\
\hline & $\begin{array}{l}\text { Cykl zobowiązań } \\
\text { bieżących w dniach }\end{array}$ & $C L * 365 / S$ & & & & & & \\
\hline & $\begin{array}{l}\text { Cykl kapitału } \\
\text { obrotowego w dniach }\end{array}$ & $W C * 365 / S$ & & & & & & \\
\hline & $\begin{array}{l}\text { Cykl środków } \\
\text { pieniężnych }\end{array}$ & $C C$ & & & & & & \\
\hline \multirow{2}{*}{$\begin{array}{l}\text { Sprawność } \\
\text { działania }\end{array}$} & $\begin{array}{l}\text { Współczynnik rotacji } \\
\text { należności }\end{array}$ & $S / A R$ & & & & & & \\
\hline & $\begin{array}{c}\text { Współczynnik rotacji } \\
\text { zobowiązań }\end{array}$ & $C S / L$ & & & & & & \\
\hline
\end{tabular}


Tabela 1.4. (cd.)

\begin{tabular}{|c|c|c|c|c|c|c|c|c|}
\hline 1 & 2 & 3 & 4 & 5 & 6 & 7 & 8 & 9 \\
\hline \multirow{3}{*}{$\begin{array}{l}\text { Dynamika } \\
\text { i struktura } \\
\text { aktywów }\end{array}$} & $\begin{array}{c}\text { Dynamika aktywów } \\
\text { ogółem }\end{array}$ & $T A_{t} / T A_{t-1}$ & & & & & & \\
\hline & $\begin{array}{l}\text { Udział aktywów } \\
\text { obrotowych w sumie } \\
\text { bilansowej }\end{array}$ & $C A / T A$ & & & & & & \\
\hline & $\begin{array}{l}\text { Udział środków pie- } \\
\text { niężnych w aktywach } \\
\text { obrotowych }\end{array}$ & $C / C A$ & & & & & & \\
\hline \multirow{14}{*}{$\begin{array}{l}\text { Struktura kapitału } \\
\text { i wypłacalność }\end{array}$} & $\begin{array}{c}\text { Współczynnik auto- } \\
\text { nomii }\end{array}$ & $E / T A$ & & & & & & \\
\hline & $\begin{array}{l}\text { Współczynnik ogólne- } \\
\text { go zadłużenia }\end{array}$ & $T L / T A$ & & & & & & \\
\hline & $\begin{array}{l}\text { Współczynnik zadłuże- } \\
\text { nia długoterminowego }\end{array}$ & $D / T A$ & & & & & & \\
\hline & $\begin{array}{c}\text { Udział pasywów } \\
\text { obrotowych w sumie } \\
\text { bilansowej }\end{array}$ & $(S R r b+O t S R+C L+S A L) / T A$ & & & & & & \\
\hline & $\begin{array}{l}\text { Udział zobowiązań } \\
\text { krótkoterminowych } \\
\text { w sumie bilansowej }\end{array}$ & $C L / T A$ & & & & & & \\
\hline & $\begin{array}{l}\text { Współczynnik zadłuże- } \\
\text { nia kapitału własnego }\end{array}$ & $D / E$ & & & & & & \\
\hline & $\begin{array}{l}\text { Współczynnik pokry- } \\
\text { cia odsetek }\end{array}$ & $E B I T / I$ & & & & & & \\
\hline & $\begin{array}{l}\text { Współczynnik pokry- } \\
\text { cia obsługi długu }\end{array}$ & $E A T /(I C+I)$ & & & & & & \\
\hline & $\begin{array}{l}\text { Współczynnik zdolno- } \\
\text { ści przepływów pie- } \\
\text { niężnych netto } \\
\text { z działalności opera- } \\
\text { cyjnej do obsługi } \\
\text { zobowiazań ogółem }\end{array}$ & $T L / O C F$ & & & & & & \\
\hline & $\begin{array}{l}\text { Współczynnik zdolno- } \\
\text { ści przepływów pie- } \\
\text { niężnych netto z dzia- } \\
\text { łalności operacyjnej do } \\
\text { obsługi zobowiązań } \\
\text { długoterminowych }\end{array}$ & $D / O C F$ & & & & & & \\
\hline & $\begin{array}{l}\text { Współczynnik zdolno- } \\
\text { ści przepływów pie- } \\
\text { niężnych netto z dzia- } \\
\text { łalności operacyjnej do } \\
\text { obsługi źródeł finanso- } \\
\text { wania działalności } \\
\text { przedsiębiorstw }\end{array}$ & $\begin{array}{l}(L R r b+R t a x+O t L R+ \\
+L A L+D+E) / O C F\end{array}$ & & & & & & \\
\hline & $\begin{array}{l}\text { Współczynnik pokrycia } \\
\text { zobowiazzań ogółem } \\
\text { gotówka operacyjna }\end{array}$ & $O C F / T L$ & & & & & & \\
\hline & $\begin{array}{l}\text { Współczynnik pokry- } \\
\text { cia odsetek z gotówki } \\
\text { operacyjnej }\end{array}$ & $O C F / I$ & & & & & & \\
\hline & $\begin{array}{l}\text { Współczynnik pokry- } \\
\text { cia obsługi długu } \\
\text { z gotówki operacyjnej }\end{array}$ & $O C F /(I C+I)$ & & & & & & \\
\hline
\end{tabular}




\begin{tabular}{|c|c|c|c|c|c|c|c|c|}
\hline 1 & 2 & 3 & 4 & 5 & 6 & 7 & 8 & 9 \\
\hline \multirow[b]{2}{*}{$\begin{array}{l}\text { Struktura } \\
\text { kapitałowo- } \\
\text {-majątkowa }\end{array}$} & $\begin{array}{c}\text { Współczynnik sfinan- } \\
\text { sowania aktywów } \\
\text { trwałych kapitałem } \\
\text { stałym }\end{array}$ & $\begin{array}{l}{[T A-(C L+S R r b+O t S R+} \\
+S A L)] / F A\end{array}$ & & & & & & \\
\hline & $\begin{array}{l}\text { Współczynnik sfinan- } \\
\text { sowania aktywów } \\
\text { obrotowych zobowią- } \\
\text { zaniami bieżącymi } \\
\text { i rezerwami krótko- } \\
\text { terminowymi }\end{array}$ & $\begin{array}{l}(C L+S R r b+O t S R+ \\
+S A L) / C A\end{array}$ & & & & & & \\
\hline \multirow{8}{*}{$\begin{array}{l}\text { Rentowność } \\
\text { i wydajność } \\
\text { pieniężna } \\
\text { (gotówkowa) }\end{array}$} & $\begin{array}{c}\text { Współczynnik ren- } \\
\text { towności kapitału } \\
\text { własnego }\end{array}$ & $E A T / \boldsymbol{E}$ & & & & & & \\
\hline & $\begin{array}{c}\text { Współczynnik } \\
\text { rentowności aktywów } \\
\text { ogółem }\end{array}$ & $E A T / \boldsymbol{T A}$ & & & & & & \\
\hline & $\begin{array}{l}\text { Współczynnik rentow- } \\
\text { ności sprzedaży }\end{array}$ & $E A T / S$ & & & & & & \\
\hline & $\begin{array}{l}\text { Współczynnik wydaj-" } \\
\text { ności pieniężnej (go- } \\
\text { tówkowej) sprzedaży }\end{array}$ & $O C F / S$ & & & & & & \\
\hline & $\begin{array}{l}\text { Współczynnik wydaj- } \\
\text { ności pieniężnej (go- } \\
\text { tówkowej) aktywów } \\
\text { ogółem }\end{array}$ & $O C F / \boldsymbol{T A}$ & & & & & & \\
\hline & $\begin{array}{c}\text { Współczynnik } \\
\text { wydajności pieniężnej } \\
\text { (gotówkowej) kapitału } \\
\text { własnego }\end{array}$ & $O C F / \boldsymbol{E}$ & & & & & & \\
\hline & $\begin{array}{c}\text { Pieniężna (gotówko- } \\
\text { wa) stopa zwrotu } \\
\text { z akcji }\end{array}$ & OCF per share & & & & & & \\
\hline & $\begin{array}{c}\text { Wskaźnik dynamiki } \\
\text { zysku netto }\end{array}$ & $E A T_{t} / E A T_{t-1}$ & & & & & & \\
\hline \multirow{2}{*}{$\begin{array}{c}\text { Rynkowa wartość } \\
\text { dodana }\end{array}$} & $\begin{array}{l}\text { Sredni ważony } \\
\text { koszt kapitału }\end{array}$ & $W A C C$ & & & & & & \\
\hline & $\begin{array}{c}\text { Ekonomiczna } \\
\text { wartość dodana }\end{array}$ & $E V A$ & & & & & & \\
\hline \multirow{3}{*}{$\begin{array}{l}\text { Rezerwy } \\
\text { finansowe }\end{array}$} & $\begin{array}{l}\text { Współczynnik } \\
\text { zabezpieczenia } \\
\text { finansowego } \\
\text { rezerwami } \\
\text { kapitałowymi }\end{array}$ & $R_{d} / T A$ & & & & & & \\
\hline & $\begin{array}{l}\text { Współczynnik } \\
\text { zabezpieczenia } \\
\text { finansowego } \\
\text { rezerwami sensu } \\
\text { stricto } * *\end{array}$ & $R_{t} / T A$ & & & & & & \\
\hline & $\begin{array}{c}\text { Współczynnik } \\
\text { zabezpieczenia } \\
\text { finansowego biernymi } \\
\text { rozliczeniami } \\
\text { międzyokresowymi } \\
\text { kosztów }\end{array}$ & $A L / T A$ & & & & & & \\
\hline
\end{tabular}


Tabela 1.4. (cd.)

\begin{tabular}{|c|c|c|c|c|c|c|c|c|}
\hline 1 & 2 & 3 & 4 & 5 & 6 & 7 & 8 & 9 \\
\hline \multirow{7}{*}{ Inwestycje } & $\begin{array}{c}\text { Relacja nakładów } \\
\text { inwestycyjnych do } \\
\text { amortyzacji }\end{array}$ & $\operatorname{Inv} / A$ & & & & & & \\
\hline & $\begin{array}{c}\text { Zmiana wartości } \\
\text { rzeczowych aktywów } \\
\text { trwałych oraz wartości } \\
\text { niematerialnych } \\
\text { i prawnych }\end{array}$ & $\triangle T F A+\triangle i T F A$ & & & & & & \\
\hline & $\begin{array}{c}\text { Zmiana wartości } \\
\text { inwestycji } \\
\text { w nieruchomości oraz } \\
\text { w wartości niemate- } \\
\text { rialne i prawne }\end{array}$ & $\Delta I r e+\triangle I i T F A$ & & & & & & \\
\hline & $\begin{array}{c}\text { Zmiana wartości } \\
\text { papierów wartościo- } \\
\text { wych }\end{array}$ & $\Delta S e$ & & & & & & \\
\hline & $\begin{array}{l}\text { Przepływy pieniężne } \\
\text { netto w związku ze } \\
\text { zbyciem/nabyciem } \\
\text { rzeczowych aktywów } \\
\text { trwałych oraz wartości } \\
\text { niematerialnych } \\
\text { i prawnych }\end{array}$ & $\begin{array}{l}\left(I C R_{T F A}-I C P_{T F A}\right)+ \\
+\left(I C R_{i T F A}-I C P_{i T F A}\right)\end{array}$ & & & & & & \\
\hline & $\begin{array}{l}\text { Przepływy pieniężne } \\
\text { netto z inwestycji } \\
\text { w nieruchomości oraz } \\
\text { w wartości niemate- } \\
\text { rialne i prawne }\end{array}$ & $\begin{array}{l}\left(I C R_{\text {Ire }}-I C P_{\text {Ire }}\right)+ \\
+\left(I C R_{\text {IITFA }}-I C P_{\text {IITFA }}\right)\end{array}$ & & & & & & \\
\hline & $\begin{array}{l}\text { Przepływy pieniężne } \\
\text { netto z inwestycji } \\
\text { w papiery wartościowe }\end{array}$ & $I C R_{S e}-I C P_{S e}$ & & & & & & \\
\hline
\end{tabular}

* Pogrubioną czcionką oznaczone są stany średnie danej zmiennej.

Kolorem zaznaczone zostały mierniki oceny bezpieczeństwa finansowego przedsiębiorstwa wskazywane przez poszczególnych Autorów.

** Klasyczne rezerwy na zobowiązania ( $\mathrm{tj}$. rezerwa $\mathrm{z}$ tytułu odroczonego podatku dochodowego, rezerwa na świadczenia emerytalne i podobne, pozostałe rezerwy).

gdzie:

TA - aktywa (majątek) ogółem (= pasywa ogółem lub suma bilansowa),

$F A \quad-$ aktywa trwałe,

$C A \quad$ - aktywa (majątek) obrotowe (bieżące),

In - zapasy,

Inv $\quad$ - inwestycje (nakłady) brutto,

$A R \quad-$ należności,

SAR - należności krótkoterminowe,

$C \quad$ - środki pieniężne,

$C_{r} \quad-$ rzeczywista dostępność środków na rachunku,

$S D E$ - rozliczenia międzyokresowe krótkoterminowe czynne,

E - kapitał własny,

$D$ - zadłużenie (zobowiązanie) długoterminowe,

$L \quad$ - zobowiązania,

$T L$ - zobowiązania ogółem,

Rtax - rezerwa $\mathrm{z}$ tytułu odroczonego podatku dochodowego, 


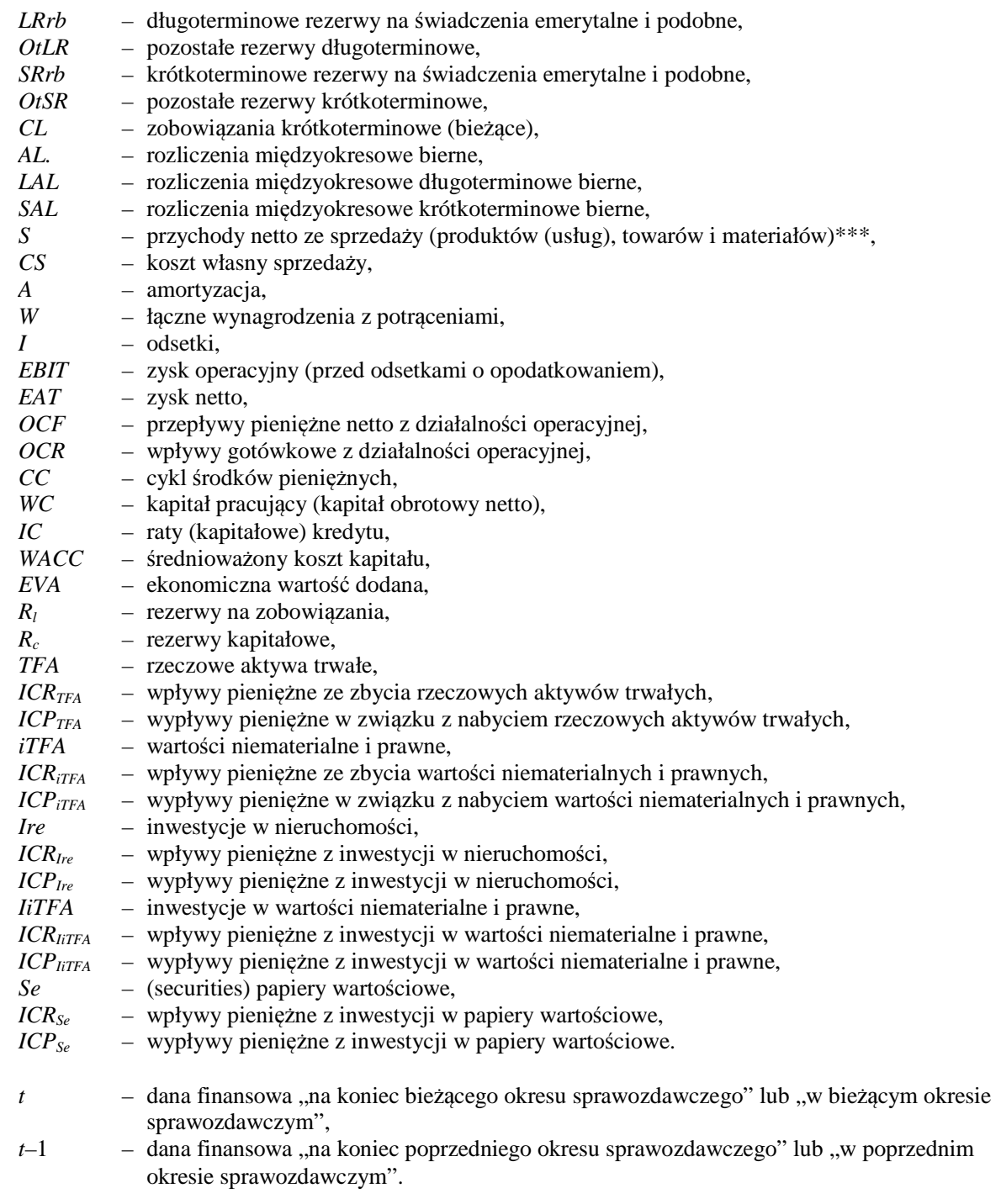

*** Dla przychodów netto ze sprzedaży produktów (usług), towarów i materiałów w dalszej części opracowania autorka będzie również zamiennie stosowała zapis ,,przychodów netto ze sprzedaży”.

Źródło: opracowanie własne na podstawie: A. N. Duraj, Nadzór korporacyjny a bezpieczeństwo finansowe przedsiębiorstw, [w:] P. U rb a n e k (red.), Nadzór korporacyjny $w$ warunkach kryzysu gospodarczego, Wydawnictwo Uniwersytetu Łódzkiego, Łódź 2010, s. 346-349; J. Franc-Dąbrowska, op. cit., s. 122; L. Pawłowicz (red.), op. cit., s. 42-45; M. Zuba, Wpływ poziomu wartości majątku na bezpieczeństwo finansowe wybranych spótdzielni mleczarskich w Polsce, Roczniki Naukowe Stowarzyszenia Ekonomistów Rolnictwa i Agrobiznesu, t. XIII, z. 1, Warszawa-Poznań-Wrocław 2011, s. 485; Л. А. З апо ро жцев а, op. cit., s. 49; L. Karbownik, Kasowe i memoriatowe..., op. cit., s. 88. 
M. Zuba dodatkowo zawarła w tej grupie mierników również cykl konwersji gotówki, a ponadto zwróciła uwagę na pomiar współczynników wypłacalności, w tym m. in. pokrycia obsługi długu, pokrycia zobowiązań odsetkowych (podobnie jak L. J. Pawłowicz), czy też współczynników zadłużenia. L. J. Pawłowicz, Л. А. Запорожцева, jak i L. Karbownik wskazywali na pomiar współczynnika zadłużenia ${ }^{28}$.

J. Franc-Dąbrowska i A. N. Duraj wśród mierników oceny bezpieczeństwa finansowego przedsiębiorstwa wyróżniły również współczynniki struktury aktywów. Л. А. Запорожцева wykazała, iż ocena ta powinna nastąpić przy użyciu takich miar jak WACC, EVA, czy też współczynnika uwzględniającego inwestycje danego podmiotu gospodarczego, dynamiki aktywów ogółem, dynamiki przychodów netto ze sprzedaży, czy też dynamiki wyniku finansowego netto. W tej ocenie równie ważnym miernikiem okazał się dla niej współczynnik rentowności aktywów ogółem oraz współczynnik rentowności kapitału własnego.

Współczynnik rentowności kapitału własnego także w ocenie A. N. Duraj jest istotnym miernikiem oceny bezpieczeństwa finansowego. Dodatkowo Autorka ta wskazała na zasadność wykorzystania w tej ocenie wartości przepływów pieniężnych netto z działalności operacyjnej oraz bilansowych rezerw finansowych.

Należy wskazać, iż wysokie zaangażowanie kapitału własnego w finansowaniu aktywów trwałych jest w wielu wypadkach zupełnie niemożliwe, a zwłaszcza w dynamicznie rozwijających się przedsiębiorstwach, które angażują znaczne środki na finansowanie podejmowanych przez nie inwestycji. Wysokie zaangażowanie kapitałów własnych może ponadto powodować obniżenie rentowności. Przyjmuje się wobec tego możliwość sfinansowania aktywów trwałych nie tylko kapitałem własnym, ale także długoterminowym kapitałem obcym. Łączy się to jednakże z pewnym ryzykiem finansowym, np. uruchamianie nowych inwestycji jest często wspomagane kredytami długoterminowymi. Niedopuszczalne są natomiast zabiegi finansowe polegające na pokrywaniu zobowiązań inwestycyjnych z kredytów krótkoterminowych, gdyż przebieg amortyzacji aktywów trwałych nie jest zgodny z terminem spłaty i wielkością kredytów krótkoterminowych, co może prowadzić do znacznych trudności płatniczych $^{29}$. Przestrzeganie reguł charakteryzujących relacje między strukturą

${ }^{28}$ Nazwy poszczególnych mierników przyjęto za: M. Sierpińska, T. Jachna, op. cit., s. 144-222; M. Jerzemowska, Analiza ekonomiczna $w$ przedsiębiorstwie, PWE, Warszawa 2006, s. 148-149; M. Gmytrasiewicz, A. Karmańska, I. Olchowicz, Rachunkowość finansowa, Wykład 1, Difin, Warszawa 1996, s. 416-417.

${ }^{29}$ Por. T. W aśnie wski, Analiza sytuacji majątkowej i finansowej przedsiębiorstwa na podstawie pionowej i poziomej oceny aktywów i pasywów bilansu, [w:] L. B e dn arski, R. Borow i e cki, J. Duraj, E. Kurtys, T. Waśn i e w ski, B. Wersty, Analiza ekonomiczna przedsiębiorstwa, Wydawnictwo Akademii Ekonomicznej im. Oskara Langego we Wrocławiu, Wrocław 1996, s. 105; T. W a śn i e w s ki, W. S k o c zyl a s, Teoria i praktyka..., op. cit., s. 435-436. 
aktywów i strukturą źródeł ich finansowania sprzyja zatem utrzymaniu równowagi finansowej przedsiębiorstwa, warunkującej jego przetrwanie i rozwój ${ }^{30}$.

Nie jest to jednakże warunek wystarczający dla utrzymania tej równowagi $\mathrm{z}$ uwagi $\mathrm{m}$. in. na potrzebę jednoczesnego stosowania w ocenie bezpieczeństwa finansowego przedsiębiorstwa podejścia kasowego. To podejście pozwala bowiem na uwidocznienie $\mathrm{m}$. in. wpływów gotówkowych z działalności operacyjnej, zdolności do obsługi zobowiązań gotówką, wydajności pieniężnej (gotówkowej) kapitału własnego oraz przepływów pieniężnych netto ze sfery działań operacyjnych, inwestycyjnych i finansowych ${ }^{31}$.

Analiza wyróżnionych w tab. 1.4 kryteriów i mierników oceny bezpieczeństwa finansowego przedsiębiorstwa wskazuje na relatywnie dominujące skupienie uwagi w literaturze przedmiotu na płynności finansowej, rentowności i wydajności pieniężnej (gotówkowej), strukturze kapitału oraz wypłacalności podmiotu gospodarczego wraz z inwestycjami. Można przeto przyjąć, iż dwie pierwsze kategorie finansowe tj. płynność finansowa, a także rentowność i wydajność pieniężna (gotówkowa) odnoszą się do problemów operacyjnych. Struktura kapitału oraz wypłacalność, jak również inwestycje przedsiębiorstwa są zaś zmiennymi zaliczonymi do strategicznych problemów bezpieczeństwa finansowego podmiotu gospodarczego.

\subsection{Przesłanki stosowania memoriałowego i kasowego podejścia w ocenie operacyjnego bezpieczeństwa finansowego przedsiębiorstwa}

Zarządzanie operacyjnym bezpieczeństwem finansowym przedsiębiorstwa jest procesem zdeterminowanym realizacją szeregu rodzaju zasad i warunków skutecznego oraz efektywnego ich stosowania i kształtowania. Jedna z nich odnosi się do cech jakościowych informacji zawartych w sprawozdaniu finansowym przedsiębiorstwa. Informacje sprawozdania finansowego powinny być bowiem użyteczne dla użytkowników przy podejmowaniu decyzji gospodar$\mathrm{czych}^{32}$ i przeto winny gwarantować realizację celów informacyjnych, kontrolnych i oceniających, które wynikają z przepisów prawa bilansowego ${ }^{33}$ oraz z przestrzegania ustawy o rachunkowości.

Obowiązek stosowania określonych ustawą zasad rachunkowości (rzetelnie i jasno przedstawić sytuację majątkową oraz finansową, a także wynik finansowy) ${ }^{34}$

${ }^{30}$ Por. A. N. Du r aj, O wartości analizy ekonomicznej rezerw przedsiębiorstwa, [w:] J. D u raj (red.), Wartość przedsiębiorstwa $-z$ teorii i praktyki zarządzania, Wydawnictwo Naukowe NOVUM Sp. z o.o., Płock-Beijing-Łódź 2004, s. 489.

${ }^{31}$ Zob. L. Karb ow ni k, Kasowe i memoriałowe..., op. cit., s. 87-92.

${ }^{32}$ W. Gabrus e wic z, M. Re mle in, Sprawozdanie finansowe przedsiębiorstwa: jednostkowe i skonsolidowane, PWE, Warszawa 2011, s. 35.

${ }^{33}$ Ibidem, s. 26.

${ }^{34}$ Zob. Art. 4 ust. 1 Ustawy z dnia 29 września 1994 r..., op. cit. 
jest główną przesłanką podjęcia badań nad operacyjnym bezpieczeństwem finansowym przedsiębiorstwa $\mathrm{z}$ jednoczesnym wykorzystaniem zasady memoriałowej oraz zasady kasowej. Przesłanka ta w jednoznaczny sposób nakłada na podmioty gospodarcze obowiązek nie tylko dostarczania informacji o minionych transakcjach oraz przyszłych zobowiązaniach i zasobach środków pieniężnych, które otrzyma w przyszłości, lecz także odnosi się do zasady kasowej, wyrażającej obligatoryjność ujmowania wszystkich wpływów oraz wydatków środków pieniężnych przedsiębiorstwa i ich ekwiwalentów w określonym czasie.

Na potrzebę jednoczesnego stosowania zasady memoriałowej i zasady kasowej wskazuje także konieczność określenia momentu uznawania zdarzenia gospodarczego za dokonane, co przekłada się w konsekwencji na moment zarejestrowania go w księgach rachunkowych oraz ujawnienia jego skutków w sprawozdaniu finansowym ${ }^{35}$.

W literaturze przedmiotu znajdujemy wiele poglądów odnoszących się do okresu wprowadzenia tych zasad do praktyki gospodarczej ${ }^{36}$. J. Płóciennik-Napierałowa wskazuje dla przykładu, że zasada memoriałowego ujmowania operacji gospodarczych jest znana tak długo w rachunkowości, jak długo istnieje rachunkowość. Dowodzi, iż została ona zastosowana już wówczas, gdy pojawiły się pierwsze zapisy na kontach, co przypada przypuszczalnie na przełom wieków XIV i XV ${ }^{37}$. Z kolei ujęcie kasowe procesów finansowych pojawiło się formalnie w Polsce w połowie lat 90 . XX w. W 1995 r. sprawozdanie z przepływu pieniężnych stało się bowiem częścią sprawozdawczości finansowej polskich przedsiębiorstw ${ }^{38}$. Pomimo tego faktu, w literaturze przedmiotu pojawiają się opinie, iż historycznie wcześniejszą - od memoriałowej - normą ewidencji księgowej, była zasada kasowa. Trudno jednakże jednoznacznie stwierdzić - wskazuje K. Stępień - która z nich była stosowana wcześniej - zwłaszcza, iż

${ }^{35}$ Por. J. Turyna, MSR 7 - Rachunek przeptywów pieniężnych, Centrum Doradztwa i Informacji Difin Sp. z o.o., Warszawa 2008, s. 14.

${ }^{36} \mathrm{~W}$ tym m. in. w: E. Wojciechowski, Zarys rozwoju rachunkowości w dawnej Polsce, Wydawnictwo Naukowe PWN, Warszawa 1964, s. 22-23; J. Płóciennik-Napierałowa, Zasada memoriału, „Rachunkowość” 1999, nr 6, s. 340; M. G mytrasie wi cz, A. Karmańska, I. Olchowicz, op. cit., s. 32; M. Gmytrasiewicz, A. Karmańska, Rachunkowość finansowa, Centrum Doradztwa i Informacji Difin Sp. z o.o., Warszawa 2002, s. 21; K. S tę pi eń, Rentowność a wyptacalność przedsiębiorstw, Centrum Doradztwa i Informacji Difin Sp. z o.o., Warszawa 2008, s. 31-34; E. Śni ż̇ek, Sprawozdawczość przeptywów pieniężnych - krytyczna ocena i propozycja modelu, Wydawnictwo Uniwersytetu Łódzkiego, Łódź 2008, s. 147-152; T. Maślanka, Przeptywy pieniężne $w$ zarzadzaniu finansami przedsiębiorstw, Wydawnictwo C. H. Beck, Warszawa 2008, s. 7.

${ }^{37}$ J. Płóciennik-N a pierałowa, op. cit., s. 340.

${ }^{38}$ T. Maślanka,op. cit., s. 7.

Dla przykładu w Stanach Zjednoczonych przed 1971 r. jedynie bilans oraz rachunek zysków i strat były tymi sprawozdaniami finansowymi, które wymagane były zgodnie z GAAP (Generally Accepted Accounting Principles, tj. Ogólnie Akceptowane Zasady Rachunkowości), [za:] R. G. Schroeder, M. W. Clark, J. M. Cathey, Financial Accounting theory and analysis: Text and cases, $9^{\text {th }}$ ed., John Wiley \& Son, New Jersey 2009, s. 237. 
pewne poglądy odnoszą się do czasów starożytnych, z których nie zachowały się księgi ani inne dokumenty rachunkowe, a w literaturze brak jest precyzyjnych potwierdzeń na temat powstania tychże zasad rachunkowości ${ }^{39}$.

\subsubsection{Przesłanki stosowania memoriałowego podejścia w ocenie operacyjnego bezpieczeństwa finansowego przedsiębiorstwa}

Zasada memoriałowa została wyrażona w art. 6 ust. 1 ustawy o rachunkowości. Wskazuje ona, że „w księgach rachunkowych jednostki należy ująć wszystkie osiągnięte, przypadające na jej rzecz przychody i obciążające ją koszty związane $\mathrm{z}$ tymi przychodami dotyczące roku obrotowego, niezależnie od terminu ich zapłaty" ${ }^{40}$.

Zawarte w tab. 1.5 wybrane określenia zasady memoriałowej wskazują, że w literaturze przedmiotu zasada ta nie jest rozumiana jednoznacznie. Różnice poglądów dotyczą także charakterystyki relacji tej zasady z innymi zasadami rachunkowości.

T. Waśniewski i W. Skoczylas wskazali, iż efekty operacji wynikowych (tj. przychody i koszty) uznawane są w momencie ich wystąpienia (tj. w okresie ich osiągnięcia), a nie dopiero po otrzymaniu związanej z tym gotówki lub ich ekwiwalentów. Jednocześnie podkreślili, iż koszty rejestrowane memoriałowo uważa się za poniesione w momencie ich wystąpienia przy oczywistym uwzględnieniu ich współmierności w stosunku do danego okresu. Autorzy ci nawiązali zatem do art. 6 ust. 2 ustawy o rachunkowości, w którym podkreślony został zasadniczy związek zasady memoriałowej z zasadą współmierności (zob. tab. 1.5).

Zasada memoriałowa odnosi się do ujmowania przychodów i kosztów w momencie, gdy przedsiębiorstwo dokonuje sprzedaży produktów (usług) i ujmowania kosztów w tym samym okresie, co powiązane z nimi przychody niezależnie od dokonania płatności gotówkowej. Zdaniem J. Turyny dominuje ona w praktyce rachunkowości. Zdaniem zaś M. Gmytrasiewicz, A. Karmańskiej oraz I. Olchowicz, jej zaletą jest szerszy ogląd rzeczywistości gospodar$\mathrm{czej}^{41}$. K. Czubakowska, W. Gabrusewicz oraz E. Nowak uwydatniają z kolei jej kluczowe znaczenie dla ustalenia realnej wartości wyniku finansowego przedsiębiorstwa (zob. tab. 1.6).

Co więcej, zasada memoriałowa pozwala łączyć minione zdarzenia z przyszłymi wynikami przedsiębiorstwa.

${ }^{39}$ K. S tęp i eń, op. cit., s. 31-34.

${ }^{40}$ Ustawa z dnia 29 września 1994 r..., op. cit.

Zasada ta została określona zarówno w standardach międzynarodowych, jak i w prawie polskim, bowiem ,konwencje krajowe i reguły rachunkowości są wzorowane na Dyrektywach Unii Europejskiej i Międzynarodowych Standardach Rachunkowości, a istniejące rozbieżności dotyczą głównie hierarchii owych zasad”, [za:] K. S tępi eń, op. cit., s. 26.

${ }^{41}$ Por. K. S tępi én, op. cit., s. 30-31 i 34. 
Tabela 1.5. Prezentacja określeń zasady memoriałowej (przegląd literatury)

\begin{tabular}{|c|c|}
\hline $\begin{array}{l}\text { Autor/Autorzy } \\
\text { (Rok publikacji) }\end{array}$ & Definicje i opisy zasady memoriałowej \\
\hline 1 & 2 \\
\hline $\begin{array}{l}\text { B. E. Needles Jr. } \\
\text { (1992) }\end{array}$ & $\begin{array}{l}\text { Zgodnie z zasadą memoriałową przychody są ujmowane nawet wtedy, } \\
\text { gdy nie nastąpił wpływ gotówki, a w przypadku kosztów - wypływ tejże } \\
\text { gotówki. }\end{array}$ \\
\hline $\begin{array}{l}\text { T. Waśniewski, } \\
\text { W. Skoczylas } \\
\quad(1995)\end{array}$ & $\begin{array}{l}\text { Zasada memoriałowa polega na tym, że efekty operacji wynikowych } \\
\text { uznawane są w momencie ich wystąpienia, a nie dopiero po otrzymaniu } \\
\text { związanej z tym gotówki lub jej ekwiwalentów. Zatem przychody są } \\
\text { ujmowane i wykazywane w sprawozdawczości finansowej w okresie, } \\
\text { w którym wystąpiły bez względu na termin zapłaty. Podobnie koszty } \\
\text { rejestrowane memoriałowo uważa się na poniesione w momencie ich } \\
\text { wystąpienia - przy oczywistym uwzględnieniu ich współmierności } \\
\text { w stosunku do danego okresu - a nie dopiero po dokonaniu odpowiada- } \\
\text { jącemu im wydatku pieniężnego. }\end{array}$ \\
\hline $\begin{array}{l}\text { E. Eljasiak, } \\
\text { W. Parteka } \\
\quad(1995)\end{array}$ & $\begin{array}{l}\text { Zasada memoriałowa mówi, że w księgach rachunkowych i wyniku } \\
\text { finansowym należy ują́ wszystkie osiągnięte, przypadające na rzecz } \\
\text { jednostki przychody i obciążające je koszty związane z tymi przycho- } \\
\text { dami dotyczące danego okresu obrotowego, niezależnie od terminu } \\
\text { zapłaty. }\end{array}$ \\
\hline $\begin{array}{l}\text { R. C. Higgins } \\
\text { (1998) }\end{array}$ & $\begin{array}{l}\text { Zgodnie z zasadą memoriałową przychody ujmuje się w momencie, gdy } \\
\text { niezbędny wysiłek podjęty w celu generowania sprzedaży został zasad- } \\
\text { niczo zakończony i istnieje wystarczająca pewność, że płatności będą } \\
\text { dokonane. }\end{array}$ \\
\hline $\begin{array}{l}\text { L. A. Bernstein, } \\
\text { J. J. Wild } \\
\quad(1998)\end{array}$ & $\begin{array}{l}\text { Zgodnie z zasadą memoriałową przychody ujmuje się w momencie, gdy } \\
\text { przedsiębiorstwo dokonuje sprzedaży dóbr i/lub świadczenia usług, } \\
\text { niezależnie od otrzymania z tego tytułu środków pieniężnych. Koszty } \\
\text { z kolei są ujmowane w tym samym okresie co powiązane z nimi przy- } \\
\text { chody, niezależnie od dokonania płatności gotówkowej. }\end{array}$ \\
\hline $\begin{array}{l}\text { I. Olchowicz, } \\
\text { A. Tłaczała } \\
\quad(2002)\end{array}$ & $\begin{array}{l}\text { Zgodnie z zasadą memoriału skutki transakcji i innych zdarzeń ujmuje } \\
\text { się z chwilą ich wystąpienia, a nie w momencie wpływu lub wypływu } \\
\text { środków pieniężnych. Skutki te wykazuje się w księgach rachunkowych } \\
\text { i w sprawozdaniu finansowym w okresie, którego dotyczą. }\end{array}$ \\
\hline $\begin{array}{c}\text { W. Wąsowski } \\
\text { (2002) }\end{array}$ & $\begin{array}{l}\text { Zgodnie z zasadą memoriałową - przychód ze sprzedaży wykazywany } \\
\text { jest w momencie wysłania lub postawienia do dyspozycji wyrobów } \\
\text { gotowych, wykonania (odbioru) usługi i innych uzasadnionych okolicz- } \\
\text { nościami przypadkach, a nie w momencie wpływu środków pieniężnych } \\
\text { z tytułu należności za sprzedaż, ani też zawarcia umowy o dostawy lub } \\
\text { usługi. Z kolei koszty wykazywane są w momencie prawnego zaciągnię- } \\
\text { cia zobowiązania z tytułu przyjętego świadczenia, a nie w momencie } \\
\text { zapłaty. }\end{array}$ \\
\hline $\begin{array}{l}\text { A. N. Duraj } \\
\text { (2003) }\end{array}$ & $\begin{array}{l}\text { Zasada memoriału polega na tym, że rezultaty określonych transakcji } \\
\text { i innych zdarzeń gospodarczych są rejestrowane w ewidencji księgowej } \\
\text { w momencie ich wystąienia, a nie w momencie wypłacenia lub otrzy- } \\
\text { mania gotówki. }\end{array}$ \\
\hline
\end{tabular}




\begin{tabular}{|c|c|}
\hline 1 & 2 \\
\hline $\begin{array}{l}\text { J. Turyna } \\
\text { (2008) }\end{array}$ & $\begin{array}{l}\text { Przychody i koszty uznaje się w momencie ich wystąpienia niezależnie } \\
\text { od tego, czy miało miejsce równoczesne otrzymanie lub wypłacenie } \\
\text { gotówki. (...) Skutki operacji gospodarczych są ujmowane i wykazy- } \\
\text { wane w księgach rachunkowych z chwilą ich wstąpienia, nie zaś } \\
\text { w momencie wpływu lub wypływu środków pieniężnych oraz wyka- } \\
\text { zywane w księgach rachunkowych i sprawozdaniu finansowym okre- } \\
\text { su, którego dotyczą. }\end{array}$ \\
\hline $\begin{array}{l}\text { E. Nowak } \\
\text { (2008) }\end{array}$ & $\begin{array}{l}\text { Zasada memoriałowa zobowiązuje jednostki do ujmowania transakcji } \\
\text { i zdarzeń z chwilą ich wystąpienia, niezależnie od momentu otrzymania } \\
\text { lub zapłaty środków pieniężnych lub ich ekwiwalentów. Koszty i przy- } \\
\text { chody powinny być wykazywane w księgach rachunkowych i sprawoz- } \\
\text { daniu finansowym za okres, którego dotyczą. Podobnie jest w przypadku } \\
\text { zobowiązań i należności, niezależnie od dokonania rozliczeń pienięż- } \\
\text { nych. }\end{array}$ \\
\hline $\begin{array}{l}\text { K. Czubakowska, } \\
\text { W. Gabrusewicz, } \\
\text { E. Nowak } \\
(2009)\end{array}$ & $\begin{array}{l}\text { Zgodnie z zasadą memoriałową - przychody oraz koszty powinny być } \\
\text { ujmowane oraz wykazywane w księgach rachunkowych oraz w spra- } \\
\text { wozdaniu finansowym w tych okresach, w których wystąpiły. Przychody } \\
\text { powinny być ujmowane w momencie ich osiągnięcia, niezależnie od } \\
\text { terminu wpływu środków pieniężnych. Koszty natomiast powinny być } \\
\text { ujmowane w momencie ich poniesienia, niezależnie od terminu wydat- } \\
\text { kowania środków pieniężnych. }\end{array}$ \\
\hline $\begin{array}{l}\text { E. Walińska (red.) } \\
\qquad(2009)\end{array}$ & $\begin{array}{l}\text { W myśl zasady memoriałowej (accrual) efekty transakcji i zdarzeń } \\
\text { gospodarczych są ujmowane w rachunkowości w momencie ich zajścia, } \\
\text { a nie w momencie wystąpienie przepływów pieniężnych z tego tytułu. }\end{array}$ \\
\hline
\end{tabular}

Źródło: opracowanie własne na podstawie: B. E. Needles Jr., Financial accounting, Houghton Mifflin Company, Boston 1992, s. 695; T. W aśniew ski, W. S k o c zylas, Cash flow w przedsiębiorstwie. Ustalanie i analiza, Fundacja Rozwoju Rachunkowości w Polsce, Warszawa 1995, s. 26; E. Elj a si ak, W. Partek a, Przeptywy gotówkowe: ustalanie, planowanie, analiza, zarzadzanie, Ośrodek Doradztwa i Doskonalenia Kadr, Gdańsk 1995, s. 11; R. C. Higgins, Analysis for Financial Management, 5th ed., McGraw-Hill Companies, Boston 1998, s. 10; L. A. B e rnstein, J. J. Wild, Financial statement analysis: Theory, application, and interpretation, 6th ed., The McGraw-Hill Companies, Boston 1998, s. 12-13; I. Olch o wi c z, A. Tła c z ała, Sprawozdawczość finansowa, Difin, Warszawa 2002, s. 19; W. Wąs ow ski, Fatszowanie sprawozdań finansowych, „Rachunkowość” 2002, nr 11, s. 3-4; A. N. D u raj, Controlling rezerw w przedsiębiorstwie, [w:] J. D u r aj (red.), Controlling w zarzadzaniu przedsiębiorstwem, Wydawnictwo Naukowe NOVUM Sp. z o.o., Płock-Łódź 2003, s. 82; J. Tu ry n a, MSR 7 - Rachunek przeptywów pieniężnych, Centrum Doradztwa i Informacji Difin Sp. z o.o., Warszawa 2008, s. 14 i 17, [za:] Międzynarodowe Standardy Sprawozdawczości Finansowej (MSSF) 2007, t. I, Stowarzyszenie Księgowych w Polsce, International Accounting Standards Committee Foundation, Warszawa-Londyn 2007, s. 52; E. Now ak, Analiza sprawozdań finansowych, PWE, Warszawa 2008, s. 21; K. Czubakowska, W. Gabrusewicz, E. Nowak, Przychody, koszty, wynik finansowy przedsiębiorstwa, PWE, Warszawa 2009, s. 185-186; E. W a li ń s k a (red.), Rachunkowość, Wolters Kluwer Polska Sp. z o.o., Warszawa 2009, s. 127-129. 
Tabela 1.6. Przesłanki zastosowania zasady memoriałowej (przegląd literatury)

\begin{tabular}{|c|c|}
\hline $\begin{array}{l}\text { Autor/Autorzy } \\
\text { (Rok publikacji) }\end{array}$ & Wnioski \\
\hline $\begin{array}{l}\text { M. Gmytrasiewicz, } \\
\text { A. Karmańska, } \\
\text { I. Olchowicz } \\
\text { (1996) }\end{array}$ & $\begin{array}{l}\text { Zasada memoriału jest nadrzędną zasadą rachunkowości. Jej przestrze- } \\
\text { ganie warunkuje kompletnośc ujęcia w księgach rachunkowych wszyst- } \\
\text { kich zmian o stanie majątku jednostki gospodarczej w danym okresie. } \\
\text { Jednocześnie - zdaniem Autorek - w krótkich okresach funkcjonowania } \\
\text { jednostki trudno zasadę kasową uznać za narzędzie prezentowania } \\
\text { informacji księgowych, bowiem walory poznawcze w takiej perspekty- } \\
\text { wie czasu stoją bezsprzecznie po stronie zasady memoriałowej. }\end{array}$ \\
\hline $\begin{array}{l}\text { J. Turyna } \\
\text { (2008) }\end{array}$ & $\begin{array}{l}\text { W praktyce rachunkowości na całym świecie dominuje zasada memo- } \\
\text { riałowa. Sprawozdanie sporządzone zgodnie z zasadą memoriału do- } \\
\text { starcza użytkownikom informacji o przeszłych transakcjach pociągają- } \\
\text { cych za sobą wypływ lub wpływ środków pieniężnych w danym przed- } \\
\text { siębiorstwie, lecz również o jego obowiązkach do zapłaty pieniężnej } \\
\text { w przyszłości, czy też o zasobach odpowiadających środkom pienięż- } \\
\text { nym, które to przedsiębiorstwo otrzyma w przyszłości. }\end{array}$ \\
\hline $\begin{array}{l}\text { K. Czubakowska, } \\
\text { W. Gabrusewicz, } \\
\text { E. Nowak } \\
(2009)\end{array}$ & $\begin{array}{l}\text { Zasada memoriałowa ma największe znaczenie dla ustalenia realnej } \\
\text { wielkości wyniku finansowego, przy czym odnosi się ona wprost za- } \\
\text { równo do przychodów, jak i do kosztów. }\end{array}$ \\
\hline $\begin{array}{c}\text { E. Walińska (red.) } \\
\text { (2009) }\end{array}$ & $\begin{array}{l}\text { Zastosowanie zasady memoriałowej, która jest jedną z najbardziej } \\
\text { charakterystycznych zasad rachunkowości, pozwala na pełną realizację } \\
\text { celu sprawozdawczości finansowej, tj. dostarczanie informacji finanso- } \\
\text { wej, wynikach działalności oraz zmianach sytuacji finansowej jednostki, } \\
\text { które będą użyteczne w procesie podejmowania decyzji gospodarczych. } \\
\text { Decyzje te bowiem wymagają zazwyczaj oceny zdolności jednostki do } \\
\text { wypracowania środków pieniężnych oraz ich ekwiwalentów, jak i oceny } \\
\text { terminów oraz stopnia pewności ich wypracowania. Godnym jednakże } \\
\text { uwagi jest fakt, iż rachunkowość oparta na zasadzie memoriałowej } \\
\text { pozwala na dostarczenie użytkownikom informacji nie tylko o prze- } \\
\text { szłych zdarzeniach gospodarczych zrealizowanych przez jednostkę, } \\
\text { które wywołały przepływ środków pieniężnch (wpływ lub wydatek), } \\
\text { ale również o obowiązkach zapłaty przez jednostkę określonej kwoty } \\
\text { w przyszłości (w tym m. in. z tytułu powstałych zobowiązań wykaza- } \\
\text { nych w bilansie) oraz o zasobach odzwierciedlających prawo jednostki } \\
\text { do otrzymania określonych środków pieniężnych w przyszłości (w tym } \\
\text { m. in. z tytułu należności handlowych wykazanych w bilansie). Zasada } \\
\text { memoriałowa jest odpowiedzialna za całokształt pomiaru dokonywane- } \\
\text { go w rachunkowości, a w praktyce gospodarczej jest często utożsamiana } \\
\text { z pomiarem wyniku finansowego. Takie też podejście obserwujemy } \\
\text { również w polskim prawie bilansowym. }\end{array}$ \\
\hline
\end{tabular}

Źródło: opracowanie własne na podstawie: M. Gmytrasiewicz, A. Karmańska, I. Olchowicz, Rachunkowość finansowa, Wykład 1, Difin, Warszawa 1996, s. 32-33; J. Turyna, op. cit., s. 14 i 17; K. Czubakowska, W. Gabrusewicz, E. Nowak, op. cit., s. 185; E. Waliń ska (red.), op. cit., s. 127-129. 


\subsubsection{Przesłanki stosowania kasowego podejścia w ocenie operacyjnego bezpieczeństwa finansowego przedsiębiorstwa}

W literaturze przedmiotu stosunkowo mniej miejsca poświęca się zasadzie kasowej, która dotyczy uznawania przychodów i kosztów w momencie wystąpienia faktycznego wpływu lub wydatku środków pieniężnych (zob. tab. 1.7). Pośrednio na zasadność jej zastosowania w rachunku przepływów pieniężnych wskazuje art. 48b ust. 3 ustawy o rachunkowości. W artykule tym znajduje się bowiem stwierdzenie, iż $w$ tej części sprawozdania finansowego „należy uwzględnić wszystkie wpływy i wydatki z działalności operacyjnej, inwestycyjnej i finansowej jednostki, z wyjątkiem wpływów i wydatków będących rezultatem zakupu lub sprzedaży środków pieniężnych" ${ }^{42}$.

Zawarte z tab. 1.7 zestawienie definicji i opisów zasady kasowej wskazuje na zróżnicowany zestaw właściwości tej reguły, które w różnym stopniu akcentuje przydatność zasady kasowej w zarządzaniu przedsiębiorstwami i tym samym pośrednio $\mathrm{w}$ kształtowaniu bezpieczeństwa finansowego tych jednostek gospodarczych.

Analizując przesłanki zastosowania zasady kasowej wskazać można, iż dominuje ona $\mathrm{w}$ prawie podatkowym ${ }^{43}$. W literaturze prezentowane są również inne poglądy. Zawierają się one również w stwierdzeniu, że zysk jest kategorią księgową, a ponadto wielkością uzależnioną od reguł oraz klasyfikacji księgowych i możliwości manewrowania jego wielkością 44 . Dla przykładu wybór metody amortyzacji, czy wyceny zapasów może znacząco wpłynąć na wielkość wyniku finansowego prezentowanego w rachunku zysków i strat.

Szeroki wachlarz metod (zasad) stwarza duże możliwości spowodowania określonego skutku w celu osiągnięcia korzyści przez zarządzających danym podmiotem gospodarczym. Ta „kreatywna rachunkowość” wynika z silnej konkurencji rynkowej ${ }^{45}$ a w wielu przypadkach dotyczy również spólek notowanych na giełdzie, które pragną zachować dobry image lub przedsiebiorstw, chcących dokonać nowych emisji akcji ${ }^{46}$.

Sytuacja ta powoduje, iż ,na porządku dziennym staje w związku z tym pytanie o wiarygodność informacji, jakie generuje system rachunkowości. Wiarygodność ta dotyczy z jednej strony zdolności do adekwatnego w stosunku do rzeczywistości odzwierciedlenia zdarzeń gospodarczych, a z drugiej - możliwości wnioskowania na ich podstawie o sytuacji” ${ }^{, 47}$ finansowej przedsiębiorstwa.

${ }^{42}$ [Za:] Ustawa z dnia 29 września 1994 r..., op. cit.

${ }^{43}$ K. Czubakowska, W. Gabrusewicz, E. Nowak, op. cit., s. 30.

${ }^{44}$ J. Du r a j, Podstawy ekonomiki przedsiębiorstwa, PWE, Warszawa 2004, s. 189.

${ }^{45} \mathrm{M}$. A d a mi k-C it a k, Creative accounting in the era of economic crisis, [w:] W. W e r e d a, S. Starnawska, Cyclicality, financial safety, and business creativity as the challenges of the modern word, University of Podlasie, Siedlce 2009, s. 163.

${ }^{46}$ A. N. Duraj, Kształtowanie rezerw $w$ przedsiębiorstwie, Wydawnictwo Uniwersytetu Łódzkiego, Łódź 2004, s. 73.

${ }^{47}$ [Za:] A. N. Du r a j, Controlling rezerw w przedsiębiorstwie, [w:] J. D u r aj (red.), Controlling w zarzadzaniu przedsiębiorstwem, Wydawnictwo Naukowe NOVUM Sp. z o.o., Płock-Łódź 2003, s. 72. 
Tabela 1.7. Prezentacja określeń zasady kasowej (przegląd literatury)

\begin{tabular}{|c|c|}
\hline $\begin{array}{l}\text { Autor/Autorzy } \\
\text { (Rok publikacji) }\end{array}$ & Opis \\
\hline $\begin{array}{l}\text { B. E. Needles Jr. } \\
\text { (1992) }\end{array}$ & $\begin{array}{l}\text { Przychody i koszty mogą być ujmowane z chwilą otrzymania lub wypła- } \\
\text { cenia gotówki. Taki sposób ujmowania przychodów i kosztów występu- } \\
\text { je w przypadku stosowania zasady kasowej. Niektóre jednostki gospo- } \\
\text { darcze mogą stosować tę zasadę w celu rozliczenia podatku. Według tej } \\
\text { zasady przychody są ujmowane w okresie wpływu gotówki, zaś koszty } \\
\text { w okresie jej wypływu. Dochód podatkowy jest zatem obliczany jako } \\
\text { różnica między wpływami i wypływami tejże gotówki. Największe } \\
\text { korzyści z stosowania tej zasady można dostrzec w przypadku małych } \\
\text { przedsiębiorstw. }\end{array}$ \\
\hline $\begin{array}{l}\text { T. Waśniewski, } \\
\text { W. Skoczylas } \\
\quad(1995)\end{array}$ & $\begin{array}{l}\text { Przy zasadzie kasowej - nie stosowanej w praktyce - przychody uznaje } \\
\text { się w okresie, w którym otrzymano gotówkę i analogicznie, koszty są } \\
\text { zaliczane do okresu w jakim nastąpiło wypłacenie gotówki. }\end{array}$ \\
\hline $\begin{array}{l}\text { E. Eljasiak, } \\
\text { W. Parteka } \\
\quad(1995)\end{array}$ & $\begin{array}{l}\text { Ujęcie kasowe polega na uznawaniu przychodów i kosztów wyłącznie } \\
\text { w momencie potwierdzenia faktycznego wystąpienia wpływu czy wy- } \\
\text { datku, lecz niestety nie jest stosowane w praktyce, co znacznie utrudnia } \\
\text { zadanie. Ustalenie przepływów polega zatem zazwyczaj na dokonaniu } \\
\text { niezbędnych korekt danych ze sprawozdań finansowych. }\end{array}$ \\
\hline $\begin{array}{l}\text { A. Ćwiąkała-Małys } \\
\qquad(2000)\end{array}$ & $\begin{array}{l}\text { Według zasady kasowej rachunkowości uznaje się, że przychody jed- } \\
\text { nostki wystapiły w momencie wpływu gotówki. Z kolei do kosztów } \\
\text { zalicza się wydatki jednostki w momencie, w którym gotówka została } \\
\text { wypłacona. Jest to zasada sprzeczna z obowiązującą w rachunkowości } \\
\text { fundamentalną zasadą memoriałową, według której przychody i koszty } \\
\text { są rejestrowane w momencie ich osiągnięcia lub wystąpienia, a nie } \\
\text { w momencie wpływu lub wypływu gotówki. }\end{array}$ \\
\hline $\begin{array}{l}\text { A. N. Duraj } \\
\text { (2003) }\end{array}$ & $\begin{array}{l}\text { Ujęcie „,kasowe” przedstawia rzeczywisty przepływ środków pienięż- } \\
\text { nych w wyniku dokonanych transakcji. Ujęcie to wymaga precyzyjnego } \\
\text { ustalenia wartości, jak również momentu i kierunku przepływów środ- } \\
\text { ków pieniężnych, jakie są związane z transakcją. }\end{array}$ \\
\hline $\begin{array}{l}\text { J. Turyna } \\
\text { (2008) }\end{array}$ & $\begin{array}{l}\text { Zasada kasowa oznacza uznawanie przychodów i kosztów z chwilą } \\
\text { otrzymania lub wypłacenia gotówki. }\end{array}$ \\
\hline $\begin{array}{l}\text { K. Stępień } \\
\text { (2008) }\end{array}$ & $\begin{array}{l}\text { Zgodnie z zasadą kasową operacje gospodarcze ujmuje się w momencie } \\
\text { przepływu środków pienężzych (bądź to wpływów, bądź wypływów). }\end{array}$ \\
\hline $\begin{array}{l}\text { E. Śnieżek, } \\
\text { M. Wiatr } \\
(2011)\end{array}$ & $\begin{array}{l}\text { Zgodnie z zasadą kasową ujmuje się realne strumienie wpływów środ- } \\
\text { ków oraz ich wydatkowanie. }\end{array}$ \\
\hline
\end{tabular}

Źródło: opracowanie własne na podstawie: B. E. Needles Jr., op. cit., s. 117-118; T. Waśniewski, W. Skoczylas, Cash flow..., op. cit., s. 26; E. Eljasiak, W. Parteka, op. cit., s. 15; A. Ć wi ąk ała-M ały s, Aspekty prawnofinansowe sprawozdawczości finansowej, Wydawnictwo Uniwersytetu Wrocławskiego, Wrocław 2000, s. 101, [za:] B. Izydorczyk, T. Ży z now ski, Sprawozdawczość finansowa jednostek gospodarczych za 1996 r., „Vademecum Rachunkowości”, Difin, Warszawa 1996, s. 20; A. N. D u r a j, Controlling rezerw..., op. cit., s. 92; J. Turyna, op. cit., s. 14; K. Stępień, Rentowność a wyptacalność przedsiębiorstw, Centrum Doradztwa i Informacji Difin Sp. z o.o., Warszawa 2008, s. 30; E. Ś n i ė̇ek, M. W i atr, Praktyczne aspekty sprawozdawczości przeptywów pieniężnych, Wolters Kluwer Polska Sp. z o.o., Warszawa 2011, s. 41. 


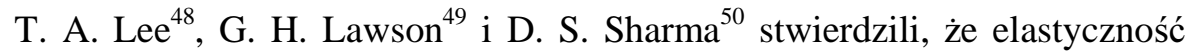
związana $\mathrm{z}$ systemem rachunkowości memoriałowej tworzy zarządzającym możliwość ,window dressing (dekorowania witryny sklepowej, strojenia okna wystawowego, mydlenia oczu)" na kontach. Zachęty do angażowania się w tego rodzaju zachowania są tym większe w przypadku ${ }^{51}$ :

- gdy, chodzi o premie (P. Healy ${ }^{52}$ ),

- gdy warunki umów, dotyczące możliwości uzyskania zewnętrznych źródeł finansowania, są bliskie naruszeniu (M. L. DeFond i J. Jiambalvo ${ }^{53}$, B. G. Dharan i B. Lev ${ }^{54}$, jak i A. P. Sweeney ${ }^{55}$ ),

- pojawienia się problemów finansowych w przedsiębiorstwie (K. B. Schwarz ${ }^{56}$, H. DeAngelo (i in. $)^{57}$, D. S. Sharma i P. A Stevenson ${ }^{58}$ ).

Tego rodzaju zachowania są jednakże działaniami ,na krótką metę”, bowiem konieczność zachowania kontynuacji działalności podmiotu gospodarczego uniemożliwia długofalowość występowania tego procederu ${ }^{59}$.

Tym samym można podkreślić, iż analiza przepływów środków pieniężnych $^{60}$ wypełnia zatem lukę w tworzeniu przez rachunkowość ,wiernego obra-

${ }^{48}$ T. A. Le e , Cash Flow Accounting and Corporate Financial Reporting, [w:] M. B r o m w i c h, A. Hopwood (red.), Essays in British Accounting Research, Ch. 3, Pitman Publishing Limited, London 1981; T. A. Le e, Cash Flow Accounting, Van Nostrand Reinhold, United Kingdom 1984.

${ }^{49}$ G. H. Law s o n, The Cash Flow Performance of UK Companies, [w:] M. B ro mw ich, A. Hop wo od (red.), Essays in British Accounting Research, Ch. 4, Pitman Publishing Limited, London 1981.

${ }^{50}$ D. S. Sharma, The Role of Cash Flow Information in Predicting Corporate Failure: The State of the Literature, „Managerial Finance” 2001, Vol. 27, No. 4, s. 3-28.

${ }^{51}$ Por. D. S. Sh arma, E. R. I s elin, The Relative Relevance of Cash Flow and Accrual Information for Solvency Assessments: A Multi-Method Approach, „Journal of Business Finance \& Accounting" 2003, Vol. 30, Issue 7/8, s. 1118.

${ }^{52} \mathrm{P} . \mathrm{He}$ aly, The Effect of Bonus Schemes on Accounting Decision, „Journal of Accounting \& Economics" 1985, Vol. 7, s. 85-107.

${ }^{53}$ M. L. De Fond, J. Ji a mbalvo, Debt Covenant Violation and Manipulation of Accruals, „Journal of Accounting and Economics” 1994, Vol. 17, Issue 1/2, s. 145-176.

${ }^{54}$ B. G. Dharan, B. Lev, The Valuation Consequence of Accounting Changes, „Journal of Accounting, Auditing \& Finance" 1993, Vol. 8, Issue 4, s. 475-494.

55 A. P. S w e e n e y, Debt Covenant Violations and Managers' accounting responses, ,Journal of Accounting \& Economics" 1994, Vol. 17, Issue 3, s. 281-308.

${ }^{56}$ K. B. Schwartz, Accounting Changes by Corporations Facing Possible Insolvency, „Journal of Accounting, Auditing \& Finance” 1982, Vol. 6, Issue 1, s. 32-43.

${ }^{57}$ H. De Angelo, L. De Angelo, D. J. Skinner, Accounting Choice in Troubled Companies, „Journal of Accounting \& Economics” 1994, Vol. 17, Issue 1/2, s. 113-143.

58 D. S. Sh arma, P. A. S te ven s o n, The Impact of Impending Corporate Failure on the Incidence and Magnitude of Discretionary Accounting Policy Changes, „British Accounting Review" 1997, Vol. 29, No. 2, s. 129-153.

59 Por. W. W ąs ow ski, Kreatywna rachunkowość, fatszowanie sprawozdań finansowych, Centrum Doradztwa i Informacji Difin Sp. z o.o., Warszawa 2005, s. 13-14.

${ }^{60}$ Rachunek przepływów pieniężnych jest na tyle ważną częścią sprawozdania finansowego, iż nie należy ograniczać się jedynie do jego sporządzania i prezentacji w dokumentacji przedsiębiorstwa (np. złożonej do Krajowego Rejestru Sądowego), ale również należy dokonywać na jego 
zu" sytuacji finansowej przedsiębiorstwa. To na podstawie sprawozdania z przepływów pieniężnych uzyskuje się dynamiczną informację w ujęciu kasowym o wpływach i wydatkach danego podmiotu gospodarczego. Z kolei, rachunek zysków i strat - pomimo dużej wartości poznawczej - nie odzwierciedla całości przepływów zasobów w przedsiębiorstwie ${ }^{61}$.

Za wzmocnieniem roli i znaczenia podejścia kasowego w ocenie operacyjnego bezpieczeństwa finansowego przedsiębiorstwa przemawia również szereg innych argumentów. Należą do nich m. in. następujące stwierdzenia:

- osiąganie zysków nie jest równoznaczne z posiadaniem gotówki, a spłata zadłużenia, zakup nieruchomości i wyposażenia ma zazwyczaj charakter gotówkowy $^{62}$,

- wypłata dywidendy ma zazwyczaj charakter gotówkowy ${ }^{63}$,

- w przypadku występowania wysokiej stopy inflacji powstaje luka między osiągniętymi przychodami a przepływami pieniężnymi, ponieważ do obliczania przychodów stosowana jest bieżąca cena sprzedaży, a spłata należności dotyczy sprzedaży z poprzedniego okresu, kiedy to ceny sprzedaży były niższe ${ }^{64}$,

- przepływy pieniężne są lepszą miarą efektywności alokacji zasobów danej jednostki gospodarczej ${ }^{65}$,

- analiza cash flow lepiej ilustruje wygospodarowaną w danym roku nadwyżkę finansową ${ }^{66}$,

- współczynniki oparte na przepływach pieniężnych mogą zapewnić lepszy obraz siły finansowej i rentowności (zyskowności) przedsiębiorstwa ${ }^{67}$,

- nie są one uzależnione od stopnia technicznego uzbrojenia procesu produkcyjnego $^{68}$,

podstawie różnorodne analizy finansowe. Por. T. Delan ey, R. Carleton, Cash flow analysis-going beyond the basics, „The RMA Journal” 2008, Vol. 90, Issue 8, s. 60-65.

${ }^{61}$ Informacje w nim zamieszczone koncentrują się wokół przepływów zasobów związanych z działalnością przynosząca dochód, nie uwzględniając zmian w stanie innych rodzajów zasobów będących następstwem działalności operacyjnej, inwestycyjnej, czy też finansowej - tj. działalności obejmujących operacje, które często w znacznej mierze decydują o wypłacalności podmiotu gospodarczego. Zob. T. W a śn i e w s ki, W. S k o c z y la s, Teoria i praktyka..., op. cit., s. 145.

${ }^{62}$ A. N. Gelle r, L. C. He ath, Solvency, Financial Statement and the Importance of Cash-Flow Information, „Cornell Hospitality Quarterly”, November 1981, Vol. 22, No. 3, s. 46.

${ }^{63} \mathrm{D}$. W ę d zki, Statystyczna weryfikacja istotności przeptywów pieniężnych, ,Zeszyty Teoretyczne Rachunkowości” 2003, nr 15(71), Warszawa, s. 104.

${ }^{64}$ A. N. Geller, L. C. He ath, op. cit., 50.

${ }^{65}$ G. Gallinger, P. Healey, Liquidity Analysis and Management, Addison-Wesley, Menlo Park 1991, s. 9.

${ }^{66}$ E. Urbań c z y k, op. cit., s. 263.

${ }^{67}$ Por. Ch. A. Cars law, J. R. Mills, Developing Ratios for Effective Cash Flow Statement Analysis, ,Journal of Accountancy”, November 1991, s. 63.

${ }^{68}$ W. S k o c z y l a s, Nadwyżka pieniężna jako miara efektywności gospodarowania przedsiębiorstwa, [w:] W. J a n as z (red.), Strategie, modele i miary efektywności przedsiębiorstwa, „Zeszyty Naukowe Uniwersytetu Szczecińskiego nr 223", Prace Instytutu Ekonomiki i Organizacji Przedsiębiorstw nr 36, Szczecin 1998, s. 132. 
- są bardziej obiektywne, bowiem w mniejszym zakresie istnieje możliwość występowania tzw. kreatywnej rachunkowości ${ }^{69}$. Tym samym wynik finansowy obciążony jest pewną dozą subiektywizmu w związku z zaliczeniem w ciężar kosztów niektórych jego bezgotówkowych elementów (w tym m. in. amortyzacji, części rezerw, czy też rozliczeń międzyokresowych kosztów) w zależności od przyjętej taktyki wykazywania zysku w danym okresie sprawozdawczym ${ }^{70}$.

Sprawozdanie z przepływów pieniężnych jest użyteczne zatem dla różnych grup interesariuszy, w tym $\mathrm{m}$. in. dla zarządzających przedsiębiorstwem, inwestorów oraz wierzycieli. Dla przykładu, zarząd może wykorzystać je m. in. w celu oceny płynności finansowej oraz efektów podejmowanych decyzji inwestycyjnych i finansowych. Inwestorzy mogą z kolei ustalić możliwość wypłaty dywidendy, zaś wierzyciele - spłaty ich zobowiązań ${ }^{71}$.

Uwzględniając zatem wysoką użyteczność sprawozdania z przepływów pieniężnych dla różnych grup interesariuszy przedsiębiorstwa, należy stwierdzić, iż powinno ono stać się integralną częścią oceny operacyjnego bezpieczeństwa finansowego przedsiębiorstwa ${ }^{72}$, by w pełniejszy sposób odzwierciedlić zachodzące w jednostce zdarzenia gospodarcze.

${ }^{69}$ Zob. A. B lack, P. Wright, J. B a ch man, W poszukiwaniu wartości dla akcjonariuszy, Oficyna ekonomiczna, Kraków 2000, s. 50-52.

Wśród najczęstszych stosowanych metod kreatywnej rachunkowości w rumuńskich przedsiębiorstwach wyróżnić można m. in. przeszacowanie wartości aktywów, niedoszacowanie wartości zadłużenia oraz te, które powiązane z przychodami i kosztami operacyjnymi.

Kreatywna rachunkowość dotyczy przede wszystkim tworzenia informacji finansowych prezentowanych zatem w takich sprawozdaniach finansowych, jak bilans oraz rachunek zysków i strat. Jej możliwości są dość ograniczone w przypadku sprawozdania z przepływów pieniężnych, choć nie są niemożliwe. Dla przykładu - sprzedaż należności może przyczynić się do zwiększenia operacyjnych przepływów pieniężnych, a tego rodzaju działania mogą mieć na celu wygenerowanie dodatniego poziomu tychże przepływów w przedsiębiorstwie. Zob. D. Matis, A. B. Vladu, L. Negrea, Cash-Flow Reporting Between Potential Creative Accounting Techniques And Hedging Opportunities Case Study Romania, „Annales Universitatis Apulensis Series Oeconomica" 2009, Vol. 1, Issue 11, s. 141-143 i 148-149.

${ }^{70}$ Por. M. Gottlie b, W. Le w c zy ński, Cash flows - sprawozdanie z przeptywów gotów$k i$ : $w$ praktyce USA $i w$ warunkach polskich, Instytut Przedsiębiorczości, Sopot 1993, s. 59; M. Si erpińska, D. W ęd zki, op. cit., s. 52; M. Si erpińsk a, Polityka dywidend w spótkach kapitałowych, Wydawnictwo Naukowe PWN, Kraków-Warszawa 1999, s. 29-32.

${ }^{71}$ B. E. N e e d le s Jr., Financial accounting, Houghton Mifflin Company, Boston 1992, s. 690.

Wierzyciele są z kolei zainteresowani realnością spłaty pożyczek i odsetek przez przedsiębiorstwo, zaś akcjonariusze potrzebują informacji o przepływów środków pieniężnych dla oceny możliwości rozwoju przedsiębiorstwa i jego wypłacalności, oceny zdolności jednostki gospodarczej do pokrywania zobowiązań z tytułu dostaw i usług, jak i regulowania innych zobowiązań finansowych. Por. J. Mackeviči u s, K. S enkus, The System of Formation and Evaluation of the Information Of Cash Flows, ,Journal of Business, Economics and Management” 2006, Vol. 7, No. 4, s. 171.

${ }^{72}$ Por. A. N. D u raj, Nadzór korporacyjny a bezpieczeństwo finansowe przedsiębiorstw, [w:] P. Urbanek (red.), Nadzór korporacyjny $w$ warunkach kryzysu gospodarczego, Wydawnictwo 


\subsubsection{Przesłanki jednoczesnego stosowania memoriałowego i kasowego podejścia w ocenie operacyjnego bezpieczeństwa finansowego przedsiębiorstwa}

J. Mackevičius oraz K Senkus wskazali, iż kreatywna rachunkowość dotyczyć może również w pewnym stopniu i sprawozdania z przepływów pieniężnych. Opisali bowiem występujące w danej jednostce gospodarczej najbardziej typowe przykłady (najczęstsze przypadki) fikcyjnych płatności, tj. fikcyjne płatności dla dostawców, bezpodstawnie wypłacone wynagrodzenia, pieniądze za nabywane towary lub usługi, które nie zwiększyły środków w kasie (w formie wpływów) lub które nie zostały zaksięgowane na koncie bankowym ${ }^{73}$. Należy wskazać jednak, iż stan i ruch środków pieniężnych, jako kategoria odporna na oddziaływanie zasad rachunkowości, pozwala na lepsze porównanie efektów działania różnych jednostek gospodarczych, funkcjonujących w odmiennych warunkach $^{74}$.

O zasadności merytorycznej i pragmatycznej wyprowadzonego wniosku o potrzebie jednoczesnego stosowania podejścia memoriałowego i kasowego w ocenie operacyjnego bezpieczeństwa finansowego przedsiębiorstwa świadczą także poglądy M. Gottlieba oraz W. Lewczyńskiego, E. Śnieżek, T. Kiziukiewicz, T. Maślanki i K. Stępnia (zob. tab. 1.8).

E. Śnieżek podkreśla, iż nie należy opowiadać się za żadną z zasad. T. Kiziukiewicz dodatkowo wskazuje, że należy stosować obie zasady w ramach poszczególnych części sprawozdania finansowego w celu pełniejszej oceny kondycji finansowej przedsiębiorstwa. Za równoległą ewidencją zachodzących procesów kasowych, obok ich memoriałowego ujęcia, opowiada się także T. Maślanka. Autor stwierdza bowiem, iż ujęcie memoriałowe procesów zachodzących w przedsiębiorstwie jest zbyt wąskie. Nie uwzględnia ono lub w małym stopniu bierze pod uwagę towarzyszące tym procesom przepływy środków pieniężnych.

Należy ponadto wskazać, iż bilans ujawnia tylko niektóre informacje o posiadanej przez przedsiębiorstwo gotówce. Jest to jednakże obraz statyczny. Nie pokazuje bowiem jak dany podmiot gospodarczy finansuje swoją działalność w trakcie roku obrotowego. Takie informacje ukazuje sprawozdanie z przepływów środków pieniężnych. Na jego podstawie można wyjaśnić różnice pomiędzy wielkością gotówki na początek (bilans otwarcia) i koniec (bilans zamknięcia) okresu sprawozdawczego ${ }^{75}$.

Uniwersytetu Łódzkiego, Łódź 2010, s. 349; A. Rutkowski, Zarzadzanie finansami, PWE, Warszawa 2000, s. 110-111.

${ }^{73}$ J. Mackevičius, K. S en ku s, op. cit., s. 177.

${ }^{74}$ Zob. E. Śni żek, Jak korzystać z rachunku przepływów pieniężnych, „Rachunkowość” 2008 , nr 1, s. 21.

${ }^{75}$ I. Gillespie, R. Lewis, K. Hamilton, Principles of Financial Accounting, Prentice Hall Europe, Hemel Hempstead 1997, s. 268. 
Tabela 1.8. Przesłanki jednoczesnego stosowania zasady memoriałowej i kasowej (przegląd literatury)

\begin{tabular}{|c|c|}
\hline $\begin{array}{l}\text { Autor/Autorzy } \\
\text { (Rok publikacji) }\end{array}$ & Wnioski \\
\hline 1 & 2 \\
\hline $\begin{array}{l}\text { M. Gottlieb, } \\
\text { W. Lewczyński } \\
\text { (1993) }\end{array}$ & $\begin{array}{l}\text { Sprawozdanie cash flows jest oparte na zasadach ewidencji gotówkowej, } \\
\text { zatem obejmuje tylko takie zaszłości, które wyrażają rzeczywiste zmiany } \\
\text { gotówki (tj. jej wpływy i wydatki), jakie miały miejsce w danym okresie } \\
\text { obrachunkowym. Jednakże księgowość jednostki gospodarczej prowadzi się } \\
\text { na zasadach ewidencji memoriałowej. Wobec czego ujmuje się w niej także } \\
\text { transakcje, które - choć miały miejsce w danym okresie obrachunkowym } \\
\text { - to jednak nie spowodowały przepływów gotówkowych. Transakcje takie } \\
\text { będą przyczyną zmian w stanie gotówki w okresie późniejszym albo są } \\
\text { skutkiem takich zmian z okresu poprzedniego. }\end{array}$ \\
\hline $\begin{array}{l}\text { E. Śnieżek } \\
\text { (1994) }\end{array}$ & $\begin{array}{l}\text { Nie zawsze odpowiednim miernikiem sukcesu przedsiębiorstwa jest wiel- } \\
\text { kość wpływów oraz wydatków, czy też relacje między nimi w danym okre- } \\
\text { sie. W wielu przypadkach lepszym wskaźnikiem sytuacji finansowej jed- } \\
\text { nostki gospodarczej jest miara oparta na założeniu memoriałowym. Zasada } \\
\text { ta bowiem jest skoncentrowana na transakcjach oraz zdarzeniach gospodar- } \\
\text { czych mogących przyczynić się do powstania przepływów pieniężnych } \\
\text { w przyszłości. Oznacza to, że nieostrożnością byłoby jednoznacznie opo- } \\
\text { wiadanie się za wyższością jednej z tych zasad. Powinny być one zawsze } \\
\text { rozpatrywane w konkretnych warunkach, jak i z uwzględnieniem specyfiki } \\
\text { cyklu przedsiębiorstwa oraz charakteru prowadzonej działalności. }\end{array}$ \\
\hline $\begin{array}{c}\text { T. Kiziukiewicz } \\
\text { (1995) }\end{array}$ & $\begin{array}{l}\text { Skoro rachunek zysków i strat jest sporządzany zgodnie z zasadą memoria- } \\
\text { łową, uznanie za przychód lub koszt nie ma związku z przepływem środków } \\
\text { pieniężnych. Przychody i koszty przypisuje się zatem do okresu, którego } \\
\text { dotyczą bez względu na moment wpływu środków pieniężnych lub ich } \\
\text { wydatkowania. Ze względu na zagrożenia finansowe, jakie są z tym powią- } \\
\text { zane, istnieje potrzeba dysponowania również informacjami o rzeczywistych } \\
\text { wpływach i wydatkach w danym okresie (według zasady kasowej). Dlatego } \\
\text { w krajach o gospodarce rynkowej stosuje się dynamiczne ujęcie sytuacji } \\
\text { finansowej, wykorzystując w tym celu sprawozdanie z przepływu środków } \\
\text { pieniężnych. }\end{array}$ \\
\hline $\begin{array}{l}\text { E. Śnieżek } \\
\text { (2008) }\end{array}$ & $\begin{array}{l}\text { Wśród argumentów za stosowaniem podejścia kasowego przemawia głównie } \\
\text { fakt, iż informacje o przepływach pieniężnych nie są zdominowane przez } \\
\text { zasady, koncepcje oraz założenia rachunkowości w takim stopniu, jak } \\
\text { w innych sprawozdaniach finansowych. Należy jednakże podkreślić, iż } \\
\text { dopiero w połączeniu z innymi informacjami finansowymi, informacje } \\
\text { o przepływach pieniężnych prezentują prawdziwy i wierny obraz dokonań } \\
\text { przedsiębiorstwa w okresie sprawozdawczym. }\end{array}$ \\
\hline $\begin{array}{l}\text { T. Maślanka } \\
\text { (2008) }\end{array}$ & $\begin{array}{l}\text { Praktyka gospodarcza pokazuje, iż - z punktu widzenia zarządzania finan- } \\
\text { sami (zwłaszcza krótkoterminowego) - ujęcie memoriałowe procesów za- } \\
\text { chodzących w przedsiębiorstwie jest zbyt wąskie (nieuwzględniające lub } \\
\text { w małym stopniu biorące pod uwagę towarzyszące tym procesom przepływy } \\
\text { środków pieniężnych). Wymaga ono zatem poszerzenia o prezentację, rów- } \\
\text { nolegle zachodzących procesów kasowych. }\end{array}$ \\
\hline
\end{tabular}


Tabela 1.8. (cd.)

\begin{tabular}{|c|c|}
\hline 1 & 2 \\
\hline $\begin{array}{l}\text { K. Stępień } \\
\text { (2008) }\end{array}$ & $\begin{array}{l}\text { W przypadku memoriałowego sposobu rejestrowania zdarzeń gospodar- } \\
\text { czych, rachunkowość rezygnuje co prawda z całkowitej pewności pomiaru } \\
\text { skutków finansowych operacji (którą to daje zasada kasowa), zyskuje jednak } \\
\text { w zamian szerszy ogląd rzeczywistości gospodarczej. Zasada memoriałowa } \\
\text { stwarza bowiem możliwość kompletnego ujęcia w księgach rachunkowych } \\
\text { (a tym samym w sprawozdaniu finansowym) zdarzeń gospodarczych danego } \\
\text { okresu, bez pomijania ich nawet wtedy, gdy nie wystąpi rozliczenie pienięż- } \\
\text { ne. Z kolei zasada kasowa ma tę podstawową zaletę, iż ustalony na jej pod- } \\
\text { stawie wynik finansowy ma pokrycie w środkach pieniężnych. Nie jest on } \\
\text { zatem wynikiem „na papierze”, tak jak się to bardzo często zdarza stosując } \\
\text { zasadę memoriału. }\end{array}$ \\
\hline
\end{tabular}

Źródło: opracowanie własne na podstawie: M. Gottlieb, W. Lewczyński, Cash flows - sprawozdanie z przeptywów gotówki: $w$ praktyce USA $i w$ warunkach polskich, Instytut Przedsiębiorczości, Sopot 1993, s. 20; E. Ś n i eżek, Rachunek przeptywów pieniężnych w teorii i praktyce rachunkowości, Fundacja Rozwoju Rachunkowości w Polsce, Warszawa 1994, s. 19-22; T. Kiziukiewicz, Sprawozdanie z przeptywu środków pieniężnych $w$ zarządzaniu firma, Wydawnictwo EKSPERT, Wrocław 1995, s. 10; E. Śnieżek, Sprawozdawczość przepływów pieniężnych - krytyczna ocena i propozycja modelu, Wydawnictwo Uniwersytetu Łódzkiego, Łódź 2008, s. 150; T. Maślanka, Przeptywy pieniężne $w$ zarzadzaniu finansami przedsiębiorstw, Wydawnictwo C. H. Beck, Warszawa 2008, s. 7 i 12; K. S tę p i eń, op. cit., s. 30-31 i 34.

Przychody ujmowane w rachunku zysków i strat nie muszą być z kolei równoznaczne $\mathrm{z}$ wpływami gotówki, a koszty - z wydatkami środków pieniężnych. Zatem zysk netto wygenerowany w trakcie prowadzonej działalności nie zawsze jest tożsamy z posiadaną kwotą środków pieniężnych, które można wykorzystać chociażby na wypłatę dywidendy.

Ponadto wpływy i wypływy gotówki powiązane są nie tylko z operacjami wynikowymi (przychodami i kosztami). Za przykład może posłużyć chociażby pozyskanie oraz spłata różnych źródeł finansowania działalności, wypłata dywidendy albo zakup czy sprzedaż środków trwałych lub wartości niematerialnych i prawnych. Tego rodzaju zdarzenia gospodarcze powiązane są w przepływem środków pieniężnych, choć nie wywierają wpływu na memoriałowy wynik finansowy danego podmiotu gospodarczego.

Odrębną kwestią jest również zmienność wyniku finansowego, zupełnie nie związana z efektami prowadzonej przez jednostkę działalności. Wzrost memoriałowego wyniku finansowego może bowiem okazać się zagrożeniem dla płynności finansowej, a w skrajnych przypadkach nawet doprowadzić do bankructwa danego podmiotu gospodarczego (tj. chociażby przy jego podziale, jeśli nie weźmie się pod uwagę, iż jego część ma memoriałowy charakter i nie znajduje pokrycia we wpływach gotówki) ${ }^{76}$.

${ }^{76}$ U. Malin ow ska, Wptyw Międzynarodowych Standardów Rachunkowości na walory informacyjne sprawozdań finansowych, [w:] Wspótczesne problemy analizy ekonomicznej, „Prace 
Zachodzące równolegle, ale oderwane od siebie przychody i wpływy, jak i koszty oraz wypływy gotówki implikują przeto konieczność jednoczesnej oceny procesów zachodzących z przedsiębiorstwie zarówno w ujęciu memoriałowym i kasowym. Oderwanie jednej płaszczyzny analizy od drugiej jest możliwe, jednakże może przedstawiać niepełny obraz ${ }^{77}$ operacyjnego bezpieczeństwa finansowego jednostki gospodarczej.

Z tego względu można przyjąć, że jednoczesne stosowanie podejścia memoriałowego i kasowego $\mathrm{w}$ ocenie operacyjnego bezpieczeństwa finansowego przedsiębiorstwa znajduje swoje uzasadnienie w tworzeniu zróżnicowanych instrumentów i sposobów kształtowania warunków efektywnej ekonomicznie kontynuacji jego działalności.

\subsection{Dylematy wyboru oraz konstrukcji memoriałowych i kasowych mierników oceny operacyjnego bezpieczeństwa finansowego przedsiębiorstwa}

Konsekwencją zdominowania w literaturze przedmiotu i praktyce gospodarczej uwagi na zasadzie memoriałowej jest istniejąca przewaga mierników oceny sytuacji finansowo-majątkowej wykorzystujących dane bilansowe oraz dane pochodzące z rachunku zysków i strat. Wskazuje się jednakże, że w okresie w którym światowe gospodarki pogrążone są w kryzysie finansowym ${ }^{78}$, coraz częściej liczą się nie tylko tradycyjne mierniki oparte na danych memoriałowych, ale również te wykorzystujące informacje $\mathrm{z}$ rachunku przepływów pieniężnych ${ }^{79}$.

W literaturze przedmiotu prezentowane są liczne opracowania dotyczące badań nad przydatnością informacyjną przepływów pieniężnych (zob. tab. 1.9), które przemawiają za kasowym podejściem do oceny operacyjnego bezpieczeństwa finansowego.

i Materiały Wydziału Zarządzania Uniwersytetu Gdańskiego 1/2006”, Wydawnictwo Wydziału Zarządzania Uniwersytetu Gdańskiego i Fundacja Rozwoju Uniwersytetu Gdańskiego, Sopot 2006, s. 277-278.

${ }^{77}$ T. Maślanka,op. cit., s. 13.

${ }^{78}$ Kryzys finansowy - ekonomiczne zjawisko przejawiające się w gwałtownym pogorszeniu większości wskaźników finansowych tj. krótkoterminowych stóp procentowych, cen ziemi, nieruchomości, akcji, niewypłacalności przedsiębiorstw i upadku instytucji finansowych, [w:] Encyklopedia PWN-wersja internetowa: http://encyklopedia.pwn.pl/haslo/3928087/kryzys-finansowy.html (dostęp: 20.01.2013).

${ }^{79}$ Por. M. Forta, Rentowność i ptynność w ujęciu kasowym i memoriałowym $w$ spótkach z branży spożywczej, [w:] T. Du d y c z, G. O s b e r t-P oc i e ch a (red.), Efektywność - rozważania nad istota i pomiarem, Wydawnictwo Uniwersytetu Ekonomicznego we Wrocławiu, Wrocław 2010, s. 130. 
J. A. Largay oraz C. P. Stickney wykazali, iż analiza przepływów pieniężnych ujawniła nieuchronnie zbliżające się trudności finansowe przedsiębiorstwa W. T. Grant Company już dziesięć lat przed upadkiem w przeciwieństwie do tradycyjnej analizy wskaźnikowej sprawozdania finansowego. Wyniki te potwierdzają J. Mackevičius i K. Senkus, twierdząc nadto, iż nawet zyskowne przedsiębiorstwa mogą znaleźć się na skraju bankructwa, jeśli stale wykazują niedobór pieniędzy. Z powodu braku pieniędzy jest ono bowiem niezdolne do spłaty swoich zobowiązań ${ }^{80}$. Pobodnie zdaniem E. Eljasiak i W. Parteki „firmy nie upadają z powodu braku zysku. Upadają z powodu braku pieniędzy na regulowanie swoich bieżących zobowiązań, mimo istnienia $\mathrm{w}$ wielu wypadkach znacznej kwoty należności" ${ }^{\prime 1}$.

Podobne wnioski z badań wyciągnęli M. A. Rujoub, D. M. Cook oraz L. E. Hay. Stwierdzili bowiem, że dane o przepływach środków pieniężnych są użyteczne same w sobie, jak i jako uzupełnienie danych rachunkowości memoriałowej w prognozowaniu upadłości przedsiębiorstw ${ }^{82}$.

Odmiennego zdania są C. J. Casey oraz N. J. Bartczak, którzy wskazali, iż dane o operacyjnych przepływach pieniężnych nie dostarczają istotnej informacji z punktu widzenia poprawy przewidywania bankructwa przedsiębiorstwa w relacji do współczynników memoriałowych.

Ważność przepływów pieniężnych w ocenie ryzyka kredytowego zbadana była przez D. Sharmę. Autor ten wskazał, że kredytodawcy wykorzystujący jedynie informacje o przepływach pieniężnych najtrafniej prognozowali upadek badanych przedsiębiorstw. D. S. Sharma i E. R. Iselin stwierdzili zaś, iż menedżerowie ds. kredytów komercyjnych (CLM), wykorzystujący jedynie informacje o przepływach pieniężnych, lepiej ocenili wypłacalność podmiotów gospodarczych niż ci, którzy korzystali wyłącznie z danych memoriałowych (zob. tab. 1.9).

Z kolei, D. Wędzki podkreślił, iż zysk (strata) netto oraz przepływy pieniężne netto niosą często różne informacje. Autor wykazał bowiem brak współzależności pomiędzy zyskiem netto a przepływami pieniężnymi netto (alternatywnie też przepływami pieniężnymi z działalności operacyjnej). Oba te sprawozdania są zatem istotne, bowiem wielkości - które w sposób syntetyczny je reprezentują

\footnotetext{
${ }^{80}$ J. Mackevičius, K. Senkus, op. cit., s. 171.

${ }^{81}$ [Za:] E. E1j a si ak, W. P artek a, Przeptywy gotówkowe: ustalanie, planowanie, analiza, zarządzanie, Ośrodek Doradztwa i Doskonalenia Kadr, Gdańsk 1995, s. 36.

${ }^{82}$ Zgodnie zaś z art. 10 i 11 Ustawy z dnia 28 lutego 2003 r. Prawo upadłościowe i naprawcze - upadłość ogłasza się w stosunku do dłużnika, który stał się niewypłacalny. Dłużnika uważa się z kolei za niewypłacalnego, jeżeli nie wykonuje swoich wymagalnych zobowiązań pieniężnych, a w przypadku dłużnika będącego osobą prawną albo jednostką organizacyjną nieposiadającą osobowości prawnej, której odrębna ustawa przyznaje zdolność prawną - także wtedy, gdy jego zobowiązania przekroczą wartość jego majątku, nawet wówczas, gdy na bieżąco te zobowiązania wykonuje. Zob. Ustawa z dnia 28 lutego 2003 r. Prawo upadtościowe i naprawcze, DzU 2003, nr 60, poz. 535 z poźn. zm.
} 
- są znacząco różne. W związku z tym, w ocenie kondycji finansowej przedsiębiorstwa nie powinno pomijać się żadnej z tych wielkości.

D. Wędzki wskazywał ponadto na wyższą zdolność predykcji mieszanego modelu upadłości przedsiębiorstw (tj. w oparciu o memoriałowe i kasowe mierniki) w relacji do modelu bazującego wyłącznie na miernikach memoriałowych.

Tabela 1.9. Wyniki badań empirycznych dotyczących przydatności informacyjnej rachunku przepływów pieniężnych (przegląd literatury)

\begin{tabular}{|c|c|}
\hline $\begin{array}{l}\text { Autor/Autorzy } \\
\text { (Rok publikacji) }\end{array}$ & Wnioski z badań \\
\hline 1 & $\begin{array}{r}2 \\
\end{array}$ \\
\hline $\begin{array}{l}\text { J. A. Largay, } \\
\text { C. P. Stickney } \\
\quad(1980)\end{array}$ & $\begin{array}{l}\text { Autorzy udowodnili, iż tradycyjna analiza wskaźnikowa sprawozdania finan- } \\
\text { sowego przedsiębiorstwa nie wykazywała istnienia wielu problemów aż do } \\
1970 \mathrm{r} \text {. lub } 1971 \mathrm{r} \text {. Z kolei wnikliwa analiza przepływów pieniężnych ujawniła } \\
\text { nieuchronnie zbliżające się trudności finansowe już dziesięć lat przed upad- } \\
\text { kiem. Zatem bankructwo tego przedsiębiorstwa nie powinno być - zdaniem } \\
\text { Autorów - zaskoczeniem dla tych, którzy śledzili z zainteresowaniem poziom } \\
\text { operacyjnych przepływów pieniężnych tego podmiotu gospodarczego. }\end{array}$ \\
\hline $\begin{array}{c}\text { C. J. Casey, } \\
\text { N. J. Bartczak } \\
(1985)\end{array}$ & $\begin{array}{l}\text { Przebadali raporty finansowe } 290 \text { podmiotów gospodarczych (w tym } 60 \text { przed- } \\
\text { siębiorstw, które złożyły wniosek o ogłoszenie upadłości w latach 1971-1982 } \\
\text { oraz } 230 \text { wciąż funkcjonujących w badanym okresie). Głównym problemem } \\
\text { badawczym była odpowiedź na pytanie, czy możliwym jest zwiększenie do- } \\
\text { kładności w klasyfikacji - do dwóch rozważanych grup - podmiotów gospo- } \\
\text { darczych przy wykorzystaniu współczynników uwzględniających operacyjne } \\
\text { przepływy pieniężne. Na podstawie otrzymanych wyników autorzy stwierdzili } \\
\text { jednakże, że dane o operacyjnych przepływach pieniężnych nie dostarczają } \\
\text { istotnej informacji - w relacji do współczynników memoriałowych - z punktu } \\
\text { widzenia poprawy przewidywania bankructwa przedsiębiorstwa. Autorzy } \\
\text { podkreślają jednocześnie, iż okres badawczy obejmował więcej niż dziesięć } \\
\text { lat, a zatem możliwym jest, iż zdolność predykcyjna operacyjnych przepływów } \\
\text { pieniężnych zmieniała się w okresie poddanym badaniu. }\end{array}$ \\
\hline $\begin{array}{l}\text { M. A. Rujoub, } \\
\text { D. M. Cook, } \\
\text { L. E. Hay } \\
(1995)\end{array}$ & $\begin{array}{l}\text { Autorzy podjęli próbę odpowiedzi na pytanie, czy dane o przepływach pie- } \\
\text { niężnych mogą zapewnić lepszą miarę przewidywania bankructwa podmiotów } \\
\text { gospodarczych niż dane pochodzące z rachunkowości memoriałowej. Stwier- } \\
\text { dzili, iż w oparciu o przepływy pieniężne można lepiej przewidywać bankruc- } \\
\text { two przedsiębiorstwa niż korzystając jedynie z danych rachunkowości memo- } \\
\text { riałowej. Ponadto, wykorzystanie informacji o przepływach pieniężnych } \\
\text { w połączeniu z danymi rachunkowości memoriałowej poprawiło całkowitą } \\
\text { zdolność przewidywania upadłości podmiotów gospodarczych w porównaniu } \\
\text { z korzystaniem tylko i wyłącznie z danych memoriałowych. Otrzymane wyniki } \\
\text { potwierdzają fakt, iż informacje o przepływach środków pieniężnych (w for- } \\
\text { mie mierników finansowych) są użyteczne same w sobie oraz jako uzupełnie- } \\
\text { nie danych rachunkowości memoriałowej w prognozowaniu upadłości przed- } \\
\text { siębiorstw. Jednakże autorzy zalecają ostrożną interpretację wyników z powo- } \\
\text { du (podobnie zresztą jak i w wielu innych badaniach) ograniczonej liczby } \\
\text { podmiotów gospodarczych, które zostały wybrane do nielosowej próby. }\end{array}$ \\
\hline
\end{tabular}


Tabela 1.9. (cd.)

\begin{tabular}{|c|c|}
\hline 1 & 2 \\
\hline $\begin{array}{l}\text { D. Sharma } \\
(2001)\end{array}$ & $\begin{array}{l}\text { Przedstawił wyniki badań, w rezultacie których stwierdził, iż dane o przepły- } \\
\text { wach pieniężnych charakteryzują się większą zawartością informacyjną } \\
\text { w ocenie kondycji finansowej firmy niż tradycyjne dane memoriałowe. Anali- } \\
\text { za rezultatów badań wskazuje, iż kredytodawcy wykorzystujący jedynie in- } \\
\text { formacje o przepływach pieniężnych podali (przeciętnie) najwyższą liczbę } \\
\text { poprawnych prognoz dotyczących upadku lub kontynuowania działalności } \\
\text { gospodarczej w badanych przedsiębiorstwach. Z kolei kredytodawcy korzysta- } \\
\text { jący jednocześnie z informacji o przepływach pieniężnych i memoriałowych } \\
\text { wykazywali nieco wyższą zdolność prognozy od kredytodawców opierających } \\
\text { się jedynie na danych memoriałowych, lecz niższą od kredytodawców wyko- } \\
\text { rzystujących tylko i wyłącznie informacje o przepływach pieniężnych. }\end{array}$ \\
\hline $\begin{array}{l}\text { D. Wędzki } \\
\text { (2003) }\end{array}$ & $\begin{array}{l}\text { Autor przeprowadził badania współzależności wielu syntetycznych miar za- } \\
\text { czerpniętych m. in. z rachunku zysków i strat z miarami różnych odmian prze- } \\
\text { pływów pieniężnych. Wyniki tychże badań potwierdziły słuszność zaleceń } \\
\text { MSR } 7 \text { odnośnie sporządzania, oprócz rachunku zysków i strat, także rachunku } \\
\text { przepływów pieniężnych. Zysk (strata) netto oraz przepływy pieniężne netto } \\
\text { niosą często różne informacje, a w związku z tym w ocenie kondycji finanso- } \\
\text { wej przedsiębiorstwa nie powinno pomijać się żadnej z tych wielkości. Autor } \\
\text { podkreślił ponadto, iż dla odzwierciedlenia sytuacji finansowej przedsię- } \\
\text { biorstw istotne są nie tylko kategorie wynikowe, ale także pośrednie, w tym } \\
\text { m. in. zysk z działalności operacyjnej czy też przepływy pieniężne z tejże } \\
\text { działalności, gdyż są one w wysokim stopniu od siebie niezależne. Cennym } \\
\text { spostrzeżeniem autora jest ponadto stwierdzenie, iż najdokładniejszym sposo- } \\
\text { bem szacowania operacyjnych przepływów pieniężnych ex post jest formuła } \\
\text { uproszczonych przepływów pieniężnych, w drugiej kolejności EBITDA } \\
\text { (tj. suma zysku z działalności operacyjnej i amortyzacji), a następnie ,zysku } \\
\text { netto + amortyzacji”. Należy jednak podkreślić, iż na otrzymane wyniki należy } \\
\text { spojrzeć z pewną dozą ostrożności bowiem - pomimo dość znacznej liczby } \\
\text { podmiotów gospodarczych poddanych badaniu - okres badawczy wynosił } \\
\text { zaledwie } 3 \text { lata. Badaniem objęto } 435 \text { spółek akcyjnych innych niż ubezpie- } \\
\text { czyciele i banki w } 1999 \text { r., } 3122 \text { spółek w } 2000 \text { r. i } 3229 \text { spółek w } 2001 \text { r. }\end{array}$ \\
\hline $\begin{array}{l}\text { D. S. Sharma, } \\
\text { E. R. Iselin } \\
(2003)\end{array}$ & $\begin{array}{l}\text { Wyniki badań obrazują, że informacje o przepływach pieniężnych są poten- } \\
\text { cjalnie bardziej obiektywne oraz istotne niż informacje o zyskach i innych } \\
\text { danych memoriałowych w ocenie płynności, jak i wypłacalności przedsiębior- } \\
\text { stwa. Doświadczenia behawioralne wskazuja, że menedżerowie ds. kredytów } \\
\text { komercyjnych (CLM) wykorzystujący jedynie informacje o przepływach } \\
\text { pieniężnych dokonali dokładniejszej oceny wypłacalności podmiotów gospo- } \\
\text { darczych niż CLM dokonujący oceny na podstawie danych memoriałowych. } \\
\text { Również model oparty na przepływach środków pieniężnych wykazywał się } \\
\text { lepszą dokładnością prognozowania niż model oparty na informacjach memo- } \\
\text { riałowych. Autorzy wskazali zatem na znacznie lepszą skuteczność przewidy- } \\
\text { wania wypłacalności badanych } 50 \text { jednostek gospodarczych (25 zbankrutowa- } \\
\text { nych podmiotów i } 25 \text { kontynuujących działalność gospodarczą) w przypadku } \\
\text { dysponowania oraz wspomagania się danymi o charakterze pieniężnym, jak } \\
\text { i znaczną dodatkową zawartość informacyjną przepływów w relacji do informa- } \\
\text { cji memoriałowych w ocenie płynności oraz wypłacalności przedsiębiorstwa. } \\
\text { Podkreślili jednakże, że interpretacja wyników musi być dokonana z należytą } \\
\text { ostrożnością z uwagi na fakt, iż opracowanie to nie jest wolne od ograniczeń } \\
\text { (ograniczeniu uległy chociażby dane finansowe wykorzystane w tym badaniu). }\end{array}$ \\
\hline
\end{tabular}




\begin{tabular}{|c|l|}
\hline 1 & \multicolumn{1}{|c|}{2} \\
\hline \hline & $\begin{array}{l}\text { Wskazał, iż badania prezentowane w literaturze przedmiotu sugerują brak } \\
\text { przydatności mierników kasowych jako samodzielnych predyktorów upadło- } \\
\text { ści. Jednakże model mieszany (tj. oparty zarówno na miernikach memoriało- } \\
\text { wych i kasowych) ma wyższą zdolność prognostyczną od modelu bazującego } \\
\text { wyłącznie na miernikach memoriałowych. Postulował wobec tego pogłębienie } \\
\text { badań nad modelami mieszanymi. }\end{array}$ \\
\hline
\end{tabular}

Źródło: opracowanie własne na podstawie: J. A. Largay, C. P. Stickney, Cash Flows, Ratio Analysis and the W. T. Grant Company Bankruptcy, „Financial Analysts Journal”, July -August 1980, s. 51-54; C. J. Cas e y, N. J. B artczak, Using Operating Cash Flow Data to Predict Financial Distress: Some Extensions, „Journal of Accounting Research” 1985, Vol. 23, No. 1, s. 384-401; Por. też: C. J. Cas e y, N. J. B artc zak, Cash Flow: It's Not the Botton Line, „Harvard Business Review”, July-August 1984, s. 61-66; M. A. Rujoub, D. M. Cook, L. E. Hay, Using Cash Flow Ratio to Predict Business Failure, „Journal of Managerial Issues”, 22 March 1995, Vol. 7, http://www.questia.com/library/1G1-16838779/using-cash-flow-ratios-topredict-business-failures (dostęp: 20.05.2011); D. Sharma, Predicting Corporate Failure: When Cash Flow Is King, „Journal of Banking and Financial Services”, June 2001, http://www.questia.com/library/1G1-76133453/predicting-corporate-failure-when-cash-flow-is-king (dostęp: 20.05.2011); D. W ę d zki, Statystyczna weryfikacja istotności przeptywów pieniężnych, „Zeszyty Teoretyczne Rachunkowości” 2003, nr 15(71), Warszawa, s. 103-119; D. S. S h arma, E. R. Is elin, The Relative Relevance of Cash Flow and Accrual Information for Solvency Assessments: A Multi-Method Approach, „Journal of Business Finance \& Accounting” 2003, Vol. 30, Issue 7/8, s. 1115-1140; D. W ęd zk i, Przeptywy pieniężne w prognozowaniu upadtości przedsiębiorstwa. Przeglad literatury, [w:] Badania operacyjne $i$ decyzje, $\mathrm{nr} 2$, Oficyna Wydawnicza Politechniki Wrocławskiej, Wrocław 2008, s. 87-104.

Można powiedzieć, że wykorzystanie mierników opartych na przepływach pieniężnych pozwala lepiej zaspokoić potrzeby informacyjne użytkowników sprawozdań i jednocześnie łagodzi niektóre słabości rachunkowości memoriałowej (tj. wymieniane wcześniej m. in. skutki przeszacowania wartości aktywów i niedoszacowania wartości zadłużenia). Użytkownicy ci uzyskają bowiem bardziej szczegółową i wiarygodną informację finansową, gdyż wielkość zysku uzależniona jest $\mathrm{m}$. in. od sposobu zarachowania niektórych operacji gospodarczych, w tym naliczenia kwoty amortyzacji. Jego kwota może bowiem być w większym lub mniejszym stopniu kształtowana w zależności od przyjętej taktyki wykazywania wyniku finansowego przez daną jednostkę gospodarczą. Fakt ten nie zmniejsza jednakże przydatności rachunku zysków i strat (i płynącej z niego treści ekonomicznej) w zarządzaniu przedsiębiorstwem.

Ocena finansowych warunków efektywnej i skutecznej kontynuacji działalności przedsiębiorstwa na podstawie sprawozdania z przepływów pieniężnych nie powinna być przeto dokonywana w izolacji, ale we wzajemnym powiązaniu poszczególnych części sprawozdania finansowego (zob. tab. 1.10). 
Tabela 1.10. Poglądy na temat użyteczności analizy mierników memoriałowych i kasowych dla różnych grup interesariuszy (przegląd literatury)

\begin{tabular}{|c|c|}
\hline $\begin{array}{c}\text { Autor/Autorzy } \\
\text { (Rok publikacji) }\end{array}$ & Wnioski \\
\hline 1 & 2 \\
\hline $\begin{array}{l}\text { Ch. A. Carslaw, } \\
\text { J. R. Mills } \\
\quad(1991)\end{array}$ & $\begin{array}{l}\text { Współczynniki oparte na sprawozdaniu z przepływów pieniężnych powinny } \\
\text { uzupełniać tradycjonalne współczynniki oparte na zasadzie przyporządko- } \\
\text { wania kosztów do okresu, którego dotyczą. Współczynniki te powinny } \\
\text { dostarczać dodatkowej informacji na temat finansowej siły i rentowności } \\
\text { (zyskowności) prowadzonej działalności, a używane - w połączeniu z mier- } \\
\text { nikami opartymi na danych z bilansu oraz rachunku zysków i strat - powin- } \\
\text { ny prowadzić do lepszego zrozumienia finansowych sił i słabości danej } \\
\text { jednostki gospodarczej. }\end{array}$ \\
\hline $\begin{array}{c}\text { W. Skoczylas } \\
\text { (1996) }\end{array}$ & $\begin{array}{l}\text { W odróżnieniu od zysku, przyrost gotówki z działalności gospodarczej ma } \\
\text { charakter wielkości obiektywnej. Może on bowiem powstać tylko jako róż- } \\
\text { nica między rzeczywistymi wpływami i wydatkami gotówkowymi. } \\
\text { W związku z tym - menedżerowie, pożyczkodawcy i inwestorzy nie opierają } \\
\text { się już wyłącznie na zysku i rentowności, ale wiele uwagi poświęcają prze- } \\
\text { pływom gotówki. Wynika to z faktu, iż szczegółowe informacje o tych } \\
\text { przepływach ujawniają rzeczywiste możliwości płatnicze przedsiębiorstwa. }\end{array}$ \\
\hline $\begin{array}{l}\text { J. Duraj } \\
\text { (2004) }\end{array}$ & $\begin{array}{l}\text { Praktyka wykazała, że na potrzeby zarządzania przedsiębiorstwem niezbędne } \\
\text { jest konstruowanie sprawozdania z przepływów pieniężnych, aby w pełniej- } \\
\text { szy sposób oceniać sytuację finansową przedsiębiorstwa. Godnym uwagi jest } \\
\text { fakt, iż zysk jest kategorią księgową i wielkością uzależnioną od reguł oraz } \\
\text { klasyfikacji księgowych, jak i możliwości manewrowania jego wielkością. } \\
\text { Bilans z kolei nie odzwierciedla wielu niezbędnych informacji do planowa- } \\
\text { nia, analizowania i kontrolowania pozycji finansowej przedsiębiorstwa. } \\
\text { Przedstawione niedomagania bilansu oraz rachunku zysków i strat wskazują } \\
\text { na potrzebę sporządzania sprawozdania z przepływów pieniężnych. }\end{array}$ \\
\hline $\begin{array}{c}\text { E. I. Dudek- } \\
\text {-Szczepankiewicz } \\
\quad(2004)\end{array}$ & $\begin{array}{l}\text { Zysk, będąc nadwyżką przychodów nad kosztami za poszczególne okresy, } \\
\text { nie wyraża w pełni rzeczywistej sytuacji finansowej przedsiębiorstwa. Ma } \\
\text { on bowiem charakter „,zysku papierowego”, a zatem nie należy go utożsa- } \\
\text { miać z wygenerowaniem faktycznej nadwyżki pieniężnej. Wynika to z faktu, } \\
\text { iż moment wystąpienia przychodów i kosztów nie jest identyczny z faktycz- } \\
\text { nym momentem realizacji wpływów i wydatków środków pieniężnych } \\
\text { w przedsiębiorstwie. Klasyczna analiza finansowa, oparta na wartościach } \\
\text { pochodzących ze sprawozdań sporządzonych według zasady memoriałowej, } \\
\text { staje się przeto niewystarczająca na potrzeby zarządzania. Dla obiektywnej } \\
\text { oceny sytuacji finansowej przedsiębiorstwa, warto tradycyjne wskaźniki } \\
\text { uzupełnić opartymi na przepływach pieniężnych, gdyż rachunek przepły- } \\
\text { wów pieniężnych jest uważany za jedno z najlepszych narzędzi badania } \\
\text { kondycji finansowej oraz jej zmian w czasie. }\end{array}$ \\
\hline $\begin{array}{l}\text { J. Watson, } \\
\text { P. Wells } \\
\text { (2005) }\end{array}$ & $\begin{array}{l}\text { Dane dotyczące zysków i przepływów środków pieniężnych odzwierciedlają } \\
\text { różne zjawiska w odniesieniu do wyników prowadzonej działalności i nie } \\
\text { stanowią doskonałych substytutów w zakresie sygnałów dostarczanych } \\
\text { uczestnikom rynku. }\end{array}$ \\
\hline $\begin{array}{l}\text { G. Forsythe } \\
\text { (2006) }\end{array}$ & $\begin{array}{l}\text { Nie ma żadnego powodu, aby wybierać pomiędzy przepływami pieniężnymi } \\
\text { a zyskami. Obie miary są ważne i z pewnością każdy inwestor, który kieruje } \\
\text { swoją uwagę na zyski, odniesie korzyść poprzez dodanie analizy przepły- } \\
\text { wów pieniężnych do swoich metod oceny inwestycji. }\end{array}$ \\
\hline
\end{tabular}




\begin{tabular}{|c|l|}
\hline 1 & \multicolumn{1}{|c|}{2} \\
\hline \hline $\begin{array}{c}\text { S. Scott } \\
(2007)\end{array}$ & $\begin{array}{l}\text { EBITDA nie powinno być ignorowane, jednakże staranna analiza przepły- } \\
\text { wów pieniężnych może złagodzić niektóre słabości rachunkowości memoria- } \\
\text { łowej. Godnym uwagi jest fakt, iż rachunek przepływów pieniężnych przy- } \\
\text { czynia się do przełożenia (przekształcenia) wyników memoriałowych w wyni- } \\
\text { ki kasowe. }\end{array}$ \\
\hline $\begin{array}{c}\text { T. Li, } \\
\text { (2009) }\end{array}$ & $\begin{array}{l}\text { Memoriałowe wyniki finansowe są szeroko wykorzystywane do oceny wy- } \\
\text { ników przedsiębiorstwa i prognozowania jego przyszłej rentowności. Mogą } \\
\text { one jednakże podlegać manipulacji poprzez stosowanie różnych zasad ra- } \\
\text { chunkowości. Dlatego też, do pomiaru wyników danego podmiotu gospodar- } \\
\text { czego należy uzupełniająco wykorzystać dane o przepływach pieniężnych. }\end{array}$ \\
\hline $\begin{array}{c}\text { E. Śnieżek, } \\
\text { M. Wiatr } \\
\text { (2011) }\end{array}$ & $\begin{array}{l}\text { Jednoczesne analizowanie informacji wynikowych z informacjami płynący- } \\
\text { mi z rachunku przepływów pieniężnych pokazuje różnicę między strumie- } \\
\text { niami memoriałowymi i kasowymi w przedsiębiorstwie. Weryfikuje niejako } \\
\text { memoriałowy wynik, pokazując jego pieniężżąakość w danym okresie. }\end{array}$ \\
\hline
\end{tabular}

Źródło: opracowanie własne na podstawie: Ch. A. Carslaw, J. R. Mills, Developing Ratios for effective Cash Flow Statement Analysis, „Journal of Accountancy”, November 1991, s. 63-64; W. S k o czylas, Kierunki analizy przeptywów pieniężnych w przedsiębiorstwie, [w:] W. J a n as z (red.), Przedsiębiorstwo $w$ procesie transformacji, ,Zeszyty Naukowe Uniwersytetu Szczecińskiego nr 172", Prace Instytutu Ekonomiki i Organizacji Przedsiębiorstw nr 34, Szczecin 1996, s. 147-148; J. D u ra j, Podstawy ekonomiki przedsiębiorstwa, PWE, Warszawa 2004, s. 189; E. I. D u d e k-S z c ze p an ki e w i c z, Analiza sytuacji finansowej przedsiębiorstwa na bazie sprawozdania z przepływów pieniężnych, „Monitor Rachunkowości i Finansów” 2004, nr 2, s. 32 i 34; J. Watson, P. Wells, The Association Between Various Earnings and Cash Flow Measures of Firm Performance and Stock Returns: Some Australian Evidence, 2005, s. 12, http://ssrn.com/abstract=815365 (dostęp: 26.05.2013); G. Fors ythe, Cash Flow vs. Earnings: Which Is More Meaningful?, September 18, 2006, http://www.schwab.com/public/schwab/research_strategies/market_insight/investing_strategies/stocks/cash_flow_vs_earnings_which_is_more _meaningful.html (dostęp: 24.10.2012); H. B u k, Nowoczesne zarządzanie finansami. Planowanie $i$ kontrola. Wydawnictwo C. H. Beck, Warszawa 2006, s. 171; S. S c ot t, The Importance of Cash Flow Analysis for Small Businesses, „Commercial Lending Review”, March-April 2007, s. 44; T. Li, X. Hu an g, A New Concept and Application of Cash Profit, [w:] International Conference on Management and Service Science, Institute of Electrical and Electronic Engineers, September 2009, http://ieeexplore.ieee.org/ (dostęp: 24.10.2012); E. Ś ni ė̇e k, M. W i a tr, op. cit., s. 41.

Oceniając operacyjne bezpieczeństwo finansowe przedsiębiorstw w wymiarze memoriałowym i kasowym, szczególną uwagę należy zwrócić na zmienne składowe mierników tej oceny, w tym w szczególności czynników determinujących wartość wyniku na sprzedaży, jak i przepływów pieniężnych netto z działalności operacyjnej. W aktualnych bowiem ,rozwiązaniach polskich - odnoszących się do wykazywania pozycji w rachunku przepływów pieniężnych - obowiązuje zasada, że jeżeli dana transakcja została zakwalifikowana do działalności operacyjnej, inwestycyjnej lub finansowej, wtedy wszystkie pieniężne koszty i korzyści z nią związane wykazuje się w tym samym rodzaju działalności. Dotyczy to w szczególności: otrzymanych odsetek i dywidend, odsetek zapłaconych, zapłaconych prowizji od obsługi zadłużenia, oprocentowania własnych 
i obcych papierów wartościowych, różnic kursowych oraz innych zrealizowanych kasowo kosztów i korzyści" ${ }^{\text {"83. }}$.

Specyfika grupowania pozycji w rachunku zysków i strat nie pozwala zatem na jednoznaczne przyporządkowanie przepływów pieniężnych powstałych z tytułu ogółu pozycji danej grupy do tego samego rodzaju działalności. Dla przykładu, istniejąca w kosztach finansowych pozycja odsetek może dotyczyć zarówno działalności operacyjnej, jak i inwestycyjnej oraz finansowej ${ }^{84}$ (zob. schemat 1.1).

\begin{tabular}{|c|c|}
\hline $\begin{array}{l}\text { Rachunek } \\
\text { zysków i strat } \\
\text { w obowiązującej } \\
\text { formie }\end{array}$ & Moduł 0 Przeksztatcony rachunek zysków i strat \\
\hline $\begin{array}{l}\text { Przychody } \\
\text { i koszty } \\
\text { działalności } \\
\text { podstawowej }\end{array}$ & $\begin{array}{c}\text { Przychody/koszty działalności podstawowej, } \\
\text { pozostałe przychody/koszty operacyjne } \\
\text { i przychody/koszty finansowe dotyczące działalności } \\
\text { operacyjnej }\end{array}$ \\
\hline & Razem/przychody i koszty z tytułu działalności operacyjnej \\
\hline \multirow[t]{2}{*}{$\begin{array}{l}\text { Pozostałe } \\
\text { przychody } \\
\text { i koszty } \\
\text { operacyjne }\end{array}$} & $\begin{array}{c}\text { Przychody/koszty działalności podstawowej, } \\
\text { pozostałe przychody/koszty operacyjne } \\
\text { 1 przychody/koszty finansowe dotyczące działalności } \\
\text { inwestycyjnej }\end{array}$ \\
\hline & $\begin{array}{c}\text { Razem przychody i koszty z tytułu działalności } \\
\text { inwestycyjnej }\end{array}$ \\
\hline \multirow{3}{*}{$\begin{array}{c}\text { Przychody } \\
\text { i koszty } \\
\text { finansowe } \\
\text { Obciążenia } \\
\text { wyniku z tytułu } \\
\text { podatku } \\
\text { dochodowego } \\
\end{array}$} & \multirow{2}{*}{$\begin{array}{l}\text { Przychody/koszty działalności podstawowej, } \\
\text { pozostałe przychody/koszty operacyjne } \\
\text { i przychody/koszty finansowe dotyczące działalności } \\
\text { finansowej }\end{array}$} \\
\hline & \\
\hline & Razem przychody i koszty z tytułu działalności finansowej \\
\hline \multicolumn{2}{|r|}{ Działalność zaniechana } \\
\hline & Podatek dochodowy \\
\hline
\end{tabular}

Schemat 1.1. Przekształcenie formatu rachunku zysków i strat na potrzeby sprawozdawczości przepływów pieniężnych

Źródło: E. Śni ż̇ek, Sprawozdawczość przeptywów pieniężnych - krytyczna ocena i propozycja modelu, Wydawnictwo Uniwersytetu Łódzkiego, Łódź 2008, s. 364.

E. Śnieżek podkreśla, iż logika podziału pozycji sprawozdania na trzy wymienione rodzaje działalności, przyjęta w rachunku przepływów pieniężnych, jest $\mathrm{z}$ kolei klasyfikacją w sposób pełny odzwierciedlającą specyfikę działalności prowadzonej przez różne podmioty gospodarcze. Dlatego należy - jej zdaniem

\footnotetext{
${ }^{83}$ [Za:] E. Ś n i eże k, Sprawozdawczość przeptywów..., op. cit., s. 353.

${ }^{84}$ Ibidem, s. 363.
} 
- przekształcić obowiązujący „,wzór” rachunku zysków i strat, tak aby wykazane w nim pozycje przychodów i kosztów były przypisane do jednego z trzech rodzajów działalności: operacyjnej, inwestycyjnej lub finansowej. Zaproponowany przez tę Autorkę, przekształcony format rachunku zysków i strat zawiera dla przykładu na poziomie operacyjnym oprócz - transakcji dotyczących zasadniczej działalności operacyjnej - także pozostałe przychody i koszty operacyjne (w tym m. in. naliczone kary, grzywny, czy też koszty sądowe), jak i przychody oraz koszty finansowe ( $\mathrm{w}$ tym $\mathrm{m}$. in. odsetki od nieterminowo regulowanych należności (zobowiązań) operacyjnych, czy też naliczone dodatnie (ujemne) różnice kursowe od zdarzeń klasyfikowanych do działalności operacyjnej) - jeśli dotyczą działalności operacyjnej ${ }^{85}$.

Propozycja E. Śnieżek stanowi cenne novum, bowiem użytkownik sprawozdania finansowego nie dysponuje wiarygodną informacją, która pozwala ocenić strukturę przepływów pieniężnych kształtujących memoriałowy wynik okresu. Jednakże w praktyce gospodarczej sprawozdania te sporządzane i publikowane są według klasycznego schematu. Zatem w aktualnych rozwiązaniach polskich - specyfika grupowania pozycji w rachunku zysków i strat nie jest tożsama z grupowaniem ich w sprawozdaniu z przepływów pieniężnych.

Wyrażony pogląd przez E. Śnieżek koresponduje wyraźnie z postawioną tezą niniejszego opracowania, iż konieczność kreowania oraz zapewniania finansowych warunków kontynuacji dziatalności gospodarczej determinuje potrzebę jednoczesnego oraz kompleksowego wykorzystania podejścia memoriałowego $i$ kasowego $w$ ocenie operacyjnego bezpieczeństwa finansowego przedsiębiorstwa, stanowiąc jednocześnie punkt wyjścia do weryfikacji postawionych hipotez badawczych o charakterze empirycznym.

Pojawiające się problemy z utrzymaniem płynności finansowej ${ }^{86}$, mające początkowo sporadyczny charakter, są pierwszym wyraźnie widocznym symptomem pogarszania się operacyjnego bezpieczeństwa finansowego przedsiębiorstwa. Pierwotną przyczyną tej sytuacji może być obniżenie wartości przychodów netto ze sprzedaży produktów (usług), towarów i materiałów ${ }^{87}$, powodujące zmniejszenie wartości generowanego strumienia przepływów pieniężnych. Trudności płatnicze doprowadzają do powstania tzw. zatorów płatniczych, wy-

${ }^{85}$ Ibidem, s. 363-364.

${ }^{86}$ Zdaniem D. Wędzkiego bezpieczeństwo finansowe w Polsce maleje, gdyż coraz mniej aktywów obrotowych można przeznaczyć na spłatę wymaganych zobowiązań krótkoterminowych. W tej sytuacji podstawę analiz powinno stanowić badanie płynności finansowej, [za:] D. W ę dzki, Strategie..., op. cit., s. 38.

${ }^{87}$ Spadek przychodów ze sprzedaży może być wynikiem spadku sprzedaży lub nieterminowych płatności ze strony partnerów handlowych. Zob. M. Burzykowska, J. Duraj, Controllingowy wymiar oceny ptynności finansowej przedsiębiorstwa, Wydawnictwo Uniwersytetu Łódzkiego, Łódź 2009, s. 24-25.

Dla przychodów netto ze sprzedaży produktów (usług), towarów i materiałów w dalszej części opracowania Autorka będzie również zamiennie stosowała zapis ,,przychodów netto ze sprzedaży”. 
dłużania okresów regulowania zobowiązań ${ }^{88}$, zachwiania sprawności operacyjnej przedsiębiorstwa oraz relatywnego wzrostu nie tylko kosztów zmiennych, lecz także i kosztów stałych ${ }^{89}$.

Nawet krótkookresowy brak popytu na produkty (usługi), towary i materiały zagraża funkcjonowaniu przedsiębiorstwa. Wielkość sprzedaży stanowi bowiem bardzo ważny czynnik określający możliwości płatnicze przedsiębiorstwa, ponieważ jest ona podstawowym źródłem wpływów środków pieniężnych ${ }^{90}$. W skali mikro operacyjne bezpieczeństwo finansowe jednostki gospodarczej jest przeto kształtowane pod wpływem sukcesów i niepowodzeń przedsiębiorstwa na rynku sprzedaży produktów (usług), towarów i materiałów. W ujęciu memoriałowym będzie to miało swoje odzwierciedlenie w wartości przychodów netto ze sprzedaży produktów (usług), towarów i materiałów, któremu należy zestawić uzyskane z niej wpływy środków pieniężnych (ujęcie kasowe) ${ }^{91}$.

Wpływy środków pieniężnych ze sprzedaży są podstawowym czynnikiem determinującym wartość przepływów pieniężnych netto, które z punktu widzenia wartości informacyjnej są najważniejszą pozycją całego rachunku przepływów pieniężnych (zob. tab. 1.11). Działalność operacyjna dotyczy bowiem tego rodzaju działalności jednostki, do którego została ona powołana (ustanowiona).

Podobny pogląd wyrażają Ch. A. Carslaw oraz J. R. Mills stwierdzając, iż operacyjne przepływy pieniężne zajmują kluczowe miejsce $\mathrm{w}$ sprawozdaniu z przepływów pieniężnych. J. Mackevičius i K Senkus wskazują zaś, iż wpływy $\mathrm{z}$ działalności operacyjnej mają charakter stały w przeciwieństwie do tych z działalności inwestycyjnej i finansowej, które występują zazwyczaj rzadko. M. Burzykowska i J. Duraj dodają z kolei, iż wczesne zdiagnozowanie niekorzystnych zmian operacyjnych przepływów pieniężnych pozwala ustrzec przedsiębiorstwo przed poważnymi trudnościami finansowymi (zob. tab. 1.11).

Środki pieniężne netto z działalności operacyjnej (tj. podstawowej działalności podmiotu gospodarczego) są najbardziej przydatne w budowie współczynników niezbędnych w analizie i ocenie sytuacji finansowej jednostki gospodarczej ${ }^{92}$.

${ }^{88}$ A. S kowronek-Mielczarek, Controlling, analiza $i$ monitoring $w$ zarzadzaniu przedsiębiorstwem, Centrum Doradztwa i Informacji Difin Sp. z o.o., Warszawa 2007, s. 217.

${ }^{89}$ M. Burzykowska, J. Duraj, op. cit., s. 24-25.

${ }^{90}$ Por. A. Ku s ak, Ptynność finansowa. Analiza i sterowanie, Wydawnictwo Naukowe Wydziału Zarządzania Uniwersytetu Warszawskiego, Warszawa 2006, s. 23.

${ }^{91}$ Zarówno przychody, jak i wpływy ze sprzedaży produktów (usług), towarów i materiałów można uznać za stymulanty, gdyż wzrost ich wartości wiąże się z poprawą bezpieczeństwa finansowego przedsiębiorstwa.

92 Por. E. Śn ni żek, Jak czytać cash flow, Fundacja Rozwoju Rachunkowości w Polsce, Warszawa 1997, s. 76-78.

W 1993 r. w Polsce po raz pierwszy zagadnienia z zakresu analizy wskaźnikowej przepływów podjęli M. Gottlieb oraz W. Lewczyński, którzy wykorzystali doświadczenia gospodarki amerykańskiej z tego zakresu. Dotychczas jednakże najszerszy zakres współczynników pod względem ich liczby - zaprezentowały w 1996 r. K. Grzelak i A. Karmańska. Zob. M. Gottli eb, 
Tabela 1.11. Użyteczność analizy operacyjnych przepływów pieniężnych (przegląd literatury)

\begin{tabular}{|c|c|}
\hline $\begin{array}{l}\text { Autor/Autorzy } \\
\text { (Rok publikacji) }\end{array}$ & Wnioski \\
\hline 1 & 2 \\
\hline $\begin{array}{l}\text { Ch. A. Carslaw, } \\
\text { J. R. Mills } \\
\quad(1991)\end{array}$ & $\begin{array}{l}\text { Chociaż inwestycyjne i finansowe przepływy pieniężne stanowią ważny skład- } \\
\text { nik sprawozdania z przepływów pieniężnych, to najbardziej kluczową daną } \\
\text { tego sprawozdania są operacyjne przepływy pieniężne. Ważnym jest jednakże, } \\
\text { aby rozważyć jedynie gotówkę z zwykłej działalności operacyjnej. Należy } \\
\text { pominąć zatem wpływ niecodziennych, jednorazowych transakcji, bowiem } \\
\text { włączenie tych pozycji może wprowadzić w błąd potencjalnego inwestora. } \\
\text { Analitycy powinny rozważać jedynie gotówkę z zwykłej działalności opera- } \\
\text { cyjnej. }\end{array}$ \\
\hline $\begin{array}{l}\text { T. Waśniewski, } \\
\text { W. Skoczylas } \\
\quad(1999)\end{array}$ & $\begin{array}{l}\text { Bardzo ważnym jest przede wszystkim określenie zdolności jednostki do } \\
\text { wypracowania środków pieniężnych z podstawowej działalności operacyjnej, } \\
\text { dla realizacji której została ona ustanowiona. }\end{array}$ \\
\hline $\begin{array}{l}\text { P. Rybicki } \\
\text { (2003) }\end{array}$ & $\begin{array}{l}\text { Przepływy pieniężne z działalności operacyjnej są z punktu widzenia wartości } \\
\text { informacyjnej najistotniejszą pozycją całego rachunku przepływów pienięż- } \\
\text { nych. Działalność operacyjna dotyczy bowiem tego rodzaju działalności jed- } \\
\text { nostki, do którego została ona utworzona. Są to zatem głównie skutki pienięż- } \\
\text { ne takich transakcji, które uwzględniane są przy ustalaniu wyniku finansowego } \\
\text { ze sprzedaży. To czy działalność przedsiębiorstwa jest opłacalna, tak naprawdę } \\
\text { zależy od tego, czy przepływy operacyjne są dodatnie. }\end{array}$ \\
\hline $\begin{array}{l}\text { J. A. Tracy } \\
(2004)\end{array}$ & $\begin{array}{l}\text { Działalność operacyjna jest dla większości jednostek gospodarczych najważ- } \\
\text { niejszym źródłem generowania dodatnich przepływów pieniężnych. }\end{array}$ \\
\hline $\begin{array}{l}\text { C. Kochalski } \\
\text { (2004) }\end{array}$ & $\begin{array}{l}\text { Przepływy pieniężne } \mathrm{z} \text { działalności operacyjnej należą do głównych kompo- } \\
\text { nentów kształtujących wartość przedsiębiorstwa. }\end{array}$ \\
\hline $\begin{array}{l}\text { J. Mackevičius, } \\
\text { K Senkus } \\
\text { (2006) }\end{array}$ & $\begin{array}{l}\text { Wpływy z działalności operacyjnej są najistotniejszymi wpływami w całym } \\
\text { sprawozdaniu z przepływów pieniężnych. Jest to uzasadnione faktem, że więk- } \\
\text { szość wpływów pochodzi z działalności operacyjnej (tj. wpływy od klientów), } \\
\text { jak i są one wpływami najbardziej stałymi, otrzymanymi każdego miesiąca, } \\
\text { w każdej dekadzie, w każdym tygodniu czy też dniu, podczas gdy wpływy } \\
\text { z inwestycji i działalności finansowej występują zazwyczaj rzadko oraz są } \\
\text { wpływami pojedynczymi. }\end{array}$ \\
\hline $\begin{array}{l}\text { E. Śnieżek } \\
\text { (2008) }\end{array}$ & $\begin{array}{l}\text { Wyniki badań ankietowych przeprowadzonych w } 2003 \text { r., jak i } 2005 \text { r. wska- } \\
\text { zują, iż przepływy pieniężne z działalności operacyjnej są najistotniejszym } \\
\text { rodzajem przepływów z punktu widzenia oceny sytuacji finansowej jednostki } \\
\text { gospodarczej. Są one obecnie również z reguły wykorzystywane w analizie } \\
\text { wskaźnikowej przepływów pieniężnych. Jest to podejście najbardziej przydat- } \\
\text { ne, bowiem zgodne z podstawowymi zasadami działania jednostki gospodar- } \\
\text { czej. W długim okresie kluczowe znaczenie dla jej przetrwania, rozwoju oraz } \\
\text { budowania pozycji na rynku ma właśnie zdolność do wypracowania środków } \\
\text { pieniężnych z tej działalności. }\end{array}$ \\
\hline
\end{tabular}

W. Lewczyński, op. cit., s. 59-63; K. Grzelak, A. Karmańska, Analiza sprawozdania z przeptywów pieniężnych, „Vademecum Przedsiębiorcy i Podatnika” 1996, nr 4, s. 33-38. 
Tabela 1.11. (cd.)

\begin{tabular}{|c|l|}
\hline \multicolumn{1}{|c|}{} & \multicolumn{1}{|c|}{2} \\
\hline $\begin{array}{c}\text { M. Burzykowska, } \\
\text { J. Duraj } \\
(2009)\end{array}$ & $\begin{array}{l}\text { Wczesne zdiagnozowanie niekorzystnych zmian operacyjnych przepływów } \\
\text { pieniężnych pozwala ustrzec przedsiębiorstwo przed poważnymi trudnościami } \\
\text { finansowymi. }\end{array}$ \\
\hline $\begin{array}{c}\text { W. Gabrusewicz, } \\
\text { M. Remlein } \\
(2011)\end{array}$ & $\begin{array}{l}\text { Działalność operacyjna generuje zasadniczą część środków pieniężnych. Ich } \\
\text { generowanie ma podstawowe znaczenie dla sytuacji finansowej jednostki, } \\
\text { gdyż środki te pozwalają na inwestowanie oraz spłatę długów bez korzystania } \\
\text { z zewnętrznych źródeł finansowania. }\end{array}$ \\
\hline $\begin{array}{c}\text { M. Lachmirowicz } \\
(2012)\end{array}$ & $\begin{array}{l}\text { Przepływy z działalności operacyjnej (dotyczące podstawowej działalności } \\
\text { zarobkowej jednostki) odzwierciedlają rzeczywiste wpływy i wydatki na ope- } \\
\text { racjach generujących wielkość osiągniętego zysku (straty) na sprzedaży. }\end{array}$ \\
\hline
\end{tabular}

Źródło: opracowanie własne na podstawie: Ch. A. Carslaw, J. R. Mills, op. cit., s. 64; T. Waśniewski, W. Skoczylas, Jak korzystać ze sprawozdania z przeptywu środków pieniężnych, „Rachunkowość” 1999, nr 12, s. 706; P. R y bi ck i, Jak interpretować rachunek przepływów pieniężnych, Dodatek do „Controlling i Rachunkowość Zarządcza” 2003, nr 8, s. II; J. A. Tr a c y, Jak czytać sprawozdania finansowe: dla zarządzajacych, przedsiębiorców, bankowców, prawników i inwestorów, Helion, Gliwice 2004, s. 87; C. K o ch a l s ki, Budowanie wartości przedsiębiorstwa w oparciu o analizę rentowności sprzedaży, [w:] E. U rb ań c z y k (red.), Strategie wzrostu wartości przedsiębiorstwa. Teoria i praktyka gospodarcza, „Zeszyty Naukowe nr 378”, Prace Instytutu Ekonomiki i Organizacji Przedsiębiorstw nr 43, t. 1, Wydawnictwo Kreos, Szczecin 2004, s. 60; J. M a ckevičiu s, K. S en ku s, The System of Formation and Evaluation of the Information Of Cash Flows, „Journal of Business, Economics and Management” 2006, Vol. 7, No. 4, s. 179; E. Śnieżek, Sprawozdawczość przeptywów..., op. cit., s. 305 i 383; M. B u r z y ko w ska, J. D u r a j, Controllingowy wymiar oceny ptynności finansowej przedsiębiorstwa, Wydawnictwo Uniwersytetu Łódzkiego, Łódź 2009, s. 25; W. Gabrusewicz, M. Remlein, Sprawozdanie finansowe przedsiębiorstwa: jednostkowe $i$ skonsolidowane, PWE, Warszawa 2011, s. 183; M. Lach mirowicz, Rachunek przeptywów pieniężnych $w$ praktyce, CeDeWu Sp. z o.o., Warszawa 2012, s. 11.

Zawarte w tab. 1.11 zestawienie wybranych ocen użyteczności analizy operacyjnych przepływów pieniężnych wskazuje na uzasadnioną potrzebę zawarcia $\mathrm{w}$ analizie operacyjnego bezpieczeństwa finansowego czterech głównych kryteriów badanego zjawiska. Należą do nich: sprzedaż produktów i/lub usług, towarów i materiałów, płynność finansowa, rentowność eksploatacyjna ${ }^{93}$ i wydajność pieniężna (gotówkowa), a także krótkoterminowe rezerwy finansowe.

Te cztery wyróżnione kryteria oceny operacyjnego bezpieczeństwa finansowego przedsiębiorstwa reprezentują szerokie spektrum problemów i warunków działania jednostek gospodarczych, które mogą być przedmiotem analizy zawierającej dane liczbowe reprezentujące zarówno ujęcie memoriałowe, jak i ujęcie kasowe.

${ }^{93}$ To relacja wyniku netto na sprzedaży do różnych podstaw odniesienia. Zob. C. Ko c h a lski, Syndrom „lasu i drzew” w analizie wskaźnikowej, „Controlling i Rachunkowość Zarządcza”, 2008, nr 8, s. 32. 
Zastosowanie wymienionych kryteriów oceny operacyjnego bezpieczeństwa finansowego $\mathrm{w}$ zarządzaniu przedsiębiorstwem wymaga uprzedniego skonkretyzowania i wyboru określonych mierników oceny. Do dyspozycji stoi wiele różnorodnych zmiennych finansowych i ekonomicznych, które nie posiadają z góry narzuconej postaci. Ich konstrukcja bowiem wynika z koncepcji zarządzania oraz praktycznych warunków działania przedsiębiorstwa i rozwiązywania powstałych problemów.

W warunkach charakterystycznych dla gospodarki rynkowej, tj. złożoności procesów gospodarczych oraz rosnącej konkurencji, zdolność do bieżącego regulowania swoich zobowiązań ma absolutnie podstawowe znaczenie dla zapewnienia przedsiębiorstwu bytu gospodarczego i prawnego. Utrata przez przedsiębiorstwo tej zdolności, nabierająca trwałego charakteru, prowadzi do jego likwidacji lub upadłości, rzadziej natomiast do przejęcia go przez inny podmiot gospodarczy lub fuzji ${ }^{94}$.

Co więcej, można powiedzieć, że:

- niski poziom współczynników płynności finansowej należy zaliczyć do finansowych symptomów zagrożenia kontynuacji działani ${ }^{95}$;

- nieutrzymanie płynności finansowej prowadzi do eliminacji przedsiębiorstwa z rynku ${ }^{96}$;

- zdolność do terminowego regulowania zobowiązań krótkoterminowych jest ważnym symptomem równowagi finansowej ${ }^{97}$;

- posiadanie płynności finansowej jest warunkiem sprawnego przebiegu bieżącej działalności przedsiębiorstwa (przedsiębiorstwo może bowiem osiągać zysk, lecz bez środków pieniężnych nie może prowadzić działalności gospodarczej) $)^{98}$;

- płynność finansowa jest kategorią ekonomiczną ważną, a zarazem podstawową dla funkcjonowania przedsiębiorstwa ${ }^{99}$.

Ocena płynności finansowej przedsiębiorstwa może być przedstawiona zarówno w ujęciu statycznym i dynamicznym. Statyczna ocena płynności finansowej jest oparta na wielkościach charakteryzujących zasoby. Dane potrzebne do tej oceny pochodzą z bilansu przedsiębiorstwa i ukazują stan zasobów na określony moment ( $\mathrm{tj}$. dzień bilansowy). $\mathrm{Z}$ kolei dynamiczna ocena płynności finansowej uwzględnia wielkości w postaci strumieni przepływów pieniężnych. Przy tego rodzaju ocenie wykorzystuje się dane pochodzące ze sprawozdania

${ }^{94}$ M. Ha mrol (red.), Analiza finansowa przedsiębiorstwa - ujęcie sytuacyjne, Wydawnictwo Akademii Ekonomicznej w Poznaniu, Poznań 2004, s. 145.

${ }^{95}$ L. B e d n ars k i, Analiza finansowa $w$ przedsiębiorstwie, PWE, Warszawa 1997, s. 160.

${ }^{96}$ T. W a śn ie w ski, W. S k oc zy las, Teoria i praktyka..., op. cit., s. 431.

${ }^{97}$ W. Gabrusewicz, Z. Kołaczy k, Bilans. Wartość poznawcza i analityczna, Centrum Doradztwa i Informacji Difin Sp. z o.o., Warszawa 2005, s. 277.

98 E. Nowak, Analiza sprawozdań finansowych, PWE, Warszawa 2008, s. 175-177, 204-209 i 249.

${ }^{99}$ M. B urzykowska, J. Duraj, op. cit., s. 8 
z przepływów pieniężnych, które ukazują rzeczywiste wpływy i wydatki środków pieniężnych ${ }^{100}$.

Współczynniki bieżącej płynności finansowej, płynności przyspieszonej i płynności natychmiastowej należy porównać z współczynnikiem zdolności do obsługi zobowiązań bieżących gotówką osiąganą z działalności operacyjnej. Ocena zdolności do regulowania zobowiązań w ujęciu memoriałowym może bowiem znacznie różnić się od tejże oceny w ujęciu kasowym. Ma to związek głównie z poziomem zapasów i należności. Jeżeli poziom zapasów i należności zmniejszył się, wówczas uwolnione środki pieniężne powiększają wartość przepływów pieniężnych netto z działalności operacyjnej ${ }^{101}$. Aktywa bieżące występujące w rachunku współczynników płynności finansowej nie odzwierciedlają zatem faktycznych możliwości płatniczych przedsiębiorstwa, gdyż o tym stanowią realne wpływy uzyskane ze sprzedaży wyrobów i usług ${ }^{102}$. Podobnie jest z ujęciem zobowiązań krótkoterminowych, które nie wyrażają wszystkich wydatków, jakie poniósł dany podmiot gospodarczy. Te niedomagania informacyjne określonej na dany moment płynności finansowej doprowadziły zatem do preferowania dynamicznych mierników oceny działalności przedsiębiorstwa. Posiadają one większą wartość poznawczą ${ }^{103}$.

Zbyt duży kapitał zaangażowany w aktywa obrotowe może wpłynąć negatywnie na płynność finansową i tym samym przyczynić się do zmniejszenia rentowności ${ }^{104}$. Zakłócenia płynności finansowej ${ }^{105}$ są powodem strat finansowych, a także podważają zaufanie kontrahentów gospodarczych oraz instytucji finansowych do przedsiębiorstwa ${ }^{106}$. Innym przeto obszarem kreowania i zapewniania operacyjnego bezpieczeństwa finansowego może być analiza rentowności eksploatacyjnej.

Za wykorzystaniem współczynników rentowności w ocenie operacyjnego bezpieczeństwa finansowego przemawia fakt, iż poziom rentowności sprzedaży świadczy nie tylko o konkurencyjności przedsiębiorstwa na rynku, ale także o jego płynności finansowej ${ }^{107}$. Należy bowiem zauważyć, iż - jak wskazuje W. Skoczylas - jednostki gospodarcze osiągające wyższą dochodowośćc ${ }^{108}$ pro-

${ }^{100}$ E. Now ak, op. cit., s. 204.

${ }^{101}$ Por. M. Fort a, op. cit., s. 140.

${ }^{102}$ A. Ku sak, op. cit., s. 47.

${ }^{103}$ T. Waśni ewski, W. S koc zyla s, Teoria i praktyka..., op. cit., s. 430.

${ }^{104}$ T. M aśl an ka, op. cit., s. 60.

${ }^{105} \mathrm{Tj}$. jej brak lub stan nadpłynności finansowej.

${ }^{106}$ A. Ku sak, op. cit., s. 5.

${ }^{107}$ C. Kochalski, Budowanie wartości przedsiębiorstwa $w$ oparciu o analize rentowności sprzedaży, [w:] E. Urbańczyk (red.), Strategie wzrostu wartości przedsiębiorstwa. Teoria i praktyka gospodarcza, ,Zeszyty Naukowe nr 378”, Prace Instytutu Ekonomiki i Organizacji Przedsiębiorstw nr 43, t. 1, Wydawnictwo Kreos, Szczecin 2004, s. 60.

Por. T. W a śn i e w ski, W. S k oc zy las, Teoria i praktyka..., op. cit., s. 253.

${ }^{108}$ Odzwierciedlona odpowiednio wyrażoną samą kwotą wyniku finansowego lub też przez odniesienie jej do osiąganych przychodów. 
wadzonej działalności są bardziej skłonne, by liberalizować warunki płatności należności, czy też szybciej spłacać zobowiązania ${ }^{109}$.

Kierownictwo przedsiębiorstwa często preferuje posługiwać się miernikami prostymi, które mogą być podstawą do podejmowania szybkich oraz niezbyt pracochłonnych decyzji. Jedną z takich miar efektywności prowadzonej działalności - dość często wykorzystywaną - jest wynik finansowy i rentownośćc ${ }^{110}$.

Zdaniem P. Urbanka - wykorzystując zysk ze sprzedaży w pomiarze rentowności brana jest pod uwagę efektywność podstawowych działań jednostki gospodarczej, dla której została ona powołana i które mają przeto decydujący wpływ na wynik finansowy netto. Jednocześnie, ten poziom wyniku w najmniejszym stopniu podlega procesom kreatywnego oddziaływania ze strony zarządu oraz nie jest on uzależniony od występowania incydentalnych zdarzeń w toku prowadzonej działalności, w tym m. in. sprzedaży składników rzeczowego majątku trwałego, czy sprzedaży papierów wartościowych, bądź innych, niecodziennych zdarzeń dotyczących pozostałej działalności operacyjnej, działalności finansowej oraz działalności nadzwyczajnej ${ }^{111}$.

Za tego rodzaju analizą rentowności opowiada się również W. Skoczylas, która wskazuje, iż trudno zachować porównywalność w analizach przestrzennych, jeśli dotyczą one rentowności netto. Duża ilość czynników ją kształtujących powoduje, iż może być ona jedynie porównywalna w czasie i planem badanego przedsiębiorstwa ${ }^{112}$.

Poziom osiągniętego wyniku ze sprzedaży kształtuje wartość współczynników rentowności eksploatacyjnej. Jest wielkością księgową ustalaną dla poszczególnych okresów zgodnie z zasadą memoriałową. Często jednak nie wyraża rzeczywistej dochodowości przedsiębiorstwa, lecz jedynie tak zwany ,zysk (stratę) papierowy(ą)". Jako wielkość księgowa jest on bowiem w dużym stopniu uzależniony od możliwości wykorzystania alternatywnych metod rachunkowości. Obliczany zgodnie z założeniami ustawy o rachunkowości może osiągnąć - w zależności od przyjętego, a jednocześnie dopuszczalnego rozwiązania wy-

${ }^{109}$ W. Skoczylas, Podejście memoriatowe a podejście kasowe $w$ ocenie dochodowości działalności operacyjnej przedsiębiorstw, [w:] T. D u d y c z, G. O s be rt-P o ci e cha (red.), Efektywność - rozważania nad istota i pomiarem, Wydawnictwo Uniwersytetu Ekonomicznego we Wrocławiu, Wrocław 2010, s. 437.

${ }^{110}$ W. S k o c z y la s, Nadwyżka pieniężna..., op. cit., s. 125.

Podobny pogląd wyraża J. Turyna - twierdząc, iż ,wynik finansowy stanowi jeden z podstawowych mierników efektywności działania podmiotu gospodarczego, jest podstawą do oceny jego sytuacji finansowej”, [za:] J. Tu ry n a, op. cit., s. 14.

111 P. Urbanek, http://www.wynagrodzenia.pl/wywiady_1.php/wpis.10/drukuj.1 (dostęp: 11.01.2013).

Tego rodzaju mierniki utożsamiane są z wskaźnikami rentowności eksploatacyjnej. Zob. M. H a m rol (red.), Analiza finansowa przedsiębiorstwa..., op. cit., s. 49-52.

112 Por. W. Skoczylas, Instrumenty oceny rentowności przedsiębiorstw, [w:] W. Skoc z y las (red.), Analiza sprawozdawczości finansowej przedsiębiorstwa, Stowarzyszenie Księgowych w Polsce. Zarząd Główny. Centralny Ośrodek Szkolenia Zawodowego, Warszawa 2009, s. 203-205. 
ceny, czy też rozliczania kosztów - różną wielkość w tym samym czasie i w tym samym przedsiębiorstwie. W niektórych przypadkach zysk ze sprzedaży może być zamieniony na stratę i odwrotnie. Elementami go różnicującymi są na przykład metody amortyzacji środków trwałych oraz wartości niematerialnych i prawnych. Amortyzacja liniowa, degresywna i progresywna inaczej bowiem ukształtuje wielkość kosztów w poszczególnych okresach, tym samym poziom wyniku na sprzedaży ${ }^{113}$.

Memoriałowej ocenie rentowności eksploatacyjnej powinno towarzyszyć ujęcie kasowe. Informacje zamieszczone w różnych częściach sprawozdania finansowego nie stanowią bowiem substytutów. Odzwierciedlają one określone rezultaty i procesy z wykorzystaniem odmiennych narzędzi analitycznych.

Współczynniki wydajności pieniężnej (pieniężne stopy zwrotu) powinny być analizowane wraz z współczynnikami rentowności eksploatacyjnej, stanowiących relację wyniku na sprzedaży do innych wielkości ekonomicznych przyjętych za podstawę odniesienia (w tym: kapitału własnego, aktywów ogółem, czy też przychodów netto ze sprzedaży produktów (usług), towarów i materiałów ${ }^{114}$ ).

Należy wskazać, iż przez niektórych Autorów ${ }^{115}$ współczynniki wydajności pieniężnej traktowane są wprost jako odpowiedniki współczynników rentowności - ze względu na umieszczenie w liczniku formuły obliczeniowej tzw. wyniku kasowego zamiast wyniku memoriałowego. Współczynniki wydajności gotówkowej (pieniężnej) umożliwiają ocenę pieniężnej efektywności gospodarowania przedsiębiorstwa. Ukazują one zatem relację przepływów pieniężnych netto z działalności operacyjnej do różnych podstaw odniesienia.

W zależności od wielkości zmiennej przyjętej za podstawę wyróżnia się trzy - najczęściej wykorzystywane - rodzaje współczynników wydajności pieniężnej. Należą do nich: współczynniki pieniężnej wydajności sprzedaży, pieniężnej wydajności aktywów ogółem oraz pieniężnej wydajności kapitału własnego. Tym samym przepływy pieniężne netto z działalności operacyjnej odnoszone są do wielkości, której efektywność poddana jest badaniu.

${ }^{113}$ W. S k o c zy la s, Nadwyżka pieniężna...,op. cit., s. 125 i 128.

${ }^{114} \mathrm{~W}$ przypadku, gdy przedsiębiorstwo prowadzi wielosegmentowy i wieloblokowy rachunek kosztów zmiennych, istnieje możliwość wykorzystania analizy kosztów w określaniu rentowności sprzedaży poszczególnych asortymentów produkcji. Nie należy jednakże zawsze oczekiwać rentownej działalności w wypadku każdego z produktów. Dostrzec można bowiem różnicę pomiędzy rentownością produktu w badanym okresie a rentownością w całym cyklu życia produktów. Zasadniczą przyczyną tej sytuacji jest chociażby ponoszenie przez przedsiębiorstwo wysokich kosztów w fazie rozwoju produktu. Zob. C. Ko ch alski, Rachunek $i$ analiza kosztów w controllingu operacyjnym $i$ strategicznym. Ocena tradycyjnego podejścia $i$ propozycje zmian, [w:] J. D u r aj (red.), Controlling w zarządzaniu przedsiębiorstwem, Omega Praksis, Łódź 2001, s. 144 i 149 .

${ }^{115}$ W tym m. in.: E. Śnieżek, Akademia Cash Flow - część IX, „Monitor Rachunkowości i Finansów" 2000, nr 1, s. 27; E. Dudek, Analiza wskaźnikowa na podstawie rachunku przeptywów pieniężnych, „Monitor Rachunkowości i Finansów” 2003, nr 6, s. 50-51; M. Sierpińska, T. Jachna, op. cit., s. 199-201; M. Jerzemowska (red.), Analiza..., op. cit., s. 151. 
Ważnym elementem zabezpieczenia bezpiecznego funkcjonowania przedsiębiorstwa na rynku jest również tworzenie przez nie rezerw - zarówno kosztowych, które wynikają w przepisów prawa bilansowego, jak i rezerw kapitałowych wynikających z postanowień Kodeksu spółek handlowych ${ }^{116}$. Ich zakres wywiera istotny wpływ na ocenę kondycji finansowej przedsiębiorstwa, ale również na tworzenie obrazu podmiotu troskliwie wypełniającego swoje powinności wobec interesariuszy, którymi mogą być nie tylko właściciele przedsiębiorstwa, ale także pracownicy, dostawcy, klienci czy społeczność lokalna ${ }^{117}$.

Tworzenie rezerwy stanowi przejaw racjonalnego myślenia i gospodarowania w przedsiębiorstwie. Racjonalność ta winna być utożsamiana z jego skutecznością oraz efektywnością działania, jak i z chęcią minimalizacji ryzyka ${ }^{118}$. Już sama definicja rezerw zamieszczona w ustawie o rachunkowości ${ }^{119}$,zawiera w sobie element niepewności i ryzyka. Nie sposób przeto nie wiązać tej istotnej kategorii bilansowej z ryzykiem, na jakie narażone jest każde przedsiębiorstwo prowadzące działalność gospodarczą" ${ }^{120}$. Ich wzrost w większości przypadków z pewnością jest jednoznaczny ze zmniejszeniem się tego ryzyka ${ }^{121}$.

W literaturze przedmiotu prezentowany jest pogląd, iż rezerwy:

- mają na celu zabezpieczenie jednostki przed znanym i przewidywanym ryzykiem gospodarczym oraz niepewnością, jakie dotyczą funkcjonowania jednostki gospodarczej ${ }^{122}$,

- stanowią wyraz samoubezpieczenia się przedsiębiorstwa przed ujemnymi skutkami ryzyka gospodarczego ${ }^{123}$,

- stanowią antidotum na przewidywane przez jednostkę gospodarczą ryzyko przyszłej działalności ${ }^{124}$,

- stanowią zabezpieczenie przed likwidacją lub upadłością przedsiębiorstwa, znacznego nieuzasadnionego ograniczenia jego działalności gospodarczej, czy też wyprzedażą jego części ${ }^{125}$,

${ }^{116}$ Są one również ważnym elementem zabezpieczenia rozwoju przedsiębiorstwa. Zob. A. N. Du r a j, $O$ wartości analizy..., op. cit., s. 493.

${ }_{117}$ A. N. Du raj, Gwarancyjna funkcja..., op. cit., s. 43.

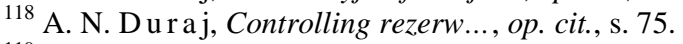

${ }^{119}$ Zgodnie z Art. 3 ust. 1 pkt 21 ustawy o rachunkowości przez rezerwy rozumie się zobowiązania, których termin wymagalności lub kwota nie są pewne. Zob. Ustawa z dnia 29 września 1994 r..., op. cit.

${ }^{120}$ [Za:] A. N. Duraj, Ryzyko i rezerwy przedsiębiorstwa, [w:] J. Duraj (red.), Wartość przedsiębiorstwa $-z$ teorii i praktyki zarzadzania, t. IV, Wydawnictwo Naukowe NOVUM Sp. z o.o., Płock-Łódź 2003, s. 227.

${ }^{121}$ Ibidem, s. 258.

${ }^{122}$ R. Ka mińs ki, Polityka bilansowa kształtowania aktywów i pasywów, „Rachunkowość - poradnik praktyczny", kwiecień 2002, nr 4, s. 17.

${ }^{123}$ A. Jaklik, Rachunkowość bankowa, Centrum Kreowania Liderów, Skierniewice 1992, s. 31 .

${ }_{124}^{124}$ M. Gmytrasiewicz, A. Karmańska, I. Olchowicz, op. cit., s. 415.

${ }^{125}$ A. N. Duraj, Ryzyko i rezerwy..., op. cit., s. 257. 
- na pewne oraz prawdopodobne straty i wydatki pozwalają na zabezpieczenie działalności gospodarczej przedsiębiorstwa przed ryzykiem bankructwa ${ }^{126}$,

- stanowią istotne narzędzie kształtowania sytuacji finansowej przedsiębiorstwa i ułatwiają zarządowi realizację zasady kontynuacji działania ${ }^{127}$,

- zwiększają płynność finansową jednostki ${ }^{128}$,

- powiązane są z koniecznością zabezpieczenia prowadzenia działalności ${ }^{129}$,

- stanowią ważny element zabezpieczenia bezpieczeństwa funkcjonowania przedsiębiorstwa na rynku, a ich tworzenie jest czynnikiem sprawczym sprawnego systemu zarządzania finansami przedsiębiorstwa ${ }^{130}$.

Rezerwy finansowe wywierają zatem istotny wpływ na funkcjonowanie przedsiębiorstwa. Niejednokrotnie decydują o przetrwania danego podmiotu na rynku. Ich zadaniem jest bowiem zapewnienie realizacji jednej z nadrzędnych zasad rachunkowości, jaką jest zasada kontynuacji działania. Brak zabezpieczenia $\mathrm{w}$ postaci rezerw może stać się podstawą utraty możliwości kontynuacji działania przez przedsiębiorstwo. Ich tworzenie - w odpowiedniej kwocie - stanowi przeto wyraz ostrożności i przezorności, jaką winien kierować się zarząd każdej jednostki gospodarczej ${ }^{131}$.

Tworzenie rezerw wynika z nadrzędnych zasad rachunkowości, którymi - oprócz wspomnianej zasady kontynuacji działania - jest również zasada ostrożności, zasada współmierności przychodów i kosztów, czy też zasada memoriału ${ }^{132}$. Powszechnie uważa się tworzenie rezerw finansowych, zwłaszcza rezerwy kapitałowej, za objaw przezornej polityki finansowej jednostki gospodarczej. Powodują one zmniejszenie zysku i dlatego kontroluje się je oraz ocenia wzajemne relacje tych rezerw do kapitałów (własnych i obcych) danej jednostki gospodarczej, wykorzystując m. in. współczynnik zabezpieczenia finansowe$\mathrm{go}^{133}$. W ujęciu memoriałowym poziom rezerw finansowych odnosi się wówczas do sumy bilansowej, co w podejściu kasowym można wyrazić poprzez zmianę

${ }^{126}$ J. J. Pringle, R. S. Harris, Essentials of Managerial Finance, Scott, Foresman and Company, Glenview-London 1987, s. 535-536.

${ }_{127}$ A. S z m e r e k i e ta, Model rachunkowości w Niemczech a wartość przedsiębiorstwa, [w:] J. Du raj (red.), Wartość przedsiębiorstwa - z teorii i praktyki zarządzania, Wydawnictwo Naukowe NOVUM Sp. z o.o., Płock-Łódź 2002, s. 336.

Jeśli przedsiębiorstwo znajduje się w sytuacji przejściowych lub długotrwałych kłopotów finansowych, a chce poprawić „na papierze” swój wynik finansowy, wówczas dokonuje ono celowego zaniżenia kwoty rezerw. Podobnie jednostka będzie postępować w sytuacji, gdy poszukuje zewnętrznych źródeł finansowania swojej działalności, tj. dla przykładu zamierza zaciągnąć kredyt. Zob. A. N. Duraj, Ksztattowanie rezerw..., op. cit., s. 74.

${ }^{128}$ A. S z merekiet a, op. cit., s. 336.

${ }^{129}$ Por. M. Wy y ch, Sprawozdania finansowe jako źródto informacji o przedsiębiorstwie i podstawa podejmowania decyzji, [w:] M. W y p y $\mathrm{ch}$ (red.), Finanse przedsiębiorstwa z elementami zarzadzania i analizy, Wydawnictwo Absolwent, Łódź 1997, s. 157.

${ }^{130}$ A. N. Du raj, Ryzyko i rezerwy..., op. cit., s. 266-267.

${ }^{131}$ A. N. Du r a j, O wartości analizy..., op. cit., s. 492-493.

${ }^{132}$ A. N. Du raj, Rezerwy w sprawozdaniach..., op. cit., s. 27-28.

${ }^{133}$ Por. M. Gmytrasiewicz, A. Karmańska, I. Olchowicz, op. cit., s. 416. 
licznika rozważanej relacji. Ze sprawozdania z przepływów pieniężnych sporządzonego metodą pośrednią można bowiem zaczerpnąc informację o korektach wyniku finansowego netto, jakim jest zmiana stanu rezerw ${ }^{134}$ i zmiana stanu rozliczeń międzyokresowych ${ }^{135}$.

Ponadto przyjęcie za A. N. Duraj założenia, iż ,kategoria rezerw na zobowiązania oraz rezerw kapitałowych winna zostać włączona do analizy sytuacji finansowo-majątkowej przedsiębiorstwa, w szczególności mając na uwadze złotą regułę bilansową czy złotą regułę finansowania"136, pozwala wyeksponować potrzebę zwrócenia uwagi na analizę krótkoterminowych rezerw finansowych w ocenie operacyjnego bezpieczeństwa finansowego.

Krótkoterminowe rezerwy finansowe mogą być uznane za narzędzie chroniące przedsiębiorstwo przed różnego rodzaju zakłóceniami ${ }^{137}$ (wewnętrznymi i/lub zewnętrznymi), jak i przeciwdziałające ich przenikaniu do przedsiębiorstwa. Z tego względu ich tworzenie można uznać za niezbędne narzędzie w procesie kształtowania i zapewniania operacyjnego bezpieczeństwa finansowego danego podmiotu gospodarczego.

Zatem operacyjne bezpieczeństwo finansowe przedsiębiorstwa zostało sprowadzone do ogółu finansowych warunków efektywnej i skutecznej kontynuacji działalności przedsiębiorstwa, który tworzą określone przychody netto ze sprzedaży produktów (usług), towarów i materiałów, płynność finansowa, rentowność eksploatacyjna i wydajność pieniężna (gotówkowa) oraz krótkoterminowe rezerwy finansowe ${ }^{138}$. Uzupełnieniem tych memoriałowych zmiennych diagnostycznych są mierniki oparte na przepływach pieniężnych netto z działalności operacyjnej (zob. tab. 1.12).

Należy jednocześnie podkreślić, iż rozważany charakter relacji memoriałowo-kasowych mierników stanowi jedynie wstępny zarys sposobów oceny operacyjnego bezpieczeństwa finansowego jednostki gospodarczej, który niewątpliwie wymaga rozwinięcia.

134 „W tej pozycji wykazuje się zmiany stanu rezerw na przyszłe zobowiązania jako różnicę między bilansem zamknięcia a bilansem otwarcia. Do pozycji tej nie wlicza się stanu rezerw na odroczony podatek dochodowy", [za:] M. S i erpińs k a, T. J a c h n a, op. cit., s. 114.

135 ,Nie wykazuje się w przepływach operacyjnych zmiany stanu ujemnej wartości firmy w roku jej powstania, a także darowizn niepieniężnych otrzymanych w postaci składników aktywów trwałych. Zmiana stanu tych rozliczeń wykazywana jest w kwocie łącznej jako saldo: saldo rozliczeń czynnych i saldo rozliczeń biernych", [za:] M. S i e r piń s k a, T. J a c h n a, op. cit., s. 115.

136 [Za:] A. N. D u r a j, O wartości analizy..., op. cit., s. 488-489.

137 Zakłócenia działalności przedsiębiorstwa:

a) zmieniają normalne warunki realizacji zasady kontynuacji i rozwoju działalności przedsiębiorstwa oraz

b) powodują konieczność wychwycenia błędów i ich naprawy - redukcji, usunięcia.

${ }^{138}$ Por. L. K a rbow n i k, Pojęcie i obszary kreowania..., op. cit., s. 76-77. 
Tabela 1.12. Zaproponowany zbiór memoriałowych i kasowych mierników oceny operacyjnego bezpieczeństwa finansowego przedsiębiorstwa ${ }^{139}$

\begin{tabular}{|c|c|c|}
\hline \multirow{2}{*}{$\begin{array}{c}\text { Główne obszary kreowania } \\
\text { i zapewniania operacyjnego } \\
\text { bezpieczeństwa finansowego } \\
\text { przedsiębiorstwa }\end{array}$} & \multicolumn{2}{|c|}{$\begin{array}{l}\text { Zasadnicze mierniki oceny operacyjnego bezpieczeństwa } \\
\text { finansowego przedsiębiorstwa w ujęciu: }\end{array}$} \\
\hline & memoriałowym & kasowym \\
\hline $\begin{array}{l}\text { Sprzedaż produktów (usług), } \\
\text { towarów i materiałów }\end{array}$ & $S_{t}$ & $O C R_{t}$ \\
\hline \multirow{3}{*}{ Płynność finansowa } & $C A_{t} / C L_{t}$ & \multirow{3}{*}{$O C F_{t} / C L_{t}$} \\
\hline & $\left(C A_{t}-I n_{t}-S D E_{t}\right) / C L_{t}$ & \\
\hline & $C_{t} / C L_{t}$ & \\
\hline \multirow{3}{*}{$\begin{array}{c}\text { Rentowność eksploatacyjna } \\
\text { i wydajność pieniężna } \\
\text { (gotówkowa) }\end{array}$} & $P o S_{t} / S_{t}$ & $O C F_{t} / S_{t}$ \\
\hline & $P O S_{t} /\left(\left(T A_{t}+T A_{t-1}\right) / 2\right)^{*}$ & $O C F_{t} /\left(\left(T A_{t}+T A_{t-1}\right) / 2\right)^{*}$ \\
\hline & $P o S_{t} /\left(\left(E_{t}+E_{t-1}\right) / 2\right)^{* *}$ & $O C F_{t} /\left(\left(E_{t}+E_{t-1}\right) / 2\right)^{* *}$ \\
\hline \multirow{3}{*}{$\begin{array}{l}\text { Krótkoterminowe rezerwy } \\
\text { finansowe }\end{array}$} & $S R r b_{t} T A_{t}$ & $\Delta S R r b_{t} T A_{t}$ \\
\hline & $O t S R_{t} / T A_{t}$ & $\Delta O t S R_{t} / T A_{t}$ \\
\hline & $S A L_{t} / T A_{t}$ & $\Delta S A L_{t} / T A_{t}$ \\
\hline
\end{tabular}

* Średnioroczny stan aktywów lepiej odzwierciedla wielkość aktywów, które były zaangażowane przy wypracowywaniu wyniku/przepływów w danym okresie obliczeniowym, więc również efektywność tychże aktywów ${ }^{140}$.

** Przeciętny stan lepiej oddaje faktyczną wysokość kapitałów własnych zaangażowanych w przedsiębiorstwie oraz lepiej realizuje zasadę współmierności. Przyczyną tego stanu jest to, iż kapitał własny zawiera w sobie również zysk roku bieżącego, który to składnik jest jego najbardziej zmienną wielkością ${ }^{141}$.

${ }^{139}$ Porównaj z memoriałowymi i kasowymi miernikami oceny bezpieczeństwa finansowego przedsiębiorstwa. Zob. L. Ka rb ow ni k, Kasowe i memoriatowe..., op. cit., s. 88-89.

${ }^{140}$ Por. W. S k oc z y las, Zakres i sposób ustalania wskaźników stosowanych do analizy finansowej przedsiębiorstw, „Rachunkowość - audytor” 2004, nr 1, s. 5.

T. Waśniewski oraz W. Skoczylas podkreślili, iż przy obliczaniu tego miernika - w celu zapewnienia zgodności licznika i mianownika - istotnym jest uwzględnienie jedynie majątku zaangażowanego w działalność operacyjną, którą można obliczyć „w oparciu o aktywną i pasywną stronę bilansu. W pierwszym przypadku, wielkość zaangażowanego majątku to suma rzeczowego majątku trwałego, wartości niematerialnych i prawnych, kapitału pracującego (bez krótkoterminowych papierów wartościowych) oraz pozostałych operacyjnych składników majątku (pomniejszonych o rezerwy na przyszłe wolne od oprocentowania zobowiązania). Przy uwzględnianiu pasywnej strony bilansu, jest ona sumą kapitału własnego i obcego oprocentowanego (kredytów bankowych, pożyczek itd.) oraz rezerw na podatek dochodowy, pomniejszona o wielkość papierów wartościowych przeznaczonych do obrotu oraz nieoperacyjnych składników majątku", [za:] T. W a śn i e w ski, W. S k o c z y la s, Cash flow w przedsiębiorstwie. Ustalanie i analiza, Fundacja Rozwoju Rachunkowości w Polsce, Warszawa 1995, s. 41-42.

W literaturze przedmiotu nie ma jednej, zgodnej formuły współczynnika pieniężnej wydajności aktywów. Największym problemem jest bowiem wskazanie najodpowiedniejszej procedury obliczania aktywów zaangażowanych w zasadniczą działalność prowadzoną przez przedsiębiorstwo Aktywa te mogą przecież być również wykorzystywane do prowadzenia innego rodzaju działalności, w tym pozostałej działalności operacyjnej, działalności finansowej czy też nadzwyczajnej.

${ }^{141}$ W. S k o c z y la s, Zakres i sposób..., op. cit., s. 7. 


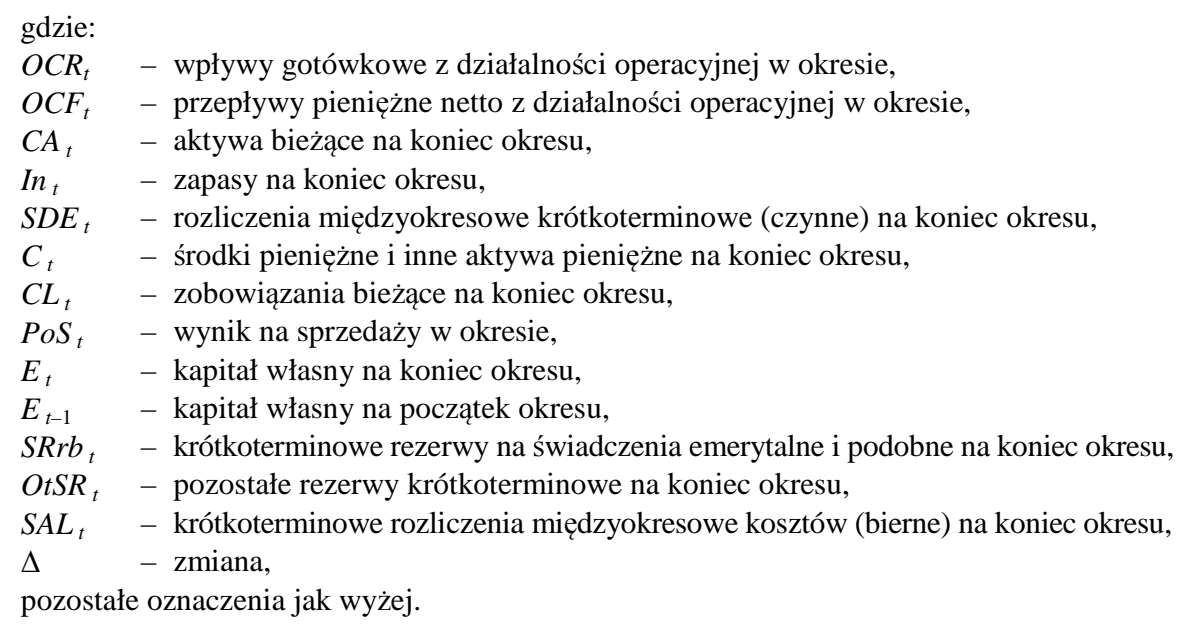

Źródło: opracowanie własne na podstawie: A. N. Duraj, Gwarancyjna funkcja rezerw finansowych przedsiębiorstwa, [w:] J. Duraj (red.), Prace z zakresu ekonomiki i zarzadzania przedsiębiorstwem, „Acta Universitatis Lodziensis”, Folia Oeconomica 200, Wydawnictwo Uniwersytetu Łódzkiego, Łódź 2006, s. 43; A. N. Du raj, Rezerwy a strategie finansowe publicznych spótek akcyjnych, Wydawnictwo Uniwersytetu Łódzkiego, Łódź 2008, s. 85-88; M. G m y trasiewicz, A. Karmańska, I. Olchowicz, op. cit., s. 416-417; W. Gos, Rachunek przeptywów pieniężnych a sterowanie płynnościa i wypłacalnością, „Rachunkowość” 2007, nr 5; M. Si r r pińska, T. J a chn a, Ocena przedsiębiorstwa wedtug standardów światowych, Wydawnictwo Naukowe PWN, Warszawa 2004, s. 93, 96, 145-149, 168-173 i 195-209; K. S tęp i é, op. cit., s. 91-158.

Mierniki te są bowiem obliczane na podstawie sprawozdania finansowego, którego niską jakość potwierdzają liczne badania. Wynika ona chociażby z prowadzonej w danym przedsiębiorstwie polityki bilansowej i możliwości alternatywnego sposobu ujmowania niektórych zjawisk w rachunkowości oraz przypisywania ich do poszczególnych okresów sprawozdawczych, a ponadto - w przypadku dużej grupy podmiotów gospodarczych (tak zwanych małych)

M. Jerzemowska wskazała, iż w celu zapewnienia współmierności licznika oraz mianownika pożądane jest uwzględnienie jedynie kapitału zaangażowanego w działalności operacyjnej. Zob. M. Je r ze mow sk a (red.), Analiza..., op. cit., s. 152.

Podobny pogląd wyrazili T. Waśniewski oraz W. Skoczylas, którzy podali jednocześnie sposób obliczenia tego kapitału. Zob. T. Waśniewski, W. Skoczylas, Cash flow..., op. cit., s. $41-42$.

W literaturze przedmiotu nie ma jednorodnej postaci współczynnika pieniężnej wydajności kapitału własnego. Największym bowiem problemem jest wskazanie najodpowiedniejszej procedury obliczania kapitałów zaangażowanych w statutową działalność przedsiębiorstwa. Kapitały te mogą przecież być również wykorzystywane do prowadzenia innego rodzaju działalności, w tym pozostałej działalności operacyjnej, działalności finansowej czy też nadzwyczajnej. 
- także z braku obowiązku badania przez biegłego rewidenta sporządzanych przez nie sprawozdań finansowych ${ }^{142}$.

Wydaje się jednak, że rozważany charakter relacji memoriałowo-kasowych mierników oceny badanego zjawiska może stanowić wystarczające instrumentarium analityczno-opisowe dla prowadzenia wstępnych badań empirycznych nad operacyjnym bezpieczeństwem finansowym przedsiębiorstwa.

${ }^{142} \mathrm{~W}$. S k o c z y las, Wskaźniki i systemy wskaźników ekonomicznych w pomiarze dokonań przedsiębiorstw, Uniwersytet Szczeciński, Szczecin 2013, s. 62. 


\section{Rozdział 2}

\section{OBSZARY DZIAŁANIA I MIERNIKI OCENY OPERACYJNEGO BEZPIECZEŃSTWA FINANSOWEGO PRZEDSIĘBIORSTW SEKTORA TSL}

\subsection{Podmioty i podstawy metodyczne oceny operacyjnego bezpieczeństwa finansowego przedsiębiorstw sektora TSL}

Najczęściej stosowanym rodzajem analizy w ocenach efektywności finansowej przedsiębiorstwa jest analiza wskaźnikowa ${ }^{1}$. Nie pozwala ona jednakże na uporządkowanie obiektów badanych ze względu na określone obserwowane cechy. Znaczne kłopoty sprawia bowiem trafna interpretacja wskaźników oraz ocena zagrożenia kontynuacji działania podmiotu gospodarczego w sytuacji, gdy jeden rodzaj wskaźników wykazuje pozytywny kierunek zmian, inny zaś - negatywny ${ }^{2}$.

Zasadniczymi ilościowymi metodami empirycznej weryfikacji sformułowanych w niniejszej monografii hipotez badawczych są - obok analizy podstawowych statystyk opisowych ${ }^{3}$ i korelacji analizowanych mierników - testy istotności różnic dla wielu prób zależnych i niezależnych, panel EGLS oraz metody wielowymiarowej analizy danych.

\footnotetext{
${ }^{1}$ Analiza wskaźnikowa jest jednym z najważniejszych obszarów analizy ekonomicznej, tj. dyscypliny naukowej - określonej i nazwanej w XVIII w. przez F. Quesnay'a (osobistego lekarza króla Francji Ludwika XV), której geneza sięga czasów starożytności. Zob. M. J e r z e mo w s k a, Przyczynek do historii analizy ekonomicznej, „Zeszyty Teoretyczne Rachunkowości” 2004, nr 20(76), Warszawa, s. 39-51; M. J e r z e mo w s ka, Analiza ekonomiczna w przedsiębiorstwie, PWE, Warszawa 2006, s. 13 i 117.

${ }^{2}$ W. Gabrus e wi c z, Analiza finansowa $w$ audycie sprawozdań finansowych, [w:] W. Gabru s e w i c z (red.), Audyt sprawozdań finansowych, PWE, Warszawa 2010, s. 156.

${ }^{3}$ Użyte zostały w tym celu najczęściej wykorzystywane w literaturze przedmiotu miary tendencji centralnej ( $\mathrm{tj}$. średnia arytmetyczna i mediana), bezwzględna miara zróżnicowania ( $\mathrm{tj}$. odchylenie standardowe), czy też względna miara zróżnicowania (tj. współczynnik zmienności).
} 
Test istotności różnic dla wielu prób zależnych (tj. test Friedmana) ${ }^{4}$ oraz dla wielu prób niezależnych (test Kruskala-Wallisa $)^{5}$ - jako nieparametryczne odpowiedniki testu $\mathrm{t}^{6}$ - zastosowane zostały $\mathrm{z}$ uwagi na brak występowania rozkładu normalnego w badanych zmiennych diagnostycznych. Ich wykorzystanie przyczyniło się do wykrycia różnic pomiędzy średnimi analizowanych mierników odpowiednio w całym badanym okresie (tj. latach 2004-2012) lub w kilku homogenicznych (ze względu na określone kryterium pomiaru) grupach podmiotów gospodarczych ${ }^{7}$. Choć są one mało popularne i rzadko stosowane jako narzędzie statystycznej analizy danych empirycznych, to nie wymagają spełnienia licznych założeń (jak ma to miejsce w klasycznej analizie wariancji). Nadto, nie wymagają one przeprowadzenia ,żmudnych" i pracochłonnych obliczeń, które można wykonać przy użyciu popularnych programów komputerowych, np. Microsoft Excel, Statistica oraz SPSS Statistics ${ }^{8}$.

Dodatkowo - w celu połączenia dwóch rodzajów badań (tj. w czasie i w przestrzeni) - została wykonana analiza danych panelowych ${ }^{9}$ do estymacji modelu objaśniającego poziom operacyjnego bezpieczeństwa finansowego badanych spółek sektora TSL.

Od pewnego czasu - zwłaszcza wśród ekonomistów - znacznie bowiem wzrosło zainteresowanie metodami analizy danych panelowych. Wynika to m. in.:

\footnotetext{
${ }^{4}$ Założenia i sposób obliczania testu Friedmana zaprezentowane są w: M. Maliński, Wybrane zagadnienia statystyki matematycznej w EXCELU i pakiecie STATISTICA, Wydawnictwo Politechniki Śląskiej, Gliwice 2010, s. 160-174.

${ }^{5}$ Założenia i sposób obliczania testu Kruskala-Wallisa zaprezentowane są w: M. Maliń ski, op. cit., s. 187-197.

${ }^{6}$ Nieparametryczne odpowiedniki testów t stosowane są m. in. wtedy, gdy zmienna mierzona jest na skali porządkowej lub wtedy, gdy zmienna zależna ma ilościowy poziom pomiaru, ale analizowane dane nie spełniają założeń przewidzianych dla testów parametrycznych, w tym założenie mówiące o rozkładzie normalnym.

Badana próba przedsiębiorstw liczyła 29 podmiotów gospodarczych - wobec tego w celu analizy zgodności rozkładu zmiennej $\mathrm{w}$ danej grupie przedsiębiorstw $\mathrm{z}$ określonym rozkładem teoretycznym wykorzystano test normalności Shapiro-Wilka. Na podstawie wyników tego testu odrzucono hipotezę o normalności rozkładu.

${ }^{7} \mathrm{~W}$ przypadku wykonywania analizy POST-HOC - w interpretacji wyników brana była pod uwagę ,istotność skorygowana”.

${ }^{8}$ Por. A. Majka, D. Jankow ska, Zastosowanie testu Kruskala-Wallisa jako alternatywy analizy wariancji w badaniach ekonomiczno-spotecznych, [w:] Rola informatyki w naukach ekonomicznych i społecznych, ,Zeszyty Naukowe WSH w Kielcach”, seria 5a, Wydawnictwo Świętokrzyskie Centrum Edukacji na Odległość WSH w Kielcach, Kielce 2007, s. 447-452; S. B e d y ńska, A. Brzezicka (red.), Statystyczny drogowskaz. Praktyczny poradnik analizy danych w naukach spotecznych na przykładach z psychologii, Wydawnictwo SWPS Academica, Warszawa 2007, s. 202-203.

${ }^{9}$ Dane panelowe to pewna liczba szeregów czasowych, z których każdy zawiera informację o wartości pewnej zmiennej (zmiennych) dla określonej jednostki w kolejnych okresach, [za:] M. Gru s z c z y ń ski (red.), Mikroekonometria. Modele i metody analizy danych indywidualnych, Wolters Kluwer Polska Sp. z o.o., Warszawa 2012, s. 267.
} 
- ze zwiększenia liczby dostępnych obserwacji w stosunku do danych przekrojowych, a jednocześnie redukuje (choć oczywiście nie eliminuje) problemy typowe dla analizy szeregów czasowych (jako, że T dla panelu jest najczęściej znacznie mniejsze niż w badaniach opartych na pojedynczym szeregu),

- z możliwości uzyskania dodatkowych informacji o badanej zbiorowości,

- z tego, iż wykorzystanie panelu umożliwia usunięcie obciążenia estymatora w związku z pominięciem ważnego czynnika (na skutek błędu pominiętych zmiennych) ${ }^{10}$.

Wskazane powyżej zalety analizy danych panelowych - przy wadach mających głównie techniczny charakter (tj. długi okres zbierania danych, wysokich kosztów ich pozyskania i kłopotów logistycznych, a także braków danych np. na skutek odmowy dalszego uczestnictwa ankietowanego w badaniach) - świadczą o znaczącej przewadze tego typu analiz nad badaniami, w których wykorzystywane są dane ,jednowymiarowe" (tj. szeregi czasowe lub dane przekrojowe) ${ }^{11}$.

Analizy zostały przeprowadzone na panelu zbilansowanym ${ }^{12}$, a dla weryfikacji sformułowanych w niniejszym opracowaniu hipotez wykorzystana została panelowa ważona Metoda Najmniejszych Kwadratów (ang. Panel EGLS) dla danych połączonych ze stałymi wagami w obrębie poszczególnych przedsiębiorstw (ang. Cross-section Weights) ${ }^{13}$.

W badaniach empirycznych wykorzystane zostały również metody badania przestrzennego zróżnicowania obiektów wielocechowych, które można podzielić na ${ }^{14}$ :

- klasyfikację - tj. grupowanie obiektów w celu utworzenia ich jednorodnych klas ze względu na wewnętrzne zróżnicowanie badanych cech (zmiennych diagnostycznych), a tym samym na badane zjawisko jakim jest w niniejszym opracowaniu operacyjne bezpieczeństwa finansowe przedsiębiorstwa,

- porządkowanie obiektów (spółek) - sprowadzające się do konstrukcji syntetycznego miernika rozwoju obrazującego zróżnicowanie obiektów w zakresie przedmiotowego zjawiska tj. badanych podmiotów gospodarczych sektora TSL w zakresie operacyjnego bezpieczeństwa finansowego.

${ }^{10}$ M. Gru s z c z y ń s ki (red.), Mikroekonometria..., op.cit., s. 267-270.
${ }^{11}$ Ibidem, s. 270.
${ }^{12}$ Zbiór danych, w którym o każdej z N jednostek dysponujemy pełnymi danymi z T okresów.
${ }^{13}$ Zob. szerzej m. in.: B. H. B a l t a g i, Econometric Analysis of Panel Data, $3^{\text {rd }}$ Edition, John Wiley \& Sons, 2005; T. Kufel, Ekonometria. Rozwiazywanie problemów z wykorzystaniem programu GRETL, Wydawnictwo Naukowe PWN, Warszawa 2011, s. 173-180; G. Manolas, K. Rontos, G. Sfakianakis, I. Vavouras, The Determinants of the Shadow Economy: The Case of Greece, ,International Journal of Criminology and Sociological Theory”, January 2013, Vol. 6, No. 1, s. 1036-1047; D. S arpong (Jr), E. Ch. W in fu 1, J. N ti a mo ah, Determinants of wide interest margins in Ghana: Panel EGLS analysis, „African Journal of Business Management”, September 2013, Vol. 7(35), s. 3535-3544; M. Gruszczyński (red.), Mikroekonometria..., op. cit., s. 267-306.

${ }^{14}$ A. Młodak, Analiza taksonomiczna $w$ statystyce regionalnej, Centrum Doradztwa i Informacji Difin Sp. z o.o., Warszawa 2006, s. 8 i 47. 
Wśród pierwszej grupy metod wyróżnić można analizę skupień obejmującą szereg różnych metod klasyfikacji ${ }^{15}$. Przez skupienie rozumie się zbiór obserwacji (np. przedsiębiorstw), „podobnych” do siebie, przy czym obserwacje należące do dwóch różnych skupień powinny różnić się między sobą w sposób istotny.

Celem tej analizy jest organizowanie obserwowalnych danych w określone struktury lub grupy poprzez analizę podobieństw w obszarach poddanych badaniu. Podobieństwa pomiędzy obiektami (spółkami) zostają wyznaczone na podstawie odpowiedniej miary podobieństwa, czy też odległości ${ }^{16}$.

Analiza skupień umożliwia przedstawienie wyników grupowania w postaci dendrogramu, który ilustruje kolejne połączenia skupień coraz to wyższego rzędu. Uzyskana hierarchia pozwala na określenie wzajemnego położenia skupień i obiektów (podmiotów) w nich zawartych. Daje również możliwość ustalenia średnich wartości zmiennych diagnostycznych dla wyłonionych w jej trakcie homogenicznych grup jednostek gospodarczych.

Opisana metoda wielowymiarowej analizy danych daje możliwość porównania zjawiska opisanego przez wiele mierników, co w dużym stopniu obiektywizuje ocenę, a tym samym proces porównania rozważanych w niniejszym opracowaniu podmiotów gospodarczych.

Dla określenia poziomu operacyjnego bezpieczeństwa finansowego badanych spółek wykorzystano również metodę porządkowania liniowego ${ }^{17}$. Jest ona jedną z uniwersalnych metod wielowymiarowej analizy porównawczej, która przyczynia się na podstawie wyników analizy fundamentalnej do budowania baz danych na potrzeby analizy portfelowej (zob. schemat 2.1$)^{18}$.

Rozwiązaniem o podłożu metodycznym istotnej wady tradycyjnej analizy finansowej, jaką jest ograniczona możliwość powiązania i kompleksowej interpretacji wskaźników finansowych, może być stworzenie jednej miary agregatowej na podstawie zestawu mierników, opisujących różne aspekty zdolności przedsiębiorstwa do uzyskania i utrzymania dobrego standingu finansowego, rynkowego, produkcyjnego i kadrowego. Skonstruowany zatem został tzw. tak-

${ }^{15} \mathrm{~W}$ tym m. in.: A. S tan is z, Przystepny kurs statystyki z zastosowaniem STATISTICA PL na przykładach medycyny. Tom 3. Analizy wielowymiarowe, StatSoft Polska Sp. z o.o., Kraków 2007, s. 113-163 oraz T. Marek, Analiza skupień w badaniach empirycznych. Metody SAHN, Wydawnictwo Naukowe PWN, Warszawa 1989, s. 9-166.

${ }^{16} \mathrm{~J}$. S u c h e c ka, E. W is z n i e w s k a, Taksonomiczna ocena poziomu realizacji polityki ekologicznej w krajach EU, [w:] M. Zaw ad a (red.), Zastosowanie metod ilościowych w badaniach ekonomiczno-społecznych, Wydawnictwo Politechniki Częstochowskiej, Częstochowa 2007, s. 162.

${ }^{17}$ Przeprowadzona analiza zmierza do uporządkowania obiektów wielocechowych, a tym samym do odnalezienia jednostki gospodarczej o najwyższym, jak i najniższym poziomie operacyjnego bezpieczeństwa finansowego.

Szczegółowa metodyka badań została przedstawiona m. in. przez: M. Kolenda, Taksonomia numeryczna. Klasyfikacja, porzadkowanie i analiza obiektów, Wydawnictwo Akademii Ekonomicznej im. Oskara Langego we Wrocławiu, Wrocław 2006, s. 21-40 i 331-353.

${ }^{18}$ M. Łuniewska, Ekonometria finansowa. Analiza rynku kapitałowego, Wydawnictwo Naukowe PWN, Warszawa 2008, s. 98. 
sonomiczny wzorzec rozwoju, czyli sztuczny obiekt odniesienia, de facto idealistycznie ukształtowany obiekt, charakteryzujący się pewnymi optymalnymi właściwościami. Do stanu tego obiektu - wyrażonego za pomocą określonych zmiennych diagnostycznych - przyrównano sytuację rzeczywistych analizowanych podmiotów gospodarczych, ustalając jak bardzo każdy z nich jest odległy od tego poziomu, który w założeniu powinny one osiągnać.

Stworzona miara agregatowa przyjmowała wartości z przedziału [0;1], przy czym wyższe jej wartości należy interpretować jako korzystniejszy poziom operacyjnego bezpieczeństwa finansowego badanych spółek sektora TSL ${ }^{19}$.

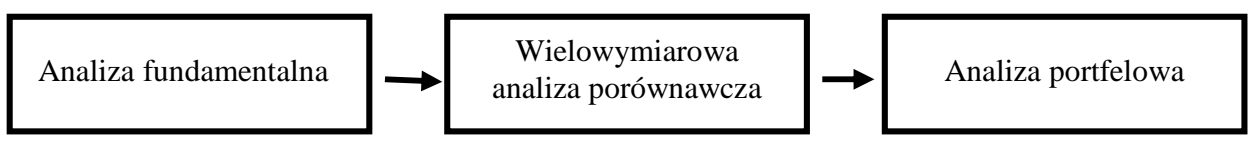

Schemat 2.1. Powiązanie analizy fundamentalnej z analizą portfelową

Źródło: M. Łuniewska, Ekonometria finansowa. Analiza rynku kapitałowego, Wydawnictwo Naukowe PWN, Warszawa 2008, s. 98.

Kolejną metodą wielowymiarowej analizy danych, która przychodzi w sukurs tradycyjnej analizie wskaźnikowej badania operacyjnego bezpieczeństwa $\mathrm{i} /$ lub zagrożenia finansowego, jest $\mathrm{m}$. in. analiza dyskryminacyjna ${ }^{20}$. Jej zastosowanie dla realizacji celu monografii tworzyć może szanse na opracowanie modelu dyskryminacyjnego, pełniącego m. in. funkcje miernika wczesnego ostrzegania lub wskaźnika oceny ryzyka kredytowego ${ }^{21}$.

Analiza dyskryminacyjna stosowana jest do rozstrzygania, które zmienne diagnostyczne pozwalają w najlepszy sposób dzielić daną grupę przedsiębiorstw na występujące w naturalny sposób ich podgrupy. Przyczynia się ona tym samym do określenia kryteriów, dzięki którym możliwe jest ich podzielenie, zaś po dokonaniu takiego podziału - technika ta pozwala na zaliczenie do wybranych klas nowych danych (przedsiębiorstw), pojawiających się na późniejszych etapach analizy ${ }^{22}$. Istotną cechą modeli dyskryminacyjnych jest ponadto możliwość określenia siły wpływu poszczególnych zmiennych objaśniających na kształtowanie się zmiennej objaśnianej ${ }^{23}$ (zob. też tab. 2.1).

${ }^{19}$ Wartości te są tym wyższe, im dany obiekt jest mniej oddalony od wzorca, zatem im wyższa jest jego wartość, tym wyższy jest poziom operacyjnego bezpieczeństwa finansowego przedsiębiorstw.

${ }^{20}$ Założenia analizy dyskryminacyjnej zostały zaprezentowane m. in. w: A. Stanisz, op. cit., s. 108-112; B. Prusak, Nowoczesne metody prognozowania zagrożenia finansowego przedsiębiorstw, Centrum Doradztwa i Informacji Difin Sp. z o.o., Warszawa 2005, s. 10-52.

${ }^{21}$ B. Prusak, op. cit., s. 8.

${ }^{22}$ A. S tanis z, op. cit., s. 9 i 15.

${ }^{23}$ B. Prusak, op. cit., s. 51-52. 
Tabela 2.1. Zalety i wady liniowej wielowymiarowej analizy dyskryminacyjnej

\begin{tabular}{|c|c|}
\hline Zalety & Wady \\
\hline $\begin{array}{l}\text { Metoda od bardzo dawna stosowana w obsza- } \\
\text { rze prognozowania zagrożenia finansowego } \\
\text { przedsiębiorstw. }\end{array}$ & "Niestabilność modeli z punktu widzenia czasu. \\
\hline Zrozumiała. & Brak ujęcia dynamicznego. \\
\hline $\begin{array}{l}\text { Istnieje możliwość uwzględnienia wielu } \\
\text { zmiennych jednocześnie poprzez przypisanie } \\
\text { im odpowiednich wag. }\end{array}$ & $\begin{array}{l}\text { Wymagana jest znajomość prawdopodobieństwa } \\
\text { a priori populacji oraz kosztów błędów I i II } \\
\text { rodzaju. }\end{array}$ \\
\hline $\begin{array}{l}\text { Przekształcenie wielowymiarowej przestrzeni } \\
\text { w jeden wymiar, w którym na podstawie } \\
\text { określonego miernika dokonuje się oceny } \\
\text { sytuacji przedsiębiorstwa. }\end{array}$ & $\begin{array}{l}\text { Założenie normalności rozkładu poszczególnych } \\
\text { zmiennych objaśniających. }\end{array}$ \\
\hline $\begin{array}{l}\text { Istnieje możliwość - choć w ograniczony } \\
\text { sposób - określenia wpływu poszczególnych } \\
\text { zmiennych objaśniających na kształtowanie } \\
\text { się zmiennej objaśnianej. Należy pamiętać, że } \\
\text { wprowadzanie dodatkowych zmiennych do } \\
\text { modelu może jednakże powodować zmianę } \\
\text { siły wpływu dotychczasowych zmiennych. } \\
\text { Z tego wynika, że nie zawsze na podstawie } \\
\text { modeli oszacowanych za pomocą liniowej } \\
\text { wielowymiarowej analizy dyskryminacyjnej } \\
\text { można określić, która ze zmiennych objaśnia- } \\
\text { jących ma największy wpływ, z punktu wi- } \\
\text { dzenia badanego zjawiska. }\end{array}$ & $\begin{array}{l}\text { Zakłada się liniową zależność między wskaźni- } \\
\text { kiem Z-Score a sytuacją finansową jednostki. } \\
\text { W rzeczywistości zależność między wieloma } \\
\text { zmiennymi objaśniającymi (w tym wskaźnikami } \\
\text { finansowymi) a kondycją przedsiębiorstwa jest } \\
\text { nieliniowa, co przyczynia się do tego, że zależ- } \\
\text { ność między Z-Score a standingiem firmy bę- } \\
\text { dzie również nieliniowa. Dlatego m. in. pojawa } \\
\text { się problem związany z rangowaniem przedsię- } \\
\text { biorstw na podstawie miernika Z-Score. }\end{array}$ \\
\hline $\begin{array}{l}\text { Uzyskiwanie wysokich ocen trafności klasy- } \\
\text { fikacji obiektów w porównaniu do innych } \\
\text { alternatywnych metod, zastosowanych } \\
\text { w obszarze prognozowania zagrożenia finan- } \\
\text { sowego przedsiębiorstw. }\end{array}$ & $\begin{array}{l}\text { Wystąpienie braków w danych opisujących } \\
\text { obiekt uniemożliwia przeprowadzenie prawi- } \\
\text { dłowej klasyfikacji obiektu. }\end{array}$ \\
\hline $\begin{array}{l}\text { Wiele programów statystycznych wyposażo- } \\
\text { nych jest w moduł analizy dyskryminacyjnej. }\end{array}$ & $\begin{array}{l}\text { Założenie o równości macierzy wariancji/kowa- } \\
\text { riancji poszczególnych grup obiektów. }\end{array}$ \\
\hline- & $\begin{array}{l}\text { Uzyskiwanie w wielu przypadkach gorszych } \\
\text { wyników klasyfikacji w porównaniu do sztucz- } \\
\text { nych sieci neuronowych i analizy logitowej. }\end{array}$ \\
\hline- & $\begin{array}{l}\text { Wykorzystywana jest do budowy modeli klasy- } \\
\text { fikacyjnych. Nie pozwala bezpośrednio na usta- } \\
\text { lenie prawdopodobieństwa upadłości. }\end{array}$ \\
\hline
\end{tabular}

Źródło: B. Prusak, Nowoczesne metody prognozowania zagrożenia finansowego przedsiębiorstw, Centrum Doradztwa i Informacji Difin Sp. z o.o., Warszawa 2005, s. 62.

Wykorzystanie w niniejszej monografii drzew klasyfikacyjnych ${ }^{24}$ jest uzasadnione m. in. potrzebą wyznaczenia przynależności przypadków (obiektów,

${ }^{24}$ Założenia zostały zaprezentowane m. in. w: http://www.statsoft.pl/textbook/stathome.html (dostęp: 02.01.2013). 
tj. spółek) do klas jakościowej zmiennej zależnej, na podstawie wartości jednej albo więcej zmiennych predykcyjnych (tj. zmiennych niezależnych). Drzewa te są bowiem metodami opisowymi oraz eksploracyjnymi, pozwalającymi wydobyć i wykorzystać ,ukrytą” informację zawartą w analizowanych danych ${ }^{25}$ (zob. tab. 2.2).

Tabela 2.2. Zalety i ograniczenia drzew klasyfikacyjnych

\begin{tabular}{|l|l|}
\hline \multicolumn{1}{|c|}{ Zalety } & \multicolumn{1}{|c|}{ Ograniczenia } \\
\hline $\begin{array}{l}\text { Brak jakichkolwiek założeń wstępnych dotyczą- } \\
\text { cych rozkładów danych. }\end{array}$ & Ryzyko dużej złożoności drzewa. \\
\hline $\begin{array}{l}\text { Czytelność i prostota algorytmu, ułatwiająca } \\
\text { stosowanie go ze zrozumieniem nawet osobom } \\
\text { bez dużego doświadczenia w analizie danych. }\end{array}$ & $\begin{array}{l}\text { Trudność w aktualizacji już istniejącego drzewa } \\
\text { po dodaniu nowych przypadków (choć niektóre } \\
\text { algorytmy realizują to zadanie). }\end{array}$ \\
\hline $\begin{array}{l}\text { Możliwość odkrycia łatwych w interpretacji } \\
\text { reguł. }\end{array}$ & $\begin{array}{l}\text { Zaktualizowane drzewo ma zazwyczaj mniejszą } \\
\text { precyzję niż drzewo zbudowane na nowo. }\end{array}$ \\
\hline $\begin{array}{l}\text { Odporność na nietypowe wartości predykatorów } \\
\text { (tj. zmiennych niezależnych). }\end{array}$ & $\begin{array}{l}\text { Służą tylko do przyporządkowania rozpatrywa- } \\
\text { nego przypadku do jednej z wcześniej wytypo- } \\
\text { wanych grup }{ }^{26} \text {. }\end{array}$ \\
\hline $\begin{array}{l}\text { Odporność na nawet dużą liczbę predykatorów } \\
\text { faktycznie niewpływających na badaną zmienną. }\end{array}$ & - \\
\hline $\begin{array}{l}\text { Wysoka efektywność procesu klasyfikacji nawet } \\
\text { dla dużych zbiorów danych. }\end{array}$ & - \\
\hline Szybkość działania. & - \\
\hline $\begin{array}{l}\text { Wysoka użyteczność w przypadku skorelowa- } \\
\text { nych ze sobą danych. }\end{array}$ & \multicolumn{1}{|c|}{-} \\
\hline
\end{tabular}

Źródło: opracowanie własne na podstawie: www.statsoft.pl; A. Matuszczyk, Przygladając się kredytobiorcom, „Bank” 2003, nr 2, s. 55 i nast.; M. Gro ma d a, Zalety i ograniczenia drzew klasyfikacyjnych. Klasyfikator SLIQ, 2003, s. 8, multifraktal.net/seminarium/sliq.pdf (dostęp: 26.05.2013); I. H. Ek ķ i, Classification of Firm Failure with Classification and Regression Trees, „International Research Journal of Finance and Economics” 2011, Issue 76, s. 113-120; http://magazyn.wsinf.edu.pl/files/wded/wstep\%20do\%20klasyfikacji\%20danych.pdf (dostęp: 24.04.2010).

Dzięki drzewom klasyfikacyjnym możliwe jest wyjaśnienie oraz przewidywanie kształtowania się kategorialnej zmiennej zależnej (np. odpowiedzi typu „tak” - „nie”, czy też ,spółka upadła” - „spółka niezagrożona upadłością”) poprzez zestaw rozmaitych zmiennych niezależnych (zarówno ciągłych (np. przychody), jak i kategorialnych). Właściwością drzew klasyfikacyjnych jest ich hierarchiczność oraz elastyczność w stosowaniu. Pierwsza cecha powiązana jest z matematycznym algorytmem pozyskiwania współczynników równań klasyfi-

${ }^{25}$ www.statsoft.pl.

${ }^{26}$ Często przedmiotem prognozy jest prawdopodobieństwo wystąpienia danego zjawiska (np. szacowanie stopnia rzetelności kredytobiorcy), a nie tylko dokonanie klasyfikacji (tj. sklasyfikowanie go jako rzetelnego, bądź nie). 
kacyjnych, który w tej metodzie jest oparty na zasadzie ,jeżeli ... to”, zaś drugą cechą metody jest elastyczność ${ }^{27}$.

Wzajemne relacje między zmienną zależną oraz zmiennymi niezależnymi mogą być wielorakie. Analiza za pomocą drzew klasyfikacyjnych jest poprawna zarówno dla dwukategorialnej zmiennej zależnej oraz wielu zmiennych niezależnych, jak również wielokategorialnej zmiennej zależnej oraz niewielkiej liczby predykatorów (tj. zmiennych niezależnych) ${ }^{28}$.

Drzewa klasyfikacyjne działają na zasadzie rekurencyjnego podziału zbiorów (w tym przypadku badanych spółek sektora TSL) na coraz mniejsze podzbiory ze względu na wartość zmiennych wybranych do klasyfikacji. Podzbiory są rozgałęziane na coraz mniejsze podzbiory, aż do pewnego - określonego przez analityka - momentu ${ }^{29}$.

Uzyskane reguły diagnostyczne $\mathrm{w}$ trakcie tworzenia drzew klasyfikacyjnych są na ogół proste $\mathrm{w}$ interpretacji, a ich graficzna i przejrzysta prezentacja ułatwia proces oceny badanego zjawiska.

Szeroki wachlarz stosowanych procedur weryfikacji zestawu cech opisujących badane zjawisko (jakim w monografii jest poziom operacyjnego bezpieczeństwa finansowego przedsiębiorstwa), konstrukcji mierników kompleksowych, grupowania i oceny jego efektywności sprzyja nie tylko obiektywnemu oraz pełniejszemu poznaniu rzeczywistości, ale i podejmowaniu trafnych decyzji ${ }^{30}$.

Dzięki nim możemy m. in. ocenić poziom udziału każdego przedsiębiorstwa w „rozwoju” całej ich zbiorowości, dokonać graficznej wizualizacji problemu, czy też określić spójność, wewnętrzną jednorodność i stabilność otrzymanego grupowania $^{31}$.

Ocena dokonywana przy wykorzystaniu metod wielowymiarowej analizy porównawczej powinna być jednakże pogłębiona analizą ekonomiczną, czy też badaniem elementów o charakterze pozabilansowych (tzw. jakościowych). Tego rodzaju podejście prowadzi do bardziej precyzyjnego i obiektywnego wyjaśniania zjawisk o charakterze ilościowym ${ }^{32}$, którym - w niniejszej monografii - jest poziom operacyjnego bezpieczeństwa finansowego przedsiębiorstw sektora TSL.

Podmioty gospodarcze prowadzące działalność transportową w 2009 r. po raz pierwszy pojawiły się w „,czołówce” upadłych podmiotów gospodarczych. $\mathrm{W}$ tego rodzaju statystykach przedsiębiorstwa transportowe $\mathrm{w}$ pierwszym półroczu 2009 r. stanowiły ponad 40\% ogółu tych, które wykonują działalność

\footnotetext{
${ }^{27}$ www.statsoft.pl.

${ }^{28}$ Ibidem.

${ }^{29} \mathrm{http}: / /$ magazyn.wsinf.edu.pl/files/wded/wstep\%20do\%20klasyfikacji\%20danych.pdf (dostęp: 03.03.2011).

${ }^{30}$ Por. A. Młoda k, op. cit., s. 222.

31 Ibidem, s. 26.

${ }^{32}$ Por. P. Ant on ow ic z, Metody oceny i prognoza kondycji ekonomiczno-finansowej przedsiębiorstw, Ośrodek Doradztwa i Doskonalenia Kadr Sp. z o.o., Gdańsk 2007, s. 47.
} 
usługową ${ }^{33}$. Informacja ta stała się zasadniczą inspiracją doboru spółek z sektora TSL (transport, spedycja i logistyka) ${ }^{34}$ do podejmowanych przez Autorkę badań naukowych.

Dodatkowym argumentem - przemawiającym za dokonanym doborem tych podmiotów gospodarczych - jest próba pełniejszego wyjaśnienia i poznania specyfiki warunków działania tego sektora. Mam tutaj na uwadze m. in.:

- istniejący system wielokrotnych powiązań i współzależności między stroną podażową i popytową,

- polaryzację rynku między dużymi sieciowymi operatorami logistycznymi - nie obciążonymi aktywami, a małymi i mikro przedsiębiorstwami, lepiej absorbującymi koszty obsługi floty (te pierwsze w okresie ostatniego kryzysu potrafiły bowiem zwiększyć marże zysku kosztem swoich podwykonawców).

Do zasadniczych badań empirycznych przyjęto z wyłonionych 144 przedsiębiorstw z sektora TSL zlokalizowanych w obrębie warszawskiego KRS ${ }^{35}$ jedynie 33 spółki (zob. wykres 2.1). Spełniły one cztery następujące kryteria doboru jednostek do badań, $\mathrm{tj}^{36}$ :

a) prowadziły działalność w sposób ciągły przez cały analizowany okres, tj. w latach $2004^{37}-2010^{38}$,

b) składały jednostkowe sprawozdania finansowe (w tym sprawozdanie z przepływów pieniężnych) w Krajowym Rejestrze Sądowym w Warszawie przez cały okres poddany analizie,

${ }^{33}$ Por. A. St e fań s k a, Polskie firmy transportowe coraz blizej katastrofy, „Rzeczpospolita” 2009, nr 247, s. B6.

${ }^{34} \mathrm{~W}$ ramach prowadzonej usługowej działalności przedsiębiorstw sektora TSL wyróżnić możemy spółki, których głównym źródłem przychodu jest:

- transport (tj. przedsiębiorstwa transportowe),

- spedycja (tj. przedsiębiorstwa spedycyjne),

- logistyka (tj. przedsiębiorstwa logistyczne),

- usługi kurierskie (tj. przedsiębiorstwa kurierskie).

Zob. P. S zreter, Lista obecności w branży transportowej, „Truck\&Business Polska” 2010, nr 3, s. 52-69.

${ }^{35} \mathrm{~W}$ warszawskim KRS wystąpiła największa liczba tychże podmiotów gospodarczych.

${ }^{36}$ Pierwsze 3 kryteria spełniło 40 spółek.

Dobór próby nie miał charakteru czysto losowego. Rozpatrywane zostały tylko te przedsiębiorstwa, które sporządzały i składały w odpowiednim dla siebie Krajowym Rejestrze Sądowym sprawozdanie z przepływów pieniężnych.

W niniejszym opracowaniu nie uwzględniono zróżnicowania przedsiębiorstw na tle sektora, w tym m. in. pod względem polityki sprzedaży i marketingu, wieku aktywów, czy sposobu współpracy z dostawcami. Zob. C. Koch alski, Przydatność standardowej analizy wskaźnikowej przy ocenie wyników dziatalności spótek giełdowych, [w:] D. Zar z e c ki (red.), Zarzadzanie finansami: mierzenie wyników $i$ wycena przedsiębiorstw, t. 1, Wydawnictwo Uniwersytetu Szczecińskiego, Szczecin 2003, s. 65.

${ }^{37}$ Wybrany okres badawczy wynika z faktu, iż w 2004 r. miała miejsce zasadnicza nowelizacja ustawy o rachunkowości.

${ }^{38}$ Brak w Krajowym Rejestrze Sądowym w Warszawie na dzień 1 września 2012 r. sprawozdań finansowych za 2011 r. dla 13 z 33 badanych podmiotów gospodarczych. 
c) dzień bilansowy przypadał na 31 grudnia w każdym roku całego okresu badawczego, $\mathrm{sie}^{39}$.

d) wykazywały dodatnią wartość kapitału własnego w całym badanym okre-

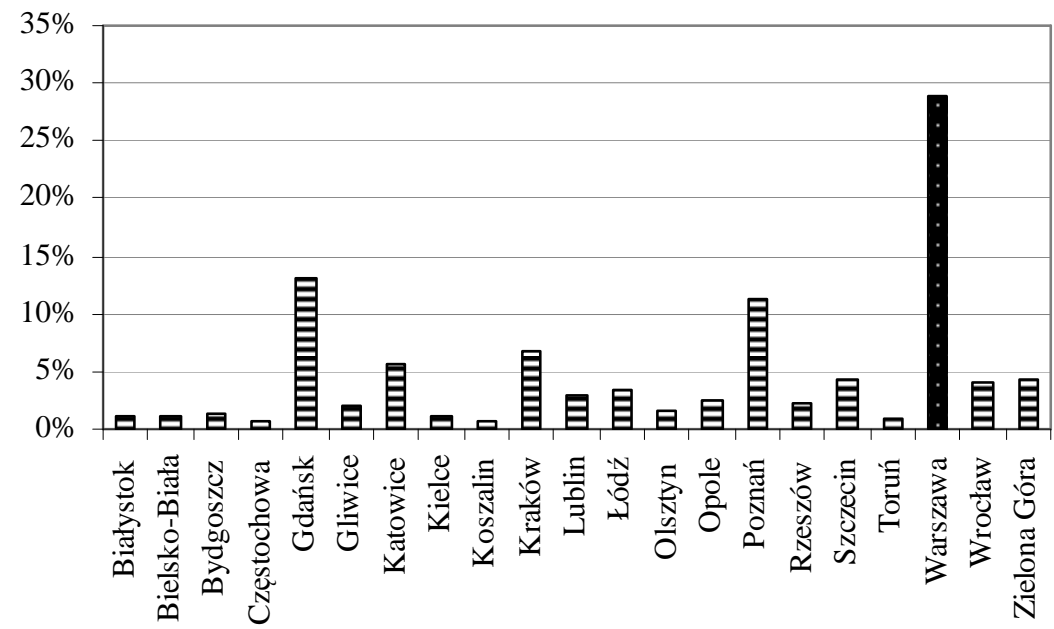

Wykres 2.1. Struktura podmiotów gospodarczych z sektora TSL wykazanych w rankingu TOP 500 według poszczególnych KRS

Źródło: obliczenia własne na podstawie: P. Szreter, Lista obecności $w$ branży transportowej, ,Truck\&Business Polska” 2010, nr 3, s. 52-69.

Z ogólnej liczby 33 spółek do docelowej analizy - w wyniku aktualizacji badań empirycznych o dwa kolejne lata (tj. za lata 2011-2012) - zostało zaklasyfikowanych jedynie 29 przedsiębiorstw $^{40}$ (zob. zał. 2), z czego $5 \mathrm{z}$ nich reali-

${ }^{39} \mathrm{Z}$ uwagi na fakt, iż trudności interpretacyjnych nastręcza sytuacja, gdy kapitały własne przedsiębiorstwa - na skutek generowania wysokich strat - mają ujemną wartość (w szczególności, gdy w przypadku posiadania negatywnych kapitałów własnych podmiot generuje stratę w bieżącym okresie), sugeruje się uwzględnienie wartości bezwzględnej kapitałów własnych lub nieliczenie wskaźnika. Por. M. Marcinkowska, Ocena dziatalności instytucji finansowych, Centrum Doradztwa i Informacji Difin Sp. z o.o., Warszawa 2007, s. 268.

Ujemny kapitał własny jest oczywistym symptomem zagrożenia bankructwem. Zob. Lista 500 największych firm - INE PAN, ,Parkiet”, maj 2003.

Wartość majątku przedsiębiorstwa jest niższa od jego długów.

${ }^{40}$ Autorce nie udało się bowiem na dzień 30 września 2014 r. pozyskać danych dla spółek:

- Zasada Logistyka Sp. z o.o., z uwagi na brak danych finansowych za lata 2011-2012 w bazie Info Veriti Polska Sp. z o.o. (spółka nieaktywna na dzień 30 września 2014 r.) oraz w Krajowym Rejestrze Sądowym w Warszawie,

- Link Sp. z o.o. oraz Przedsiębiorstwo Wielobranżowe Podkowa Sp. z o.o., z uwagi na brak na dzień 30 września 2014 r. sprawozdania z przepływów pieniężnych za 2012 r. w dokumentacji spółki złożonej w Krajowym Rejestrze Sądowym w Warszawie, 
zowało głównie działalność spedycyjną, 11 spółek osiągało przychód przede wszystkim z świadczenia usług transportowych, 9 spółek - z usług logistycznych oraz 4 spółki - z usług kurierskich (zob. wykres 2.2).

Niemal wszystkie z badanych podmiotów gospodarczych (za wyjątkiem spółki Dartom Sp. z o.o.) to przedsiębiorstwa dysponujące bogatym pakietem wieloletnich doświadczeń sięgających ponad 10 lat.

Uzupełniającą, w celu dokonania analizy dyskryminacyjnej, próbę badawczą stanowiły spółki sektora TSL, wobec których w latach 2004-2012 wydane zostało sądowe postanowienie o ogłoszeniu upadłości ${ }^{41}$, a ich dokumentacja (w tym sprawozdanie z przepływów pieniężnych za okres trzech lat przed datą ogłoszenia upadłości) znajdowała się w Krajowym Rejestrze Sądowym w Warszawie.

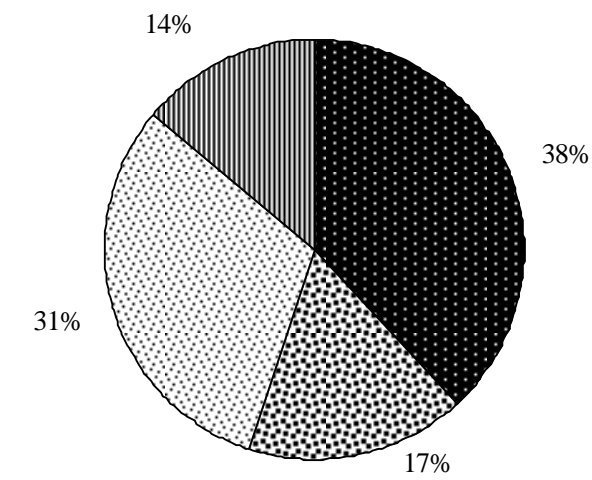

- Transport Dedycja Usistyka 四 Usługi kurierskie

Wy kre s 2.2. Struktura podmiotów gospodarczych z sektora TSL wykazanych w rankingu TOP 500 według głównego źródła przychodów

Źródło: obliczenia własne na podstawie danych zebranych w Krajowym Rejestrze Sądowym w Warszawie i P. S z re te r, op. cit., s. 52-69.

zaś w M\&M Militzer \& Münch Polska Sp. z o.o. wystąpiła ujemna wartość kapitału własnego za lata 2011-2012.

Por. L. Ka rbownik, Zróżnicowanie poziomu operacyjnego bezpieczeństwa finansowego przedsiębiorstw sektora TSL, [w:] J. Duraj (red.), Instrumenty kształtowania dochodowości i rentowności przedsiębiorstwa, ,Acta Universitatis Lodziensis”, Folia Oeconomica 278, Wydawnictwo Uniwersytetu Łódzkiego, Łódź 2013, s. 247.

Dobór próby jest celowy (tj. są to jednostki spełniające określone kryteria), zatem nie można dokonywać tzw. uogólnienia wyników z badania częściowego na zbiorowość statystyczną - typowego dla doboru próby w sposób losowy. Zob. M. S ł a wińska, H. Witc zak (red.), Podstawy metodologiczne prac doktorskich w naukach ekonomicznych, PWE, Warszawa 2008, s. 116.

${ }^{41}$ Dane na dzień 8 sierpnia $2012 \mathrm{r}$. 
Badane spółki prowadzą zasadniczą swoją działalność w sekcji H według PKD 2007, czyli „Transport i gospodarka magazynowa" ${ }^{2}$. Analizie poddano zatem również dane dotyczące grup PKD 2007 zadeklarowanych w dokumentacji badanych spółek złożonej do Krajowego Rejestru Sądowego w Warszawie.

$\mathrm{Z}$ uwagi na występujący (w przypadku niektórych podmiotów gospodarczych poddanych badaniu) jedynie trzypoziomowy podział $w$ ramach PKD 2007, dokonano zestandaryzowanego ujęcia obejmującego:

- poziom pierwszy - SEKCJE - oznaczoną symbolem jednoliterowym, która dzieli ogólną zbiorowość na 21 ugrupowań rodzajów działalności, na które składają się czynności związane ze sobą z punktu widzenia tradycyjnie ukształtowanego, ogólnego podziału pracy,

- poziom drugi - DZIAŁ - oznaczony dwucyfrowym kodem numerycznym, który dzieli ogólną zbiorowość na 88 ugrupowań rodzajów działalności, na które składają się czynności według cech mających zasadnicze znaczenie zarówno przy określaniu stopnia podobieństwa, jak i przy rozpatrywaniu powiązań występujących w gospodarce narodowej (np. w tablicach przepływów międzygałęziowych),

- poziom trzeci - GRUPE - oznaczoną trzycyfrowym kodem numerycznym, obejmującą 272 grupowania rodzajów działalności dających się wyodrębnić z punktu widzenia procesu produkcyjnego, przeznaczenia produkcji bądź też charakteru usługi lub charakteru odbiorcy tych usług ${ }^{43}$.

Sekcja „Transport i gospodarka magazynowa” obejmuje 5 działów (zob. schemat 2.2), a mianowicie:

1) dział nr 49 „Transport lądowy oraz transport rurociągowy”, składający się z 5 grup, tj.:

a) transport kolejowy pasażerski międzymiastowy,

b) transport kolejowy towarów,

c) pozostały transport lądowy pasażerski,

d) transport drogowy towarów oraz działalność usługowa związana z przeprowadzkami,

e) transport rurociągowy;

2) dział nr 50 „Transport wodny”, w skład którego wchodzą 4 grupy:

a) transport morski i przybrzeżny pasażerski,

b) transport morski i przybrzeżny towarów,

${ }^{42}$ Wydaje się, że przyjęta przez GUS klasyfikacja działalności transportowej i gospodarki magazynowej jest w dużej mierze zgodna z definicją usług TSL. Zob. L. Karbown i k, Pomiar i ocena zróżnicowania zakresu działalności gospodarczej przedsiębiorstw sektora TSL, [w:] N. Duraj, A. Pieloch-Babiarz (red.), Przedsiębiorczość, strategie i metody zarzadzania przedsiębiorstwem, Wydawnictwo Uniwersytetu Łódzkiego, Łódź 2014, s. 45 i literatura tam cytowana.

${ }^{43}$ Polska Klasyfikacja Działalności (PKD) - Załacznik do Rozporzadzenia Rady Ministrów z dnia 24 grudnia 2007 r., DzU 2007, nr 251, poz. 1885: Zasady budowy klasyfikacji. http://www.stat.gov.pl/klasyfikacje/pkd_07/pdf/zasady_budowy_pkd.pdf (dostęp: 26.05.2013). 
c) transport wodny śródlądowy pasażerski,

d) transport wodny śródlądowy towarów;

3) dział nr 51 ,Transport lotniczy”, zawierający 2 grupy:

a) transport lotniczy pasażerski,

b) transport lotniczy towarów i transport kosmiczny;

4) dział $\mathrm{nr} 52$ „Magazynowanie i działalność usługowa wspomagająca transport", składający się z 2 grup:

a) magazynowanie ${ }^{44}$ i przechowywanie ${ }^{45}$ towarów,

b) działalność usługowa wspomagająca transport ${ }^{46}$;

5) dział nr 53 „Działalność pocztowa i kurierska”, w skład którego wchodzą 2 grupy:

a) działalność pocztowa objęta obowiązkiem świadczenia usług powszechnych (operatora publicznego),

b) pozostała działalność pocztowa i kurierska.

Zgrupowane w ramach tej sekcji podmioty gospodarcze realizują zatem:

- działalność związaną z przewozem osób lub towarów realizowaną przez transport kolejowy, rurociągowy, drogowy, wodny lub powietrzny;

- działalność wspomagającą przewozy, świadczoną przez stacje, porty, dworce kolejowe, autobusowe itp., terminale w zakresie kontroli ruchu, obsługi pasażerów, bagażu i ładunków;

- wynajem sprzętu transportowego z kierowcą lub załogą;

- usługi pocztowe i kurierskie ${ }^{47}$.

${ }^{44}$ Magazynowanie to zespół czynności związanych z czasowym przyjmowaniem, składowaniem, przechowywaniem, kompletowaniem, przemieszczeniem, konserwacją, ewidencjonowaniem, kontrolowaniem i wydawaniem dóbr materialnych, [za:] M. F e r t s c h (red.), Stownik terminologii logistycznej, Instytut Logistyki i Magazynowania, Poznań 2006, s. 99.

${ }^{45}$ Przechowywanie to jeden $z$ wielu elementów składowych magazynowania. Przechowywanie to zbiór czynności związanych z zapewnieniem określonych warunków mikroklimatycznych w określonym czasie zapasom umieszczonym w budowli magazynowej, [za:] M. F e rt s c h (red.), op. cit., s. 154.

${ }^{46}$ Jest to działalność usługowa wspomagająca transport lądowy, wodny i lotniczy, przeładunek towarów oraz pozostała działalność usługowa wspomagająca transport (w tym agencji transportowych). Zob. Załąznik do Rozporzq̨dzenia Rady Ministrów z dnia 24 grudnia 2007 r.: Wyjaśnienia PKD 2007, http://www.stat.gov.pl/klasyfikacje/pkd_07/pdf/3_PKD-2007-wyjasnienia.pdf (dostepp: 26.05.2013).

${ }^{47}$ Sekcja ta nie obejmuje:

- przemieszczania drewna na terenie lasu związanego z jego pozyskaniem, sklasyfikowanego w 02.40.10.4,

- zamrażania żywności wykonywanego na zlecenie, sklasyfikowanego w odpowiednich grupowaniach w dziale 10 ,

- usług dystrybucji gazu ziemnego w systemie sieciowym, sklasyfikowanych w 35.22.10.0,

- usług dystrybucji pary wodnej i gorącej wody w systemie sieciowym, sklasyfikowanych w 35.30.12.0,

- usług dystrybucji wody samochodami cysternami i za pośrednictwem sieci wodociągowej, sklasyfikowanych w 36.00.20.0, 


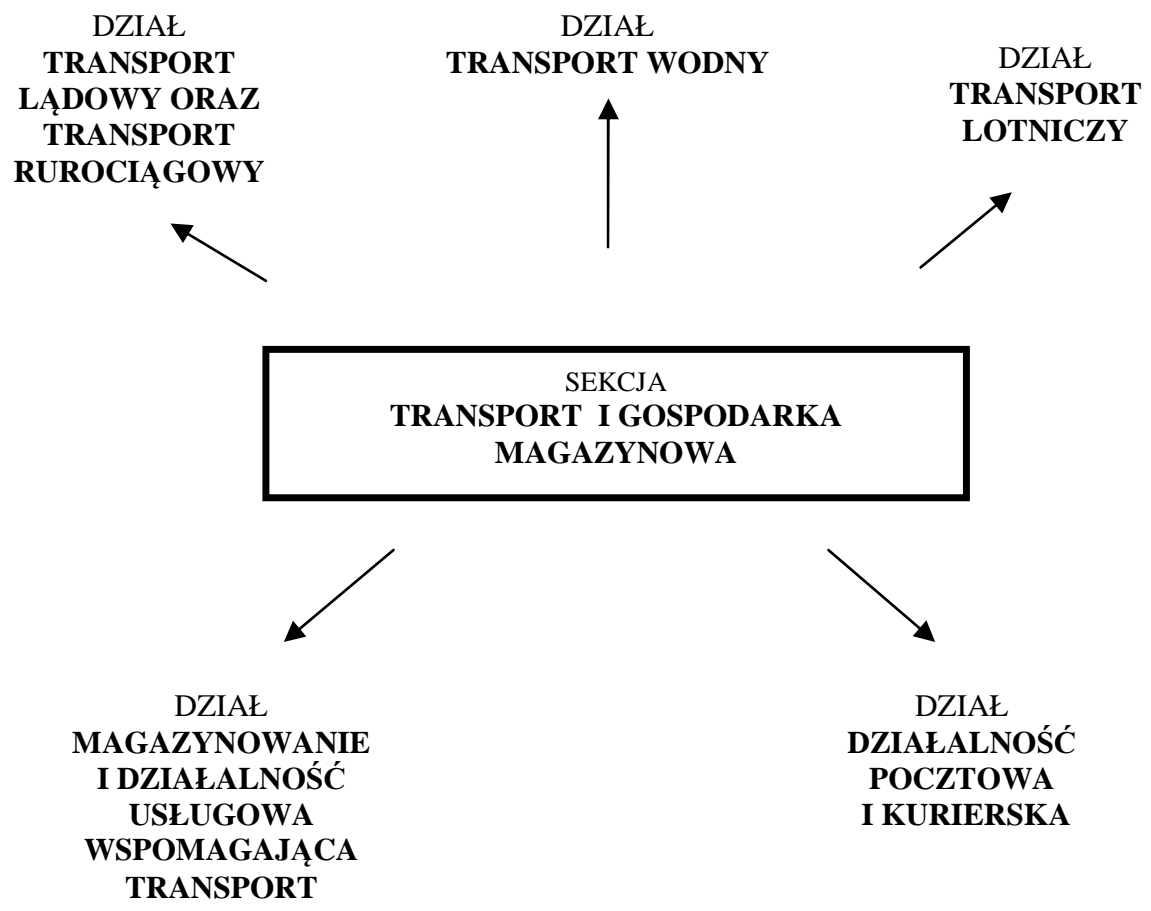

Schemat 2.2. Struktura sekcji „Transport i gospodarka magazynowa”

Źródło: opracowanie własne na podstawie schematu klasyfikacji PKD 2007 dostępnego na stronie Głównego Urzędu Statystycznego w Warszawie:

http://www.stat.gov.pl/klasyfikacje/pkd_07/pkd_07.htm (dostęp: 26.05.2013).

i 38.12.1,

- usług świadczonych przez wagony sypialne, sklasyfikowanych w 55.90.13.0,

- usług świadczonych przez wagony restauracyjne, sklasyfikowanych w 56.10.12.0,

- usług pośrednictwa finansowego związanych z pocztową obsługą kredytów i oszczędności oraz pozostałymi operacjami finansowymi, sklasyfikowanych w 64.19 ,

- wynajmowania samochodów ciężarowych bez kierowcy, sklasyfikowanego w 77.12.11.0,

- wynajmowania środków transportu wodnego bez załogi, sklasyfikowanego w 77.34.10.0,

- wynajmowania środków transportu lotniczego bez załogi, sklasyfikowanego w 77.35.10.0,

- usług świadczonych przez szkoły nauki pilotażu lub żeglarstwa, sklasyfikowanych w 85.53.12.0,

- transportu sanitarnego, sklasyfikowanego w 86.90.14.0,

- usług mycia autobusów i innych pojazdów transportu lądowego, sklasyfikowanych w 81.29.19.0.

Zob. http://www.klasyfikacje.gofin.pl/pkwiu/1,1,6363,sekcja-h-transport-i-gospodarka-magazynowa.html (dostęp: 24.10.2012). 
Badania empiryczne zostały przeprowadzone w oparciu o dane pochodzące z następujących źródeł:

- Krajowego Rejestru Sądowego w Warszawie,

- bazy danych Info Veriti Polska Sp. z o.o.,

- portali finansowych (m. in.: Bankier.pl, Money.pl),

- Elektronicznego Systemu Przekazywania Informacji (ESPI),

- Głównego Urzędu Statystycznego w Warszawie,

- Centralnego Ośrodka Informacji Gospodarczej Sp. z o.o.,

- czasopisma „EuroLogistics”.

Niezbędne obliczenia wykonane zostały w programach Microsoft Excel, Statistica 10, Taksonomia numeryczna ${ }^{48}$, SPSS Statistics (wersja 22) oraz EViews 7.

\subsection{Wybrane memoriałowe i kasowe mierniki oceny operacyjnego bezpieczeństwa finansowego przedsiębiorstw sektora TSL}

Ze względu na występujące bariery dostępu do danych liczbowych, zbiór potencjalnych finansowych zmiennych diagnostycznych operacyjnego bezpieczeństwa finansowego spółek sektora TSL ograniczony został do 13 mierników, przy czym najbogatszy zbiór mierników przypisany został do rentowności eksploatacyjnej i wydajności pieniężnej (gotówkowej) oraz płynności finansowej przedsiębiorstwa (zob. tab. 2.3, por. tab. 1.12). Mierniki te odnoszą się do memoriałowego i kasowego wymiaru analizowanych problemów.

Część z nich została sklasyfikowana jako stymulanta ${ }^{49}$, część zaś jako nominanta ${ }^{50}$. Jedynie współczynniki płynności finansowej oraz współczynniki zabezpieczenia finansowego uznane zostały jako nominanty.

Wartość mediany zmiennych będących nominantami, niekiedy znacznie różniła się od wartości średniej arytmetycznej. W tej sytuacji dla wyznaczenia wartości optymalnych dla tych mierników ${ }^{51}$ w dalszych badaniach posłużono się kwartylem 1 (będącym dolną granicą przedziału) i kwartylem 3 (będącym górną granicą przedziału).

\footnotetext{
${ }^{48}$ Program ten jest integralną częścią książki: M. Kol e n d a, op. cit.

${ }^{49} \mathrm{Tj}$. zmienne, których wysokie wartości są pożądane z punktu widzenia ogólnej charakterystyki badanego zjawiska.

${ }^{50} \mathrm{Tj}$. zmienne, których wszelkie odchylenia od poziomu normalnego (tj. wartości bądź też przedziału wartości) są niepożądane z punktu widzenia ogólnej charakterystyki badanego zjawiska.

${ }^{51} \mathrm{Z}$ uwagi na duże zróżnicowanie wartości mediany w relacji do średniej arytmetycznej, dolną granicę stanowiła wartość „,pierwszego kwartyla”, a górną granicę - wartość „trzeciego kwartyla”. Dzięki temu dla roku ustalone zostały wartości miernika nie uwzględniającego obserwacji nietypowych (odstających).
} 
Tabela 2.3. Wybrane obszary i zastosowane mierniki oceny operacyjnego bezpieczeństwa finansowego przedsiębiorstw sektora TSL

\begin{tabular}{|c|c|c|c|c|}
\hline Lp. & $\begin{array}{c}\text { Główne obszary oceny } \\
\text { operacyjnego bezpieczeństwa } \\
\text { finansowego przedsiębiorstwa } \\
\end{array}$ & Miernik & $\begin{array}{c}\text { Ujęcie } \\
\text { memoriałowe/ } \\
\text { kasowe } \\
\end{array}$ & Symbol \\
\hline 1 & $\begin{array}{l}\text { Sprzedaż produktów (usług), } \\
\text { towarów i materiałów }{ }^{52}\end{array}$ & $\begin{array}{l}\text { przychody netto ze sprzedaży usług, } \\
\text { towarów i materiałów }\end{array}$ & memoriałowe & $\mathrm{m}_{1}$ \\
\hline 2 & \multirow{4}{*}{$\begin{array}{l}\text { Płynność } \\
\text { finansowa }\end{array}$} & $\begin{array}{l}\text { współczynnik bieżącej płynności } \\
\text { finansowej }\end{array}$ & memoriałowe & $\mathrm{m}_{2}$ \\
\hline 3 & & $\begin{array}{l}\text { współczynnik przyspieszonej płynności } \\
\text { finansowej }\end{array}$ & memoriałowe & $\mathrm{m}_{3}$ \\
\hline 4 & & $\begin{array}{c}\text { współczynnik natychmiastowej płynności } \\
\text { finansowej }\end{array}$ & memoriałowe & $\mathrm{m}_{4}$ \\
\hline 5 & & $\begin{array}{c}\text { Współczynnik zdolności do obsługi } \\
\text { zobowiązań bieżących gotówką osiąganą } \\
\text { z działalności operacyjnej }\end{array}$ & kasowe & $\mathrm{m}_{5}$ \\
\hline 6 & \multirow{6}{*}{$\begin{array}{l}\text { Rentowność eksploatacyjna } \\
\text { i wydajność pieniężna } \\
\text { (gotówkowa) }\end{array}$} & $\begin{array}{c}\text { współczynnik eksploatacyjnej } \\
\text { rentowności sprzedaży }\end{array}$ & memoriałowe & $\mathrm{m}_{6}$ \\
\hline 7 & & $\begin{array}{l}\text { współczynnik eksploatacyjnej } \\
\text { rentowności aktywów ogółem }\end{array}$ & memoriałowe & $\mathrm{m}_{7}$ \\
\hline 8 & & $\begin{array}{l}\text { współczynnik eksploatacyjnej } \\
\text { rentowności kapitału własnego }\end{array}$ & memoriałowe & $\mathrm{m}_{8}$ \\
\hline 9 & & $\begin{array}{l}\text { współczynnik wydajności pieniężnej } \\
\text { (gotówkowej) sprzedaży }\end{array}$ & kasowe & $\mathrm{m}_{9}$ \\
\hline 10 & & $\begin{array}{c}\text { współczynnik wydajności } \\
\text { pieniężnej (gotówkowej) aktywów } \\
\text { ogółem }\end{array}$ & kasowe & $\mathrm{m}_{10}$ \\
\hline 11 & & $\begin{array}{c}\text { współczynnik wydajności } \\
\text { pieniężnej (gotówkowej) kapitału } \\
\text { własnego }\end{array}$ & kasowe & $\mathrm{m}_{11}$ \\
\hline 12 & \multirow{2}{*}{$\begin{array}{l}\text { Krótkoterminowe rezerwy } \\
\text { finansowe }\end{array}$} & $\begin{array}{c}\text { współczynnik zabezpieczenia } \\
\text { finansowego } \mathrm{nr} 1\end{array}$ & memoriałowe & $\mathrm{m}_{12}$ \\
\hline 13 & & $\begin{array}{l}\text { współczynnik zabezpieczenia } \\
\text { finansowego } \mathrm{nr} 2\end{array}$ & memoriałowe & $\mathrm{m}_{13}$ \\
\hline
\end{tabular}

Źródło: opracowanie własne na podstawie: M. Gmytrasiewicz, A. Karmańska, I. Olchow i c z, Rachunkowość finansowa, Wykład 1, Difin, Warszawa 1996, s. 416-417; M. S i e r p i ń s k a, T. J a c h n a, Ocena przedsiębiorstwa wedtug standardów światowych, Wydawnictwo Naukowe PWN, Warszawa 2004, s. 93, 96, 145-149 i 195-209; A. N. Du raj, Rezerwy a strategie finansowe publicznych spółek akcyjnych, Wydawnictwo Uniwersytetu Łódzkiego, Łódź 2008, s. 85-88.

${ }^{52}$ Badane spółki sporządzały sprawozdanie z przepływów pieniężnych metodą pośrednią, zatem miernik kasowy (OCR - wpływy gotówkowe z działalności operacyjnej) nie jest daną ujawnianą przez nie w sprawozdaniu finansowym złożonym do Krajowego Rejestru Sądowego w Warszawie.

${ }^{53} \mathrm{~W}$ przypadku krótkoterminowych rezerw na zobowiązania za miary operacyjnego bezpieczeństwa finansowego przyjęte zostały jedynie dwa współczynniki zabezpieczenia finansowego, które w liczniku mają albo krótkoterminowe rezerwy na świadczenia emerytalne i podobne albo pozostałe rezerwy krótkoterminowe.

Okazało się bowiem, iż bierne rozliczenia międzyokresowe kosztów mogą być zawarte zarówno w pozycji B.I.2 i B.I.3, jak i w pozycji B.IV.2. bilansu (tutaj wraz z rozliczeniami międzyokresowymi przychodów). Nie wszystkie spółki w informacjach dodatkowych i objaśnieniach ujawniały szczegółową informację na temat rozliczeń międzyokresowych kosztów (RMK).

Kasowe ujęcie zmiany rezerw w rachunku przepływów pieniężnych obejmuje z kolei zmianę rezerw na zobowiązania ogółem (tj. długo- i krótkoterminowych), zaś w zmianie stanu rozliczeń międzyokresowych występuje tzw. łączne saldo rozliczeń międzyokresowych czynnych i biernych. 
Tego rodzaju podejście pozwoliło na wykluczenie obserwacji nietypowych, mających istotny wpływ na wartość średniej arytmetycznej danego miernika oceny operacyjnego bezpieczeństwa finansowego (zob. tab. 2.4)

Obliczona i zawarta na wykresie 2.3 przeciętna oraz środkowa wartość przychodów netto ze sprzedaży usług, towarów i materiałów spółek sektora TSL wykazywała tendencję rosnącą w całym badanym okresie (za wyjątkiem niewielkiego spadku odnotowanego dla średniej wartości tego miernika w 2009 r., zaś środkowej - w latach 2008-2009). Jednocześnie zaistniało bardzo wysokie przestrzenne (tj. między przedsiębiorstwami) zróżnicowanie badanej zmiennej, które w latach 2008-2012 było o ponad 20 punktów procentowych wyższe niż w $2004 r^{55}$

${ }^{54} \mathrm{~W}$ literaturze przedmiotu pojawiają się liczne (często odmienne) opinie na temat dokładnych lub przynajmniej przybliżonych poziomów wartości wskaźników finansowych uznawanych za optymalne. T. Korol wskazuje, iż optymalne wartości wskaźników finansowych trzeba wyznaczać cyklicznie i nie da się ich określić raz na zawsze. Zależą one bowiem od szybkości zmian zachodzących na rynkach, specyfiki poszczególnych branż gospodarki, jak również od samego badanego przedsiębiorstwa i jego pozycji rynkowej, [za:] T. Ko rol, Nowe podejście do analizy wskaźnikowej w przedsiębiorstwie, Wolters Kluwer Polska SA, Warszawa 2013, s. 23-24.

P. Figura zwraca z kolei uwagę na potrzebę definiowania odrębnych, optymalnych przedziałów dla poszczególnych wskaźników finansowych ze względu na cel działalności gospodarczej badanych przedsiębiorstw (tj. maksymalizacji zysku, przetrwania lub maksymalizacji wartości). Dokonał wyznaczenia nowych wartości rekomendowanych 16 wskaźników finansowych, różnicując je w zależności od celu nadrzędnego przedsiębiorstwa oraz jego przynależności sektorowej. Zob. P. Figura, Wartości wzorcowe wskaźników finansowych przedsiębiorstw giełdowych, CeDeWu, Warszawa 2012, s. 1-169.

Pomimo opublikowania przez P. Figurę rekomendowanych wartości 16 wskaźników finansowych oraz publikowanych przez T. Dudycza oraz W. Skoczylas cyklicznie (corocznie) w czasopiśmie „Rachunkowość” sektorowych wskaźników finansowych - dokonano wyznaczenia optymalnych wartości analizowanych zmiennych na podstawie danych finansowych spółek sektora TSL zakwalifikowanych do próby badawczej z uwagi na:

- specyficzną postać (formułę) mierników oceny operacyjnego bezpieczeństwa przedsiębiorstwa (znaczna ich część nie była w ogóle wykazywana przez wyżej wymienionych Autorów w tworzonych przez nich zestawieniach),

- rodzaj prowadzonej przez nie działalności gospodarczej,

- to, iż większość badanych przedsiębiorstw z tego sektora nie jest notowana na GPW w Warszawie.

Nominalne wartości ze sprawozdania finansowego zostały zdeflowane wskaźnikiem cen usług transportu i gospodarki magazynowej za lata 2006-2011 podanym w: Ceny $w$ gospodarce narodowej w 2012 r., Główny Urząd Statystyczny - Departament Handlu i Usług, Urząd Statystyczny w Opolu, Warszawa 2013, s. 283; z uwagi na brak danych w wyżej wymienionej publikacji za lata 2004-2005 wykorzystany został wskaźnik cen usług transportu, gospodarki magazynowej i łączności podany w: Rocznik Statystyczny Rzeczpospolitej Polskiej, Główny Urząd Statystyczny, Warszawa 2008, s. 449 i Rocznik Statystyczny Rzeczpospolitej Polskiej, Główny Urząd Statystyczny, Warszawa 2007, s. 445.

${ }_{55}$ Współczynnik zmienności przychodów netto ze sprzedaży usług, towarów i materiałów w 2004 r. wynosił $111,17 \%$, a dla lat 2008-2012 - ponad $134 \%$. 


\begin{tabular}{|c|c|c|c|c|c|c|c|c|c|c|c|c|c|c|c|c|}
\hline 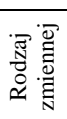 & 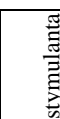 & & 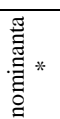 & 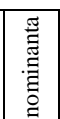 & 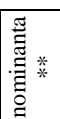 & 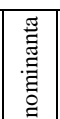 & & & & 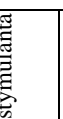 & 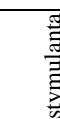 & & 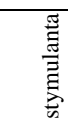 & & & \\
\hline 䚯 & 莌 & 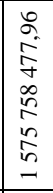 & 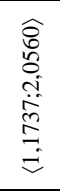 & 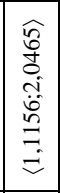 & 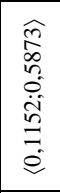 & 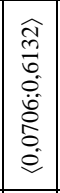 & 关 & $\begin{array}{l}\frac{1}{n} \\
\frac{0}{0}\end{array}$ & 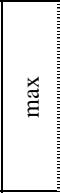 & 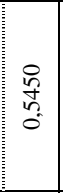 & 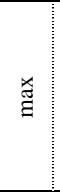 & : & 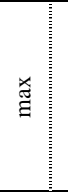 & $\begin{array}{l}\bar{\infty} \\
\stackrel{0}{\rightarrow} \\
0\end{array}$ & $\stackrel{×}{\sharp}$ & 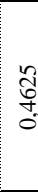 \\
\hline$\dot{\vec{\sigma}}$ & $\stackrel{×}{\stackrel{\rightleftarrows}{g}}$ & 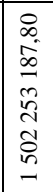 & 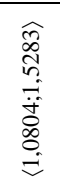 & $\begin{array}{l}\widehat{\widehat{a}} \\
\bar{b} \\
\vec{a} \\
\vec{d} \\
\stackrel{0}{0} \\
\dot{0}\end{array}$ & 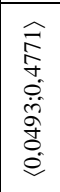 & 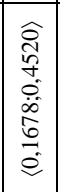 & $\stackrel{×}{\stackrel{Ð}{\Xi}}$ & $\begin{array}{l}\frac{0}{0} \\
\frac{0}{0}\end{array}$ & 曾 & 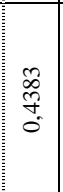 & 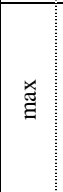 & 夺 & 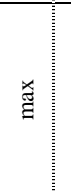 & $\begin{array}{l}\frac{\tilde{b}}{d} \\
\text { d. }\end{array}$ & $\stackrel{\circlearrowright}{\stackrel{\varpi}{\exists}}$ & 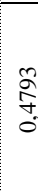 \\
\hline 菅 & $\stackrel{×}{\stackrel{\rightleftarrows}{\sharp}}$ & 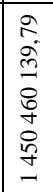 & 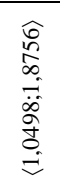 & 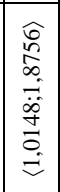 & 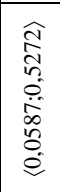 & 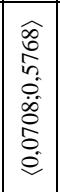 & 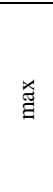 & $\begin{array}{l}0 \\
\stackrel{0}{\circ} \\
0\end{array}$ & 急 & {$\left[\begin{array}{l}8 \\
+ \\
0 \\
0\end{array}\right.$} & 嘪 & $\begin{array}{l}\frac{n}{\vec{n}} \\
\infty \\
0 \\
0\end{array}$ & $\underset{\sharp}{\stackrel{\varkappa}{\sharp}}$ & $\begin{array}{l}\text { ôd } \\
\text { d̦ } \\
0\end{array}$ & $\stackrel{\gtrless}{\sharp}$ & 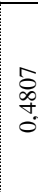 \\
\hline ठ্ণ & $\stackrel{×}{\stackrel{一}{\Xi}}$ & 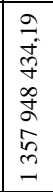 & 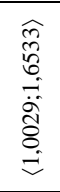 & 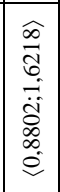 & $\begin{array}{l}\hat{5} \\
\text { 今. } \\
0 \\
0 \\
\dot{0} \\
0 \\
0 \\
0 \\
0\end{array}$ & 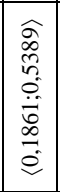 & 哯 & $\begin{array}{l}\frac{\sigma}{n} \\
\frac{\sigma}{0}\end{array}$ & 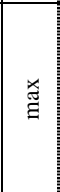 & $\begin{array}{l}\text { त्: } \\
0.0\end{array}$ & 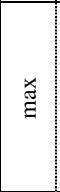 & 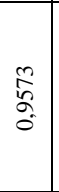 & 曽 & $\begin{array}{l}\text { to } \\
\text { bn } \\
\text { s. }\end{array}$ & $\stackrel{×}{\stackrel{\odot}{\sharp}}$ & gे \\
\hline 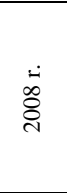 & 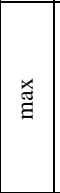 & 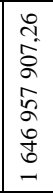 & 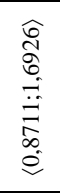 & 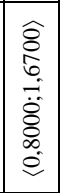 & $\begin{array}{l}\widehat{0} \\
0 \\
0 \\
0 \\
\dot{0} \\
+ \\
0 \\
0 \\
0\end{array}$ & 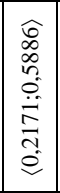 & 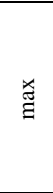 & $\begin{array}{l}\text { gy } \\
\text { dy }\end{array}$ & $\stackrel{×}{\stackrel{Æ}{\sharp}}$ & $\stackrel{\infty}{0}_{0}^{\infty}$ & 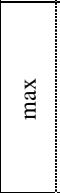 & 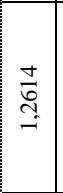 & 弟 & 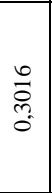 & 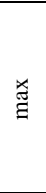 & d্ㅇㅇㅇ \\
\hline 客 & $\stackrel{×}{\stackrel{一}{\sharp}}$ & 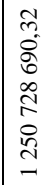 & $\begin{array}{l}\widehat{\widehat{d}} \\
\dot{0} \\
\ddot{\dot{\theta}} \\
\frac{0}{\dot{\theta}}\end{array}$ & 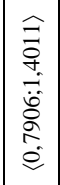 & 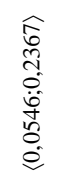 & $\begin{array}{l}\widehat{r} \\
0 \\
0 \\
0 \\
0 \\
\dot{0} \\
0 \\
0 \\
0 \\
0 \\
0 \\
0\end{array}$ & $\stackrel{×}{\stackrel{×}{\Xi}}$ & $\begin{array}{l}\text { fै } \\
\text { तै } \\
\text { o. }\end{array}$ & $\underset{\Xi}{\stackrel{×}{\sharp}}$ & : & 思 & 等 & 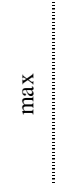 & $\begin{array}{l}0.0 \\
\text { g. } \\
0 \\
0\end{array}$ & 羞 & $\frac{7}{8}$ \\
\hline ठ워 & $\stackrel{×}{\stackrel{一}{\sharp}}$ & 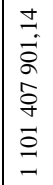 & 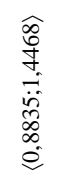 & $\begin{array}{l}\widehat{\vec{E}} \\
\vec{c} \\
\overrightarrow{\tilde{d}} \\
\infty \\
\infty \\
\dot{e}\end{array}$ & 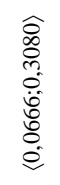 & 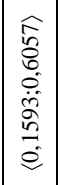 & $\stackrel{×}{\sharp}$ & 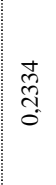 & $\stackrel{×}{\sharp}$ & 竎 & 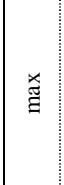 & 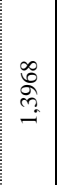 & $\stackrel{×}{\rightleftarrows}$ & $\begin{array}{l}\text { के } \\
0 \\
0.2 \\
0\end{array}$ & $\stackrel{×}{\stackrel{Ð}{\sharp}}$ & 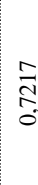 \\
\hline 峁 & $\stackrel{×}{\stackrel{一}{\Xi}}$ & 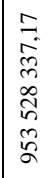 & $\begin{array}{l}\widehat{\hat{D}} \\
\stackrel{\infty}{n} \\
\hat{\overrightarrow{\hat{N}}} \\
\alpha \\
\hat{e}\end{array}$ & 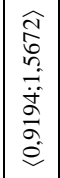 & $\begin{array}{l}\widehat{\vec{v}} \\
\vec{d} \\
\dot{0} \\
\dot{0} \\
\stackrel{0}{0} \\
\stackrel{0}{0}\end{array}$ & 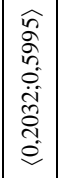 & $\stackrel{×}{\stackrel{Ð}{\Xi}}$ & $\begin{array}{l}\tilde{N} \\
\text { ते } \\
\text { on }\end{array}$ & 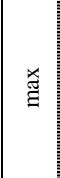 & $\begin{array}{l}\infty \\
0 \\
0 \\
0 \\
0 \\
0\end{array}$ & $\stackrel{\times}{\stackrel{\circ}{\Xi}}$ & $\frac{f}{=}$ & $\stackrel{\times}{\stackrel{×}{\sharp}}$ & $\begin{array}{l}\text { त्ञ } \\
\text { त̂. } \\
0\end{array}$ & $\stackrel{\times}{\stackrel{\sim}{\sharp}}$ & 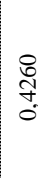 \\
\hline 蛋 & $\stackrel{×}{\stackrel{一}{\Xi}}$ & 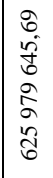 & 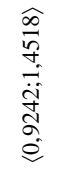 & 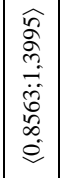 & $\begin{array}{l}\widehat{\overrightarrow{8}} \\
\dot{+} \\
\stackrel{0}{0} \\
\frac{8}{0} \\
0\end{array}$ & 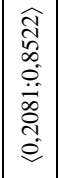 & $\underset{\Xi}{\stackrel{\varpi}{\Xi}}$ & $\begin{array}{l}\infty \\
0 \\
i \\
0 \\
0\end{array}$ & $\stackrel{×}{\stackrel{一}{\sharp}}$ & $\begin{array}{c}\text { 竞 } \\
0 \\
0\end{array}$ & $\stackrel{×}{\stackrel{\varpi}{\Xi}}$ & 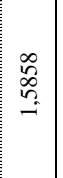 & $\stackrel{×}{\stackrel{\overbrace{}}{\Xi}}$ & $\begin{array}{l}\text { to } \\
\text { o. } \\
m_{0}^{2}\end{array}$ & $\stackrel{\text { }}{\stackrel{\text { }}{\Xi}}$ & $\begin{array}{l}\infty \\
\text { है } \\
0\end{array}$ \\
\hline 今ి & $\bar{a}$ & & $\Xi$ & 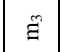 & 売 & $\curvearrowleft$ & 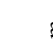 & छ̊ & 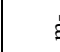 & $\underline{\Xi}$ & 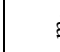 & $\stackrel{\infty}{\approx}$ & g & & & \\
\hline
\end{tabular}




\begin{tabular}{|c|c|c|c|}
\hline 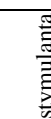 & & 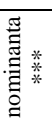 & 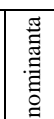 \\
\hline 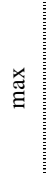 & $\begin{array}{l}\text { ते } \\
\stackrel{-}{=}\end{array}$ & 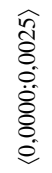 & $\begin{array}{l}\widehat{\sigma} \\
\tilde{b} \\
0 \\
\dot{0} \\
\dot{0} \\
\dot{0} \\
\dot{0}\end{array}$ \\
\hline$\stackrel{\text { 局 }}{\text { : }}$ & $\begin{array}{l}\text { ô } \\
\dot{q} \\
\dot{0}\end{array}$ & $\begin{array}{l}\widehat{\pi} \\
\frac{\pi}{8} \\
0 \\
\dot{8} \\
8 \\
\dot{0}\end{array}$ & $\begin{array}{l}\widehat{\omega} \\
\dot{m} \\
0 \\
0 \\
\dot{0} \\
0 \\
0 \\
\dot{0}\end{array}$ \\
\hline 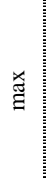 & ণิ & $\begin{array}{l}\widehat{0} \\
\overline{8} \\
0 \\
\dot{8} \\
8 \\
0 \\
0\end{array}$ & $\begin{array}{l}\widehat{\hat{E}} \\
0 \\
0 \\
\dot{8} \\
\dot{8} \\
\dot{\theta}\end{array}$ \\
\hline 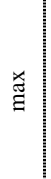 & 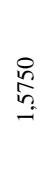 & $\begin{array}{l}\widehat{\bar{\Xi}} \\
\dot{8} \\
\dot{0} \\
\dot{8} \\
\dot{0}\end{array}$ & 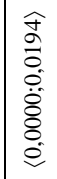 \\
\hline 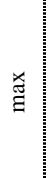 & 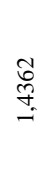 & 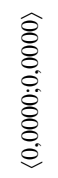 & $\begin{array}{c}\widehat{o} \\
0 \\
0 \\
0 \\
0 \\
0 \\
0 \\
0 \\
0\end{array}$ \\
\hline 肴 & $\begin{array}{l}\text { बे } \\
\text { مू. } \\
\text { aे }\end{array}$ & 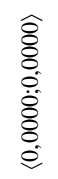 & 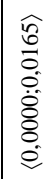 \\
\hline$\stackrel{×}{\stackrel{\varpi}{\Xi}}$ & $\begin{array}{l}\text { 总 } \\
\text { : } \\
\end{array}$ & 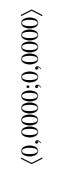 & $\begin{array}{l}\widehat{\infty} \\
0 \\
0 \\
0 \\
0 \\
\dot{0} \\
0 \\
0 \\
0\end{array}$ \\
\hline$\stackrel{×}{\dddot{\Xi}}$ & 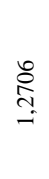 & 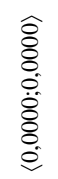 & 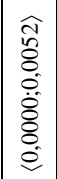 \\
\hline$\stackrel{×}{\dddot{\Xi}}$ & $\begin{array}{l}\stackrel{0}{\tilde{n}} \\
\vec{m}\end{array}$ & 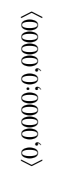 & $\begin{array}{l}\widehat{0} \\
\stackrel{0}{0} \\
\dot{0} \\
\dot{0} \\
\dot{8} \\
\dot{0}\end{array}$ \\
\hline 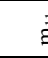 & & $\stackrel{\tilde{\Xi}}{\tilde{E}}$ & $\stackrel{m}{\Xi}$ \\
\hline
\end{tabular}

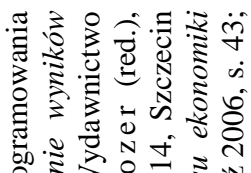

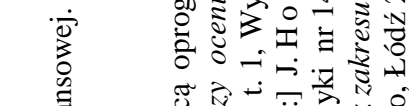

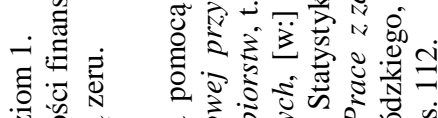

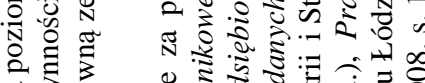

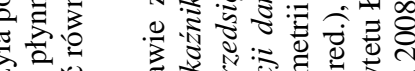

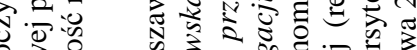

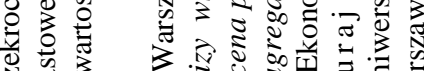

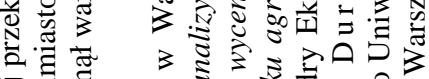

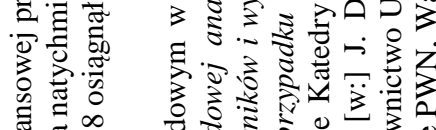

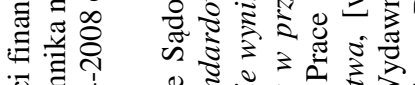

氙势

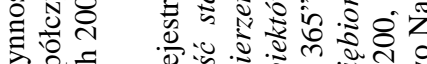

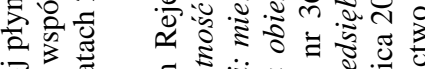

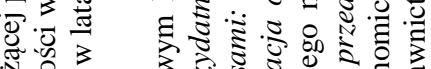

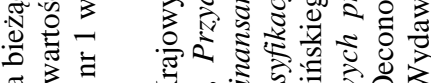

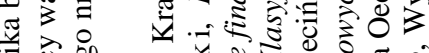

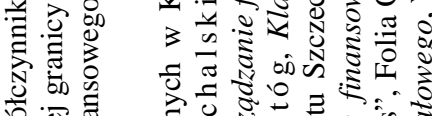

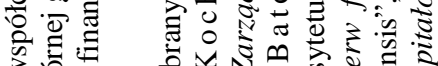

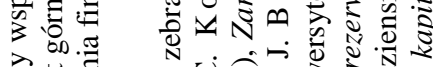

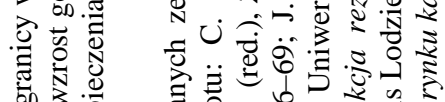

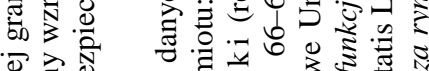

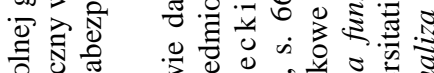

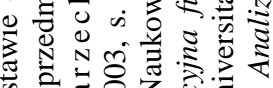

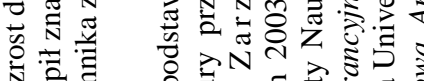

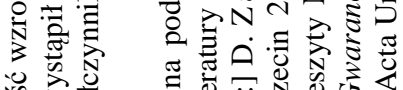

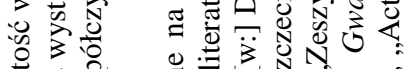

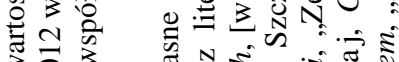

उั)

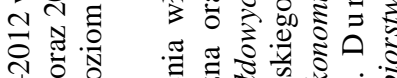

1)

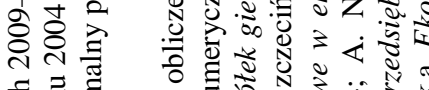

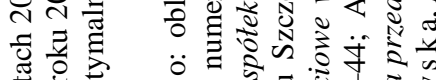

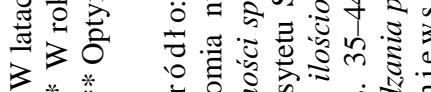

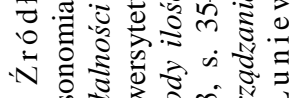

离. 


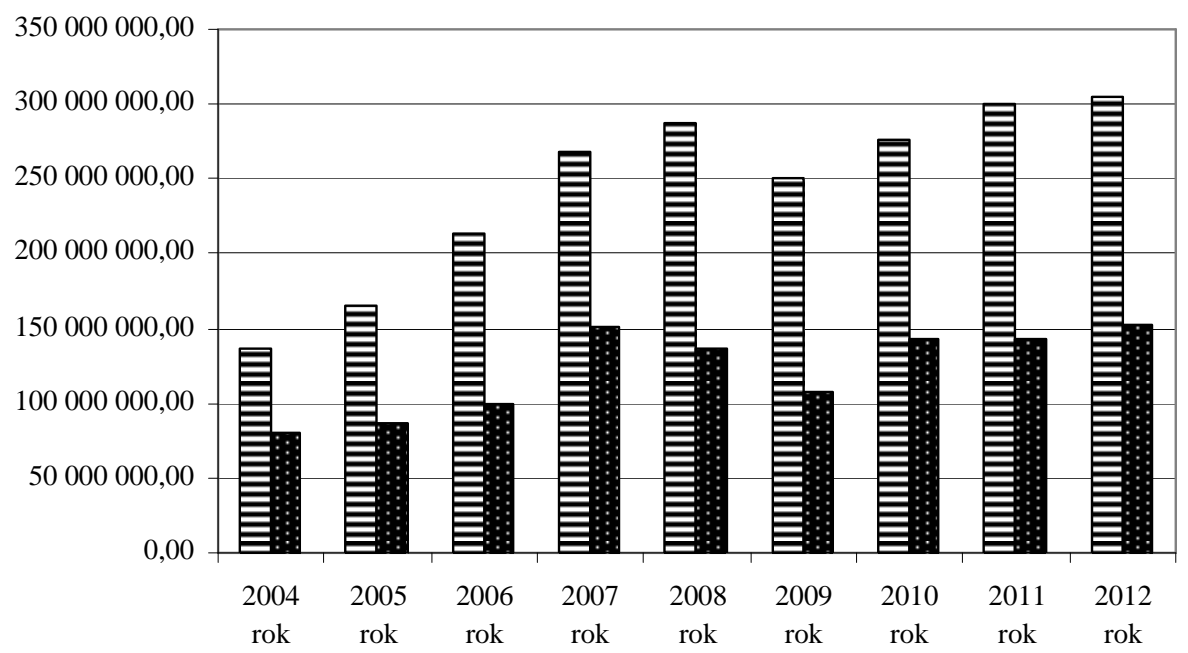

曰 Średnia Mediana

Wykres 2.3. Średnia i środkowa wartość przychodów netto ze sprzedaży usług, towarów i materiałów spółek sektora TSL w latach 2004-2012

(ceny stałe - dane w zł)

Źródło: obliczenia własne na podstawie danych zebranych w Krajowym Rejestrze Sądowym w Warszawie przy wykorzystaniu programu Microsoft Excel.

Tabela 2.5. Wartości podstawowych statystyk opisowych przychodów netto ze sprzedaży usług, towarów i materiałów w latach 2004-2012

(ceny stałe - dane w zl)

\begin{tabular}{|c|c|c|c|c|c|c|}
\hline $\begin{array}{c}\text { Wy- } \\
\text { szczegól- } \\
\text { nienie }\end{array}$ & Średnia & Mediana & Minimum & Maksimum & Odch.std. & $\begin{array}{c}\text { Wsp. } \\
\text { zmn. }\end{array}$ \\
\hline 2004 r. & 136582823,58 & 80111335,05 & 3116341,66 & 625979645,69 & 151845648,49 & 111,17 \\
\hline 2005 r. & 165172546,49 & 86567953,69 & 2331257,63 & 953528337,17 & 210882699,90 & 127,67 \\
\hline 2006 r. & 214064544,54 & 99519093,24 & 21134747,88 & 1101407901,14 & 278007427,82 & 129,87 \\
\hline 2007 r. & 268523478,65 & 150356500,66 & 21418002,24 & 1250728690,32 & 321113917,46 & 119,59 \\
\hline 2008 r. & 287252162,47 & 136104945,73 & 16087849,54 & 1646957907,26 & 397267678,82 & 138,30 \\
\hline 2009 r. & 249888388,87 & 108303696,99 & 10314967,28 & 1357948434,19 & 345814403,68 & 138,39 \\
\hline 2010 r. & 276858905,61 & 142476991,53 & 9640158,20 & 1450460139,79 & 379713495,17 & 137,15 \\
\hline 2011 r. & 300846795,12 & 142932192,82 & 7309483,88 & 1502253187,80 & 405198510,95 & 134,69 \\
\hline 2012 r. & 304985070,75 & 152699222,48 & 6014152,84 & 1575758477,96 & 410495663,21 & 134,60 \\
\hline
\end{tabular}

Źródło: obliczenia własne na podstawie danych zebranych w Krajowym Rejestrze Sądowym w Warszawie przy wykorzystaniu programu Microsoft Excel i Statistica 10. 
Wykorzystany został dodatkowo nieparametryczny test istotności różnicy dla wielu prób zależnych ${ }^{56} \mathrm{w}$ celu ustalenia, czy w tym obszarze kreowania i zapewniania dobrego standingu finansowego obserwuje się znaczący spadek wartości przychodów netto ze sprzedaży usług, towarów i materiałów przedsiębiorstw sektora TSL w latach 2004-2012.

Na podstawie otrzymanych i poddanych analizie wyników badań empirycznych (przy poziomie istotności wynoszącym 0,05 ) odrzucona została hipoteza zerowa o braku występowania istotnych różnic badanej zmiennej diagnostycznej $^{57}$.

Analiza POST-HOC ujawniła (zob. wykres 2.4), iż istotne różnice powstały odpowiednio między rokiem:

-2004 a 2007 ,

-2004 a 2008 ,

-2004 a 2011,

-2004 a 2012 ,

-2005 a 2007 ,

-2005 a 2008 ,

-2005 a 2011 ,

-2005 a 2012 ,

- 2007 a 2009.

Najczęściej najniższa wartość przychodów netto ze sprzedaży usług, towarów i materiałów została osiągnięta przez badane spółki sektora TSL odpowiednio w 2004 i 2005 roku, a ich poziom różnił się istotnie od tego, który został wypracowany w latach 2007-2008 oraz 2011-2012. Dla 2007 r. wartość badanej zmiennej dodatkowo istotnie różniła się od tej z 2009 r. (średnia ranga dla 2009 r. wynosiła bowiem 4,03).

Analiza średniej wartości współczynnika bieżącej płynności finansowej $\left(\mathrm{m}_{2}\right)$ wykazała, iż jego wartość była w całym badanym okresie wyższa od wartości środkowej, w tym w szczególności w 2006 r. (zob. wykres 2.5). Tak wysoki spread (różnica) między nimi był wynikiem wystąpienia obserwacji nietypowej (tj. spółki PEKAES SA, dla której rozważana zmienna osiągnęła wartość 39,24 - zob. tab. 2.6).

${ }^{56}$ Badana próba przedsiębiorstw liczyła 29 podmiotów gospodarczych. W celu analizy zgodności rozkładu zmiennej w danej grupie przedsiębiorstw z określonym rozkładem teoretycznym wykorzystany został zatem test normalności Shapiro-Wilka. Na podstawie wyników tego testu odrzucona została hipoteza o normalności rozkładu.

${ }^{57}$ Wystąiły statystycznie istotne różnice między określonymi latami dla wartości miernika oceny operacyjnego bezpieczeństwa finansowego. 


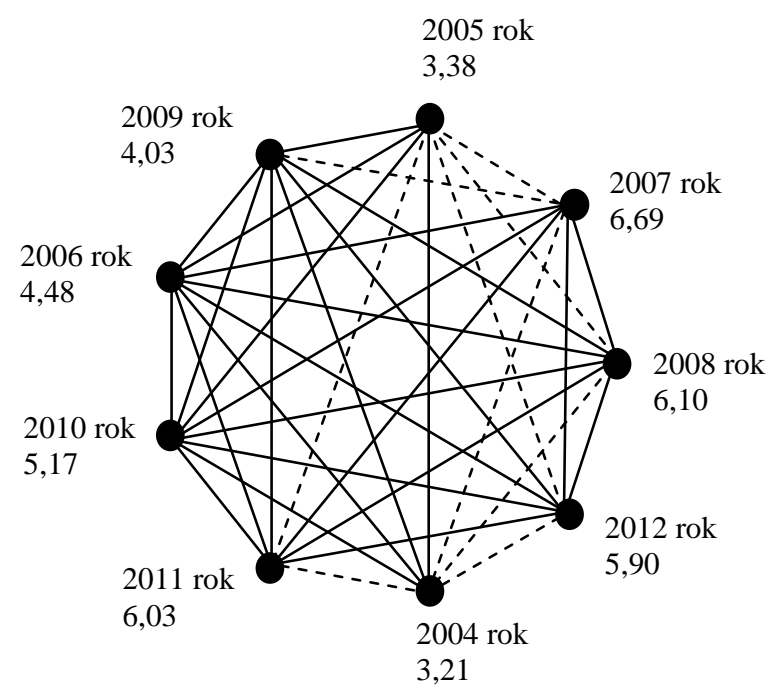

* Linie przerywane obrazują istotne różnice między określonymi latami dla analizowanego miernika oceny operacyjnego bezpieczeństwa finansowego (poziom istotności wynosi 0,05).

Wykres 2.4. Średnia ranga dla wartości przychodów netto ze sprzedaży usług, towarów i materiałów w latach $2004-2012{ }^{* 58}$ (ceny stałe)

Źródło: obliczenia własne na podstawie danych zebranych w Krajowym Rejestrze Sądowym w Warszawie przy wykorzystaniu programu SPSS Statistics (wersja 22).

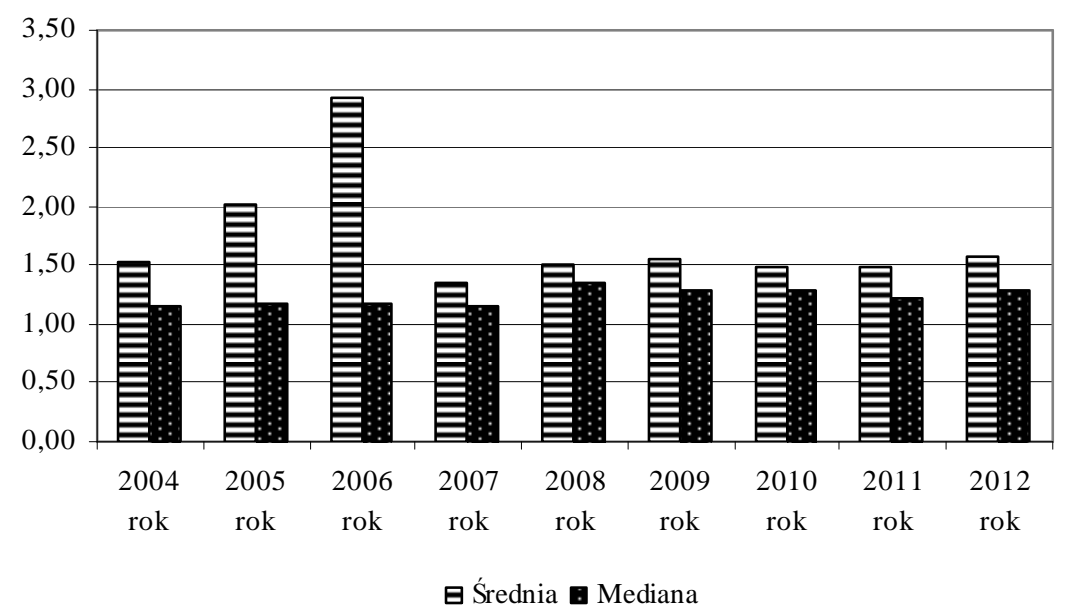

Wykres 2.5. Średnia i środkowa wartość współczynnika bieżącej płynności finansowej spółek sektora TSL w latach 2004-2012

Źródło: jak do wykresu 2.3.

${ }^{58}$ Prezentowane są istotności asymptotyczne (testy dwustronne). 
Tabela 2.6. Wartości podstawowych statystyk opisowych współczynnika bieżącej płynności finansowej w latach 2004-2012

\begin{tabular}{|c|c|c|c|c|c|c|}
\hline Wyszczególnienie & Średnia & Mediana & Minimum & Maksimum & Odch.std. & Wsp.zmn. \\
\hline \hline 2004 r. & 1,5289 & 1,1437 & 0,5736 & 10,3497 & 1,7471 & 114,27 \\
\hline 2005 r. & 2,0222 & 1,1799 & 0,6685 & 15,3314 & 2,8287 & 139,88 \\
\hline 2006 r. & 2,9139 & 1,1717 & 0,6492 & 39,2422 & 7,2802 & 249,85 \\
\hline 2007 r. & 1,3425 & 1,1487 & 0,4608 & 3,4479 & 0,6906 & 51,44 \\
\hline 2008 r. & 1,5062 & 1,3516 & 0,5012 & 4,5332 & 0,8746 & 58,07 \\
\hline 2009 r. & 1,5526 & 1,2773 & 0,6810 & 4,9319 & 0,9231 & 59,46 \\
\hline 2010 r. & 1,4857 & 1,2779 & 0,7232 & 3,6924 & 0,6426 & 43,25 \\
\hline 2011 r. & 1,4826 & 1,2289 & 0,6584 & 3,9672 & 0,7001 & 47,22 \\
\hline 2012 r. & 1,5812 & 1,2825 & 0,6960 & 3,4673 & 0,7149 & 45,21 \\
\hline
\end{tabular}

Źródło: jak do tab. 2.5.

W całym badanym okresie (za wyjątkiem lat 2004-2006) miernik ten charakteryzował się niższym poziomem zmienności w relacji do przychodów netto ze sprzedaży usług, towarów i materiałów. Jednakże nie we wszystkich latach poddanych analizie rozkład zmiennej $\mathrm{m}_{2}$ był identyczny (zob. wykres 2.6). Najczęściej najniższa jej wartość w spółkach sektora TSL występowała w 2007 r. i statystycznie istotnie różniła się od tej, która została osiągnięta przez nie w 2011 i 2012 r.

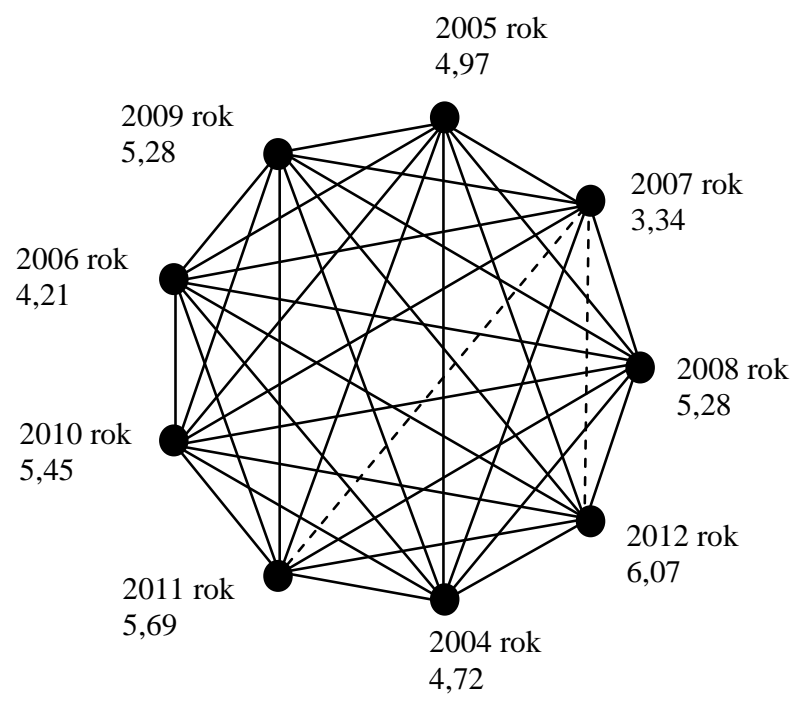

* Oznaczenia jak do wykresu 2.4.

Wykres 2.6. Średnia ranga dla wartości współczynnika bieżącej płynności finansowej w latach 2004-2012*

Źródło: jak do wykresu 2.4. 
Zbliżone wyniki podstawowych statystyk opisowych uzyskane zostały dla kolejnego miernika oceny operacyjnego bezpieczeństwa finansowego przedsiębiorstw sektora TSL, tj. współczynnika przyspieszonej płynności finansowej (zob. wykres 2.7 i tab. 2.7). Podobnie istotne różnice dla analizowanej zmiennej wystąpiły między 2007 a 2011 i 2012 r. (zob. wykres 2.8).

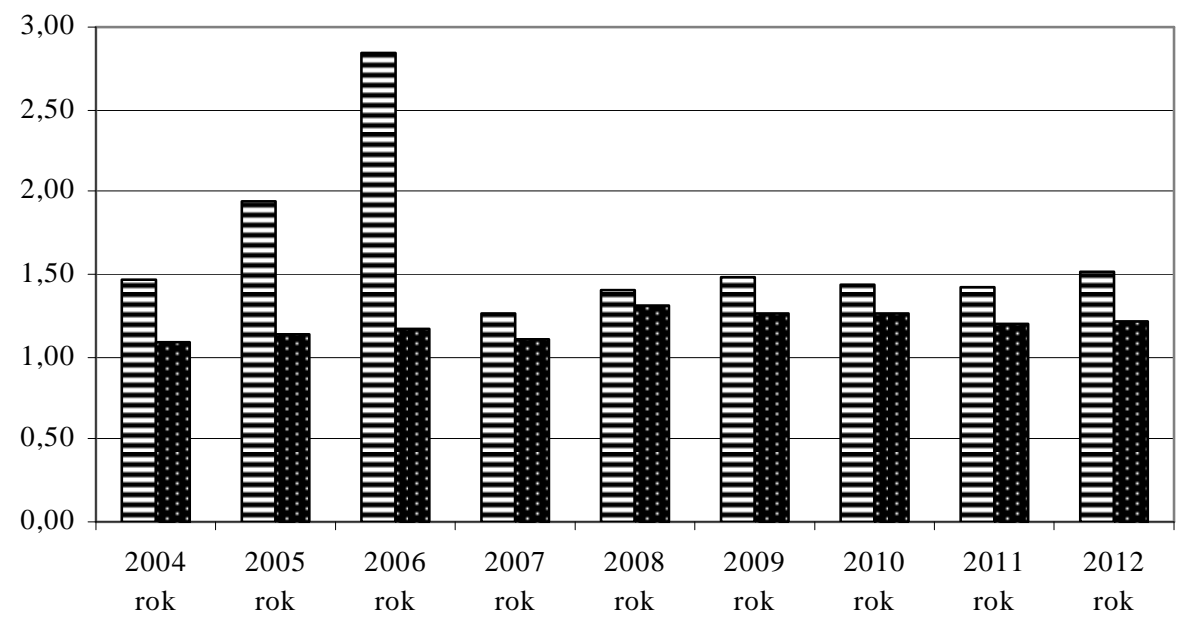

曰

Wykres 2.7. Średnia i środkowa wartość współczynnika przyspieszonej płynności finansowej spółek sektora TSL w latach 2004-2012

Źródło: jak do wykresu 2.3.

Ta b e la 2.7. Wartości podstawowych statystyk opisowych współczynnika przyspieszonej płynności finansowej w latach 2004-2012

\begin{tabular}{|c|c|c|c|c|c|c|}
\hline Wyszczególnienie & Średnia & Mediana & Minimum & Maksimum & Odch.std. & Wsp.zmn. \\
\hline \hline 2004 r. & 1,4687 & 1,0816 & 0,5549 & 10,3404 & 1,7538 & 119,42 \\
\hline 2005 r. & 1,9461 & 1,1309 & 0,5752 & 15,3156 & 2,8224 & 145,02 \\
\hline 2006 r. & 2,8404 & 1,1673 & 0,6314 & 39,2235 & 7,2585 & 255,55 \\
\hline 2007 r. & 1,2595 & 1,1111 & 0,4578 & 3,4289 & 0,6775 & 53,79 \\
\hline 2008 r. & 1,4032 & 1,3183 & 0,4736 & 4,5295 & 0,8062 & 57,46 \\
\hline 2009 r. & 1,4782 & 1,2640 & 0,6594 & 4,5112 & 0,8674 & 58,68 \\
\hline 2010 r. & 1,4293 & 1,2667 & 0,6953 & 3,6761 & 0,6356 & 44,47 \\
\hline 2011 r. & 1,4282 & 1,1964 & 0,6536 & 3,9663 & 0,6899 & 48,31 \\
\hline 2012 r. & 1,5132 & 1,2234 & 0,6752 & 3,4638 & 0,6802 & 44,95 \\
\hline
\end{tabular}

Źródło: jak do tab. 2.5. 


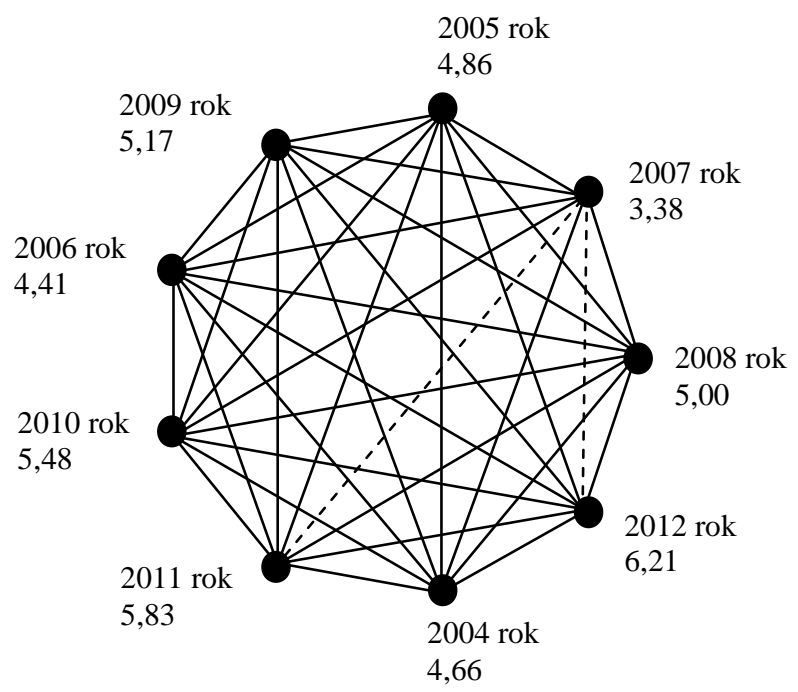

* Oznaczenia jak do wykresu 2.4.

Wykres 2.8. Średnia ranga dla wartości współczynnika przyspieszonej płynności finansowej w latach 2004-2012*

Źródło: jak do wykresu 2.4.

Środkowa wartość współczynnika natychmiastowej płynności finansowej - podobnie jak w przypadku przychodów netto ze sprzedaży usług, towarów i materiałów - kształtowała się na znacznie niższym poziomie niż jej wartość średnia (zob. wykres 2.9). W latach 2004-2012 w badanych jednostkach gospodarczych zaobserwowane zostało ponadto znaczne zróżnicowanie tego miernika, w tym w szczególności w 2004 r., w którym dla spółki Fiege Sp. z o.o. osiągnął on wartość zaledwie 0,0017, zaś dla PEKAES SA aż 5,1081 (zob. tab. 2.8). Dodatkowo poprowadzona analiza istotności różnic dla prób zależnych (tj. między kolejnymi latami) nie ujawniła jednakże ich występowania przy poziomie istotności wynoszącym 0,05 .

W przeciwieństwie do memoriałowych współczynników płynności finansowej - wartość minimalna zmiennej $\mathrm{m}_{5}$ była dla każdego roku poddanego analizie (za wyjątkiem 2005 r.) ujemna. Srodkowa wartość tej zmiennej była niższa od środkowej wartości miernika $\mathrm{m}_{2}$ i $\mathrm{m}_{3}$, wyższa zaś (za wyjątkiem $2010 \mathrm{r}$.) od $\mathrm{m}_{4}$ (por. tab. 2.6, 2.7, 2.8 i 2.9). Wartość współczynnika zdolności do obsługi zobowiązań bieżących gotówką osiąganą z działalności operacyjnej, podobnie jak dla współczynnika natychmiastowej płynności finansowej, nie wykazywała jednakże istotnych różnic między latami 2004-2012. 


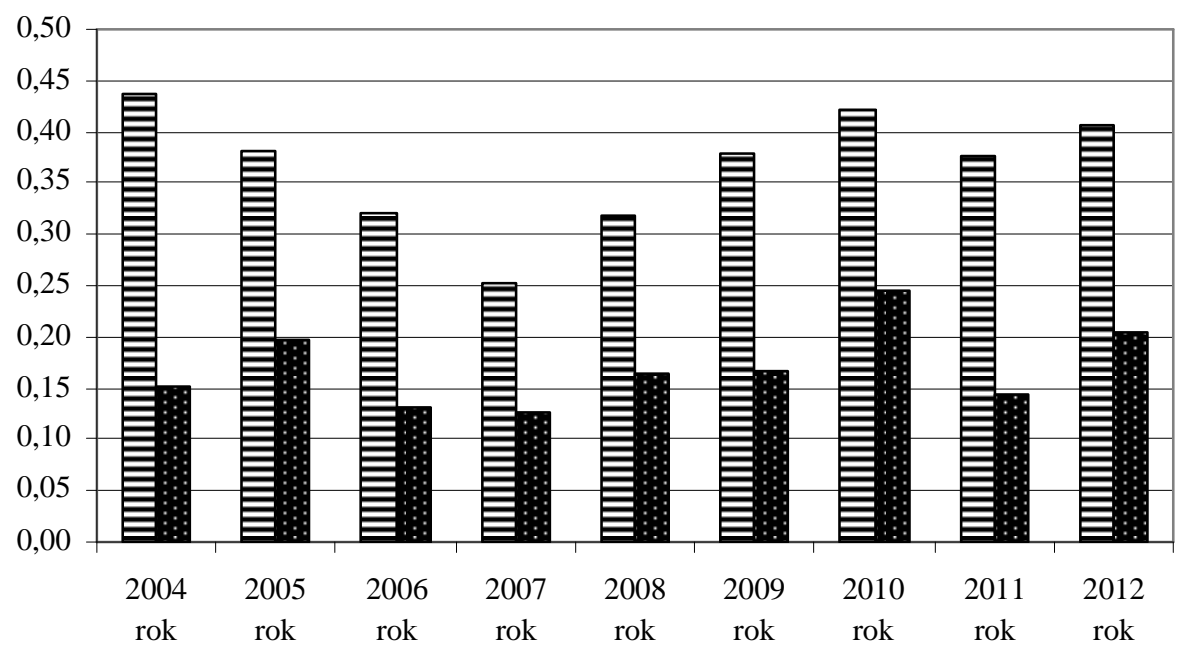

日 Średnia : Mediana

Wykres 2.9. Średnia i środkowa wartość współczynnika natychmiastowej płynności finansowej spółek sektora TSL w latach 2004-2012

Źródło: jak do wykresu 2.3.

Tabela 2.8. Wartości podstawowych statystyk opisowych współczynnika natychmiastowej płynności finansowej w latach 2004-2012

\begin{tabular}{|c|c|c|c|c|c|c|}
\hline Wyszczególnienie & Średnia & Mediana & Minimum & Maksimum & Odch.std & Wsp.zmn. \\
\hline \hline 2004 r. & 0,4361 & 0,1505 & 0,0017 & 5,1081 & 0,9305 & 213,39 \\
\hline 2005 r. & 0,3806 & 0,1962 & 0,0364 & 2,2103 & 0,4876 & 128,12 \\
\hline 2006 r. & 0,3199 & 0,1312 & 0,0032 & 1,5977 & 0,3996 & 124,90 \\
\hline 2007 r. & 0,2537 & 0,1269 & 0,0075 & 1,6556 & 0,3538 & 139,44 \\
\hline 2008 r. & 0,3191 & 0,1639 & 0,0083 & 1,5704 & 0,3805 & 119,26 \\
\hline 2009 r. & 0,3797 & 0,1677 & 0,0048 & 1,8512 & 0,4972 & 130,94 \\
\hline 2010 r. & 0,4229 & 0,2440 & 0,0143 & 2,6343 & 0,5807 & 137,29 \\
\hline 2011 r. & 0,3763 & 0,1441 & 0,0007 & 1,9699 & 0,5110 & 135,79 \\
\hline 2012 r. & 0,4067 & 0,2038 & 0,0011 & 2,1696 & 0,5384 & 132,38 \\
\hline
\end{tabular}

Źródło: jak do tab. 2.5. 


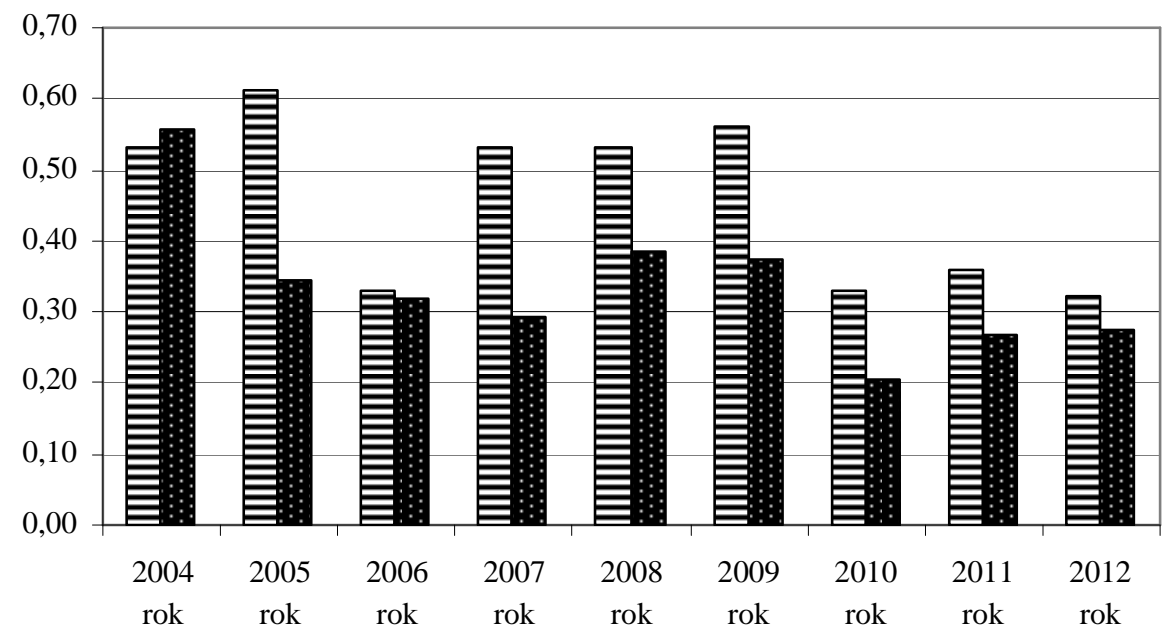

E Średnia : Mediana

Wykres 2.10. Średnia i środkowa wartość współczynnika zdolności do obsługi zobowiązań bieżących gotówką osiąganą z działalności operacyjnej spółek sektora TSL w latach 2004-2012

Źródło: jak do wykresu 2.3.

Tabela 2.9. Wartość podstawowych statystyk opisowych współczynnika zdolności do obsługi zobowiązań bieżących gotówką osiąganą z działalności operacyjnej w latach 2004-2012

\begin{tabular}{|c|c|c|c|c|c|c|}
\hline Wyszczególnienie & Średnia & Mediana & Minimum & Maksimum & Odch.std & Wsp.zmn. \\
\hline \hline 2004 r. & 0,5311 & 0,5581 & $-1,6139$ & 1,7906 & 0,6298 & 118,60 \\
\hline 2005 r. & 0,6134 & 0,3430 & 0,0060 & 4,3309 & 0,8420 & 137,28 \\
\hline 2006 r. & 0,3304 & 0,3199 & $-5,4166$ & 3,1847 & 1,3299 & 402,46 \\
\hline 2007 r. & 0,5328 & 0,2929 & $-0,3187$ & 5,3738 & 1,0407 & 195,32 \\
\hline 2008 r. & 0,5328 & 0,3852 & $-0,0764$ & 2,2786 & 0,5941 & 111,49 \\
\hline 2009 r. & 0,5608 & 0,3749 & $-0,0989$ & 3,5136 & 0,7821 & 139,47 \\
\hline 2010 r. & 0,3298 & 0,2058 & $-0,5923$ & 1,6145 & 0,4449 & 134,89 \\
\hline 2011 r. & 0,3598 & 0,2690 & $-0,0078$ & 1,6095 & 0,3306 & 91,88 \\
\hline 2012 r. & 0,3241 & 0,2736 & $-0,3868$ & 1,3243 & 0,3774 & 116,43 \\
\hline
\end{tabular}

Źródło: jak do tab. 2.5. 
Każdy przedsiębiorca prowadząc działalność gospodarczą dąży do maksymalizacji efektu, którym w wymiarze finansowym jest najczęściej zysk zrelacjonowany do określonej podstawy analitycznej. W przypadku związania działalności finansowej z działalnością marketingową wynik finansowy jest zestawiany ze sprzedażą.

Kolejnym przyjętym do badań empirycznych miernikiem oceny operacyjnego bezpieczeństwa finansowego jest współczynnik eksploatacyjnej rentowności sprzedaży. Średnia jego wartość w całym badanym okresie wykazywała tendencję malejącą (za wyjątkiem 2009 r. - zob. wykres 2.11), choć maksymalna - utrzymywała się w latach 2004-2009 na zbliżonym poziomie. W 2008 r. zwiększyła się ponadto ( $\mathrm{w}$ relacji do pozostałych lat poddanych analizie) znacznie wartość współczynnika zmienności. Spowodowane było to spadkiem minimalnej wartości analizowanego miernika przy jednocześnie wykazanej najwyższej w całym analizowanym okresie badawczym maksymalnej wartości tej zmiennej.

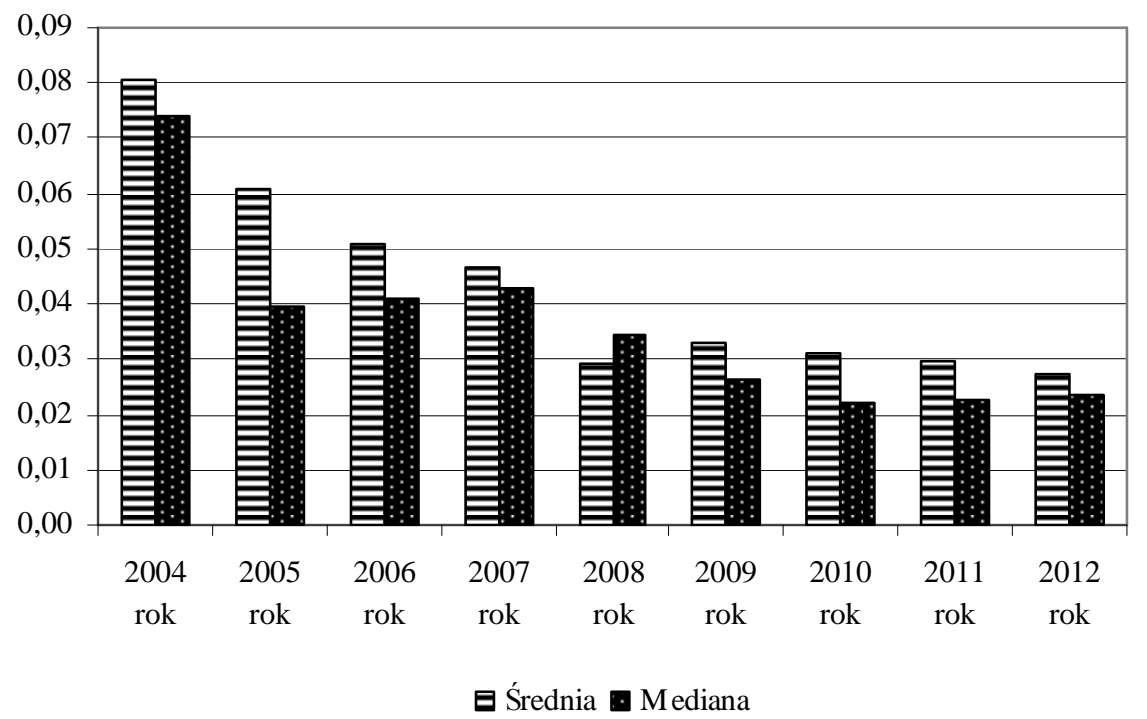

Wykres 2.11. Średnia i środkowa wartość współczynnika eksploatacyjnej rentowności sprzedaży spółek sektora TSL w latach 2004-2012

Źródło: jak do wykresu 2.3.

Najczęściej najwyższe wartości zmiennej $\mathrm{m}_{6}$ zostały osiągane $\mathrm{w}$ badanych spółkach sektora TSL w 2004 r. i istotnie różniły się od jej poziomu dla 2008, 2010, 2011 i 2012 r. Najwyższy spread średnich rang dla wartości współczynnika eksploatacyjnej rentowności sprzedaży wystąpił jednakże między 2004 a 2012 r. (zob. wykres 2.12). 
Tabela 2.10. Wartości podstawowych statystyk opisowych współczynnika eksploatacyjnej rentowności sprzedaży w latach 2004-2012

\begin{tabular}{|c|c|c|c|c|c|c|}
\hline Wyszczególnienie & Średnia & Mediana & Minimum & Maksimum & Odch.std & Wsp.zmn. \\
\hline \hline 2004 r. & 0,0806 & 0,0738 & $-0,0094$ & 0,2385 & 0,0586 & 72,63 \\
\hline 2005 r. & 0,0610 & 0,0397 & $-0,0281$ & 0,2252 & 0,0632 & 103,56 \\
\hline 2006 r. & 0,0507 & 0,0409 & $-0,2121$ & 0,2334 & 0,0801 & 157,84 \\
\hline 2007 r. & 0,0466 & 0,0431 & $-0,0782$ & 0,2342 & 0,0643 & 138,13 \\
\hline 2008 r. & 0,0293 & 0,0342 & $-0,1334$ & 0,2427 & 0,0752 & 256,52 \\
\hline 2009 r. & 0,0330 & 0,0262 & $-0,0868$ & 0,2159 & 0,0648 & 196,24 \\
\hline 2010 r. & 0,0310 & 0,0222 & $-0,1283$ & 0,1765 & 0,0525 & 169,42 \\
\hline 2011 r. & 0,0299 & 0,0224 & $-0,1149$ & 0,1666 & 0,0569 & 190,20 \\
\hline 2012 r. & 0,0271 & 0,0234 & $-0,1472$ & 0,1572 & 0,0540 & 198,94 \\
\hline
\end{tabular}

Źródło: jak do tab. 2.5.

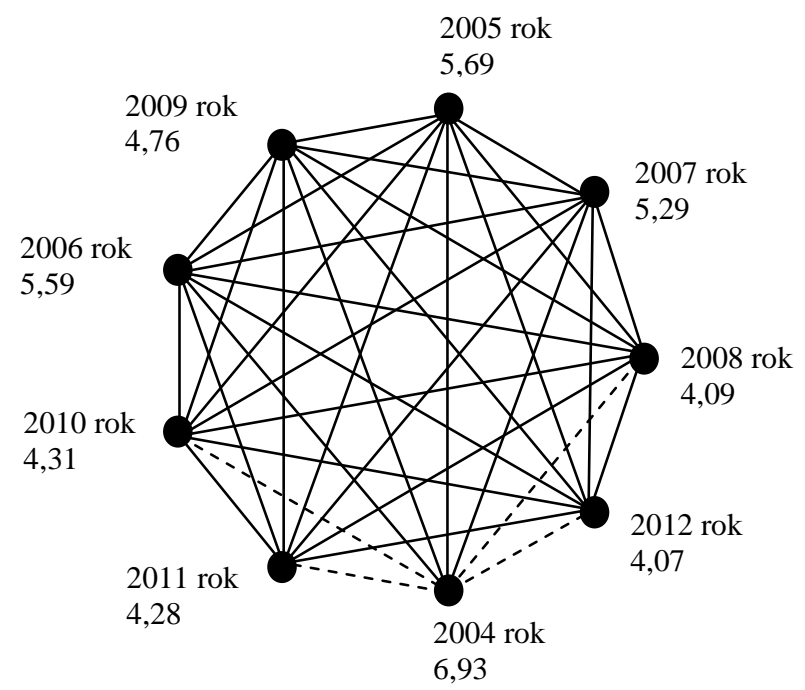

* Oznaczenia jak do wykresu 2.4.

Wykres 2.12. Średni ranga dla wartości współczynnika eksploatacyjnej rentowności sprzedaży w latach 2004-2012*

Źródło: jak do wykresu 2.4.

Bardzo zbliżone wyniki - $\mathrm{w}$ porównaniu ze zmienną $\mathrm{m}_{6}$ - prezentują wartości podstawowych statystyk opisowych współczynnika eksploatacyjnej rentowności aktywów ogółem. Średnia wartość miernika $\mathrm{m}_{7}$ wykazywała również w latach 
2004-2012 tendencję malejącą (za wyjątkiem 2010 r. - zob. wykres 2.13). Ponadto istotne różnice dla tej zmiennej diagnostycznej wystąpiły między 2004 a 2008, 2010, 2011 i 2012 r. (zob. wykres 2.14).

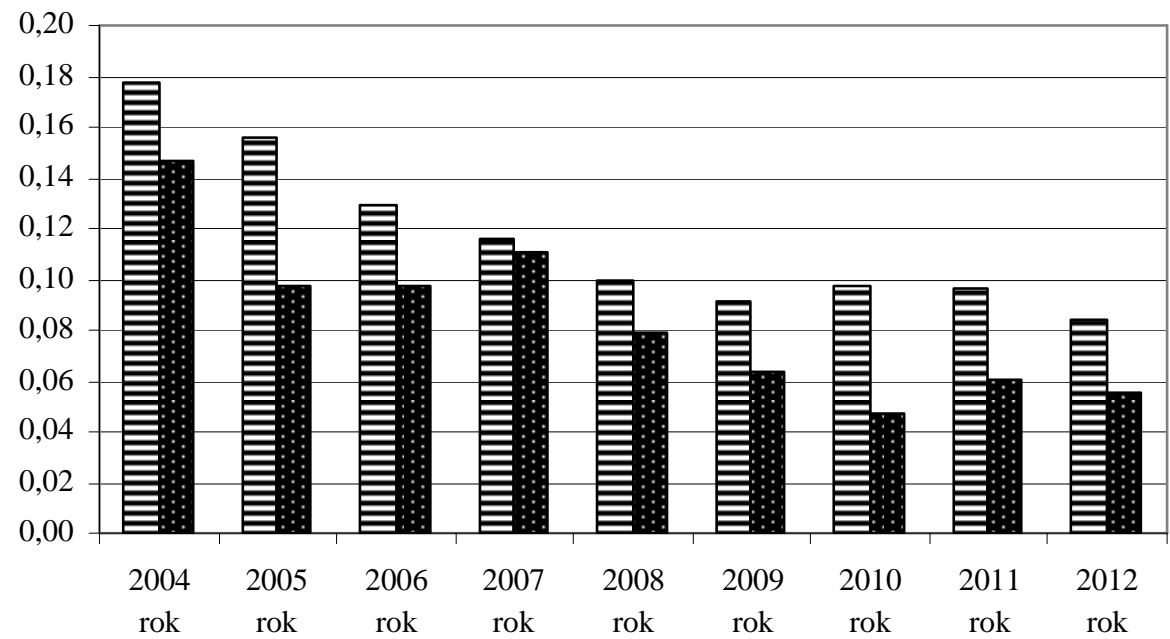

曰 Średnia : Mediana

Wykres 2.13. Średnia i środkowa wartość współczynnika eksploatacyjnej rentowności aktywów ogółem spółek sektora TSL w latach 2004-2012

Źródło: jak do wykresu 2.3.

Tabela 2.11. Wartości podstawowych statystyk opisowych współczynnika eksploatacyjnej rentowności aktywów ogółem w latach 2004-2012

\begin{tabular}{|c|c|c|c|c|c|c|}
\hline Wyszczególnienie & Średnia & Mediana & Minimum & Maksimum & Odch.std. & Wsp.zmn. \\
\hline \hline 2004 r. & 0,1773 & 0,1472 & $-0,0301$ & 0,7574 & 0,1527 & 86,12 \\
\hline 2005 r. & 0,1563 & 0,0972 & $-0,0407$ & 0,8568 & 0,1897 & 121,36 \\
\hline 2006 r. & 0,1290 & 0,0972 & $-0,0452$ & 0,6428 & 0,1389 & 107,66 \\
\hline 2007 r. & 0,1157 & 0,1105 & $-0,0844$ & 0,6260 & 0,1355 & 117,08 \\
\hline 2008 r. & 0,0998 & 0,0785 & $-0,2360$ & 0,7798 & 0,1837 & 184,17 \\
\hline 2009 r. & 0,0916 & 0,0634 & $-0,1276$ & 0,6520 & 0,1644 & 179,50 \\
\hline 2010 r. & 0,0979 & 0,0468 & $-0,0785$ & 0,4720 & 0,1266 & 129,36 \\
\hline 2011 r. & 0,0961 & 0,0605 & $-0,0816$ & 0,4383 & 0,1289 & 134,10 \\
\hline 2012 r. & 0,0841 & 0,0558 & $-0,0812$ & 0,5450 & 0,1263 & 150,10 \\
\hline
\end{tabular}

Źródło: jak do tab. 2.5. 


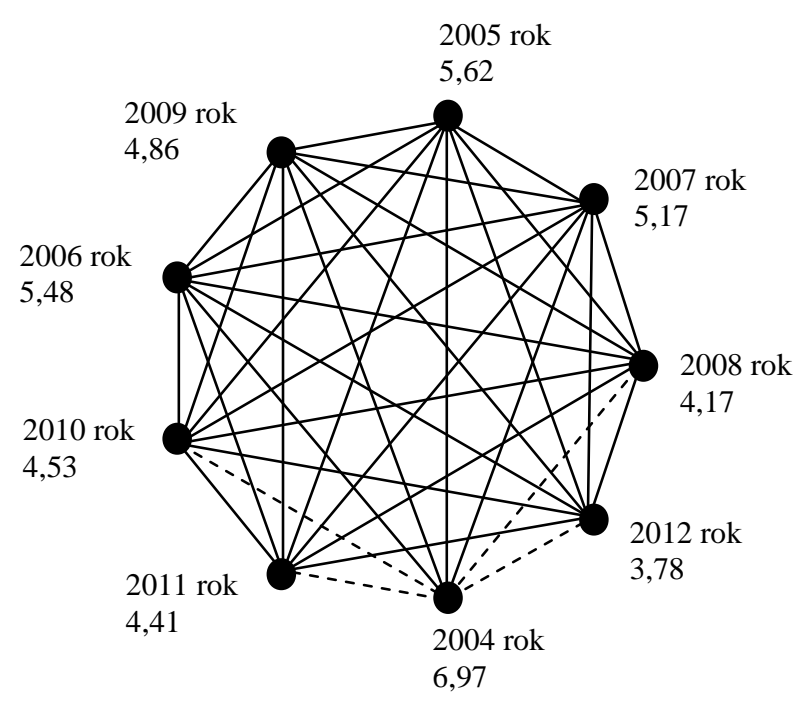

* Oznaczenia jak do wykresu 2.4.

Wykres 2.14. Średnia ranga dla wartości współczynnika eksploatacyjnej rentowności aktywów ogółem w latach 2004-2012*

Źródło: jak do wykresu 2.4.

W przypadku miernika $m_{8}$ dla 2008 r. wystąpiła obserwacja nietypowa. Miała ona miejsce w spółce VOS Logistics Polska Sp. z o.o. Badana zmienna ukształtowała się w tym podmiocie gospodarczym na poziomie $-176,57 \mathrm{w}$ wyniku bardzo niskiej wartości kapitałów własnych w relacji do ujemnego wyniku ze sprzedaży. Obserwacje nietypowe wywierają znaczny wpływ na średnią badanej zmiennej (zob. wykres 2.15) - wobec tego analizie poddana została jej wartość środkowa. W latach 2004-2010 odznaczała się ona tendencją spadkową, choć nadal była wyższa od wartości mediany dla współczynnika eksploatacyjnej rentowności sprzedaży i aktywów ogółem.

Dla współczynnika eksploatacyjnej rentowności kapitału własnego została wykazana największa liczba statystycznie istotnych różnic między określonymi latami dla jego wartości w latach 2004-2012. Najczęściej najniższy jego poziom występował w badanych podmiotach gospodarczych w 2008 r., najwyższy zaś - w 2004 r. (zob. wykres 2.16). Dla lat 2004-2005 średnia ranga była znacznie wyższa od tej, która pojawiła się dla 2008 oraz dodatkowo dla 2004 r. - w relacji do 2009, 2010, 2011 i 2012 r.

Średnia oraz środkowa wartość współczynnika wydajności pieniężnej sprzedaży była większa od tej, która została obliczona dla współczynnika eksploatacyjnej rentowności sprzedaży. Choć minimalna jego wartość w każdym $\mathrm{z}$ analizowanych lat była niższą od zera (za wyjątkiem 2005 r.), to kasowe mierniki ukształtowały się $\mathrm{w}$ badanych spółkach sektora TSL przeważnie na wyższym poziomie w relacji do mierników memoriałowych (por. tab. 2.10 i 2.13). 


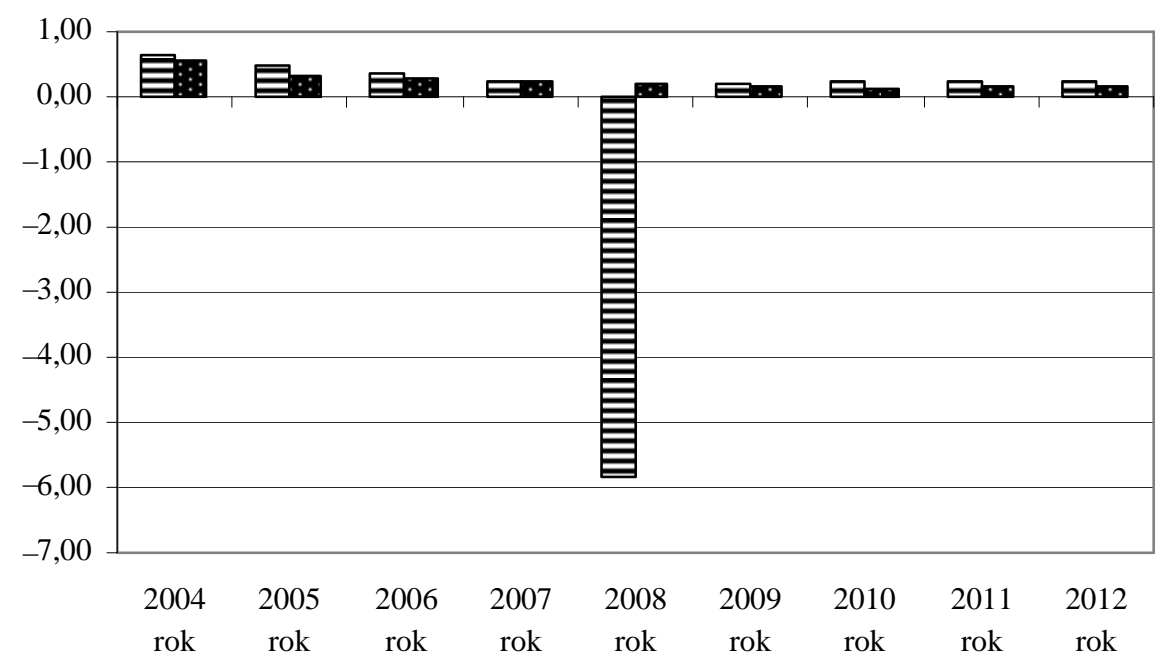

曰 Średnia Mediana

Wykres 2.15. Średnia i środkowa wartość współczynnika eksploatacyjnej rentowności kapitału własnego spółek sektora TSL w latach 2004-2012

Źródło: jak do wykresu 2.3.

Tabela 2.12. Wartości podstawowych statystyk opisowych współczynnika eksploatacyjnej rentowności kapitału własnego w latach 2004-2012

\begin{tabular}{|c|c|c|r|r|r|r|}
\hline Wyszczególnienie & Średnia & Mediana & Minimum & Maksimum & Odch.std. & Wsp.zmn. \\
\hline \hline 2004 r. & 0,6367 & 0,5787 & 0,0192 & 1,5858 & 0,4197 & 65,92 \\
\hline 2005 r. & 0,4686 & 0,3017 & $-0,0948$ & 2,1146 & 0,5261 & 112,28 \\
\hline 2006 r. & 0,3752 & 0,2939 & $-0,5144$ & 1,3968 & 0,4109 & 109,52 \\
\hline 2007 r. & 0,2534 & 0,2418 & $-3,5823$ & 1,4647 & 0,8472 & 334,32 \\
\hline 2008 r. & $-5,8215$ & 0,1866 & $-176,5701$ & 1,2614 & 32,8419 & $564,15^{*}$ \\
\hline 2009 r. & 0,1961 & 0,1644 & $-0,6889$ & 0,9573 & 0,3595 & 183,31 \\
\hline 2010 r. & 0,2520 & 0,1387 & $-0,1430$ & 0,8215 & 0,2765 & 109,71 \\
\hline 2011 r. & 0,2487 & 0,1682 & $-0,2461$ & 1,4494 & 0,3439 & 138,23 \\
\hline 2012 r. & 0,2251 & 0,1686 & $-0,2278$ & 1,2037 & 0,3068 & 136,28 \\
\hline
\end{tabular}

* Z uwagi na ujemną wartość średniej arytmetycznej dla 2008 r. podany został moduł liczby.

Źródło: jak do tab. 2.5. 


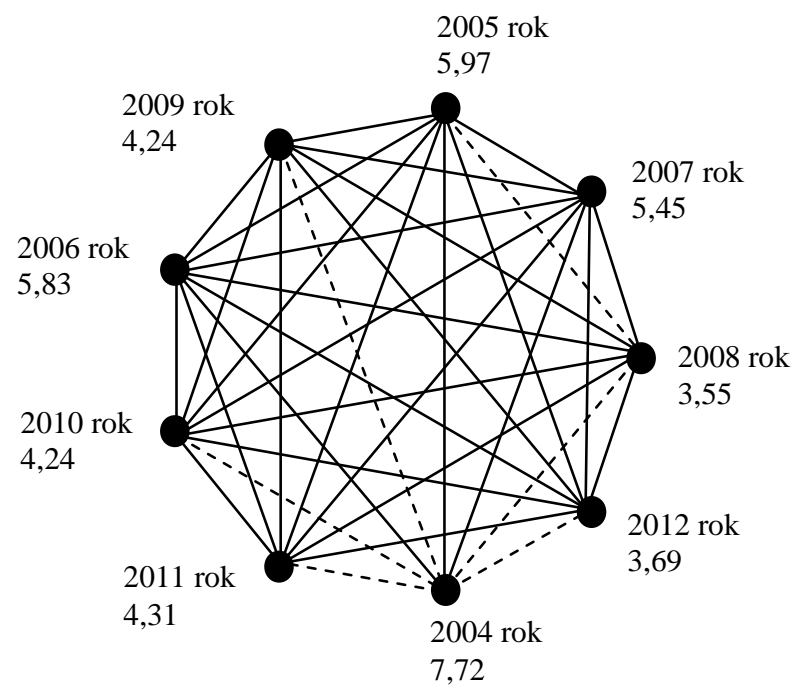

* Oznaczenia jak do wykresu 2.4.

Wykres 2.16. Średnia ranga dla wartości współczynnika eksploatacyjnej rentowności kapitału własnego w latach 2004-2012*

Źródło: jak do wykresu 2.4.

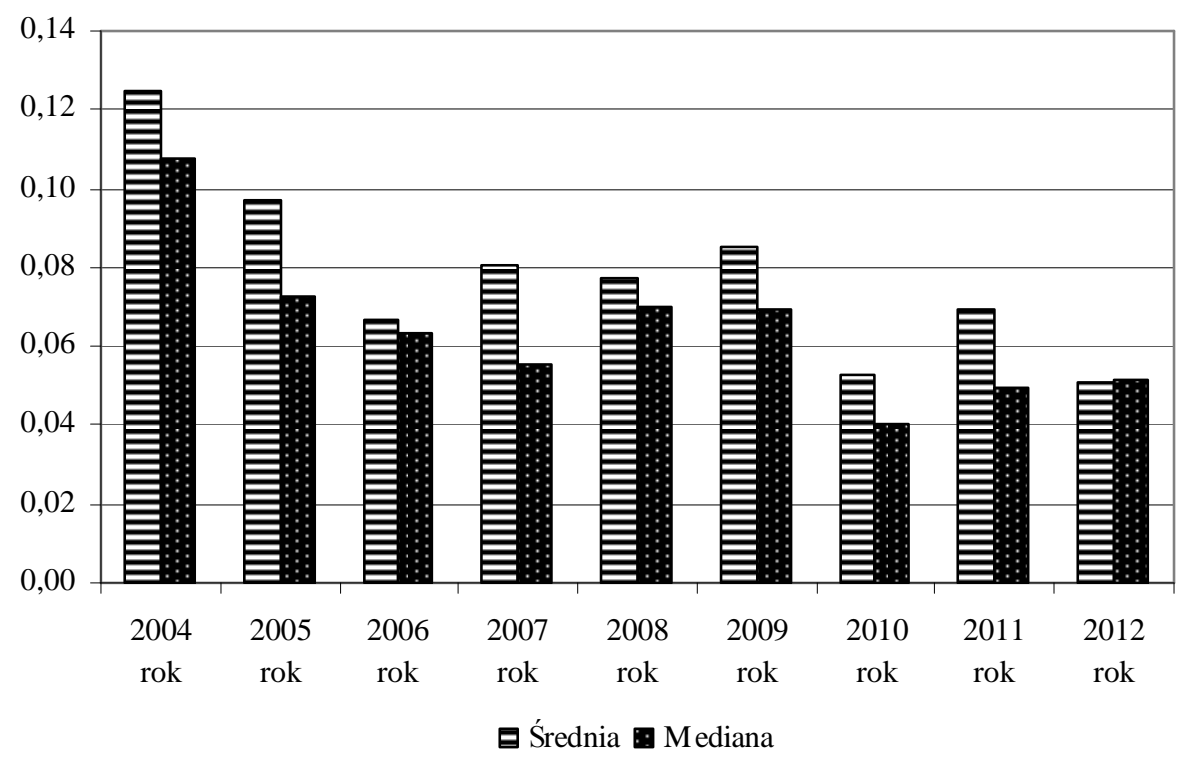

Wykres 2.17. Średnia i środkowa wartość współczynnika wydajności pieniężnej (gotówkowej) sprzedaży spółek sektora TSL w latach 2004-2012

Źródło: jak do wykresu 2.3. 
Tabela 2.13. Wartości podstawowych statystyk opisowych współczynnika wydajności pieniężnej (gotówkowej) sprzedaży w latach 2004-2012

\begin{tabular}{|c|c|c|c|c|c|c|}
\hline Wyszczególnienie & Średnia & Mediana & Minimum & Maksimum & Odch.std & Wsp.zmn. \\
\hline \hline 2004 r. & 0,1245 & 0,1079 & $-0,2339$ & 0,5864 & 0,1535 & 123,26 \\
\hline 2005 r. & 0,0974 & 0,0729 & 0,0011 & 0,5274 & 0,1011 & 103,76 \\
\hline 2006 r. & 0,0669 & 0,0636 & $-0,4630$ & 0,3086 & 0,1305 & 195,06 \\
\hline 2007 r. & 0,0808 & 0,0555 & $-0,0473$ & 0,4930 & 0,1059 & 130,95 \\
\hline 2008 r. & 0,0773 & 0,0698 & $-0,0231$ & 0,3016 & 0,0718 & 92,87 \\
\hline 2009 r. & 0,0850 & 0,0690 & $-0,0137$ & 0,5047 & 0,0957 & 112,55 \\
\hline 2010 r. & 0,0529 & 0,0403 & $-0,2147$ & 0,2487 & 0,0847 & 160,00 \\
\hline 2011 r. & 0,0695 & 0,0495 & $-0,0025$ & 0,2167 & 0,0571 & 82,06 \\
\hline 2012 r. & 0,0506 & 0,0518 & $-0,0672$ & 0,1381 & 0,0556 & 109,91 \\
\hline
\end{tabular}

Źródło: jak do tab. 2.5 .

Istotne różnice dla analizowanej zmiennej wystąpiły jedynie między 2004 a 2010 i 2012 r. (zob. wykres 2.18). W badanych spółkach sektora TSL w 2004 r. wartość tej zmiennej diagnostycznej była najczęściej najwyższa, najniższa przeto - w $2010 \mathrm{r}$.

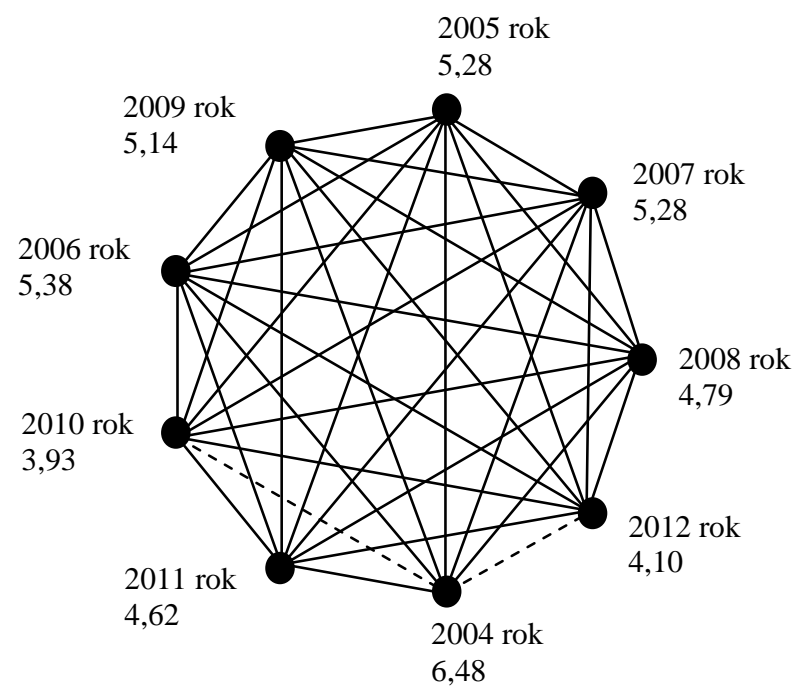

* Oznaczenia jak do wykresu 2.4.

Wykres 2.18. Średnia ranga dla wartości współczynnika wydajności pieniężnej (gotówkowej) sprzedaży w latach 2004-2012*

Źródło: jak do wykresu 2.4. 
Zbliżone wyniki uzyskane zostały w trakcie analizy współczynnika wydajności pieniężnej aktywów ogółem, którego środkowa i średnia wartość ukształtowała się na wyższym poziomie w relacji do wyróżnionych odpowiednio statystyk opisowych współczynnika eksploatacyjnej rentowności tych aktywów (por. tab. 2.11 i 2.14). Statystycznie istotne różnice dla miernika $m_{10}$ wystąpiły dokładnie na poziomie 0,05 wyłącznie pomiędzy 2004 a 2012 r., osiągając w spółkach sektora TSL najczęściej największą wartość na początku analizowanego w niniejszym opracowaniu okresu.

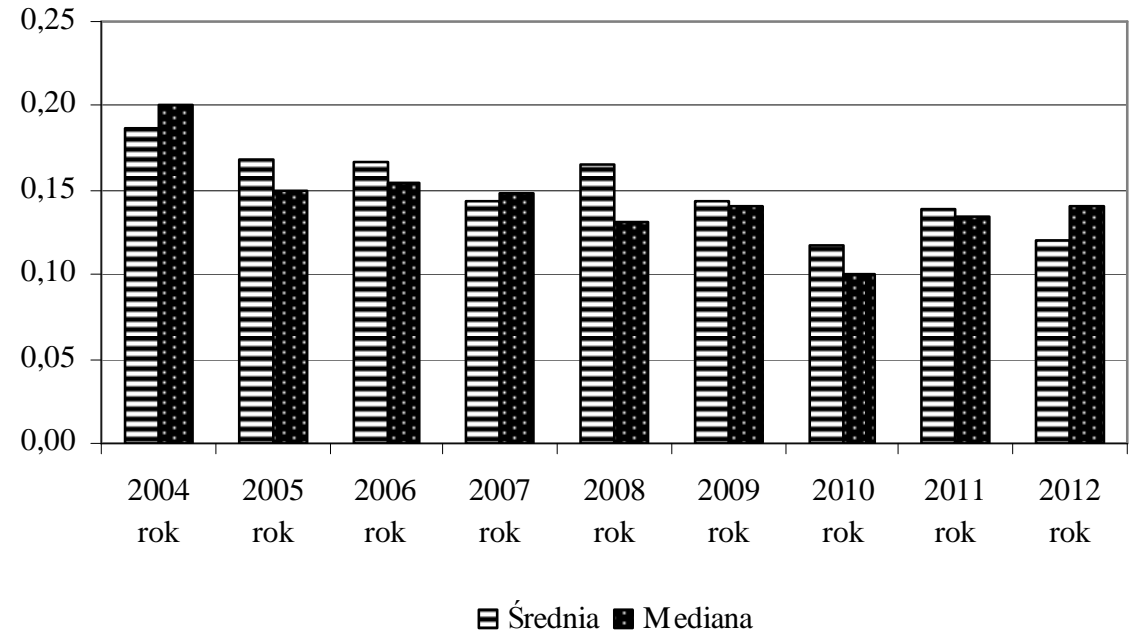

Wykres 2.19. Średnia i środkowa wartość współczynnika wydajności pieniężnej (gotówkowej) aktywów ogółem spółek sektora TSL w latach 2004-2012

Źródło: jak do wykresu 2.3.

Tabela 2.14. Wartości podstawowych statystyk opisowych współczynnika wydajności pieniężnej (gotówkowej) aktywów ogółem w latach 2004-2012

\begin{tabular}{|c|c|c|c|c|c|c|}
\hline Wyszczególnienie & Średnia & Mediana & Minimum & Maksimum & Odch.std. & Wsp.zmn. \\
\hline \hline 2004 r. & 0,1867 & 0,2003 & $-0,6582$ & 0,6598 & 0,2306 & 123,49 \\
\hline 2005 r. & 0,1680 & 0,1494 & 0,0065 & 0,4260 & 0,1097 & 65,26 \\
\hline 2006 r. & 0,1660 & 0,1550 & $-0,1397$ & 0,7217 & 0,1498 & 90,26 \\
\hline 2007 r. & 0,1434 & 0,1477 & $-0,1641$ & 0,4517 & 0,1351 & 94,24 \\
\hline 2008 r. & 0,1649 & 0,1310 & $-0,0478$ & 0,6948 & 0,1551 & 94,06 \\
\hline 2009 r. & 0,1433 & 0,1405 & $-0,0285$ & 0,4919 & 0,1086 & 75,78 \\
\hline 2010 r. & 0,1177 & 0,1005 & $-0,3598$ & 0,4807 & 0,1559 & 132,37 \\
\hline 2011 r. & 0,1385 & 0,1345 & $-0,0058$ & 0,4793 & 0,1018 & 73,48 \\
\hline 2012 r. & 0,1201 & 0,1398 & $-0,1173$ & 0,4625 & 0,1200 & 99,89 \\
\hline
\end{tabular}

Źródło: jak do tab. 2.5. 


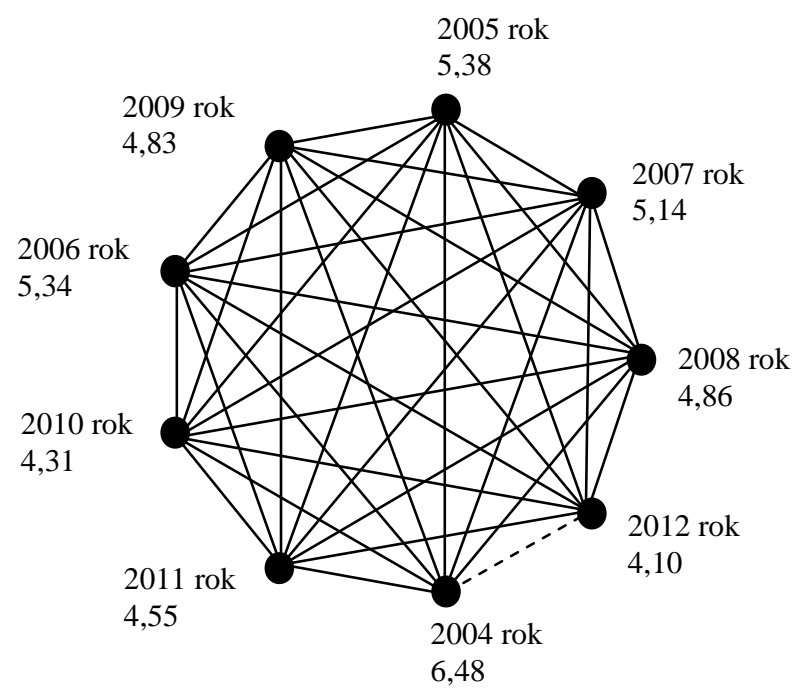

* Linia przerywana obrazuje istotne różnice między określonymi latami dla analizowanego miernika oceny operacyjnego bezpieczeństwa finansowego (poziom istotności równy 0,05).

Wykres 2.20. Średnia ranga dla wartości współczynnika wydajności pieniężnej (gotówkowej) aktywów ogółem w latach 2004-2012*

Źródło: jak do wykresu 2.4 .

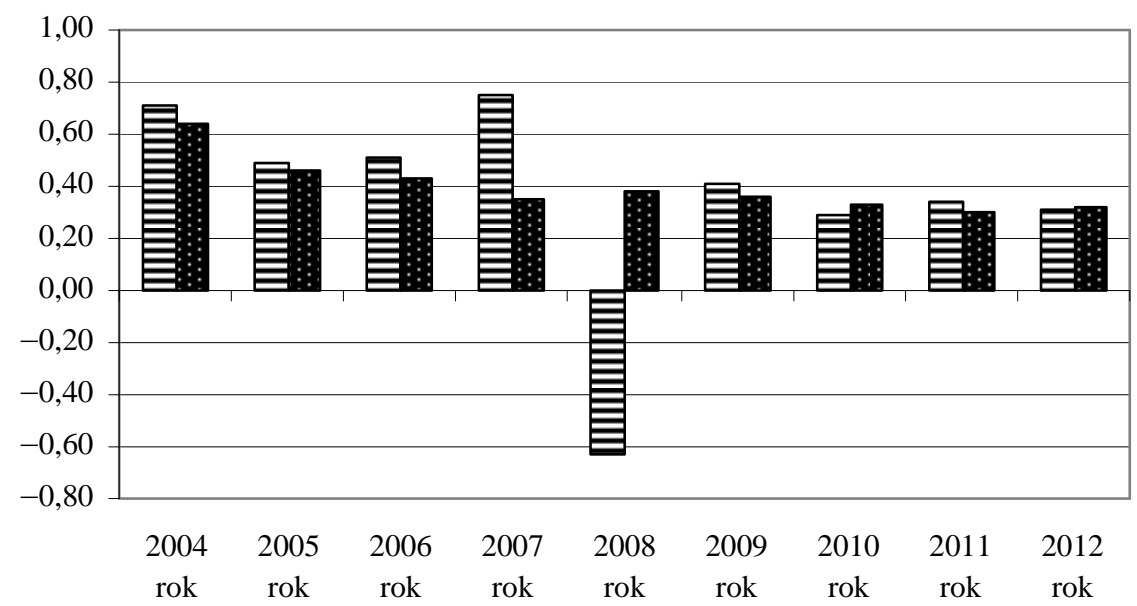

曰 Średnia : Mediana

Wykres 2.21. Średnia i środkowa wartość współczynnika wydajności pieniężnej (gotówkowej) kapitału własnego spółek sektora TSL w latach 2004-2012

Źródło: jak do wykresu 2.3. 
Dla miernika $\mathrm{m}_{11}$, podobnie jak w przypadku współczynnika eksploatacyjnej rentowności kapitału własnego, pojawiła się ujemna wartość średniej w 2008 r. w wyniku występowania obserwacji (przedsiębiorstwa) odstającej (zob. wykres 2.21). W 2008 r. znacznemu zwiększeniu uległ współczynnik zmienności tego miernika, jak i wystąpił najwyższy spread między jego minimalną a maksymalną wartością (zob. tab. 2.15). Środkowy i średni poziom analizowanej zmiennej utrzymywał się natomiast na wyższym poziomie od tych, które zostały obliczone dla miernika $\mathrm{m}_{8}$.

Tabela 2.15. Wartości podstawowych statystyk opisowych współczynnika wydajności pieniężnej (gotówkowej) kapitału własnego w latach 2004-2012

\begin{tabular}{|c|c|c|c|c|c|c|}
\hline Wyszczególnienie & Średnia & Mediana & Minimum & Maksimum & Odch.std. & Wsp.zmn. \\
\hline \hline 2004 r. & 0,7084 & 0,6401 & $-3,8399$ & 3,2310 & 1,1077 & 156,36 \\
\hline 2005 r. & 0,4864 & 0,4631 & 0,0208 & 1,2706 & 0,3041 & 62,51 \\
\hline 2006 r. & 0,5105 & 0,4332 & $-0,3770$ & 1,5684 & 0,4301 & 84,26 \\
\hline 2007 r. & 0,7484 & 0,3461 & $-0,3782$ & 9,5099 & 1,7380 & 232,21 \\
\hline 2008 r. & $-0,6277$ & 0,3834 & $-30,6089$ & 1,4362 & 5,7768 & $920,39^{*}$ \\
\hline 2009 r. & 0,4112 & 0,3561 & $-0,0883$ & 1,5750 & 0,3516 & 85,50 \\
\hline 2010 r. & 0,2856 & 0,3271 & $-1,4005$ & 1,2395 & 0,4250 & 148,82 \\
\hline 2011 r. & 0,3445 & 0,2952 & $-0,0202$ & 0,9403 & 0,2536 & 73,61 \\
\hline 2012 r. & 0,3086 & 0,3234 & $-0,6529$ & 1,1320 & 0,3509 & 113,72 \\
\hline
\end{tabular}

* Z uwagi na ujemną wartość średniej arytmetycznej dla 2008 r. podany został moduł liczby.

Źródło: jak do tab. 2.5.

Obliczone poziomy współczynników wydajności pieniężnej kapitału własnego ponownie okazały się najwyższymi w badanych podmiotach gospodarczch najczęściej dla 2004 r. i istotnie różnymi od tych, które zostały wypracowane przez nie odpowiednio w latach 2008-2012 (zob. wykres 2.22).

Dość nietypowymi zmiennymi okazały się współczynniki zabezpieczenia finansowego, bowiem dla przykładu dla pierwszego z nich środkowa wartość była równa zero w całym badanym okresie, zaś dla drugiego - odpowiednio w latach 2004-2008 (zob. tab. 2.16 i 2.17). Średnia wartość tego drugiego miernika okazała się być wyższą od tej dla miernika $\mathrm{m}_{12}$ i tym samym można wskazać, iż badane spółki sektora TSL skłonne były bardziej tworzyć pozostałe krótkoterminowe rezerwy na zobowiązania niż krótkoterminowe rezerwy na świadczenie emerytalne i podobne. Ponadto bardzo niskie wartości ich średniej arytmetycznej (zwłaszcza w przypadku miernika $\mathrm{m}_{12}$ ) były zasadniczą determinantą dość wysokiego poziomu współczynnika zmienności tych mierników. 


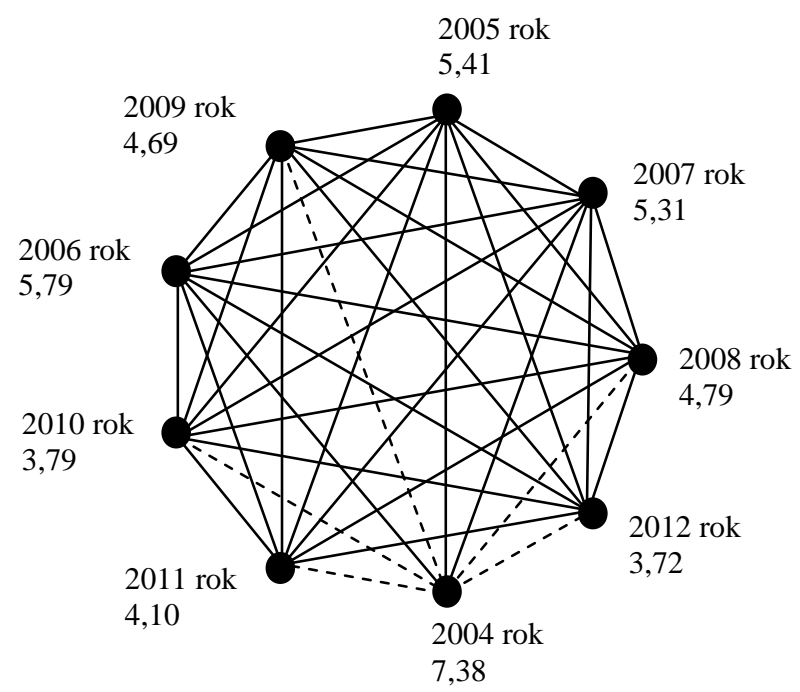

* Oznaczenia jak do wykresu 2.4.

Wykres 2.22. Średnia ranga dla wartości współczynnika wydajności pieniężnej (gotówkowej) kapitału własnego w latach 2004-2012*

Źródło: jak do wykresu 2.4.

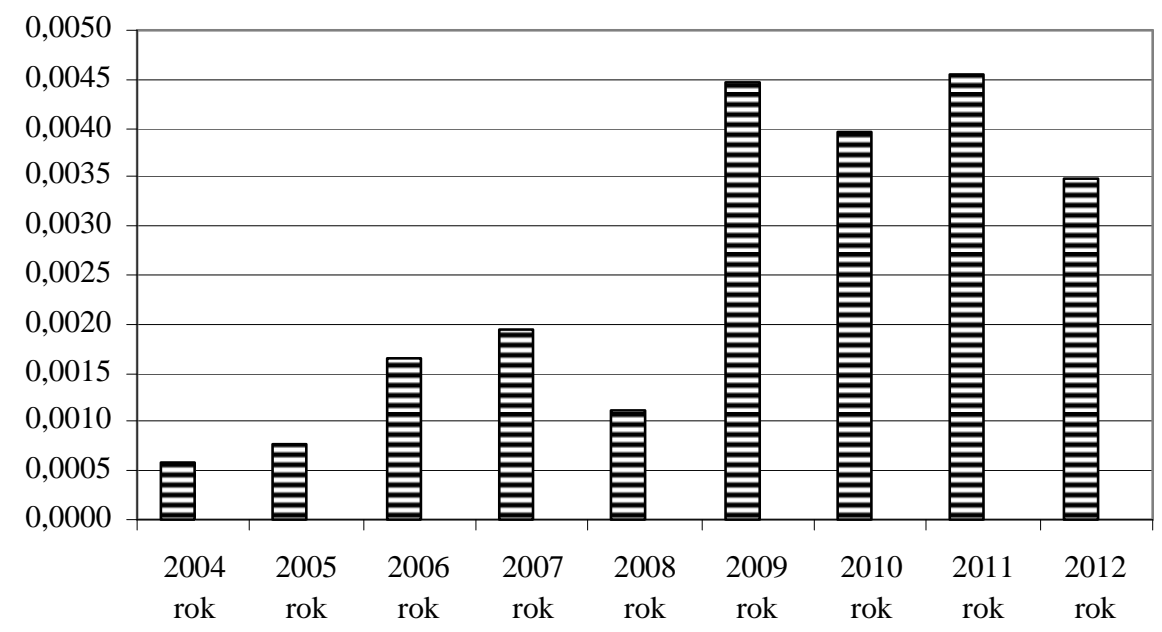

曰 Średnia Mediana

Wykres 2.23. Średnia i środkowa wartość współczynnika zabezpieczenia finansowego nr 1 spółek sektora TSL w latach 2004-2012

Źródło: jak do wykresu 2.3. 
Tabela 2.16. Wartości podstawowych statystyk opisowych współczynnika zabezpieczenia finansowego nr 1 w latach 2004-2012

\begin{tabular}{|c|c|c|c|c|c|c|}
\hline Wyszczególnienie & Średnia & Mediana & Minimum & Maksimum & Odch.std. & Wsp.zmn. \\
\hline \hline 2004 r. & 0,0006 & 0,0000 & 0,0000 & 0,0140 & 0,0026 & 443,63 \\
\hline 2005 r. & 0,0008 & 0,0000 & 0,0000 & 0,0147 & 0,0030 & 385,37 \\
\hline 2006 r. & 0,0016 & 0,0000 & 0,0000 & 0,0370 & 0,0069 & 422,10 \\
\hline 2007 r. & 0,0020 & 0,0000 & 0,0000 & 0,0309 & 0,0067 & 343,90 \\
\hline 2008 r. & 0,0011 & 0,0000 & 0,0000 & 0,0223 & 0,0044 & 390,41 \\
\hline 2009 r. & 0,0045 & 0,0000 & 0,0000 & 0,0381 & 0,0104 & 232,82 \\
\hline 2010 r. & 0,0040 & 0,0000 & 0,0000 & 0,0273 & 0,0085 & 215,13 \\
\hline 2011 r. & 0,0046 & 0,0000 & 0,0000 & 0,0341 & 0,0096 & 210,02 \\
\hline 2012 r. & 0,0035 & 0,0000 & 0,0000 & 0,0263 & 0,0069 & 196,44 \\
\hline
\end{tabular}

Źródło: jak do tab. 2.5 .

Dla zmiennej $\mathrm{m}_{12}$, jak i $\mathrm{m}_{13}$ nie wystąpiły statystycznie istotne różnice między latami 2004-2012. Otrzymane wyniki są zatem zgodne z tymi, które uzyskano dla współczynnika natychmiastowej płynności finansowej $\left(\mathrm{m}_{4}\right)$ oraz współczynnika zdolności do obsługi zobowiązań bieżących gotówką osiąganą $\mathrm{z}$ działalności operacyjnej $\left(\mathrm{m}_{5}\right)$.

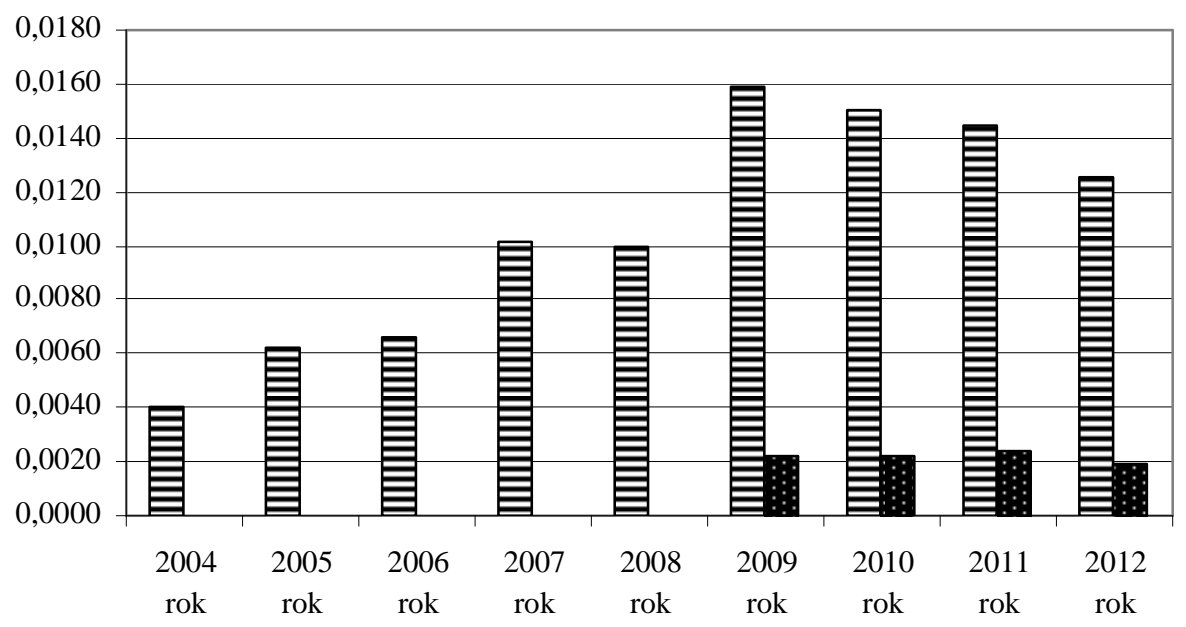

日 Średnia Mediana

Wykres 2.24. Średnia i środkowa wartość współczynnika zabezpieczenia finansowego nr 2 spółek sektora TSL w latach 2004-2012

Źródło: jak do wykresu 2.3. 
Tabela 2.17. Wartość podstawowych statystyk opisowych współczynnika zabezpieczenia finansowego nr 2 w latach 2004-2012

\begin{tabular}{|c|c|c|c|c|c|c|}
\hline Wyszczególnienie & Średnia & Mediana & Minimum & Maksimum & Odch.std. & Wsp.zmn. \\
\hline \hline 2004 r. & 0,0040 & 0,0000 & 0,0000 & 0,0269 & 0,0075 & 187,17 \\
\hline 2005 r. & 0,0062 & 0,0000 & 0,0000 & 0,0426 & 0,0110 & 177,77 \\
\hline 2006 r. & 0,0066 & 0,0000 & 0,0000 & 0,0282 & 0,0099 & 149,46 \\
\hline 2007 r. & 0,0102 & 0,0000 & 0,0000 & 0,0856 & 0,0195 & 191,35 \\
\hline 2008 r. & 0,0100 & 0,0000 & 0,0000 & 0,0816 & 0,0182 & 182,73 \\
\hline 2009 r. & 0,0159 & 0,0022 & 0,0000 & 0,1253 & 0,0282 & 177,44 \\
\hline 2010 r. & 0,0150 & 0,0022 & 0,0000 & 0,1193 & 0,0267 & 177,25 \\
\hline 2011 r. & 0,0144 & 0,0024 & 0,0000 & 0,1184 & 0,0269 & 186,38 \\
\hline 2012 r. & 0,0125 & 0,0019 & 0,0000 & 0,1163 & 0,0247 & 197,03 \\
\hline
\end{tabular}

Źródło: jak do tab. 2.5.

Zbiorcze zestawienie wyników badań dotyczących tempa zmian średniej i środkowej wartości mierników oceny operacyjnego bezpieczeństwa finansowego wskazuje, iż w 2012 r. w relacji do 2004 r. nastąpiło zmniejszenie wartości badanych zmiennych diagnostycznych $\mathrm{z}$ obszaru rentowności eksploatacyjnej i wydajności pieniężnej. Miało ono miejsce także w przypadku współczynnika zdolności do obsługi zobowiązań bieżących gotówką osiąganą z działalności operacyjnej oraz - dla analizy wyłącznie tempa zmian dla średniej - także w przypadku współczynnika natychmiastowej płynności finansowej (zob. tab. 2.18).

Najwyższy spadek średniej i środkowej wartości miernika oceny operacyjnego bezpieczeństwa finansowego wystąił $\mathrm{w}$ przypadku zmiennej $\mathrm{m}_{6}$, tj. współczynnika eksploatacyjnej rentowności sprzedaży.

Zbiorcze zestawienie wyników badań dotyczących istotności różnic między określonymi latami (tj. 2004-2012) dla analizowanych mierników oceny operacyjnego bezpieczeństwa finansowego, wskazuje (zob. tab. 2.19), że różnice takie nie wystąiły w przypadku współczynnika natychmiastowej płynności finansowej $\left(\mathrm{m}_{4}\right)$, współczynnika zdolności do obsługi zobowiązań bieżących gotówką osiąganą z działalności operacyjnej $\left(\mathrm{m}_{5}\right)$ oraz obydwu rozważanych współczynników zabezpieczenia finansowego $\left(\mathrm{tj} . \mathrm{m}_{12} \mathrm{i} \mathrm{m}_{13}\right.$ ). Takie różnice pojawiły się (z wyjątkiem zmiennych $\mathrm{m}_{2}$ i $\mathrm{m}_{3}$ ) między 2004 a 2012 r., przy czym dla $2012 \mathrm{r}$. wiązało się to z wystąpieniem istotnie różnej, najczęściej najwyższej wartości przychodów netto ze sprzedaży usług, towarów i materiałów spółek sektora TSL oraz najniższą ich wartością współczynników eksploatacyjnej rentowności i wydatności pieniężnej. Identyczna sytuacja wystąpiła również między rokiem 2004 a 2008 i 2004 a $2011 \mathrm{w}$ przypadku mierników $\mathrm{m}_{1}, \mathrm{~m}_{6}, \mathrm{~m}_{7}, \mathrm{~m}_{8}$ i $\mathrm{m}_{11}$, zaś między rokiem 2004 a $2010 \mathrm{w}$ przypadku mierników $\mathrm{m}_{6}, \mathrm{~m}_{7}, \mathrm{~m}_{8}, \mathrm{~m}_{9} \mathrm{i} \mathrm{m}_{11}$. Wśród tych współczynników dla zmiennej $\mathrm{m}_{8}$ uzyskana została największa liczba statystycznie istotnych różnic. Dla niej też najczęściej najmniejsza wartość w spółkach sektora TSL pojawiała się w 2008 r. 
Jedynie w przypadku współczynnika bieżącej i natychmiastowej płynności finansowej analizowane różnice pojawiły się głównie pomiędzy 2007 a 2011 i 2012 r., przy czym najczęściej najwyższy jej poziom występował w badanych przedsiębiorstwach w $2012 \mathrm{r}$.

Tabela 2.18. Tempo zmian średniej i środkowej wartości mierników oceny operacyjnego bezpieczeństwa finansowego spółek sektora TSL między latami 2004-2012 $2^{59}$

\begin{tabular}{|c|c|c|c|c|c|c|}
\hline \multirow{2}{*}{$\begin{array}{l}\text { Wyszcze- } \\
\text { gólnienie }\end{array}$} & \multicolumn{2}{|c|}{ Średnia } & \multirow{2}{*}{$\begin{array}{c}\text { Tempo } \\
\text { zmian dla } \\
\text { średniej } \\
\text { 2012/2004* } \\
\quad(\mathrm{w} \%)\end{array}$} & \multicolumn{2}{|c|}{ Mediana } & \multirow{2}{*}{$\begin{array}{c}\text { Tempo } \\
\text { zmian dla } \\
\text { średniej } \\
2012 / 2004 * \\
(\mathrm{w} \%) \\
\end{array}$} \\
\hline & $2004 \mathrm{r}$. & $2012 \mathrm{r}$. & & $2004 \mathrm{r}$. & $2012 \mathrm{r}$. & \\
\hline $\mathrm{m}_{1}$ & 136582823,58 & 304985070,75 & 123,30 & 80111335,05 & 152699222,48 & 90,61 \\
\hline $\mathrm{m}_{2}$ & 1,5289 & 1,5812 & 3,42 & 1,1437 & 1,2825 & 12,14 \\
\hline $\mathrm{m}_{3}$ & 1,4687 & 1,5132 & 3,03 & 1,0816 & 1,2234 & 13,10 \\
\hline $\mathrm{m}_{4}$ & 0,4361 & 0,4067 & $-6,73$ & 0,1505 & 0,2038 & 35,42 \\
\hline $\mathrm{m}_{5}$ & 0,5311 & 0,3241 & $-38,96$ & 0,5581 & 0,2736 & $-50,98$ \\
\hline $\mathrm{m}_{6}$ & 0,0806 & 0,0271 & $-66,33$ & 0,0738 & 0,0234 & $-68,25$ \\
\hline $\mathrm{m}_{7}$ & 0,1773 & 0,0841 & $-52,56$ & 0,1472 & 0,0558 & $-62,12$ \\
\hline $\mathrm{m}_{8}$ & 0,6367 & 0,2251 & $-64,64$ & 0,5787 & 0,1686 & $-70,86$ \\
\hline $\mathrm{m}_{9}$ & 0,1245 & 0,0506 & $-59,39$ & 0,1079 & 0,0518 & $-51,97$ \\
\hline $\mathrm{m}_{10}$ & 0,1867 & 0,1201 & $-35,66$ & 0,2003 & 0,1398 & $-30,17$ \\
\hline $\mathrm{m}_{11}$ & 0,7084 & 0,3086 & $-56,44$ & 0,6401 & 0,3234 & $-49,48$ \\
\hline $\mathrm{m}_{12}$ & 0,0006 & 0,0035 & 494,88 & 0,0000 & 0,0000 & $\mathrm{x}$ \\
\hline $\mathrm{m}_{13}$ & 0,0040 & 0,0125 & 211,63 & 0,0000 & 0,0019 & $\mathrm{x}$ \\
\hline
\end{tabular}

* Pogrubioną czcionką zaznaczone zostało ujemne tempo zmian pomiędzy latami 2004-2010.

Źródło: jak do tab. 2.5 .

Zaprezentowane wyniki badań potwierdziły przeto hipotezę badawczą stanowiącą, iż rentowność eksploatacyjna i wydajność pieniężna (gotówkowa) jest tym obszarem kreowania i zapewniania dobrego standingu finansowego przedsiębiorstw sektora TSL, w którym obserwuje się znaczqcy spadek wartości memoriałowych i kasowych mierników oceny operacyjnego bezpieczeństwa finansowego.

${ }^{59}$ Porównania w czasie można przeprowadzić dla dowolnych okresów (momentów), ale najczęściej dotyczą one kolejnych okresów odniesionych do bezpośrednio je poprzedzających lub też kolejnych okresów porównywanych z jednym, przyjętym za podstawę, [za:] G. Juszczak-S zu ma cher, Miary dynamiki, [w:] W. S tar z yń s ka (red.), Podstawy statystyki: podręcznik, Centrum Doradztwa i Informacji Difin Sp. z o.o., Warszawa 2004, s. 194.

W niniejszej analizie podstawą porównań był początek badanego okresu, tj. 2004 r. 


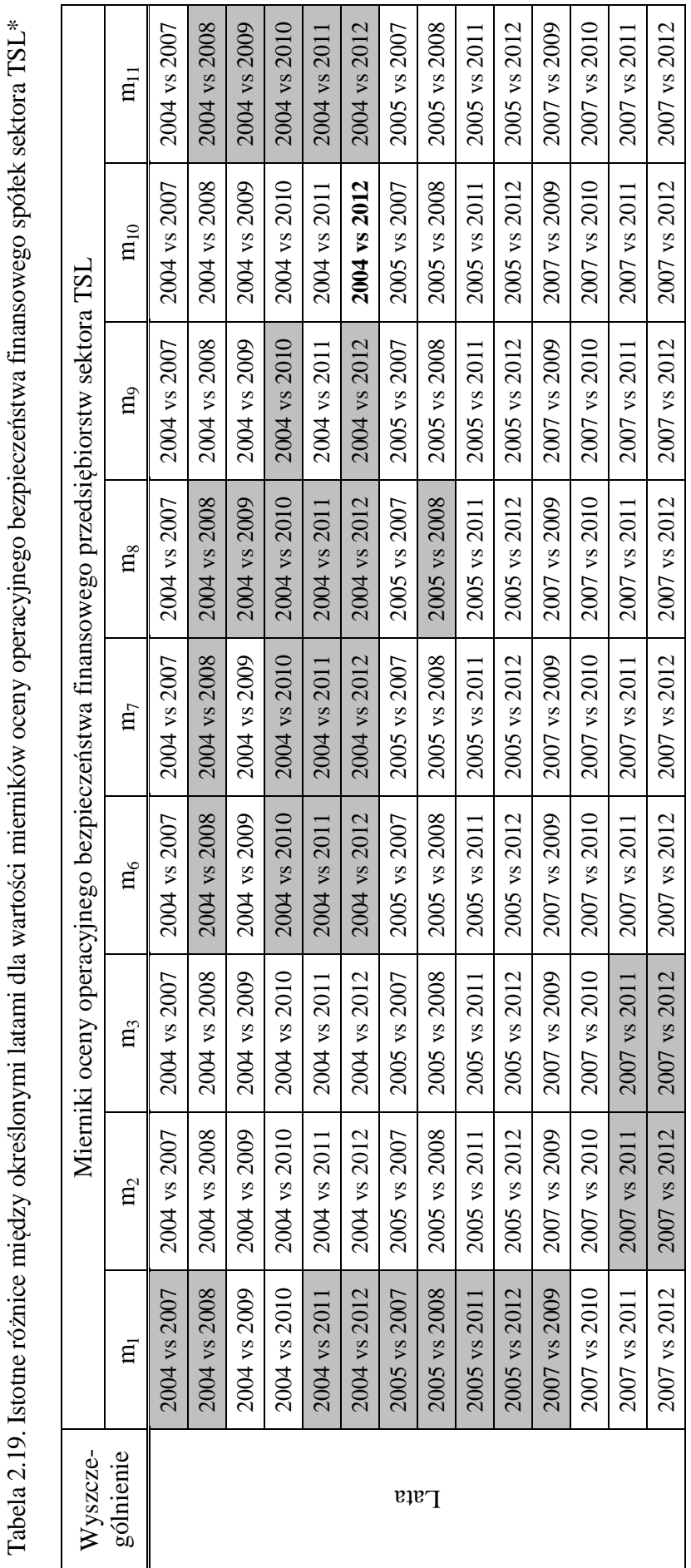

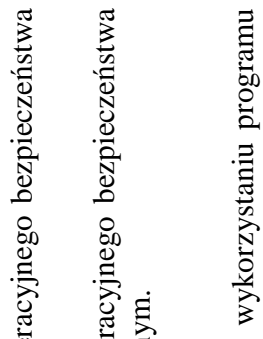

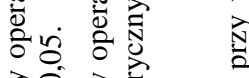

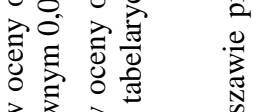

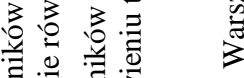

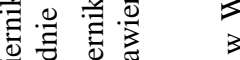

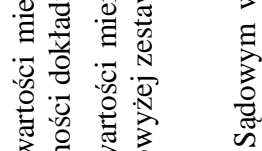

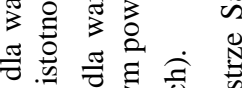

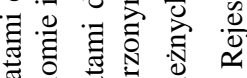

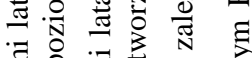

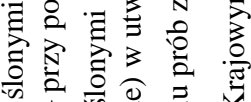

娄

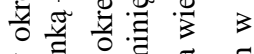

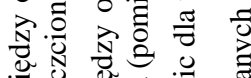

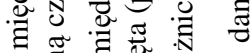

จ

总.

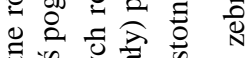

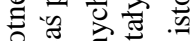

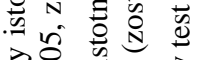

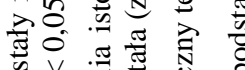

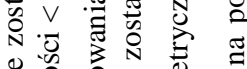

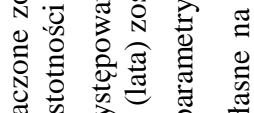

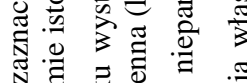

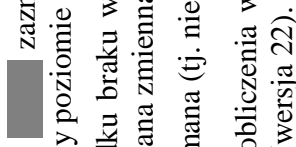

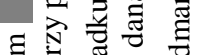

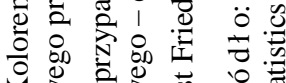

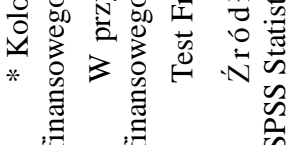




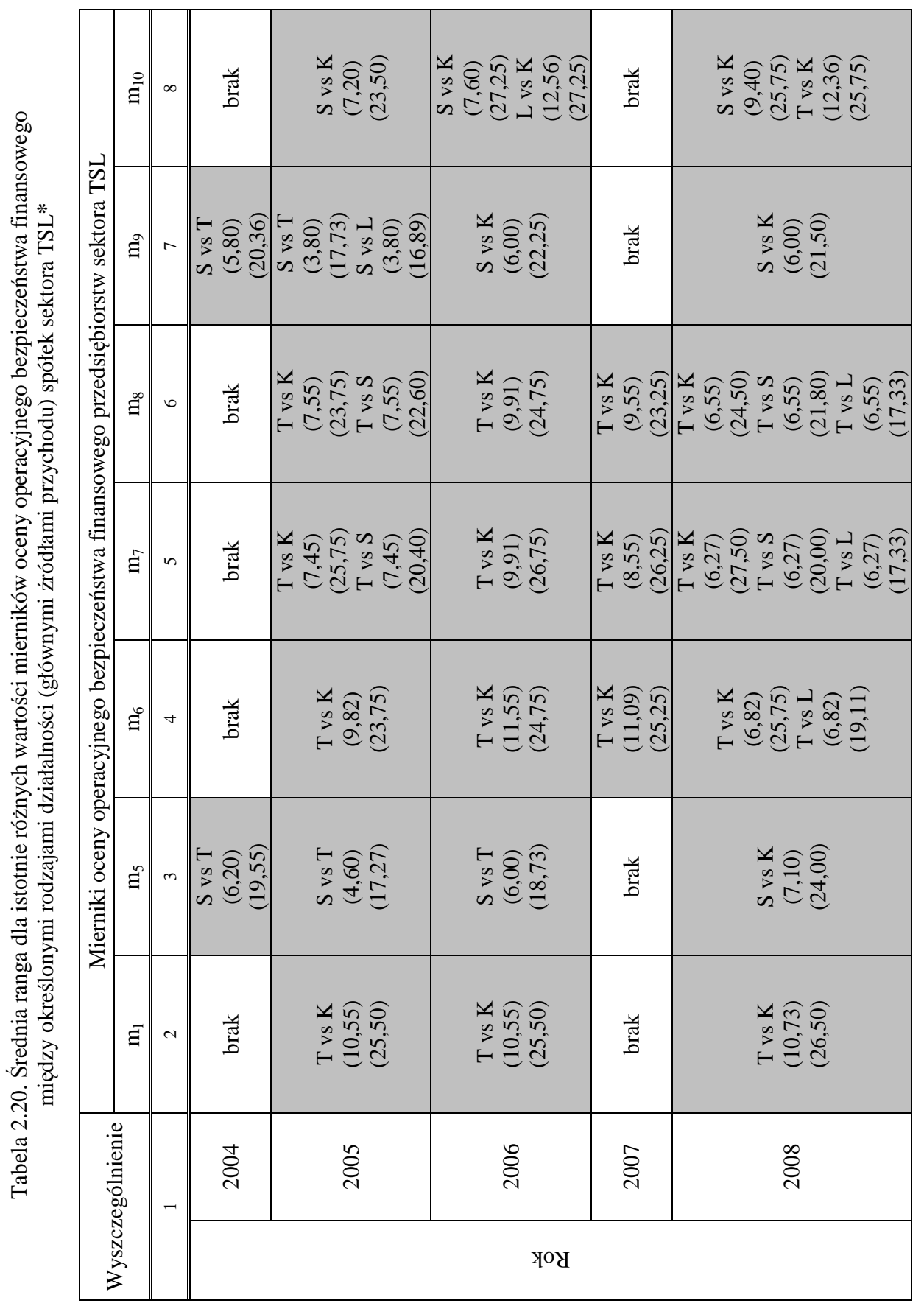




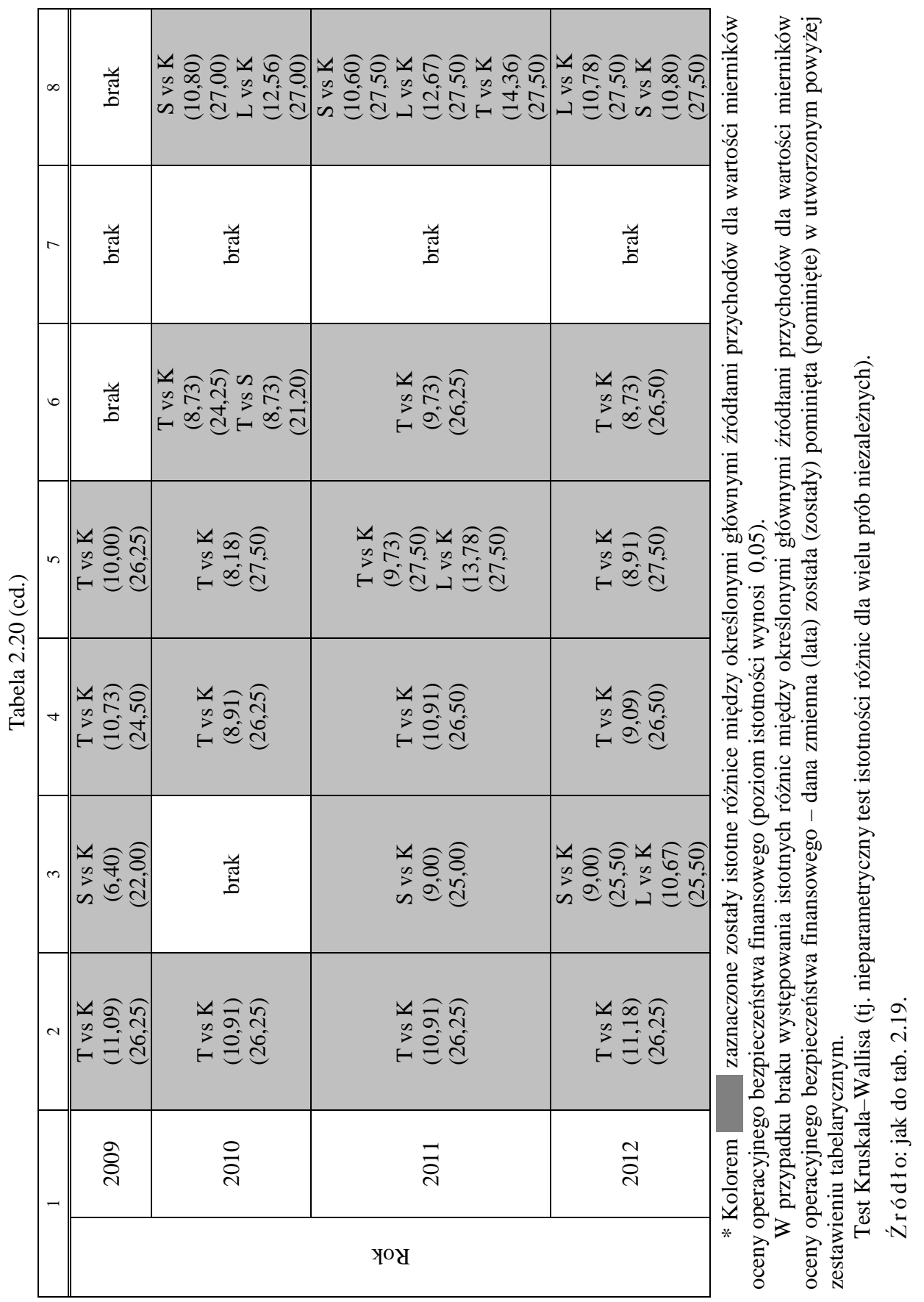


Wykonane ponadto testy istotności różnic dla mierników oceny operacyjnego bezpieczeństwa finansowego między różnymi rodzajami (głównymi źródłami przychodów) działalności prowadzonej przez spółki sektora TSL wskazały, iż działalność transportowa wiązała się (za wyjątkiem 2004 i 2007 r.) osiąganiem istotnie różnych (niższych w relacji do przedsiębiorstw kurierskich) wartości przychodów netto ze sprzedaży usług, towarów i materiałów (zob. tab. 2.20). W latach 2005-2012 istotnie różne (niższe) wartości współczynnika eksploatacyjnej rentowności aktywów ogółem, sprzedaży i kapitału własnego spółki transportowe osiągały również głównie w relacji przedsiębiorstw świadczących usługi kurierskie.

Współczynniki wydajności pieniężnej aktywów ogółem w spółkach kurierskich istotnie różniły się (za wyjątkiem 2004, 2007 i 2009 r.) od tych, osiąganych przeważnie przez przedsiębiorstwa spedycyjne. Spółki spedycyjne ponadto w latach 2004-2006 osiągały istotnie różną (niższą) wartość współczynnika zdolności do obsługi zobowiązań bieżących gotówką osiąganą z działalności operacyjnej $\left(\mathrm{m}_{5}\right)$ w relacji do spółek transportowych, zaś w latach 2008-2009 i 2011-2012 - do spółek kurierskich.

Na podstawie zaprezentowanych wyników badań nie można jednoznacznie potwierdzić ani zanegować sformułowanej w niniejszym opracowaniu hipotezy badawczej stanowiącej, iż przedsiębiorstwa transportowe utrzymuja najczęściej najniższy poziom memoriałowych $i$ kasowych mierników oceny operacyjnego bezpieczeństwa finansowego $w$ relacji do pozostatych spótek sektora TSL.

Jednakże wyniki badań wskazują jednoznacznie na występowanie w całym badanym okresie wysokiego poziomu zróżnicowania wielkości analizowanych mierników oceny analizowanego zjawiska i na sektorowy charakter ich zróżnicowania.

\subsection{Pomiar i ocena zróżnicowania zakresu działalności gospodarczej przedsiębiorstw sektora TSL $^{60}$}

Sektor TSL obejmuje całokształt działalności gospodarczej związanej z przestrzennym przepływem środków pracy, przedmiotów pracy i kapitału ludzkiego. Sektor ten w Polsce, skupiając przedsiębiorstwa zróżnicowane własnościowo, organizacyjnie, kapitałowo oraz ze względu na wielkość, zakres i zasięg działania, zmienia i rozwija się pod wpływem różnorodnych czynników. Operatorzy poszukują bowiem dla siebie trwałego miejsca na rynku, precyzując zakres swoich usług ${ }^{61}$.

\footnotetext{
${ }^{60}$ L. Karbown i k, Pomiar i ocena..., op. cit., s. 45-62.

${ }^{61} \mathrm{P}$. W a le w s k i, Integracja i specjalizacja ustug, ,Eurologistics” 2009, nr 5, s. 35.
} 
Różnorodność oferowanego asortymentu może być jednym z głównych czynników determinujących poziom operacyjnego bezpieczeństwa finansowego danego podmiotu gospodarczego. Powinna ona stać się zatem przedmiotem szczególnego zainteresowania w badaniach analizowanego zjawiska także wśród podmiotów gospodarczych z sektora TSL.

Przedsiębiorstwa sektora TSL prowadzą działalność znacznie wykraczającą poza świadczenie usług w sekcji „Transport i gospodarka magazynowa”. Podawana w dokumentacji składanej do KRS w Warszawie liczba grup PKD w sekcji „Transport i gospodarka magazynowa" stanowiła niekiedy bardzo nieznaczny udział w ogólnej ich liczbie wskazywanej przez spółki ${ }^{62}$.

Analizowane podmioty gospodarcze prowadziły przeto zróżnicowaną usługową działalność gospodarczą w latach 2004-2012 ${ }^{63}$. W latach 2004-2005 blisko $71 \%$ badanych przedsiębiorstw zadeklarowało do 20 grup PKD $2007^{64}$, w 2006 r. udział udział ten zmniejszył się o 8 punktów procentowych, wzrósł zaś o 4 punkty procentowe dopiero w 2010 r. (zob. wykres 2.25). Od 2008 r. spółka TARGOR--TRUCK Sp. z o.o. deklarowała ponad 60 grup PKD 2007 w których prowadziła swoją działalność, z kolei Zakład Transportu Energetyki „ZTiSZE” Sp. z o.o. już od 2005 r. podawał ich ilość w granicach od 52 do 53. W latach 2006-2012 widać sukcesywny spadek liczby podmiotów które deklarowały od 21 do 30 grup PKD 2007 na rzecz tych, które wskazywały od 31 do 40 grup PKD 2007.

W latach 2004-2012 jedynie spółka M\&M air sea cargo SA oraz Rhenus Logistics SA zmniejszyły zakres swojej działalności odpowiednio o 6 i 9 grup PKD 2007 (zob. tab. 2.21). Z kolei 8 badanych podmiotów gospodarczych - tj. CAT Polska Sp. z o.o., Neovia Logistics Services Polska Sp. z o.o., DARTOM Sp. z o.o., DIREX Sp. z o.o., TRANS-PETRO-COLOR Sp. z o.o., UPS Polska Sp. z o.o., VAN CARGO SA oraz VOS Logistics Polska Sp. z o.o. - na początku,

${ }^{62}$ Zob. L. Karbownik, Dyferencjacja rozwoju działalności gospodarczej przedsiębiorstw sektora TSL w Polsce, [w:] J. Du raj (red.), Prace z zakresu ekonomiki i zarzadzania przedsiębiorstwem, „Acta Universitatis Lodziensis”, Folia Oeconomica 272, Wydawnictwo Uniwersytetu Łódzkiego, Łódź 2012, s. 49-74.

${ }^{63} \mathrm{~W}$ literaturze przedmiotu prezentowane są liczne koncepcje mierników dywersyfikacji prowadzonej działalności. Zob. Z. Pi e rści o ne k, Strategie rozwoju firmy, Wydawnictwo Naukowe PWN, Warszawa 1996, s. 274-279; M. R o m a n ow s ka, Planowanie strategiczne w przedsiębiorstwie, PWE, Warszawa 2004, s. 102-108.

$\mathrm{Z}$ uwagi na liczne utrudnienia w ich obliczeniu, w niniejszej monografii poziom dywersyfikacji działalności przedsiębiorstw sektora TSL mierzony został liczbą grup PKD 2007.

${ }^{64}$ Przekształcenie z PKD 2004 na PKD 2007 nastąpiło za pomocą tzw. „klucza powiązań” dostępnego na stronie: http://www.stat.gov.pl/klasyfikacje/pkd_07/pdf/4_PKD-klucz_2004-2007.pdf (dostęp: 24.10.2011). W przypadku 5 spółek nie udało się dokonać przeklasyfikowania prowadzonej przez te podmioty działalności gospodarczej na PKD 2007 z uwagi na zbyt ogólne dane znajdujące się w dokumentacji złożonej w Krajowym Rejestrze Sądowym w Warszawie.

W nielicznych przypadkach przyjęto najbardziej prawdopodobny numer działu PKD 2007 z uwagi na konieczność dokonania wyboru w trakcie przekształcania danych na podstawie „klucza powiązań". 
jak i na końcu badanego okresu wykazywały identyczną liczbę grup PKD 2007, przy czym w przypadku ostatniego z nich - dostrzegane były niewielkie wahania liczby grup PKD. Aż 14 podmiotów gospodarczych dokonało dywersyfikacji działalności gospodarczej poszerzając ją od $1 \mathrm{w}$ spółkach Mexem Sp. z o.o. i TNT Express Worldwide (Poland) Sp. z o.o. do nawet 36 grup PKD 2007 w DSV Road Sp. z o.o.

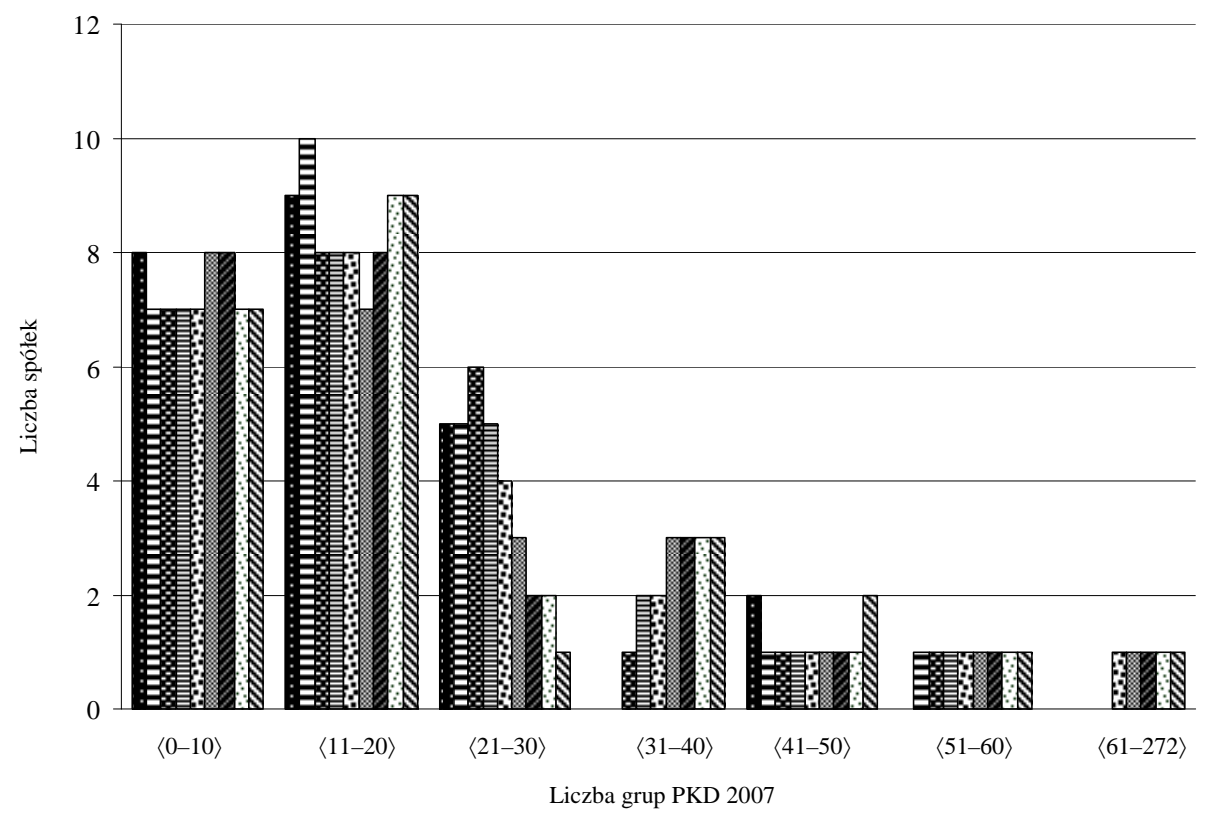

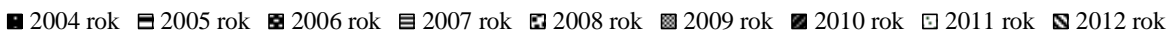

Wykres 2.25. Liczba spółek sektora TSL w latach 2004-2012 według ilości grup PKD $2007^{65}$

Źródło: obliczenia własne na podstawie danych zebranych w Krajowym Rejestrze Sądowym w Warszawie przy wykorzystaniu programu Microsoft Excel.

W całym analizowanym okresie zwiększyła się średnia, jak i środkowa liczba grup PKD 2007 deklarowanych przez spółki sektora TSL (zob. wykres 2.26). Dla średniej ich liczby dostrzegany jest wzrost z 16 w 2004 r. do 22 w 2012 r. i odpowiednio dla środkowej - z 13 do 16 grup PKD 2007.

${ }^{65}$ Próba liczyła zatem 24 spółki, bowiem dla 5 badanych podmiotów gospodarczych nie udało się dokonać klasyfikacji według grup PKD 2007 ze względu na zbyt zagregowane dane. 


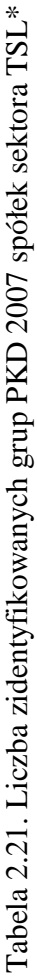

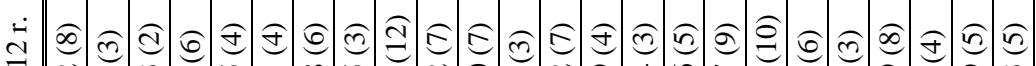

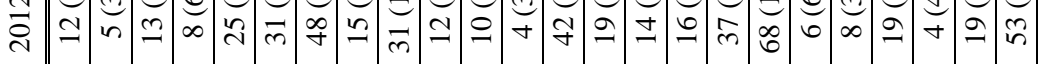

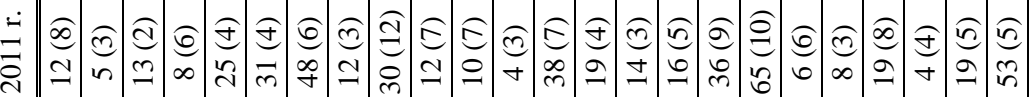

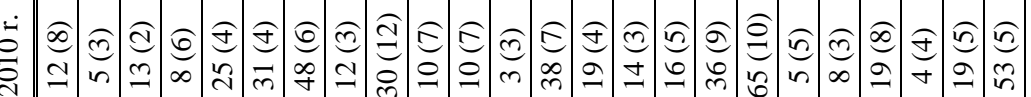

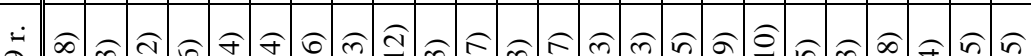

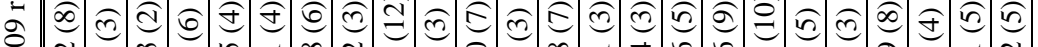

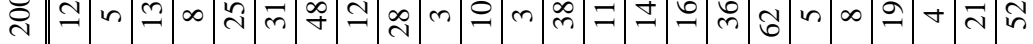

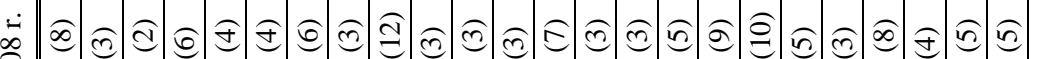

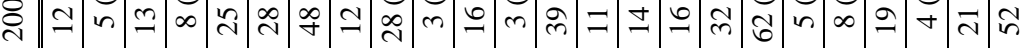

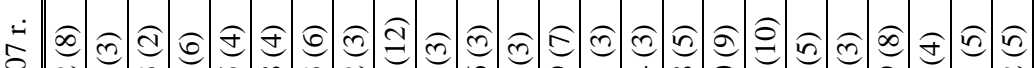

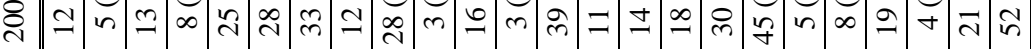

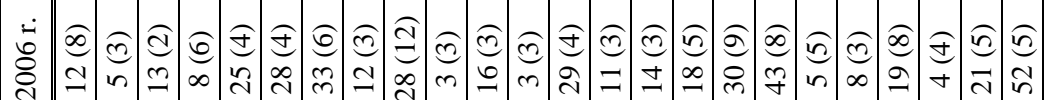

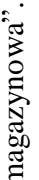

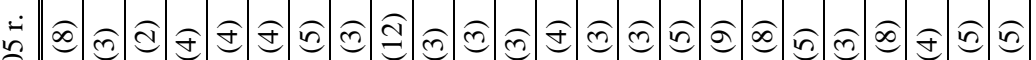

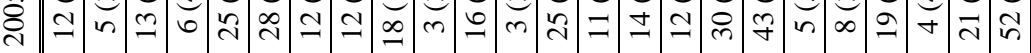

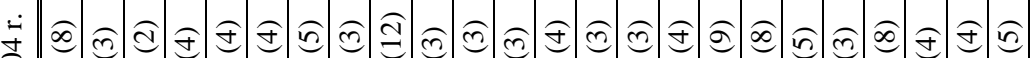

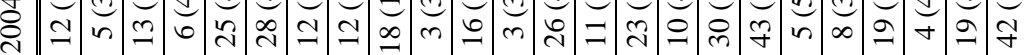

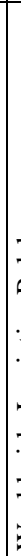

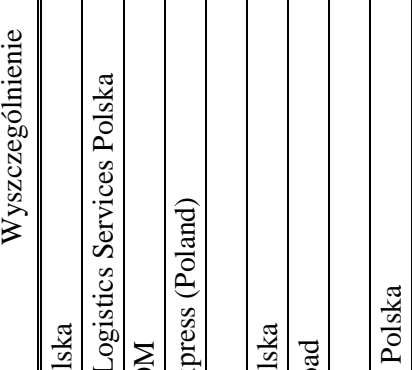

$\frac{\sqrt{2}}{\frac{3}{2}}$

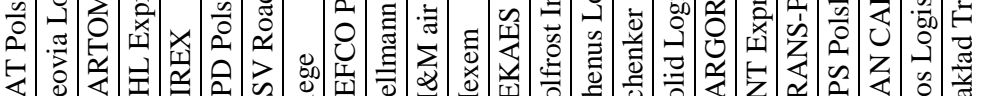

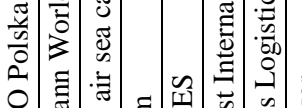

: $\quad$ : $\quad$ 홇

N

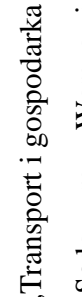

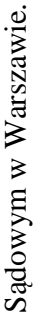

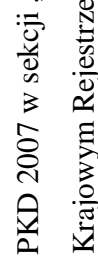

कू

중

造

$\stackrel{0}{=}$ 


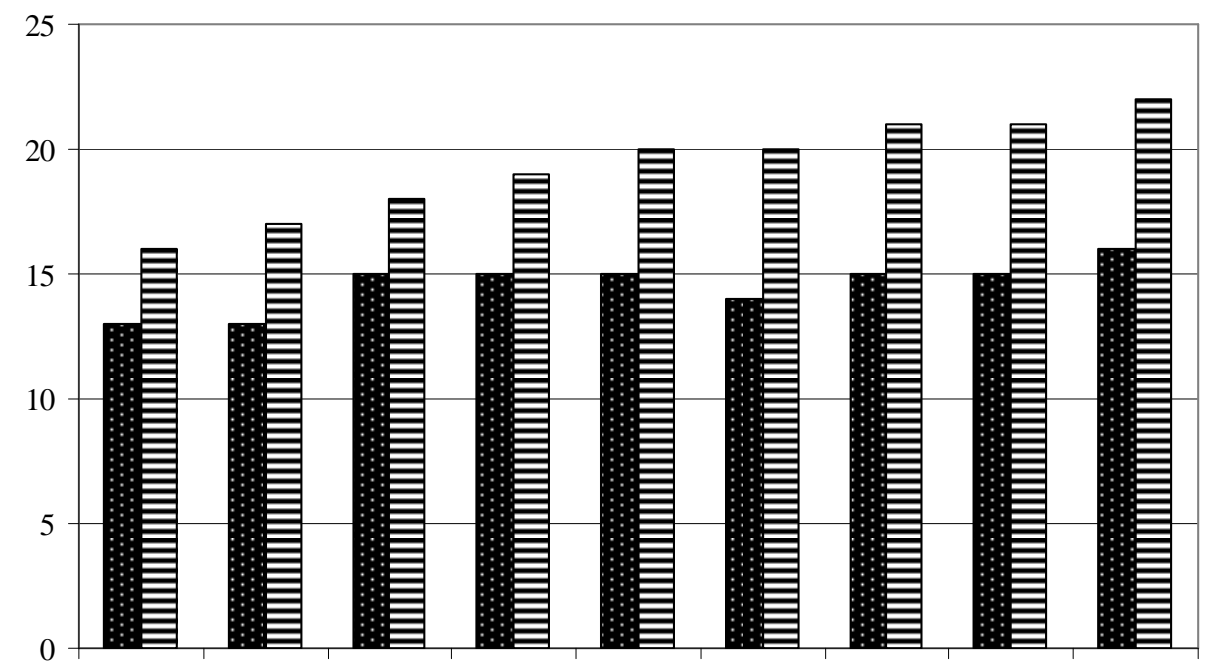

2004 rok 2005 rok 2006 rok 2007 rok 2008 rok 2009 rok 2010 rok 2011 rok 2012 rok

Mediana $\boxminus$ Średnia

Wykres 2.26. Średnia i środkowa liczba zidentyfikowanych grup PKD 2007 spółek sektora TSL

Źródło: jak do wykresu 2.25.

Pogłębiona analiza dotyczyła odpowiedzi na pytanie: czy przedsiębiorstwa sektora TSL w badanym okresie dokonały znaczącej dywersyfikacji swojej działalności gospodarczej. Sformułowana została zatem zerowa hipoteza robocza stanowiąca, iż w badanych podmiotach gospodarczych nie wystąpiła zmiana liczby grup PKD 2007 w latach 2004-2012, a hipoteza alternatywna z kolei, iż nie we wszystkich analizowanych latach rozkład badanej zmiennej był identyczny.

$\mathrm{Na}$ podstawie otrzymanych wyników analizy istotności różnic dla prób zależnych (przy poziomie istotności wynoszącym 0,05) odrzucona została hipoteza zerowa o braku występowania istotnych różnic liczby grup PKD 2007 deklarowanej przez spółki sektora TSL w latach 2004-2012. Analiza POST-HOC wykazała, iż średnia ranga dla 2012 r. była najwyższa (tj. najczęściej w 2012 r. występowała najwyższa liczba grup PKD 2007) i istotnie różniła się od analizowanej zmiennej dla 2004 i 2005 r. (zob. wykres 2.27) ${ }^{66}$.

Spółka DPD Polska Sp. z o.o., GEFCO Polska Sp. z o.o., Mexem Sp. z o.o., Solid Logistics Sp. z o.o. i Zakład Transportu Energetyki „ZTiSZE” Sp. z o.o. zwiększały zakres swoich usług poza kluczową sekcją ,Transport i gospodarka

${ }^{66}$ Istotne różnice analizowanej miary nie wystąpiły jednakże między różnymi rodzajami działalności (tj. głównymi źródłami przychodu) spółek sektora TSL. 
magazynowa”, podobnie jak DSV Road Sp. z o.o., PEKAES SA, Polfrost Internationale Spedition Sp. z o.o., Schenker Sp. z o.o. oraz TARGOR--TRUCK Sp. z o.o., które również dywersyfikowały go głównie poza tą sekcją. Jedynie dwie spółki ograniczyły zakres prowadzonej działalności ogółem. M\&M air sea cargo SA uczyniła to zwiększając go jednocześnie w samej sekcji „Transport i gospodarka magazynowa”, zaś Rhenus Logistics SA wskazała mniejszą liczbę PKD 2007 jedynie poza tą sekcją.

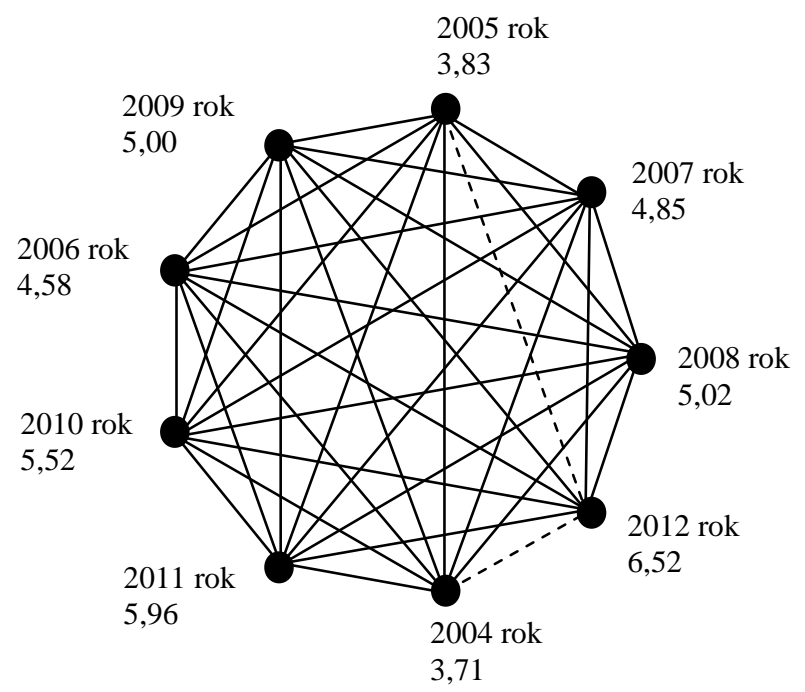

* Linie przerywane obrazują istotne różnice między określonymi latami dla liczby grup PKD 2007 przedsiębiorstw sektora TSL (poziom istotności wynosi 0,05).

Wykres 2.27. Średnia ranga dla liczby grup PKD 2007 przedsiębiorstw sektora TSL w latach $2004-2012 *^{67}$

Źródło: obliczenia własne na podstawie danych zebranych w Krajowym Rejestrze Sądowym w Warszawie przy wykorzystaniu programu SPSS Statistics (wersja 22).

Szczegółowa analiza liczby grup PKD 2007 w sekcji „Transport i gospodarka magazynowa" wykazała, iż w latach 2004-2012 średnia i środkowa ilość analizowanej zmiennej nieznacznie wzrosła, tj. zaledwie o jedną grupę PKD 2007 odpowiednio w 2010 r. i 2007 r. (zob. wykres 2.28). Wyniki te zostały potwierdzone również przez testy istotności różnic dla wielu prób zależnych. Przyjęta bowiem została hipoteza zerowa stanowiąca, iż w badanych podmiotach gospodarczych nie wystąpiła zmiana liczby grup PKD 2007 w sekcji „Transport i gospodarka magazynowa” w latach 2004-2012.

\footnotetext{
${ }^{67}$ Prezentowane są istotności asymptotyczne (testy dwustronne).
} 


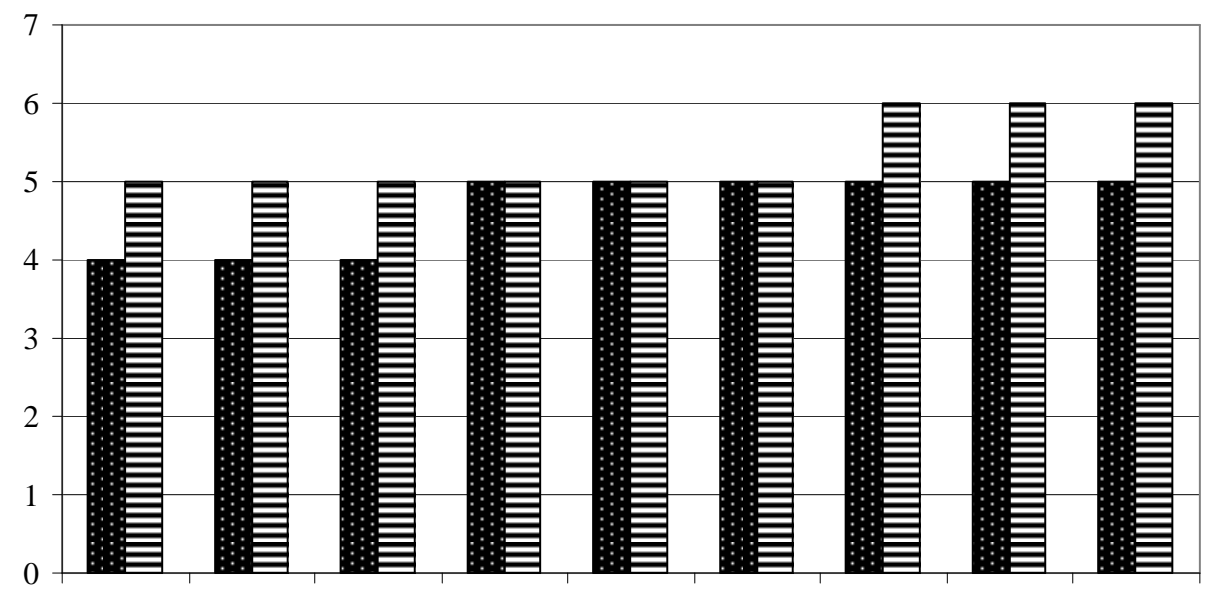

2004 rok 2005 rok 2006 rok 2007 rok 2008 rok 2009 rok 2010 rok 2011 rok 2012 rok

- Mediana $\boxminus$ Średnia

Wykres 2.28. Średnia i środkowa liczba zidentyfikowanych grup PKD 2007 w sekcji „Transport i gospodarka magazynowa” spółek sektora TSL

Źródło: jak do wykresu 2.25.

W całym badanym okresie wszystkie spółki sektora TSL w ramach sekcji „Transport i gospodarka magazynowa” prowadziły działalność usługową wspomagającą transport, zaś w latach 2004-2008 jedynie w M\&M air sea cargo SA nie wystąiła grupa PKD 2007 o numerze 49.4 (tj. transport drogowy towarów oraz działalność usługowa związana z przeprowadzkami - zob. tab. 2.22). Magazynowaniem i przechowywaniem towarów zajmowało się 21 przedsiębiorstw w 2004 r, a w następnych analizowanych latach - już 22 podmioty gospodarcze.

Żadna ze spółek w ramach sekcji „Transport i gospodarka magazynowa” w całym badanym okresie nie świadczyła usług transportu rurociągowego, jak i działalności pocztowej objętej obowiązkiem świadczenia usług powszechnych (operatora publicznego). Ponadto $\mathrm{w}$ badanym okresie nie zmieniła się liczba podmiotów gospodarczych, które świadczyły usługi transportu kolejowego międzymiastowego, transportu morskiego i przybrzeżnego, czy też transportu wodnego śródlądowego pasażerów. Największe tempo zmian liczby podmiotów dodatkowo podejmujących się świadczenia usług w poszczególnych grupach PKD w tej sekcji wystąpiło $\mathrm{w}$ działalności związanej z transportem kolejowym towarów (o $250,00 \%{ }^{68}$, tj. wzrost z 2 do 7 spółek poddanych analizie) oraz trans-

${ }^{68}$ Przez fakt, iż jest to miara relatywna, odnosząca przyrost absolutny do wielkości zrealizowanej w roku porównywanym t (tj. 2004 r.), jest pozbawiona miana. Najczęściej zamienia się ją na procenty i nazywa tempem zmian, [za:] G. Ju szczak-S zu macher, Miary dynamiki..., op. cit., s. 196. 
portem lotniczym towarów i transportem kosmicznym (o 83,33\%, tj. wzrost również o 5 podmiotów gospodarczych, jednakże z 6 do 11 przedsiębiorstw - zob. wykres 2.29). Ponadto 4 spółki rozpoczęły w badanym okresie dodatkowo świadczenie usług transportu morskiego i przybrzeżnego towarów (czyli wzrost z 5 do 9 jednostek gospodarczych, co w ujęciu procentowym dało 80,00\%). Nieco mniejszy wzrost liczby podmiotów zaobserwowany został w przypadku pozostałej działalności pocztowej i kurierskiej oraz transportu wodnego śródlądowego towarów (tj. o 2 spółki, w ujęciu procentowym odpowiednio 20\% i 50\%).

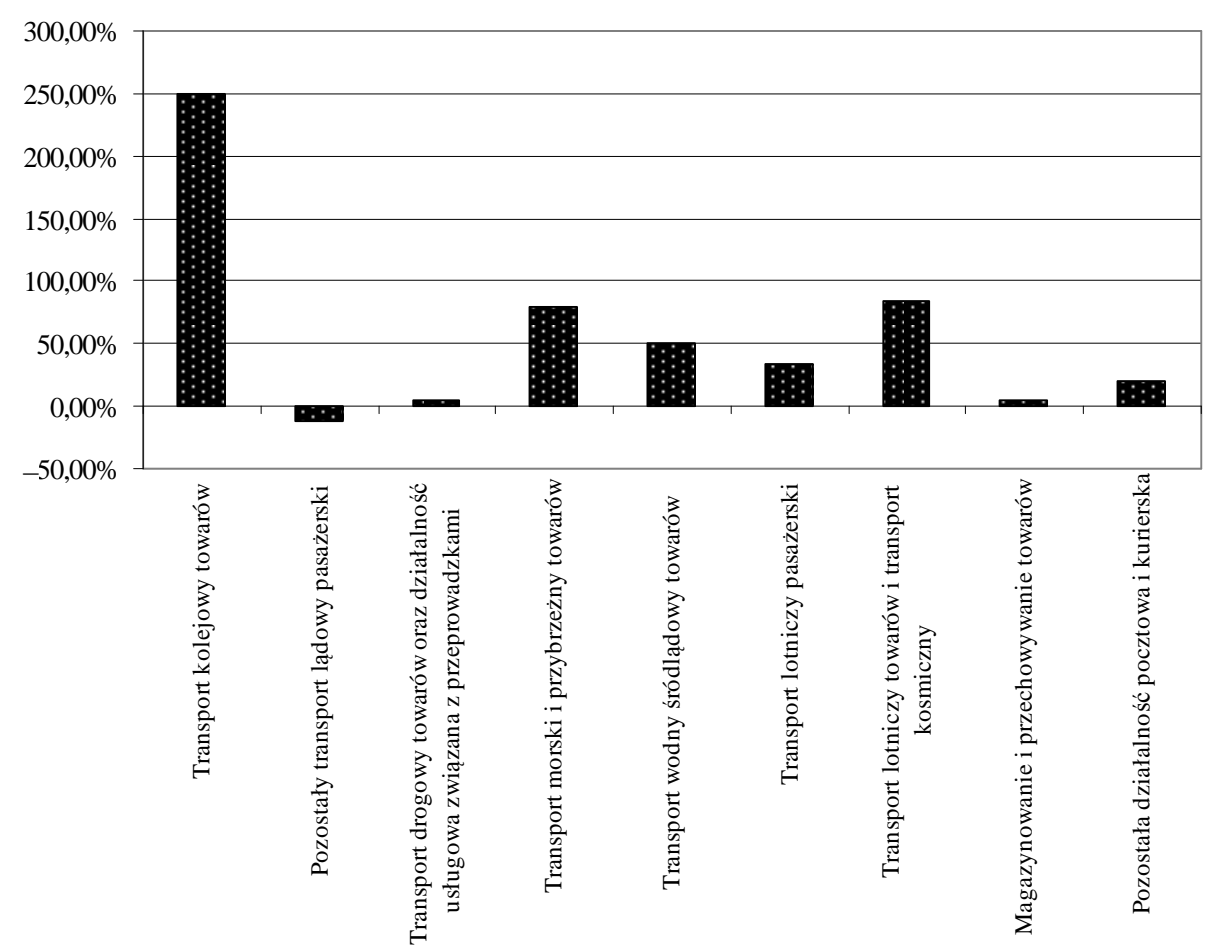

Wykres 2.29. Tempo zmian (2012/2004) zakresu prowadzonej działalności spółek sektora TSL w sekcji „Transport i gospodarka magazynowa”

Źródło: jak do wyk. 2.25 .

Na polskim rynku TSL zwiększa się liczba przedsiębiorstw, które w większym stopniu, niż to było w przeszłości, dywersyfikują ryzyko poprzez prowadzenie różnej działalności biznesowej ${ }^{69}$. Taka sytuacja wystąpiła również w przypadku badanych podmiotów gospodarczych.

${ }^{69}$ H. B rd u lak, Polski rynek TSL w 2010 r., ostatnia aktualizacja 22.06.2011, http://www.rp.pl/artykul/677116.html (dostęp: 26.05.2013). 


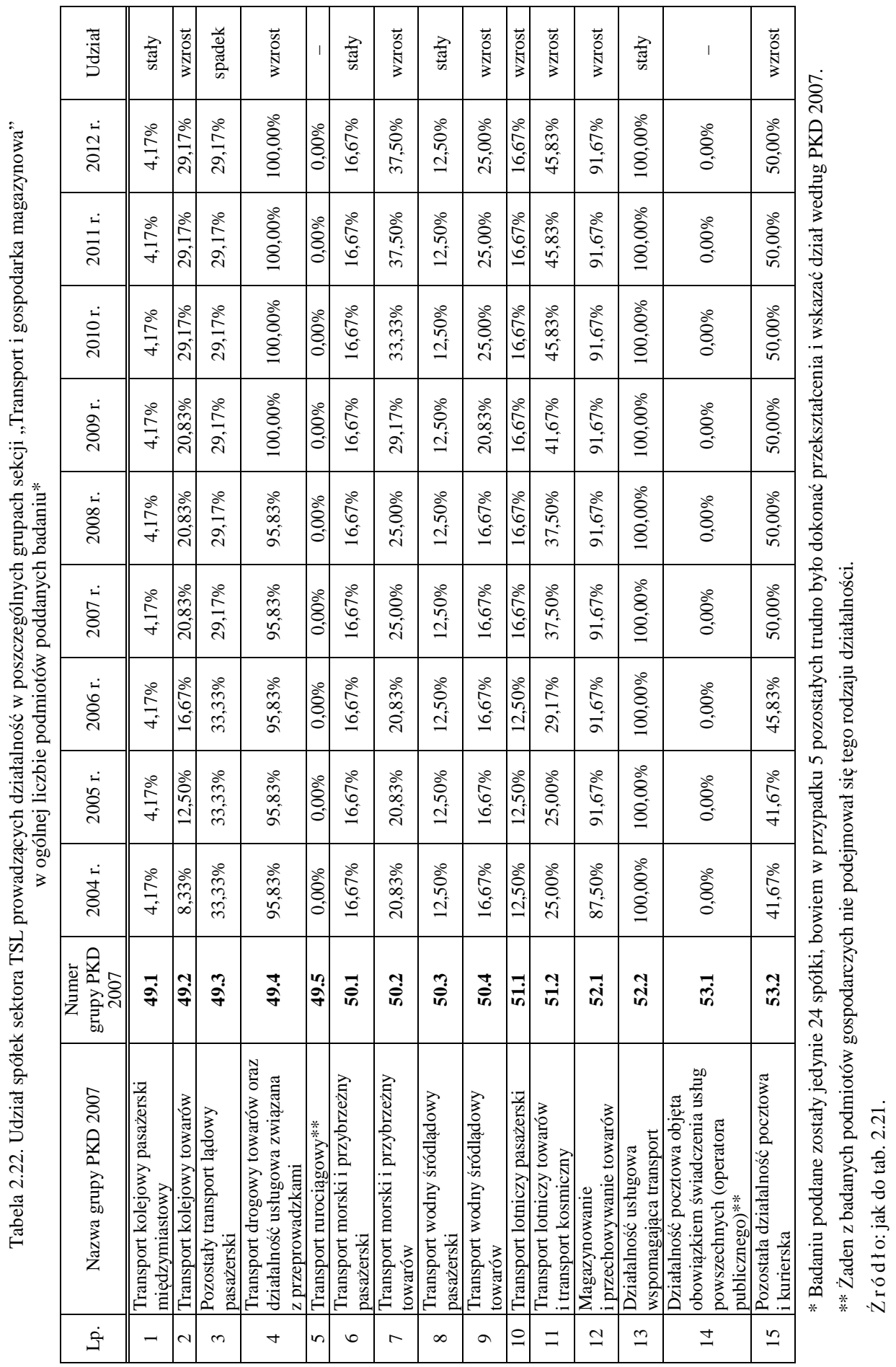


Wśród najczęściej wymienianych grup PKD 2007 - poza sekcją „Transport i gospodarka magazynowa" - można wyróżnić chociażby konserwację i naprawę pojazdów samochodowych (z wyłączeniem motocykli), wynajem i zarządzanie nieruchomościami własnymi lub dzierżawionymi, wynajem i dzierżawę pojazdów samochodowych (z wyłączeniem motocykli), czy też wynajem i dzierżawę pozostałych maszyn, urządzeń i dóbr materialnych (zob. wykres 2.30). Wysokie tempo wzrostu w ramach najczęściej wyróżnianych rodzajów działalności wystąpiło (w całym badanym okresie) w przypadku podejmowania przez badane spółki działalności komercyjnej, gdzie indziej niesklasyfikowanej (100,00\%) oraz kupna i sprzedaży nieruchomości na własny rachunek $(66,67 \%)$.

Bardzo wysokie tempo wzrostu poza sekcją „Transport i gospodarka magazynowa" odnotowane zostało w działalności związanej ze zbieraniem odpadów (tj. 300\%, wzrost z 1 do 4 spółek), czy też naprawą oraz konserwacją komputerów i sprzętu komunikacyjnego (także o 300\%, wzrost z 1 do 4 podmiotów gospodarczych).

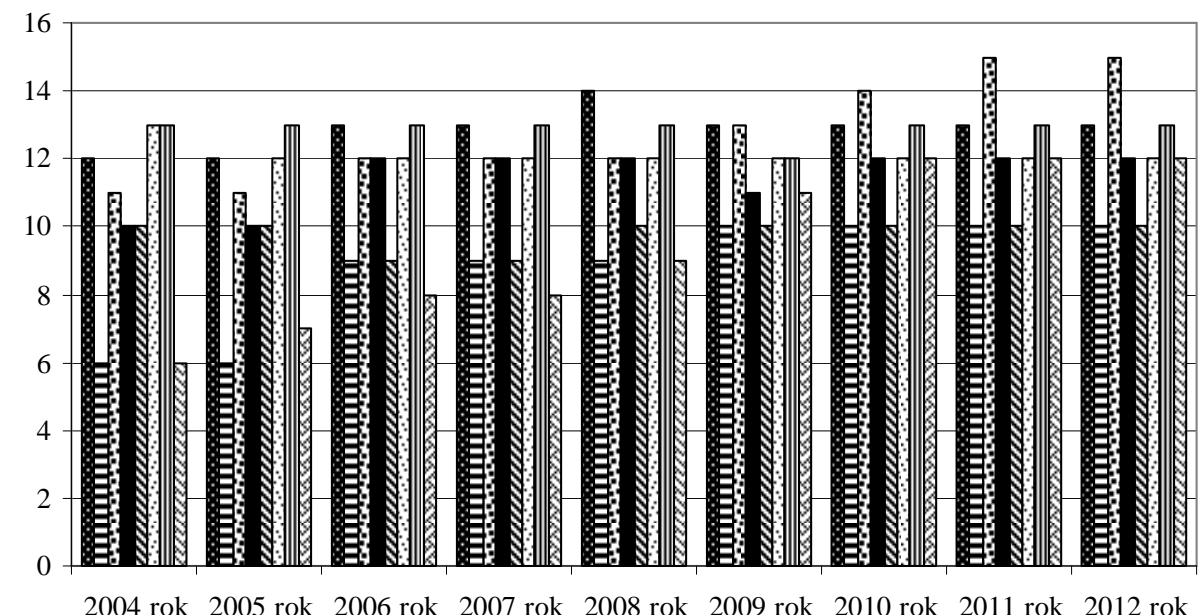

Konserwacja i naprawa pojazdów samochodowych, z wyłączeniem motocykli

曰 Kupno i sprzedaż nieruchomości na własny rachunek

(⿴囗十 Wynajem i zarządzanie nieruchomościami własnymi lub dzierżawionymi

Doradztwo związane z zarządzaniem

\$ Pozostała działalność profesjonalna, naukowa i techniczna, gdzie indziej niesklasyfikowana

ㄱ.? Wynajem i dzierżawa pojazdów samochodowych, z wyłączeniem motocykli

m Wynajem i dzierżawa pozostałych maszyn, urządzeń oraz dóbr materialnych

Ð Działalność komercyjna, gdzie indziej niesklasyfikowana

Wykres 2.30. Liczba spółek sektora TSL według najczęściej wykazywanych grup PKD 2007 poza sekcją „Transport i gospodarka magazynowa”

Źródło: jak do wyk. 2.25. 
Zaprezentowane wyniki badań - m. in. średnia i mediana liczby grup PKD 2007 (w tym w samej sekcji „Transport i gospodarka magazynowa”), czy też wyniki testów istotności różnic dla wielu prób zależnych - mogą świadczyć o tym, iż znaczaca dywersyfikacja działalności przedsiębiorstw sektora TSL ma miejsce głównie poza sekcja „Transport i gospodarka magazynowa”. Istotne różnice liczby grup PKD 2007 wystąpiły bowiem między 2012 a 2004 i 2005 r. (zob. wykres 2.27). 



\section{Rozdział 3}

\section{ANALIZA EMPIRYCZNA SPREADU ORAZ ZALEŻNOŚCI MIEDZY MIERNIKAMI OCENY OPERACYJNEGO BEZPIECZEŃSTWA FINANSOWEGO SPÓŁEK SEKTORA TSL}

\subsection{Analiza empiryczna spreadu memoriałowych i kasowych mierników oceny operacyjnego bezpieczeństwa finansowego spółek sektora TSL}

$\mathrm{Z}$ uwagi, iż specyfika grupowania pozycji w rachunku zysków i strat nie pozwala na jednoznaczne przyporządkowanie przepływów pieniężnych powstałych z tytułu ogółu pozycji danej grupy do tego samego rodzaju działalności, powstawanie różnicy między memoriałowymi a kasowymi miernikami oceny operacyjnego bezpieczeństwa finansowego ${ }^{1}$ (zob. tab. 1.12) jawi się zatem jako sytuacja typowa i uzasadniona odmiennymi podejściami.

Ważnym problemem jest tutaj kwestia charakteru oraz bezpiecznej wielkości spreadu między wartościami analizowanych zmiennych dla konkretnego przedsiębiorstwa w danym czasie i określonych warunkach jego działania. Jest to problem nie dość wystarczająco zbadany i bardzo złożony. Nie można bowiem jednoznacznie twierdzić, że podejście memoriałowe jest mniej ważne od podejścia kasowego i odwrotnie. Istnieją w literaturze przedmiotu liczne argumenty przemawiające za jednym i drugim podejściem w ocenie działalności przedsiębiorstwa (zob. m. in. tab. 1.10).

Podejmując próbę zweryfikowania hipotezy badawczej stanowiącej, iż bieżaca ptynność finansowa jest tym obszarem kreowania i zapewniania dobrego standingu finansowego, w którym obserwuje się najwyższy poziom spreadu pomiędzy memoriałowymi a kasowymi miernikami oceny operacyjnego bezpieczeństwa finansowego, wskazać należy, że w analizie różnicy memoriałowych i kasowych zmiennych diagnostycznych badanego zjawiska - w przypadku spółek sektora TSL - można poddać jedynie mierniki z obszaru rentowności eksploata-

${ }^{1}$ Wartość spreadu między memoriałowymi i kasowymi miernikami operacyjnego bezpieczeństwa finansowego przedsiębiorstw sektora TSL przedstawia ich różnicę w ramach poszczególnych obszarów oceny badanego zjawiska (zob. tab. 1.12) dla każdego analizowanego przedsiębiorstwa w poszczególnych latach. 
cyjnej i wydajności pieniężnej (gotówkowej), jak i płynności finansowej². Zgodnie z przyjętymi formułami analizowanych zmiennych (zob. tab. 2.3) szczególna uwaga została zwrócona na ich licznik, bowiem bez względu na przyjęty w opracowaniu wymiar badawczy, mianownik pozostaje w niezmienionej (jednakowej) postaci.

W latach 2006, 2008 i 2010-2012 w żadnej z analizowanych spółek współczynnik zdolności do obsługi zobowiązań bieżących gotówką osiąganą z działalności operacyjnej $\left(\mathrm{m}_{5}\right)$ nie uzyskał wartości wyższej od współczynnika bieżącej płynności finansowej $\left(\mathrm{m}_{2}\right)$ i współczynnika przyspieszonej płynności finansowej $\left(\mathrm{m}_{3}\right)$, zaś w pozostałych latach poddanych analizie - zmienna kasowa wypracowała ją jedynie w przypadku od 3,45\% do 20,69\% badanych spółek (zob. tab. 3.1).

Tabela 3.1. Liczba spółek sektora TSL w których wartość mierników kasowych była wyższa od memoriałowych mierników oceny operacyjnego bezpieczeństwa finansowego przedsiębiorstw

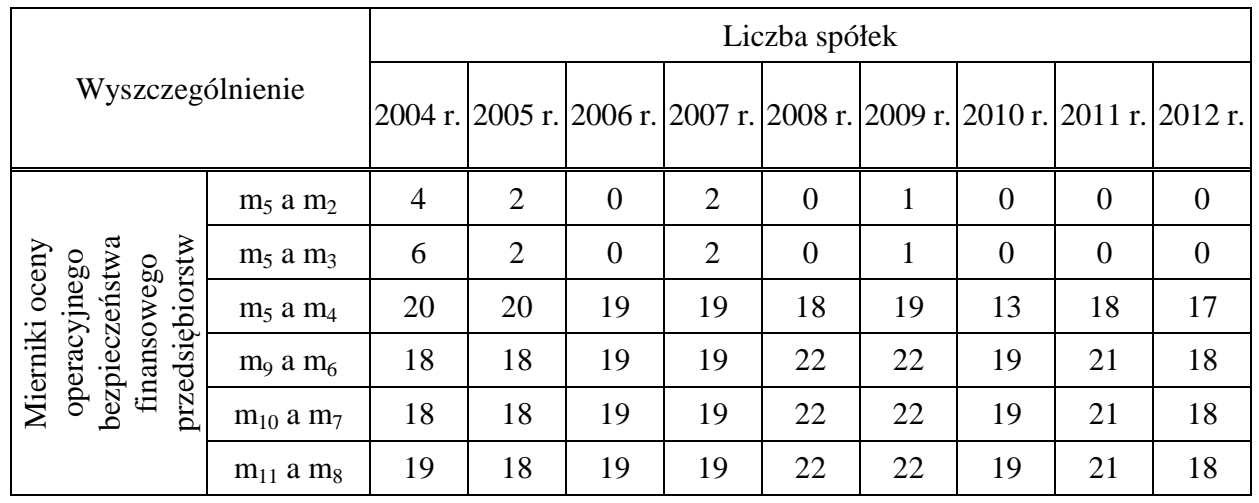

Źródło: obliczenia własne na podstawie danych zebranych w Krajowym Rejestrze Sądowym w Warszawie przy wykorzystaniu programu Microsoft Excel.

Liczba podmiotów gospodarczych - w przypadku których wartość współczynnika zdolności do obsługi zobowiązań bieżących gotówką osiąganą z działalności operacyjnej $\left(\mathrm{m}_{5}\right)$ była wyższa w relacji do współczynnika natychmiastowej płynności finansowej $\left(\mathrm{m}_{4}\right)$ - kształtowała się na zbliżonym poziomie do liczby podmiotów, w których wartości współczynników wydajności pieniężnej były wyższe od tych obliczonych dla współczynników rentowności. W latach 2004-2008 zaobserwowany został wzrost liczby podmiotów gospodarczych

${ }^{2}$ Ze względu na ograniczenia związane z możliwością pozyskania danych w ujęciu kasowych dla wpływów ze sprzedaży produktów (usług), towarów i materiałów, jak i krótkoterminowych rezerw finansowych - analiza spreadu między memoriałowymi i kasowymi miernikami oceny operacyjnego bezpieczeństwa finansowego została ograniczona do analizy poziomu płynności finansowej, jak i rentowności eksploatacyjnej oraz wydajności pieniężnej. 
(z odpowiednio 18 lub 19 do 22), w których współczynniki rentowności eksploatacyjnej kształtowały się na niższym poziomie w relacji do ich kasowych odpowiedników. W 2009 r. liczba tych przedsiębiorstw utrzymała się z kolei na poziomie $\mathrm{z}$ roku poprzedniego, nieznacznie zmniejszając się w kolejnych latach poddanych analizie.

Na podstawie zaprezentowanych danych zaobserwowane zostały znaczące dysproporcje między liczbą podmiotów osiągających wyższe poziomy kasowych niż memoriałowych współczynników oceny operacyjnego bezpieczeństwa finansowego. W obszarze płynności finansowej w 2009 r. jedynie spółce Neovia Logistics Services Polska Sp. z o.o. udało się wypracować wyższy poziom współczynnika zdolności do obsługi zobowiązań bieżących gotówką osiąganą z działalności operacyjnej w relacji do współczynnika bieżącej i przyspieszonej płynności finansowej. W przypadku pozostałych zmiennych oceny badanego zjawiska, większość przedsiębiorstw generowała wyższe wartości dla kasowych mierników tego pomiaru. Taka sytuacja miała miejsce w całym badanym okresie w 8 podmiotach gospodarczych (zob. tab. 3.2).

Tabela 3.2. Liczba spółek sektora TSL w których wartość mierników kasowych była wyższa od memoriałowych mierników oceny operacyjnego bezpieczeństwa finansowego w całym badanym okresie (tj. w latach 2004-2012)

\begin{tabular}{|c|c|c|}
\hline \multicolumn{2}{|c|}{ Wyszczególnienie } & Liczba spółek \\
\hline \multirow{6}{*}{ 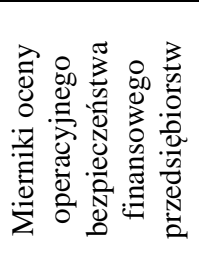 } & $\mathrm{m}_{5}$ a $\mathrm{m}_{2}$ & 0 \\
\hline & $\mathrm{m}_{5}$ a $\mathrm{m}_{3}$ & 0 \\
\hline & $\mathrm{m}_{5}$ a $\mathrm{m}_{4}$ & 8 \\
\hline & $\mathrm{m}_{9} \mathrm{a} \mathrm{m}_{6}$ & 8 \\
\hline & $\mathrm{m}_{10} \mathrm{a} \mathrm{m}_{7}$ & 8 \\
\hline & $\mathrm{m}_{11} \mathrm{a} \mathrm{m}_{8}$ & 8 \\
\hline
\end{tabular}

Źródło: jak do tab. 3.1.

Opisywane zjawisko wystąpiło odpowiednio dla spreadu zmiennych:

- $\mathbf{m}_{5} \mathbf{i ~ m}_{4}$ W spółkach: DARTOM Sp. z o.o., DHL Express (Poland) Sp. z o.o., DIREX Sp. z o.o., Fiege Sp. z o.o., Mexem Sp. z o.o., Mostva Sp. z o.o., TARGOR-TRUCK Sp. z o.o. oraz TRANS-PETRO-COLOR Sp. z o.o.,

- $\mathbf{m}_{9}$ i $\mathbf{m}_{6}, \mathbf{m}_{10} \mathbf{i} \mathbf{m}_{7}, \mathbf{m}_{11}$ i $\mathbf{m}_{8}$ w spółkach: CHARTER Sp. z o.o., DARTOM Sp. z o.o., DIREX Sp. z o.o., Mexem Sp. z o.o., Mostva Sp. z o.o., TARGOR-TRUCK Sp. z o.o., VOS Logistics Polska Sp. z o.o., a także ZTE RADOM Sp. z o.o.

W całym zatem badanym okresie w przedsiębiorstwach: DARTOM Sp. z o.o., DIREX Sp. z o.o., Mexem Sp. z o.o., Mostva Sp. z o.o. oraz TARGOR-TRUCK 
Sp. z o.o. wszystkie cztery rozważane rodzaje spreadu osiągnęły wartość dodatnią, zaś w przypadku spółek CHARTER Sp. z o.o., VOS Logistics Polska Sp. z o.o. i ZTE RADOM Sp. z o.o. - kryterium to zostało spełnione jedynie w obszarze rentowności eksploatacyjnej i wydajności pieniężnej (gotówkowej).

W celu weryfikacji postawionej hipotezy badawczej stanowiącej, iż bieżaca ptynność finansowa jest tym obszarem kreowania i zapewniania dobrego standingu finansowego, w którym obserwuje się najwyższy poziom spreadu pomiędzy memoriałowymi a kasowymi miernikami oceny operacyjnego bezpieczeństwa finansowego, obliczona została średnia dla modułu wartości różnicy między zmiennymi poddanymi analizie (zob. tab. 3.3).

Tabela 3.3. Średnia dla modułu wartości spreadu między memoriałowymi i kasowymi miernikami oceny operacyjnego bezpieczeństwa finansowego przedsiębiorstw sektora TSL*

\begin{tabular}{|c|c|c|c|c|c|c|c|c|c|}
\hline Wyszczególnienie & 2004 r. & 2005 r. & 2006 r. & 2007 r. & 2008 r. & 2009 r. & 2010 r. & 2011 r. & 2012 r. \\
\hline \hline Moduł liczby $\left(\mathrm{m}_{2}-\mathrm{m}_{5}\right)$ & 1,0513 & 1,4116 & 2,5834 & 0,9430 & 0,9733 & 1,0205 & 1,1558 & 1,1229 & 1,2571 \\
\hline Moduł liczby $\left(\mathrm{m}_{3}-\mathrm{m}_{5}\right)$ & 1,0038 & 1,3413 & 2,5099 & 0,8681 & 0,8703 & 0,9462 & 1,0995 & 1,0684 & 1,1890 \\
\hline Moduł liczby $\left(\mathrm{m}_{4}-\mathrm{m}_{5}\right)$ & 0,5353 & 0,4395 & 0,5563 & 0,4727 & 0,3844 & 0,3719 & 0,3470 & 0,2600 & 0,4863 \\
\hline Moduł liczby $\left(\mathrm{m}_{6}-\mathrm{m}_{9}\right)$ & 0,0820 & 0,0605 & 0,0546 & 0,0651 & 0,0611 & 0,0671 & 0,0501 & 0,0495 & 0,0431 \\
\hline Moduł liczby $\left(\mathrm{m}_{7}-\mathrm{m}_{10}\right)$ & 0,1411 & 0,1167 & 0,0844 & 0,1173 & 0,1118 & 0,1030 & 0,0873 & 0,0778 & 0,0828 \\
\hline Moduł liczby $\left(\mathrm{m}_{8}-\mathrm{m}_{11}\right)$ & 0,6410 & 0,3897 & 0,3197 & 0,7881 & $5,3348 * *$ & 0,3342 & 0,2734 & 0,2373 & 0,2535 \\
\hline
\end{tabular}

* Kolorem oznaczona jest dla danego roku maksymalna z średnich wartości spreadu między memoriałowymi i kasowymi miernikami oceny operacyjnego bezpieczeństwa finansowego.

Kolorem oznaczona jest dla danego roku minimalna z średnich wartości spreadu między memoriałowymi i kasowymi miernikami oceny operacyjnego bezpieczeństwa finansowego.

** Tak wysoka wartość spreadu pomiędzy współczynnikiem eksploatacyjnej rentowności kapitału własnego a współczynnikiem wydajności pieniężnej (gotówkowej) kapitału własnego wystapiła w wyniku pojawienia się obserwacji nietypowej, tj. bardzo niskiej wartości współczynnika eksploatacyjnej rentowności kapitału własnego w spółce VOS Logistics Polska Sp. z o.o. - wynikającej w dużej straty na sprzedaży i niskiego kapitału własnego (którego wartość została znacznie zaniżona przez bardzo dużą stratę netto). Pominięcie tej nietypowej obserwacji spowodowałaby powstanie najwyższej średniej wartości spreadu w 2008 r. między współczynnikiem bieżącej płynności finansowej a współczynnikiem zdolności do obsługi zobowiązań bieżących gotówką osiąganą z działalności operacyjnej.

Źródło: jak do tab. 3.1.

Ze względu na fakt, iż w 2008 r. w przypadku spółki VOS Logistics Polska Sp. z o.o. wystąpiła obserwacja nietypowa, weryfikacja hipotezy badawczej została przeprowadzona przy wykorzystaniu mediany, która to - w przeciwieństwie do średniej arytmetycznej - jest podstawową statystyką opisową odporną na elementy odstające (zob. tab. 3.4). 
Tabela 3.4. Środkowa wartość* dla modułu spreadu między memoriałowymi i kasowymi miernikami oceny operacyjnego bezpieczeństwa finansowego przedsiębiorstw sektora TSL**

\begin{tabular}{|c|c|c|c|c|c|c|c|c|c|}
\hline Wyszczególnienie & $2004 \mathrm{r}$. & $2005 \mathrm{r}$. & $2006 \mathrm{r}$. & $2007 \mathrm{r}$. & $2008 \mathrm{r}$. & $2009 \mathrm{r}$. & $2010 \mathrm{r}$. & $2011 \mathrm{r}$. & $2012 \mathrm{r}$. \\
\hline \hline Moduł liczby $\left(\mathrm{m}_{2}-\mathrm{m}_{5}\right)$ & 0,7427 & 0,9248 & 0,8538 & 0,9483 & 0,8499 & 1,0052 & 1,0652 & 0,9600 & 1,0789 \\
\hline Moduł liczby $\left(\mathrm{m}_{3}-\mathrm{m}_{5}\right)$ & 0,7266 & 0,8585 & 0,8010 & 0,9420 & 0,8421 & 0,9976 & 1,0587 & 0,9008 & 1,0739 \\
\hline Moduł liczby $\left(\mathrm{m}_{4}-\mathrm{m}_{5}\right)$ & 0,3282 & 0,2289 & 0,2014 & 0,2291 & 0,1712 & 0,1769 & 0,2125 & 0,1781 & 0,2983 \\
\hline Moduł liczby $\left(\mathrm{m}_{6}-\mathrm{m}_{9}\right)$ & 0,0438 & 0,0350 & 0,0287 & 0,0401 & 0,0447 & 0,0414 & 0,0292 & 0,0226 & 0,0372 \\
\hline Moduł liczby $\left(\mathrm{m}_{7}-\mathrm{m}_{10}\right)$ & 0,1119 & 0,1228 & 0,0710 & 0,0981 & 0,0850 & 0,0898 & 0,0770 & 0,0678 & 0,0797 \\
\hline Moduł liczby $\left(\mathrm{m}_{8}-\mathrm{m}_{11}\right)$ & 0,3074 & 0,3361 & 0,1991 & 0,2766 & 0,2370 & 0,1986 & 0,1762 & 0,1433 & 0,1787 \\
\hline
\end{tabular}

* Tj. mediana.

** Kolorem oznaczona jest dla danego roku maksymalna z środkowych wartości spreadu między memoriałowymi i kasowymi miernikami oceny operacyjnego bezpieczeństwa finansowego.

Kolorem oznaczona jest dla danego roku minimalna $\mathrm{z}$ środkowych wartości spreadu między memoriałowymi i kasowymi miernikami oceny operacyjnego bezpieczeństwa finansowego.

Źródło: jak do tab. 3.1.

Zaprezentowane wyniki badań potwierdziły sformułowaną hipotezę badawczą. W każdym analizowanym roku między $\mathrm{m}_{2}$ a $\mathrm{m}_{5}$, tj. współczynnikiem bieżącej płynności finansowej a współczynnikiem zdolności do obsługi zobowiązań bieżących gotówką osiąganą z działalności operacyjnej, wystąpił najwyższy poziom środkowej wartości dla modułu spreadu pomiędzy memoriałowymi a kasowymi miernikami oceny operacyjnego bezpieczeństwa finansowego przedsiębiorstw sektora TSL.

Analiza średniego poziomu tego spreadu dla lat 2004-2012 również ujawniła, iż najwyższa przeciętna różnica dotyczyła obszaru płynności finansowej (zob. tab. 3.5). Najwyższy poziom analizowanej wartości wystąpił między współczynnikiem bieżącej płynności finansowej $\left(\mathrm{m}_{2}\right)$ a współczynnikiem zdolności do obsługi zobowiązań bieżących gotówką osiąganą z działalności operacyjnej $\left(\mathrm{m}_{5}\right)$, a następnie współczynnikiem przyspieszonej płynności finansowej $\left(\mathrm{m}_{3}\right)$ a współczynnikiem zdolności do obsługi zobowiązań bieżących gotówką osiąganą z działalności operacyjnej $\left(\mathrm{m}_{5}\right)$, najniższy zaś - pomiędzy współczynnikiem eksploatacyjnej rentowności sprzedaży $\left(\mathrm{m}_{6}\right)$ a współczynnikiem wydajności pieniężnej (gotówkowej) sprzedaży $\left(\mathrm{m}_{9}\right)$.

Wśród podmiotów gospodarczych o najwyższym poziomie modułu spreadu między memoriałowymi a kasowymi miernikami oceny operacyjnego bezpieczeństwa finansowego wyróżnić można chociażby spółkę PEKAES SA, VOS Logistics Polska Sp. z o.o., Go-Trans GmbH Sp. z o.o. i Zakład Transportu Ener- 
getyki „ZTiSZE” Sp. z o.o., czy też Neovia Logistics Services Polska Sp. z o.o. (zob. tab. 3.6). W przypadku czterech pierwszych wymienionych przedsiębiorstw głównym źródłem prowadzonej działalności gospodarczej było świadczenie usług transportowych ${ }^{3}$, w piątym zaś - usług logistycznych. Nasuwa się zatem pytanie, czy w przypadku przedsiębiorstw transportowych wielkość spreadu memoriałowych i kasowych mierników oceny badanego zjawiska może istotnie różnić się od ich różnicy dla pozostałych podmiotów gospodarczych sektora TSL.

Tabela 3.5. Ranking średniej wartości dla modułu spreadu między memoriałowymi i kasowymi miernikami oceny operacyjnego bezpieczeństwa finansowego przedsiębiorstw sektora TSL dla lat 2004-2012

\begin{tabular}{|c|c|c|}
\hline Wyszczególnienie & Średnia & Ranking \\
\hline \hline Moduł liczby $\left(\mathrm{m}_{2}-\mathrm{m}_{5}\right)$ & 0,9365 & 1 \\
\hline Moduł liczby $\left(\mathrm{m}_{3}-\mathrm{m}_{5}\right)$ & 0,9113 & 2 \\
\hline Moduł liczby $\left(\mathrm{m}_{4}-\mathrm{m}_{5}\right)$ & 0,2250 & 4 \\
\hline Moduł liczby $\left(\mathrm{m}_{6}-\mathrm{m}_{9}\right)$ & 0,0359 & 6 \\
\hline Moduł liczby $\left(\mathrm{m}_{7}-\mathrm{m}_{10}\right)$ & 0,0892 & 5 \\
\hline Moduł liczby $\left(\mathrm{m}_{8}-\mathrm{m}_{11}\right)$ & 0,2281 & 3 \\
\hline
\end{tabular}

Źródło: jak do tab. 3.1.

W tym celu sformułowana została hipoteza badawcza stanowiąca, iż poziom spreadu memoriałowych i kasowych mierników oceny operacyjnego bezpieczeństwa finansowego przedsiębiorstw transportowych istotnie różni się od poziomu spreadu mierników w pozostatych spótkach sektora TSL. Do jej weryfikacji wykorzystany zosta1 ${ }^{4}$ nieparametryczny test istotności różnic dla wielu prób niezależnych (nieparametryczny odpowiednik testu t $)^{5}$.

Zerowa hipotezę robocza brzmiała: poziom spreadu memoriałowych i kasowych mierników oceny badanego zjawiska nie różni się w zależności od rodzaju usługowej działalności przedsiębiorstw sektora TSL.

$$
\mathrm{H}_{0}: \mathrm{F}_{1}(\mathrm{x})=\mathrm{F}_{2}(\mathrm{x})=\mathrm{F}_{3}(\mathrm{x})=\mathrm{F}_{4}(\mathrm{x})
$$

\footnotetext{
${ }^{3}$ Spółki transportowe stanowiły 50\% podmiotów gospodarczych wykazanych w tab. 3.6.

${ }^{4}$ Badana próba przedsiębiorstw liczyła 29 podmiotów gospodarczych - wobec tego, w celu analizy zgodności rozkładu zmiennej w danej grupie przedsiębiorstw z określonym rozkładem teoretycznym, wykorzystano test normalności Shapiro-Wilka. Na podstawie wyników tego testu odrzucono hipotezę o normalności rozkładu.

${ }^{5}$ Nieparametryczne odpowiedniki testów t stosowane są m.in. wtedy gdy zmienna mierzona jest na skali porządkowej lub wtedy, gdy zmienna zależna ma ilościowy poziom pomiaru, ale analizowane dane nie spełniają założeń przewidzianych dla testów parametrycznych, w tym założenie mówiące o rozkładzie normalnym.
} 


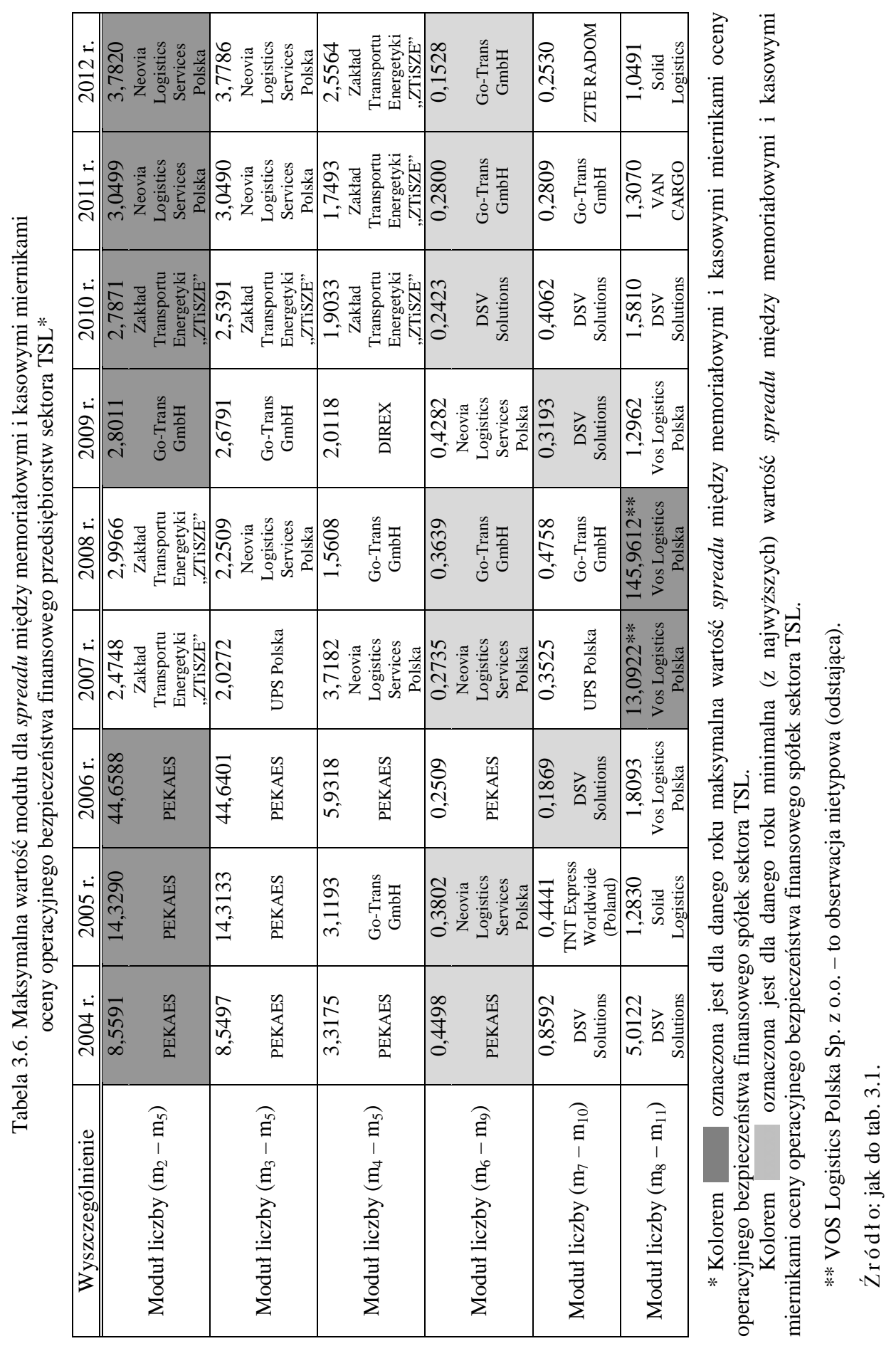


Hipoteza alternatywna mówiła z kolei, iż nie we wszystkich rodzajach usługowej działalności przedsiębiorstw sektora TSL rozkład badanej zmiennej jest identyczny.

$$
\mathrm{H}_{1}: \mathrm{F}_{1}(\mathrm{x}) \neq \mathrm{F}_{2}(\mathrm{x}) \neq \mathrm{F}_{3}(\mathrm{x}) \neq \mathrm{F}_{4}(\mathrm{x})
$$

Wyniki poprowadzonych badań wskazują, iż istotne różnice wystąiły w przypadku spreadu mierników:

$-\mathrm{m}_{4} \mathrm{i} \mathrm{m}_{5}-\mathrm{w}$ latach 2004-2008 (przy czym w 2008 r. na poziomie tendencji),

$-\mathrm{m}_{6}$ i m $\mathrm{m}_{9}$ - w latach 2006-2008, 2010 i 2012 przy p < 0,05, zaś w 2004 oraz 2009 r. przy $\mathrm{p}<0,1$,

- $\mathrm{m}_{2}$ i $\mathrm{m}_{5}$ w 2004 r., $\mathrm{m}_{3}$ i $\mathrm{m}_{5} \mathrm{w} 2004$ oraz 2011 r., $\mathrm{m}_{7} \mathrm{i} \mathrm{m}_{10} \mathrm{w} 2012$ r., a także $\mathrm{m}_{8}$ i $\mathrm{m}_{11} \mathrm{w}$ latach 2007-2009 - jedynie na poziomie tendencji (zob. tab. 3.7).

Na tym etapie poprowadzonych badań nie została jednakże przeprowadzona identyfikacja między którymi rodzajami usługowej działalności przedsiębiorstw sektora TSL występują te różnice.

Tabela 3.7. Poziom istotności różnic między określonymi rodzajami działalności (głównymi źródłami przychodu) dla spreadu memoriałowych i kasowych mierników oceny operacyjnego bezpieczeństwa finansowego przedsiębiorstw sektora TSL (próba niezależna)*

\begin{tabular}{|c|c|c|c|c|c|c|c|c|c|c|}
\hline \multicolumn{2}{|c|}{ Wyszczególnienie } & 2004 r. & $2005 \mathrm{r}$. & $2006 \mathrm{r}$. & 2007 r. & $2008 \mathrm{r}$. & 2009 r. & $2010 \mathrm{r}$. & $2011 \mathrm{r}$. & 2012 r. \\
\hline \multirow{6}{*}{ 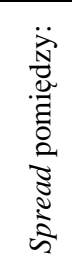 } & $\mathrm{m}_{2} \mathrm{i} \mathrm{m}_{5}$ & 0,098 & 0,452 & 0,611 & 0,448 & 0,432 & 0,230 & 0,582 & 0,104 & 0,521 \\
\hline & $\mathrm{m}_{3} \mathrm{i} \mathrm{m}_{5}$ & 0,067 & 0,539 & 0,664 & 0,342 & 0,406 & 0,199 & 0,513 & 0,056 & 0,458 \\
\hline & $\mathrm{m}_{4} \mathrm{i} \mathrm{m}_{5}$ & 0,012 & 0,042 & 0,004 & 0,003 & 0,078 & 0,257 & 0,176 & 0,364 & 0,402 \\
\hline & $\mathrm{m}_{6} \mathrm{i} \mathrm{m}_{9}$ & 0,090 & & (0רנ & 0,005 & 0,002 & 0,084 & 0,044 & 0,448 & 0,007 \\
\hline & $\mathrm{m}_{7} \mathrm{i} \mathrm{m}_{10}$ & 0,955 & 0,888 & 0,182 & 0,146 & 0,196 & 0,242 & 0,390 & 0,215 & 0,098 \\
\hline & $\mathrm{m}_{8} \mathrm{i} \mathrm{m}_{11}$ & 0,742 & 0,345 & 0,230 & 0,097 & 0,084 & 0,065 & 0,198 & 0,248 & 0,210 \\
\hline
\end{tabular}

* Kolorem zaznaczone są istotne różnice przy poziomie istotności 0,05.

Kolorem zaznaczone są istotne różnice na poziomie tendencji (poziom istotności 0,1).

Źródło: obliczenia danych zebranych w Krajowym Rejestrze Sądowym w Warszawie przy wykorzystaniu programu SPSS Statistics (wersja 22).

Przeprowadzone (przy poziomie istotności skorygowanej $\mathrm{p}<0,05$ ) porównania międzygrupowe wykazały, iż w przypadku poziomu spreadu współczynnika natychmiastowej płynności finansowej $\left(\mathrm{m}_{4}\right)$ i współczynnika zdolności do obsługi zobowiązań bieżących gotówką osiąganą z działalności operacyjnej $\left(\mathrm{m}_{5}\right)$ istotne różnice wystąpiły w latach 2004-2007 pomiędzy przedsiębiorstwami, 
których główne źródło przychodów netto ze sprzedaży pochodziło z prowadzenia działalności spedycyjnej ${ }^{6} \mathrm{w}$ relacji do innych podmiotów gospodarczych sektora TSL (zob. tab. 3.8).

Tabela 3.8. Średnia ranga dla istotnie różnych wartości spreadu mierników oceny operacyjnego bezpieczeństwa finansowego między określonymi rodzajami działalności (głównym źródłem przychodu) spółek sektora TSL* (próba niezależna)

\begin{tabular}{|c|c|c|}
\hline \multirow{2}{*}{ Wyszczególnienie } & \multicolumn{2}{|c|}{ Spread pomiędzy: } \\
\hline & $\mathrm{m}_{4} \mathrm{i} \mathrm{m}_{5}$ & $\mathrm{~m}_{6} \mathrm{i} \mathrm{m}_{9}$ \\
\hline $2004 \mathrm{r}$. & $\begin{array}{c}\text { S vs T } \\
(4,20)(18,36) \\
\text { S vs } L \\
(4,20)(17,78)\end{array}$ & - \\
\hline 2005 r. & $\begin{array}{c}\text { S vs T } \\
(6,20)(18,55)\end{array}$ & - \\
\hline $2006 \mathrm{r}$. & $\begin{array}{c}\text { S vs T } \\
(4,40) \quad(20,91)\end{array}$ & $\begin{array}{c}\text { S vs T } \\
(8,80)(21,00)\end{array}$ \\
\hline $2007 \mathrm{r}$. & $\begin{array}{c}\text { S vs K } \\
(6,00)(22,00) \\
\text { S vs T } \\
(6,00)(19,91)\end{array}$ & $\begin{array}{c}\text { S vs T } \\
(7,80)(21,91) \\
\text { L vs T } \\
(11,11)(21,91)\end{array}$ \\
\hline $2008 \mathrm{r}$. & - & $\begin{array}{c}\text { K vs T } \\
(7,75)(22,73) \\
\text { S vs T } \\
(9,20)(22,73) \\
\text { L vs T } \\
(12,00)(22,73) \\
\end{array}$ \\
\hline $2009 \mathrm{r}$. & - & - \\
\hline $2010 \mathrm{r}$. & - & $\begin{array}{c}\text { K vs T ** } \\
(6,25)(19,00)\end{array}$ \\
\hline $2011 \mathrm{r}$. & - & - \\
\hline $2012 \mathrm{r}$. & - & $\begin{array}{c}\text { K vs T } \\
(7,00)(20,82) \\
\text { S vs T } \\
(7,80)(20,82)\end{array}$ \\
\hline
\end{tabular}

* Kolorem zaznaczone są istotne różnice przy poziomie istotności 0,05.

** Istotne różnice na poziomie tendencji (poziom istotności 0,1 ).

Źródło: jak do tab. 3.7.

\footnotetext{
${ }^{6}$ Najczęściej spread między analizowanymi miernikami był najniższy.
} 
W przypadku spreadu między miernikiem $\mathrm{m}_{6}$ i $\mathrm{m}_{9} \mathrm{w}$ 2006, 2007, 2008, 2010 i 2012 r. można było odrzucić hipotezę zerową, bowiem poziom różnicy badanych zmiennych diagnostycznych dla przedsiębiorstw transportowych był wyższy i istotnie różnił się od tego poziomu dla pozostałych spółek sektora TSL.

Na podstawie zaprezentowanych wyników badań empirycznych nie można jednakże jednoznacznie potwierdzić, jak i zanegować hipotezy badawczej stanowiącej, iż poziom spreadu memoriatowych i kasowych mierników oceny operacyjnego bezpieczeństwa finansowego przedsiębiorstw transportowych istotnie różni się od poziomu speadu mierników $w$ pozostatych spótkach sektora TSL. Sytuacja taka wystąpiła bowiem jedynie w:

- 2004 i 2005 r. dla spreadu pomiędzy $\mathrm{m}_{4} \mathrm{i} \mathrm{m}_{5}$,

- 2006 i 2007 r. dla spreadu pomiędzy $\mathrm{m}_{4} \mathrm{i}_{5}$ oraz $\mathrm{m}_{6} \mathrm{i} \mathrm{m}_{9}$,

- 2008, 2010 i 2012 r. dla spreadu pomiędzy $\mathrm{m}_{6} \mathrm{i} \mathrm{m}_{9}$.

W toku prowadzonej działalności podmioty gospodarcze powinny również zwrócić szczególną uwagę na poziom oraz charakter spreadu między memoriałowymi i kasowymi miernikami oceny operacyjnego bezpieczeństwa finansowego. Nabiera on szczególnego znaczenia zwłaszcza w okresie kryzysu światowego, który wywołał nieuniknione jego objawy również w polskiej rzeczywistości gospodarczo-społecznej. Jego wzrost może przyczynić się bowiem do zagrożenia funkcjonowania danego podmiotu gospodarczego na rynku.

Przedsiębiorstwa funkcjonują $\mathrm{w}$ określonym otoczeniu makroekonomicznym. W związku z tym podlegają, jako składniki systemu, takim samym prawidłowościom jak cała gospodarka. Kryzys w gospodarce przekłada się na pojedyncze przedsiębiorstwa albo ich grupy ${ }^{7}$. Dodatkowo może być on wywołany przez czynniki należące do otoczenia konkurencyjnego, jak i wynikać z wnętrza samego przedsiębiorstwa.

Przedsiębiorstwa sektora TSL, podobnie jak i inne podmioty gospodarcze w Polsce, zostały w ciągu lat 2008-2009 poddane silnej próbie wytrzymałości, spowodowanej ogólnoświatowym kryzysem gospodarczym ${ }^{8}$.

${ }^{7}$ „Stan koniunktury gospodarczej traktowany jest jako jeden z podstawowych czynników decydujących o skłonności przedsiębiorstw do upadłości. W okresach wzrostu gospodarczego poprawia się kondycja finansowa przedsiębiorstw i słabnie ich zagrożenie upadłością", [za:] A. Skowronek-Mielczarek, Controlling, analiza i monitoring $w$ zarzadzaniu przedsiębiorstwem, Centrum Doradztwa i Informacji Difin Sp. z o.o., Warszawa 2007, s. 218-219.

W sferze gospodarczej kryzys definiuje się jako zjawisko załamania równowagi między podażą a popytem na dobra i usługi, [w:] Stownik ekonomiczny i finansowy, Wydawnictwo Książnica, Katowice 1994, s. 90.

${ }^{8}$ Za graniczną datę rozpoczęcia kryzysu przyjmuje się 15 września 2008 r., to jest dzień ogłoszenia upadłości czwartej co do wielkości korporacji finansowej Lehman Brothers, [w:] C. Mańk ow ski, Krajowy rynek ustug TSL w warunkach ogólnoświatowego kryzysu gospodarczego i finansowego, ,Logistyka” 2010, $\mathrm{nr}$ 1, s. 39.

Po latach wzrostu (tj. 2005-2008) i gwałtownego odwrócenia tego trendu w 2009 r. (w którym połowa czołowych przedsiębiorstw zanotowała spadek sprzedaży), rynek usług logistycznych 
Kluczowa działalność usługowa spółek sektora TSL wykazywana w dokumentacji składanej do Krajowego Rejestru Sądowego w Warszawie wchodziła w zakres sekcji „Transport i gospodarka magazynowa”. Tym samym za pierwsze symptomy dekoniunktury dla sektora $\mathrm{TSL}^{9} \mathrm{w}$ podjętych badaniach empirycznych Autorka przyjęła już koniec 2008 r. $^{10}$, a za jej koniec - grudzień 2009 r. (zob. wykres 3.1).

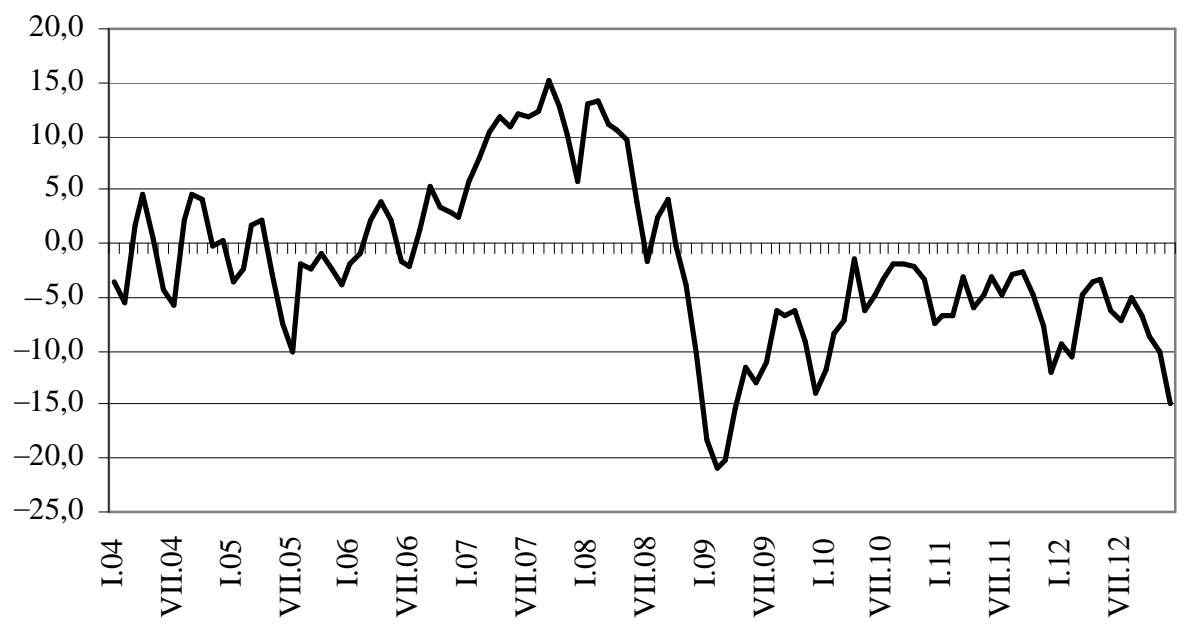

Wykres 3.1. Wskaźnik ogólnego klimatu koniunktury w sekcji „Transport i gospodarka magazynowa”

Źródło: Koniunktura w usługach, Główny Urząd Statystyczny w Warszawie (dostęp: 19.03.2014).

W toku dalszych rozważań poprowadzona została weryfikacja hipotezy stanowiącej, iż na ksztattowanie się spreadu memoriałowych i kasowych mierników

w Polsce w grudniu 2010 r. powoli wychodził z zapaści, [w:] P. S zreter, Perspektywy rozwoju rynku ustug logistycznych, ,EuroLogistics” 2010, nr 6 (61), s. 106.

Niezależnie od tego, czy lata 2008-2009 będą określane w Polsce jako kryzys, czy tylko spowolnienie, jego skutki są zauważalne zarówno w skali makro- (np. spadek PKB), jak i mikroekonomicznej. 2010 rok - jest różnie postrzegany dla sektora TSL - zatem przyjęto w niniejszym opracowaniu, że jest to okres stagnacji.

${ }^{9}$ Wskaźnik ogólnego klimatu koniunktury gospodarczej jednostek jest wskaźnikiem złożonym, liczonym jako średnia arytmetyczna sald odpowiedzi na pytania dotyczące bieżącej i przewidywanej ogólnej sytuacji jednostki w zakresie prowadzonej działalności usługowej.

„Dobry” klimat koniunktury odnotowywany jest, gdy powyższy wskaźnik jest większy od zera. W przeciwnym wypadku klimat jest oceniany jako „zły”.

Zob. http://www.stat.gov.pl/cps/rde/xbcr/gus/m-uslugi.pdf (dostęp: 24.05.2012).

${ }^{10}$ Pierwsze symptomy globalnej dekoniuktury zaczęto odczuwać w Polsce w IV kwartale 2008 r., chociaż ich przełożenie na wyniki finansowe przedsiębiorstw nastąpiło dopiero kilka miesięcy później. Por. M. Zysińska, Kierunki rozwoju przedsiębiorstw branży TSL w Polsce w okresie dekoniunktury - wnioski z badań, „Transport Samochodowy” 2010, nr 3, s. 47-60. 
oceny operacyjnego bezpieczeństwa finansowego przedsiębiorstw sektora TSL istotny wptyw wywiera koniunktura gospodarcza na rynku. W celu weryfikacji tej hipotezy wykorzystany został nieparametryczny test istotności różnic dla wielu prób zależnych ${ }^{11}$.

Sformułowana została zatem zerowa hipoteza robocza zakładająca, iż nie wystąpiła zmiana poziomu spreadu memoriałowych i kasowych mierników badanego zjawiska wśród przedsiębiorstw sektora TSL w latach 2004-2012. Hipoteza alternatywna mówiła z kolei, iż nie we wszystkich analizowanych latach rozkład badanej zmiennej był identyczny.

Na podstawie otrzymanych wyników analizy dla prób zależnych (przy poziomie istotności wynoszącym 0,05 ) odrzucona została hipoteza zerowa o braku występujących istotnych różnic średnich dla spreadu mierników $\mathrm{m}_{2}, \mathrm{~m}_{3}, \mathrm{~m}_{4}$ a $\mathrm{m}_{5}$, jak i $\mathrm{m}_{8}$ a $\mathrm{m}_{11}$ między latami 2004-2012 (zob. tab. 3.9).

Tabela 3.9. Poziom istotności różnic między określonymi latami dla spreadu memoriałowych i mierników kasowych oceny operacyjnego bezpieczeństwa finansowego spółek sektora TSL* (próba zależna)

\begin{tabular}{|c|c|}
\hline Wyszczególnienie & Poziom istotności \\
\hline \hline $\mathrm{m}_{2}-\mathrm{m}_{5}$ & 0,003 \\
\hline $\mathrm{m}_{3}-\mathrm{m}_{5}$ & 0,000 \\
\hline $\mathrm{m}_{4}-\mathrm{m}_{5}$ & 0,005 \\
\hline $\mathrm{m}_{6}-\mathrm{m}_{9}$ & 0,271 \\
\hline $\mathrm{m}_{7}-\mathrm{m}_{10}$ & 0,166 \\
\hline $\mathrm{m}_{8}-\mathrm{m}_{11}$ & $0,018^{* *}$ \\
\hline
\end{tabular}

* Kolorem zaznaczone są istotne różnice przy poziomie istotności 0,05.

** Analiza POST-HOC nie ujawniła istotnych różnic między analizowanymi zmiennymi przy poziomie istotności skorygowanej $\mathrm{p}<0,05$.

Źródło: jak do tab. 3.7.

Analiza POST-HOC wykazała jednakże, że w całym obszarze rentowności eksploatacyjnej i wydajności pieniężnej (gotówkowej) różnica dla spreadu poszczególnych zmiennych diagnostycznych między analizowanymi latami jest nieistotna statystycznie, a zatem nie ma podstaw (przy poziomie istotności skorygowanej równym 0,05 ) do odrzucenia hipotezy zerowej o braku istotnej różnicy dla spreadu memoriałowych i kasowych mierników oceny operacyjnego bezpieczeństwa finansowego przedsiębiorstw sektora TSL w okresie koniunktury i dekoniunktury gospodarczej na rynku.

${ }^{11}$ Badana próba przedsiębiorstw liczyła 29 podmiotów gospodarczych - wobec tego, w celu analizy zgodności rozkładu zmiennej w danej grupie przedsiębiorstw z określonym rozkładem teoretycznym, wykorzystano test normalności Shapiro-Wilka. Na podstawie wyników tego testu odrzucono hipotezę o normalności rozkładu. 
Tabela 3.10. Istotne różnice między określonymi latami dla spreadu memoriałowych i kasowych mierników oceny operacyjnego bezpieczeństwa finansowego spółek sektora TSL* (analiza POST-HOC)

\begin{tabular}{|c|c|c|c|}
\hline \multirow{2}{*}{ Wyszczególnienie } & \multicolumn{3}{|c|}{ Spread pomiędzy: } \\
\cline { 2 - 4 } & $\mathrm{m}_{2}$ do $\mathrm{m}_{5}$ & $\mathrm{~m}_{3}$ do $\mathrm{m}_{5}$ & $\mathrm{~m}_{4}$ do $\mathrm{m}_{5}$ \\
\hline \hline \multirow{3}{*}{} & 2004 vs 2010 & 2004 vs 2010 & 2004 vs 2010 \\
\cline { 2 - 4 } & $\mathbf{2 0 0 4}$ vs 2011 & 2004 vs 2011 & $\mathbf{2 0 0 4}$ vs 2011 \\
\cline { 2 - 4 } & 2004 vs 2012 & 2004 vs 2012 & 2004 vs 2012 \\
\cline { 2 - 4 } & 2009 vs 2012 & 2009 vs 2012 & $\mathbf{2 0 0 9}$ vs $\mathbf{2 0 1 2}$ \\
\cline { 2 - 4 } & 2011 vs 2012 & 2011 vs 2012 & 2011 vs 2012 \\
\hline
\end{tabular}

* Kolorem zaznaczone są istotne różnice przy poziomie istotności 0,05.

Pogrubioną czcionką zaznaczone są istotne różnice przy poziomie istotności 0,1 .

W przypadku braku występowania istotnych różnic między określonymi latami dla spreadu memoriałowych i kasowych mierników oceny operacyjnego bezpieczeństwa finansowego - dana zmienna (lata) została (zostały) pominięta (pominięte) w utworzonym powyżej zestawieniu tabelarycznym.

Źródło: jak do tab. 3.7.

Przeprowadzona dla trzech pierwszych rodzajów spreadu analiza POST-HOC - dla wskazania okresu, w którym występowały istotne różnice dla wartości analizowanych mierników z obszaru płynności finansowej - uwidoczniła, że różnice te wystąiły między $2004^{12}$ i 2012 r. w pierwszym przypadku, między 2004 a 2010, 2011 i 2012 r. - w drugim przypadku, jak i między 2011 a 2012 r. - w ostatnim z nich (przy istotności skorygowanej $\mathrm{p}<005$ - zob. tab. 3.10). Najwyższy poziom spreadu najczęściej występował w 2012 r., a najniższy odpowiednio w 2004, 2004 i 2011 r. (por. wykres 3.2, 3.3 i 3.4).

${ }^{12}$ Bez wątpienia przystapienie Polski do Unii Europejskiej - a wcześniej także sama jego perspektywa - przyczyniły się do poprawy politycznego i gospodarczego wizerunku kraju, podniesienia tempa wzrostu gospodarczego, silnego impulsu dostosowawczo-modernizacyjnego dla polskich przedsiębiorstw, ożywienia polskiego eksportu, boomu w sektorach związanych z produkcją rolno-spożywczą, ale również do zmniejszenia kosztów prowadzenia działalności gospodarczej w wielu sektorach (w tym w szczególności w branży transportowej). Oszczędności dla firm transportowych wynikały ze zniesienia z dniem 1 maja 2004 r. wszelkich ograniczeń w przewozach na trasach międzynarodowych w całej Unii Europejskiej (5-letni okres przejściowy dotyczył wyłącznie przewozów kabotażowych). Zniesienie fizycznych kontroli, eliminacja formalności administracyjnych oraz celnych, jak i wyeliminowanie kosztów związanych z uzyskaniem koniecznych pozwoleń w znacznym stopniu przełożyły się na poprawę kondycji finansowej polskich firm transportowych oraz możliwość uruchomienia nowych rodzajów usług. Obniżenie kosztów poprawiło konkurencyjność polskich przewoźników i tym samym polskiej oferty eksportowej, przekładając się na zwiększenie zamówień na dostawy do krajów UE. Ponadto, w 2004 r. zaobserwowany został proces „odnawiania” taboru w firmach transportowych. Zob. Polska w Unii Europejskiej - doświadczenia pierwszych miesięcy członkostwa, Urząd Komitetu Integracji Europejskiej - Departament Analiz i Strategii, Warszawa, luty 2005, s. 3.

Zatem 2004 r. - to okres korzystnej koniunktury na rynku TSL w Polsce, tzw. boom akcesyjny na rynku krajowym. 


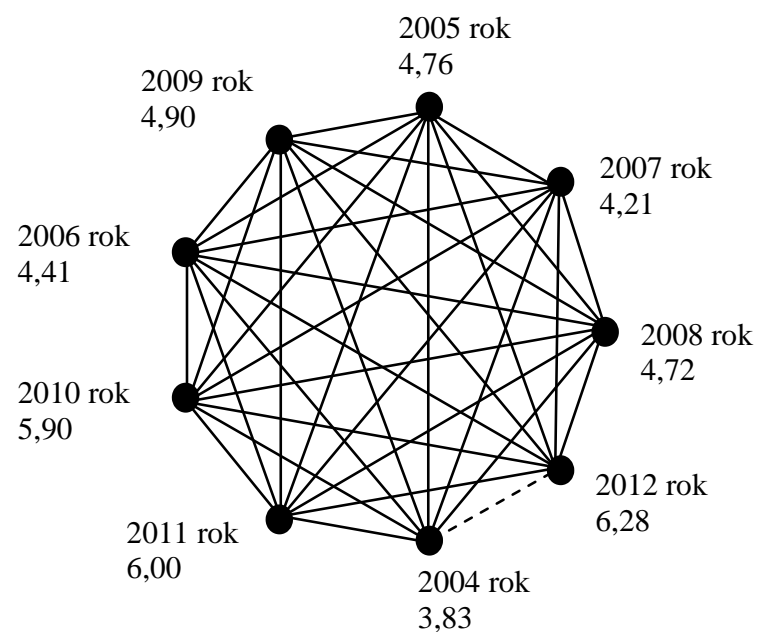

* Linie(a) przerywane(a) obrazują(e) istotne różnice między określonymi latami dla spreadu analizowanych mierników oceny operacyjnego bezpieczeństwa finansowego (poziom istotności wynosi 0,05).

Wykres 3.2. Średnie rangi dla poziomu spreadu współczynnika bieżącej płynności finansowej i współczynnika zdolności do obsługi zobowiązań bieżących gotówką osiąganą z działalności operacyjnej (porównania parami)

Źródło: obliczenia własne na podstawie danych zebranych w Krajowym Rejestrze Sądowym w Warszawie za pomocą programu SPSS Statistics (wersja 22).

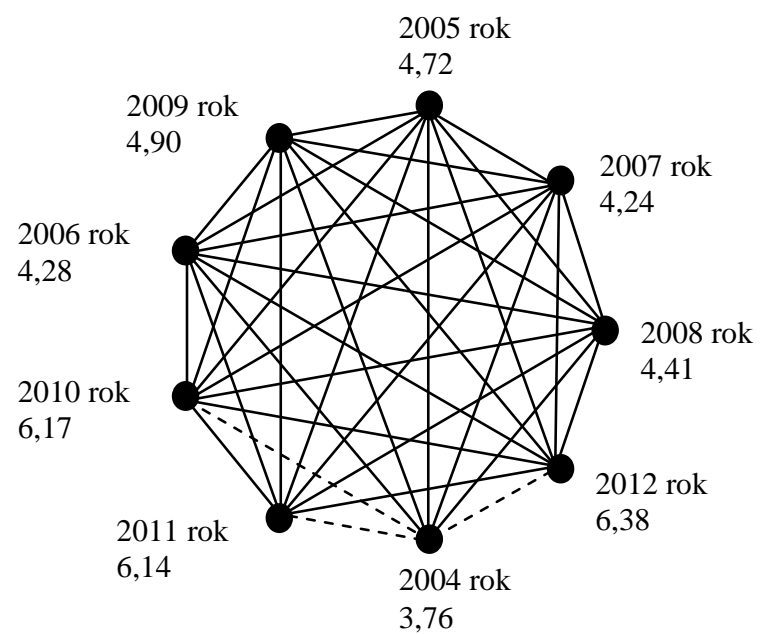

* Oznaczenia jak do wykresu 3.2.

Wykres 3.3. Średnie rangi dla poziomu spreadu współczynnika przyspieszonej płynności finansowej i współczynnika zdolności do obsługi zobowiązań bieżących gotówką osiąganą z działalności operacyjnej (porównania parami)

Źródło: jak do wykresu 3.2. 


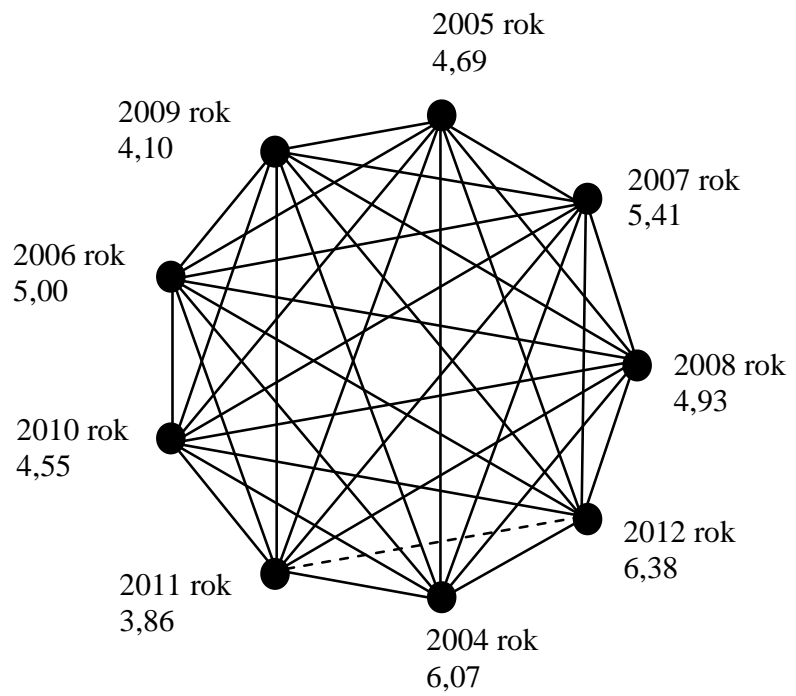

* Oznaczenia jak do wykresu 3.2.

Wykres 3.4. Średnie rangi dla poziomu spreadu współczynnika natychmiastowej płynności finansowej i współczynnika zdolności do obsługi zobowiązań bieżących gotówką osiąganą z działalności operacyjnej (porównania parami)

Źródło: jak do wykresu 3.2.

W sektorze TSL negatywne skutki kryzysu uwidoczniły się z pewnym opóźnieniem w stosunku do całej gospodarki. Wynika to z faktu, iż usługi tego sektora mają charakter wtórny w stosunku do popytu generowanego na rynku dóbr transportowych ${ }^{13}$.

W zaprezentowanych przez Autorkę wynikach badań opóźnienie to jednakże miało znacznie większy zakres. Ponadto istotne różnice między określonymi latami dla spreadu pomiędzy analizowanymi zmiennymi wystąpiły jedynie w przypadku spreadu mierników $\mathrm{m}_{2}, \mathrm{~m}_{3}, \mathrm{~m}_{4} \mathrm{a}_{5}$. Nie można wobec tego jednoznacznie potwierdzić ani zanegować hipotezy badawczej stanowiącej, iż $n a$ ksztattowanie się spreadu memoriałowych i kasowych mierników oceny operacyjnego bezpieczeństwa finansowego przedsiębiorstw sektora TSL istotny wptyw wywiera koniunktura gospodarcza na rynku.

${ }^{13}$ Por. R. Rolbi e cki, Analiza dyskryminacyjna w ocenie zmian kondycji finansowej przedsiębiorstw transportowych, ,Controlling” 2010, nr 8, s. 50. 


\subsection{Analiza zależności między memoriałowymi a kasowymi miernikami oceny operacyjnego bezpieczeństwa finansowego przedsiębiorstw sektora TSL}

Zarówno rachunek zysków i strat, jak i rachunek przepływów pieniężnych są istotnymi częściami sprawozdania finansowego, sporządzanego przez dany podmiot gospodarczy. Są one ze sobą powiązane, choć zawierają różne informacje, a między zyskiem netto a przepływami pieniężnymi netto (alternatywnie też przepływami pieniężnymi netto $\mathrm{z}$ działalności operacyjnej) obserwuje się brak współzależności ${ }^{14}$.

Głównym z kolei obszarem aktywnego oddziaływania przedsiębiorstwa na tworzenie warunków trwałej zdolności kreowania zysku netto jest działalność operacyjna, a w szczególności działalność na rynku sprzedaży świadczonych usług. Tym samym wynik (zysk) ze sprzedaży usług stanowi zasadniczą podstawę sukcesu przedsiębiorstwa, rozumianego w kontekście zarówno celu działalności finansowej, jak i tworzenia trwałych warunków otrzymywania przez przedsiębiorstwo zysku netto ${ }^{15}$.

Należy zauważyć, iż w okresie dekoniunktury gospodarczej następuje zmniejszenie popytu na dobra konsumpcyjne. Sytuacja ta przyczynia się do powstania znaczących strat operacyjnych w jednostkach gospodarczych i ujemnych przepływów pieniężnych netto z działalności operacyjnej. Wzrost konkurencji, a zatem również spadek cen dóbr konsumpcyjnych ${ }^{16}$ powoduje spadek

${ }^{14}$ D. Wędzki przeprowadził badania współzależności wielu syntetycznych miar zaczerpniętych $\mathrm{m}$. in. z rachunku zysków i strat z miarami różnych odmian przepływów pieniężnych. Wyniki tychże badań potwierdziły słuszność zaleceń MSR 7 odnośnie sporządzania, oprócz rachunku zysków i strat, także rachunku przepływów pieniężnych. Zysk (strata) netto oraz przepływy pieniężne netto niosą często różne informacje, a w związku z tym w ocenie kondycji finansowej przedsiębiorstwa nie powinno pomijać się żadnej z tych wielkości. Autor podkreślił ponadto, iż dla odzwierciedlenia sytuacji finansowej przedsiębiorstw istotne są nie tylko kategorie wynikowe, ale także pośrednie, w tym m. in. zysk z działalności operacyjnej, czy też przepływy pieniężne z tejże działalności, gdyż są one w wysokim stopniu od siebie niezależne. Cennym spostrzeżeniem Autora jest ponadto stwierdzenie, iż najdokładniejszym sposobem szacowania operacyjnych przepływów pieniężnych ex post jest formuła uproszczonych przepływów pieniężnych, w drugiej kolejności EBITDA (tj. suma zysku z działalności operacyjnej i amortyzacji), a następnie ,zysku netto + amortyzacji”. Należy jednak podkreślić, iż na otrzymane wyniki należy spojrzeć z pewną dozą ostrożności bowiem - pomimo dość znacznej liczby podmiotów gospodarczych poddanych badaniu - okres badawczy wynosił zaledwie 3 lata. Badaniem objęto 435 spółek akcyjnych innych niż ubezpieczyciele i banki w roku 1999, 3122 spółek w roku 2000 i 3229 spółek w roku 2001. Zob. D. W ę dzki, Statystyczna weryfikacja istotności przeptywów pieniężnych, „Zeszyty Teoretyczne Rachunkowości” 2003, nr 15(71), Warszawa, s. 103-119.

${ }^{15}$ J. D u r a j, Podstawy ekonomiki przedsiębiorstwa, PWE, Warszawa 2004, s. 175.

${ }^{16} \mathrm{M}$. A d a mi k-C it a k, Creative accounting in the era of economic crisis, [w:] W. W e r e$\mathrm{d}$ a, S. S t a r n a w s ka, Cyclicality, financial safety, and business creativity as the challenges of the modern word, University of Podlasie, Siedlce 2009, s. 167. 
rentowności eksploatacyjnej, który może prowadzić do zagrożenia upadłością przedsiębiorstwa.

W monografii sformułowane zostały zatem następujące hipotezy badawcze odnoszące się do zależności między memoriałowymi i kasowymi miernikami oceny operacyjnego bezpieczeństwa finansowego przedsiębiorstw sektora TSL, a mianowicie:

- w przedsiębiorstwach sektora TSL nie występuje znaczaca dodatnia zależność korelacyjna pomiędzy memoriałowymi a kasowymi miernikami oceny operacyjnego bezpieczeństwa finansowego,

- rentowność eksploatacyjna $i$ wydajność pieniężna (gotówkowa) jest tym obszarem kreowania $i$ zapewniania dobrego standingu finansowego, $w$ którym obserwuje się najsilniejszy dodatni związek korelacyjny pomiędzy memoriatowymi i kasowymi miernikami oceny operacyjnego bezpieczeństwa finansowego przedsiębiorstw sektora TSL.

Dla weryfikacji empirycznej wyżej wymienionych hipotez obliczone zostały współczynniki korelacji rang Spearmana między badanymi zmiennymi diagnostycznymi (zob. zał. 3). Podobnie jak w analizie spreadu poziomu mierników oceny operacyjnego bezpieczeństwa finansowego, szczególna uwaga została zwrócona na zależność korelacyjną występującą między zmiennymi z tego samego obszaru oceny, tj. płynności finansowej, rentowności eksploatacyjnej i wydajności pieniężnej (gotówkowej). W obszarach tych udało się bowiem wyznaczyć mierniki w ujęciu memoriałowym i kasowym ${ }^{17}$. Zgodnie zatem z przyjętymi formułami analizowanych zmiennych jedynie licznik danej formuły ulegał zmianie, pozostawiając mianownik w niezmienionej (jednakowej) postaci.

Wyniki przeprowadzonych badań nad poziomem oraz charakterem zależności między memoriałowymi i kasowymi miernikami badanego zjawiska jednoznacznie wskazują, iż pomiędzy rozważanymi zmiennymi w latach 2004-2012 występowała dodatnia zależność korelacyjna. Wyjątkiem była zależność między zmiennymi m m $_{2}$ w 2007 r., m m $_{3}$ i m w 2007 i 2012 r., a także m i m$_{5}$ w 2012 r. (zob. tab. 3.11).

Zależność ta miała jednakże w badanym okresie zróżnicowaną siłę. Umiarkowana zależność korelacyjna występowała:

- w latach 2006, 2008, 2010-2012 pomiędzy zmienną $\mathrm{m}_{7} \mathrm{a}_{10}$,

- w 2004, 2006 i 2010 r. w przypadku m 6 i m,

- w 2006 roku i latach 2010-2011 dla mierników $\mathrm{m}_{8}$ i m $\mathrm{m}_{11}$,

- w latach 2005-2006 oraz 2008 i 2011 r. pomiędzy zmiennymi $\mathrm{m}_{4} \mathrm{i} \mathrm{m}_{5}$,

- w 2008 i 2011 r. między miernikami $\mathrm{m}_{2}$ oraz $\mathrm{m}_{5}$, jak i $\mathrm{m}_{3}$ oraz $\mathrm{m}_{5}$.

${ }^{17}$ Ze względu na ograniczenia związane z możliwością pozyskania danych w ujęciu kasowych dla wpływów ze sprzedaży produktów (usług), towarów i materiałów, jak i krótkoterminowych rezerw finansowych - analiza korelacji między memoriałowymi a kasowymi miernikami oceny operacyjnego bezpieczeństwa finansowego została ograniczona do analizy zależności pomiędzy zmiennymi z obszaru płynności finansowej, jak i rentowności oraz wydajności pieniężnej. 
Tabela 3.11. Wartości współczynników korelacji rang Spearmana pomiędzy miernikami oceny operacyjnego bezpieczeństwa finansowego przedsiębiorstw sektora TSL w latach 2004-2012 $2^{18}$ *

\begin{tabular}{|c|c|c|c|c|c|c|}
\hline Wyszczególnienie & $\mathrm{m}_{2} \mathrm{i} \mathrm{m}_{5}$ & $\mathrm{~m}_{3} \mathrm{i} \mathrm{m}_{5}$ & $\mathrm{~m}_{4} \mathrm{i} \mathrm{m}_{5}$ & $\mathrm{~m}_{6} \mathrm{i}_{9}$ & $\mathrm{~m}_{7} \mathrm{i}_{10}$ & $\mathrm{~m}_{8} \mathrm{i}_{11}$ \\
\hline \hline 2004 r. & 0,08 & 0,09 & 0,32 & $\mathbf{0 , 6 4}$ & 0,31 & 0,25 \\
\hline 2005 r. & 0,29 & 0,33 & $\mathbf{0 , 6 0}$ & $\mathbf{0 , 3 8}$ & 0,36 & 0,32 \\
\hline 2006 r. & 0,29 & 0,25 & $\mathbf{0 , 4 8}$ & $\mathbf{0 , 5 9}$ & $\mathbf{0 , 5 5}$ & $\mathbf{0 , 4 3}$ \\
\hline 2007 r. & $-0,08$ & $-0,05$ & 0,12 & 0,29 & 0,20 & 0,18 \\
\hline 2008 r. & $\mathbf{0 , 4 1}$ & $\mathbf{0 , 4 2}$ & $\mathbf{0 , 4 1}$ & 0,34 & $\mathbf{0 , 4 3}$ & 0,29 \\
\hline 2009 r. & 0,36 & 0,35 & $\mathbf{0 , 3 8}$ & 0,36 & $\mathbf{0 , 3 8}$ & 0,36 \\
\hline 2010 r. & 0,12 & 0,10 & 0,29 & $\mathbf{0 , 4 4}$ & $\mathbf{0 , 5 1}$ & $\mathbf{0 , 4 5}$ \\
\hline 2011 r. & $\mathbf{0 , 4 1}$ & $\mathbf{0 , 4 2}$ & $\mathbf{0 , 5 6}$ & 0,20 & $\mathbf{0 , 4 7}$ & $\mathbf{0 , 4 5}$ \\
\hline 2012 r. & $0,00 * *$ & $-0,05$ & $-0,08$ & 0,33 & $\mathbf{0 , 4 8}$ & 0,33 \\
\hline
\end{tabular}

* Pogrubioną czcionką oznaczone zostały wartości współczynników korelacji rang Spearmana istotne dla $\mathrm{p}<0,05$.

$* * 0,0015$.

Źródło: obliczenia własne na podstawie danych zebranych w Krajowym Rejestrze Sądowym w Warszawie przy wykorzystaniu programu Statistica 10.

W pozostałych przypadkach kształtowała się ona na niskim poziomie lub w ogóle nie występowała. Taka sytuacja miała miejsce dla przykładu między współczynnikami bieżącej i przyspieszonej płynności a współczynnikiem zdolności do obsługi zobowiązań bieżących gotówką osiąganą z działalności operacyjnej w całym badanym okresie za wyjątkiem 2008 i 2011 r.

Taki długotrwały brak związku korelacyjnego między rozważanymi miarami oceny płynności finansowej i rentowności (tj. wykorzystującymi podejście memoriałowe i kasowe) może wskazywać na pewną nieprawidłowość oraz zagrożenie kontynuacji działania przedsiębiorstw.

Potwierdzona została zatem hipoteza badawcza stanowiąca, iż $w$ przedsiębiorstwach sektora TSL nie wystęuje znaczaca dodatnia zależność korelacyjna pomiędzy memoriałowymi a kasowymi miernikami oceny operacyjnego bezpieczeństwa finansowego.

\footnotetext{
${ }^{18}$ Do celów opracowania przyjęto następujące założenia:

a) mniej niż 0,2 - to brak związku między badanymi zmiennymi,

b) $0,2-0,4 \quad-$ to zależność jest wyraźna, ale niska,

c) $0,4-0,7 \quad-$ to zależność umiarkowana,

d) $0,7-0,9 \quad-$ to zależność znacząca,

e) powyżej 0,9 - to zależność bardzo silna.
}

Zob. S. O st a si e wi c z, Z. Ru sn ak, U. Si ed le ck a, Statystyka. Elementy teorii i zadania, Wydawnictwo Akademii Ekonomicznej im. Oskara Langego we Wrocławiu, Wrocław 2003, s. 311. 
Najwyższy średni, jak i środkowy współczynnik korelacji rang Spearmana wystąpił między współczynnikiem eksploatacyjnej rentowności aktywów ogółem $\left(\mathrm{m}_{7}\right)$ a współczynnikiem wydajności pieniężnej (gotówkowej) aktywów ogółem $\left(\mathrm{m}_{10}\right)$.

$\mathrm{Na}$ podstawie utworzonego rankingu wartości współczynników korelacji między memoriałowymi a kasowymi miernikami w głównych obszarach ceny operacyjnego bezpieczeństwa finansowego przedsiębiorstw sektora TSL w latach 2004-2012 można zaobserwować, iż na pierwszym miejscu - o najwyższej średniej i środkowej wartości tego współczynnika - znajdują się związki pomiędzy analizowanymi zmiennymi diagnostycznymi z obszaru rentowności eksploatacyjnej i wydajności pieniężnej (zob. tab. 3.12).

Kwestią odrębną od siły i charakteru związku między analizowanymi zmiennymi jest istotność tego związku. Związek ten można uznać za statystyczne istotny, gdy wartość p jest niższa od 0,05 (p<0,05).

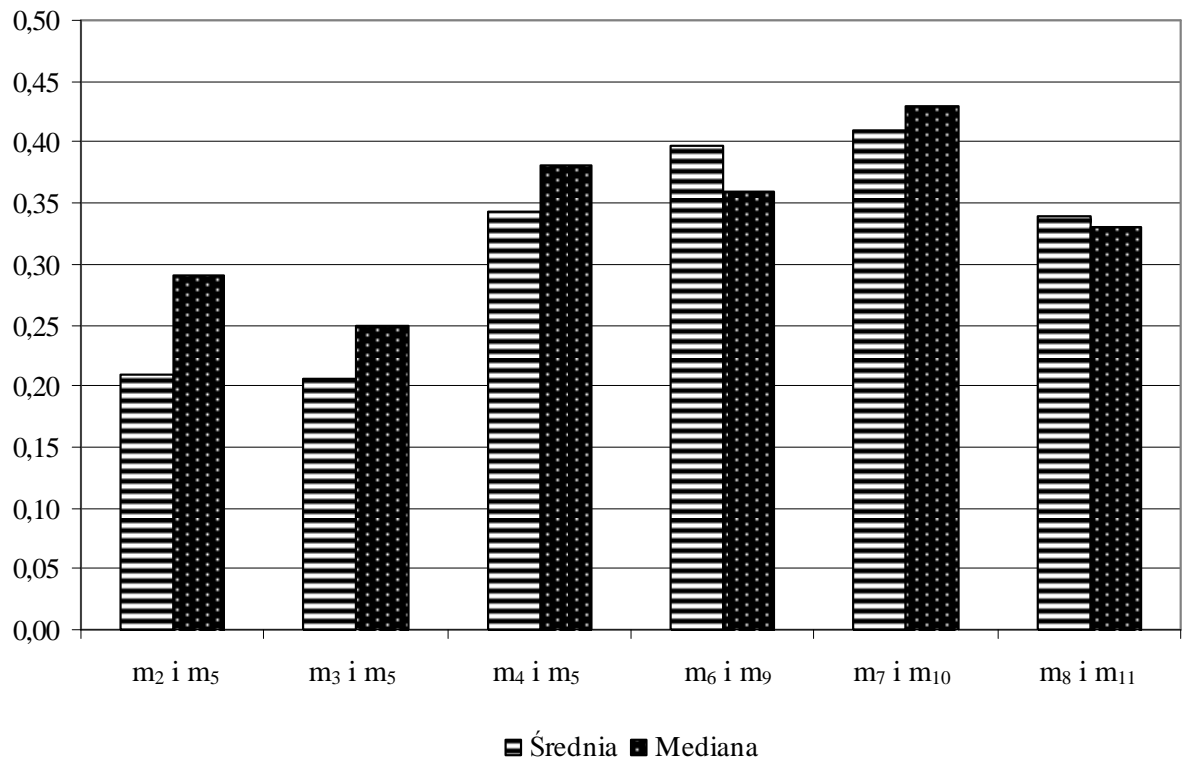

Wykres 3.5. Średnia oraz środkowa wartość współczynników korelacji rang Spearmana między memoriałowymi i kasowymi miernikami oceny operacyjnego bezpieczeństwa finansowego przedsiębiorstw sektora TSL w latach 2004-2012

Źródło: obliczenia własne na podstawie danych zebranych w Krajowym Rejestrze Sądowym w Warszawie przy wykorzystaniu programu Statistica 10 oraz Microsoft Excel. 
Tabela 3.12. Ranking wartości współczynników korelacji rang Spearmana między memoriałowymi a kasowymi miernikami w głównych obszarach oceny operacyjnego

bezpieczeństwa finansowego przedsiębiorstw sektora TSL w latach 2004-2012

\begin{tabular}{|c|c|c|c|c|c|}
\hline \multirow{2}{*}{\multicolumn{2}{|c|}{ Wyszczególnienie }} & \multicolumn{2}{|c|}{ Średnia } & \multicolumn{2}{|c|}{ Mediana } \\
\hline & & \multirow{2}{*}{$\begin{array}{c}\text { wartość } \\
0,38\end{array}$} & \multirow{2}{*}{$\begin{array}{c}\text { pozycja } \\
\text { w rankingu } \\
\\
1\end{array}$} & \multirow{2}{*}{$\begin{array}{c}\text { wartość } \\
0,36\end{array}$} & \multirow{2}{*}{$\begin{array}{c}\text { pozycja } \\
\text { w rankingu } \\
\\
1\end{array}$} \\
\hline 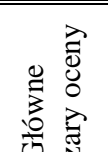 & $\begin{array}{c}\text { rentowność } \\
\text { eksploatacyjna } \\
\text { i wydajność } \\
\text { pieniężna } \\
\end{array}$ & & & & \\
\hline 0 & $\begin{array}{c}\text { płynność } \\
\text { finansowa }\end{array}$ & 0,25 & 2 & 0,29 & 2 \\
\hline
\end{tabular}

Źródło: obliczenia własne na podstawie danych zebranych w Krajowym Rejestrze Sądowym w Warszawie przy wykorzystaniu programu Statistica 10 oraz Microsoft Excel.

Z przedstawionych wyników badań wynika, iż najczęściej istotna statystycznie korelacja występowała między współczynnikiem eksploatacyjnej rentowności aktywów ogółem $\left(\mathrm{m}_{7}\right)$ a współczynnikiem wydajności pieniężnej (gotówkowej) aktywów ogółem $\left(\mathrm{m}_{10}\right)$. Nie była to jednakże najwyższa średnia i środkowa, istotna zależność między rozważanymi miernikami oceny operacyjnego bezpieczeństwa finansowego (zob. wykres 3.6), bowiem zajmowała dopiero 3 miejsce.

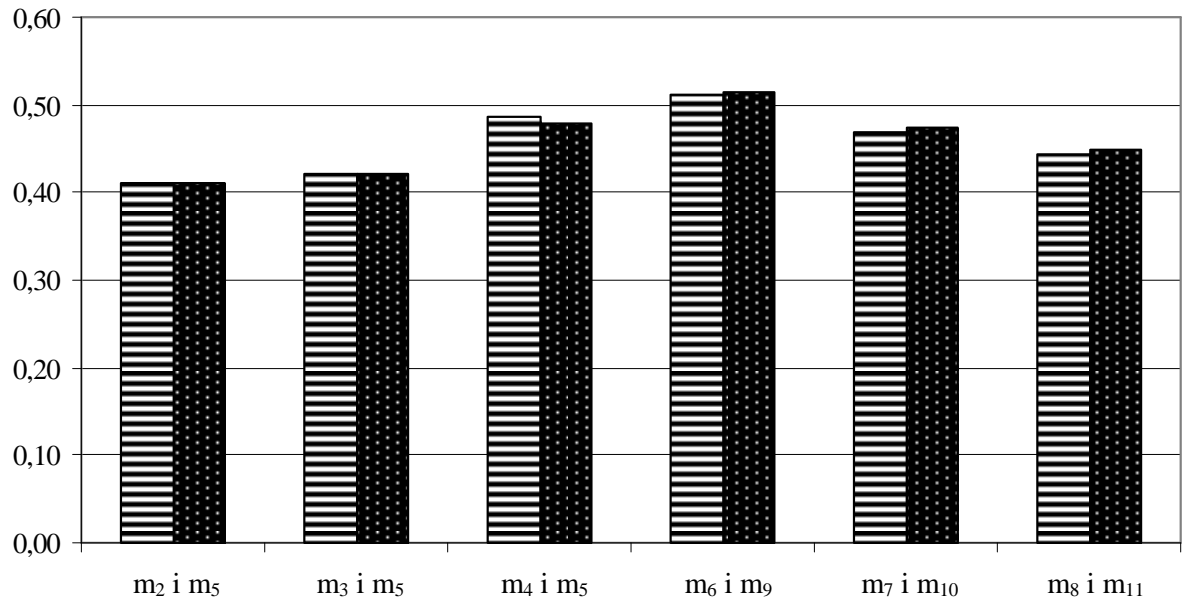

曰 Średnia Mediana

Wykres 3.6. Średnia oraz środkowa wartość istotnych statystycznie współczynników korelacji rang Spearmana między memoriałowymi i kasowymi miernikami oceny operacyjnego bezpieczeństwa finansowego przedsiębiorstw sektora TSL w latach 2004-2012

Źródło: jak do wykresu 3.5. 
Analizując istotne statystycznie wartości współczynników korelacji między badanymi memoriałowymi i kasowymi zmiennymi diagnostycznymi można zaobserwować, iż na pierwszym miejscu o najwyższej średniej, ale i środkowej wartości współczynnika korelacji znajduje się związek pomiędzy miernikami $\mathrm{m}_{6} \mathrm{i} \mathrm{m}_{9}$.

$\mathrm{Z}$ utworzonego rankingu - ponownie jak w poprzednim przypadku - wynika, iż najwyższa średnia i środkowa wartość analizowanej zmiennej została zanotowana dla związku między miernikami oceny badanego zjawiska z obszaru rentowności ekspoatacyjnej i wydajności pieniężnej (zob. tab. 3.13).

Tabela 3.13. Ranking istotnych statystycznie wartości współczynników korelacji rang Spearmana między memoriałowymi a kasowymi miernikami w głównych obszarach oceny operacyjnego bezpieczeństwa finansowego przedsiębiorstw sektora TSL w latach 2004-2012

\begin{tabular}{|c|c|c|c|c|c|}
\hline \multirow{2}{*}{\multicolumn{2}{|c|}{ Wyszczególnienie }} & \multicolumn{2}{|c|}{ Średnia } & \multicolumn{2}{|c|}{ Mediana } \\
\hline & & \multirow{2}{*}{$\begin{array}{c}\text { wartość } \\
0,48\end{array}$} & \multirow{2}{*}{$\begin{array}{c}\text { pozycja } \\
\text { w rankingu } \\
1\end{array}$} & \multirow{2}{*}{$\begin{array}{c}\text { wartość } \\
0,45\end{array}$} & \multirow{2}{*}{$\begin{array}{c}\text { pozycja } \\
\text { w rankingu } \\
\\
1\end{array}$} \\
\hline 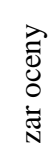 & $\begin{array}{l}\text { rentowność } \\
\text { eksploatacyjna } \\
\text { i wydajność } \\
\text { pieniężna }\end{array}$ & & & & \\
\hline 0 & $\begin{array}{l}\text { płynność } \\
\text { finansowa }\end{array}$ & 0,45 & 2 & 0,42 & 2 \\
\hline
\end{tabular}

Źródło: jak do tab. 3.12 .

Wobec powyższego można uznać za trafną hipotezę badawczą stwierdzającą iż rentowność eksploatacyjna $i$ wydajność pieniężna (gotówkowa) jest tym obszarem kreowania $i$ zapewniania dobrego standingu finansowego, w którym obserwuje się najsilniejszy dodatni związek korelacyjny pomiędzy memoriałowymi i kasowymi miernikami oceny operacyjnego bezpieczeństwa finansowego przedsiębiorstw sektora TSL.

\subsection{Analiza zależności między memoriałowymi i kasowymi miernikami oceny operacyjnego bezpieczeństwa finansowego a poziomem dywersyfikacji działalności gospodarczej spółek sektora TSL}

Badanie i ocena operacyjnego bezpieczeństwa finansowego przedsiębiorstwa może dotyczyć zarówno mierników finansowego obszaru prowadzonej działalności gospodarczej, jak i obszaru usługowego (produktowego), rynkowego i kadrowego. Wydaje się, że między tymi obszarami powinna istnieć silna zależność korelacyjna.

W opracowaniu sformułowana została hipoteza badawcza, iż pomiędzy wykazywana $w$ przedsiębiorstwach sektora TSL liczba grup PKD a memoriatowymi i kasowymi miernikami oceny operacyjnego bezpieczeństwa finansowego wystę- 
puje co najwyżej umiarkowana zależność korelacyjna, a do jej weryfikacji wykorzystany został współczynnik korelacji rang Spearmana.

Wyniki przeprowadzonych badań nad poziomem i charakterem zależności pomiędzy analizowanymi zmiennymi diagnostycznymi jednoznacznie wskazują, iż jedynie w latach 2006-2008 między współczynnikiem zabezpieczenia finansowego $\mathrm{nr} 1\left(\mathrm{~m}_{12}\right)$ a liczbą grup PKD 2007 deklarowaną przez spółki sektora TSL wystąpiła umiarkowana zależność korelacyjna i była istotną dla $\mathrm{p}<0,05$. W pozostałych przypadkach (za wyjątkiem 2007 r. dla nieistotnej umiarkowanej zależności korelacyjnej między współczynnikiem wydajności pieniężnej (gotówkowej) aktywów ogółem a liczbą grup PKD 2007) była ona jedynie niska lub nie występowała w ogóle (zob. tab. 3.14) ${ }^{19}$.

Tabela 3.14. Współczynniki korelacji rang Spearmana między memoriałowymi i kasowymi miernikami oceny operacyjnego bezpieczeństwa finansowego a liczbą grup PKD 2007 spółek sektora TSL*

\begin{tabular}{|c|c|c|c|c|c|c|c|c|c|c|}
\hline \multirow{2}{*}{\multicolumn{2}{|c|}{ Wyszczególnienie }} & \multicolumn{9}{|c|}{ Liczba grup PKD 2007} \\
\hline & & \multirow{2}{*}{$\begin{array}{c}2004 \mathrm{r} . \\
-0,35\end{array}$} & \multirow{2}{*}{$\frac{2005 \mathrm{r} .}{-0,23}$} & \multirow{2}{*}{$\begin{array}{c}2006 \mathrm{r} . \\
-0,13\end{array}$} & \multirow{2}{*}{$2007 \mathrm{r}}$. & \multirow{2}{*}{$\frac{2008 \mathrm{r} .}{0,05}$} & \multirow{2}{*}{$\frac{2009 \mathrm{r} .}{0,08}$} & \multirow{2}{*}{$\begin{array}{r}2010 \mathrm{r} \text {. } \\
0,10\end{array}$} & \multirow{2}{*}{$\begin{array}{r}2011 \mathrm{r} . \\
0,07\end{array}$} & \multirow{2}{*}{$\begin{array}{r}2012 \mathrm{r} . \\
0,08\end{array}$} \\
\hline \multirow{13}{*}{ 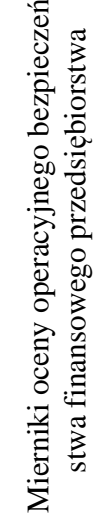 } & $\mathrm{m}_{1}{ }^{(\mathrm{a})}$ & & & & & & & & & \\
\hline & $\mathrm{m}_{2}$ & 0,08 & 0,24 & 0,17 & 0,09 & 0,07 & $-0,06$ & 0,09 & $-0,08$ & 0,08 \\
\hline & $\mathrm{m}_{3}$ & 0,04 & 0,17 & 0,11 & 0,04 & 0,05 & $0,00^{(\mathrm{b})}$ & 0,08 & $-0,11$ & 0,08 \\
\hline & $\mathrm{m}_{4}$ & 0,15 & 0,09 & 0,10 & $-0,08$ & 0,01 & 0,05 & 0,05 & 0,04 & 0,07 \\
\hline & $\mathrm{m}_{5}$ & 0,07 & $-0,09$ & $-0,06$ & $-0,40^{(\mathrm{c})}$ & $-0,29$ & $-0,27$ & $-0,29$ & $-0,11$ & $-0,16$ \\
\hline & $\mathrm{m}_{6}$ & $-0,26$ & $-0,28$ & $-0,25$ & $-0,18$ & $-0,26$ & $-0,35$ & $-0,32$ & $-0,11$ & $-0,19$ \\
\hline & $\mathrm{m}_{7}$ & $-0,34$ & $-0,23$ & $-0,19$ & $-0,18$ & $-0,17$ & $-0,25$ & $-0,23$ & $-0,08$ & $-0,08$ \\
\hline & $\mathrm{m}_{8}$ & $-0,27$ & $-0,25$ & -0 & $-0,06$ & $-0,17$ & $-0,16$ & $-0,14$ & $-0,07$ & $-0,06$ \\
\hline & $\mathrm{m}_{9}$ & 0,14 & $-0,16$ & $-0,08$ & $-0,38$ & $-0,35$ & $-0,25$ & $-0,31$ & $-0,14$ & $-0,25$ \\
\hline & $\mathrm{m}_{10}$ & 0,02 & $-0,23$ & 0,03 & $-0,40^{(\mathrm{d})}$ & $-0,29$ & $-0,29$ & $-0,17$ & 0,06 & $-0,22$ \\
\hline & $\mathrm{m}_{11}$ & 0,05 & 0,04 & $-0,08$ & $-0,24$ & $-0,22$ & $-0,13$ & 0,03 & 0,15 & $-0,32$ \\
\hline & $\mathrm{m}_{12}$ & 0,29 & 0,36 & 0,49 & $\mathbf{0 , 5 1}$ & 0,48 & 0,23 & 0,15 & 0,15 & 0,13 \\
\hline & $\mathrm{m}_{13}$ & 0,04 & $-0,11$ & 0,14 & 0,19 & 0,21 & 0,14 & 0,22 & 0,15 & 0,16 \\
\hline
\end{tabular}

* Pogrubioną czcionką oznaczone zostały wartości współczynników korelacji rang Spearmana istotne dla $\mathrm{p}<0,05$.

(a) Por. L. Karbownik, Dyferencjacja rozwoju działalności gospodarczej przedsiębiorstw sektora TSL w Polsce, [w:] J. Duraj (red.), Prace z zakresu ekonomiki i zarzadzania przedsiębiorstwem, „Acta Universitatis Lodziensis”, Folia Oeconomica 272, Wydawnictwo Uniwersytetu Łódzkiego, Łódź 2012, s. 70.
(b) $-0,003$.
(c) $-0,398$.
(d) $-0,402$.

Źródło: obliczenia własne na podstawie danych zebranych w Krajowym Rejestrze Sądowym w Warszawie przy wykorzystaniu programu Statistica 10.

${ }^{19}$ Ibidem, s. 311. 
Pomiędzy wszystkimi współczynnikami rentowności eksploatacyjnej oraz wydajności pieniężnej a liczbą grup PKD 2007 - średnie, jak i środkowe wartości współczynnika korelacji rang Spearmana miały wartość ujemną (zob. wykres 3.7). Podobne wyniki uzyskane zostały dla badanego związku między liczbą tych grup a współczynnikiem zdolności do obsługi zobowiązań bieżących gotówką osiąganą z działalności operacyjnej $\left(\mathrm{m}_{5}\right)$. Wyłącznie dla zmiennej $\mathrm{m}_{12}$ badana relacja była relacją dodatnią $\mathrm{w}$ całym badanym okresie, zaś dla $\mathrm{m}_{2}$ oraz

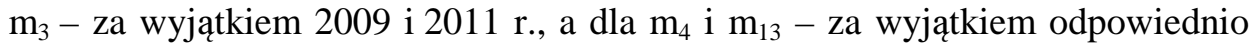
2007 i 2005 r.

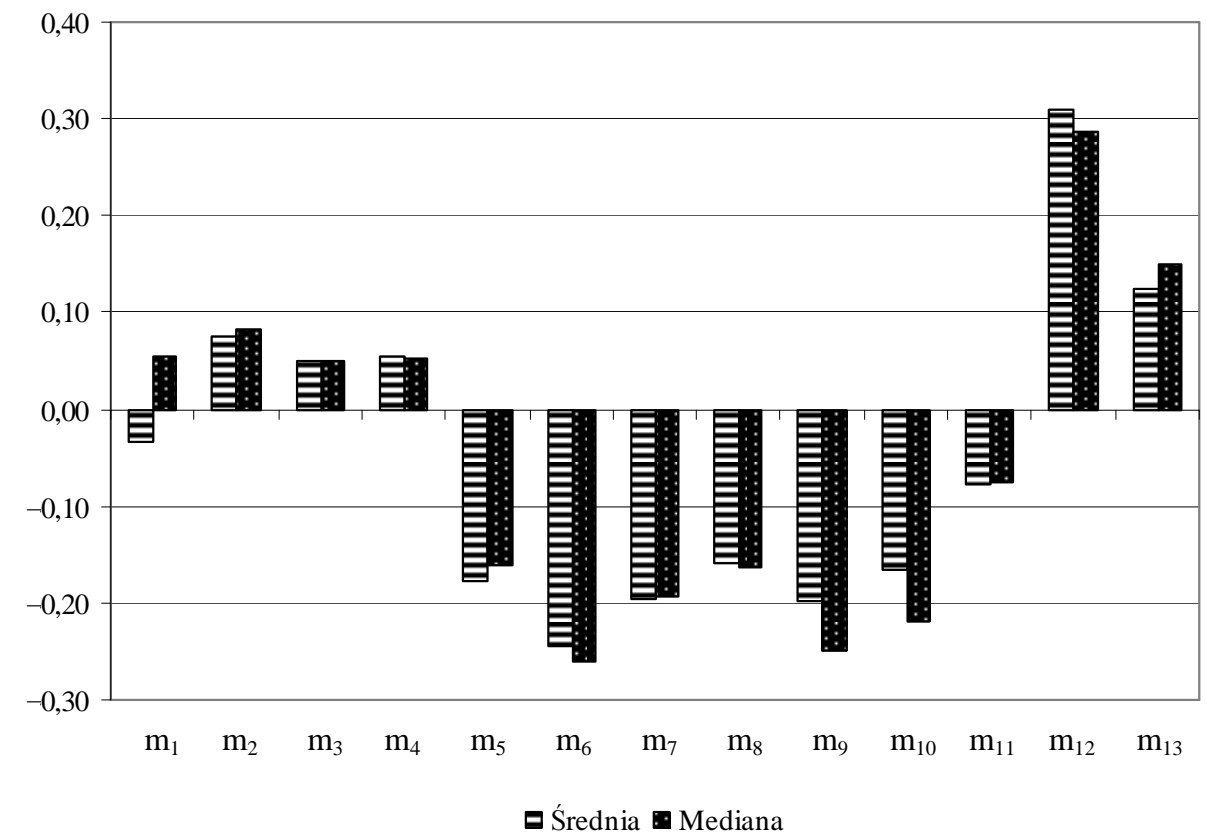

Wykres 3.7. Średni i środkowy poziom korelacji rang Spearmana między memoriałowymi i kasowymi miernikami oceny operacyjnego bezpieczeństwa finansowego a liczbą grup PKD 2007 spółek sektora TSL w latach 2004-2012

Źródło: jak do wykresu 3.5.

Współczynniki korelacji rang Spearmana zostały dodatkowo obliczone między liczbą grup PKD 2007 w sekcji „Transport i gospodarka magazynowa” a memoriałowymi oraz kasowymi miernikami oceny analizowanego zjawiska.

Uzyskana została znacznie wyższa siła zależności dla średnich i środkowych wartości współczynników korelacji między liczbą tych grup a przychodami netto ze sprzedaży usług, towarów i materiałów, zaś nieznacznie wyższa (co do modułu) - odpowiednio dla współczynników bieżącej i przyspieszonej płyn- 
ności finansowej, współczynnika zdolności do obsługi zobowiązań bieżących gotówką osiąganą z działalności operacyjnej, współczynników eksploatacyjnej rentowności aktywów ogółem i kapitału własnego, współczynnika wydajności pieniężnej (gotówkowej) sprzedaży oraz współczynników zabezpieczenia finansowego. Jedynie w przypadku zmiennej $\mathrm{m}_{12}$ w latach 2007-2009 i 2011-2012, m 13 w 2006 r., $\mathrm{m}_{11}$ w 2011 r., $\mathrm{m}_{9}$ w 2010 r. i m ${ }_{1}$ w latach 2007-2008 badana zależność miała umiarkowaną siłę (istotną dla $\mathrm{p}<0,05$ ). Dla pozostałych relacji była ona niską lub nie występowała wcale (zob. tab. 3.15).

Tabela 3.15. Współczynniki korelacji rang Spearmana między memoriałowymi i kasowymi miernikami oceny operacyjnego bezpieczeństwa finansowego a liczbą grup PKD 2007 w sekcji „Transport i gospodarka magazynowa” spółek sektora TSL*

\begin{tabular}{|c|c|c|c|c|c|c|c|c|c|c|}
\hline \multirow{2}{*}{\multicolumn{2}{|c|}{ Wyszczególnienie }} & \multicolumn{9}{|c|}{ Liczba grup PKD 2007 w sekcji „Transport i gospodarka magazynowa” } \\
\hline & & \multirow{2}{*}{$2004 \mathrm{r}}$. & \multirow{2}{*}{\begin{tabular}{|c}
$2005 \mathrm{r}$. \\
0,31
\end{tabular}} & \multirow{2}{*}{\begin{tabular}{|c|}
$2006 \mathrm{r}$. \\
0,39
\end{tabular}} & \multirow{2}{*}{\begin{tabular}{|c|}
$2007 \mathrm{r}$ \\
$\mathbf{0 , 4 8}$
\end{tabular}} & \multirow{2}{*}{\begin{tabular}{|c|}
$2008 \mathrm{r}$ \\
$\mathbf{0 , 4 8}$ \\
\end{tabular}} & \multirow{2}{*}{\begin{tabular}{|c|}
$2009 \mathrm{r}$. \\
0,35 \\
\end{tabular}} & \multirow{2}{*}{$\begin{array}{c}2010 \mathrm{r} . \\
0,38 \\
\end{array}$} & \multirow{2}{*}{$\begin{array}{c}2011 \mathrm{r} . \\
0,36\end{array}$} & \multirow{2}{*}{$\begin{array}{r}2012 \mathrm{r} . \\
0,33 \\
\end{array}$} \\
\hline \multirow{13}{*}{ 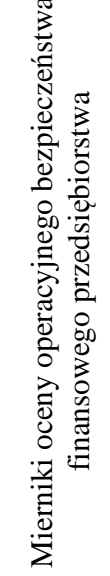 } & $\mathrm{m}_{1}$ & & & & & & & & & \\
\hline & $\mathrm{m}_{2}$ & 0,19 & 0,26 & 0,05 & 0,21 & 0,20 & $-0,07$ & 0,07 & 0,13 & $-0,03$ \\
\hline & $\mathrm{m}_{3}$ & 0,17 & 0,22 & 0,05 & 0,20 & 0,20 & $0,00^{(\mathrm{a})}$ & 0,07 & 0,10 & $-0,02$ \\
\hline & $\mathrm{m}_{4}$ & 0,17 & 0,06 & 0,04 & $-0,14$ & $-0,07$ & $-0,14$ & $-0,10$ & $-0,02$ & $-0,07$ \\
\hline & $\mathrm{m}_{5}$ & $-0,29$ & $-0,18$ & $-0,13$ & $-0,31$ & $-0,19$ & $-0,26$ & $-0,35$ & $-0,04$ & $-0,17$ \\
\hline & $\mathrm{m}_{6}$ & $-0,22$ & 0,13 & $-0,04$ & 0,08 & 0,04 & $-0,19$ & $-0,02$ & 0,12 & $-0,03$ \\
\hline & $\mathrm{m}_{7}$ & 0,12 & 0,32 & 0,24 & 0,38 & 0,22 & $0,00^{(\mathrm{b})}$ & 0,21 & 0,32 & 0,20 \\
\hline & $\mathrm{m}_{8}$ & 0,26 & 0,22 & 0,18 & 0,36 & 0,25 & 0,03 & 0,35 & 0,38 & 0,30 \\
\hline & $\mathrm{m}_{9}$ & $-0,21$ & $-0,28$ & $-0,12$ & $-0,33$ & $-0,31$ & $-0,25$ & $-0,41$ & $-0,22$ & $-0,30$ \\
\hline & $\mathrm{m}_{10}$ & $-0,07$ & 0,03 & 0,14 & $-0,14$ & $-0,05$ & 0,04 & $-0,17$ & 0,31 & $-0,09$ \\
\hline & $\mathrm{m}_{11}$ & 0,04 & 0,21 & 0,06 & $-0,17$ & $-0,10$ & 0,17 & 0,05 & 0,47 & $-0,17$ \\
\hline & $\mathrm{m}_{12}$ & 0,24 & 0,27 & 0,36 & 0,41 & 0,42 & 0,54 & 0,39 & 0,44 & 0,45 \\
\hline & $\mathrm{m}_{13}$ & 0,09 & $-0,02$ & 0,42 & 0,36 & 0,24 & 0,21 & 0,33 & 0,28 & 0,31 \\
\hline
\end{tabular}

* Oznaczenia jak w tab. 3.14.

(a) $-0,004$.

(b) 0,001 .

Źródło: jak do tab. 3.14.

Ujemne wartości analizowanych relacji częściej, niż w przypadku badania współzależności z liczbą grup PKD 2007, pojawiały się dla współczynnika natychmiastowej płynności finansowej, współczynnika zdolności do obsługi zobowiązań bieżących gotówką osiąganą z działalności operacyjnej oraz współczynnika wydajności pieniężnej (gotówkowej) sprzedaży, a dla współczynnika eksploatacyjnej rentowności aktywów ogółem i kapitału własnego - zmieniły jej 
znak. W całym badanym okresie jedynie dla zmiennych $\mathrm{m}_{5}$ i $\mathrm{m}_{9}$ współczynnik korelacji rang Spearmana miał ujemną wartość, tym samym dla tych mierników oceny operacyjnego bezpieczeństwa finansowego przedsiębiorstw sektora TSL środkowa i średnia wartość tego współczynnika korelacji rang Spearmana kształtowała się na poziomie poniżej zera. Podobna sytuacja dotyczyła współczynnika natychmiastowej płynności finansowej $\left(\mathrm{m}_{4}\right)$ oraz współczynnika eksploatacyjnej rentowności sprzedaży $\left(\mathrm{m}_{6}\right)$, gdzie analizowane podstawowe statystyki opisowe były także ujemnymi (zob. wykres 3.8).

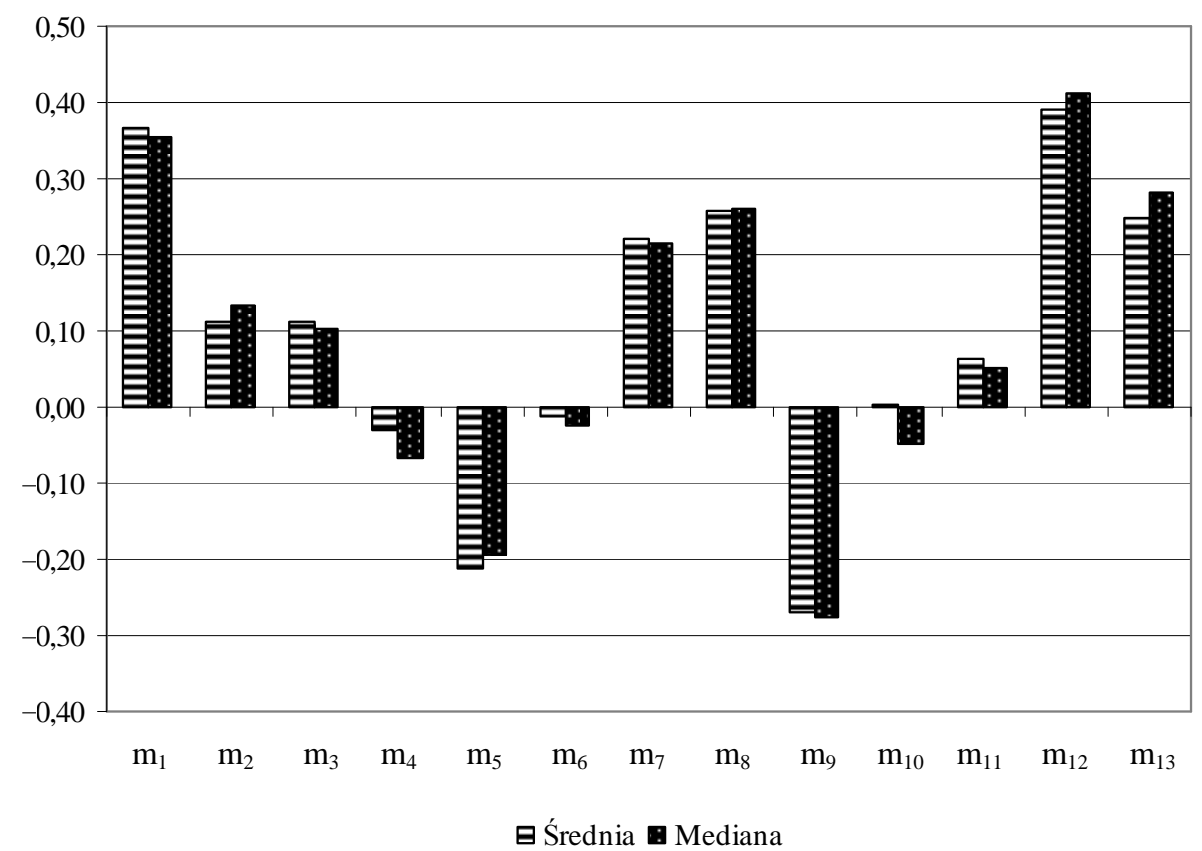

Wykres 3.8. Średni i środkowy poziom korelacji rang Spearmana między memoriałowymi i kasowymi miernikami oceny operacyjnego bezpieczeństwa finansowego a liczbą grup PKD 2007 w sekcji „Transport i gospodarka magazynowa” spółek sektora TSL w latach 2004-2012

Źródło: jak do wykresu 3.5.

Prezentowane wyniki badań potwierdziły zatem hipotezę badawczą stanowiącą, iż pomiędzy wykazywana w przedsiębiorstwach sektora TSL liczba grup PKD a memoriałowymi i kasowymi miernikami oceny operacyjnego bezpieczeństwa finansowego występuje co najwyżej umiarkowana zależność korelacyjna. Pomiędzy współczynnikiem zabezpieczenia finansowego $\mathrm{nr} 1$ a liczbą grup 
PKD 2007 (odpowiednio także w samej sekcji „Transport i gospodarka magazynowa") średnia i środkowa wartość badanej zależności była najwyższa, zaś ujemna - dla współczynnika zdolności do obsługi zobowiązań bieżących gotówką osiąganą z działalności operacyjnej, współczynnika eksploatacyjnej rentowności sprzedaży i współczynnika wydajności pieniężnej (gotówkowej) sprzedaży. Z kolei, znak współczynnika korelacji rang Spearmana (bez względu na dokonany wybór wariantu liczby grup PKD 2007) był dodatni w całym badanym okresie tylko dla zmiennej $\mathrm{m}_{12}$. 


\section{Rozdział 4}

\section{OCENA OPERACYJNEGO BEZPIECZEŃSTWA FINANSOWEGO PRZEDSIĘBIORSTW SEKTORA TSL}

\subsection{Koniunktura gospodarcza a poziom operacyjnego bezpieczeństwa finansowego spółek sektora TSL}

Sformułowany w rozdziale trzecim niniejszej monografii wniosek, że nie można jednoznacznie potwierdzić ani też zanegować twierdzenia, iż na ksztattowanie się spreadu memoriałowych i kasowych mierników oceny operacyjnego bezpieczeństwa finansowego przedsiębiorstw sektora TSL istotny wpływ wywiera koniunktura gospodarcza na rynku (zob. s. 137), stanowi dobry asumpt do kontynuacji badań empirycznych nad analizowanym problemem przy użyciu metod wielowymiarowej analizy danych.

W tym celu postawiona została hipoteza badawcza stanowiąca, iż poziom operacyjnego bezpieczeństwa finansowego spótek sektora TSL ulega obniżeniu w okresie dekoniunktury ${ }^{1}$.

Dla zweryfikowania tej hipotezy zostało najpierw dokonane uporządkowanie liniowe badanych podmiotów gospodarczych za pomocą taksonomicznego miernika rozwoju ${ }^{2}$. Zastępuje on opis badanych obiektów (spółek) przy użyciu wielu cech (zmiennych) opisem za pomocą jednej agregatowej wielkości. Tego rodzaju procedura badawcza umożliwia - oprócz uszeregowania przedsiębiorstw - również ich podział na grupy o zbliżonym poziomie badanego zjawiska. Punktem wyjścia do budowy taksonomicznego miernika rozwoju było określenie macierzy obserwacji, dokonane na zmiennych wcześniej zakwalifikowanych do analizy.

\footnotetext{
${ }^{1}$ Za pierwsze symptomy dekoniunktury dla sektora TSL w Polsce w toku dalszych badań empirycznych przyjęto już koniec 2008 r., a za jej koniec - grudzień 2009 r. (zob. wykres 3.1).

${ }_{2}^{2}$ Tak skonstruowany miernik przyjmuje wartości z przedziału [0;1], przy czym wyższe jego wartości należy interpretować jako korzystniejszy poziom operacyjnego bezpieczeństwa finansowego przedsiębiorstwa.

Wartości te są tym wyższe im dany obiekt jest mniej oddalony od wzorca, zatem im wyższa jest jego wartość tym wyższy jest poziom operacyjnego bezpieczeństwa finansowego przedsiębiorstw sektora TSL.
} 
Z uwagi na sygnalizowane wcześniej bariery dostępu do danych finansowych, wstępne analizy przeprowadzone zostały z wykorzystaniem 13 mierników oceny operacyjnego bezpieczeństwa finansowego spółek sektora TSL (zob. tab. 2.3).

W wyniku postępowania badawczego (uwzględniając kryterium merytoryczne i statystyczne) ustalona została ostateczna lista zmiennych spełniających jednocześnie kryterium krytycznej wartości współczynnika zmienności na poziomie $\mathrm{V}=0,2$. Wszystkie analizowane mierniki spełniły kryterium dostatecznego zróżnicowania i żadnego z nich nie wyeliminowano z badań na tym etapie.

W wyniku kolejnej selekcji w dalszych rozważaniach uwzględnionych zostało jedynie 8 cech diagnostycznych. Sytuacja ta wyniknęła ze znaczącej zależności między miernikami oceny operacyjnego bezpieczeństwa finansowego (zob. tab. 4.1). Analiza została zatem przeprowadzona przy uwzględnieniu jedynie tych, dla których współczynnik korelacji rang Spearmana między analizowanymi zmiennymi objaśniającymi osiągnął wartość z przedziału $(-0,8 ; 0,8)$ w całym badanym okresie (przy poziomie istotności 0,05 ).

Ostatecznie do tworzenia syntetycznego miernika oceny operacyjnego bezpieczeństwa finansowego spółek sektora TSL zostały zakwalifikowane następujące mierniki: $\mathrm{m}_{1}, \mathrm{~m}_{2}, \mathrm{~m}_{4}, \mathrm{~m}_{5}, \mathrm{~m}_{8}, \mathrm{~m}_{11}, \mathrm{~m}_{12}$ oraz $\mathrm{m}_{13}$.

W kolejnym etapie przekształcone zostały nominanty (zob. tab. 4.2) na stymulanty ${ }^{3}$ posługując się przy tym się kwartylem 1 (będącym dolną granicą przedziału) i kwartylem 3 (będącym górną granicą przedziału). Dokonany wybór pozwolił wykluczyć obserwacje nietypowe - mające istotny wpływ na wartość średniej arytmetycznej danej zmiennej diagnostycznej.

Dla każdego badanego przedsiębiorstwa (na podstawie obliczonych odległości danych od wzorca i antywzorca) wyznaczony został syntetyczny miernik oceny operacyjnego bezpieczeństwa finansowego, nazywany także metacecha. Jego budowa pozwoliła na zagregowanie informacji dotyczących różnych obszarów tej oceny, a jego wartości - odpowiednio dla każdego rozpatrywanego roku - przedstawia tab. 4.3.

\footnotetext{
${ }^{3}$ Wyznaczenie wartości pożądanych (optymalnych) jest niezbędne do przekształcenia nominant na stymulanty.

Do tego celu zostało wykorzystane oprogramowanie Taksonomia numeryczna oraz przyjęte następujące założenia: $\mathrm{p}_{1}=2, \mathrm{p}_{2}=2, \mathrm{c}_{1}=$ kwartyl $1, \mathrm{c}_{2}=$ kwartyl $3, \mathrm{a}=0$ oraz $\mathrm{b}=\mathrm{sym}$,

gdzie:

$\mathrm{c}_{1}$ i $\mathrm{c}_{2}$ - to parametry określające przedział najbardziej pożądanych wartości nominanty,

a i b - miejsca zerowe funkcji $\mathrm{f}(\mathrm{x})$, parametry określające przedział tzw. dopuszczalnych wartości nominanty,

$\mathrm{p}_{1}$ i $\mathrm{p}_{2}$ - parametry odpowiedzialne za typ funkcji $\mathrm{f}(\mathrm{x})$.

Zob. M. Kolend a, Taksonomia numeryczna. Klasyfikacja, porzadkowanie i analiza obiektów, Wydawnictwo Akademii Ekonomicznej im. Oskara Langego we Wrocławiu, Wrocław 2006, s. 21-40.
} 
Tabela 4.1. Mierniki o wysokim współczynniku korelacji rang Spearmana* w latach 2004-2012

\begin{tabular}{|c|c|c|c|c|c|c|c|c|c|}
\hline Lp. & 2004 r. & 2005 r. & 2006 r. & 2007 r. & 2008 r. & 2009 r. & 2010 r. & $2011 \mathrm{r}$. & 2012 r. \\
\hline 1 & $\mathrm{~m}_{2}$ lub $\mathrm{m}_{3}$ & $\mathrm{~m}_{2}$ lub $\mathrm{m}_{3}$ & $\mathrm{~m}_{2}$ lub $\mathrm{m}_{3}$ & $\mathrm{~m}_{2}$ lub $\mathrm{m}_{3}$ & $\mathrm{~m}_{2}$ lub $\mathrm{m}_{3}$ & $\mathrm{~m}_{2}$ lub $\mathrm{m}_{3}$ & $\mathrm{~m}_{2}$ lub $\mathrm{m}_{3}$ & $\mathrm{~m}_{2}$ lub $\mathrm{m}_{3}$ & $\mathrm{~m}_{2}$ lub $\mathrm{m}_{3}$ \\
\hline 2 & $\mathrm{~m}_{3}$ lub $\mathrm{m}_{4}$ & $\mathrm{~m}_{5}$ lub $\mathrm{m}_{9}$ & $\mathrm{~m}_{5}$ lub $\mathrm{m}_{9}$ & $\begin{array}{c}\mathrm{m}_{5} \text { lub } \mathrm{m}_{9} \\
\text { lub } \mathrm{m}_{10}\end{array}$ & $\mathrm{~m}_{5}$ lub $\mathrm{m}_{9}$ & $\mathrm{~m}_{5}$ lub $\mathrm{m}_{9}$ & $\begin{array}{c}\mathrm{m}_{5} \text { lub } \mathrm{m}_{9} \\
\text { lub } \mathrm{m}_{10}\end{array}$ & $\mathrm{~m}_{5}$ lub $\mathrm{m}_{9}$ & $\begin{array}{c}\mathrm{m}_{5} \text { lub } \mathrm{m}_{9} \\
\text { lub } \mathrm{m}_{10}\end{array}$ \\
\hline 3 & $\mathrm{~m}_{5}$ lub $\mathrm{m}_{9}$ & $\mathrm{~m}_{7}$ lub $\mathrm{m}_{8}$ & $\mathrm{~m}_{6}$ lub $\mathrm{m}_{7}$ & $\mathrm{~m}_{7}$ lub $\mathrm{m}_{8}$ & $\mathrm{~m}_{6}$ lub $\mathrm{m}_{7}$ & $\begin{array}{c}\mathrm{m}_{6} \mathrm{lub} \mathrm{m}_{7} \\
\text { lub } \mathrm{m}_{8}\end{array}$ & $\mathrm{~m}_{6}$ lub $\mathrm{m}_{7}$ & $\begin{array}{c}\mathrm{m}_{6}{\text { lub } \mathrm{m}_{7}} \\
\text { lub } \mathrm{m}_{8}\end{array}$ & $\begin{array}{c}\mathrm{m}_{6} \mathrm{lub}_{7} \\
\text { lub } \mathrm{m}_{8}\end{array}$ \\
\hline 4 & - & - & $\mathrm{m}_{7}$ lub $\mathrm{m}_{8}$ & $\mathrm{~m}_{9}$ lub $\mathrm{m}_{10}$ & $\mathrm{~m}_{7}$ lub $\mathrm{m}_{8}$ & $\mathrm{~m}_{7}$ lub $\mathrm{m}_{8}$ & $\mathrm{~m}_{7}$ lub $\mathrm{m}_{8}$ & $\mathrm{~m}_{7}$ lub $\mathrm{m}_{8}$ & $\mathrm{~m}_{7}$ lub $\mathrm{m}_{8}$ \\
\hline 5 & - & - & - & $\begin{array}{c}\mathrm{m}_{10} \text { lub } \\
\mathrm{m}_{11}\end{array}$ & $\begin{array}{c}\mathrm{m}_{10} \text { lub } \\
\mathrm{m}_{11}\end{array}$ & - & $\mathrm{m}_{9}$ lub $\mathrm{m}_{10}$ & $\begin{array}{c}\mathrm{m}_{10} \text { lub } \\
\mathrm{m}_{11}\end{array}$ & $\mathrm{~m}_{9}$ lub $\mathrm{m}_{10}$ \\
\hline 6 & - & - & - & - & - & - & $\begin{array}{c}\mathrm{m}_{10} \text { lub } \\
\mathrm{m}_{11}\end{array}$ & - & $\begin{array}{c}\mathrm{m}_{10} \text { lub } \\
\mathrm{m}_{11}\end{array}$ \\
\hline
\end{tabular}

* Co najmniej na poziomie co do wartości bezwzględnej 0,8 (przy p < 0,05).

Źródło: obliczenia własne na podstawie danych zebranych w Krajowym Rejestrze Sądowym w Warszawie przy wykorzystaniu programu Statistica 10.

Tabela 4.2. Charakter zmiennych diagnostycznych poziomu operacyjnego bezpieczeństwa finansowego

\begin{tabular}{|c|c|c|}
\hline Symbol & Miernik & $\begin{array}{c}\text { Charakter zmiennej } \\
\text { diagnostycznej }\end{array}$ \\
\hline \hline $\mathrm{m}_{1}$ & Przychody netto ze sprzedaży usług, towarów i materiałów & stymulanta \\
\hline $\mathrm{m}_{2}$ & Współczynnik bieżącej płynności finansowej & nominanta \\
\hline $\mathrm{m}_{4}$ & Współczynnik natychmiastowej płynności finansowej & nominanta \\
\hline $\mathrm{m}_{5}$ & Współczynnik zdolności do obsługi zobowiązań bieżących gotówką & osiąganą z działalności operacyjnej \\
\hline $\mathrm{m}_{8}$ & Współczynnik eksploatacyjnej rentowności kapitału własnego & stymulanta \\
\hline $\mathrm{m}_{11}$ & Współczynnik wydajności pieniężnej (gotówkowej) kapitału własnego & stymulanta \\
\hline $\mathrm{m}_{12}$ & Współczynniki zabezpieczenia finansowego (1) & nominanta \\
\hline $\mathrm{m}_{13}$ & Współczynniki zabezpieczenia finansowego (2) & nominanta \\
\hline
\end{tabular}

Źródło: jak do tab. 2.3.

W analizowanych spółkach najczęściej najwyższy w całym badanym okresie poziom operacyjnego bezpieczeństwa finansowego występował w $2008 \mathrm{r}$. (dla aż blisko 69\% podmiotów), zaś nigdy w latach 2005-2007, 2009 i 2011 (zob. tab. 4.4). Najniższa z kolei wartość analizowanej metacechy pojawiała się najczęściej w badanych podmiotach gospodarczych w 2007 r., a jednorazowo - w 2004, 2006, 2008 i 2010 r. 


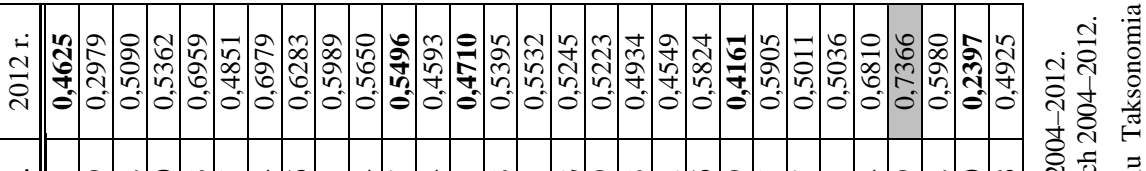

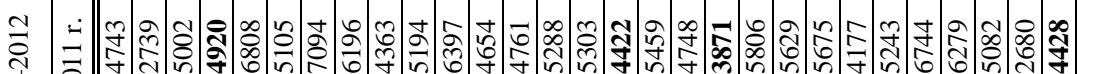

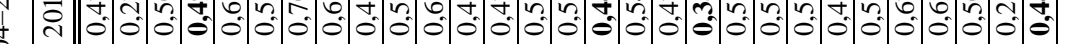

兽

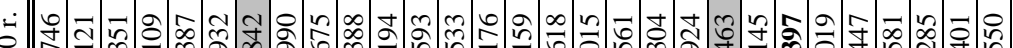

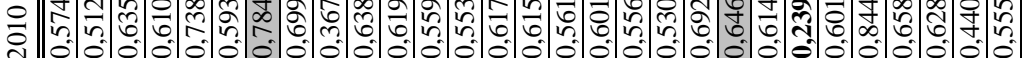

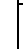

-

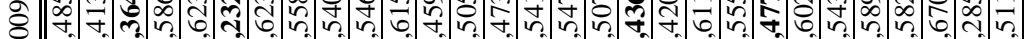

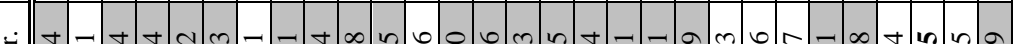

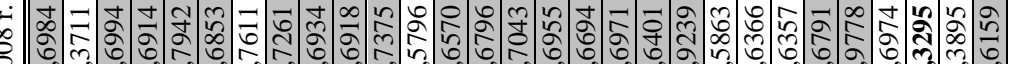

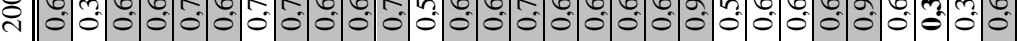

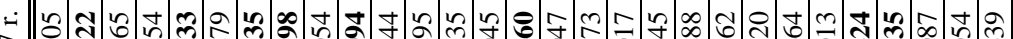

5 की

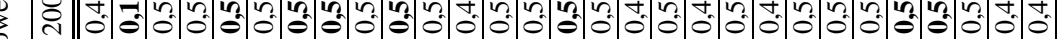

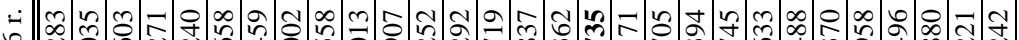

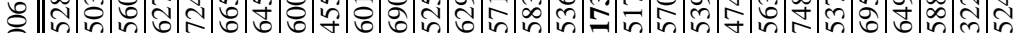

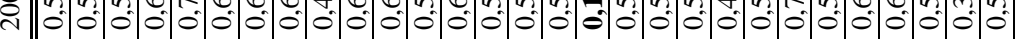

म்

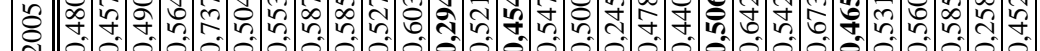

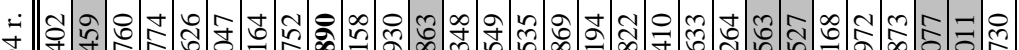

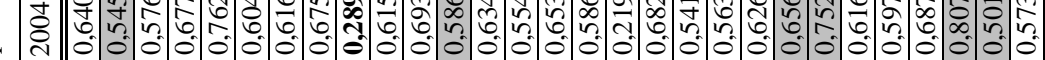$$
\text { ํํํ }
$$ 
Tabela 4.4. Udział procentowy spółek sektora TSL o najwyższej i najniższej wartości syntetycznego miernika oceny operacyjnego bezpieczeństwa finansowego w latach 2004-2012* (w \%)

\begin{tabular}{|c|c|c|}
\hline Wyszczególnienie & $\begin{array}{c}\text { MAX wartość } \\
\text { miernika }\end{array}$ & $\begin{array}{c}\text { MIN wartość } \\
\text { miernika }\end{array}$ \\
\hline \hline 2004 r. & 20,69 & 3,45 \\
\hline 2005 r. & 0,00 & 13,79 \\
\hline 2006 r. & 0,00 & 3,45 \\
\hline 2007 r. & 0,00 & $\mathbf{2 7 , 5 9}$ \\
\hline 2008 r. & $\mathbf{6 8 , 9 7}$ & 3,45 \\
\hline 2009 r. & 0,00 & 13,79 \\
\hline 2010 r. & 6,90 & 3,45 \\
\hline 2011 r. & 0,00 & 13,79 \\
\hline 2012 r. & 3,45 & 17,24 \\
\hline
\end{tabular}

* Pogrubioną czcionką zaznaczona została wartość najwyższego udziału procentowego występującego odpowiednio dla maksymalnej i minimalnej wartości badanej zmiennej diagnostycznej.

Źródło: obliczenia własne na podstawie danych zebranych w Krajowym Rejestrze Sądowym w Warszawie przy wykorzystaniu programu Taksonomia numeryczna i Microsoft Excel.

Obliczone wyniki otrzymane zostały przy założeniu optymalnych (indywidualnych dla każdego roku poddanego analizie) wartości mierników operacyjnego bezpieczeństwa finansowego przedsiębiorstw sektora TSL. Należy zauważyć, iż w całym badanym okresie zmieniała się efektywność funkcjonowania podmiotów gospodarczych z tego sektora. Wskazują na tę sytuację chociażby zmniejszające się w latach 2008-2010 maksymalne wartości współczynnika eksploatacyjnej rentowności kapitału własnego oraz niemal stale wzrastająca (za wyjątkiem 2009 r.) maksymalna wartość przychodów netto ze sprzedaży usług, towarów i materiałów (zob. tab. 2.4). Na uwagę zasługuje także i to, że dla przykładu w przypadku miernika $\mathrm{m}_{12} \mathrm{w}$ latach 2004-2008 zakładany był poziom równy zero, z kolei w latach 2009-2012 wartość optymalna kształtowała się już w przedziale odpowiednio dla 2009 r. $\langle 0 ; 0,0011\rangle$, dla 2010 r. $\langle 0 ; 0,0010\rangle$, dla 2011 r. $\langle 0 ; 0,0015\rangle$, zaś w 2012 r. $\langle 0 ; 0,0025\rangle^{4}$.

Najniższy przeciętny poziom badanej metacechy spółki sektora TSL wypracowały w 2007 r., zaś najwyższy - w 2008 r. (zob. tab. 4.5). Niemal identyczne rezultaty badań zostały uzyskane w wyniku obliczenia wartości środkowej syntetycznego miernika oceny operacyjnego bezpieczeństwa finansowego (zob. wykres 4.1).

${ }^{4}$ Uzyskane wyniki opierały się na indywidualnie wyznaczonych wzorcach dla poszczególnych lat, bowiem w literaturze przedmiotu nie wskazano optymalnych poziomów analizowanych mierników oceny operacyjnego bezpieczeństwa finansowego dla przedsiębiorstw sektora TSL w Polsce. 
Tabela 4.5. Podstawowe statystyki opisowe syntetycznego miernika oceny operacyjnego bezpieczeństwa finansowego przedsiębiorstw sektora TSL w latach 2004-2012

\begin{tabular}{|c|c|c|c|c|c|c|}
\hline Wyszczególnienie & Średnia & Mediana & Minimum & Maksimum & Odch.std & Wsp.zmn. \\
\hline \hline 2004 r. & 0,6047 & 0,6164 & 0,2194 & 0,8077 & 0,1195 & 19,77 \\
\hline 2005 r. & 0,5101 & 0,5211 & 0,2457 & 0,7377 & 0,1088 & 21,33 \\
\hline 2006 r. & 0,5639 & 0,5705 & 0,1735 & 0,7488 & 0,1154 & 20,46 \\
\hline 2007 r. & 0,4965 & 0,5094 & 0,1522 & 0,5733 & 0,0762 & 15,35 \\
\hline 2008 r. & 0,6670 & 0,6914 & 0,3295 & 0,9778 & 0,1340 & 20,09 \\
\hline 2009 r. & 0,5141 & 0,5415 & 0,2322 & 0,6704 & 0,1011 & 19,66 \\
\hline 2010 r. & 0,5962 & 0,6109 & 0,2397 & 0,8447 & 0,1155 & 19,36 \\
\hline 2011 r. & 0,5131 & 0,5105 & 0,2680 & 0,7094 & 0,1053 & 20,52 \\
\hline 2012 r. & 0,5306 & 0,5245 & 0,2397 & 0,7366 & 0,1078 & 20,32 \\
\hline
\end{tabular}

Źródło: jak do tab. 4.4.

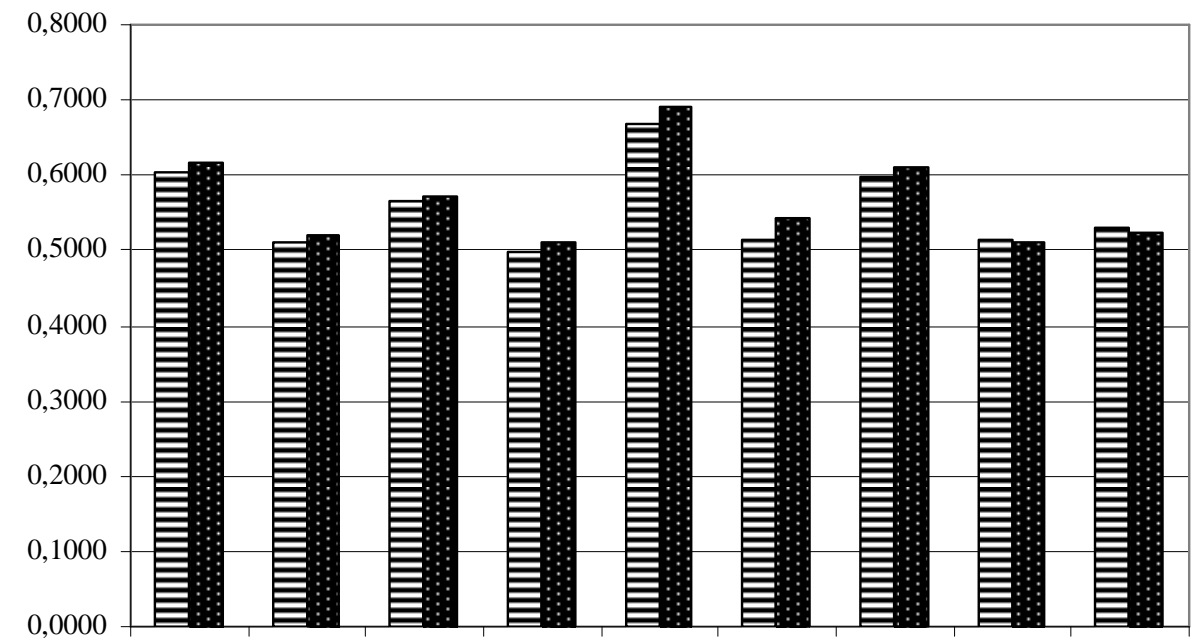

2004 rok 2005 rok 2006 rok 2007 rok 2008 rok 2009 rok 2010 rok 2011 rok 2012 rok

曰Ś́rednia : Mediana

Wykres 4.1. Średnia i środkowa wartość syntetycznego miernika oceny operacyjnego bezpieczeństwa finansowego przedsiębiorstw sektora TSL w latach 2004-2012

Źródło: obliczenia własne na podstawie danych zebranych w Krajowym Rejestrze Sądowym w Warszawie przy wykorzystaniu programu Taksonomia numeryczna i Microsoft Excel.

W 2008 r. aż dla 17 podmiotów gospodarczych wartość badanej zmiennej mieściła się w przedziale $(0,6 ; 0,7\rangle$, a ponadto dla 5 przedsiębiorstw wartość ta 
przekroczyła poziom 0,7 (w tym dla dwóch z nich - nawet 0,9). W 2007 r. wartość tejże metacechy najczęściej (aż w 21 przypadkach) mieściła się w przedziale $(0,5 ; 0,6)$, zaś spółka Neovia Logistics Services Polska Sp. z o.o. osiągnęła najniższy poziom operacyjnego bezpieczeństwa finansowego, będący jednocześnie najniższym w relacji do pozostałych spółek w całym analizowanym okresie badawczym (por. wykres 4.2).

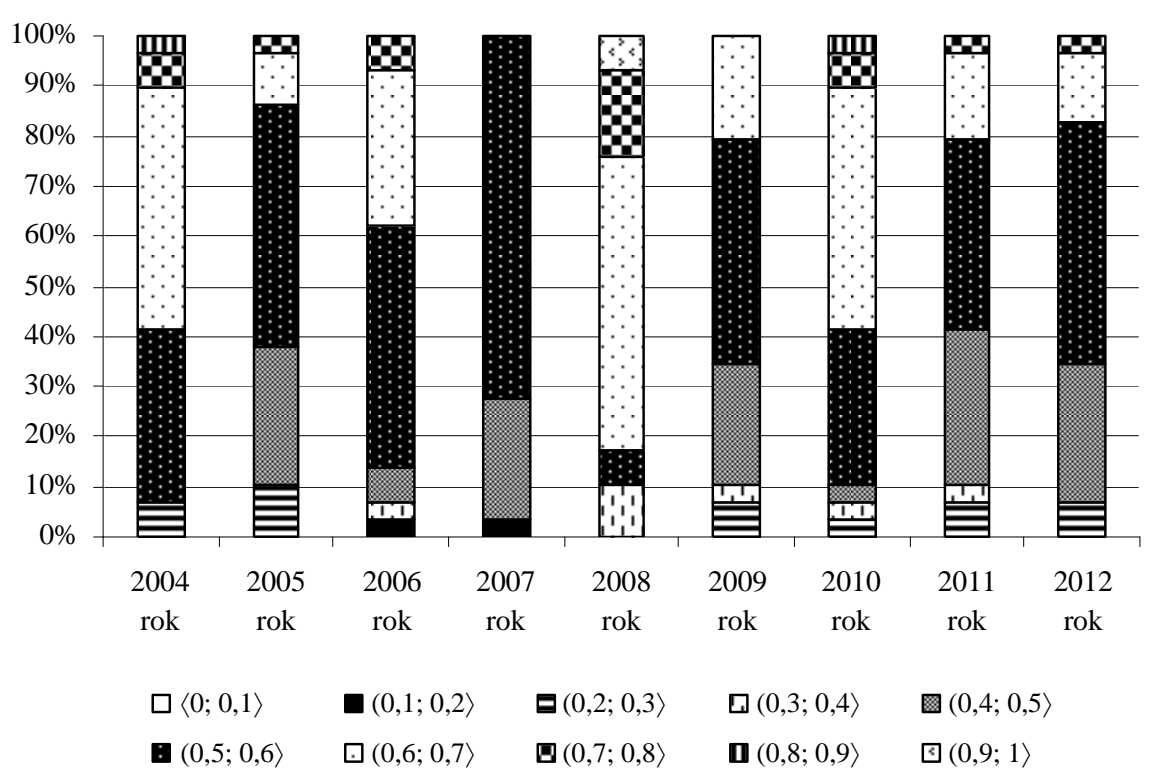

Wykres 4.2. Struktura spółek sektora TSL w latach 2004-2012 według wartości syntetycznej miary oceny operacyjnego bezpieczeństwa finansowego przedsiębiorstw

Źródło: jak do wyk. 4.1.

W celu weryfikacji sformułowanej hipotezy badawczej stanowiącej, iż w okresie dekoniunktury obniżeniu ulega poziom operacyjnego bezpieczeństwa finansowego spótek sektora TSL, wykorzystany został ponadto nieparametryczny test istotności różnic dla wielu prób zależnych ${ }^{5}$.

Sformułowana została zatem zerowa hipoteza robocza stanowiąca, iż nie wystąpiła zmiana poziomu operacyjnego bezpieczeństwa finansowego przedsiębiorstw sektora TSL w latach 2004-2012. Hipoteza alternatywna stanowiła

${ }^{5}$ Badana próba przedsiębiorstw liczyła 29 podmiotów gospodarczych - wobec tego, w celu analizy zgodności rozkładu zmiennej w danej grupie przedsiębiorstw z określonym rozkładem teoretycznym, wykorzystano test normalności Shapiro-Wilka. Na podstawie wyników tego testu odrzucono hipotezę o normalności rozkładu. 
z kolei, iż nie we wszystkich analizowanych latach rozkład badanej zmiennej był identyczny.

Na podstawie otrzymanych wyników analizy dla prób zależnych (przy poziomie istotności wynoszącym 0,05 ) odrzucona została hipoteza zerowa o braku występujących istotnych różnic w poziomie operacyjnego bezpieczeństwa finansowego pomiędzy latami 2004-2012 $2^{6}$.

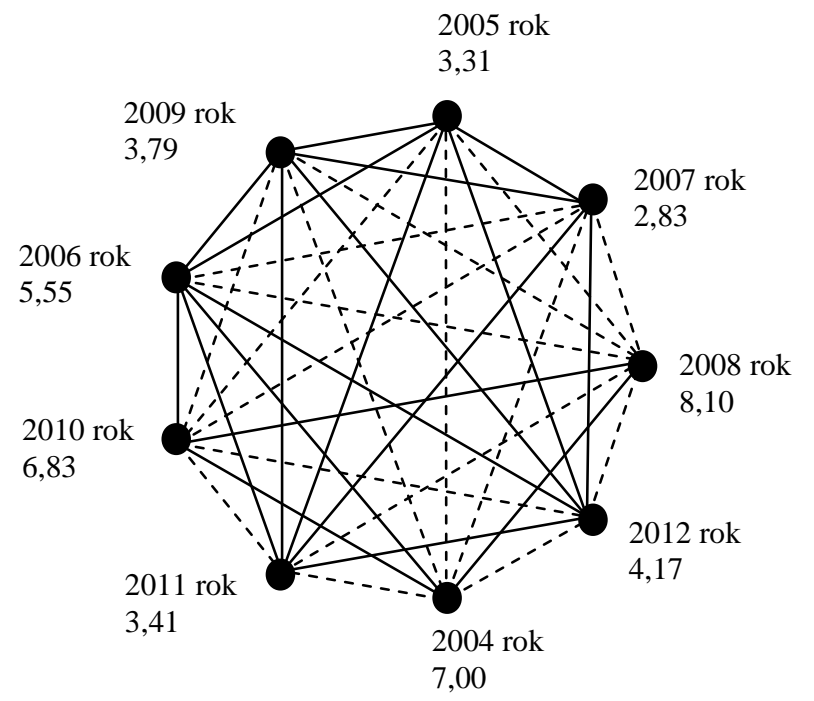

* Linie przerywane obrazują istotne różnice między określonymi latami dla wartości syntetycznego miernika oceny operacyjnego bezpieczeństwa finansowego (poziom istotności wynosi 0,05$)$.

Wykres 4.3. Średnia ranga dla wartości syntetycznego miernika oceny operacyjnego

bezpieczeństwa finansowego przedsiębiorstw sektora TSL w latach 2004-2012*7

Źródło: obliczenia własne na podstawie danych zebranych w Krajowym Rejestrze Sądowym w Warszawie przy wykorzystaniu programu SPSS Statistics (wersja 22).

Analiza POST-HOC (zob. wykres 4.3) ujawniła, iż takie istotne różnice występowały odpowiednio między rokiem:

- 2004 a 2005 ,

- 2004 a 2007,

- 2004 a 2009 ,

- 2004 a 2011,

- 2004 a 2012 ,

- 2006 a 2007 ,

${ }^{6}$ Wystąpiły statystycznie istotne różnice między określonymi latami dla wartości syntetycznego miernika oceny operacyjnego bezpieczeństwa finansowego.

${ }^{7}$ Prezentowane są istotności asymptotyczne (testy dwustronne). Poziom istotności wynosi 0,05. 
-2006 a 2008 ,

- 2008 a 2005 ,

-2008 a 2007 ,

-2008 a 2009 ,

-2008 a 2011 ,

-2008 a 2012 ,

-2010 a 2005 ,

-2010 a 2007 ,

- 2010 a 2009 ,

- 2010 a 2011 ,

- 2010 a 2012.

Stwierdzić należy, iż poziom operacyjnego bezpieczeństwa finansowego spółek sektora TSL w latach 2004, 2008 i 2010 istotnie różnił się od poziomu z lat 2005, 2007, 2009, 2011 i 2012 r. W latach 2004, 2008 i 2010 badane podmioty gospodarcze osiągały najczęściej najwyższy poziom badanej zmiennej diagnostycznej i tym samym znajdowały się najbliżej wyznaczonego wzorca (stanu optymalnego) operacyjnego bezpieczeństwa finansowego. Średnia ranga dla analizowanego miernika osiągnęła najwyższą wartość dla 2008 r., stąd dodatkowo jego wartość istotnie różniła się od wartości zanotowanej w 2006 r., a ta $\mathrm{z}$ kolei od $2007 \mathrm{r}$.

W 2008 r. miał miejsce wzrost syntetycznego miernika oceny w stosunku do 2007 r., w którym osiągnął on najniższą średnią rangę (tj. 2,83). W 2009 r. nastąpił z kolei wyraźny jej spadek, choć nadal na poziomie wyższym niż w 2005 i 2007 r. ${ }^{8}$

W celu sprawdzenia stabilności wyników w opracowaniu wykorzystana została ponadto panelowa ważona Metoda Najmniejszych Kwadratów (ang. Panel $E G L S$ ) dla danych połączonych ze stałymi wagami w obrębie poszczególnych przedsiębiorstw (ang. Cross-section Weights).

Dokonano estymacji modelu, w którym wpływ koniunktury wyrażają zmienne zerojedynkowe dla lat 2008, 2009 i $2010\left(Y_{2008}, Y_{2009}, Y_{2010}\right)^{9}$, co formalnie można zapisać:

\footnotetext{
${ }^{8}$ Uzyskane wyniki opierały się na indywidualnie wyznaczonych wzorcach dla poszczególnych lat.

${ }^{9}$ P. Antonowicz wskazuje, iż koniecznym jest, aby ocena przedsiębiorstwa (ex post i/lub ex ante) przeprowadzana była zawsze w oparciu o informacje dodatkowe (często jakościowe), obejmujące m. in.: strukturę własnościową, powiązania kapitałowe, specyficzne uwarunkowania sektorowe, poziom dywersyfikacji rynków zbytu, stopień koncentracji sektora dostawców i odbiorców, a także przy uwzględnieniu innych - mających wpływ na funkcjonowanie badanego podmiotu - informacji, [za:] P. An t o n o w i c z, Zatożenia analizy dyskryminacyjnej $w$ konstruowaniu nowych wielowymiarowych modeli klasyfikacyjnych $w$ celu prognozowania upadtości przedsiębiorstw, [w:] A. A d a m ska, E. Mą c z y ń s ka (red.), Upadtości, bankructwa i naprawa przedsiębiorstw. Wybrane zagadnienia, Oficyna Wydawnicza Szkoły Głównej Handlowej w Warszawie, Warszawa 2013, s. 225-226.
} 


$$
\begin{aligned}
O B F_{i, t}=\alpha_{0}+\alpha_{2} \log (T A)_{i, t}+ & \alpha_{3} z ́ r o ́ d t o 2+\alpha_{4} z ́ r o ́ d t o 4+\gamma_{1} Y_{2008}+\gamma_{2} Y_{2009}+ \\
& +\gamma_{3} Y_{2010}+\varepsilon_{i, t}
\end{aligned}
$$

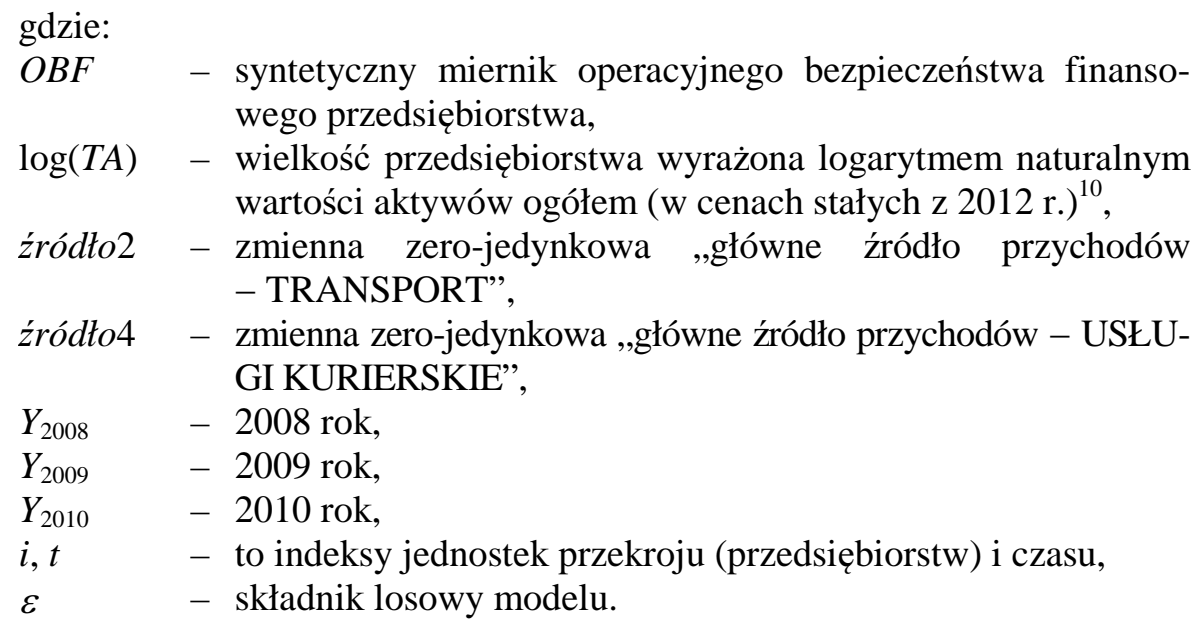

Uzyskane wyniki wskazują na dodatni i statystycznie istotny wpływ zmiennej wyrażającej wielkość przedsiębiorstwa (mierzoną logarytmem naturalnym realnej wartości aktywów ogólem) na syntetyczny miernik operacyjnego bezpieczeństwa finansowego badanych przedsiębiorstw sektora TSL. Ponadto dodatnie (ujemne) oszacowanie parametru $\alpha_{4}\left(\alpha_{3}\right)$ wskazuje, że przedsiębiorstwa kurierskie (transportowe) utrzymują wyższy (niższy) poziom operacyjnego bezpieczeństwa finansowego w relacji do pozostałych spółek sektora.

Z kolei W. Doryń za zasadne uznała włączenie do oszacowywanych modeli na szczeblu mikro (tj. opisujących aktywność eksportową i wyniki ekonomiczne przedsiębiorstw) - danych makroekonomicznych. Zob. W. D or y ń, Związek pomiędzy wielkością przedsiębiorstwa i jego aktywnościa eksportowa, [w:] A. M i kuls k a (red.), Zarządzanie nowoczesnym przedsiębiorstwem: wybrane aspekty, Politechnika Gdańska. Wydział Zarządzania i Ekonomii, Gdańsk 2013, s. 174 -183; W. Doryń, J. Franek, A. Gaweł, B. Lobmayr, J. Peterkova, B. Prusak, Ch. Stehr, A. Sobiechowska-Ziegert, J. Wasilczuk, K. Zi ęba, Internationalization, Innovativeness and Growth of Modern Enterprises, ICAN Sp. z o.o., Warszawa 2010, s. 6-19.

Na podstawie powyżej zaprezentowanych opinii i wniosków z badań - w niniejszych rozważaniach Autorka uznała za słuszne włączenie do oszacowywanego modelu zmiennych opisujących wpływ koniunktury gospodarczej na analizowane zjawisko.

${ }^{10}$ Wartości nominalne zostały zdeflowane wskaźnikiem cen usług transportu i gospodarki magazynowej za lata 2006-2011, podanym w: Ceny w gospodarce narodowej w 2012 r., Główny Urząd Statystyczny - Departament Handlu i Usług, Urząd Statystyczny w Opolu, Warszawa 2013, s. 283; z uwagi na brak danych w wyżej wymienionej publikacji za lata 2004-2005 wykorzystany został wskaźnik cen usług transportu, gospodarki magazynowej i łączności podany w: Rocznik Statystyczny Rzeczpospolitej Polskiej, Główny Urząd Statystyczny, Warszawa 2008, s. 449 i Rocznik Statystyczny Rzeczpospolitej Polskiej, Główny Urząd Statystyczny, Warszawa 2007, s. 445. 
Tabela 4.6. Wyniki estymacji modelu objaśniającego poziom bezpieczeństwa finansowego przedsiębiorstw sektora TSL (1)

\begin{tabular}{|c|c|c|c|}
\hline $\begin{array}{c}\text { Zmienna } \\
\text { objaśniająca }\end{array}$ & $\begin{array}{c}\text { Oszacowanie } \\
\text { parametru }\end{array}$ & $\begin{array}{c}\text { Statystyka } \\
\text { t-Studenta }\end{array}$ & $\begin{array}{c}\text { Istotność zmiennej } \\
\text { (p-value) }\end{array}$ \\
\hline$C$ & 0,22 & 2,60 & 0,01 \\
\hline $\log (T A)$ & 0,02 & 3,83 & 0,00 \\
\hline źródto2 & $-0,03$ & $-3,84$ & 0,00 \\
\hline źródto4 & 0,08 & 5,00 & 0,00 \\
\hline$Y_{2008}$ & 0,14 & 10,76 & 0,00 \\
\hline$Y_{2009}$ & $-0,02$ & $-1,76$ & 0,08 \\
\hline$Y_{2010}$ & 0,07 & 5,24 & 0,00 \\
\hline \multicolumn{2}{|c|}{$\mathrm{R}^{2}$} & \multicolumn{2}{|c|}{$50,30 \%$} \\
\hline \multicolumn{2}{|c|}{ skor. $\mathrm{R}^{2}$} & \multicolumn{2}{|c|}{$49,12 \%$} \\
\hline \multicolumn{2}{|c|}{ SEE } & \multicolumn{2}{|c|}{0,10} \\
\hline \multicolumn{2}{|c|}{$\mathrm{F}$} & \multicolumn{2}{|c|}{42,84} \\
\hline \multicolumn{2}{|c|}{$p(\mathrm{~F})$} & \multicolumn{2}{|c|}{$<0,001$} \\
\hline \multicolumn{2}{|c|}{$\mathrm{J}-\mathrm{B}$} & \multicolumn{2}{|c|}{0,75} \\
\hline \multicolumn{2}{|c|}{$p(\mathrm{~J}-\mathrm{B})$} & \multicolumn{2}{|c|}{0,69} \\
\hline \multicolumn{4}{|c|}{$\mathrm{N}=261$} \\
\hline
\end{tabular}

Źródło: obliczenia własne na podstawie danych zebranych w Krajowym Rejestrze Sądowym w Warszawie przy wykorzystaniu programu EViews 7.

Z kolei statystycznie istotne i dodatnie oszacowania parametrów $\gamma_{1}$ i $\gamma_{3}$ wyrażają wyższy poziom operacyjnego bezpieczeństwa finansowego $\mathrm{w}$ badanych podmiotach w 2008 i 2010 r., natomiast ujemne oszacowanie parametru związanego ze zmienną $Y_{2009}$ świadczyło o niższym poziomie zmiennej $O B F$ w 2009 r. w następstwie kryzysu światowego ${ }^{11}$, którego skutki zaczęły się ujawniać w Polsce począwszy od IV kwartału $2008 \mathrm{r}$.

Na podstawie zaprezentowanych wyników badań można zatem potwierdzić sformułowaną $\mathrm{w}$ niniejszym opracowaniu hipotezę badawczą stanowiącą, iż poziom operacyjnego bezpieczeństwa finansowego spótek sektora TSL ulega obniżeniu w okresie dekoniunktury.

W latach 2004-2012 wartość analizowanej metacechy mieściła się odpowiednio $\mathrm{w}$ przedziale:

- $\langle 0,2194 ; 0,8077\rangle$ w 2004 r.,

$-\langle 0,2457 ; 0,7377\rangle$ w 2005 r.,

$-\langle 0,1735 ; 0,7488\rangle \mathrm{w} 2006 \mathrm{r}$.,

${ }^{11}$ Statystycznie istotne i ujemne oszacowanie parametru związanego z wpływem warunków makroekonomicznych występujących w 2009 r. otrzymała również W. Doryń dokonując badania wpływu internacjonalizacji na wyniki ekonomiczne spółek giełdowych. Zob. W. D or y ń, Wptyw internacjonalizacji na wyniki ekonomiczne polskich przedsiębiorstw przemystowych, Wydawnictwo Uniwersytetu Łódzkiego, Łódź 2011, s. 130. 
$-\langle 0,1522 ; 0,5733\rangle \mathrm{w} 2007 \mathrm{r}$.,

$-\langle 0,3295 ; 0,9778\rangle \mathrm{w} 2008 \mathrm{r}$.,

$-\langle 0,2322 ; 0,6704\rangle \mathrm{w} 2009$ r.,

$-\langle 0,2397 ; 0,8447\rangle$ w 2010 r.,

- $\langle 0,2680 ; 0,7094\rangle \mathrm{w} 2011 \mathrm{r} .$,

- $\langle 0,2397 ; 0,7366\rangle$ w 2012 r.

Opisana sytuacja świadczy o zmieniającej się efektywności funkcjonowania badanych podmiotów gospodarczych sektora TSL. Należy wskazać, iż wartości te były zatem stosunkowo niskie, za wyjątkiem 2008 r. - w którym wartość analizowanej metacechy wynosiła dla spółki UPS Polska Sp. z o.o. aż 0,9778 (zob. wykres 4.4). Wartości mierników $\mathrm{m}_{1}, \mathrm{~m}_{2}, \mathrm{~m}_{4}, \mathrm{~m}_{5}, \mathrm{~m}_{8}, \mathrm{~m}_{11}, \mathrm{~m}_{12} \mathrm{i} \mathrm{m}_{13} \mathrm{w}$ tym podmiocie gospodarczym w 2008 r. kształtowały się odpowiednio na poziomie 1412732 746,95 zł (w cenach stałych z 2012 r. to wartość 1646957 907,26 zł); 2,$1586 ; 0,6343 ; 0,5035 ; 0,5228 ; 0,4051 ; 0,0000 ; 0,0125$. Spółka ta osiągnęła zatem optymalny poziom przychodów netto ze sprzedaży usług, towarów i materiałów, współczynnika zdolności do obsługi zobowiązań bieżących gotówką osiąganą z działalności operacyjnej, współczynnika zabezpieczenia finansowego $\mathrm{nr} 1 \mathrm{i} \mathrm{nr} 2$. W analizowanej jednostce gospodarczej wystąpiła jednocześnie nieznaczna nadpłynność finansowa, a współczynnik eksploatacyjnej rentowności kapitału własnego oraz współczynnik pieniężnej (gotówkowej) wydajności kapitału własnego kształtował się odpowiednio na poziomie $41,45 \%$ i $28,21 \%$ wartości optymalnych dla badanych spółek sektora TSL.

W 2008 r. nastąpiło jednakże znaczne poszerzenie przedziału wartości syntetycznego miernika oceny operacyjnego bezpieczeństwa finansowego w stosunku do roku poprzedniego, co świadczy o znacznym zróżnicowaniu badanych przedsiębiorstw pod względem analizowanej metacechy. Najniższy poziom spreadu wystąił w 2007 r., bowiem wartość badanego wskaźnika w spółce DHL Express (Poland) Sp. z o.o. ukształtowała się na poziomie 0,5733 i była wartością najwyższą. Z kolei w spółce Neovia Logistics Services Polska Sp. z o.o. na poziomie 0,1522 (zob. wykres 4.4). Jednakże w tym też roku spółki przeciętnie osiągały najniższy poziom operacyjnego bezpieczeństwa finansowego.

Najwyższy poziom spreadu syntetycznego miernika oceny operacyjnego bezpieczeństwa finansowego wystąpił w latach 2004-2012 odpowiednio w następujących spółkach: TNT Express Worldwide (Poland) Sp. z o.o., PEKAES SA i VOS Logistics Polska Sp. z o.o. (zob. tab. 4.7). W spółkach ZTE RADOM Sp. z o.o., Mexem Sp. z o.o. oraz TARGOR-TRUCK Sp. z o.o., poziom spreadu osiągnął najniższą wartość, tym samym te jednostki gospodarcze w latach 2004-2012 znajdowały się na podobnej (niemal stałe oddalonej) pozycji w relacji do wyznaczonego wzorca (tj. stanu optymalnego). 


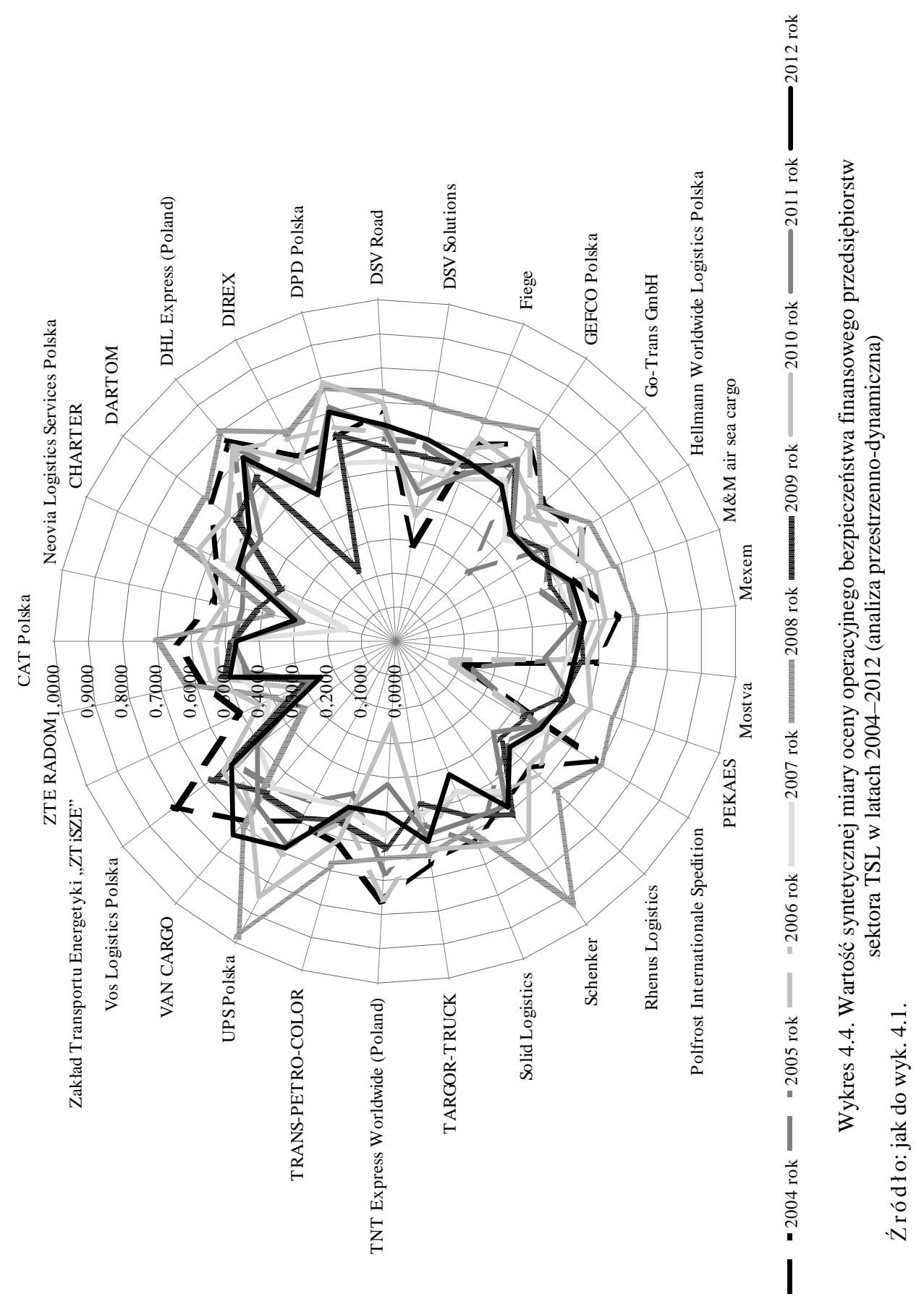


Tabela 4.7. Ranking wartości spreadu syntetycznego miernika oceny operacyjnego bezpieczeństwa finansowego przedsiębiorstw sektora TSL w latach 2004-2012 (analiza przestrzenna)

\begin{tabular}{|c|c|c|c|}
\hline Lp. & Nazwa spółki & $\begin{array}{c}\text { Wartość spreadu } \\
\text { (różnicy wartości } \\
\text { syntetycznego } \\
\text { miernika oceny } \\
O B F)^{*} \\
\end{array}$ & $\begin{array}{l}\text { Główne źródło } \\
\text { przychodu }\end{array}$ \\
\hline 1 & TNT Express Worldwide (Poland) Sp. z o.o. & 0,5130 & Usługi kurierskie \\
\hline 2 & PEKAES SA & 0,4959 & Transport \\
\hline 3 & VOS Logistics Polska Sp. z o.o. & 0,4782 & Transport \\
\hline 4 & UPS Polska Sp. z o.o. & 0,4554 & Usługi kurierskie \\
\hline 5 & DIREX Sp. z o.o. & 0,4531 & Transport \\
\hline 6 & Schenker Sp. z o.o. & 0,4177 & Logistyka \\
\hline 7 & DSV Solutions Sp. z o.o. & 0,4045 & Logistyka \\
\hline 8 & Neovia Logistics Services Polska Sp. z o.o. & 0,3937 & Logistyka \\
\hline 9 & CHARTER Sp. z o.o. & 0,3348 & Transport \\
\hline 10 & Go-Trans GmbH Sp. z o.o. & 0,2920 & Transport \\
\hline 11 & $\begin{array}{l}\text { Zakład Transportu Energetyki „ZTiSZE” } \\
\text { Sp. z o.o. }\end{array}$ & 0,2615 & Transport \\
\hline 12 & Polfrost Internationale Spedition Sp. z o.o. & 0,2610 & Spedycja \\
\hline 13 & Mostva Sp. z o.o. & 0,2533 & Transport \\
\hline 14 & Rhenus Logistics SA & 0,2530 & Logistyka \\
\hline 15 & DPD Polska Sp. z o.o. & 0,2507 & Usługi kurierskie \\
\hline 16 & CAT Polska Sp. z o.o. & 0,2359 & Logistyka \\
\hline 17 & Solid Logistics Sp. z o.o. & 0,2302 & Spedycja \\
\hline 18 & M\&M air sea cargo SA & 0,2256 & Spedycja \\
\hline 19 & DHL Express (Poland) Sp. z o.o. & 0,2209 & Usługi kurierskie \\
\hline 20 & TRANS-PETRO-COLOR Sp. z o.o. & 0,2140 & Transport \\
\hline 21 & DSV Road Sp. z o.o. & 0,2063 & Spedycja \\
\hline 22 & DARTOM Sp. z o.o. & 0,1994 & Transport \\
\hline 23 & GEFCO Polska Sp. z o.o. & 0,1879 & Logistyka \\
\hline 24 & $\begin{array}{l}\text { Hellmann Worldwide Logistics Polska } \\
\text { Sp. z o.o. Sp. komandytowa }\end{array}$ & 0,1860 & Logistyka \\
\hline 25 & VAN CARGO SA & 0,1832 & Spedycja \\
\hline 26 & Fiege Sp. z o.o. & 0,1824 & Logistyka \\
\hline 27 & TARGOR-TRUCK Sp. z o.o. & 0,1791 & Transport \\
\hline 28 & Mexem Sp. z o.o. & 0,1784 & Logistyka \\
\hline 29 & ZTE RADOM Sp. z o.o. & 0,1731 & Transport \\
\hline
\end{tabular}

* Wartość spreadu syntetycznego miernika oceny operacyjnego bezpieczeństwa finansowego przedsiębiorstw sektora TSL przedstawia różnicę między najwyższą a najniższą wartością tego miernika w badanych latach dla każdego analizowanego przedsiębiorstwa.

Źródło: jak do tab. 4.4. 
Tabela 4.8. Średnia i środkowa wartość syntetycznego miernika oceny operacyjnego bezpieczeństwa finansowego spółek sektora TSL za lata 2004-2012

\begin{tabular}{|c|c|c|c|c|}
\hline Lp. & Nazwa spółki & Średnia & Nazwa spółki & Mediana \\
\hline 1 & DHL Express (Poland) Sp. z o.o. & 0,7034 & DHL Express (Poland) Sp. z o.o. & 0,7240 \\
\hline 2 & UPS Polska Sp. z o.o. & 0,6794 & UPS Polska Sp. z o.o. & 0,6744 \\
\hline 3 & DPD Polska Sp. z o.o. & 0,6584 & VAN CARGO SA & 0,6496 \\
\hline 4 & VAN CARGO SA & 0,6392 & DPD Polska Sp. z o.o. & 0,6459 \\
\hline 5 & GEFCO Polska Sp. z o.o. & 0,6348 & DSV Road Sp. z o.o. & 0,6196 \\
\hline 6 & DSV Road Sp. z o.o. & 0,6238 & GEFCO Polska Sp. z o.o. & 0,6194 \\
\hline 7 & Schenker Sp. z o.o. & 0,6143 & $\begin{array}{l}\text { TNT Express Worldwide (Poland) } \\
\text { Sp. z o.o. }\end{array}$ & 0,6024 \\
\hline 8 & DARTOM Sp. z o.o. & 0,5901 & VOS Logistics Polska Sp. z o.o. & 0,5880 \\
\hline 9 & Mexem Sp. z o.o. & 0,5839 & DARTOM Sp. z o.o. & 0,5860 \\
\hline 10 & VOS Logistics Polska Sp. z o.o. & 0,5805 & Schenker Sp. z o.o. & 0,5806 \\
\hline 11 & Fiege Sp. z o.o. & 0,5795 & TARGOR-TRUCK Sp. z o.o. & 0,5675 \\
\hline 12 & TARGOR-TRUCK Sp. z o.o. & 0,5734 & Fiege Sp. z o.o. & 0,5650 \\
\hline 13 & $\begin{array}{l}\text { TNT Express Worldwide (Poland) } \\
\text { Sp. z o.o. }\end{array}$ & 0,5709 & Solid Logistics Sp. z o.o. & 0,5629 \\
\hline 14 & Solid Logistics Sp. z o.o. & 0,5541 & Mexem Sp. z o.o. & 0,5532 \\
\hline 15 & TRANS-PETRO-COLOR Sp. z o.o. & 0,5525 & M\&M air sea cargo SA & 0,5395 \\
\hline 16 & $\begin{array}{l}\text { Hellmann Worldwide Logistics } \\
\text { Polska Sp. z o.o. Sp. komandytowa }\end{array}$ & 0,5524 & $\begin{array}{l}\text { TRANS-PETRO-COLOR } \\
\text { Sp. z o.o. }\end{array}$ & 0,5370 \\
\hline 17 & M\&M air sea cargo SA & 0,5471 & CHARTER Sp. z o.o. & 0,5365 \\
\hline 18 & Mostva Sp. z o.o. & 0,5445 & Mostva Sp. z o.o. & 0,5362 \\
\hline 19 & CHARTER Sp. z o.o. & 0,5413 & DIREX Sp. z o.o. & 0,5279 \\
\hline 20 & $\begin{array}{l}\text { Polfrost Internationale Spedition } \\
\text { Sp. z o.o. }\end{array}$ & 0,5374 & $\begin{array}{l}\text { Hellmann Worldwide Logistics } \\
\text { Polska Sp. z o.o. Sp. komandytowa }\end{array}$ & 0,5235 \\
\hline 21 & CAT Polska Sp. z o.o. & 0,5350 & ZTE RADOM Sp. z o.o. & 0,5110 \\
\hline 22 & DIREX Sp. z o.o. & 0,5343 & PEKAES SA & 0,5078 \\
\hline 23 & ZTE RADOM Sp. z o.o. & 0,5145 & DSV Solutions Sp. z o.o. & 0,5054 \\
\hline 24 & DSV Solutions Sp. z o.o. & 0,4969 & $\begin{array}{l}\text { Polfrost Internationale Spedition } \\
\text { Sp. z o.o. }\end{array}$ & 0,5017 \\
\hline 25 & Rhenus Logistics SA & 0,4943 & CAT Polska Sp. z o.o. & 0,4857 \\
\hline 26 & Go-Trans GmbH Sp. z o.o. & 0,4842 & Go-Trans GmbH Sp. z o.o. & 0,4654 \\
\hline 27 & PEKAES SA & 0,4414 & Rhenus Logistics SA & 0,4645 \\
\hline 28 & $\begin{array}{l}\text { Neovia Logistics Services Polska } \\
\text { Sp. z o.o. }\end{array}$ & 0,3920 & $\begin{array}{l}\text { Neovia Logistics Services Polska } \\
\text { Sp. z o.o. }\end{array}$ & 0,4137 \\
\hline 29 & $\begin{array}{l}\text { Zakład Transportu Energetyki } \\
\text { „ZTiSZE” Sp. z o.o. }\end{array}$ & 0,3454 & $\begin{array}{l}\text { Zakład Transportu Energetyki } \\
\text {,ZTiSZE”Sp. z o.o. }\end{array}$ & 0,3221 \\
\hline
\end{tabular}

Źródło: jak do tab. 4.4. 
Utworzony ranking średniej i środkowej wartości analizowanej metacechy za lata 2004-2012 wskazuje, że zdecydowanie najkorzystniejszym poziomem operacyjnego bezpieczeństwa finansowego charakteryzowała się spółka DHL Express (Poland) Sp. z o.o. (zob. tab. 4.8). Wartość badanej zmiennej diagnostycznej $\mathrm{w}$ tym podmiocie gospodarczym kształtowała się $\mathrm{w}$ przedziale od 0,5733 (w 2007 r.) do 0,7942 (w 2008 r.). W relacji do innych przedsiębiorstw wartość najwyższą analizowanej metacechy (zajmując pierwsze miejsce w rankingu - zob. tab. 4.9) spółka ta osiągnęła w 2005 r. (tj. 0,7377) i 2007 r. (tj. 0,5733). W 2004 i 2009 r. pierwsze miejsce zajęła spółka VOS Logistics Polska Sp. z o.o., w 2006 r. odpowiednio - TNT Express Worldwide (Poland) Sp. z o.o., w 2008 i 2010 r. - UPS Polska Sp. z o.o., w 2011 r. - DPD Polska Sp. z o.o., a w 2012 r. - VAN CARGO SA. W latach 2004-2012 na pierwszych trzech miejscach utworzonego rankingu przedsiębiorstw o najwyższym średnim poziomie badanej metacechy znalazły się 3 z 4 badanych spółek kurierskich (odpowiednio od najlepszej: DHL Express (Poland) Sp. z o.o., UPS Polska Sp. z o.o. oraz DPD Polska Sp. z o.o.). Bardzo zbliżone wyniki pochodzą z analizy wartości środkowej syntetycznego miernika oceny operacyjnego bezpieczeństwa finansowego spółek sektora TSL. Jedynie DPD Polska Sp. z o.o. ustąpiła (zajmując tym samym 4 pozycję w rankingu) miejsca spółce VAN CARGO SA świadczącej przede wszystkim usługi spedycyjne, która to uprzednio zajmowała 4 miejsce (tj. pod względem średniej wartości badanej zmiennej diagnostycznej).

Nawet najniższa wartość metacechy osiągnięta przez te podmioty gospodarcze w analizowanym okresie, gwarantowała im wysokie pozycje w stworzonym rankingu. Spółka DHL Express (Poland) Sp. z o.o. zajęła bowiem w 2007 r. odpowiednio 1 miejsce, UPS Polska Sp. z o.o. - 12 miejsce, DPD Polska Sp. z o.o.- 6 miejsce, zaś VAN CARGO SA - 4 miejsce (por. tab. 4.3 i 4.9).

W ostatniej trójce podmiotów o najniższym średnim, jak i środkowym poziomie operacyjnego bezpieczeństwa finansowego (zob. tab. 4.8) znalazły się takie podmioty gospodarcze, jak: Zakład Transportu Energetyki „ZTiSZE” Sp. z o.o. (o wartościach metacechy na poziomie od 0,2397 w 2012 r. do 0,5011 w 2004 r.), Neovia Logistics Services Polska Sp. z o.o. (od 0,1522 w 2007 r. do 0,5459 w 2004 r.) oraz odpowiednio PEKAES SA (od 0,1735 w 2006 r. do 0,6694 w 2008 r.), a Rhenus Logistics SA (od 0,3871 w 2011 r. do 0,6401 w 2008 r.). Osiągnięta przez te przedsiębiorstwa maksymalna wartość badanej zmiennej diagnostycznej nie gwarantowała im jednakże - w relacji do pozostałych jednostek poddanych analizie - jednych z najlepszych miejsc w utworzonym rankingu. Uplasowały się bowiem one odpowiednio na 27, 25, 19 oraz 21 miejscu (zob. tab. 4.9). Głównym źródłem przychodów była dla pierwszej i trzeciej spółki działalność transportowa, w pozostałych dwóch przypadkach - działalność logistyczna. 
Tabela 4.9. Ranking spółek sektora TSL według wartości syntetycznego miernika oceny operacyjnego bezpieczeństwa finansowego

\begin{tabular}{|c|c|c|c|c|c|c|c|c|c|c|}
\hline Lp. & Nazwa spółki & 2004 & 2005 & 2006 & 2007 & 2008 & 2009 & 2010 & 2011 & 2012 \\
\hline 1 & CAT Polska Sp. z o.o. & 11 & 20 & 21 & 24 & 9 & 20 & 19 & 21 & 24 \\
\hline 2 & $\begin{array}{l}\text { Neovia Logistics Services } \\
\text { Polska Sp. z o.o. }\end{array}$ & 25 & 23 & 25 & 29 & 28 & 26 & 26 & 28 & 28 \\
\hline 3 & CHARTER Sp. z o.o. & 21 & 19 & 17 & 5 & 8 & 27 & 9 & 17 & 17 \\
\hline 4 & DARTOM Sp. z o.o. & 7 & 8 & 9 & 10 & 15 & 8 & 15 & 18 & 14 \\
\hline 5 & $\begin{array}{l}\text { DHL Express (Poland) } \\
\text { Sp. z o.o. }\end{array}$ & 2 & 1 & 2 & 1 & 3 & 2 & 3 & 2 & 3 \\
\hline 6 & DIREX Sp. z o.o. & 17 & 17 & 5 & 8 & 16 & 29 & 18 & 15 & 22 \\
\hline 7 & DPD Polska Sp. z o.o. & 15 & 10 & 7 & 6 & 4 & 3 & 2 & 1 & 2 \\
\hline 8 & DSV Road Sp. z o.o. & 8 & 5 & 11 & 13 & 6 & 10 & 4 & 6 & 5 \\
\hline 9 & DSV Solutions Sp. z o.o. & 28 & 7 & 27 & 17 & 13 & 16 & 28 & 25 & 6 \\
\hline 10 & Fiege Sp. z o.o. & 16 & 14 & 10 & 15 & 14 & 13 & 8 & 14 & 10 \\
\hline 11 & GEFCO Polska Sp. z o.o. & 4 & 4 & 4 & 3 & 5 & 4 & 11 & 4 & 12 \\
\hline 12 & Go-Trans GmbH Sp. z o.o. & 20 & 27 & 22 & 27 & 26 & 23 & 21 & 22 & 25 \\
\hline 13 & $\begin{array}{l}\text { Hellmann Worldwide } \\
\text { Logistics Polska Sp. z o.o. } \\
\text { Sp. komandytowa }\end{array}$ & 12 & 15 & 8 & 11 & 20 & 19 & 24 & 19 & 23 \\
\hline 14 & M\&M air sea cargo SA & 24 & 24 & 14 & 19 & 17 & 22 & 12 & 12 & 13 \\
\hline 15 & Mexem Sp. z o.o. & 10 & 11 & 13 & 9 & 7 & 15 & 13 & 11 & 11 \\
\hline 16 & Mostva Sp. z o.o. & 19 & 18 & 20 & 18 & 12 & 12 & 20 & 24 & 15 \\
\hline 17 & PEKAES SA & 29 & 29 & 29 & 22 & 19 & 18 & 17 & 10 & 16 \\
\hline 18 & $\begin{array}{l}\text { Polfrost Internationale Spedi- } \\
\text { tion Sp. z o.o. }\end{array}$ & 6 & 21 & 24 & 20 & 11 & 24 & 22 & 20 & 20 \\
\hline 19 & Rhenus Logistics SA & 26 & 26 & 15 & 25 & 21 & 25 & 25 & 27 & 26 \\
\hline 20 & Schenker Sp. z o.o. & 23 & 16 & 18 & 7 & 2 & 5 & 5 & 7 & 9 \\
\hline 21 & Solid Logistics Sp. z o.o. & 13 & 3 & 26 & 23 & 25 & 11 & 7 & 9 & 27 \\
\hline 22 & TARGOR-TRUCK Sp. z o.o. & 9 & 12 & 16 & 14 & 22 & 21 & 14 & 8 & 8 \\
\hline 23 & $\begin{array}{l}\text { TNT Express Worldwide } \\
\text { (Poland) Sp. z o.o. }\end{array}$ & 3 & 2 & 1 & 2 & 23 & 6 & 29 & 26 & 19 \\
\hline 24 & $\begin{array}{l}\text { TRANS-PETRO-COLOR } \\
\text { Sp. z o.o. }\end{array}$ & 14 & 22 & 19 & 21 & 18 & 14 & 16 & 13 & 18 \\
\hline 25 & UPS Polska Sp. z o.o. & 18 & 13 & 3 & 12 & 1 & 7 & 1 & 3 & 4 \\
\hline 26 & VAN CARGO SA & 5 & 9 & 6 & 4 & 10 & 9 & 6 & 5 & 1 \\
\hline 27 & $\begin{array}{l}\text { VOS Logistics Polska } \\
\text { Sp. z o.o. }\end{array}$ & 1 & 6 & 12 & 16 & 29 & 1 & 10 & 16 & 7 \\
\hline 28 & $\begin{array}{l}\text { Zakład Transportu Energetyki } \\
\text { „ZTiSZE” Sp. z o.o. }\end{array}$ & 27 & 28 & 28 & 28 & 27 & 28 & 27 & 29 & 29 \\
\hline 29 & ZTE RADOM Sp. z o.o. & 22 & 25 & 23 & 26 & 24 & 17 & 23 & 23 & 21 \\
\hline
\end{tabular}

Źródło: jak do tab. 4.4. 
Podejmując próbę wyjaśnienia i bliższej interpretacji powstałego odchylenia wartości syntetycznego miernika operacyjnego bezpieczeństwa finansowego przedsiębiorstw sektora TSL - dalszym badaniom zostały poddane dwa podmioty gospodarcze. Są nimi DHL Express (Poland) Sp. z o.o., w którym dla lat 2004-2012 wystąpiła najwyższa średnia oraz środkowa wartość wyżej wymienionego miernika oraz Zakład Transportu Energetyki „ZTiSZE” Sp. z o.o., w którym zanotowano najniższe wartości obydwu wymienionych podstawowych statystyk opisowych.

Wartość spreadu średniego (środkowego) poziomu operacyjnego bezpieczeństwa finansowego w latach 2004-2012 między spółką DHL Express (Poland) Sp. z o.o. a Zakładem Transportu Energetyki „ZTiSZE” Sp. z o.o. wynosiła $0,3580(0,4019)$. Porównanie wartości indywidualnych zmiennych wchodzących w skład analizowanej metacechy, uwidoczniło występowanie znacznej różnicy poziomu poszczególnych mierników oceny operacyjnego bezpieczeństwa finansowego. Zakład Transportu Energetyki „ZTiSZE” Sp. z o.o. osiągnął znacznie wyższe średnie oraz środkowe wartości współczynnika bieżącej i natychmiastowej płynności finansowej (zob. wykresy 4.5 i 4.6), które (za wyjątkiem 2004 r. w przypadku pierwszego tych mierników) przewyższały ich wartości optymalne wyznaczone dla analizowanych spółek sektora TSL w całym okresie badawczym. W spółce DHL Express (Poland) Sp. z o.o. dla porównania wartość miernika $\mathrm{m}_{2} \mathrm{~W}$ latach 2007-2010 i 2012, a miernika $\mathrm{m}_{4}$ w latach 2005-2007 mieściła się w wyznaczonym na potrzeby badań przedziale tych zmiennych oraz dodatkowo (za wyjątkiem 2011 r. dla współczynnika bieżącej płynności finansowej) była niższa od wyznaczonych wartości optymalnych (zob. zał. 4).

Osiągnięte przez Zakład Transportu Energetyki „ZTiSZE” Sp. z o.o. średnie wartości współczynników zabezpieczenia finansowego również utrzymywały się na poziomie wyższym niż w przedsiębiorstwie niezagrożonym upadłością, zaś średnia (środkowa) wartość przychodów netto ze sprzedaży usług, towarów i materiałów, współczynnika zdolności do obsługi zobowiązań bieżących gotówką osiąganą z działalności operacyjnej, współczynnika eksploatacyjnej rentowności kapitału własnego oraz współczynnika wydajności pieniężnej (gotówkowej) kapitału własnego - odpowiednio na dużo niższym poziomie.

W Zakładzie Transportu Energetyki „ZTiSZE” Sp. z o.o. występowała zatem znaczna nadpłynność finansowa, przy niewielkim (w relacji do spółki DHL Express (Poland) Sp. z o.o.) - choć wciąż dodatnim - średnim (środkowym) memoriałowym i kasowym współczynniku rentowności kapitału własnego. Przedsiębiorstwo DHL Express (Poland) Sp. z o.o. - prowadząc działalność kurierską - zajmował się w całym okresie poddanym analizie w pierwszej trójce podmiotów gospodarczych o najwyższym poziomie operacyjnego bezpieczeństwa finansowego. 


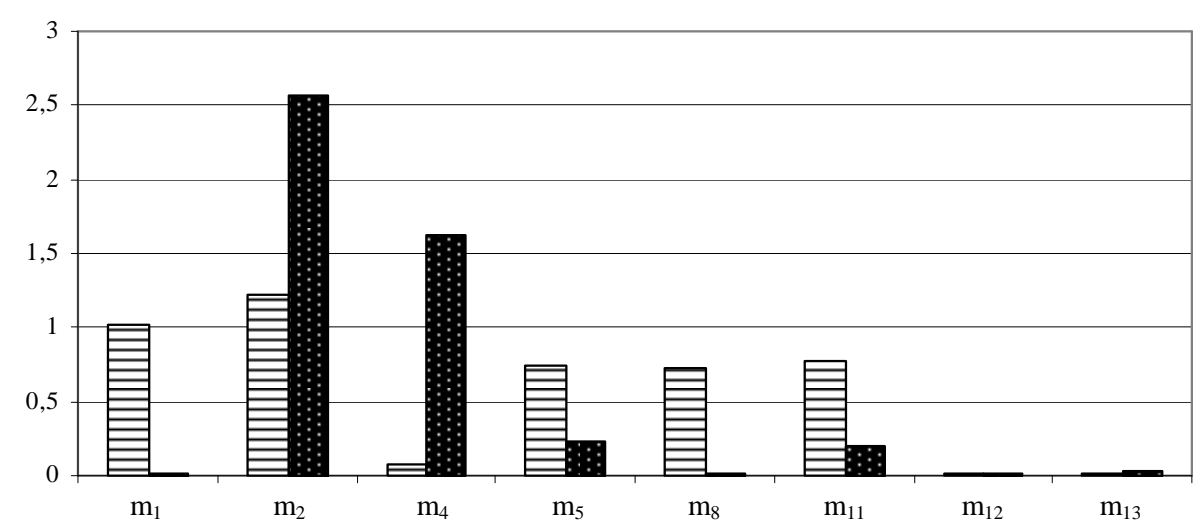

曰DHL Express (Poland) - Zakład Transportu Energetyki „ZTiSZE”

* Dane dla miernika $\mathrm{m}_{1}$ są podane w mld zł

Wykres 4.5. Średnie wartości mierników oceny operacyjnego bezpieczeństwa finansowego spółki

DHL Express (Poland) Sp. z o.o. oraz Zakładu Transportu Energetyki „ZTiSZE” Sp. z o.o. dla lat 2004-2012*

Źródło: obliczenia własne na podstawie danych zebranych w Krajowym Rejestrze Sądowym w Warszawie przy wykorzystaniu programu Microsoft Excel.

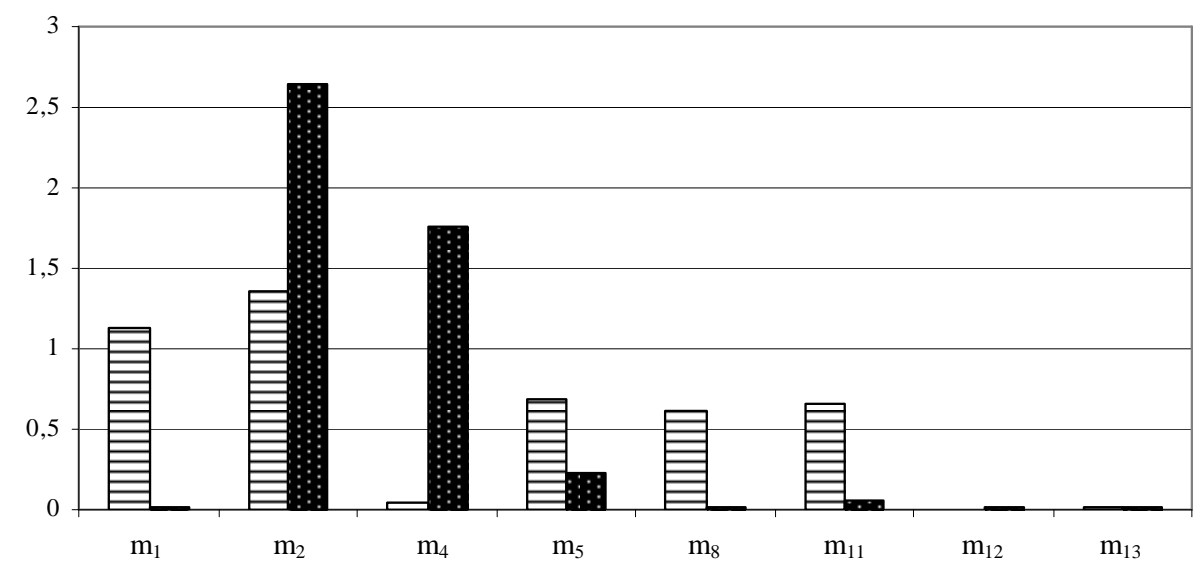

日DHL Express (Poland) - Zakład Transportu Energetyki „ZTiSZE”

* Dane dla miernika $\mathrm{m}_{1}$ są podane w mld zł

Wykres 4.6. Środkowe wartości mierników oceny operacyjnego bezpieczeństwa finansowego spółki DHL Express (Poland) Sp. z o.o. oraz Zakładu Transportu Energetyki „ZTiSZE” Sp. z o.o. dla lat 2004-2012*

Źródło: jak do wyk. 4.5. 
W literaturze przedmiotu spotykamy się z poglądem o ewoluowaniu ekonomiki transportu w kierunku ekonomiki usług logistycznych ${ }^{12}$ oraz spedycyjnych. W znaczącej liczbie przedsiębiorstw sektora TSL następuje zmiana zakresu i rodzaju prowadzonej działalności - z świadczenia usług transportowych na rzecz spedycji. Działalność spedycyjna pozwala bowiem na osiągnięcie wielokrotnie wyższego wzrostu sprzedaży ${ }^{13}$. Wzrost wartości wypracowanych przychodów netto ze sprzedaży usług, towarów i materiałów stanowić może przeto jedną z kluczowych determinant poziomu operacyjnego bezpieczeństwa finansowego przedsiębiorstwa.

Sformułowana została zatem hipoteza badawcza stanowiąca, iż przedsiębiorstwa spedycyjne utrzymuja wyższy poziom operacyjnego bezpieczeństwa finansowego $w$ relacji do pozostałych spótek sektora $T S L^{14}$.

Tabela 4.10. Rodzaj działalności (główne źródło przychodu) spółek sektora TSL o najwyższym poziomie syntetycznego miernika oceny operacyjnego

bezpieczeństwa finansowego w latach 2004-2012

\begin{tabular}{|c|c|c|c|c|c|c|c|c|c|}
\hline \multirow{2}{*}{ Lp. } & \multicolumn{70}{|c|}{ Główne źródło przychodu } \\
\cline { 2 - 12 } & 2004 r. & 2005 r. & 2006 r. & 2007 r. & 2008 r. & 2009 r. & $2010 \mathrm{r}$. & $2011 \mathrm{r}$. & $2012 \mathrm{r}$. \\
\hline \hline 1 & $\mathrm{~T}$ & $\mathrm{~K}$ & $\mathrm{~K}$ & $\mathrm{~K}$ & $\mathrm{~K}$ & $\mathrm{~T}$ & $\mathrm{~K}$ & $\mathrm{~K}$ & $\mathrm{~S}$ \\
\hline 2 & $\mathrm{~K}$ & $\mathrm{~K}$ & $\mathrm{~K}$ & $\mathrm{~K}$ & $\mathrm{~L}$ & $\mathrm{~K}$ & $\mathrm{~K}$ & $\mathrm{~K}$ & $\mathrm{~K}$ \\
\hline 3 & $\mathrm{~K}$ & $\mathrm{~S}$ & $\mathrm{~K}$ & $\mathrm{~L}$ & $\mathrm{~K}$ & $\mathrm{~K}$ & $\mathrm{~K}$ & $\mathrm{~K}$ & $\mathrm{~K}$ \\
\hline 4 & $\mathrm{~L}$ & $\mathrm{~L}$ & $\mathrm{~L}$ & $\mathrm{~S}$ & $\mathrm{~K}$ & $\mathrm{~L}$ & $\mathrm{~S}$ & $\mathrm{~L}$ & $\mathrm{~K}$ \\
\hline 5 & $\mathrm{~S}$ & $\mathrm{~S}$ & $\mathrm{~T}$ & $\mathrm{~T}$ & $\mathrm{~L}$ & $\mathrm{~L}$ & $\mathrm{~L}$ & $\mathrm{~S}$ & $\mathrm{~S}$ \\
\hline 6 & $\mathrm{~S}$ & $\mathrm{~T}$ & $\mathrm{~S}$ & $\mathrm{~K}$ & $\mathrm{~S}$ & $\mathrm{~K}$ & $\mathrm{~S}$ & $\mathrm{~S}$ & $\mathrm{~L}$ \\
\hline 7 & $\mathrm{~T}$ & $\mathrm{~L}$ & $\mathrm{~K}$ & $\mathrm{~L}$ & $\mathrm{~L}$ & $\mathrm{~K}$ & $\mathrm{~S}$ & $\mathrm{~L}$ & $\mathrm{~T}$ \\
\hline 8 & $\mathrm{~S}$ & $\mathrm{~T}$ & $\mathrm{~L}$ & $\mathrm{~T}$ & $\mathrm{~T}$ & $\mathrm{~T}$ & $\mathrm{~L}$ & $\mathrm{~T}$ & $\mathrm{~T}$ \\
\hline 9 & $\mathrm{~T}$ & $\mathrm{~S}$ & $\mathrm{~T}$ & $\mathrm{~L}$ & $\mathrm{~L}$ & $\mathrm{~S}$ & $\mathrm{~T}$ & $\mathrm{~S}$ & $\mathrm{~L}$ \\
\hline 10 & $\mathrm{~L}$ & $\mathrm{~K}$ & $\mathrm{~L}$ & $\mathrm{~T}$ & $\mathrm{~S}$ & $\mathrm{~S}$ & $\mathrm{~T}$ & $\mathrm{~T}$ & $\mathrm{~L}$ \\
\hline
\end{tabular}

gdzie:

$\mathrm{T}-$ Transport,

S - Spedycja,

L - Logistyka,

$\mathrm{K}$ - Usługi kurierskie.

Źródło: jak do tab. 4.3.

${ }^{12}$ Por. M. Ci e si els k i (red.), Rynek ustug logistycznych, Difin, 2005, s. 9.

${ }^{13}$ Por. P. S zreter, Niepewność perspektyw rozwoju sprzedaży, „EuroLogistics” 2010, nr 1, s. 19.

${ }^{14}$ Por. L. Ka r b o w n i k, Zróżnicowanie poziomu operacyjnego bezpieczeństwa finansowego przedsiębiorstw sektora TSL, [w:] J. Duraj (red.), Instrumenty ksztattowania dochodowości i rentowności przedsiębiorstwa, „Acta Universitatis Lodziensis”, Folia Oeconomica 278, Wydawnictwo Uniwersytetu Łódzkiego, Łódź 2013, s. 223-247. 
Przeprowadzona analiza ujawniła, iż w 2006 i 2009 r. wszystkie badane przedsiębiorstwa kurierskie uplasowały swoją pozycję wśród 10 podmiotów gospodarczych o najwyższym poziomie analizowanej metacechy. W 2006, 2010 i $2011 \mathrm{r}$. znajdowały się one na trzech pierwszych pozycjach, z kolei odpowiednio w 2004 i 2009 r. - jedna z nich ustąpiła miejsca spółce transportowej, w 2005 i 2012 r. - podmiotowi gospodarczemu, którego głównym źródłem przychodów netto ze sprzedaży było świadczenie usług spedycyjnych, a w 2007 i 2008 r. - prowadzącemu działalność logistyczną (zob. tab. 4.10).

Podobnie ocena średniego, jak i środkowego poziomu badanej zmiennej diagnostycznej wykazała, iż najwyższa jej wartość w całym badanym okresie została osiągnięta przez przedsiębiorstwa kurierskie (zob. wykres 4.7 i 4.8). Natomiast najniższa przeciętna wartość metacechy wystąpiła w przypadku spólek transportowych w latach 2005-2006, 2008-2009 oraz 2011-2012, zaś w podmiotach gospodarczych świadczących usługi logistyczne - w 2004, 2007 i $2010 \mathrm{r}$.

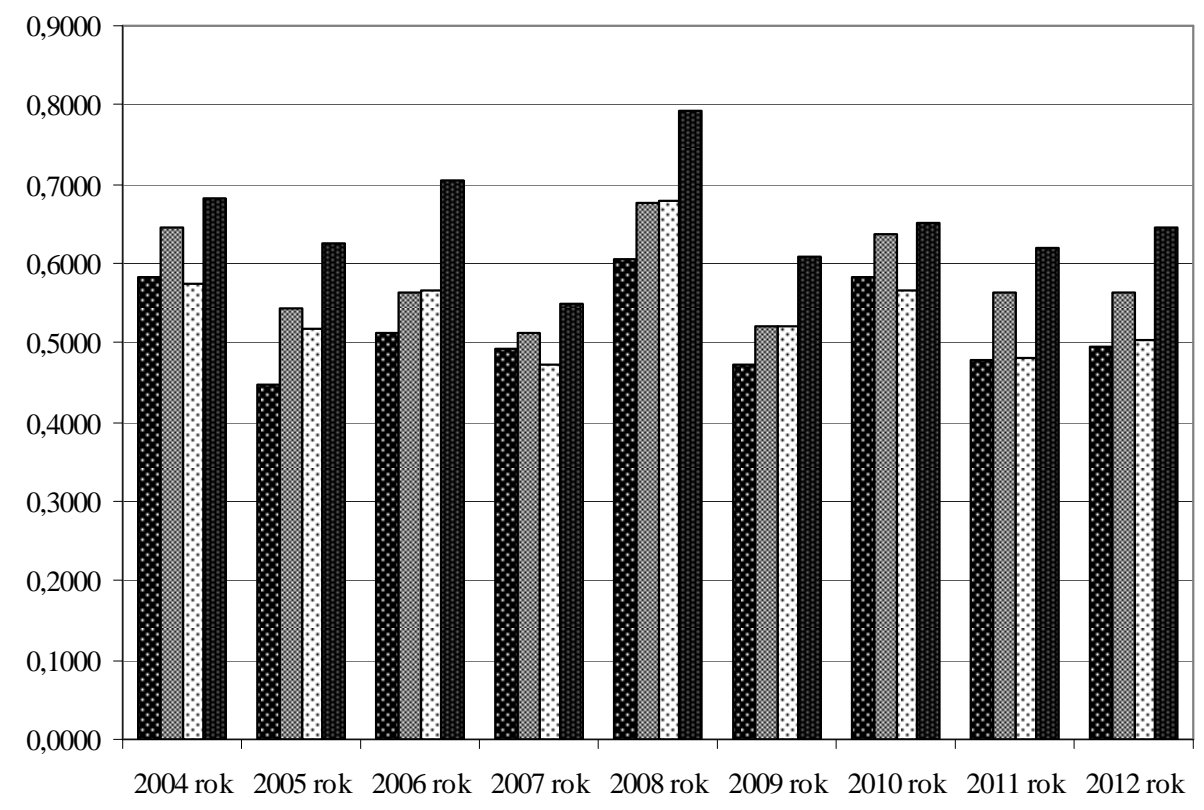

Transport 圆 Spedycja $\square$ Logistyka $\mathbf{m}$ Usługi kurierskie

Wykres 4.7. Średni poziom operacyjnego bezpieczeństwa finansowego spółek sektora TSL w latach 2004-2012 według głównego źródła przychodu

Źródło: jak do wyk. 4.1. 


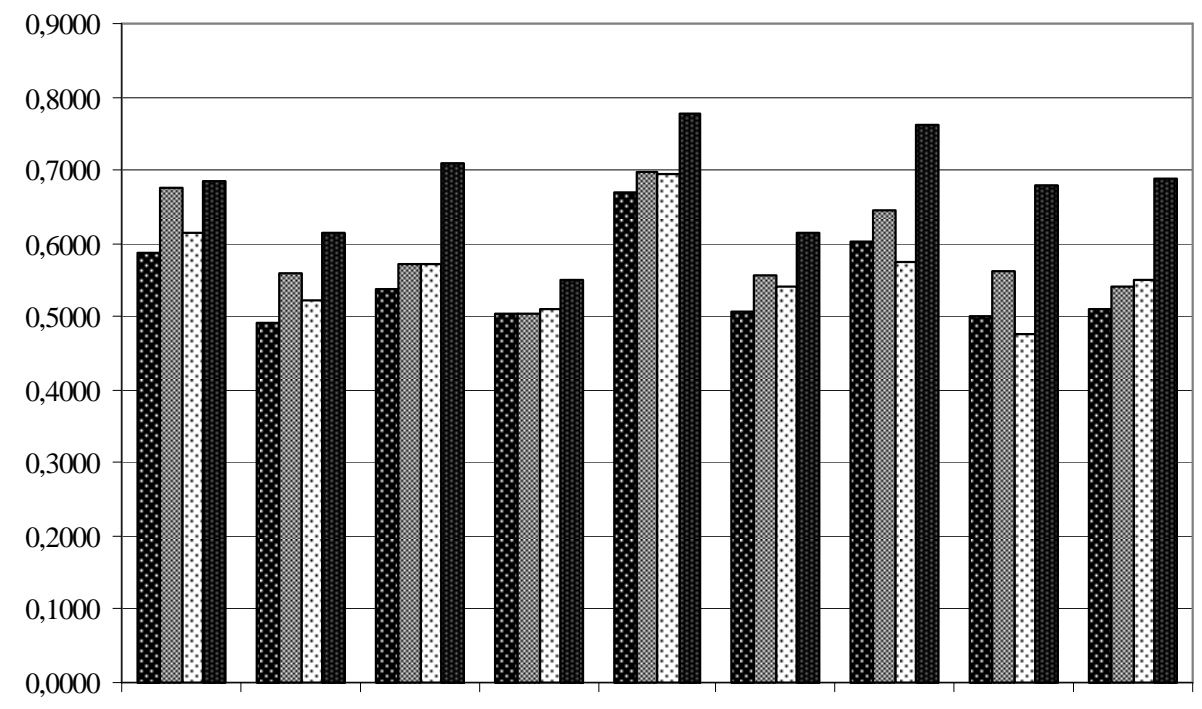

2004 rok 2005 rok 2006 rok 2007 rok 2008 rok 2009 rok 2010 rok 2011 rok 2012 rok

Transport 圆 Spedycja $\mathrm{Q}$ Logistyka $\mathbf{m}$ Usługi kurierskie

Wykres 4.8. Środkowy poziom operacyjnego bezpieczeństwa finansowego spółek sektora TSL w latach 2004-2012 według głównego źródła przychodu

Źródło: jak do wyk. 4.1.

Wykorzystując do dalszych badań nieparametryczny test istotności różnic dla wielu prób niezależnych ${ }^{15}$ sformułowana została następująca zerowa hipoteza robocza: przedsiębiorstwa sektora TSL prowadzące zróżnicowane rodzaje podstawowej działalności usługowej nie różniły się poziomem operacyjnego bezpieczeństwa finansowego.

$$
\mathrm{H}_{0}: \mathrm{F}_{1}(\mathrm{x})=\mathrm{F}_{2}(\mathrm{x})=\mathrm{F}_{3}(\mathrm{x})=\mathrm{F}_{4}(\mathrm{x})
$$

Hipoteza alternatywna mówiła z kolei, iż nie we wszystkich rodzajach usługowej działalności przedsiębiorstw sektora TSL rozkład badanej zmiennej był identyczny.

$$
\mathrm{H}_{1}: \mathrm{F}_{1}(\mathrm{x}) \neq \mathrm{F}_{2}(\mathrm{x}) \neq \mathrm{F}_{3}(\mathrm{x}) \neq \mathrm{F}_{4}(\mathrm{x})
$$

${ }^{15}$ Badana próba przedsiębiorstw liczyła 29 podmiotów gospodarczych - wobec tego, w celu analizy zgodności rozkładu zmiennej $\mathrm{w}$ danej grupie przedsiębiorstw $\mathrm{z}$ określonym rozkładem teoretycznym, wykorzystano test normalności Shapiro-Wilka. Na podstawie wyników tego testu odrzucono hipotezę o normalności rozkładu. 
Zaprezentowane w tab. 4.11 wyniki badań wskazują, iż w 2006 r. wystąpiły statystycznie istotne różnice dla wartości syntetycznego miernika oceny operacyjnego bezpieczeństwa finansowego (na poziomie istotności 0,05) między przedsiębiorstwami, których główne źródło przychodów netto ze sprzedaży pochodziło z prowadzenia działalności transportowej, spedycyjnej, logistycznej lub kurierskiej. W latach 2005, 2007, 2008 i 2009 istotne różnice wystąpiły na tzw. poziomie tendencji (tj. przy $\mathrm{p}<0,1)$.

Tabela 4.11. Poziom istotności różnicy między określonymi rodzajami działalności (głównymi źródłami przychodu) dla wartości syntetycznego miernika oceny operacyjnego bezpieczeństwa finansowego przedsiębiorstw sektora TSL* (próba niezależna)

\begin{tabular}{|c|c|c|c|c|c|c|c|c|c|}
\hline Wyszczególnienie & 2004 r. & 2005 r. & 2006 r. & 2007 r. & 2008 r. & 2009 r. & 2010 r. & 2011 r. & 2012 r. \\
\hline $\begin{array}{c}\text { Istotność } \\
\text { asymptotyczna }\end{array}$ &, 280 &, 069 &, 025 &, 091 &, 084 &, 056 &, 144 &, 113 &, 174 \\
\hline
\end{tabular}

* Kolorem zaznaczone są istotne różnice przy poziomie istotności 0,05.

Kolorem zaznaczone są istotne różnice na poziomie tendencji (poziom istotności 0,10).

Źródło: obliczenia własne na podstawie danych zebranych w Krajowym Rejestrze Sądowym w Warszawie przy wykorzystaniu programu Taksonomia numeryczna i SPSS Statistics (wersja 22).

Dla 2006 r. (przy poziomie istotności wynoszącym 0,05) odrzucona została hipoteza zerowa, bowiem rodzaj prowadzonej działalności spółek sektora TSL wpływał statystycznie istotnie na poziom operacyjnego bezpieczeństwa finansowego. Nie we wszystkich przeto ich rodzajach rozkład badanej zmiennej jest identyczny. Nie została jednakże na tym etapie badań dokonana identyfikacja między którymi rodzajami usługowej działalności przedsiębiorstw sektora TSL występują te różnice.

Przeprowadzona analiza POST-HOC ${ }^{16}$ wykazała, iż w 2006 r. ${ }^{17}$ wartość syntetycznego miernika oceny operacyjnego bezpieczeństwa finansowego dla przedsiębiorstw świadczących usługi kurierskie istotnie różniła się od wartości tego miernika dla przedsiębiorstw transportowych (zob. tab. 4.12). Podobna sytuacja - na tzw. poziomie tendencji ( $<<0,1)$ - miała miejsce w 2005, 2007, 2008 i 2009 r., bowiem wartość analizowanej zmiennej diagnostycznej dla przedsiębiorstw świadczących usługi kurierskie znacząco różniła się od jej war-

${ }^{16} \mathrm{Tj}$. analiza szczegółowa.

${ }^{17}$ W 2006 r. badana zmienna diagnostyczna istotnie statystycznie różniła się dla dwóch rodzajów usługowej działalności przedsiębiorstw sektora TSL, tj. działalności transportowej i kurierskiej. Średnie rangi (podane w tab. 4.12) wykazują, iż przedsiębiorstwa kurierskie osiągały najczęściej zasadniczo wyższy poziom $(26,75)$ operacyjnego bezpieczeństwa finansowego niż spółki transportowe. 
tości odpowiednio dla spółek transportowych i logistycznych ${ }^{18}$. Podsumowując można wskazać, że w przypadku występowania statystycznie istotnych różnic między określonymi głównymi źródłami przychodu - działalność kurierska charakteryzowała się najczęściej najwyższym poziomem operacyjnego bezpieczeństwa finansowego, który różnił się znacznie od poziomu operacyjnego bezpieczeństwa finansowego przedsiębiorstw transportowych i logistycznych.

Tabela 4.12. Średnia ranga dla istotnie różnych wartości syntetycznego miernika oceny operacyjnego bezpieczeństwa finansowego między określonymi rodzajami działalności (głównymi źródłami przychodu) spółek sektora TSL*

\begin{tabular}{|c|c|}
\hline Wyszczególnienie & Średnia ranga \\
\hline \hline \multirow{2}{*}{$2006 \mathrm{r}}$. & T vs K \\
$(11,82)(26,75)$
\end{tabular}

* Kolorem zaznaczone są istotne różnice przy poziomie istotności 0,05.

\begin{tabular}{|c|c|}
\hline Wyszczególnienie & Średnia ranga \\
\hline $2005 \mathrm{r}$. & \begin{tabular}{c}
\multicolumn{1}{c}{ T vs $\mathrm{K}$} \\
$(10,82) \quad(23,50)$
\end{tabular} \\
\hline $2006 \mathrm{r}$. & $\begin{array}{c}\text { T vs K } \\
(11,82) \quad(26,75) \\
\text { L vs K } \\
(14,33) \quad(26,75)\end{array}$ \\
\hline $2007 \mathrm{r}$. & $\begin{array}{c}\text { T vs } \mathrm{K} \\
(12,27) \quad(24,75)\end{array}$ \\
\hline $2008 \mathrm{r} . * *$ & $\begin{array}{c}\text { T vs } K \\
(10,36) \quad(22,25) \\
\end{array}$ \\
\hline $2009 \mathrm{r}$. & $\begin{array}{c}\text { T vs } \mathrm{K} \\
(12,00) \quad(25,50)\end{array}$ \\
\hline
\end{tabular}

* Kolorem zaznaczone są istotne różnice przy poziomie istotności 0,10.

** Istotność skorygowana na poziomie 0,101 .

Źródło: jak do tab. 4.11 .

Podobne wnioski - w relacji do badania występowania istotnych różnic między spółkami sektora TSL, których główne źródło przychodów netto ze sprzedaży pochodziło ze świadczenia usług transportowych, logistycznych, spedycyjnych lub kurierskich - ujawnia estymacja dokonana na danych panelowych.

${ }^{18}$ Średnie rangi uzyskane w trakcie analizy wykazały, iż spółki kurierskie osiągały istotnie różny (wyższy) poziom operacyjnego bezpieczeństwa finansowego w relacji do podmiotów gospodarczych, których główne źródło przychodów pochodziło ze świadczenia usług transportowych i logistycznych. 
W celu weryfikacji stabilności oszacowań parametrów wskazanych w opracowaniu (zob. tab. 4.13) wykorzystana została kolejno panelowa ważona Metoda Najmniejszych Kwadratów (ang. Panel EGLS) dla danych połączonych ze stałymi wagami w obrębie poszczególnych przedsiębiorstw (ang. Cross-section Weights). Dokonano estymacji modelu, w którym zmienną objaśnianą jest syntetyczny miernik $O B F$ wyrażający poziom operacyjnego bezpieczeństwa finansowego badanych spółek sektora TSL. Model ten można zapisać formalnie w następujący sposób:

$$
O B F_{i, t}=\alpha_{0}+\alpha_{2} \log (T A)_{i, t}+\alpha_{3} z ́ r o ́ d t o 2+\alpha_{4} z ́ r o ́ d t o 4+\alpha_{5} K O N+\varepsilon_{i, t}
$$

$$
\begin{aligned}
& \text { gdzie: } \\
& O B F \quad-\text { syntetyczny miernik operacyjnego bezpieczeństwa finanso- } \\
& \text { wego przedsiębiorstwa, } \\
& \log (T A) \quad \text { - wielkość przedsiębiorstwa wyrażona logarytmem naturalnym } \\
& \text { wartości aktywów ogółem (w cenach stałych z } 2012 \text { r.) }{ }^{19} \text {, } \\
& \text { źródło2 - zmienna zero-jedynkowa ,główne źródło przychodów } \\
& \text { - TRANSPORT", } \\
& \text { źródto4 - zmienna zero-jedynkowa ,główne źródło przychodów - USŁU- } \\
& \text { GI KURIERSKIE", } \\
& \text { KON - wskaźnik ogólnego klimatu koniunktury dla sekcji ,,Transport } \\
& \text { i gospodarka magazynowa" (średnia wartość dla każdego } \\
& \text { roku poddanego analizie), } \\
& i, t \quad-\text { to indeksy jednostek przekroju (przedsiębiorstw) i czasu, } \\
& \varepsilon \quad-\text { składnik losowy modelu. }
\end{aligned}
$$

Uzyskane wyniki wskazują, że poziom operacyjnego bezpieczeństwa finansowego badanych przedsiębiorstw sektora TSL jest statystycznie istotnie i dodatnio skorelowany $\mathrm{z}$ wielkością przedsiębiorstwa mierzoną logarytmem naturalnym realnej wartości aktywów ogółem. Ponadto dodatnie (ujemne) oszacowanie parametru $\alpha_{4}\left(\alpha_{3}\right)$ wskazuje, że przedsiębiorstwa kurierskie (transportowe) utrzymują wyższy (niższy) poziom operacyjnego bezpieczeństwa finansowego w relacji do pozostałych spółek sektora, a parametr przy zmiennej $K O N$ wyraża oczekiwany, dodatni związek pomiędzy nastrojami przedsiębiorców mierzonymi syntetycznym wskaźnikiem koniunktury a poziomem zmiennej zależnej $O B F^{20}$.

${ }^{19}$ Wartości nominalne zostały zdeflowane wskaźnikiem cen usług transportu i gospodarki magazynowej za lata 2006-2011 podanym w: Ceny w gospodarce..., op. cit., s. 283; z uwagi na brak danych w wyżej wymienionej publikacji za lata 2004-2005 wykorzystany został wskaźnik cen usług transportu, gospodarki magazynowej i łączności podany w: Rocznik Statystyczny Rzeczpospolitej Polskiej, Główny Urząd Statystyczny, Warszawa 2008, s. 449 i Rocznik Statystyczny Rzeczpospolitej Polskiej, Główny Urząd Statystyczny, Warszawa 2007, s. 445.

${ }^{20}$ Koniunktura gospodarcza wywiera istotny wpływ na poziom operacyjnego bezpieczeństwa finansowego przedsiębiorstw sektora TSL. 
Tabela 4.13. Wyniki estymacji modelu objaśniającego poziom bezpieczeństwa finansowego przedsiębiorstw sektora TSL (2)

\begin{tabular}{|c|c|c|c|}
\hline $\begin{array}{c}\text { Zmienna } \\
\text { objaśniająca }\end{array}$ & $\begin{array}{c}\text { Oszacowanie } \\
\text { parametru }\end{array}$ & $\begin{array}{c}\text { Statystyka } \\
\text { t-Studenta } \\
\end{array}$ & $\begin{array}{c}\text { Istotność zmiennej } \\
\text { (p-value) }\end{array}$ \\
\hline$C$ & 0,20 & 1,71 & 0,09 \\
\hline $\log (T A)$ & 0,02 & 3,28 & 0,00 \\
\hline zrodlo 2 & $-0,03$ & $-2,82$ & 0,01 \\
\hline zrodlo4 & 0,07 & 3,54 & 0,00 \\
\hline KON & 0,002 & 2,45 & 0,01 \\
\hline \multicolumn{2}{|c|}{$\mathrm{R}^{2}$} & \multicolumn{2}{|c|}{$22,45 \%$} \\
\hline \multicolumn{2}{|c|}{ skor. $\mathrm{R}^{2}$} & \multicolumn{2}{|c|}{$21,24 \%$} \\
\hline \multicolumn{2}{|c|}{ SEE } & \multicolumn{2}{|c|}{0,11} \\
\hline \multicolumn{2}{|c|}{$\mathrm{F}$} & \multicolumn{2}{|c|}{18,53} \\
\hline \multicolumn{2}{|c|}{$p(\mathrm{~F})$} & \multicolumn{2}{|c|}{$<0,001$} \\
\hline \multicolumn{2}{|c|}{ J-B } & \multicolumn{2}{|c|}{3,11} \\
\hline \multicolumn{2}{|c|}{$p(\mathrm{~J}-\mathrm{B})$} & \multicolumn{2}{|c|}{0,21} \\
\hline \multicolumn{4}{|c|}{$\mathrm{N}=261$} \\
\hline
\end{tabular}

Źródło: jak do tab. 4.6.

Odrzucona została przeto hipoteza badawcza stanowiąca o tym, iż przedsiębiorstwa spedycyjne utrzymuja wyższy poziom operacyjnego bezpieczeństwa finansowego $w$ relacji do pozostatych spótek sektora TSL. Analiza podstawowych statystyk opisowych dla badanej zmiennej diagnostycznej, testu istotności różnic dla wielu prób niezależnych oraz wyniki estymacji modeli objaśniających badane zjawisko wskazują nadto, iż spółki kurierskie posiadają na ogół najwyższą (w relacji do innych podmiotów sektora TSL) wartość rozważanego syntetycznego miernika oceny operacyjnego bezpieczeństwa finansowego.

\subsection{Analiza porównawcza struktury skupień przedsiębiorstw sektora TSL o zbliżonym poziomie operacyjnego bezpieczeństwa finansowego}

Ocena operacyjnego bezpieczeństwa finansowego została rozwinięta przy zastosowaniu - jako zasadniczego narzędzia badawczego - analizy skupień. Analiza ta pozwala sklasyfikować obiekty (spółki) we względnie homogeniczne ich grupy. Do zgrupowania jednostek ujmowanych w wielowymiarowych przestrzeniach zmiennych wykorzystana została metoda Warda ${ }^{21}$.

\footnotetext{
${ }^{21}$ Jest to metoda należąca do grupy metod taksonomii numerycznej (analizy skupień) i zaliczana jest do aglomeracyjnych metod grupowania, w których początkowo każdy obiekt jest odręb-
} 
Podstawą grupowania przedsiębiorstw stało się podobieństwo między obiektami, które jest wyrażone przy pomocy miary odległości euklidesowej ${ }^{22}$. Ilustracją graficzną wyników grupowania hierarchicznego jest diagram drzewka połączeń, tzw. dendrogram ${ }^{23}$, który ilustruje kolejne połączenia skupień coraz to wyższego rzędu ${ }^{24}$. Uzyskana hierarchia pozwala na określenie wzajemnego położenia skupień i obiektów w nich zawartych. Na osi pionowej odłożone są wartości miar euklidesowych, przy których następuje połączenie kolejnych grup jednostek gospodarczych, zaś na poziomej - położenie badanych spółek sektora TSL. Biorąc pod uwagę odległości taksonomiczne i położenie analizowanych podmiotów gospodarczych możliwe jest określenie, na jakim poziomie tworzą one jedno skupienie.

Wszystkie obliczenia zostały przeprowadzone na podstawie zestandaryzowanych danych macierzy obserwacji (mierników), których współczynnik korelacji rang Spearmana między analizowanymi zmiennymi objaśniającymi (tj. miernikiem $O B F$ w każdym roku całego okresu badawczego) osiągnął wartość z przedziału $(-0,8 ; 0,8)$ przy poziomie istotności $0,05^{25}$. Dla przyporządkowania podmiotów gospodarczych do homogenicznych grup przedsiębiorstw o zbliżonym poziomie operacyjnego bezpieczeństwa finansowego w latach 2004-2012 - pozostawiono zmienne $O B F$ za 2004, 2005, 2007, 2008, 2009, 2010 i 2012 r. (zob. tab. 4.14), dokonano ich standaryzacji, a następnie przystąpiono do zasadniczej analizy skupień (zob. schemat 4.1).

nym skupieniem, a następnie stopniowo łączy się najbliższe siebie obiekty w nowe skupienia, aż do uzyskania jednego skupienia. Metoda Warda traktowana jest jako bardzo efektywna, chociaż zmierza do tworzenia skupień o małej wielkości. Zob. szerzej: A. S tanis z, Przystępny kurs statystyki z zastosowaniem STATISTICA PL na przyktadach medycyny. Tom 3. Analizy wielowymiarowe, StatSoft Polska Sp. z o.o., Kraków 2007, s. 122.

${ }^{22}$ Zob. A. S t a n is z, op. cit., s. 115-116.

${ }^{23} \mathrm{Im}$ silniejszy związek między obiektami skupienia (czyli mniejsza odległość) według pewnej miary podobieństwa (w tym przypadku odległości euklidesowej), tym są mniejsze i bardziej spójne skupienia. Zatem na coraz wyższych poziomach znajdować się będą coraz to większe, mniej spójne skupienia. Por. C. N o w o ro 1, Analiza skupień w badaniach empirycznych. Rozmyte modele hierarchiczne, Wydawnictwo Naukowe PWN, Warszawa 1989, s. 137.

${ }^{24}$ Dokonane zostało grupowanie przedsiębiorstw, zaczynając od jednoelementowego skupiska, po takie, które łączny ze sobą wszystkie najbardziej do siebie podobne podmioty gospodarcze pod względem poziomu operacyjnego bezpieczeństwa finansowego osiąganego w latach 2004-2012, kończąc zaś na jednym, łączącym wszystkie badane spółki.

${ }^{25}$ Do celów opracowania przyjęto następujące założenia:

a) mniej niż 0,2 - to brak związku między badanymi zmiennymi,

b) 0,2-0,4 - to zależność jest wyraźna, ale niska,

c) $0,4-0,7 \quad-$ to zależność umiarkowana,

d) $0,7-0,9 \quad$ - to zależność znacząca,

e) powyżej 0,9 - to zależność bardzo silna.

S. Ostasiewicz, Z. Rusnak, U. Siedlecka, Statystyka. Elementy teorii $i$ zadania, Wydawnictwo Akademii Ekonomicznej im. Oskara Langego we Wrocławiu, Wrocław 2003, s. 311. 
Tabela 4.14. Macierz korelacji dla wartości syntetycznego miernika oceny operacyjnego bezpieczeństwa finansowego przedsiębiorstw sektora TSL w latach 2004-2012 $2^{26}$

\begin{tabular}{|c|c|c|c|c|c|c|c|c|c|}
\hline Wyszczególnienie & 2004 r. & 2005 r. & 2006 r. & 2007 r. & 2008 r. & 2009 r. & 2010 r. & 2011 r. & 2012 r. \\
\hline \hline 2004 r. & 1,00 & $\mathbf{0 , 7 2}$ & $\mathbf{0 , 6 1}$ & $\mathbf{0 , 5 6}$ & 0,20 & $\mathbf{0 , 5 6}$ & 0,33 & $\mathbf{0 , 3 8}$ & 0,36 \\
\hline 2005 r. & $\mathbf{0 , 7 2}$ & 1,00 & $\mathbf{0 , 6 0}$ & $\mathbf{0 , 7 0}$ & 0,34 & $\mathbf{0 , 7 4}$ & $\mathbf{0 , 4 5}$ & $\mathbf{0 , 4 7}$ & $\mathbf{0 , 5 7}$ \\
\hline 2006 r. & $\mathbf{0 , 6 1}$ & $\mathbf{0 , 6 0}$ & 1,00 & $\mathbf{0 , 8 0}$ & $\mathbf{0 , 4 3}$ & $\mathbf{0 , 5 2}$ & $\mathbf{0 , 4 5}$ & $\mathbf{0 , 4 9}$ & $\mathbf{0 , 5 1}$ \\
\hline 2007 r. & $\mathbf{0 , 5 6}$ & $\mathbf{0 , 7 0}$ & $\mathbf{0 , 8 0}$ & 1,00 & $\mathbf{0 , 6 3}$ & $\mathbf{0 , 5 6}$ & $\mathbf{0 , 5 1}$ & $\mathbf{0 , 5 8}$ & $\mathbf{0 , 6 5}$ \\
\hline 2008 r. & 0,20 & 0,34 & $\mathbf{0 , 4 3}$ & $\mathbf{0 , 6 3}$ & 1,00 & $\mathbf{0 , 4 1}$ & $\mathbf{0 , 6 2}$ & $\mathbf{0 , 6 3}$ & $\mathbf{0 , 6 4}$ \\
\hline 2009 r. & $\mathbf{0 , 5 6}$ & $\mathbf{0 , 7 4}$ & $\mathbf{0 , 5 2}$ & $\mathbf{0 , 5 6}$ & $\mathbf{0 , 4 1}$ & 1,00 & $\mathbf{0 , 5 8}$ & $\mathbf{0 , 5 8}$ & $\mathbf{0 , 6 8}$ \\
\hline 2010 r. & 0,33 & $\mathbf{0 , 4 5}$ & $\mathbf{0 , 4 5}$ & $\mathbf{0 , 5 1}$ & $\mathbf{0 , 6 2}$ & $\mathbf{0 , 5 8}$ & 1,00 & $\mathbf{0 , 9 0}$ & $\mathbf{0 , 6 9}$ \\
\hline 2011 r. & $\mathbf{0 , 3 8}$ & $\mathbf{0 , 4 7}$ & $\mathbf{0 , 4 9}$ & $\mathbf{0 , 5 8}$ & $\mathbf{0 , 6 3}$ & $\mathbf{0 , 5 8}$ & $\mathbf{0 , 9 0}$ & 1,00 & $\mathbf{0 , 7 1}$ \\
\hline 2012 r. & 0,36 & $\mathbf{0 , 5 7}$ & $\mathbf{0 , 5 1}$ & $\mathbf{0 , 6 5}$ & $\mathbf{0 , 6 4}$ & $\mathbf{0 , 6 8}$ & $\mathbf{0 , 6 9}$ & $\mathbf{0 , 7 1}$ & 1,00 \\
\hline
\end{tabular}

* Pogrubioną czcionką oznaczone zostały wartości współczynników korelacji rang Spearmana istotne dla $\mathrm{p}<0,05$.

Źródło: obliczenia własne na podstawie danych zebranych w Krajowym Rejestrze Sądowym w Warszawie przy wykorzystaniu programu Taksonomia numeryczna i Statistica 10.

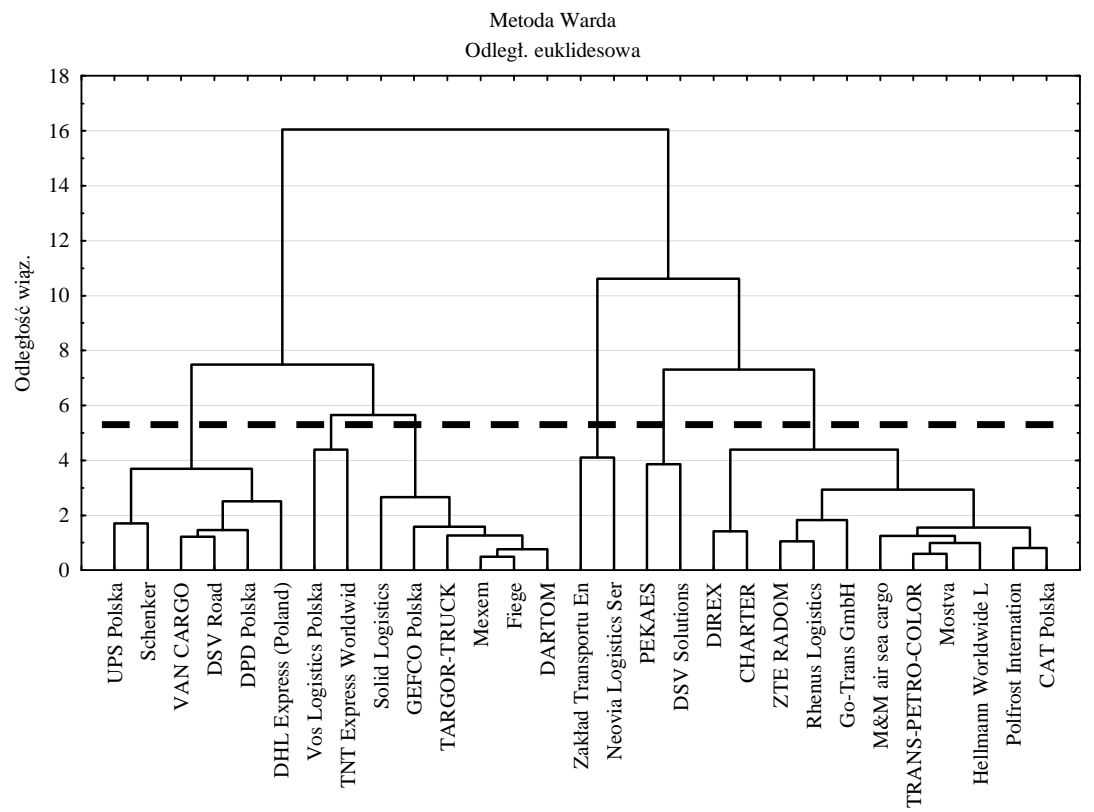

Schemat 4.1 . Dendogram spółek sektora TSL według wartości syntetycznego miernika oceny operacyjnego bezpieczeństwa finansowego w latach 2004-2012

Źródło: obliczenia własne na podstawie danych zebranych w Krajowym Rejestrze Sądowym w Warszawie przy wykorzystaniu programu Taksonomia numeryczna i Statistica 10.

${ }^{26}$ Wyniki macierzy uzyskano dzięki wykorzystaniu współczynnika korelacji rang Spearmana. 
Pomocnym przy ustaleniu tego, na której odległości wiązania należy odciąć dendogram ( $\mathrm{tj}$. do wyłonienia homogenicznych grup podmiotów gospodarczych) okazał się wykres prezentujący odległości wiązań względem kolejnych etapów wiązania przedsiębiorstw (zob. wykres 4.9). Na jego podstawie wyłonionych zostało 6 skupień:

a) skupienie nr 1 - UPS Polska Sp. z o.o., Schenker Sp. z o.o., VAN CARGO SA, DSV Road Sp. z o.o., DPD Polska Sp. z o.o. oraz DHL Express (Poland) Sp. z o.o.,

b) skupienie nr 2 - VOS Logistics Polska Sp. z o.o. i TNT Express Worldwide (Poland) Sp. z o.o.,

c) skupienie nr 3 - Solid Logistics Sp. z o.o., GEFCO Polska Sp. z o.o., TARGOR-TRUCK Sp. z o.o., Mexem Sp. z o.o., Fiege Sp. z o.o. oraz DARTOM Sp. z o.o.,

d) skupienie nr 4 - Zakład Transportu Energetyki „ZTiSZE” Sp. z o.o. i Neovia Logistics Services Polska Sp. z o.o.,

e) skupienie nr 5 - PEKAES SA oraz DSV Solutions Sp. z o.o.,

f) skupienie nr 6 - DIREX Sp. z o.o., CHARTER Sp. z o.o., ZTE RADOM Sp. z o.o., Rhenus Logistics SA, Go-Trans GmbH Sp. z o.o., M\&M air sea cargo SA, TRANS-PETRO-COLOR Sp. z o.o., Mostva Sp. z o.o., Hellmann Worldwide Logistics Polska Sp. z o.o. Sp. Komandytowa, Polfrost Internationale Spedition Sp. z o.o. oraz CAT Polska Sp. z o.o.

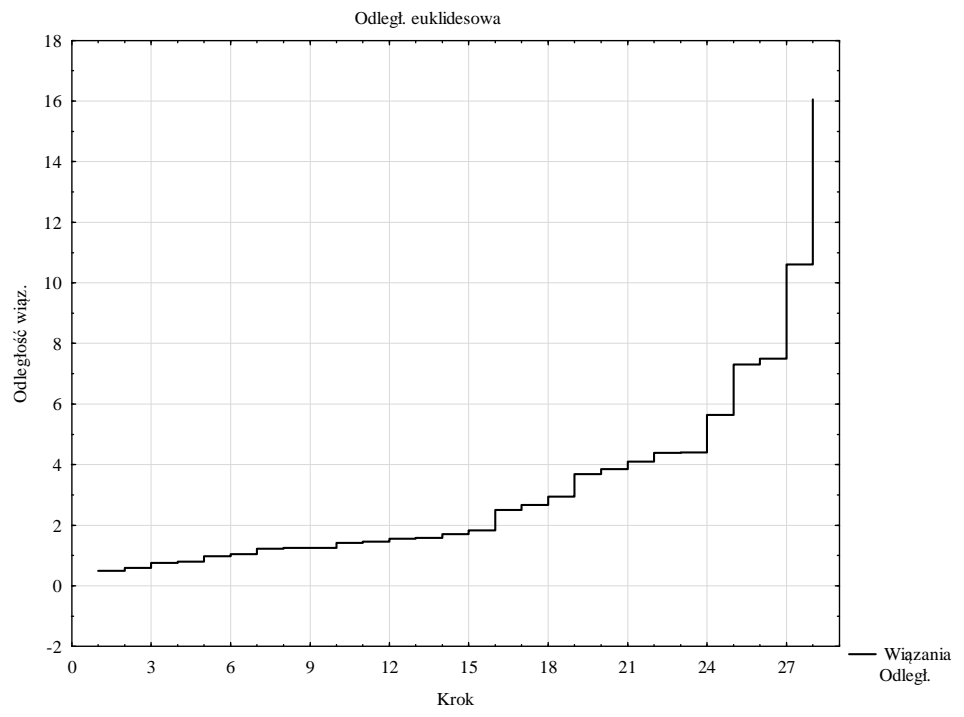

Wykres 4.9. Wykres odległości wiązania względem etapów wiązania przedsiębiorstw

Źródło: opracowanie własne na podstawie danych zebranych w Krajowym Rejestrze Sądowym w Warszawie przy wykorzystaniu programu Taksonomia numeryczna i Statistica 10. 
Pewne przedsiębiorstwa, dla przykładu Mexem Sp. z o.o. oraz Fiege Sp. z o.o., w całym badanym okresie osiągały niemal identyczny poziom operacyjnego bezpieczeństwa finansowego (zob. tab. 4.3). Wobec tego zostały one połączone w pary już w pierwszych krokach grupowania.

W najgorszym położeniu pod względem średniego poziomu analizowanej metacechy - znalazły się spółki ze skupienia $\mathrm{nr} 4$, grupujące 2 przedsiębiorstwa, których głównym źródłem przychodu netto ze sprzedaży było odpowiednio świadczenie usług transportowych i logistycznych. W nieco lepszym sytuacji znajdowały się podmioty gospodarcze zgrupowane w skupieniu nr 5 (także składającego się z dwóch spółek świadczących ten sam rodzaj usług), choć zarówno średnia, jak i środkowa wartość badanej zmiennej kształtowała się znacznie poniżej wartości osiąganej przez jednostki gospodarcze wchodzące w skład skupienia nr 1 lub 2 (zob. wykres 4.10). Pierwsze skupienie reprezentowane było przez 3 z 4 spółek kurierskich wchodzących w skład próby badawczej, a ponadto odpowiednio przez 2 spółki spedycyjne i 1 spółkę logistyczną.

Przedsiębiorstwa ze skupienia $\mathrm{nr} 2 \mathrm{w}$ latach 2004-2006 i 2009 r. oraz ze skupienia $\mathrm{nr} 1 \mathrm{w}$ latach 2007-2008 i 2010-2012 uzyskiwały najwyższy średni poziom operacyjnego bezpieczeństwa finansowego przedsiębiorstw sektora TSL, zaś najczęściej najniższy - ze skupienia $\mathrm{nr}$ 4. W całym analizowanym okresie maksymalny poziom badanej zmiennej pojawił się w 2008 r. dla homogenicznej grupy podmiotów gospodarczych ze skupienia o nr 1,3, 5 i 6, dla skupienia o nr 2 i 4 z kolei w 2004 r. Ponadto w całym badanym okresie wykazywał on bardzo zróżnicowane tempo wzrostu/spadku. Dla przykładu średni poziom operacyjnego bezpieczeństwa finansowego dla spółek ze skupienia nr 1 i 6 wykazał z roku na rok naprzemiennie tendencję wzrostową i spadkową (zob. wykres 4.11).

Ta b e la 4.15. Podstawowe statystyki opisowe syntetycznego miernika oceny operacyjnego bezpieczeństwa finansowego dla homogenicznych grup przedsiębiorstw sektora TSL w latach 2004-2012

\begin{tabular}{|l|c|c|c|c|}
\hline \multicolumn{1}{|c|}{ Wyszczególnienie } & Średnia & Mediana & Maksimum & Minimum \\
\hline \hline Skupienie nr 1 & 0,6531 & 0,6371 & 0,9778 & 0,5061 \\
\hline Skupienie nr 2 & 0,5757 & 0,5930 & 0,8077 & 0,2397 \\
\hline Skupienie nr 3 & 0,5860 & 0,5849 & 0,7375 & 0,4161 \\
\hline Skupienie nr 4 & 0,3687 & 0,3803 & 0,5459 & 0,1522 \\
\hline Skupienie nr 5 & 0,4692 & 0,5066 & 0,6934 & 0,1735 \\
\hline Skupienie nr 6 & 0,5307 & 0,5243 & 0,6994 & 0,2322 \\
\hline
\end{tabular}

Źródło: jak do tab. 4.14. 


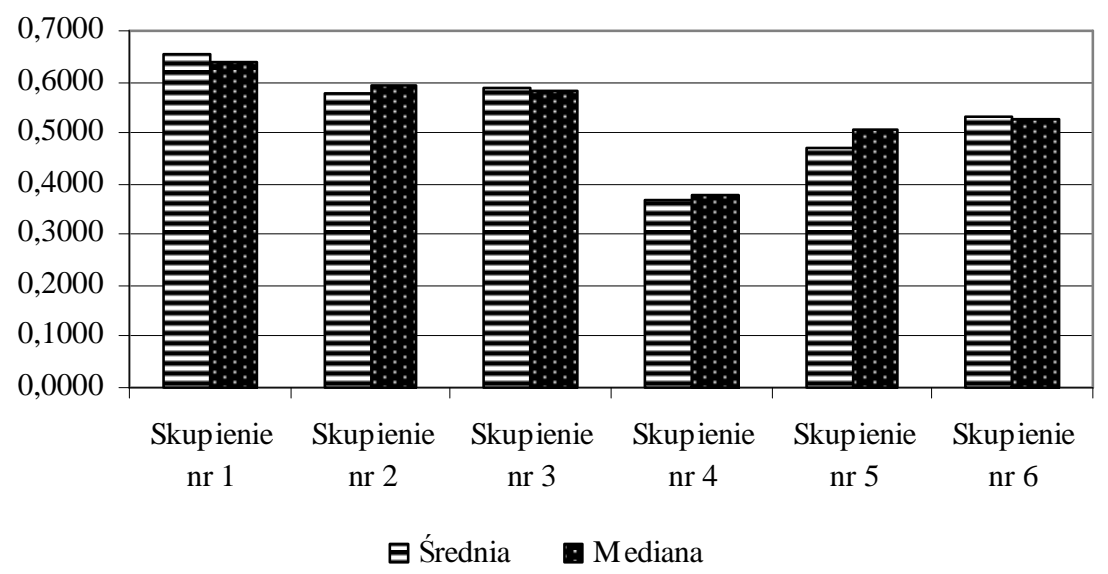

Wykres 4.10. Średnia i środkowa wartość syntetycznego miernika oceny operacyjnego bezpieczeństwa finansowego dla jednorodnych grup podmiotów gospodarczych sektora TSL

Źródło: obliczenia własne na podstawie danych zebranych w Krajowym Rejestrze Sądowym w Warszawie przy wykorzystaniu programu Taksonomia numeryczna, Statistica 10 i Microsoft Excel.

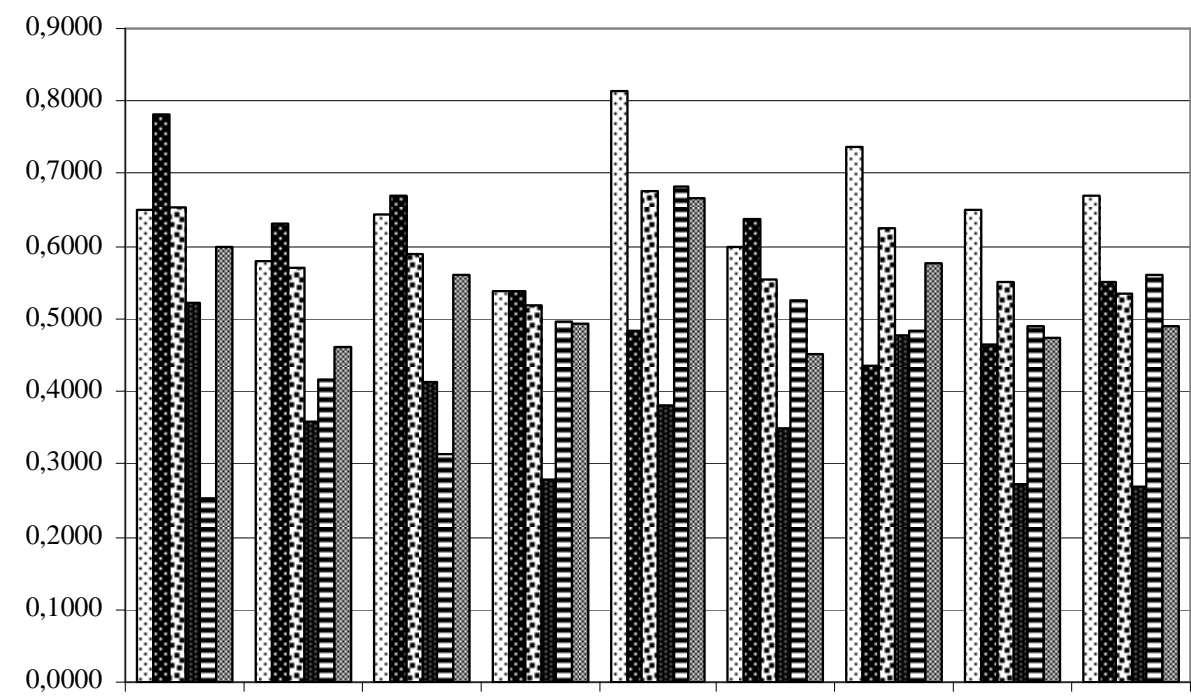

2004 rok 2005 rok 2006 rok 2007 rok 2008 rok 2009 rok 2010 rok 2011 rok 2012 rok

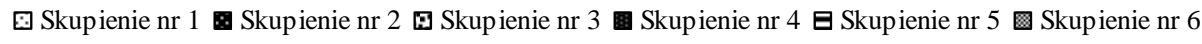

Wykres 4.11. Średni poziom operacyjnego bezpieczeństwa finansowego w poszczególnych latach poddanych analizie dla homogenicznych grup przedsiębiorstw sektora TSL

Źródło: jak do wyk. 4.10. 
Zaprezentowane w tab. 4.16 wyniki badań wskazują, iż wystąpiły statystycznie istotne różnice dla wartości syntetycznego miernika oceny operacyjnego bezpieczeństwa finansowego (na poziomie istotności 0,05 ) między homogenicznymi - wyodrębnionymi w niniejszym opracowaniu - 6 grupami przedsiębiorstw.

Tabela 4.16. Poziom istotności różnic między homogenicznymi grupami przedsiębiorstw dla wartości syntetycznego miernika oceny operacyjnego bezpieczeństwa finansowego spółek sektora TSL* (próba niezależna)

\begin{tabular}{|c|c|c|c|c|c|c|c|c|c|}
\hline Wyszczególnienie & 2004 r. & 2005 r. & 2006 r. & 2007 r. & 2008 r. & 2009 r. & 2010 r. & 2011 r. & 2012 r. \\
\hline \hline Istotność asymptotyczna &, 005 &, 002 &, 008 &, 015 &, 004 &, 001 &, 001 &, 001 &, 001 \\
\hline
\end{tabular}

* Kolorem zaznaczone są istotne różnice przy poziomie istotności 0,05.

Źródło: obliczenia własne na podstawie danych zebranych w Krajowym Rejestrze Sądowym w Warszawie przy wykorzystaniu programu Taksonomia numeryczna i SPSS Statistics (wersja 22).

Przeprowadzona analiza POST-HOC ${ }^{27}$ wykazała, iż w 2004 r. wartość syntetycznego miernika oceny operacyjnego bezpieczeństwa finansowego dla przedsiębiorstw należących do skupienia nr 2, zaś w latach 2007-2012 tych należących do skupienia $\mathrm{nr} 1$ istotnie różniła się od jego wartości dla spółek odpowiednio skupienia nr 5, a także o numerach 4 i 6 (zob. tab. 4.17).

Średnie rangi uzyskane w trakcie analizy wykazały, iż to głównie podmioty gospodarcze ze skupienia nr 4 i 6 osiągały istotnie różny (niższy) poziom operacyjnego bezpieczeństwa finansowego w relacji do tych przedsiębiorstw, które zostały zaklasyfikowane do skupienia $\mathrm{nr} 1$.

W skupieniu $\mathrm{nr} 4$ zostały zgrupowane jedynie 2 spółki (jedna prowadząca głównie działalność transportową, a druga - logistyczną), z kolei w skupieniu nr 6 - odpowiednio 6,3 i 2 przedsiębiorstwa transportowe, logistyczne oraz spedycyjne.

Podsumowując można wskazać, że występowanie statystycznych istotnie różnic dla wartości syntetycznego miernika oceny operacyjnego bezpieczeństwa finansowego dotyczy głównie podmiotów gospodarczych ze skupienia nr 4 i 6 (prowadzących przede wszystkim działalność transportową i logistyczną), które to charakteryzowały się najczęściej najniższym poziomem analizowanego zjawiska, różniącym się znacznie od poziomu operacyjnego bezpieczeństwa finansowego przedsiębiorstw wchodzących w skład skupienia $\mathrm{nr} 1$ (składającego się w $50 \%$ ze spółek kurierskich).

\footnotetext{
${ }^{27} \mathrm{Tj}$. analiza szczegółowa.
} 
Tabela 4.17. Średnia ranga dla istotnie różnych wartości syntetycznego miernika oceny operacyjnego bezpieczeństwa finansowego między homogenicznymi grupami spółek sektora TSL*

\begin{tabular}{|c|c|}
\hline Wyszczególnienie ${ }^{* *}$ & Średnia ranga \\
\hline 2004 r. & $\begin{array}{cc}\text { S5 } 5 \text { vs } S 2 \\
(1,50) \quad(28,00) \\
\end{array}$ \\
\hline $2007 \mathrm{r}$. & $\begin{array}{c}\text { S4 vs S1 } \\
(1,50) \quad(22,83)\end{array}$ \\
\hline $2008 \mathrm{r}$. & $\begin{array}{c}\text { S4 vs S1 } \\
(2,50) \quad(25,67)\end{array}$ \\
\hline 2009 r. & $\begin{array}{c}\mathrm{S} 4 \text { vs } \mathrm{S} 1 \\
(3,00) \quad(24,00) \\
\mathrm{S} 6 \text { vs } \mathrm{S} 1 \\
(8,91) \quad(24,00) \\
\end{array}$ \\
\hline $2010 \mathrm{r}$. & $\begin{array}{c}\text { S4 vs } S 1 \\
(3,50) \quad(26,50) \\
\text { S6 vs } S 1 \\
(11,00) \quad(26,50)\end{array}$ \\
\hline $2011 \mathrm{r}$. & $\begin{array}{c}\text { S4 vs } S 1 \\
(1,50) \quad(26,00) \\
\text { S6 vs } S 1 \\
(10,64) \quad(26,00)\end{array}$ \\
\hline $2012 \mathrm{r}$. & $\begin{array}{c}\text { S4 vs } S 1 \\
(1,50) \quad(26,00) \\
\text { S6 vs } S 1 \\
(9,64) \quad(26,00)\end{array}$ \\
\hline
\end{tabular}

* Kolorem zaznaczone są istotne różnice przy poziomie istotności 0,05.

** Lata 2005-2006 zostały pominięte, bowiem analiza POST-HOC wykazała na występowanie istotnych różnić przy poziomie istotności 0,10 .

Źródło: jak do tab. 4.16.

\subsection{Analiza zależności między syntetycznym miernikiem oceny operacyjnego bezpieczeństwa finansowego a poziomem dywersyfikacji działalności gospodarczej spółek sektora TSL}

Wyniki badań zawarte $\mathrm{w}$ rozdziale drugim monografii wskazały $\mathrm{m}$. in. na występowanie dywersyfikacji działalności gospodarczej w przedsiębiorstwach sektora TSL i tym samym na możliwość zmniejszenia zagrożenia finansowego tych jednostek gospodarczych ${ }^{28}$. Poziom dywersyfikacji powinien być zatem

${ }^{28}$ M. Gruszczyński, Empiryczne finanse przedsiębiorstw. Mikroekonomia finansowa, Difin SA \& Marek Gruszczyński, Warszawa 2012, s. 131. 
ujemnie skorelowany z zagrożeniem finansowym, a tym samym pozytywnie $-\mathrm{z}$ bezpieczeństwem finansowym.

Stawiając do weryfikacji empirycznej hipotezę badawczą stanowiącą, iż wzrostowi dywersyfikacji dziatalności towarzyszy wzrost poziomu operacyjnego bezpieczeństwa finansowego przedsiębiorstw sektora TSL, zasadniczą część badań oparto na analizie współczynnika korelacji rang Spearmana między syntetycznym miernikiem oceny operacyjnego bezpieczeństwa finansowego a liczbą grup PKD 2007 ogółem i liczbą grup PKD 2007 jedynie w sekcji ,Transport i gospodarka magazynowa" ${ }^{, 29}$ (zob. tab. 4.3 i zał. 5).

Wyniki przeprowadzonych badań empirycznych nad poziomem i charakterem zależności między analizowanymi zmiennymi jednoznacznie wskazują, iż - za wyjątkiem 2004, 2006 i 2007 r. - nie można mówić o występowaniu współzależności między analizowaną metacecha a liczbą grup PKD 2007 (zob. tab. 4.18$)^{30}$.

Tabela 4.18. Współczynnik korelacji rang Spearmana między liczbą grup PKD 2007 a wartością syntetycznego miernika oceny operacyjnego bezpieczeństwa finansowego przedsiębiorstw sektora TSL $^{31}$

\begin{tabular}{|c|c|c|c|c|c|c|c|c|c|}
\hline $\begin{array}{c}\text { Wyszczegól- } \\
\text { nienie }\end{array}$ & 2004 r. & 2005 r. & 2006 r. & 2007 r. & 2008 r. & 2009 r. & 2010 r. & 2011 r. & 2012 r. \\
\hline \hline $\begin{array}{c}\text { Współczynnik } \\
\text { korelacji rang } \\
\text { Spearmana }\end{array}$ & $-0,345$ & $-0,128$ & $-0,255$ & $-0,214$ & $-0,074$ & 0,004 & 0,147 & 0,187 & $-0,002$ \\
\hline
\end{tabular}

Źródło: obliczenia własne na podstawie danych zebranych w Krajowym Rejestrze Sądowym w Warszawie przy wykorzystaniu programu Taksonomia numeryczna i Statistica 10.

Współczynnik korelacji rang Spearmana między liczbą grup PKD 2007 w sekcji „Transport i gospodarka magazynowa” a wartością syntetycznego miernika oceny operacyjnego bezpieczeństwa finansowego przedsiębiorstw sektora TSL jedynie w latach 2005 i 2009-2011 wskazywał na niską zależność (zob. tab. 4.19) ${ }^{32}$. W pozostałych analizowanych latach występował brak współzależności między tymi miernikami.

Najwyższy poziom spreadu między obliczonymi współczynnikami korelacji rang Spearmana wystąpił odpowiednio w 2004 r. (tj. 0,519) i 2005 r. (tj. 0,505), najniższy zaś - w 2012 r. (tj. 0,068). Bez względu przeto na fakt, czy w 2012 r. działalność byłaby wykonywana przez spółki sektora TSL jedynie w sekcji

${ }^{29}$ Liczbą grup PKD, która wykazywana była przez badane spółki sektora TSL w dokumentacji składanej do Krajowego Rejestru Sądowego w Warszawie.

${ }^{30}$ Zob. S. Ostasi e wi c z, Z. Rusnak, U. Si ed lecka,op. cit., s. 311.

${ }^{31}$ Wartości współczynników korelacji rang Spearmana są nieistotne dla $\mathrm{p}<0,05$.

${ }^{32}$ Zob. S. O st a si e wi c z, Z. Ru sn ak, U. Si ed le ck ka, op. cit., s. 311. 
„Transport i gospodarka magazynowa”, czy też również poza nią - współzależność (a dokładniej jej brak) z miernikiem operacyjnego bezpieczeństwa finansowego tychże podmiotów gospodarczych kształtowała się niemal na jednakowym poziomie.

Tabela 4.19. Współczynnik korelacji rang Spearmana między liczbą grup PKD 2007 w sekcji „Transport i gospodarka magazynowa” a wartością syntetycznego miernika oceny operacyjnego bezpieczeństwa finansowego przedsiębiorstw sektora $\mathrm{TSL}^{33}$

\begin{tabular}{|c|c|c|c|c|c|c|c|c|c|}
\hline Wyszczególnienie & 2004 r. & 2005 r. & 2006 r. & 2007 r. & 2008 r. & 2009 r. & 2010 r. & 2011 r. & 2012 r. \\
\hline \hline $\begin{array}{c}\text { Współczynnik korelacji } \\
\text { rang Spearmana }\end{array}$ & 0,174 & 0,377 & 0,126 & 0,118 & 0,150 & 0,220 & 0,220 & 0,345 & 0,066 \\
\hline
\end{tabular}

Źródło: jak do tab. 4.18 .

Na podstawie zaprezentowanych wyników należy zatem odrzucić sformułowaną hipotezę badawczą stanowiącą, iż wzrostowi dywersyfikacji działalności towarzyszy wzrost poziomu operacyjnego bezpieczeństwa finansowego przedsiębiorstw sektora TSL.

Bliski zeru poziom badanej zależności stał się kluczową determinantą podjętych w monografii rozważań nad optymalizacją pakietu usług świadczonych przez przedsiębiorstwa sektora TSL ${ }^{34}$. Przeprowadzona została $\mathrm{w}$ tym celu analiza rozkładu badanych spółek według poziomu operacyjnego bezpieczeństwa finansowego oraz liczby grup PKD 2007 (odpowiednio liczby grup PKD 2007 w sekcji „Transport i gospodarka magazynowa”).

Analiza badanego zjawiska dotyczyła w szczególności 5 spółek o najwyższym i najniższym poziomie operacyjnego bezpieczeństwa finansowego (zob. wykresy od 4.12 do 4.20). W każdym $\mathrm{z}$ analizowanych lat wśród tych 10 podmiotów gospodarczych maksymalna liczba grup PKD 2007 została wykazana przez spółkę o najniższym poziomie operacyjnego bezpieczeństwa finansowego. Z kolei, analiza liczby grup PKD jedynie w sekcji „Transport i gospodarka magazynowa" wykazała odmienną tendencję (za wyjątkiem 2012 r.). Wśród tych 10 podmiotów gospodarczych najwyższa ich liczba w latach 2004-2009 i 2011 wystąpiła w spółce GEFCO Polska Sp. z o.o., zaś w 2010 r. w UPS Polska Sp. z o.o. (zob. tab. 4.20), tj. w jednostkach gospodarczych o najwyższym poziomie operacyjnego bezpieczeństwa finansowego.

\footnotetext{
${ }^{33}$ Wartości współczynników korelacji rang Spearmana są nieistotne dla $\mathrm{p}<0,05$.

${ }^{34}$ Por. http://nauka.money.pl/wnioski-o-dofinansowanie/konkurs-39/model-optymalizacjipakietu-uslug-logistycznych-swiadczonych-przez-przedsiebiorstwa-sektora-tsl-trasport-spedycjalogistyka-262738.html (dostęp: 26.05.2013).
} 


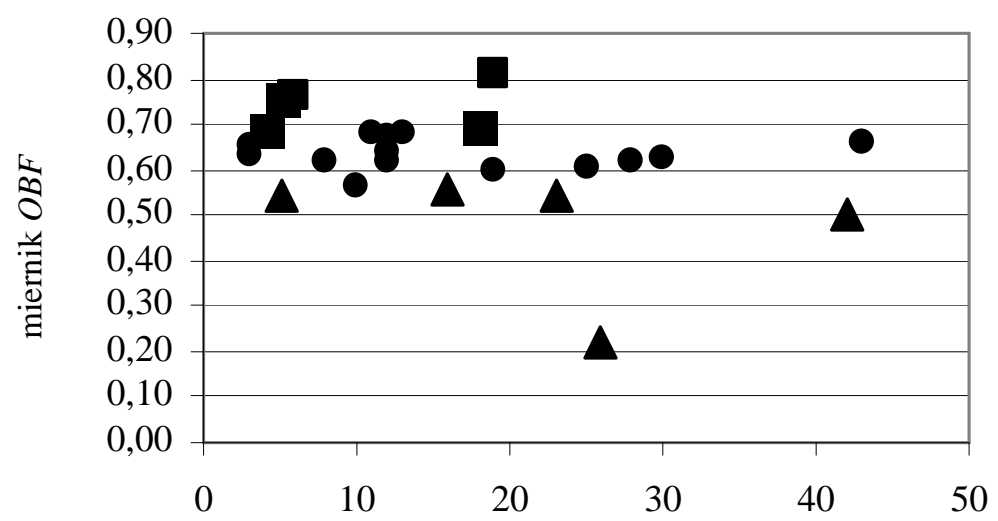

liczba grup PKD 2007

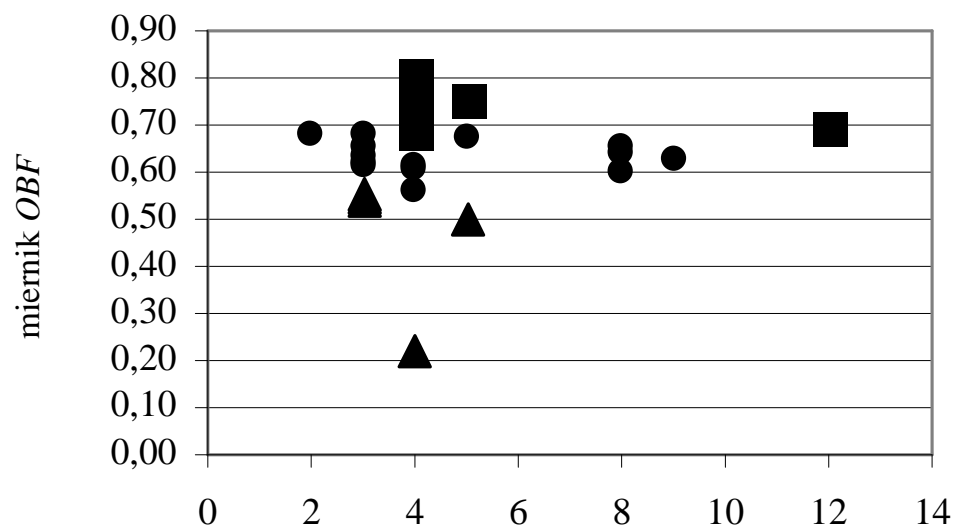

liczba grup PKD 2007 w sekcja H

* - zaznaczono 5 spółek sektora TSL o najwyższej wartości syntetycznego miernika oceny operacyjnego bezpieczeństwa finansowego.

$\boldsymbol{\Delta}$ - oznaczono 5 spółek sektora TSL o najniższej wartości syntetycznego miernika oceny operacyjnego bezpieczeństwa finansowego.

Wykres 4.12. Rozkład badanych spółek sektora TSL według liczby grup PKD 2007 (liczby grup PKD 2007 w sekcji ,Transport i gospodarka magazynowa”) i wartości syntetycznego miernika oceny operacyjnego bezpieczeństwa finansowego w 2004 r.**

Źródło: obliczenia własne na podstawie danych zebranych w Krajowym Rejestrze Sądowym w Warszawie przy wykorzystaniu programu Taksonomia numeryczna i Microsoft Excel. 


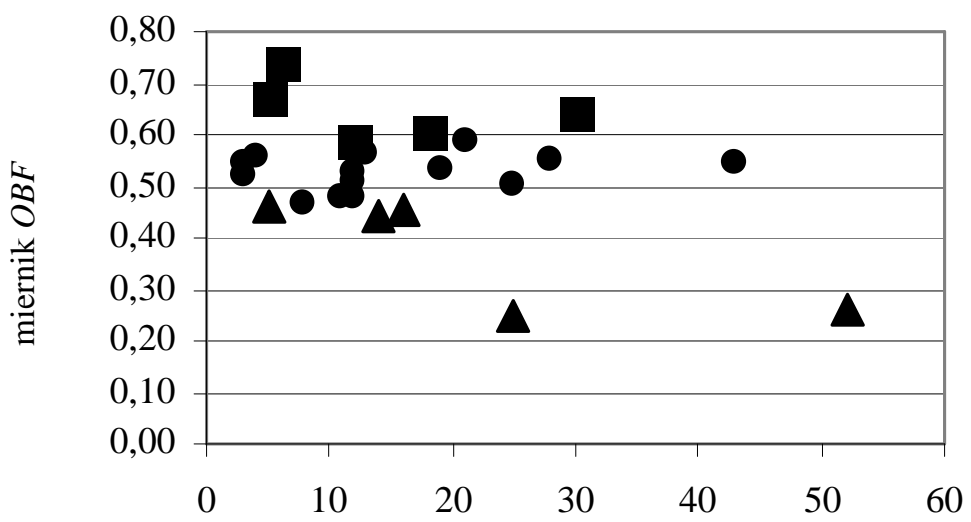

liczba grup PKD 2007

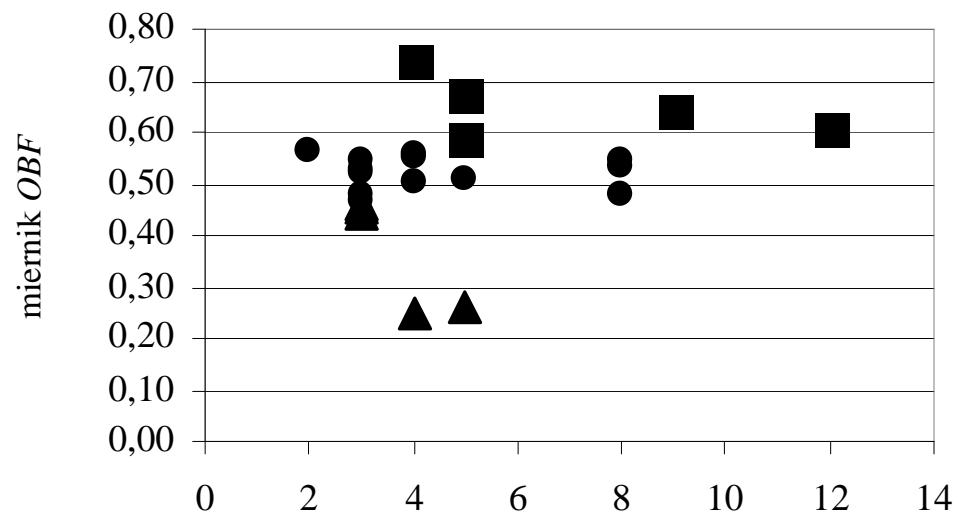

liczba grup PKD 2007 w sekcja H

* Oznaczenia jak do wykresu 4.12.

Wykres 4.13. Rozkład badanych spółek sektora TSL według liczby grup PKD 2007 (liczby grup PKD 2007 w sekcji ,Transport i gospodarka magazynowa”) i wartości syntetycznego miernika oceny operacyjnego bezpieczeństwa finansowego w 2005 r.* Źródło: jak do wykresu 4.12. 


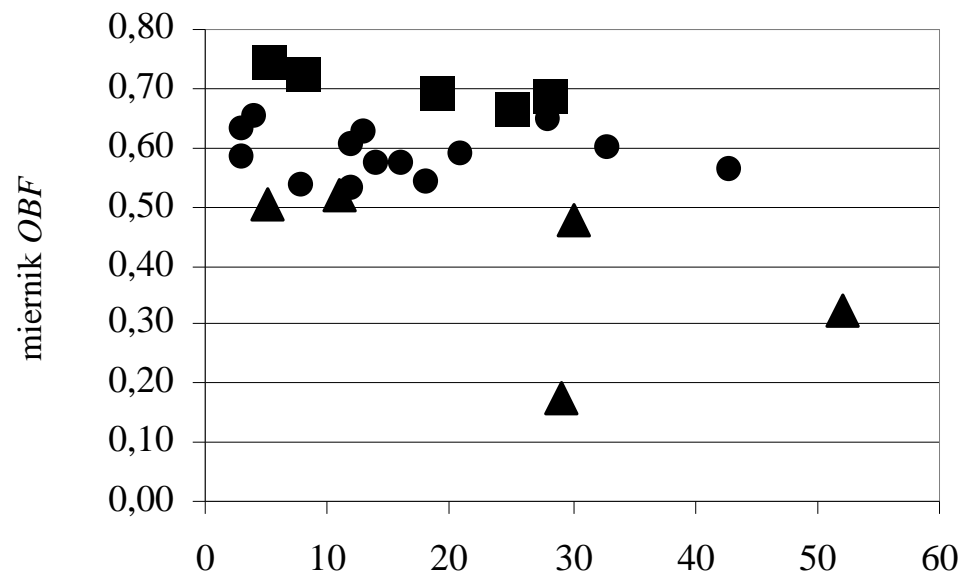

liczba grup PKD 2007

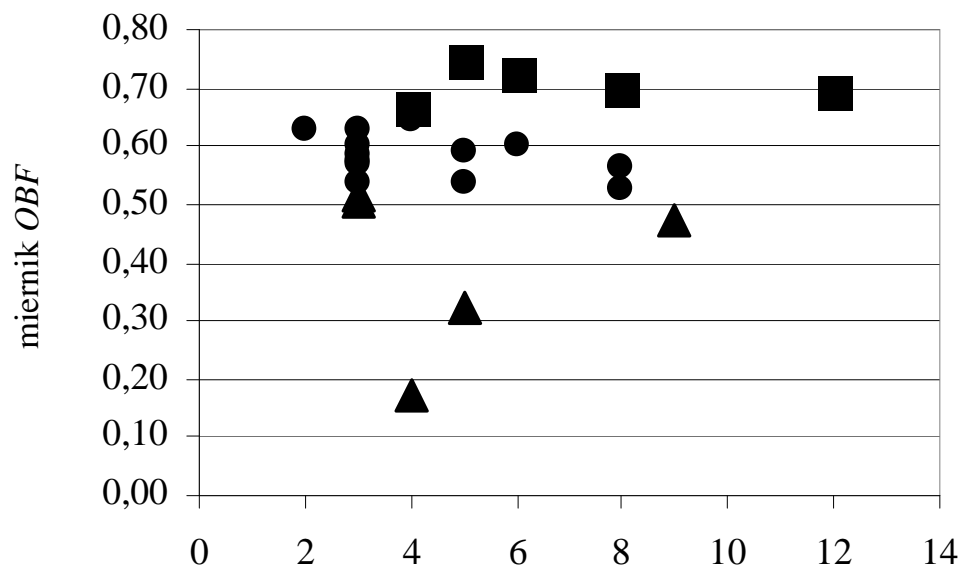

liczba grup PKD 2007 w sekcja H

* Oznaczenia jak do wykresu 4.12.

Wykres 4.14. Rozkład badanych spółek sektora TSL według liczby grup PKD 2007 (liczby grup PKD 2007 w sekcji ,Transport i gospodarka magazynowa”) i wartości syntetycznego miernika oceny operacyjnego bezpieczeństwa finansowego w 2006 r.*

Źródło: jak do wykresu 4.12. 


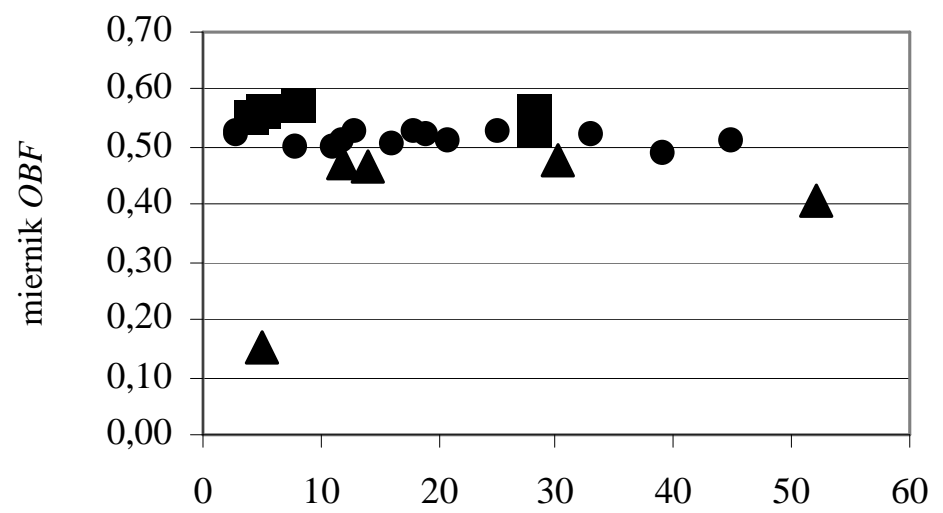

liczba grup PKD 2007

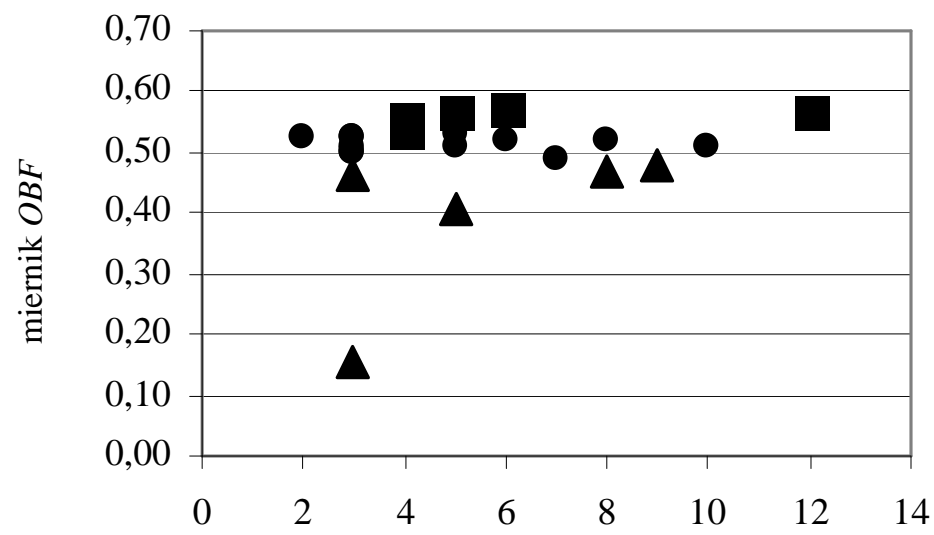

liczba grup PKD 2007 w sekcja H

* Oznaczenia jak do wykresu 4.12.

Wykres 4.15. Rozkład badanych spółek sektora TSL według liczby grup PKD 2007 (liczby grup PKD 2007 w sekcji „Transport i gospodarka magazynowa”) i wartości syntetycznego miernika oceny operacyjnego bezpieczeństwa finansowego w 2007 r.*

Źródło: jak do wykresu 4.12. 


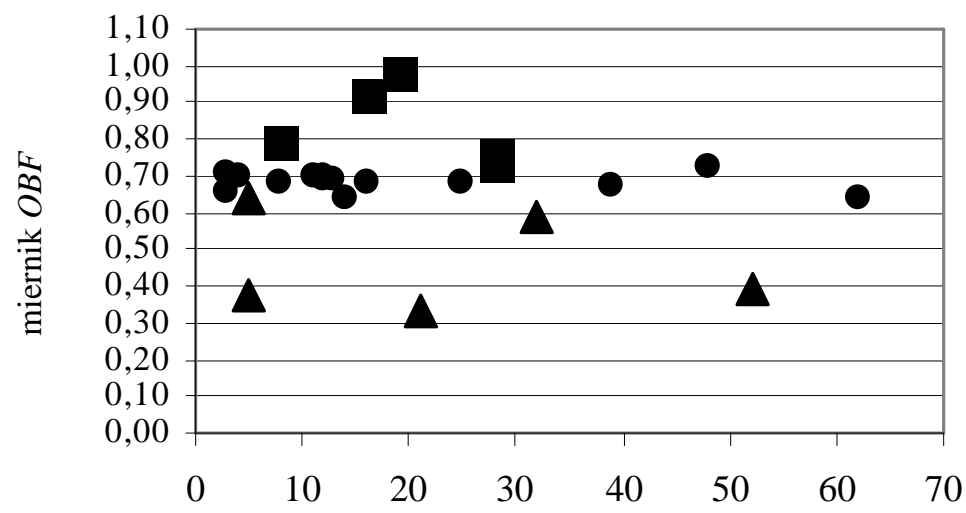

liczba grup PKD 2007

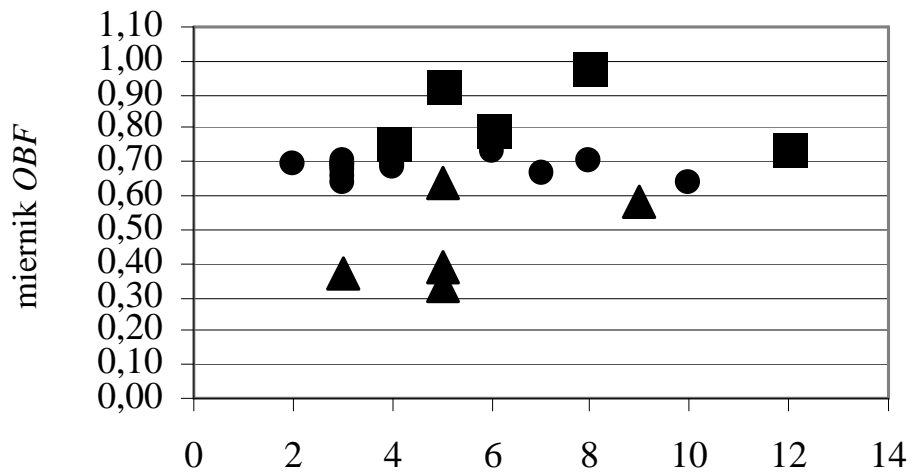

liczba grup PKD 2007 w sekcja H

* Oznaczenia jak do wykresu 4.12.

Wykres 4.16. Rozkład badanych spółek sektora TSL według liczby grup PKD 2007 (liczby grup PKD 2007 w sekcji ,Transport i gospodarka magazynowa”) i wartości syntetycznego miernika oceny operacyjnego bezpieczeństwa finansowego w 2008 r.*

Źródło: jak do wykresu 4.12. 


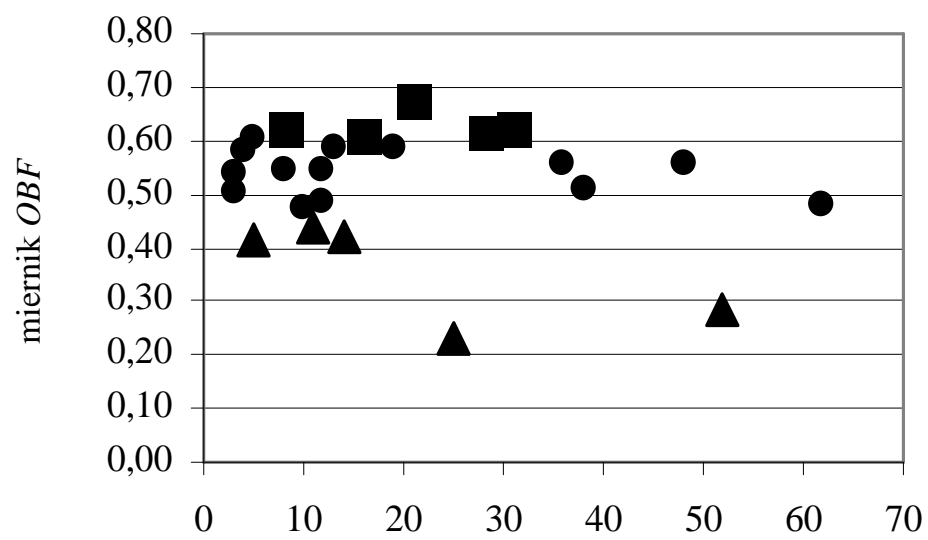

liczba grup PKD 2007

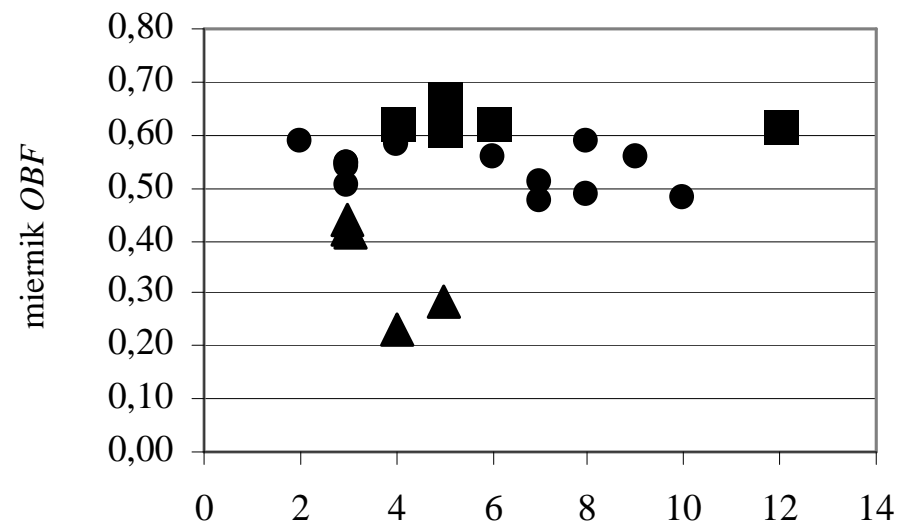

liczba grup PKD 2007 w sekcja H

* Oznaczenia jak do wykresu 4.12.

Wykres 4.17. Rozkład badanych spółek sektora TSL według liczby grup PKD 2007 (liczby grup PKD 2007 w sekcji ,Transport i gospodarka magazynowa”) i wartości syntetycznego miernika oceny operacyjnego bezpieczeństwa finansowego w 2009 r.*

Źródło: jak do wykresu 4.12. 


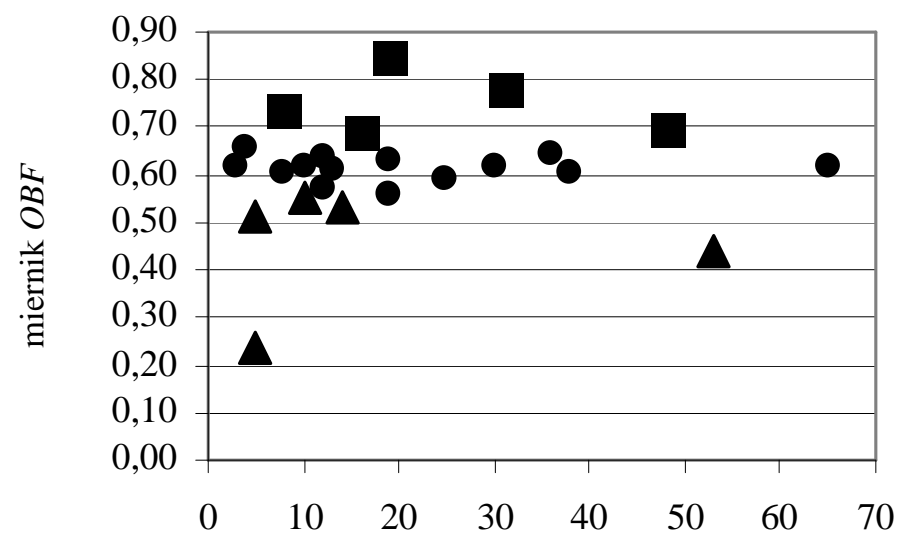

liczba grup PKD 2007

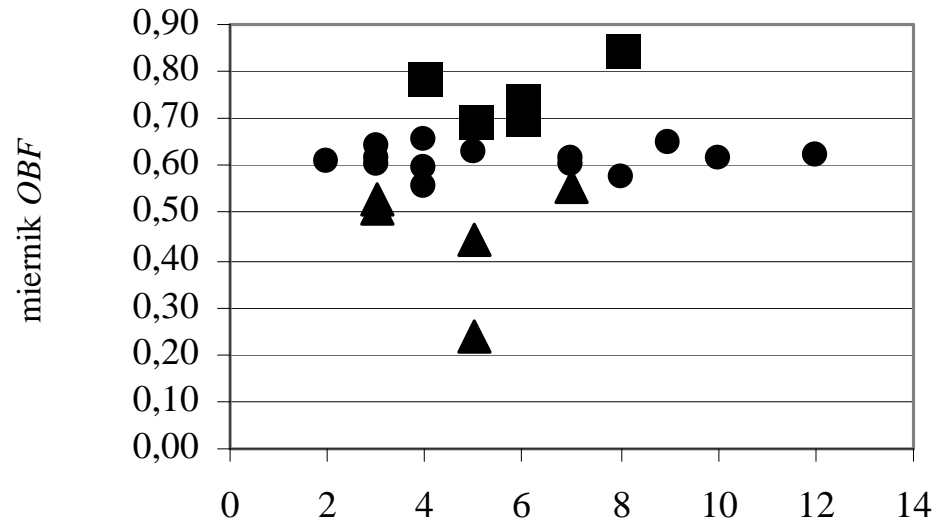

liczba grup PKD 2007 w sekcja H

* Oznaczenia jak do wykresu 4.12.

Wykres 4.18. Rozkład badanych spółek sektora TSL według liczby grup PKD 2007 (liczby grup PKD 2007 w sekcji ,Transport i gospodarka magazynowa”) i wartości syntetycznego miernika oceny operacyjnego bezpieczeństwa finansowego w 2010 r.*

Źródło: jak do wykresu 4.12. 


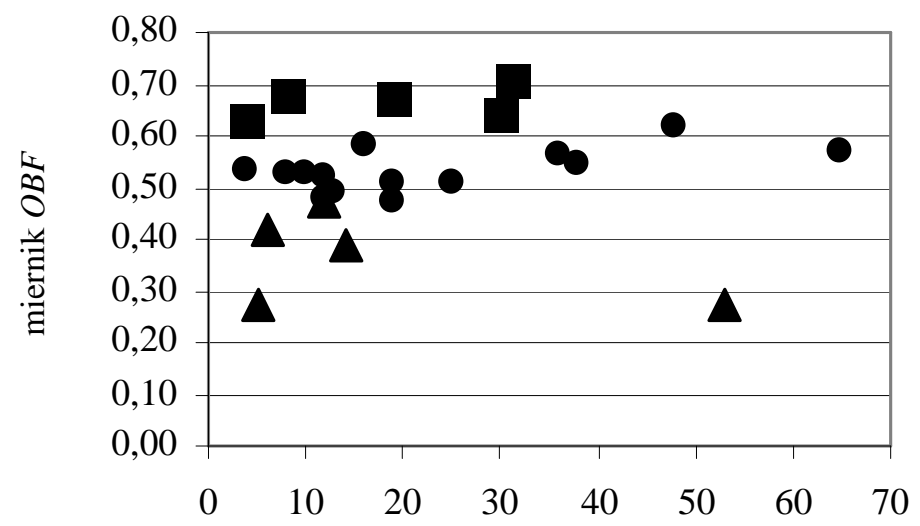

liczba grup PKD 2007

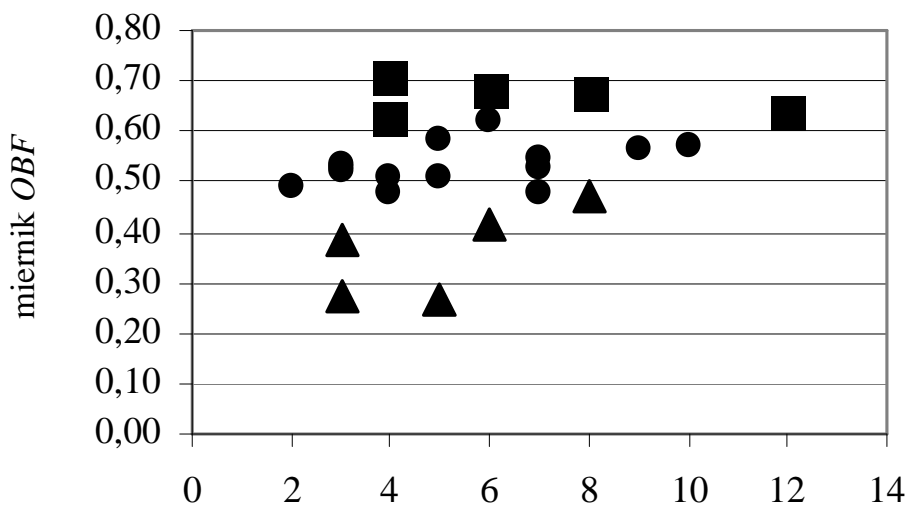

liczba grup PKD 2007 w sekcja H

* Oznaczenia jak do wykresu 4.12.

Wykres 4.19. Rozkład badanych spółek sektora TSL według liczby grup PKD 2007 (liczby grup PKD 2007 w sekcji „Transport i gospodarka magazynowa”) i wartości syntetycznego miernika oceny operacyjnego bezpieczeństwa finansowego w $2011 \mathrm{r}$.*

Źródło: jak do wykresu 4.12. 


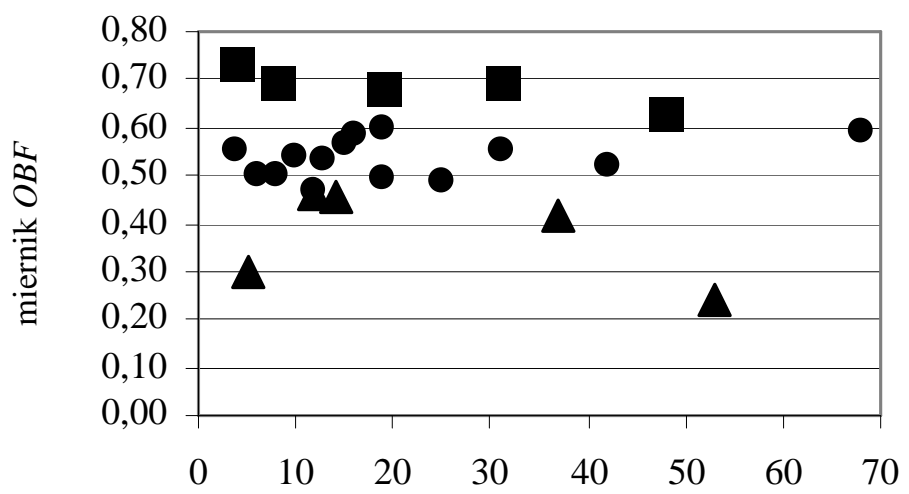

liczba grup PKD 2007

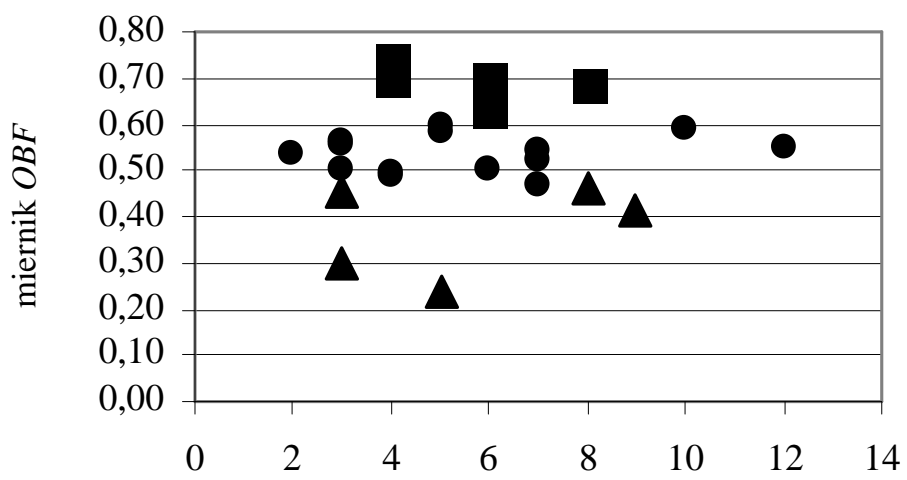

liczba grup PKD 2007 w sekcja H

* Oznaczenia jak do wykresu 4.12.

Wykres 4.20. Rozkład badanych spółek sektora TSL według liczby grup PKD 2007 (liczby grup PKD 2007 w sekcji ,Transport i gospodarka magazynowa”) i wartości syntetycznego miernika oceny operacyjnego bezpieczeństwa finansowego w 2012 r.**

Źródło: jak do wykresu 4.12. 


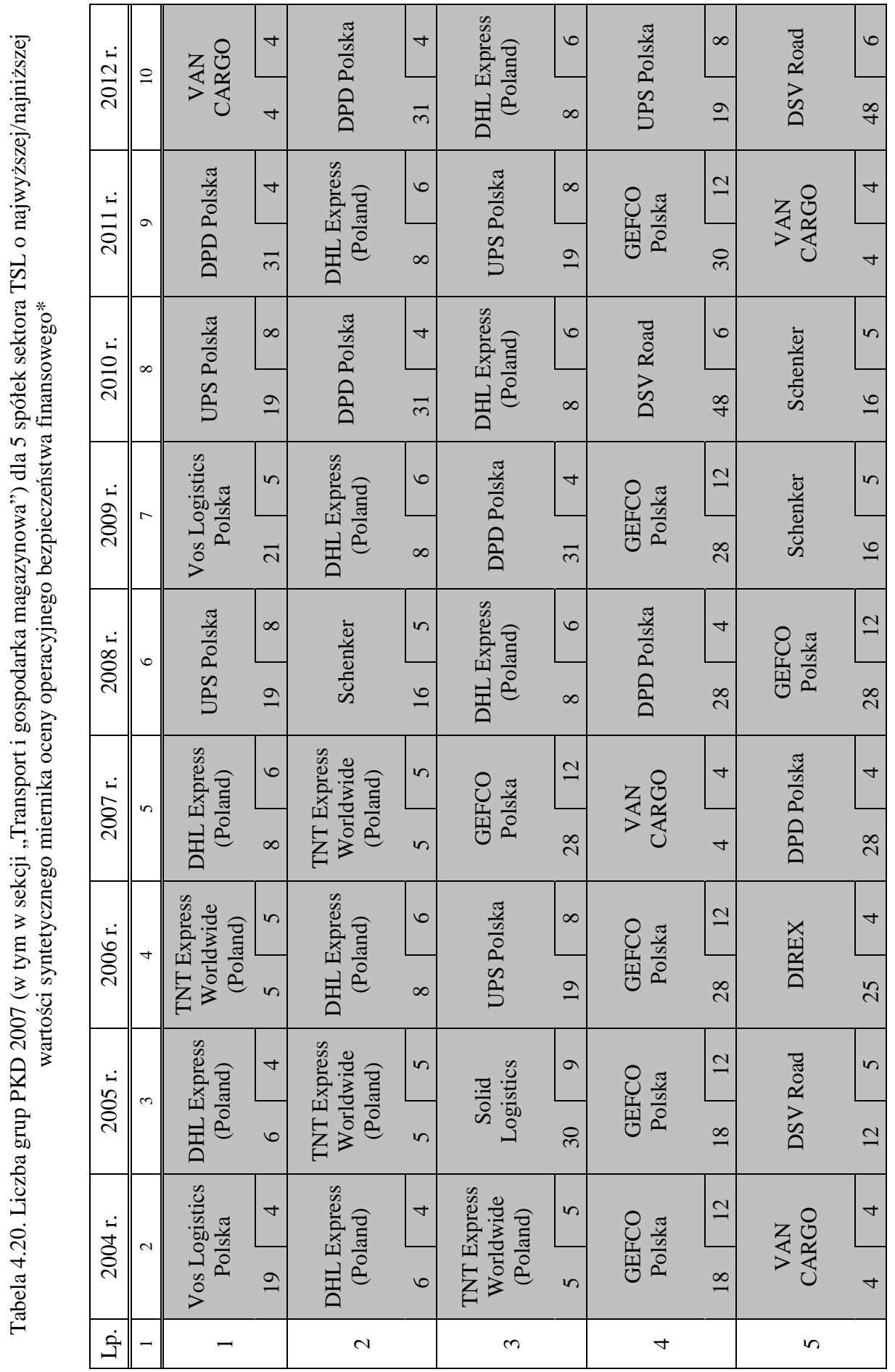




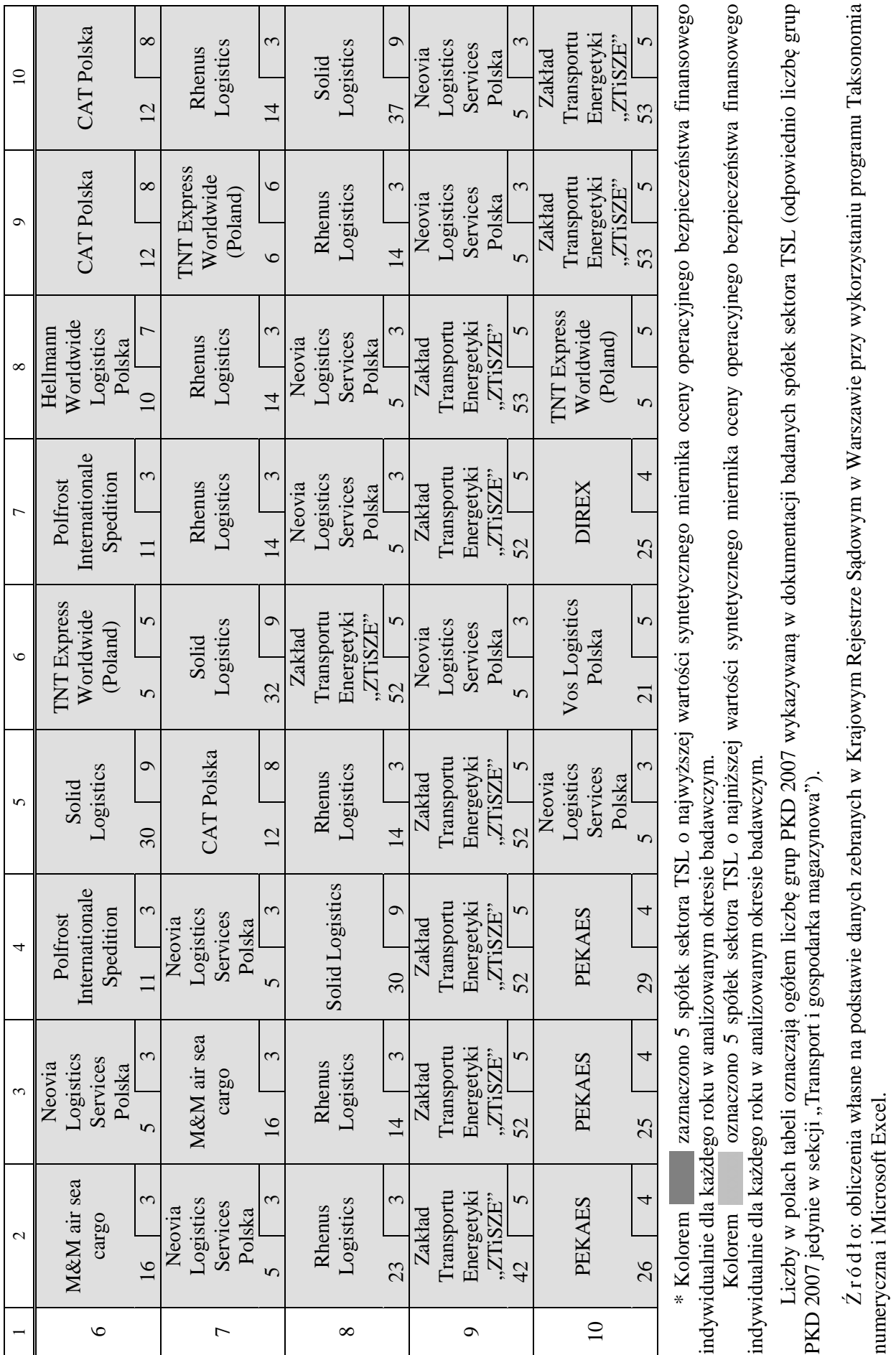


W przypadku pięciopodmiotowej grupy spółek sektora TSL o najwyższej wartości analizowanej metacechy, środkowa i średnia liczba grup PKD 2007 utrzymywała się na jednakowym poziomie. Ta grupa przedsiębiorstw wykazywała ponadto nieco wyższą średnią i środkową liczbę grup PKD w sekcji „Transport i gospodarka magazynowa” (zob. tab. 4.21), co świadczyło o większej dywersyfikacji działalności w sekcji ściśle związanej z prowadzoną przez nie zasadniczą usługową działalnością gospodarczą. W jej skład (za wyjątkiem spółki DIREX Sp. z o.o. w 2006 r.) wchodziły podmioty gospodarcze należące do wyłonionych we wcześniejszym etapie analizy skupień o numerach od 1 do 3 . W blisko $67 \%$ tej grupy w całym okresie badawczym były to spółki ze skupienia numer 1, stanowiąc w 2010 i 2012 r. 100\% tej pięciopodmiotowej grupy przedsiębiorstw.

Tabela 4.21. Podstawowe statystyki opisowe liczby grup PKD 2007 dla 5 spółek sektora TSL o najwyższej i najniższej wartości syntetycznego miernika oceny operacyjnego bezpieczeństwa finansowego w latach 2004-2012

\begin{tabular}{|l|c|c|}
\hline \multicolumn{1}{|c|}{ Wyszczególnienie } & $\begin{array}{c}5 \text { spółek } \\
\text { o najwyższym } \\
\text { poziomie } \\
\text { miernika } \text { OBF }\end{array}$ & $\begin{array}{c}5 \text { spółek } \\
\text { o najniższym } \\
\text { poziomie } \\
\text { miernika } O B F\end{array}$ \\
\hline \hline Średnia liczba działów PKD 2007 & 18 & 22 \\
\hline Środkowa liczna działów PKD 2007 & 18 & 14 \\
\hline $\begin{array}{l}\text { Średnia liczba działów PKD 2007 w sekcji „Transport } \\
\text { i gospodarka magazynowa” }\end{array}$ & 6 & 5 \\
\hline $\begin{array}{l}\text { Środkowa liczba działów PKD 2007 w sekcji „Transport } \\
\text { i gospodarka magazynowa” }\end{array}$ & 5 & 4 \\
\hline
\end{tabular}

Źródło: jak do tab. 4.20.

W przypadku drugiej pięciopodmiotowej grupy spółek sektora TSL o najniższej wartości analizowanej metacechy - aż o 8 grup PKD 2007 różniła się wartość średnia od ich wartości środkowej (była niższa). W skład tej grupy wchodziły (za wyjątkiem spółek Solid Logistics Sp. z o.o. w latach 2006-2008 i 2012 oraz VOS Logistics Polska Sp. z o.o. w 2008 r. ze skupienia o numerze 2, a ponadto spółki TNT Express Worldwide (Poland) Sp. z o.o. w 2008, 2010 i 2011 r. ze skupienia o numerze 3) podmioty gospodarcze należące do wyłonionych we wcześniejszym etapie analizy skupień o numerach od 4 do 6 . Przedsiębiorstwa ze skupienia numer 4 - o najniższym średnim poziomie operacyjnego bezpieczeństwa finansowego w badanej grupie spółek - stanowiły 40\%, zaś te ze skupienia nr 6 - blisko $36 \%$.

Przeprowadzając podobne badania również w ramach wyodrębnionych - w poprzednim punkcie niniejszego rozdziału - homogenicznych grup przedsiębiorstw o zbliżonym poziomie operacyjnego bezpieczeństwa finansowego 
zauważyć można, że spółki ze skupienia nr 4 i 5, o odpowiednio najniższym średnim poziomie analizowanej metacechy, deklarowały najwyższą średnią i środkową liczbę grup PKD 2007. Nie wykazały one jednakże maksymalnej, faktycznie zadeklarowanej ich liczby przez badane podmioty gospodarcze sektora TSL. Sytuacja ta dotyczyła spółki ze skupienia nr 3, w którym pozostałe wyróżnione statystyki opisowe ukształtowały się na niższym poziomie w relacji do przedsiębiorstw wchodzących w skład skupień o numerach 4 i 5 . Średnia i środkowa liczba grup PKD 2007 w spółkach ze skupienia numer 1 (o najwyższym średnim poziomie operacyjnego bezpieczeństwa finansowego) była niższa od tych ze skupienia nr 4 i 5 , jednakże nie stanowiła wartości minimalnej wśród analizowanych homogenicznych grup przedsiębiorstw. Wartość minimalna średniej i środkowej liczby grup PKD 2007 wystąpiła odpowiednio dla skupienia nr 2 i 6 (zob. tab. 4.22).

Tabela 4.22. Podstawowe statystyki opisowe liczby grup PKD 2007 w latach 2004-2012 według wyłonionych homogenicznych grup przedsiębiorstw sektora TSL ${ }^{35}$

\begin{tabular}{|c|c|c|c|c|}
\hline Nr skupienia & Średnia & Mediana & MAX & MIN \\
\hline \hline Skupienie nr 1 & 19 & 17 & 48 & 4 \\
\hline Skupienie nr 2 & 13 & 13 & 21 & 5 \\
\hline Skupienie nr 3 & 24 & 17 & 68 & 3 \\
\hline Skupienie nr 4 & 28 & 24 & 53 & 5 \\
\hline Skupienie nr 5 & 35 & 38 & 42 & 25 \\
\hline Skupienie nr 6 & 13 & 12 & 25 & 3 \\
\hline
\end{tabular}

Źródło: obliczenia własne na podstawie danych zebranych w Krajowym Rejestrze Sądowym w Warszawie przy wykorzystaniu programu Statistica 10 .

W przypadku podmiotów gospodarczych ze skupienia o numerze 1 i 2 środkowa oraz średnia liczba grup PKD 2007 w sekcji „Transport i gospodarka magazynowa" wynosiła 5, zaś dla skupienia o numerze 3 - odpowiednio 6 i była wartością wyższą od wyróżnionych statystyk opisowych dla wyłonionych skupień o numerze 4 i 6 (zob. tab. 4.23). W skupieniu numer 6 znalazła się duża liczba przedsiębiorstw deklarujących - zwłaszcza w początkowym okresie prowadzonych analiz - niewielką (wynoszącą 3) liczbę tychże grup, co doprowadziło to znacznego obniżenia ich średniej liczby. W skupieniu numer 3 z kolei dostrzec można najwyższy poziom spreadu między wartością maksymalną (dla spółki GEFCO Polska Sp. z o.o.) i minimalną (dla spółki DARTOM Sp. z o.o.) analizowanej zmiennej w całym okresie badawczym.

${ }^{35} \mathrm{Z}$ uwagi na utrudnienia w identyfikacji liczby grup PKD 2007 w skupieniu 5 pominięta została jedna spółka, a w skupieniu 6 - 4 jednostki gospodarcze. Zob. schemat 4.1. 
Tabela 4.23. Podstawowe statystyki opisowe liczby grup PKD $2007 \mathrm{w}$ sekcji „Transport i gospodarka magazynowa” w latach 2004-2012 według wyłonionych homogenicznych grup przedsiębiorstw sektora TSL $^{36}$

\begin{tabular}{|c|c|c|c|c|}
\hline Nr skupienia & Średnia & Mediana & MAX & MIN \\
\hline \hline Skupienie nr 1 & 5 & 5 & 8 & 4 \\
\hline Skupienie nr 2 & 5 & 5 & 6 & 4 \\
\hline Skupienie nr 3 & 6 & 6 & 12 & 2 \\
\hline Skupienie nr 4 & 4 & 4 & 5 & 3 \\
\hline Skupienie nr 5 & 6 & 7 & 7 & 4 \\
\hline Skupienie nr 6 & 4 & 3 & 8 & 3 \\
\hline
\end{tabular}

Źródło: jak do tab. 4.22 .

Na podstawie zaprezentowanych wyników badań nie można jednoznacznie wskazać optymalnego pakietu (liczby) grup PKD 2007 (w tym w samej sekcji „Transport i gospodarka magazynowa”). Można jednakże stwierdzić, iż zwiększanie poziomu dywersyfikacji usługowej działalności gospodarczej spółek sektora TSL nie prowadzi do wzrostu operacyjnego bezpieczeństwa finansowego. Pomiędzy tymi zmiennymi w większości przypadków nie wystąpiła w ogóle zależność korelacyjna. Można jednak zaobserwować, iż przedsiębiorstwa, które prowadziły średnio zdywersyfikowaną działalność w relacji do innych podmiotów gospodarczych (gdzie dla skupienia nr 1 była to liczba 17-19 grup PKD 2007, a dla pięciopodmiotowych grup spółek o najwyższym poziomie operacyjnego bezpieczeństwa finansowego - 18 grup PKD 2007), osiągały najczęściej wyższy poziom analizowanej metacechy.

${ }^{36} \mathrm{Z}$ uwagi na utrudnienia w identyfikacji liczby grup PKD $2007 \mathrm{w}$ sekcji $\mathrm{H}$ w skupieniu 5 pominięta została jedna spółka, a w skupieniu 6 - 4 jednostki gospodarcze. Zob. schemat 4.1. 



\section{Rozdział 5}

\section{ZASTOSOWANIE MEMORIAŁOWYCH ORAZ KASOWYCH MIERNIKÓW W PROGNOZOWANIU OPERACYJNEGO ZAGROŻENIA FINANSOWEGO PRZEDSIĘBIORSTW SEKTORA TSL}

\subsection{Zakres badań empirycznych}

Pomimo wstępowania wielu licznych opracowań dotyczących prognozowania zagrożenia finansowego przedsiębiorstw ${ }^{1}$, wciąż brak jest $\mathrm{w}$ literaturze przedmiotu modeli dotyczących prognozowania operacyjnego zagrożenia finansowego. Jego pomiar oraz ocena są niezwykle ważne zarówno dla interesariuszy wewnętrznych, jak i zewnętrznych przedsiębiorstwa. Regularnie przeprowadzona ocena umożliwia nie tylko identyfikację czynników ryzyka niesystematycznego, lecz także stanowi o możliwości podjęcia określonych działań, mających na celu poprawę operacyjnego bezpieczeństwa finansowego przedsiębiorstwa. W skrajnych przypadkach działania te mogą uchronić dany podmiot gospodarczy przed upadłością ${ }^{2}$.

${ }^{1} \mathrm{~W}$ tym $\mathrm{m}$. in.: B. Prusak, Nowoczesne metody prognozowania zagrożenia finansowego przedsiębiorstw, Centrum Doradztwa i Informacji Difin Sp. z o.o., Warszawa 2005, s. 105-207; M. Hamrol, J. Chodakowski, Prognozowanie zagrożenia finansowego przedsiębiorstwa. Wartość predykcyjna polskich modeli analizy dyskryminacyjnej, [w:] Badania Operacyjne i Decyzje, nr 3, Oficyna Wydawnicza Politechniki Wrocławskiej, Wrocław 2008, s. 17-32; M. Gruszczyński, Empiryczne finanse przedsiębiorstw. Mikroekonomia finansowa, Difin SA \& Marek Gruszczyński, Warszawa 2012, s. 129-179.

${ }^{2}$ Upadłość przedsiębiorstwa ma poważne konsekwencje dla osób bezpośrednio z nim związanych i dla otoczenia. Oprócz negatywnych implikacji dla różnorodnych grup interesariuszy, ma ona dodatni wpływ na sytuację spółek pozostających na rynku. Przysparza bowiem wielu korzyści konkurentom, przyczyniając się chociażby do pomniejszenia konkurencji i zwolnienia części rynku, pozyskiwania czynników produkcji po atrakcyjnych cenach oraz wykwalifikowanych pracowników bez konieczności ponoszenia kosztów szkoleń. Konkurenci otrzymują ponadto darmową informację o poziomie przepływów pieniężnych zagrażających zachowaniu ciągłości działania, [za:] M. J e r ze mo w s ka, K. Ca m pbell, Nadzór korporacyjny a zagrożenie przedsiębiorstwa bankructwem, [w:] E. M ąc zyńsk a (red.), Bankructwa przedsiębiorstw. Wybrane aspekty instytucjonalne, Szkoła Główna Handlowa w Warszawie - Oficyna Wydawnicza, Warszawa 2008, s. 196-197. 
Przyjmując za uzasadnioną tezę, iż osiąganie i utrzymanie bezpieczeństwa finansowego przedsiębiorstwa wymaga od kadry kierowniczej m. in. wcześniejszego rozpoznania niebezpieczeństwa zagrożenia działalności i tym samym zastosowania określonych środków obrony, wskazać należy, iż postawienie spółki w stan upadłości regulują określone akty prawne ${ }^{3}$, zaś zagrożenie finansowe nie jest jednoznacznie odczytywane $\mathrm{i}$ interpretowane ${ }^{4}$. Jego identyfikację należy uznać za podstawowy wymóg realizacji zadań controllingu finansowego przedsiębiorstwa.

Wykorzystując 43 spółki sektora TSL wobec których wydane zostało sądowe postanowienie o ogłoszeniu upadłości, prowadzących podstawową działalność gospodarczą w sekcji „Transport i gospodarka magazynowa”, oraz mających swoją siedzibę w województwie mazowieckim ${ }^{6}$ (zob. schemat 5.1) wskazać należy, iż dalsza selekcja próby badawczej do oceny zdolności predykcyjnej ${ }^{7}$ wybranych modeli dyskryminacyjnych w prognozowaniu zagrożenia upadłością spółek sektora TSL została ograniczona do tych przedsiębiorstw, które:

a) miały sądownie ogłoszoną upadłość w latach 2004-2012 ${ }^{8}$ (tj. w dokumentacji spółki znajdują się sądowe postanowienia o ogłoszeniu upadłości),

b) składały jednostkowe sprawozdania finansowe (w tym sprawozdanie z przepływów pieniężnych) w Krajowym Rejestrze Sądowym w Warszawie na rok, dwa i trzy lata przed datą ogłoszenia upadłości ${ }^{9}$,

${ }^{3} \mathrm{Z}$ art. 10. Ustawy z dnia 28 lutego 2003 r. Prawo upadtościowe i naprawcze, DzU 2003, nr 60, poz. 535 z późn. zm. wynika, iż upadłość ogłasza się w stosunku do dłużnika, który stał się niewypłacalny.

Art. 11 tejże ustawy ponadto wskazuje, iż dłużnika uważa się za niewypłacalnego, jeżeli nie wykonuje swoich wymagalnych zobowiązań pieniężnych, zaś dłużnika będącego osobą prawną albo jednostką organizacyjną nieposiadającą osobowości prawnej, której odrębna ustawa przyznaje zdolność prawną, uważa się za niewypłacalnego także wtedy, gdy jego zobowiązania przekroczą wartość jego majątku, nawet wówczas, gdy na bieżąco zobowiązania te wykonuje.

${ }^{4}$ Zagrożenie finansowe jest kategorią płynną i dynamiczną, znajdującą się pomiędzy sytuacją najlepszą (tj. przedsiębiorstwem ,zdrowym”) a ostateczną (tj. upadłość podmiotu gospodarczego). Zob. M. Gru s z c z y ń s ki, Empiryczne finanse..., op. cit., s. 132.

${ }^{5}$ Badane spółki prowadzą zasadniczą działalność gospodarczą w sekcji H według PKD 2007, tj. ,Transport i gospodarka magazynowa”.

${ }^{6} \mathrm{Z}$ danych Centralnego Ośrodka Informacji Gospodarczej Sp. z o.o. wynika, iż największa liczba upadłości podmiotów gospodarczych z sekcji H wystąiła w województwie mazowieckim (tj. 43 spółki) i to one stanowiły podstawę do dalszej selekcji próby badawczej.

${ }^{7} \mathrm{Tj}$. trafność klasyfikacji przedsiębiorstw do grupy zagrożonych i niezagrożonych upadłością, która oceniana jest $\mathrm{m}$. in. na podstawie często stosowanej metody, jaką jest tzw. macierz pomyłek (ang. confusion matrix).

Przejawem wyższej zdolności predykcyjnej modeli dyskryminacyjnych jest wyższa trafność klasyfikacji badanych przedsiębiorstw do jednej z dwóch grup podmiotów gospodarczych, tj. zagrożonych i niezagrożonych upadłością.

${ }^{8}$ Do 8 sierpnia $2012 \mathrm{r}$.

${ }^{9} \mathrm{~W}$ dalszej części niniejszego opracowania zamiennie stosowane będzie sformułowanie „na rok, dwa i trzy lata przed upadłością". 
c) jako dzień bilansowy przyjęły 31 grudnia w każdym roku całego okresu badawczego (zob. zał. 6-7).

Liczba upadłych podmiotów gospodarczych poddanych badaniu została ograniczona $\mathrm{z}$ wyłonionych wstępnie 43 spółek sektora TSL, składających sprawozdania finansowe w Krajowym Rejestrze Sądowym w Warszawie, do 6 przedsiębiorstw. Aż 30 upadłych podmiotów gospodarczych nie składało bowiem w całym analizowanym okresie sprawozdania $\mathrm{z}$ przepływów pieniężnych, a w przypadku 7 kolejnych przedsiębiorstw - sprawozdanie to nie zostało złożone w przynajmniej jednym $\mathrm{z}$ badanych lat.

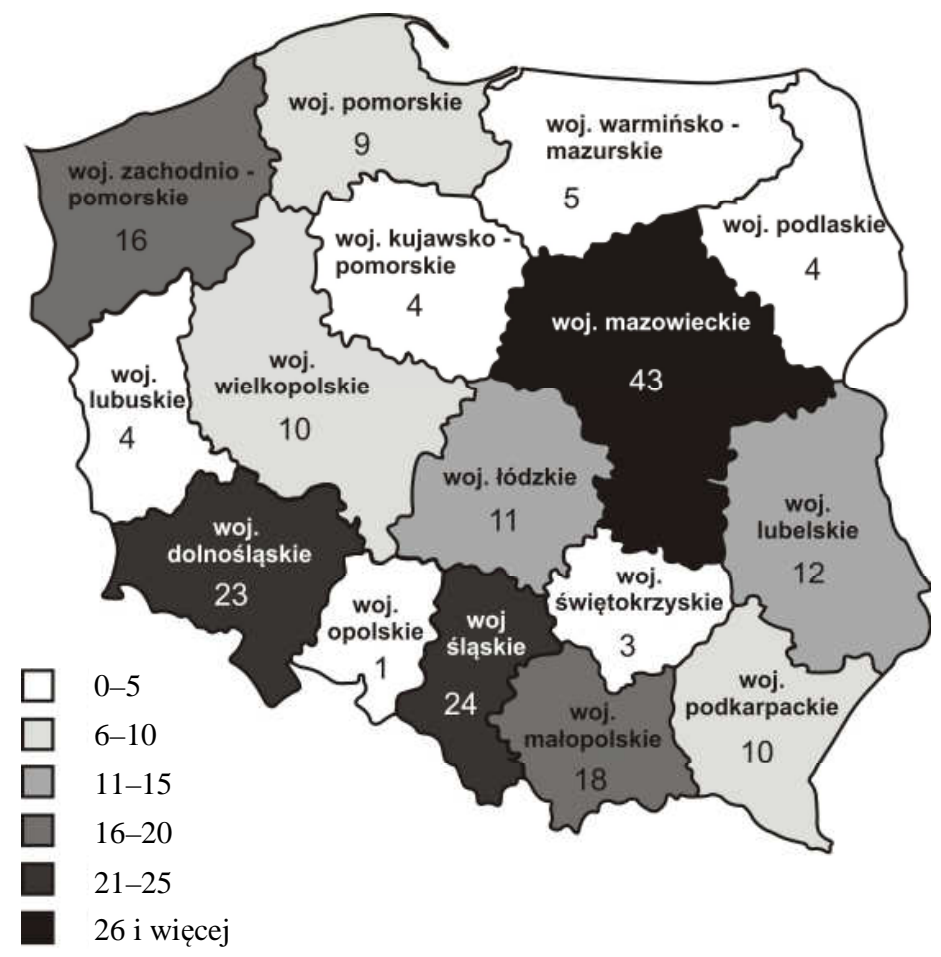

* Stan na 8 sierpnia 2012 r.

Schemat 5.1 . Liczba upadłych spółek z sekcji „Transport i gospodarka magazynowa” w Polsce w latach 2004-2012* według województw

Źródło: obliczenia własne na podstawie danych Centralnego Ośrodka Informacji Gospodarczej Sp. z o.o.

Analiza dyskryminacyjna wymaga uwzględnienia dwóch grup podmiotów gospodarczych, wobec tego weryfikacja zdolności predykcyjnej wybranych modeli dyskryminacyjnych została poprowadzona na rok, dwa i trzy lata dla 
6 spółek przed datą ogłoszenia ich upadłości oraz dla 6 spółek niezagrożonych upadłością ${ }^{10}$. Jedną $\mathrm{z}$ nich tworzą przedsiębiorstwa zagrożone upadłością, drugą zaś jednostki o dobrej kondycji finansowej. Dla analizy każdej ze spółek należących do obydwu grup przedsiębiorstw przyjęto trzyletni okres badawczy. Wybrane do badań spółki posiadające dobrą kondycję finansową musiały spełnić następujące kryteria doboru:

- prowadzić działalność w sektorze TSL,

- składać jednostkowe sprawozdania finansowe do tego samego Krajowego Rejestru Sądowego (w tym sprawozdanie z przepływów pieniężnych),

- posiadać porównywalną wartość aktywów ogółem w roku, który poddawany był analizie ${ }^{11}$.

Docelowa próba badawcza objęła zatem 12 podmiotów dla każdego okresu poddanego analizie (zob. zał. 7).

W celu oszacowania modelu operacyjnego zagrożenia finansowego próba badawcza (zob. zał. 8-9) została podzielona na tzw. próbę analityczną (dane finansowe za lata 2004-2010) i walidacyjną (dane finansowe za lata 2011-2012). Z danych Centralnego Ośrodka Informacji Gospodarczej Sp. z o.o. wynika, iż największa liczba upadłości podmiotów gospodarczych w latach 2004-2010 r. z sekcji „Transport i gospodarka magazynowa” wystąpiła również w województwie mazowieckim (31 spółek - zob. schemat 5.2).

W latach 2006-2010 liczba ogłoszonych upadłości przedsiębiorstw - których dominujące źródło przychodu pochodziło ze świadczenia usług transportowych, spedycyjnych, logistycznych, czy też kurierskich - w województwie mazowieckim utrzymywała się na poziomie od 15 do $32 \%$ wszystkich upadłości tego rodzaju podmiotów w Polsce. Największa liczba upadłości w analizowanym okre-

${ }^{10}$ M. Pogodzińska i S. Sojak jako pierwsi w Polsce oszacowali - za pomocą techniki liniowej wielowymiarowej analizy dyskryminacyjnej - model jedynie dla 10 obserwacji. Zob. M. P og odzińska, S. Sojak, Wykorzystanie analizy dyskryminacyjnej $w$ przewidywaniu bankructwa przedsiębiorstw, [w:] „Acta Universitatis Nicolai Copernici”, Ekonomia XXV, Zeszyt 299, Torun 1995 , s. 53-61.

Model ten stanowił dobry przykład wykorzystania analizy wielowymiarowej w prowadzonych badaniach empirycznych przez Autorów, choć miał ograniczoną wartość użytkową dla praktyki gospodarczej.

${ }^{11}$ Ta część badań poprowadzona była we wrześniu 2012 r. - wobec czego wybór spółek niezagrożonych upadłością był dokonywany spośród 33 podmiotów gospodarczych spełniających kryterium doboru próby badawczej (tj. dodatkowo oprócz przedsiębiorstw wykazanych w załączniku 2 - zostały do niej zaklasyfikowane także 4 następujące spółki: Link Sp. z o.o., M\&M Militzer \& Münch Polska Sp. z o.o., Przedsiębiorstwo Wielobranżowe Podkowa Sp. z o.o. oraz Zasada Logistyka Sp. z o.o. [por. zał. 2 i L. Ka r b o w n i k, Zróżnicowanie poziomu operacyjnego bezpieczeństwa finansowego przedsiębiorstw sektora TSL, [w:] J. D u r a j (red.), Instrumenty ksztattowania dochodowości i rentowności przedsiębiorstwa, „Acta Universitatis Lodziensis”, Folia Oeconomica 278, Wydawnictwo Uniwersytetu Łódzkiego, Łódź 2013, s. 247]).

Wobec czego w przypadku zmiany nazwy danego podmiotu gospodarczego użyta została nazw przedsiębiorstw wykazanych w sprawozdaniu finansowym na dzień 31.12.2011. 
sie w województwie mazowieckim została ogłoszona w 2009 r. (zob. wykres 5.1). Sytuacja ta dotyczyła 9 następujących jednostek gospodarczych:

- EUROPEAN IN-TERLINK Sp. z o.o. w upadłości likwidacyjnej (numer działu PKD 2007: 49.4),

- TIME 2 INVEST Sp. z o.o. w upadłości likwidacyjnej (numer działu PKD 2007: 52.1),

- T.P.S. Sp. z o.o. w upadłości likwidacyjnej (numer działu PKD 2007: 49.4),

- EP Services Sp. z o.o. (numer działu PKD 2007: 49.4),

- LOT Ground Services Sp. z o.o. w upadłości likwidacyjnej (numer działu PKD 2007: 52.2),

- Nowy Przewoźnik Sp. z o.o. w upadłości likwidacyjnej (numer działu PKD 2007: 51.1),

- TX Spedition Sp. z o.o. w upadłości likwidacyjnej (numer działu PKD 2007: 49.4),

- Polski Express Sp. z o.o. (numer działu PKD 2007: 49.3),

- BTM Transport Polska Sp. z o.o. w upadłości likwidacyjnej (numer działu PKD 2007: 49.4).

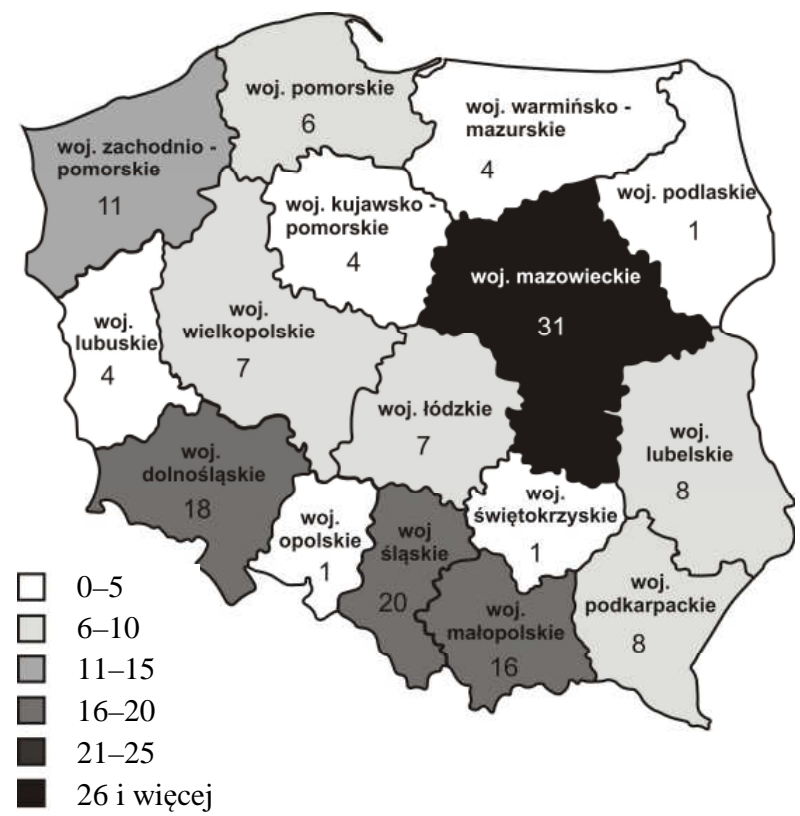

Schemat 5.2. Liczba upadłych spółek z sekcji „Transport i gospodarka magazynowa” w Polsce w latach 2004-2010 według województw

Źródło: jak do schematu 5.1. 
Aż 55\% upadłych spółek w 2009 r. z województwa mazowieckiego to spółki, których dominującym rodzajem działalności było świadczenie usług transportu drogowego towarów oraz działalność usługowa związana z przeprowadzkami. W całym badanym okresie natomiast nie upadło ani jedno przedsiębiorstwo w tym województwie, w którym dominującym źródłem przychodów netto ze sprzedaży było świadczenie usług kurierskich.

Dalsza selekcja analitycznej próby badawczej ograniczona została zatem jedynie do tych przedsiębiorstw, które:

a) miały sądownie ogłoszoną upadłość w latach 2004-2010 (tj. w dokumentacji spółki znajdują się postanowienia sądowe o ogłoszeniu upadłości),

b) składały jednostkowe sprawozdania finansowe (w tym sprawozdanie z przepływów pieniężnych) w Krajowym Rejestrze Sądowym w Warszawie na rok, dwa i trzy lata przed datą ogłoszenia upadłości,

c) jako dzień bilansowy przyjęły 31 grudnia w każdym roku całego okresu badawczego $^{12}$.

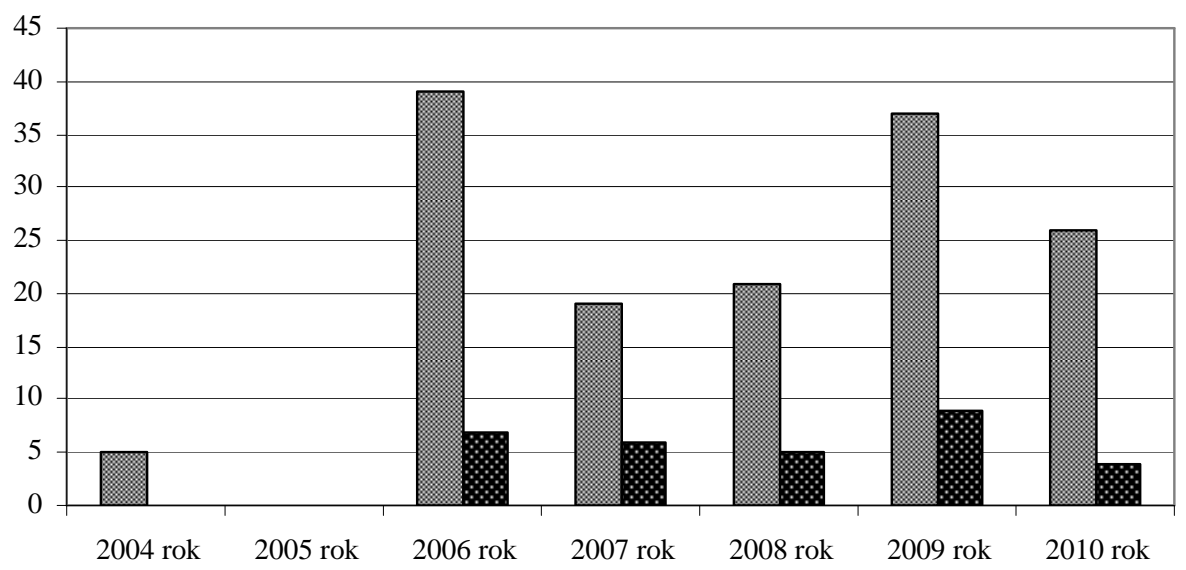

Liczba upadły ch spółek w Polsce

Liczba upadły ch spółek w województwie mazowieckim

Wykres 5.1. Porównanie liczby upadłych spółek z sekcji „Transport i gospodarka magazynowa” w województwie mazowieckim z ich liczbą w Polsce w latach 2004-2010

Źródło: obliczenia własne na podstawie danych Centralnego Ośrodka Informacji Gospodarczej Sp. z o.o. przy wykorzystaniu programu Microsoft Excel.

Liczba upadłych podmiotów gospodarczych poddanych tej analizie została znacznie ograniczona (z 31 spółek sektora TSL składających sprawozdania finansowe w Krajowym Rejestrze Sądowym w Warszawie do 5 przedsiębiorstw

${ }^{12}$ Brak pełnych danych finansowych uniemożliwił przeprowadzenie analizy dyskryminacyjnej dla większej próby badawczej w tym okresie. 
- zob. zał. 6 oraz 8) z powodu nie składania sprawozdania z przepływów pieniężnych przez 20 upadłych przedsiębiorstw, a w kolejnych 6 przypadkach - z powodu braku dostępności tego sprawozdania na rok, dwa lub trzy lata przed ogłoszeniem upadłości.

Podobnie jak w przypadku badania zdolności predykcyjnej wybranych modeli dyskryminacyjnych podjęta została - przy tych samych kryteriach doboru - próba przypisania badanym spółkom upadłym podmiotów gospodarczych o dobrej kondycji finansowej (zob. zał. 8) ${ }^{13}$. Docelowa próba badawcza objęła zatem 10 podmiotów dla każdego okresu poddanego analizie.

Dane dla drugiej z analizowanych grup przedsiębiorstw zostały obliczone odpowiednio dla lat przyporządkowanych im upadłym podmiotom gospodarczym.

$\mathrm{Z}$ powodu braku możliwości wyznaczenia wartości kilku mierników oceny operacyjnego bezpieczeństwa finansowego na podstawie sprawozdań finansowych składanych do Krajowego Rejestru Sądowego w Warszawie przez spółki sektora TSL, analiza została ograniczona już na wstępnym etapie badania do 13 mierników operacyjnego zagrożenia finansowego przedsiębiorstwa, $\mathrm{tj}$. od $\mathrm{m}_{1}$ do $\mathrm{m}_{13}$ (zob. tab. 2.3).

Dalsza selekcja mierników operacyjnego zagrożenia finansowego dotyczyła oszacowania średnich wartości analizowanych mierników, współczynników zmienności oraz oceny zdolności prognostycznych zmiennych diagnostycznych, jak i analizy korelacji zachodzących między nimi ${ }^{14}$.

Do kolejnego etapu analizy zostały zaklasyfikowane jedynie te mierniki, które $^{15}$ :

- różniły się znacząco w obu grupach (tj. w spółkach upadłych, jak i niezagrożonych upadłością) - w tym celu zostały wyznaczone wewnątrzgrupowe współczynniki zmienności oraz międzygrupowe współczynniki zmienności ${ }^{16}$;

- były skorelowane ze sobą na poziomie $(-0,8 ; 0,8)$.

${ }^{13}$ Drugą część próby stanowiły odpowiednio dobrane przedsiębiorstwa w dobrej kondycji finansowej, tj. te, które kontynuowały swoją działalność gospodarczą (przynajmniej po upływie roku od momentu, z którego dane wykorzystano do oszacowania parametrów funkcji dyskryminacyjnej).

${ }^{14}$ Dodatkowe założenie o normalności rozkładu jest ważne ze statystycznego punktu widzenia, jednak w literaturze przedmiotu Autorzy podkreślają, iż pojawienie się rozkładu normalnego jest niezmiernie rzadkie, co nie wpływa w praktyce na pogorszenie zdolności prognostycznych funkcji dyskryminacyjnych. Zob. D. Had asi k, Upadtość przedsiębiorstw w Polsce i metody jej prognozowania, ,Zeszyty Naukowe - Seria II. Publikacje habilitacyjne” 1998, z. 153, s. 146-148 oraz M. Li pi e c-Z aj chow sk a (red.), Wspomaganie procesów decyzyjnych, Ekonometria, Warszawa 2003, s. 145.

${ }^{15}$ Problematyka odpowiedniej selekcji mierników oceny badanego zjawiska oraz weryfikacja założeń analizy dyskryminacyjnej została przedstawiona m. in. w publikacjach: D. Hadasik, op. cit., s. 136-148; B. Pru sak, op. cit., s. 20-27; T. M á́1 a n k a, Przeptywy pieniężne w zarzqdzaniu finansami przedsiębiorstw, Wydawnictwo C. H. Beck, Warszawa 2008, s. 196-229.

${ }^{16}$ Pożądane jest, aby współczynniki wewnątrzgrupowe były jak najniższe, z kolei międzygrupowe - jak najwyższe. 


\subsection{Ocena zdolności predykcyjnej wybranych modeli dyskryminacyjnych w prognozowaniu operacyjnego zagrożenia finansowego przedsiębiorstw sektora TSL $^{17}$}

Wzrastające ryzyko działalności gospodarczej i potrzeby jego ograniczania tworzą duże zapotrzebowanie kadry kierowniczej przedsiębiorstwa na modele oceny zagrożenia upadłością, zwłaszcza w okresach nasilających się niekorzystnych zjawisk w gospodarce ${ }^{18}$. Szczególnie ważnym jest przeprowadzenie analizy dyskryminacyjnej $\mathrm{w}$ kolejnych latach funkcjonowania przedsiębiorstwa i obserwowania występującej tendencji zmian. Uzyskane wyniki nie powinny być jednakże traktowane jako rozstrzygające o sposobie wnioskowania. Mogą one stanowić jedynie ważną pomoc w ocenie rzeczywistej kondycji finansowej badanych spółek ${ }^{19}$.

W Polsce doświadczenia badawcze z zakresu predykcji zagrożenia upadłością sięgają lat $90 . \mathrm{XX} \mathrm{w.}{ }^{20}$ Systematycznie rozwijano ideę E. I. Altmana ${ }^{21}$, będącą punktem zwrotnym w badaniach dotyczących możliwości wczesnego rozpoznawania zagrożenia upadłością przedsiębiorstw przy zastosowaniu mierników finansowych. Istotny wkład w tej materii wnieśli m. in. J. Gajdka i D. Stos, D. Hadasik, E. Mączyńska, B. Prusak oraz T. Maślanka.

Powstała naturalna potrzeba opracowania modeli opartych na oryginalnych danych dla przedsiębiorstw z polskiej gospodarki. Z uwagi na ograniczenie terytorialne oraz ze względu na nieporównywalną specyfikę gospodarek zagranicznych i gospodarki polskiej, niemożliwa stała się implementacja modeli opracowanych w krajach wysokorozwiniętych. Modele prognostyczne gwarantują bowiem dużą trafność prognoz tylko wtedy, gdy wykorzystywane są w warunkach zbliżonych do tych, w jakich funkcjonowały przedsiębiorstwa, na podstawie

${ }^{17}$ Zob. L. Karbownik, Ocena zdolności predykcyjnej wybranych modeli dyskryminacyjnych w prognozowaniu upadtości przedsiębiorstw sektora TSL, [w:] J. D u r a j, A. S a j ó g (red.), Ekonomiczne i pozaekonomiczne czynniki zarządzania wartościa przedsiębiorstwa, Wydawnictwo Uniwersytetu Łódzkiego, Łódź 2013, s. 113-129.

${ }^{18}$ E. M ą c z y ń s ka, Globalizacja ryzyka a systemy wczesnego ostrzegania przed upadtościa przedsiębiorstw, [w:] D. A p penzelle r, Upadtość przedsiębiorstw w Polsce $w$ latach 1990 -2003. Teoria i praktyka, ,Zeszyty Naukowe” 2004, nr 49, Wydawnictwo Akademii Ekonomicznej w Poznaniu, Poznań 2004, s. 111.

${ }^{19}$ M. Ha mrol, J. Chod akow ski, op. cit., s. 30.

${ }^{20}$ Wyróżnić tutaj można m. in. takie opracowania, jak: E. Mąc zyń ska, Ocena kondycji przedsiębiorstwa (uproszczone metody), „Życie Gospodarcze” 1994, nr 38, s. 42-45; J. G a j d ka, D. S to s, Wykorzystanie analizy dyskryminacyjnej w ocenie kondycji finansowej przedsiębiorstw, [w:] R. B orowiecki (red.), Restrukturyzacja $w$ procesie przeksztatceń i rozwoju przedsiębiorstw, Wydawnictwo Akademii Ekonomicznej w Krakowie, Kraków 1996, s. 56-65; D. Had a si k, op. cit., s. 133-176.

${ }^{21}$ E. I. Altma n, Financial Ratios. Discriminant Analysis and the Prediction of Corporate Bankruptcy, „Journal of Finance” 1968, Vol. 23, No. 4, s. 589-609. 
których modele te zostały oszacowane (przenoszenie modeli między gospodarkami jest generalnie niedopuszczalne $)^{22}$.

W literaturze przedmiotu odnaleźć można wiele modeli służących prognozowaniu zagrożenia upadłością polskich przedsiębiorstw ${ }^{23}$. Modele te stanowią uzupełnienie tradycyjnej analizy finansowej ${ }^{24}$, w której znaczna liczba wykorzystywanych mierników finansowych utrudnia jednoznaczną diagnozę rzeczywistej kondycji przedsiębiorstwa. Uzyskane wyniki badań w poszczególnych jej obszarach oceny mogą bowiem między sobą wykazywać znaczące różnice. W sukurs licznym zmiennym diagnostycznym wykorzystywanym do oceny sytuacji finansowej podmiotu gospodarczego przychodzi szereg innych, popularnych narzędzi analitycznych, pozwalających na identyfikację mogącego się pojawić zagrożenia upadłością przedsiębiorstwa, w tym m. in. wielokryterialna analiza dyskryminacyjna ${ }^{25}$.

Modele te pozwalają z reguły jednoznacznie określić kondycję finansową podmiotów gospodarczych. Umożliwiają ponadto wczesne identyfikowanie nieprawidłowości w funkcjonowaniu spółek, gwarantując tym samym wczesne ostrzeganie $^{26}$ różnorodnych grup interesariuszy $\mathrm{m}$. in. o zagrożeniu upadłością przedsiębiorstwa.

W celu oceny zdolności predykcyjnej wybranych modeli dyskryminacyjnych w prognozowaniu zagrożenia upadłością spółek sektora TSL wybrane zostały modele oszacowane dla polskiej gospodarki, w tym m. in. O. H. Jacobsa ${ }^{27}$, E. Mączyńskiej i B. Prusaka. Zdaniem P. Antonowicza modele te charakteryzują się najwyższą zdolnością predykcyjną dla przedsiębiorstw usługowych ${ }^{28}$ (zob. tab. 5.1).

${ }^{22}$ U. Malinowska, W. R o gow ski, Rola modeli oceny zagrożenia upadtościa $w$ nowoczesnej analizie finansowej, [w:] M. H a m rol (red.), Analiza finansowa jako narzędzie zarzadzania przedsiębiorstwem, Katedra Analizy Finansowej i Strategicznej, Akademia Ekonomiczna w Poznaniu, Poznań 2005, s. 71. Zob. też: J. G aj d k a, D. S to s, Wykorzystanie analizy..., op. cit., s. $56-65$.

${ }^{23}$ W tym. m. in.: E. Mączyńska, Ocena kondycji...,op. cit., s. 42-45; E. Mączyńska, Globalizacja ryzyka..., op. cit., s. 107-117; B. Prusak, op. cit., s. 5-207; U. Malinowska, W. Rog o w ski, op. cit., s. 69-91; P. Ant on ow i c z, Metody oceny i prognoza kondycji ekonomiczno-finansowej przedsiębiorstw, Ośrodek Doradztwa i Doskonalenia Kadr Sp. z o.o., Gdańsk 2007, s. 38-199; P. D e c, Modele wczesnego ostrzegania przed upadtościa przedsiębiorstw i badania nad ich skutecznościa w Polsce, [w:] E. Mą c y ń sk a (red.), Bankructwa przedsiębiorstw. Wybrane aspekty instytucjonalne, Szkoła Główna Handlowa w Warszawie - Oficyna Wydawnicza, Warszawa 2008, s. 219-227; M. Gr u s z c z y ń s k i, Empiryczne finanse..., op. cit., s. 129-179.

${ }^{24}$ Poprzez tradycyjną analizę finansową rozumiemy analizę sprawozdań finansowych oraz analizę wskaźnikową opartą o tradycyjne wskaźniki finansowe, tj. płynności finansowej, rentowności, sprawności działania, zadłużenia. Zob. U. Ma li n ow s ka, W. R og o w s ki, op. cit., s. 69 i 82.

${ }^{25}$ R. Rolbiecki, Analiza dyskryminacyjna $w$ ocenie zmian kondycji finansowej przedsiębiorstw transportowych, „Controlling” 2010, nr 8, s. 44.

${ }^{26}$ E. Mąc zyńska (red.), Bankructwa przedsiębiorstw. Wybrane aspekty instytucjonalne, Szkoła Główna Handlowa w Warszawie - Oficyna Wydawnicza, Warszawa 2008, s. 18.

27 Adaptacja modelu O. H. Jacobsa do polskich została wykonana przez E. Mączyńską. Zob. E. M ą c z y ń s k a, Ocena kondycji..., op. cit., s. 42-45.

${ }^{28} \mathrm{P}$. An to now ic z, Metody oceny..., op. cit., s. 170. 
$\mathrm{W}$ modelach tych uwzględniane są odmienne mierniki oceny. Jedynie w nielicznych przypadkach pojawiają się w nich miary wykorzystujące dane ze sprawozdania z przepływów pieniężnych.

D. Wędzki wskazał, iż uwzględnienie mierników finansowych - wykorzystujących dane ze sprawozdania z przepływów pieniężnych - stanowi nie do końca rozpoznany obszar badań nad upadłościami przedsiębiorstw ${ }^{29}$.

Wyniki badań empirycznych prezentowane w literaturze przedmiotu dostarczają licznych argumentów uzasadniających potrzebę wykorzystania zmiennych diagnostycznych opartych na przepływach pieniężnych w predykcji zagrożenia upadłości przedsiębiorstw ${ }^{30}$. Przeto $\mathrm{w}$ prowadzonych badaniach uwzględnione zostały ponadto modele zaproponowane przez T. Maślankę, bowiem mierniki tych modeli uwzględniają dodatkowo dane ze sprawozdania z przepływów pieniężnych (zob. tab. 5.2)

Sformułowana została ponadto hipoteza badawcza stanowiąca, iż $w$ przypadku prognozowania zagrożenia upadłościa przedsiębiorstw sektora TSL modele dyskryminacyjne wykorzystujace dane ze sprawozdania z przeptywów pieniężnych wykazuja wyższa zdolność predykcyjna od modeli uwzględniajacych jedynie dane z bilansu oraz rachunku zysków i strat.

Wybrane do analizy modele dyskryminacyjne różnią się między sobą trafnością klasyfikacji ze względu na zróżnicowaną listę zmiennych diagnostycznych i odmienne wartości współczynników tych modeli.

W obliczaniu wartości poszczególnych mierników przyjęta została zasada „uśredniania” wartości bilansowych. Tym samym, dane pochodzące z bilansu badanych przedsiębiorstw zostały obliczone jako średnia arytmetyczna z wartości na początek i na koniec danego roku obrotowego, zaś z rachunku zysków i strat oraz sprawozdania z przepływów pieniężnych zostały wprowadzone do wzoru funkcji dyskryminacyjnej bezpośrednio za dany rok. Autorzy modeli dyskryminacyjnych wskazują bowiem na taki sposób dokonywania obliczeń. Jednakże ten sposób obliczania wartości zmiennych nie jest regułą ${ }^{32}$.

${ }^{29}$ D. W ę d zki, Przeptywy pieniężne w prognozowaniu upadtości przedsiębiorstwa. Przegląd literatury, [w:] Badania operacyjne $i$ decyzje, $\mathrm{nr}$ 2, Oficyna Wydawnicza Politechniki Wrocławskiej, Wrocław 2008, s. 101.

${ }^{30}$ W tym m. in.: J. A. Largay, C. P. Stickney, Cash Flows, Ratio Analysis and the W. T. Grant Company Bankruptcy, „Financial Analysts Journal”, July-August 1980, s. 51-54; M. A. Rujoub, D. M. Cook, L. E. Hay, Using Cash Flow Ratio to Predict Business Failure, „Journal of Managerial Issues” 1995, Vol. 7, s. 75-90; T. M állanka, op. cit., s. 193-254; D. W ę d z ki, Przeptywy pieniężne..., op. cit., s. 87-102.

${ }^{31}$ Obliczone wskaźniki pomnożone zostały przez odpowiednie wagi, a następnie dokonana została interpretacja obliczonych wartości funkcji dla kolejnych lat analizy.

${ }^{32}$ P. Anton ow ic z, Metody oceny..., op. cit., s. 45 i 53. 
Tabela 5.1. Modele dyskryminacyjne o najwyższych zdolnościach predykcyjnych dla przedsiębiorstw usługowych

\begin{tabular}{|l|c|l|c|}
\hline $\begin{array}{c}\text { Symbol } \\
\text { modelu }\end{array}$ & Autor modelu & \multicolumn{1}{|c|}{ Postać funkcji modelu } & $\begin{array}{c}\text { Trafność } \\
\text { klasyfikacji* }\end{array}$ \\
\hline \hline Model $\mathrm{Z}_{\mathrm{BP} 1}$ & B. Prusak & $\begin{array}{l}\mathrm{Z}_{\mathrm{BP} 1}=6,5245 * \mathrm{WO} / \mathrm{A}+0,1480 * \mathrm{~K}_{\mathrm{op}} / \mathrm{ZK}_{\mathrm{op}}+ \\
0,4061 * \mathrm{MO} / \mathrm{ZK}+2,1754 * \mathrm{WO} / \mathrm{P}-1,5685\end{array}$ & $98,08 \%$ \\
\hline $\begin{array}{l}\text { Model } \mathrm{Z}_{7 \mathrm{INE}} \\
\text { PAN }\end{array}$ & E. Mączyńska & $\begin{array}{l}\mathrm{Z}_{7 \mathrm{INE}} \mathrm{PAN}=9,498 * \mathrm{WO} / \mathrm{A}+3,566 * \mathrm{KW} / \mathrm{A}+ \\
2,903 *(\mathrm{WN}+\mathrm{Am}) / \mathrm{Z}+0,452 * \mathrm{MO} / \mathrm{ZK}-\end{array}$ & $97,92 \%$ \\
\hline $\begin{array}{l}\text { Model } \mathrm{Z}_{6 \mathrm{INE}} \\
\text { PAN }\end{array}$ & E. Mączyńska & $\begin{array}{l}\mathrm{Z}_{6 \mathrm{INE} \text { PAN }}=9,478 * \mathrm{WO} / \mathrm{A}+3,613 * \mathrm{KW} / \mathrm{A}+ \\
0,802 * \mathrm{~W} / \mathrm{A}+2,478\end{array}$ & $97,92 \%$ \\
\hline Model $\mathrm{Z}_{\mathrm{M}}$ & O. H. Jacobs & $\begin{array}{l}\mathrm{Z}_{\mathrm{M}}=1,5 *(\mathrm{WB}+\mathrm{Am}) / \mathrm{Z}+0,08 * \mathrm{~A} / \mathrm{Z}+10,0 * \\
\mathrm{WB} / \mathrm{A}+5,0 * \mathrm{WB} / \mathrm{P}+0,30 * \mathrm{ZAP} / \mathrm{P}+0,10 * \\
\mathrm{P} / \mathrm{A}\end{array}$ & $97,83 \%$ \\
\hline
\end{tabular}

* Trafność klasyfikacji poszczególnych modeli dla przedsiębiorstw usługowych.

gdzie:

WO - wynik z działalności operacyjnej (wynik operacyjny),

A - suma bilansowa (aktywów) ${ }^{33}$,

$\mathrm{K}_{\mathrm{op}} \quad$ - koszty operacyjne (bez pozostałych kosztów operacyjnych),

$\mathrm{ZK}_{\mathrm{op}}$ - średnia wartość zobowiązań krótkoterminowych (bez funduszy specjalnych i krótkoterminowych zobowiązań finansowych),

MO - aktywa obrotowe,

ZK - zobowiązania krótkoterminowe,

$\mathrm{P} \quad-$ przychody netto ze sprzedaży (przychody netto ze sprzedaży produktów, towarów i materiałów),

KW - kapitał własny,

WN - wynik finansowy netto (wynik netto),

Am - amortyzacja,

Z - suma zobowiązań (zobowiązania ogółem),

WB - wynik brutto,

ZAP - zapasy.

Źródło: opracowanie własne na podstawie: E. Mączyńska, Ocena kondycji przedsiębiorstwa (uproszczone metody), „Życie Gospodarcze” 1994, nr 38, s. 42-45; E. M ąc z y ńs ka, Globalizacja ryzyka a systemy wczesnego ostrzegania przed upadtościa przedsiębiorstw, [w:] D. A p penzelle r, Upadtość przedsiębiorstw w Polsce w latach 1990-2003. Teoria i praktyka, „Zeszyty Naukowe” 2004, nr 49, Wydawnictwo Akademii Ekonomicznej w Poznaniu, Poznań 2004, s. 107-117; B. Prusak, Nowoczesne metody prognozowania zagrożenia finansowego przedsiębiorstw, Centrum Doradztwa i Informacji Difin Sp. z o.o., Warszawa 2005, s. 149-153; P. Antonowi cz, Metody oceny i prognoza kondycji ekonomiczno-finansowej przedsiębiorstw, Ośrodek Doradztwa i Doskonalenia Kadr Sp. z o.o., Gdańsk 2007, s. 170-172.

${ }^{33} \mathrm{~W}$ modelu M. Prusaka pojawia się informacja, iż jest to „średnia suma bilansowa”. 
Zastosowanie modeli dyskryminacyjnych pozwala agregować informację zawartą w poszczególnych miernikach oceny kondycji finansowej przedsiębiorstwa. Wykorzystując do tej oceny modele B. Prusaka, E. Mączyńskiej, O. H. Jacobsa oraz T. Maślanki wskazać można, że modele te opierają się na różnorodnym zestawie zmiennych diagnostycznych i różnych wagach nadanym tym zmiennym ${ }^{34}$.

Tabela 5.2. Modele dyskryminacyjne wykorzystujące dane ze sprawozdania z przepływów pieniężnych

\begin{tabular}{|l|l|l|c|}
\hline \multicolumn{1}{|c|}{ Symbol } & \multicolumn{1}{|c|}{$\begin{array}{c}\text { Autor } \\
\text { modelu }\end{array}$} & \multicolumn{1}{c|}{ Postać funkcji modelu } & $\begin{array}{c}\text { Trafność } \\
\text { klasyfikacji }\end{array}$ \\
\hline \hline $\begin{array}{l}\text { Model } \\
\text { (rok przed upadłością) }\end{array}$ & T. Maślanka & $\begin{array}{l}\mathrm{Z}_{\mathrm{TM} 5}=3,73253 * \mathrm{KW} / \mathrm{A}+8,83939 * \\
\mathrm{WS} / \mathrm{A}+0,04658 * \mathrm{P} / \mathrm{AT}+0,95617 * \\
\mathrm{OCF} / \mathrm{Z}-1,6524\end{array}$ & $92,50 \%$ \\
\hline $\begin{array}{l}\text { Model } \mathrm{Z}_{\mathrm{TM} 10} \\
\text { (dwa lata przed upadłością) }\end{array}$ & T. Maślanka & $\begin{array}{l}\mathrm{Z}_{\mathrm{TM} 10}=12,01553 * \mathrm{WS} / \mathrm{A}+3,08576 * \\
\mathrm{OCF} / \mathrm{Z}+1,08672 *(\mathrm{WN}+\mathrm{Am}) / \mathrm{Z}-\end{array}$ & $\begin{array}{l}3,13194 *(\mathrm{WO}+\mathrm{Am}) / \mathrm{Z}-1,52065 \\
* \mathrm{OCF} / \mathrm{ZK}-4,02261 * \mathrm{ZK} / \mathrm{A}+1,82057\end{array}$ \\
\hline $\begin{array}{l}\text { Model } \mathrm{Z}_{\mathrm{TM} 11} \\
\text { (trzy lata przed upadłością) }\end{array}$ & T. Maślanka & $\begin{array}{l}\mathrm{Z}_{\mathrm{TM} 11}=-0,020133 *(\mathrm{ZK} * 360) / \mathrm{KWS}+ \\
0,786465 * \mathrm{OCF} / \mathrm{Z}+1,803759\end{array}$ & $78,75 \%$ \\
\hline
\end{tabular}

$$
\begin{aligned}
& \text { gdzie: } \\
& \text { WS - wynik na sprzedaży, } \\
& \text { AT - aktywa trwałe, } \\
& \text { OCF - operacyjne przepływy pieniężne netto, } \\
& \text { KWS - koszt własny sprzedaży, } \\
& \text { pozostałe oznaczenia jak wyżej. }
\end{aligned}
$$

Źródło: opracowanie własne na podstawie: T. M aśl an ka, Przeptywy pieniężne $w$ zarzadzaniu finansami przedsiębiorstw, Wydawnictwo C. H. Beck, Warszawa 2008, s. 206-208 i 230-241.

Nadrzędnym celem podejmowanych badań empirycznych jest weryfikacja zdolności predykcyjnej (tj. trafności kasyfikacji spółek do grupy niezagrożonych i zagrożonych upadłością) wybranych modeli dyskryminacyjnych w ocenie zagrożenia upadłością przedsiębiorstw sektora TSL. W tym celu zbiorcze zestawienie otrzymanych wyników zostało podzielone na trzy okresy z wyodrębnieniem badanych jednostek analizy na rok, dwa i trzy lata przed upadłością.

${ }^{34}$ Wartości poszczególnych współczynników funkcji dyskryminacyjnej (wag) pozwalają na dokonanie interpretacji kierunku i rozmiaru wpływu poszczególnych mierników kondycji finansowej na ocenę stopnia zagrożenia upadłością.

Współczynniki funkcji dyskryminacyjnej określają bowiem indywidualny (cząstkowy) wkład każdej zmiennej do funkcji dyskryminacyjnej. Zob. http://www.statsoft.pl/textbook/. 
Wykorzystując w analizie jednorocznej pięć wymienionych modeli prognozujących zagrożenie upadłością badanych podmiotów gospodarczych z sektora TSL na rok przed ogłoszeniem sądowego postanowienia o upadłości przedsiębiorstwa (zob. tab. 5.3) wskazać należy, że błędnie zaklasyfikowana została upadła spółka EP Services Sp. z o.o. Wszystkie modele wykazały, iż przedsiębiorstwo to zaliczyć można do jednostki niezagrożonej upadłością, natomiast potwierdziły one jednoznacznie występowanie stanu zagrożenia upadłością w trzech spółkach.

Tabela 5.3. Zbiorcze zestawienie modeli prognozujących zagrożenie upadłością badanych spółek sektora TSL na rok przed wydaniem sądowego postanowienia o ogłoszeniu upadłości*

\begin{tabular}{|c|c|c|c|c|c|c|}
\hline $\begin{array}{l}\text { Rodzaj } \\
\text { spółki }\end{array}$ & Spółka & $\begin{array}{c}\text { Model } \\
\mathrm{Z}_{\mathrm{BP} 1}\end{array}$ & $\begin{array}{c}\text { Model } \\
Z_{7 \mathrm{INE}} \\
\text { PAN } \\
\end{array}$ & $\begin{array}{c}\text { Model } \\
Z_{6 \text { INE }} \\
\text { PAN } \\
\end{array}$ & $\begin{array}{c}\text { Model } \\
\mathrm{Z}_{\mathrm{M}}\end{array}$ & $\begin{array}{c}\text { Model } \\
\mathbf{Z}_{\text {TM5 }}\end{array}$ \\
\hline \multirow{6}{*}{ 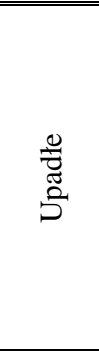 } & Corrida SA w upadłości likwidacyjnej & $\mathrm{U}$ & $\mathrm{U}$ & $\mathrm{U}$ & $\mathrm{U}$ & $\mathrm{U}$ \\
\hline & AMP Logistyka Sp. z o.o. & $\mathrm{O}$ & U & $\mathrm{U}$ & $\mathrm{U}$ & U \\
\hline & $\begin{array}{l}\text { LOT Ground Services Sp. z o.o. w upadło- } \\
\text { ści likwidacyjnej }\end{array}$ & $\mathrm{O}$ & $\mathrm{N}$ & $\mathrm{N}$ & $\mathrm{N}$ & $\mathrm{U}$ \\
\hline & EP Services Sp. z o.o. & $\mathrm{N}$ & $\mathrm{N}$ & $\mathrm{N}$ & $\mathrm{N}$ & $\mathrm{N}$ \\
\hline & $\begin{array}{l}\text { Nowy Przewoźnik Sp. z o.o. w upadłości } \\
\text { likwidacyjnej }\end{array}$ & $\mathrm{U}$ & $\mathrm{U}$ & $\mathrm{U}$ & $\mathrm{U}$ & $\mathrm{U}$ \\
\hline & $\begin{array}{l}\text { Przedsiębiorstwo Spedycji Międzynarodo- } \\
\text { wej C. Hartwig Warszawa SA }\end{array}$ & $\mathrm{U}$ & $\mathrm{U}$ & $\mathrm{U}$ & $\mathrm{U}$ & $\mathrm{U}$ \\
\hline \multirow{6}{*}{ 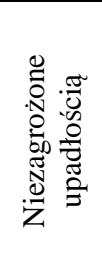 } & M\&M Militzer \& Münch Polska Sp. z o.o. & $\mathrm{O}$ & $\mathrm{N}$ & $\mathrm{N}$ & $S$ & $\mathrm{~N}$ \\
\hline & $\begin{array}{l}\text { Przedsiębiorstwo Wielobranżowe Podkowa } \\
\text { Sp. z o.o. }\end{array}$ & $\mathrm{N}$ & $\mathrm{N}$ & $\mathrm{N}$ & $\mathrm{N}$ & $\mathrm{N}$ \\
\hline & Hellmann Worldwide Logistics Sp. z o.o. & $\mathrm{N}$ & $\mathrm{N}$ & $\mathrm{N}$ & $\mathrm{N}$ & $\mathrm{N}$ \\
\hline & Zasada Logistyka Sp. z o.o. & $\mathrm{O}$ & $\mathrm{N}$ & $\mathrm{N}$ & $\mathrm{N}$ & $\mathrm{N}$ \\
\hline & CAT Polska Sp. z o.o. & $\mathrm{N}$ & $\mathrm{N}$ & $\mathrm{N}$ & $\mathrm{N}$ & $\mathrm{N}$ \\
\hline & DSV Solutions Sp. z o.o. & U & $\mathrm{N}$ & $\mathrm{N}$ & S & U \\
\hline
\end{tabular}

* Kolorem zaznaczone zostały błędnie dokonane klasyfikacje badanych spółek sektora TSL na podstawie wartości granicznych poszczególnych modeli. Jedynie w przypadku modelu B. Prusaka wartość graniczna została wyznaczona na poziomie $-0,13$, w pozostałych przypadkach wartość ta wynosiła 0 .

Pogrubioną czcionką oznaczony został model wykorzystujący dane ze sprawozdania z przepływów pieniężnych.

gdzie:

U - przedsiębiorstwo zagrożone upadłością,

O - „strefa pośrednia”,

S - przedsiębiorstwo o dość słabym wyniku, ale niezagrożone upadłością,

$\mathrm{N}$ - przedsiębiorstwo niezagrożone upadłością.

Źródło: obliczenia własne na podstawie danych zebranych w Krajowym Rejestrze Sądowym w Warszawie przy wykorzystaniu programu Microsoft Excel. 
Wśród spółek niezagrożonych upadłością jedynie jedna z nich (tj. DSV Solution Sp. z o.o.) została zaklasyfikowana do upadłych podmiotów gospodarczych przy wykorzystaniu modeli B. Prusaka i T. Maślanki.

Wszystkie modele dyskryminacyjne (za wyjątkiem modelu B. Prusaka) wykazały podobną zdolność predykcyjną, która kształtowała się na poziomie $83,33 \%$. Na podstawie ustalonej bowiem przez B. Prusaka wartości granicznej równiej -0,13 aż dla 4 przedsiębiorstw dokonano błędnej klasyfikacji. Jednakże w przypadku uwzględnienia tzw. strefy pośredniej wyznaczonej przez tego $\mathrm{Au}-$ tora $^{35}$, całkowity błąd klasyfikacji badanych spółek sektora TSL zmniejszył się do $16,67 \%$.

Tabela 5.4. Zbiorcze zestawienie modeli prognozujących zagrożenie upadłością badanych spółek sektora TSL na dwa lata przed wydaniem sądowego postanowienia o ogłoszeniu upadłości*

\begin{tabular}{|c|c|c|c|c|c|c|}
\hline $\begin{array}{l}\text { Rodzaj } \\
\text { spółki }\end{array}$ & Spółka & $\begin{array}{c}\text { Model } \\
\mathrm{Z}_{\mathrm{BP} 1}\end{array}$ & $\begin{array}{c}\text { Model } \\
Z_{7 \text { INE }} \\
\text { PAN }\end{array}$ & $\begin{array}{c}\text { Model } \\
Z_{6 \text { INE }} \\
\text { PAN }\end{array}$ & $\begin{array}{c}\text { Model } \\
\mathrm{Z}_{\mathrm{M}}\end{array}$ & $\begin{array}{r}\text { Model } \\
\mathbf{Z}_{\mathrm{TM10}}\end{array}$ \\
\hline \multirow{6}{*}{$\begin{array}{l}\frac{0}{\tilde{\sigma}} \\
\stackrel{\tilde{\sigma}}{\sigma}\end{array}$} & Corrida SA w upadłości likwidacyjnej & $\mathrm{O}$ & $\mathrm{U}$ & $\mathrm{U}$ & $\mathrm{U}$ & $\mathrm{N}$ \\
\hline & AMP Logistyka Sp. z o.o. & $\mathrm{U}$ & U & $\mathrm{U}$ & $\mathrm{U}$ & $\mathrm{N}$ \\
\hline & $\begin{array}{l}\text { LOT Ground Services Sp. z o.o. w upadłości } \\
\text { likwidacyjnej }\end{array}$ & $\mathrm{U}$ & $\mathrm{U}$ & $\mathrm{U}$ & $\mathrm{U}$ & $\mathrm{U}$ \\
\hline & EP Services Sp. z o.o. & $\mathrm{N}$ & $\mathrm{N}$ & $\mathrm{N}$ & $\mathrm{N}$ & $\mathrm{U}$ \\
\hline & $\begin{array}{l}\text { Nowy Przewoźnik Sp. z o.o. w upadłości } \\
\text { likwidacyjnej }\end{array}$ & $\mathrm{U}$ & $\mathrm{U}$ & $\mathrm{U}$ & $\mathrm{U}$ & $\mathrm{U}$ \\
\hline & $\begin{array}{l}\text { Przedsiębiorstwo Spedycji Międzynarodowej } \\
\text { C. Hartwig Warszawa SA }\end{array}$ & $\mathrm{U}$ & $\mathrm{U}$ & $\mathrm{U}$ & $\mathrm{U}$ & $\mathrm{U}$ \\
\hline \multirow{6}{*}{ 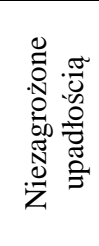 } & M\&M Militzer \& Münch Polska Sp. z o.o. & $\mathrm{U}$ & $\mathrm{N}$ & $\mathrm{N}$ & $\mathrm{S}$ & $\mathrm{U}$ \\
\hline & Polfrost Internationale Spedition Sp. z o.o. & $\mathrm{N}$ & $\mathrm{N}$ & $\mathrm{N}$ & $\mathrm{N}$ & $\mathrm{N}$ \\
\hline & Mexem Sp. z o.o. & One & N & $\mathrm{N}$ & $\mathrm{N}$ & $\mathrm{N}$ \\
\hline & M\&M air cargo service Polska SA & $\mathrm{O}$ & $\mathrm{N}$ & $\mathrm{N}$ & $\mathrm{N}$ & $\mathrm{U}$ \\
\hline & Charter Sp. z o.o. & $\mathrm{O}$ & $\mathrm{N}$ & $\mathrm{N}$ & $\mathrm{N}$ & U \\
\hline & DSV Solutions Sp. z o.o. & $\mathrm{U}$ & $\mathrm{U}$ & $\mathrm{U}$ & $\mathrm{U}$ & $\mathrm{N}$ \\
\hline
\end{tabular}

Oznaczenia jak do tab. 5.3.

Źródło: jak do tab. 5.3.

Spółka EP Services Sp. z o.o. na dwa lata przed upadłością jedynie według modelu T. Maślanki spełniła kryterium pozwalające uznać ją za upadły podmiot gospodarczy, zaś spółka DSV Solution Sp. z o.o. - za przedsiębiorstwo niezagrożone upadłością (zob. tab. 5.4). Niestety model ten okazał się nieskuteczny w przypadku klasyfikacji aż 5 pozostałych badanych spółek sektora TSL, tj. Corrida SA w upadłości likwidacyjnej, AMP Logistyka Sp. z o.o., M\&M Militzer \& Münch Polska Sp. z o.o., M\&M air cargo service Polska SA oraz

\footnotetext{
${ }^{35} \mathrm{Tj} .\langle-0,13 ; 0,65\rangle$. Zob. B. Prusak, op. cit., s. 151.
} 
Charter Sp. z o.o. Przyczyniło się to do osiągnięcia przez ten model najniższego - w relacji do pozostałych modeli - poziomu zdolności predykcyjnej $(58,33 \%)$.

W przypadku modeli O. H. Jacobsa i E. Mączyńskiej uzyskana została niemal identyczna klasyfikacja przedsiębiorstw sektora TSL. Różnica wystąpiła wyłącznie w zaklasyfikowaniu przez model O. H. Jacobsa spółki M\&M Militzer \& Münch Polska Sp. z o.o. do podmiotów gospodarczych o dość słabym wyniku finansowym, lecz niezagrożonym upadłością ${ }^{36}$. Obydwa modele identycznie, choć błędnie, sklasyfikowały również dwa poddane badaniu podmioty gospodarcze, tj. EP Services Sp. z o.o. oraz DSV Solutions Sp. z o.o.

Model B. Prusaka charakteryzował się z kolei 33,33\% całkowitym błędem klasyfikacji. Błąd ten - w przypadku uwzględnienia tzw. strefy pośredniej wyznaczonej przez tego Autora - uległby zmniejszeniu o ponad 8 punktów procentowych. Wartość funkcji dyskryminacyjnej dla spółki Corrida SA w upadłości likwidacyjnej wynosiła bowiem około $-0,11$, a zatem nieznacznie przewyższała wartość graniczną tego modelu.

Tabela 5.5. Zbiorcze zestawienie modeli prognozujących zagrożenie upadłością badanych spółek sektora TSL na trzy lata przed wydaniem sądowego postanowienia o ogłoszeniu upadłości*

\begin{tabular}{|c|c|c|c|c|c|c|}
\hline $\begin{array}{l}\text { Rodzaj } \\
\text { spółki }\end{array}$ & Spółka & $\begin{array}{c}\text { Model } \\
\mathrm{Z}_{\mathrm{BP} 1}\end{array}$ & $\begin{array}{c}\text { Model } \\
Z_{7 \text { INE }} \\
\text { PAN } \\
\end{array}$ & $\begin{array}{c}\text { Model } \\
Z_{6 \text { INE }} \\
\text { PAN } \\
\end{array}$ & $\begin{array}{c}\text { Model } \\
\mathrm{Z}_{\mathrm{M}}\end{array}$ & $\begin{array}{c}\text { Model } \\
\mathbf{Z}_{\text {TM11 }}\end{array}$ \\
\hline \multirow{6}{*}{$\begin{array}{l}\frac{0}{\tilde{\sigma}} \\
\stackrel{\tilde{\sigma}}{\sigma}\end{array}$} & Corrida SA w upadłości likwidacyjnej & $\mathrm{O}$ & $\mathrm{N}$ & $\mathrm{N}$ & $\mathrm{S}$ & $\mathrm{N}$ \\
\hline & AMP Logistyka Sp. z o.o. & $\mathrm{O}$ & $\mathrm{N}$ & $\mathrm{N}$ & S & U \\
\hline & $\begin{array}{l}\text { LOT Ground Services Sp. z o.o. w upadłości } \\
\text { likwidacyjnej }\end{array}$ & $\mathrm{O}$ & $\mathrm{N}$ & $\mathrm{N}$ & $\mathrm{N}$ & $\mathrm{N}$ \\
\hline & EP Services Sp. z o.o. & $\mathrm{N}$ & $\mathrm{N}$ & $\mathrm{N}$ & $\mathrm{N}$ & $\mathrm{N}$ \\
\hline & $\begin{array}{l}\text { Nowy Przewoźnik Sp. z o.o. w upadłości } \\
\text { likwidacyjnej }\end{array}$ & $\mathrm{U}$ & $\mathrm{U}$ & $\mathrm{U}$ & $\mathrm{U}$ & $\mathrm{N}$ \\
\hline & $\begin{array}{l}\text { Przedsiębiorstwo Spedycji Międzynarodo- } \\
\text { wej C. Hartwig Warszawa SA }\end{array}$ & $\mathrm{U}$ & $\mathrm{U}$ & U & U & $\mathrm{U}$ \\
\hline \multirow{6}{*}{ 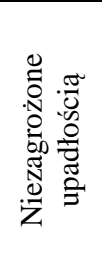 } & Trans-Petro-Color Sp. z o.o. & $\mathrm{N}$ & $\mathrm{N}$ & $\mathrm{N}$ & $\mathrm{N}$ & $\mathrm{N}$ \\
\hline & Mostva Sp. z o.o. & $\mathrm{O}$ & U & $\mathrm{U}$ & S & $\mathrm{N}$ \\
\hline & DPD Polska Sp. z o.o. & $\mathrm{N}$ & $\mathrm{N}$ & $\mathrm{N}$ & $\mathrm{N}$ & $\mathrm{N}$ \\
\hline & $\begin{array}{l}\text { Przedsiębiorstwo Wielobranżowe Podkowa } \\
\text { Sp. z o.o. }\end{array}$ & $\mathrm{O}$ & $\mathrm{N}$ & $\mathrm{N}$ & $\mathrm{N}$ & $\mathrm{N}$ \\
\hline & VAN Cargo SA & $\mathrm{N}$ & $\mathrm{N}$ & $\mathrm{N}$ & $\mathrm{N}$ & $\mathrm{N}$ \\
\hline & Solid Logistics Sp. z o.o. & $\mathrm{N}$ & $\mathrm{N}$ & $\mathrm{N}$ & $\mathrm{N}$ & $\mathrm{N}$ \\
\hline
\end{tabular}

Oznaczenia jak do tab. 5.3.

Źródło: jak do tab. 5.3.

${ }^{36} \mathrm{Z}_{\mathrm{M}}<0 \quad$ przedsiębiorstwo zagrożone upadłością,

$0<\mathrm{Z}_{\mathrm{M}}<1$ przedsiębiorstwo o dość słabym wyniku, ale niezagrożone upadłością,

$1 \leq \mathrm{Z}_{\mathrm{M}}<2$ przedsiębiorstwo dość dobre,

$\mathrm{Z}_{\mathrm{M}} \geq 2$ przedsiębiorstwo bardzo dobre.

[za:] E. Mąc z yń s k a, Ocena kondycji..., op. cit., s. 44. 
Większość upadłych spółek sektora TSL na trzy lata przed upadłością została błędnie zaklasyfikowana do podmiotów gospodarczych niezagrożonych upadłością (zob. tab. 5.5). W przypadku tego rodzaju przedsiębiorstw wszystkie modele charakteryzowały się aż $80 \%$ całkowitym błędem klasyfikacji. Jednakże w modelu B. Prusaka, po uwzględnieniu tzw. strefy pośredniej, znacznie wzrosła zdolność predykcyjna tego modelu - z 66,67\% do 91,67\%. Jedynie dla spółki EP Services Sp. z o.o. wartość funkcji dyskryminacyjnej nie przekroczyła w nim punktu granicznego, co wskazywało na brak zagrożenia upadłością.

Spółka Corrida SA w upadłości likwidacyjnej oraz AMP Logistyka Sp. z o.o. zostały w modelu O. H. Jacobsa zaliczone do przedsiębiorstw o dość słabym wyniku finansowym, choć niezagrożonych upadłością. Z kolei najniższa zdolność predykcyjna wystąpiła w przypadku stosowania modeli E. Mączyńskiej, bowiem dodatkowo jeden podmiot gospodarczy niezagrożony upadłością uznany został za spółkę upadłą.

W badanym okresie zdolność predykcyjna rozważanych modeli uległa obniżeniu w relacji do jej wyjściowego poziomu, tj. deklarowanego przez badaczy przedmiotu. Nie ma jednakże modeli uniwersalnych dla przedsiębiorstw wszystkich typów i wielkości ${ }^{37}$.

Należy bowiem zauważyć, iż zamierzeniem B. Prusaka było stosowanie modelu głównie do analizy przedsiębiorstw produkcyjnych. Dla spółek sektora TSL średnia trafność klasyfikacji tego modelu wynosiła 66,67\%. Niemniej jednak - po uwzględnieniu wyznaczonej przez Autora tzw. strefy pośredniej - trafność ta zwiększyła się aż blisko o 17 punktów procentowych i stała się jednocześnie najwyższą (zob. tab. 5.6).

Publikowana przez Autorów poszczególnych modeli ich trafność klasyfikacji uległa przeto zmianie przy zastosowaniu odmiennych danych. Dla sektora TSL obniżała się ona dodatkowo w miarę wydłużania badanego okresu przed wystąpieniem upadłości. Tym samym w analizowanym okresie średni całkowity błąd klasyfikacji uległ zwiększeniu z 20\% na rok przed upadłością do 36,67\% na trzy lata przed upadłością ${ }^{38}$.

Jedynie w przypadku modeli T. Maślanki obserwuje się wzrost zdolności predykcyjnej w miarę wydłużania okresu predykcji z dwóch do trzech lat przed upadłością badanych przedsiębiorstw. Przyczyną tego stanu mogło być oszacowanie różnych postaci modelu w zależności od liczby lat do upadłości analizowanych przez tego Autora podmiotów gospodarczych oraz wykorzystanie zróżnicowanego zestawu mierników, z założenia lepiej prognozujących badane zjawisko w długim okresie ${ }^{39}$.

\footnotetext{
${ }^{37}$ U. Malinowska, W. Rogowski, op. cit., s. 79.

${ }^{38} \mathrm{Tj}$. średnia ogólna trafność klasyfikacji badanych spółek sektora TSL wynosiła odpowiednio $80,00 \%, 75,00 \%$ i 63,33\% na rok, dwa i trzy lata przed upadłością.

${ }^{39}$ U. Malinowska, W. Rogowski, op. cit., s. 79-80.
} 
Tabela 5.6. Trafność klasyfikacji w prognozowaniu zagrożenia upadłości przedsiębiorstw sektora

TSL charakteryzująca wybrane funkcje dyskryminacyjne (w \%)

\begin{tabular}{|c|c|c|c|c|c|}
\hline \multirow{2}{*}{ Symbol modelu } & \multicolumn{3}{|c|}{ Okresy sprawozdawcze objęte analizą } & \multirow{2}{*}{\begin{tabular}{|c} 
Średnia trafność \\
klasyfikacji \\
badanych spółek \\
sektora TSL
\end{tabular}} & \multirow{2}{*}{$\begin{array}{c}\text { Wyjściowa trafność } \\
\text { klasyfikacji }\end{array}$} \\
\hline & $\begin{array}{l}\text { rok przed } \\
\text { upadłością }\end{array}$ & $\begin{array}{l}\text { dwa lata } \\
\text { przed } \\
\text { upadłością }\end{array}$ & $\begin{array}{l}\text { trzy lata } \\
\text { przed } \\
\text { upadłością }\end{array}$ & & \\
\hline Model $\mathrm{Z}_{\mathrm{BP} 1}$ * & $\begin{array}{c}66,67 \\
(83,33) \\
\end{array}$ & $\begin{array}{c}66,67 \\
(75,00) \\
\end{array}$ & $\begin{array}{c}66,67 \\
(91,67) \\
\end{array}$ & $\begin{array}{c}66,67 \\
(83,33) \\
\end{array}$ & $98,08 * *$ \\
\hline Model $Z_{7 \text { INE PAN }}$ & 83,33 & 83,33 & 58,33 & 75,00 & $97,92 * *$ \\
\hline Model $Z_{6 \text { INE PAN }}$ & 83,33 & 83,33 & 58,33 & 75,00 & $97,92 * *$ \\
\hline Model $\mathrm{Z}_{\mathrm{M}}$ & 83,33 & 83,33 & 66,67 & 77,78 & $97,83 * *$ \\
\hline Model $\mathbf{Z}_{\mathrm{TM}}$ & 83,33 & 58,33 & 66,67 & 69,44 & $78,75-92,50 * * *$ \\
\hline
\end{tabular}

* W nawiasie podana została trafność klasyfikacji po uwzględnieniu tzw. strefy pośredniej wyznaczonej przez Autora modelu.

** Trafność klasyfikacji poszczególnych modeli dla przedsiębiorstw usługowych.

*** Trafność klasyfikacji uzależniona jest od okresu objętego analizą (tj. na rok przed upadłością wynosiła $92,50 \%$ i odpowiednio na dwa lata przed upadłością - 82,50\%, a na trzy lata przed upadłością $-78,75 \%$ ).

Pogrubioną czcionką oznaczony został model wykorzystujący dane ze sprawozdania z przepływów pieniężnych.

Źródło: jak do tab. 5.3.

Modelem o najwyższej średniej zdolności predykcyjnej (przy uwzględnieniu tzw. strefy pośredniej) okazał się model B. Prusaka, dając najlepsze wyniki na trzy lata przed upadłością. Najniższą średnią trafność klasyfikacji cechowały się modele T. Maślanki wykorzystujące dane ze sprawozdania z przepływów pieniężnych.

Rezultaty przeprowadzonych badań empirycznych wskazują zatem, iż w przypadku prognozowania zagrożenia upadłością przedsiębiorstw sektora TSL modele dyskryminacyjne wykorzystujące dane ze sprawozdania z przepływów pieniężnych wykazują nieznacznie niższą średnią zdolność predykcyjną od modeli uwzględniających jedynie dane z bilansu oraz rachunku zysków i strat ${ }^{40} . \mathrm{Na}$ podstawie otrzymanych wyników nie została przeto potwierdzona postawiona hipoteza badawcza.

Należy jednocześnie zauważyć, iż dla spółek sektora TSL zdolność predykcyjna badanych modeli dyskryminacyjnych uległa obniżeniu w relacji jej wyjściowego poziomu, tj. deklarowanego przez badaczy przedmiotu. Przeprowa-

\footnotetext{
${ }^{40} \mathrm{~W}$ przypadku modelu B. Prusaka uwzględniona została tutaj tzw. strefa pośrednia.
} 
dzone badania odnoszą się jednakże do wyselekcjonowanej liczby podmiotów gospodarczych, a zatem ze względu na swój „,sektorowy” i wąski zasięg nie predysponują do sformułowania zgeneralizowanych wniosków.

\subsection{Ocena zdolności predykcyjnych wybranych zmiennych diagnostycznych operacyjnego zagrożenia finansowego dla przedsiębiorstw sektora TSL}

\subsubsection{Ocena zdolności predykcyjnych mierników na rok przed upadłością przedsiębiorstw ${ }^{41}$}

W pierwszym etapie analizy skuteczności zmiennych diagnostycznych ${ }^{42}$ poddanych badaniu określone zostały punkty graniczne, które posłużyły do oszacowania ich zdolności prognostycznej. Punkty graniczne wyznaczone zostały jako średnia ze średnich uzyskanych w obu analizowanych grupach przedsiębiorstw $^{43}$ (tj. upadłych, jak i niezagrożonych upadłością - zob. tab. 5.7).

Spółki upadłe osiągały (na rok przed upadłością) znacznie niższy średni i środkowy poziom memoriałowych współczynników płynności finansowej $\left(\mathrm{m}_{2}\right.$, $\mathrm{m}_{3}, \mathrm{~m}_{4}$ ) oraz współczynnika zdolności do obsługi zobowiązań bieżących gotówką osiąganą z działalności operacyjnej $\left(\mathrm{m}_{5}\right) \mathrm{w}$ relacji do przedsiębiorstw niezagrożonych upadłością (zob. wykres 5.2 i 5.3). Ponadto za wyjątkiem współczynnika wydajności pieniężnej (gotówkowej) sprzedaży $\left(\mathrm{m}_{9}\right)$ wszystkie rozważane zmienne dotyczące obszaru rentowności w wymiarze kasowym i memoriałowym w przypadku upadłych jednostek gospodarczych osiągały ujemną wartość średnią. Analiza wartości miernika $m_{9}$ wskazuje na występowanie obserwacji nietypowej w spółce AMP Logistyka Sp. z o.o. W badanym okresie (tj. na rok przed upadłością) wartość tego współczynnika wynosiła aż 0,3257 i była znacznie wyższa nawet od tych, które zostały osiągnięte przez jednostki gospodarcze niezagrożone upadłością.

Przedsiębiorstwa upadłe wykazywały średni poziom współczynników zabezpieczenia finansowego wyższy od zera, a te niezagrożone upadłością - jedynie ten, który oparty był na pozostałych krótkoterminowych rezerwach finansowych. Ponadto, znacznie wyższa średnia i środkowa wartość przychodów netto

${ }^{41}$ Sprawność modelu obniża się w miarę wydłużania badanego okresu przed wystąpieniem upadłości. Problem ten rozwiązany został poprzez oszacowania różnych postaci modeli w zależności od liczby lat do upadłości, uzyskując ostatecznie inny zestaw mierników w modelu, lepiej prognozujących w długim okresie czasu. Zob. U. Mali n o w s ka, W. R o go w ski, op. cit., s. 79-80.

Dane finansowe pozyskane zostały na rok, dwa i trzy okresy sprawozdawcze przed złożeniem wniosku o upadłość.

${ }^{42} \mathrm{~W}$ dalszych analizach pominięto zmienną $\mathrm{m}_{8}$ i $\mathrm{m}_{11} \mathrm{z}$ uwagi na ujemną wartość kapitału własnego w niektórych badanych podmiotach gospodarczych.

${ }^{43}$ T. Maśl an k a, op. cit., s. 210. 
ze sprzedaży usług, towarów i materiałów została osiągnięta przez pierwszą grupę analizowanych podmiotów gospodarczych, bowiem dla przykładu spółka Nowy Przewoźnik Sp. z o.o. w upadłości likwidacyjnej na rok przed upadkiem wypracowała aż 536297 645,96 zł z tytułu realizacji podstawowego rodzaju prowadzonej działalności usługowej.

Tabela 5.7. Średnie wartości wybranych mierników oceny operacyjnego zagrożenia finansowego w upadłych, jak i niezagrożonych upadłością przedsiębiorstwach sektora TSL (rok przed upadłością)

\begin{tabular}{|c|c|c|c|}
\hline \multirow{2}{*}{ Miernik } & \multicolumn{2}{|c|}{ Wartość średnia miernika } & Punkt graniczny \\
& spółki upadłe & $\begin{array}{c}\text { spółki } \\
\text { niezagrożone } \\
\text { upadłością }\end{array}$ & \begin{tabular}{c} 
średnich) \\
\cline { 2 - 3 }
\end{tabular} \\
\hline $\mathrm{m}_{1}$ & 161179895,70 & 87865269,90 & 124522582,80 \\
\hline $\mathrm{m}_{2}$ & 0,7123 & 1,2606 & 0,9864 \\
\hline $\mathrm{m}_{3}$ & 0,6692 & 1,1607 & 0,9149 \\
\hline $\mathrm{m}_{4}$ & 0,0277 & 0,1083 & 0,0680 \\
\hline $\mathrm{m}_{5}$ & 0,0984 & 0,2388 & 0,1686 \\
\hline $\mathrm{m}_{6}$ & $-0,0266$ & 0,0195 & $-0,0035$ \\
\hline $\mathrm{m}_{7}$ & $-0,2504$ & 0,0738 & $-0,0883$ \\
\hline $\mathrm{m}_{9}$ & 0,0634 & 0,0309 & 0,0472 \\
\hline $\mathrm{m}_{10}$ & $-0,0415$ & 0,0631 & 0,0108 \\
\hline $\mathrm{m}_{12}$ & 0,0075 & 0,0000 & 0,0038 \\
\hline $\mathrm{m}_{13}$ & 0,0012 & 0,0091 & 0,0052 \\
\hline
\end{tabular}

Źródło: obliczenia własne na podstawie danych zebranych w Krajowym Rejestrze Sądowym w Warszawie oraz Centralnego Ośrodka Informacji Gospodarczej Sp. z o.o. przy wykorzystaniu programu Microsoft Excel.

W kolejnym etapie analizowane zostały jedynie te mierniki, które poprawnie klasyfikowały badane podmioty przynajmniej w 50\%. W badanym okresie wszystkie zmienne diagnostyczne spełniły to kryterium (zob. tab. 5.8).

W przypadku spółek niezagrożonych upadłością miernikiem o największej zdolności predykcyjnej (100\%) był współczynnik eksploatacyjnej rentowności aktywów ogółem $\left(\mathrm{m}_{7}\right)$ oraz współczynnik zabezpieczenia finansowego $\mathrm{nr} 1$ $\left(\mathrm{m}_{12}\right)$. Wysoka trafność klasyfikacji dla tych przedsiębiorstw (80\%) wystąpiła w przypadku współczynnika bieżącej płynności finansowej $\left(\mathrm{m}_{2}\right)$, współczynnika przyspieszonej płynności finansowej $\left(\mathrm{m}_{3}\right)$, współczynnika eksploatacyjnej rentowności sprzedaży $\left(\mathrm{m}_{6}\right)$, współczynnika wydajności pieniężnej (gotówkowej) sprzedaży $\left(\mathrm{m}_{9}\right)$ oraz współczynnika wydajności pieniężnej (gotówkowej) aktywów ogółem $\left(\mathrm{m}_{10}\right)$. 


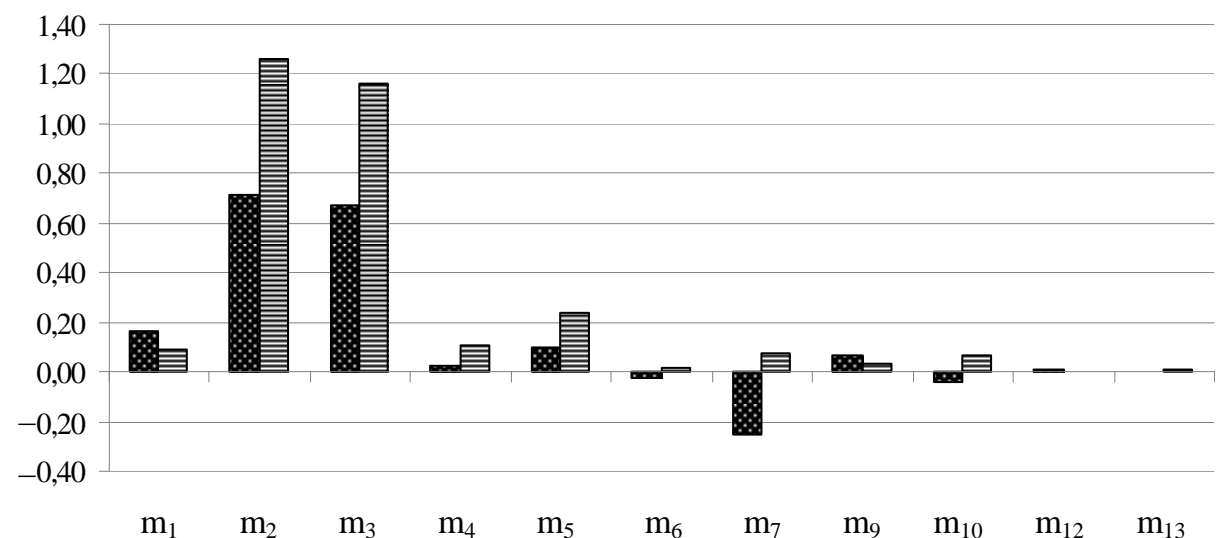

spółki upadłe 目 spółki niezagrożone upadłością

* Dane dla miernika $\mathrm{m}_{1}$ są podane w mld zł.

Wykres 5.2 . Średnia wartość mierników oceny operacyjnego zagrożenia finansowego w spółkach niezagrożonych upadłością i upadłych (rok przed upadłością)*

Źródło: obliczenia własne na podstawie danych zebranych w Krajowym Rejestrze Sądowym w Warszawie oraz Centralnego Ośrodka Informacji Gospodarczej Sp. z o.o. przy wykorzystaniu programu Microsoft Excel.

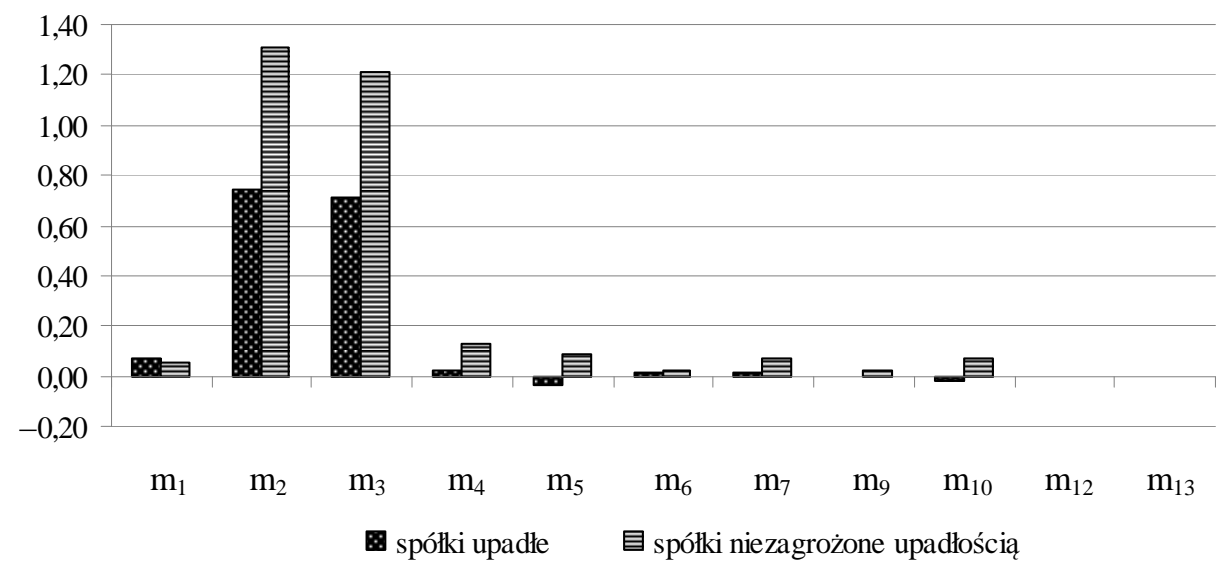

* Oznaczenia jak do wykresu 5.2.

Wykres 5.3. Środkowa wartość mierników oceny operacyjnego zagrożenia finansowego w spółkach niezagrożonych upadłością i upadłych (rok przed upadłością)*

Źródło: jak do wykresu 5.2. 
Tabela 5.8. Trafność klasyfikacji wybranych mierników oceny operacyjnego zagrożenia finansowego ${ }^{44}$ (rok przed upadłością)* $(\mathrm{w} \%)$

\begin{tabular}{|c|c|c|c|c|c|c|}
\hline Miernik & $\begin{array}{c}\text { Błąd } \\
\text { I typu** }\end{array}$ & $\begin{array}{c}\text { Sprawność } \\
\text { I typu }\end{array}$ & $\begin{array}{c}\text { Błąd } \\
\text { II typu*** }\end{array}$ & $\begin{array}{c}\text { Sprawnośćc } \\
\text { II typu }\end{array}$ & $\begin{array}{c}\text { Błąd } \\
\text { ogółem }\end{array}$ & $\begin{array}{c}\text { Sprawność } \\
\text { ogółem }\end{array}$ \\
\hline \hline $\mathrm{m}_{1}$ & 60,00 & 40,00 & 40,00 & $\mathbf{6 0 , 0 0}$ & 50,00 & 50,00 \\
\hline $\mathrm{m}_{2}$ & 20,00 & $\mathbf{8 0 , 0 0}$ & 20,00 & $\mathbf{8 0 , 0 0}$ & 20,00 & 80,00 \\
\hline $\mathrm{m}_{3}$ & 20,00 & $\mathbf{8 0 , 0 0}$ & 20,00 & $\mathbf{8 0 , 0 0}$ & 20,00 & 80,00 \\
\hline $\mathrm{m}_{4}$ & 0,00 & $\mathbf{1 0 0 , 0 0}$ & 40,00 & 60,00 & 20,00 & 80,00 \\
\hline $\mathrm{m}_{5}$ & 40,00 & $\mathbf{6 0 , 0 0}$ & 60,00 & 40,00 & 50,00 & 50,00 \\
\hline $\mathrm{m}_{6}$ & 60,00 & 40,00 & 20,00 & $\mathbf{8 0 , 0 0}$ & 40,00 & 60,00 \\
\hline $\mathrm{m}_{7}$ & 60,00 & 40,00 & 0,00 & $\mathbf{1 0 0 , 0 0}$ & 30,00 & 70,00 \\
\hline $\mathrm{m}_{9}$ & 80,00 & 20,00 & 20,00 & $\mathbf{8 0 , 0 0}$ & 50,00 & 50,00 \\
\hline $\mathrm{m}_{10}$ & 40,00 & 60,00 & 20,00 & $\mathbf{8 0 , 0 0}$ & 30,00 & 70,00 \\
\hline $\mathrm{m}_{12}$ & 80,00 & 20,00 & 0,00 & $\mathbf{1 0 0 , 0 0}$ & 40,00 & 60,00 \\
\hline $\mathrm{m}_{13}$ & 20,00 & $\mathbf{8 0 , 0 0}$ & 60,00 & 40,00 & 40,00 & 60,00 \\
\hline
\end{tabular}

* Pogrubioną czcionką została znaczona wyższa z wartości procentowych z dwóch typów sprawności, osiągnięta dla poszczególnych mierników oceny operacyjnego zagrożenia finansowego (w przypadku identycznego poziomu analizowanego udziału procentowego - zostały zaznaczone obydwie wartości procentowe dla dwóch typów sprawności).

** Błąd I typu polega na zaliczeniu przedsiębiorstwa upadłego do grupy przedsiębiorstw niezagrożonych upadłością.

*** Błąd II typu polega na zaliczeniu przedsiębiorstwa niezagrożonego upadłością do grupy przedsiębiorstw upadłych.

Źródło: jak do tab. 5.7.

W drugiej grupie przedsiębiorstw najwyższą (100\%) zdolność predykcyjną posiadał jedynie współczynnik natychmiastowej płynności finansowej $\left(\mathrm{m}_{4}\right)$, zaś 80\% - współczynnik bieżącej płynności finansowej $\left(\mathrm{m}_{2}\right)$, współczynnik przyspieszonej płynności finansowej $\left(\mathrm{m}_{3}\right)$, a także współczynnik zabezpieczenia finansowego $\mathrm{nr} 2\left(\mathrm{~m}_{13}\right)$. Istotny jest fakt, iż miernik $\mathrm{m}_{5}$ odznaczał się $60 \%$ trafnością klasyfikacji w przypadku spółek upadłych i jedynie $40 \%$ w przypadku spółek niezagrożonych upadłością. Argumentów za wykorzystaniem tej miary w predykcji analizowanego zjawiska dostarczają dane zawarte w tab. 5.9, w której zestawione zostały $\mathrm{m}$. in. wewnątrzgrupowe i międzygrupowe współczynniki zmienności wybranych mierników oceny operacyjnego zagrożenia finansowego.

${ }^{44}$ Por. S. H. Pen man, Financial Statement Analysis and Security Valuation, McGraw-Hill/ Irwin, New York 2001, s. 730; J. G a j d k a, D. S to s, Predicting Corporate Bankruptcy - the Polish Experience, [w:] R. B o r o w i e ck i (red.), Management of Organization During Economic Integration and Globalization, Department of Economic and Organization of Enterprise, Cracow University of Economics, Warsaw-Cracow 2003, s. 78; B. Prusak, op. cit., s. 68-69; P. Antonowi c z, Metody oceny..., op. cit., 38-39 i 46; T. M aśl a n k a, op. cit., s. 210-251. 


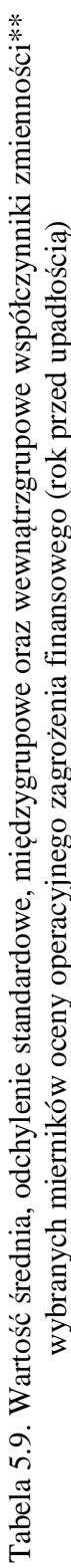

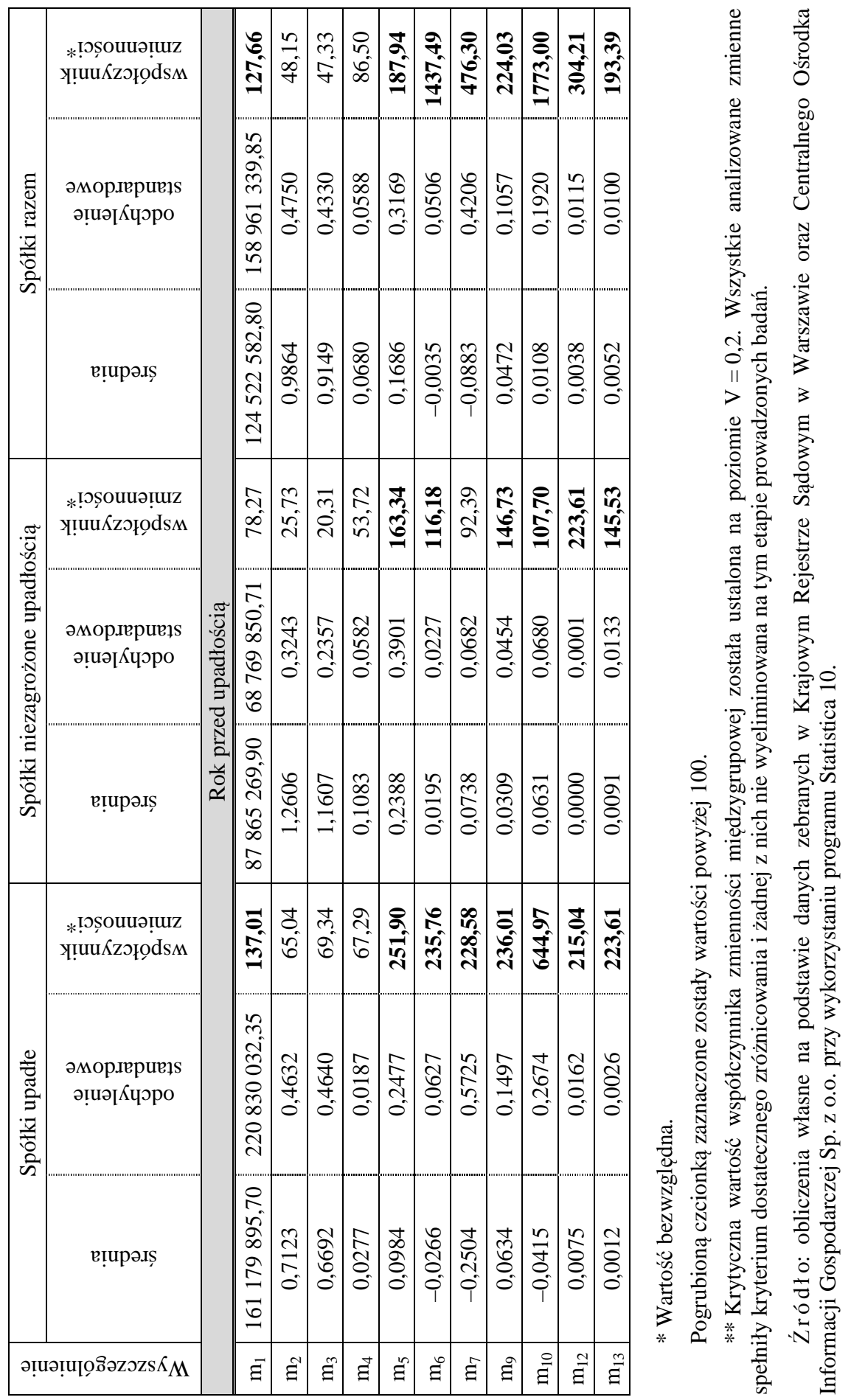


Memoriałowe współczynniki płynności finansowej charakteryzują się najniższymi współczynnikami zmienności zarówno wewnątrzgrupowych (zwłaszcza w przypadku przedsiębiorstw niezagrożonych upadłością), jak i międzygrupowych. Niskie wartości wewnątrzgrupowego współczynnika zmienności najczęściej świadczą o wysokiej przydatności tych mierników w predykcji analizowanego zjawiska. Kasowy miernik płynności finansowej posiada z kolei podobny poziom współczynników zmienności do zmiennej $\mathrm{m}_{13}$, $\mathrm{tj}$. zmiennej o nieco wyższych od niego trafności klasyfikacji ogółem (tj. 60\%).

Wysoka zdolność prognostyczna danego miernika występuje w przypadku wysokiego poziomu współczynnika zmienności międzygrupowego (najkorzystniej przy minimalnych poziomach współczynników zmienności w obu grupach przedsiębiorstw) ${ }^{45}$. Taka sytuacja dotyczyła dla przykładu współczynnika eksploatacyjnej rentowności sprzedaży $\left(\mathrm{m}_{6}\right)$, współczynnika wydajności pieniężnej (gotówkowej) aktywów ogółem $\left(\mathrm{m}_{10}\right)$ oraz współczynnika eksploatacyjnej rentowności aktywów ogółem $\left(\mathrm{m}_{7}\right)$.

\subsubsection{Ocena zdolności predykcyjnych mierników na dwa lata przed upadłością przedsiębiorstw}

W obu badanych grupach przedsiębiorstw sektora TSL relacja rozważanych mierników utrzymała się na zbliżonym poziomie w stosunku do poprzedniego okresu poddanego badaniu (zob. wykres 5.4 i 5.5). Jedyna różnica dotyczyła występowania niższej środkowej wartości przychodów netto ze sprzedaży usług, towarów i materiałów w spółkach upadłych w relacji do przedsiębiorstw niezagrożonych upadłością oraz występowania dodatniej wartości współczynnika zabezpieczenia finansowego tylko w pierwszej grupie analizowanych podmiotów gospodarczych.

Wyznaczone i zaprezentowane w tab. 5.10 punkty graniczne pozwoliły ocenić zdolność predykcyjną rozważanych w niniejszym opracowaniu mierników oceny operacyjnego zagrożenia finansowego. Wszystkie z nich spełniły minimum założonej zdolności predykcyji analizowanego zjawiska przy ustalonym kryterium wyboru zmiennych na poziomie 50\% ich trafności klasyfikacji.

W przypadku spółek niezagrożonych upadłością miernikami o największych zdolnościach prognostycznych (100\%) okazał się nie tylko współczynnik eksploatacyjnej rentowności aktywów ogółem $\left(\mathrm{m}_{7}\right)$ i współczynnik zabezpieczenia finansowego $\mathrm{nr} 1\left(\mathrm{~m}_{12}\right)$, ale również współczynnik eksploatacyjnej rentowności sprzedaży $\left(\mathrm{m}_{6}\right)$, współczynnik wydajności pieniężnej (gotówkowej) aktywów ogółem $\left(\mathrm{m}_{10}\right)$ oraz współczynnik zabezpieczenia finansowego $\mathrm{nr} 2\left(\mathrm{~m}_{13}\right)$ - zob. tab. 5.11.

${ }^{45}$ T. Maśla n ka, op. cit., s. 216. 
Tabela 5.10. Średnie wartości wybranych mierników oceny operacyjnego zagrożenia finansowego w upadłych, jak i niezagrożonych upadłością przedsiębiorstwach sektora TSL (dwa lata przed upadłością)

\begin{tabular}{|c|c|c|c|}
\hline \multirow{2}{*}{ Miernik } & \multicolumn{2}{|c|}{ Wartość średnia miernika } & \multirow{2}{*}{ Punkt graniczny } \\
\cline { 2 - 3 } & spółki upadłe & $\begin{array}{c}\text { spółki } \\
\text { niezagrożone } \\
\text { upadłością }\end{array}$ & \\
\hline \hline $\mathrm{m}_{1}$ & 144384713,36 & 71723900,80 & 108054307,08 \\
\hline $\mathrm{m}_{2}$ & 0,7501 & 1,0144 & 0,8823 \\
\hline $\mathrm{m}_{3}$ & 0,6738 & 0,9870 & 0,8304 \\
\hline $\mathrm{m}_{4}$ & 0,0534 & 0,1543 & 0,1038 \\
\hline $\mathrm{m}_{5}$ & 0,0540 & 0,2271 & 0,1405 \\
\hline $\mathrm{m}_{6}$ & $-0,0409$ & 0,0280 & $-0,0064$ \\
\hline $\mathrm{m}_{7}$ & $-0,4707$ & 0,0990 & $-0,1859$ \\
\hline $\mathrm{m}_{9}$ & 0,0491 & 0,0413 & 0,0452 \\
\hline $\mathrm{m}_{10}$ & $-0,3011$ & 0,1354 & $-0,0829$ \\
\hline $\mathrm{m}_{12}$ & 0,0055 & 0,0000 & 0,0028 \\
\hline $\mathrm{m}_{13}$ & 0,0030 & 0,0000 & 0,0015 \\
\hline & & & \\
\hline
\end{tabular}

Źródło: jak do tab. 5.7.

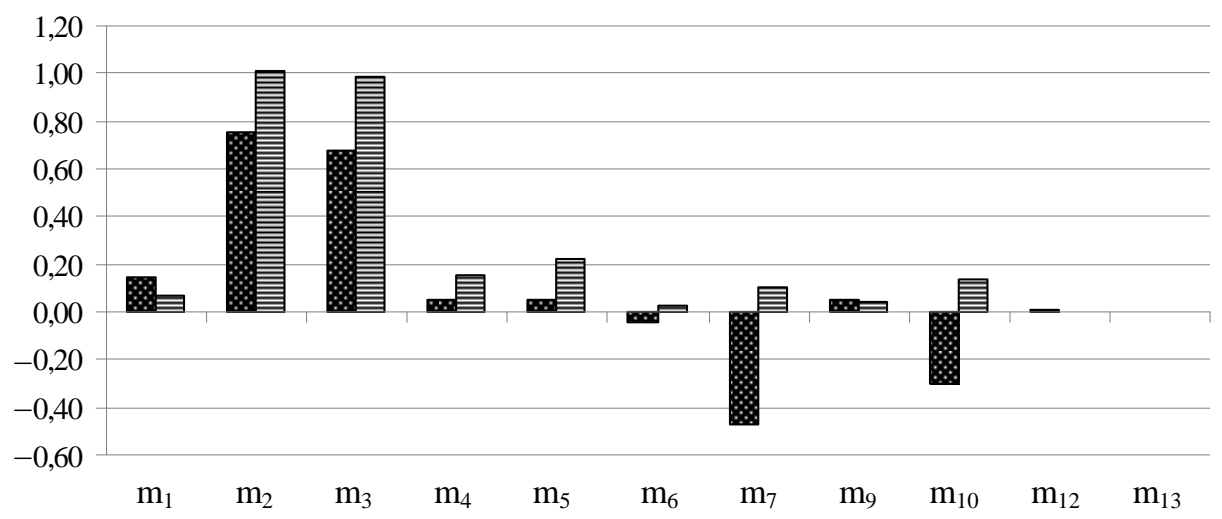

spółki upadłe 目 spółki niezagrożone upadłością

* Dane dla miernika $\mathrm{m}_{1}$ są podane w mld zł.

Wykres 5.4. Średnia wartość mierników oceny operacyjnego zagrożenia finansowego w spółkach niezagrożonych upadłością i upadłych (dwa lata przed upadłością)*

Źródło: jak do wykresu 5.2. 


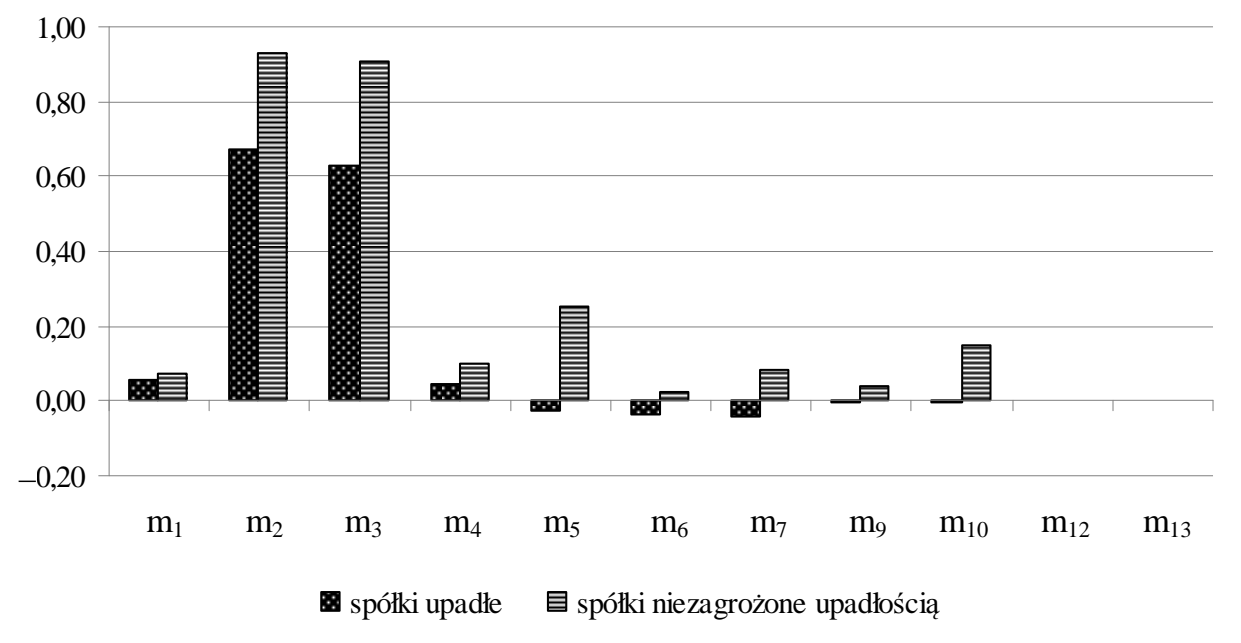

* Oznaczenia jak do wykresu 5.4.

Wykres 5.5. Środkowa wartość mierników oceny operacyjnego zagrożenia finansowego w spółkach niezagrożonych upadłością i upadłych (dwa lata przed upadłością)*

Źródło: jak do wykresu 5.2.

Zaskakująco wysoką trafność klasyfikacji dla przedsiębiorstw niezagrożonych upadłością posiada miernik $\mathrm{m}_{13}$, bowiem w poprzednim badanym okresie osiągnęła ona poziom zalewie 40\%. Równie wysoka zdolność predykcji dla tych spółek $(80 \%)$ wystąpiła po raz kolejny w przypadku współczynnika bieżącej płynności finansowej $\left(\mathrm{m}_{2}\right)$, współczynnika przyspieszonej płynności finansowej $\left(\mathrm{m}_{3}\right)$, ale również dla przychodów netto ze sprzedaży usług, towarów i materiałów $\left(\mathrm{m}_{1}\right)$ oraz współczynnika zdolności do obsługi zobowiązań bieżących gotówką osiąganą z działalności operacyjnej $\left(\mathrm{m}_{5}\right)$.

W drugiej grupie przedsiębiorstw najwyższą (100\%) zdolność prognostyczną posiadał ponownie współczynnik natychmiastowej płynności finansowej $\left(\mathrm{m}_{4}\right)$, zaś $80 \%$ - podobnie jak i poprzednio - współczynnik bieżącej płynności finansowej $\left(\mathrm{m}_{2}\right)$ oraz współczynnik przyspieszonej płynności finansowej $\left(\mathrm{m}_{3}\right)$. Miernik $\mathrm{m}_{9}$ odznaczał się jedynie $40 \%$ trafnością klasyfikacji w przypadku spółek upadłych (wyższą jednakże niż na rok przed upadłością) i 60\% - w relacji do spółek niezagrożonych upadłością. Zdecydowanie najniższą zdolnością predykcyjną (zaledwie 20\%) odznaczały się w przypadku upadłych podmiotów gospodarczych mierniki $\mathrm{m}_{7}, \mathrm{~m}_{12}$ i $\mathrm{m}_{13}$, choć to one posiadły najwyższą trafność klasyfikacji w drugiej grupie analizowanych jednostek gospodarczych.

Badanie ogólnej zmienności analizowanych mierników dało zbliżone wyniki w relacji do tych, które uzyskano na rok przed upadłością. Z tab. 5.12 wynika, iż ponownie memoriałowe współczynniki płynności finansowej cechowały się 
najniższym zróżnicowaniem wewnątrzgrupowym, co najczęściej świadczy o wysokiej przydatności tych mierników w predykcji bankructwa. Podobna sytuacja wystapiła w przypadku pozostałych (za wyjątkiem $\mathrm{m}_{12} \mathrm{i} \mathrm{m}_{13}$ ) zmiennych diagnostycznych dla spółek niezagrożonych upadłością.

W przypadku obydwu współczynników zabezpieczenia finansowego, które charakteryzowały się bardzo wysoką zdolnością prognostyczną dla spółek niezagrożonych upadkiem, nie udało się wyznaczyć wewnątrzgrupowego współczynnika zmienności. Średnia wartość tych mierników była równa zeru, co uniemożliwiło dokonanie obliczeń z zakresu zróżnicowania tych zmiennych.

Tabela 5.11. Trafność klasyfikacji wybranych mierników oceny operacyjnego zagrożenia finansowego (dwa lata przed upadłością)* (w \%)

\begin{tabular}{|c|c|c|c|c|c|c|}
\hline Miernik & $\begin{array}{c}\text { Błąd } \\
\text { typu I** }\end{array}$ & $\begin{array}{c}\text { Sprawność } \\
\text { typu I }\end{array}$ & $\begin{array}{c}\text { Błąd typu } \\
\text { II*** }\end{array}$ & $\begin{array}{c}\text { Sprawnośćc } \\
\text { typu II }\end{array}$ & $\begin{array}{c}\text { Błąd } \\
\text { ogółem }\end{array}$ & $\begin{array}{c}\text { Sprawność } \\
\text { ogółem }\end{array}$ \\
\hline \hline $\mathrm{m}_{1}$ & 60,00 & 40,00 & 20,00 & $\mathbf{8 0 , 0 0}$ & 40,00 & 60,00 \\
\hline $\mathrm{m}_{2}$ & 20,00 & $\mathbf{8 0 , 0 0}$ & 20,00 & $\mathbf{8 0 , 0 0}$ & 20,00 & 80,00 \\
\hline $\mathrm{m}_{3}$ & 20,00 & $\mathbf{8 0 , 0 0}$ & 20,00 & $\mathbf{8 0 , 0 0}$ & 20,00 & 80,00 \\
\hline $\mathrm{m}_{4}$ & 0,00 & $\mathbf{1 0 0 , 0 0}$ & 60,00 & 40,00 & 30,00 & 70,00 \\
\hline $\mathrm{m}_{5}$ & 40,00 & 60,00 & 20,00 & $\mathbf{8 0 , 0 0}$ & 30,00 & 70,00 \\
\hline $\mathrm{m}_{6}$ & 40,00 & 60,00 & 0,00 & $\mathbf{1 0 0 , 0 0}$ & 20,00 & 80,00 \\
\hline $\mathrm{m}_{7}$ & 80,00 & 20,00 & 0,00 & $\mathbf{1 0 0 , 0 0}$ & 40,00 & 60,00 \\
\hline $\mathrm{m}_{9}$ & 60,00 & 40,00 & 40,00 & $\mathbf{6 0 , 0 0}$ & 50,00 & 50,00 \\
\hline $\mathrm{m}_{10}$ & 60,00 & 40,00 & 0,00 & $\mathbf{1 0 0 , 0 0}$ & 30,00 & 70,00 \\
\hline $\mathrm{m}_{12}$ & 80,00 & 20,00 & 0,00 & $\mathbf{1 0 0 , 0 0}$ & 40,00 & 60,00 \\
\hline $\mathrm{m}_{13}$ & 80,00 & 20,00 & 0,00 & $\mathbf{1 0 0 , 0 0}$ & 40,00 & 60,00 \\
\hline
\end{tabular}

* Pogrubioną czcionką została znaczona wyższa z wartości procentowych z dwóch typów sprawności, osiągnięta dla poszczególnych mierników oceny operacyjnego zagrożenia finansowego (w przypadku identycznego poziomu analizowanego udziału procentowego - zostały zaznaczone obydwie wartości procentowe dla dwóch typów sprawności).

** Błąd I typu polega na zaliczeniu przedsiębiorstwa upadłego do grupy przedsiębiorstw niezagrożonych upadłością.

*** Błąd II typu polega na zaliczeniu przedsiębiorstwa niezagrożonego upadłością do grupy przedsiębiorstw upadłych.

Źródło: jak do tab. 5.7.

Wysoki poziom współczynnika zmienności międzygrupowego przy ,,minimalnych" poziomach współczynników zmienności w obu grupach przedsiębiorstw, podobnie jak w poprzednim badanym okresie, wystąpił dla współczynnika eksploatacyjnej rentowności sprzedaży $\left(\mathrm{m}_{6}\right)$, współczynnika wydajności pieniężnej (gotówkowej) aktywów ogółem $\left(\mathrm{m}_{10}\right)$ oraz współczynnika eksploatacyjnej rentowności aktywów ogółem $\left(\mathrm{m}_{7}\right)$. 


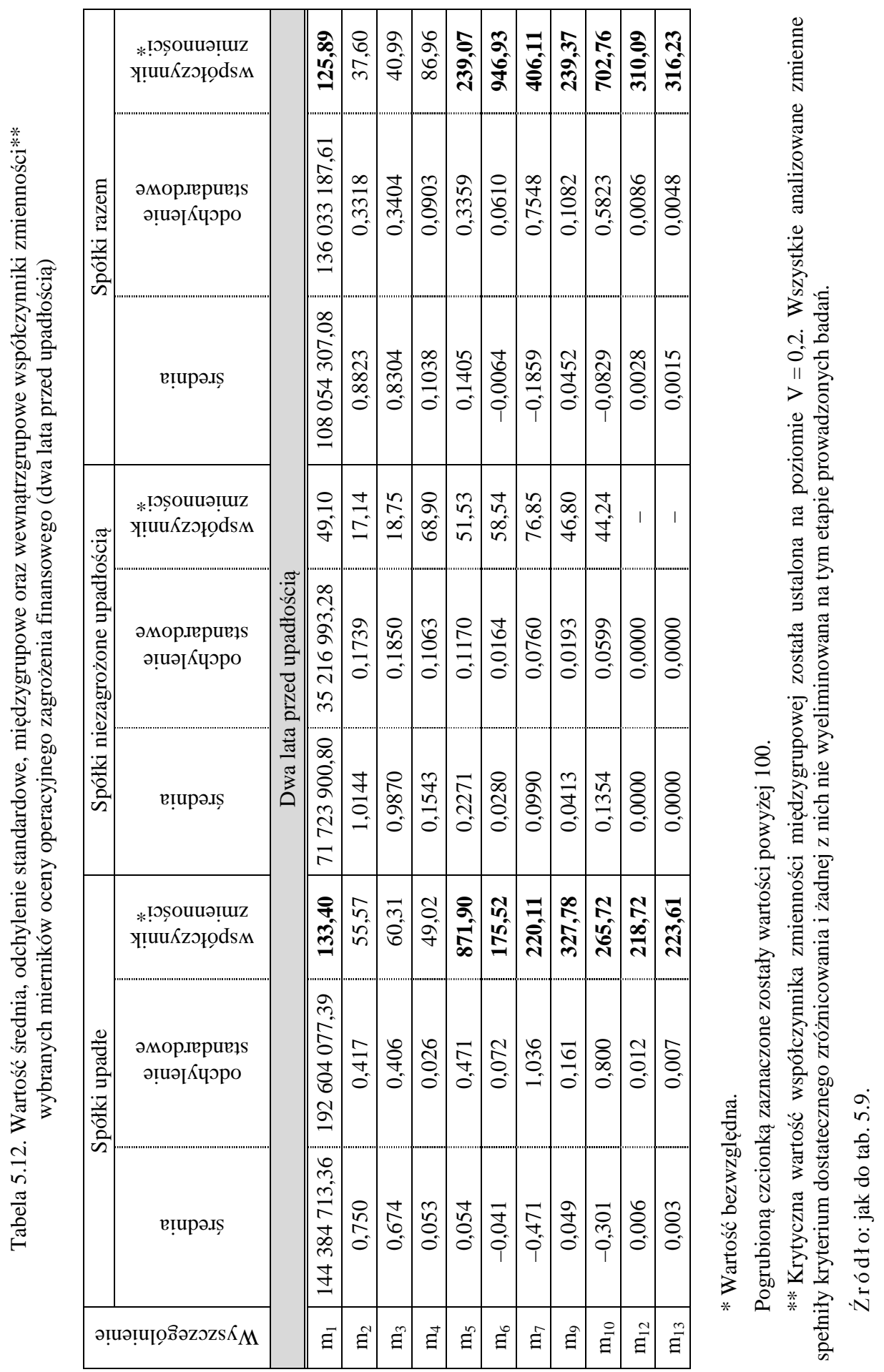




\subsubsection{Ocena zdolności predykcyjnych mierników na trzy lata przed upadłością przedsiębiorstw}

Z przeprowadzonej analizy średniej wartości mierników oceny operacyjnego zagrożenia finansowego dwóch grup spółek z sektora TSL: upadłych, jak i niezagrożonych upadłością wynika, iż na trzy lata przed upadłością jedynie średnie wartości przychodów netto ze sprzedaży usług, towarów i materiałów oraz współczynników zabezpieczenia finansowego w spółkach upadłych osiągnęły poziom wyższy w relacji do mierników obliczanych dla drugiego rodzaju badanych podmiotów gospodarczych (zob. tab. 5.13).

Nieco odmienne wyniki uzyskane zostały w wyniku obliczenia mediany dla rozważanych w niniejszym opracowaniu zmiennych diagnostycznych na trzy lata przed upadłością. W spółkach upadłych wszystkie kasowe mierniki oceny operacyjnego zagrożenia finansowego, jak i wartość przychodów netto ze sprzedaży usług, towarów i materiałów osiągnęły wyższą wartość w relacji do podmiotów niezagrożonych upadłością (zob. wykres 5.6 i 5.7). Środkowa wartość współczynników zabezpieczenia finansowego w obydwu grupach jednostek gospodarczych była równa zeru, tym samym większość badanych spółek nie tworzyła ani krótkoterminowych rezerw na świadczenia emerytalne, ani pozostałych rezerw krótkoterminowych.

Tabela 5.13. Średnie wartości wybranych mierników oceny operacyjnego zagrożenia finansowego w upadłych, jak i niezagrożonych upadłością przedsiębiorstwach sektora TSL (trzy lata przed upadłością)

\begin{tabular}{|c|c|c|c|}
\hline \multirow{2}{*}{ Miernik } & \multicolumn{2}{|c|}{ Wartość średnia miernika } & \multirow{2}{*}{ Punkt graniczny } \\
\cline { 2 - 3 } & spółki upadłe & $\begin{array}{c}\text { spółki } \\
\text { niezagrożone } \\
\text { upadłością }\end{array}$ & \\
\hline \hline $\mathrm{m}_{1}$ & 108264706,13 & 65736925,88 & 87000816,00 \\
\hline $\mathrm{m}_{2}$ & 1,0198 & 1,2253 & 1,1225 \\
\hline $\mathrm{m}_{3}$ & 0,9118 & 1,1264 & 1,0191 \\
\hline $\mathrm{m}_{4}$ & 0,1052 & 0,2530 & 0,1791 \\
\hline $\mathrm{m}_{5}$ & 0,0876 & 0,1211 & 0,1044 \\
\hline $\mathrm{m}_{6}$ & $-0,0310$ & 0,0323 & 0,0006 \\
\hline $\mathrm{m}_{7}$ & $-0,5228$ & 0,1343 & $-0,1943$ \\
\hline $\mathrm{m}_{9}$ & 0,0051 & 0,0118 & 0,0085 \\
\hline $\mathrm{m}_{10}$ & $-0,0856$ & 0,0798 & $-0,0029$ \\
\hline $\mathrm{m}_{12}$ & 0,0051 & 0,0000 & 0,0025 \\
\hline $\mathrm{m}_{13}$ & 0,0018 & 0,0013 & 0,0016 \\
\hline
\end{tabular}

Źródło: jak do tab. 5.7. 


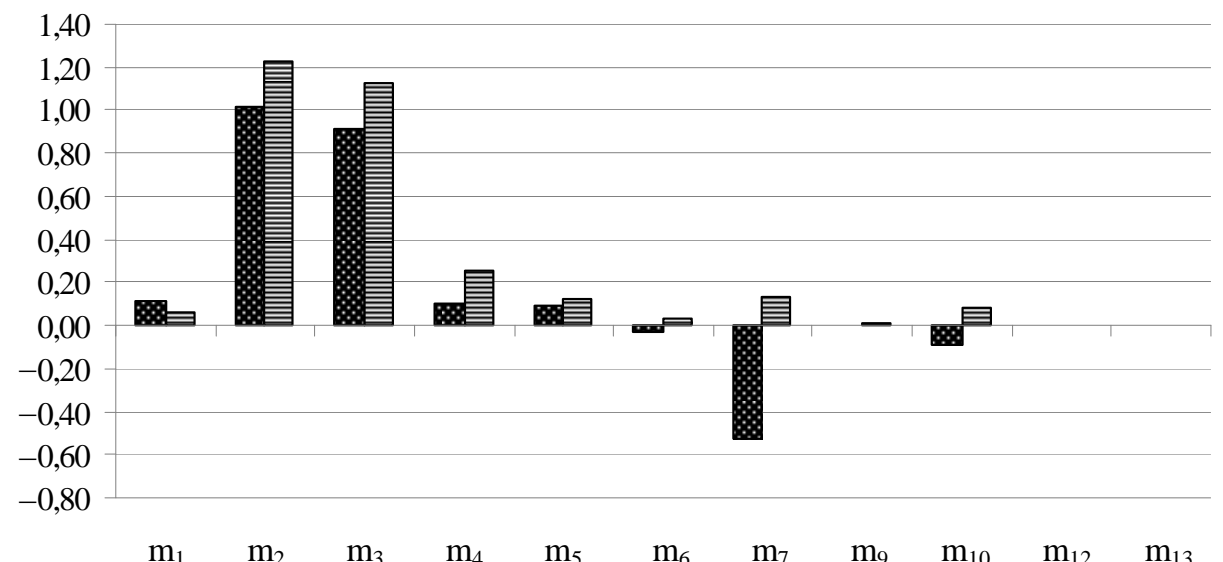

spółki upadłe 目 spółki niezagrożone upadłością

* Dane dla miernika $\mathrm{m}_{1}$ są podane w mld zł

Wykres 5.6. Średnia wartość mierników oceny operacyjnego zagrożenia finansowego w spółkach niezagrożonych upadłością i upadłych (trzy lata przed upadłością)*

Źródło: jak do wykresu 5.2.

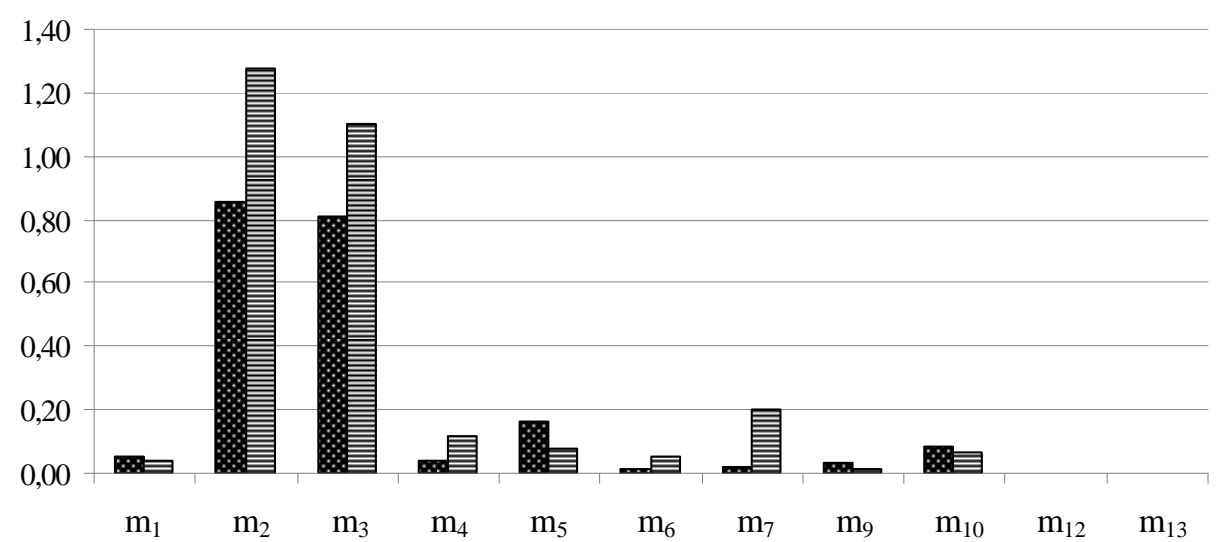

spółki upadłe 目 spółki niezagrożone upadłością

* Oznaczenia jak do wykresu 5.6.

Wykres 5.7. Środkowa wartość mierników oceny operacyjnego zagrożenia finansowego w spółkach niezagrożonych upadłością i upadłych (trzy lata przed upadłością)*

Źródło: jak do wykresu 5.2.

Na podstawie wyznaczonych punktów granicznych ustalone zostały możliwości predykcyjne analizowanych mierników na trzy lata przed upadłością. Jedynie współczynnik zdolności do obsługi zobowiązań bieżących gotówką osią- 
ganą z działalności operacyjnej $\left(\mathrm{m}_{5}\right)$ nie spełnił założonego w niniejszym opracowaniu kryterium wyboru na poziomie minimum 50\% trafności klasyfikacji. Najlepszą wśród omawianych zmiennych diagnostycznych w przypadku podmiotów gospodarczych niezagrożonych upadłością ponownie okazał się współczynnik eksploatacyjnej rentowności aktywów ogółem $\left(\mathrm{m}_{7}\right)$ oraz współczynnik zabezpieczenia finansowego $\mathrm{nr} 1\left(\mathrm{~m}_{12}\right)$. Słabiej zaprezentowały się współczynniki płynności finansowej, bowiem chociażby dla współczynnika natychmiastowej płynności finansowej dostrzegany jest stały spadek trafności klasyfikacji w całym badanym okresie (tj. $60 \%$ na rok przed upadłością do $20 \%$ na trzy lata przed upadłością).

W spółkach upadłych żaden z mierników nie uzyskał aż 100\% trafności klasyfikacji (zob. tab. 5.14). Najwyższa zdolność prognostyczna w tych podmiotach gospodarczych $(80 \%)$ wystąiła w przypadku współczynnika natychmiastowej płynności finansowej $\left(\mathrm{m}_{4}\right)$, a zaledwie $20 \%$ - dla współczynnika eksploatacyjnej rentowności aktywów ogółem $\left(\mathrm{m}_{7}\right)$ oraz współczynnika zabezpieczenia finansowego $\mathrm{nr} 2\left(\mathrm{~m}_{13}\right)$.

Tabela 5.14. . Trafność klasyfikacji wybranych mierników oceny operacyjnego zagrożenia finansowego (trzy lata przed upadłością)* (w \%)

\begin{tabular}{|c|c|c|c|c|c|c|}
\hline Miernik & $\begin{array}{c}\text { Błąd } \\
\text { typu I** }\end{array}$ & $\begin{array}{c}\text { Sprawność } \\
\text { typu I }\end{array}$ & $\begin{array}{c}\text { Błąd typu } \\
\text { II*** }\end{array}$ & $\begin{array}{c}\text { Sprawnośćc } \\
\text { typu II }\end{array}$ & $\begin{array}{c}\text { Błąd } \\
\text { ogółem }\end{array}$ & $\begin{array}{c}\text { Sprawność } \\
\text { ogółem }\end{array}$ \\
\hline \hline $\mathrm{m}_{1}$ & 60,00 & 40,00 & 40,00 & $\mathbf{6 0 , 0 0}$ & 50,00 & 50,00 \\
\hline $\mathrm{m}_{2}$ & 40,00 & $\mathbf{6 0 , 0 0}$ & 40,00 & $\mathbf{6 0 , 0 0}$ & 40,00 & 60,00 \\
\hline $\mathrm{m}_{3}$ & 40,00 & $\mathbf{6 0 , 0 0}$ & 40,00 & $\mathbf{6 0 , 0 0}$ & 40,00 & 60,00 \\
\hline $\mathrm{m}_{4}$ & 20,00 & $\mathbf{8 0 , 0 0}$ & 80,00 & 20,00 & 50,00 & 50,00 \\
\hline $\mathrm{m}_{5}$ & 60,00 & 40,00 & 60,00 & 40,00 & 60,00 & 40,00 \\
\hline $\mathrm{m}_{6}$ & 60,00 & 40,00 & 20,00 & $\mathbf{8 0 , 0 0}$ & 40,00 & 60,00 \\
\hline $\mathrm{m}_{7}$ & 80,00 & 20,00 & 0,00 & $\mathbf{1 0 0 , 0 0}$ & 40,00 & 60,00 \\
\hline $\mathrm{m}_{9}$ & 60,00 & 40,00 & 40,00 & $\mathbf{6 0 , 0 0}$ & 50,00 & 50,00 \\
\hline $\mathrm{m}_{10}$ & 60,00 & 40,00 & 20,00 & $\mathbf{8 0 , 0 0}$ & 40,00 & 60,00 \\
\hline $\mathrm{m}_{12}$ & 60,00 & 40,00 & 0,00 & $\mathbf{1 0 0 , 0 0}$ & 30,00 & 70,00 \\
\hline $\mathrm{m}_{13}$ & 80,00 & 20,00 & 20,00 & $\mathbf{8 0 , 0 0}$ & 50,00 & 50,00 \\
\hline
\end{tabular}

* Pogrubioną czcionką została znaczona wyższa z wartości procentowych z dwóch typów sprawności, osiągnięta dla poszczególnych mierników oceny operacyjnego zagrożenia finansowego (w przypadku identycznego poziomu analizowanego udziału procentowego - zostały zaznaczone obydwie wartości procentowe dla dwóch typów sprawności).

** Błąd I typu polega na zaliczeniu przedsiębiorstwa upadłego do grupy przedsiębiorstw niezagrożonych upadłością.

*** Błąd II typu polega na zaliczeniu przedsiębiorstwa niezagrożonego upadłością do grupy przedsiębiorstw upadłych.

Źródło: jak do tab. 5.7. 
Na trzy lata przed upadłością jedynie dwa z trzech memoriałowych współczynników płynności finansowej charakteryzowały się bardzo niską wartością współczynnika zmienności zarówno wewnątrzgrupowej i międzygrupowej, podobnie jak i przychody netto ze sprzedaży usług, towarów i materiałów $\left(\mathrm{m}_{1}\right)$.

Wyłącznie w przypadku współczynnika zabezpieczenia finansowego $\mathrm{nr} 1$ nie udało się wyznaczyć wewnątrzgrupowego współczynnika zmienności dla spółek niezagrożonych upadłością. Średnia jego wartość dla tych przedsiębiorstw była równa zeru, co uniemożliwiło dokonanie obliczeń z zakresu zróżnicowania tej zmiennej.

$\mathrm{Na}$ uwagę zasługują wartości mierników $\mathrm{m}_{6}, \mathrm{~m}_{7}$, oraz $\mathrm{m}_{10}$, które - podobnie jak w poprzednich badanych okresach - posiadają bardzo wysokie poziomy współczynnika zmienności międzygrupowego przy znacząco niższych poziomach współczynników zmienności w obu grupach przedsiębiorstw.

Ze względu na występowanie w analizowanej próbie badawczej obserwacji nietypowych, poprowadzona została dodatkowa analiza środkowych wartości mierników operacyjnego zagrożenia finansowego przy wykorzystaniu mediany, która w przeciwieństwie do średniej arytmetycznej jest podstawową statystyką opisową odporną na elementy odstające. Zaprezentowane wyniki ujawniły podobne tendencje kształtowania się wartości współczynnika bieżącej i przyspieszonej płynności finansowej (najniższa ich wartość wystąpiła na dwa lata przed upadłością) oraz zabezpieczenia finansowego (którego środkowa wartość było równa zeru) w dwóch grupach badanych podmiotów gospodarczych (zob. wykres 5.8 i 5.9).

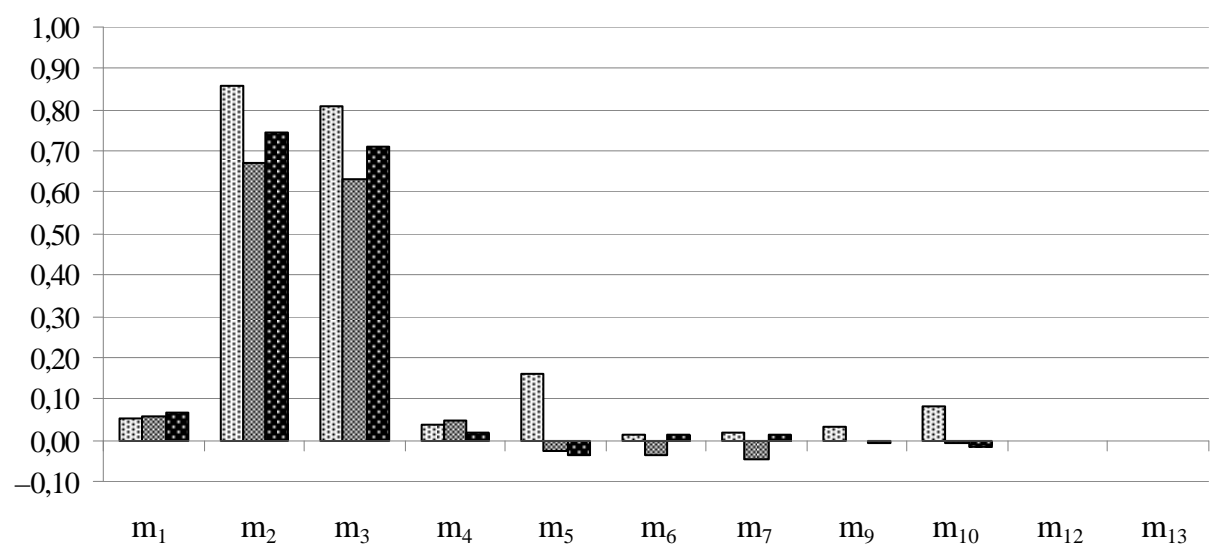

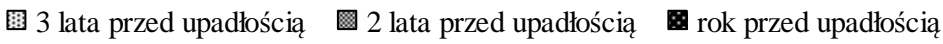

Oznaczenia jak do wykresu 5.6.

Wykres 5.8. Środkowa wartość mierników oceny operacyjnego zagrożenia finansowego w upadłych spółkach sektora TSL*

Źródło: jak do wykresu 5.2. 


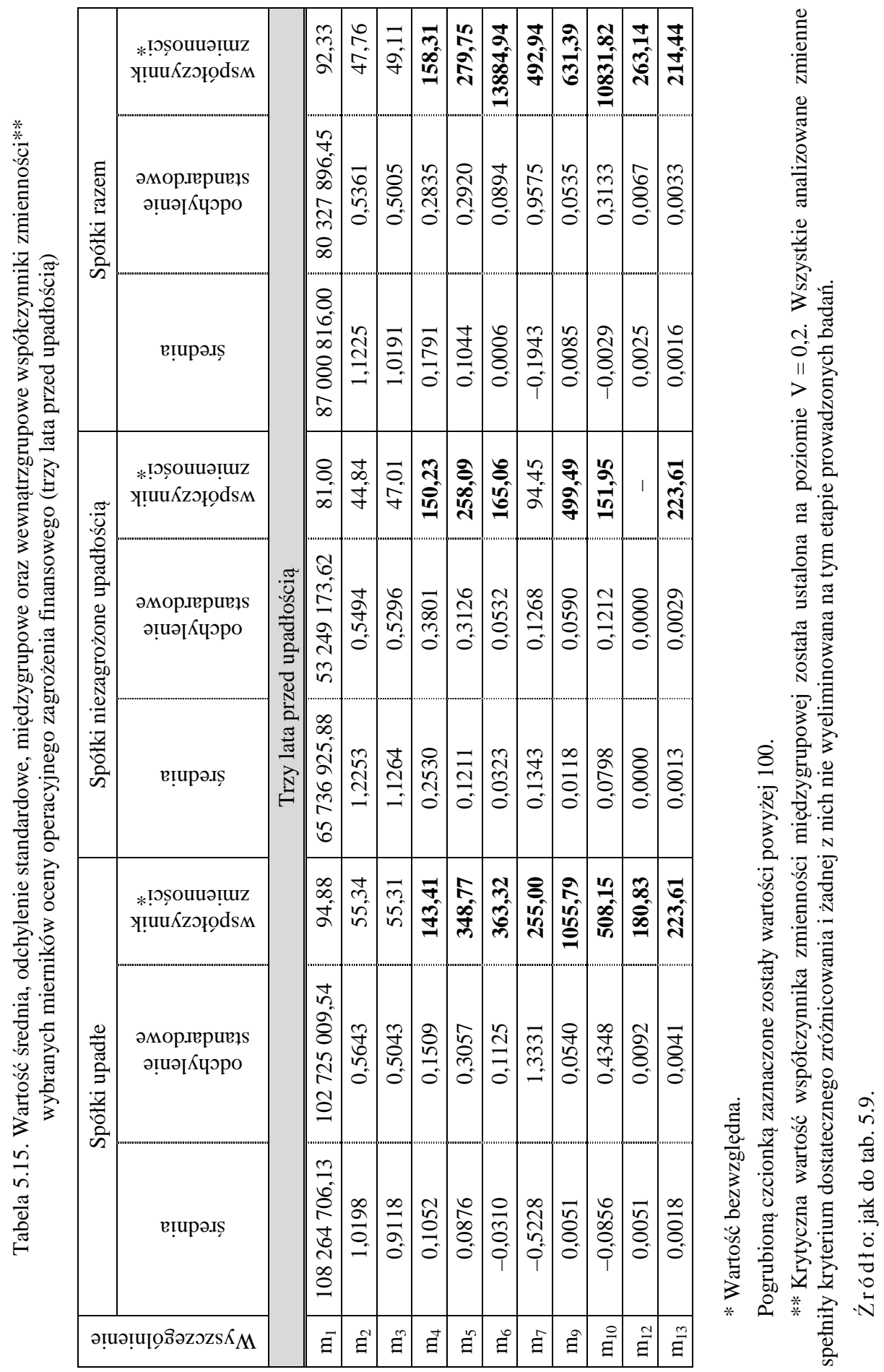




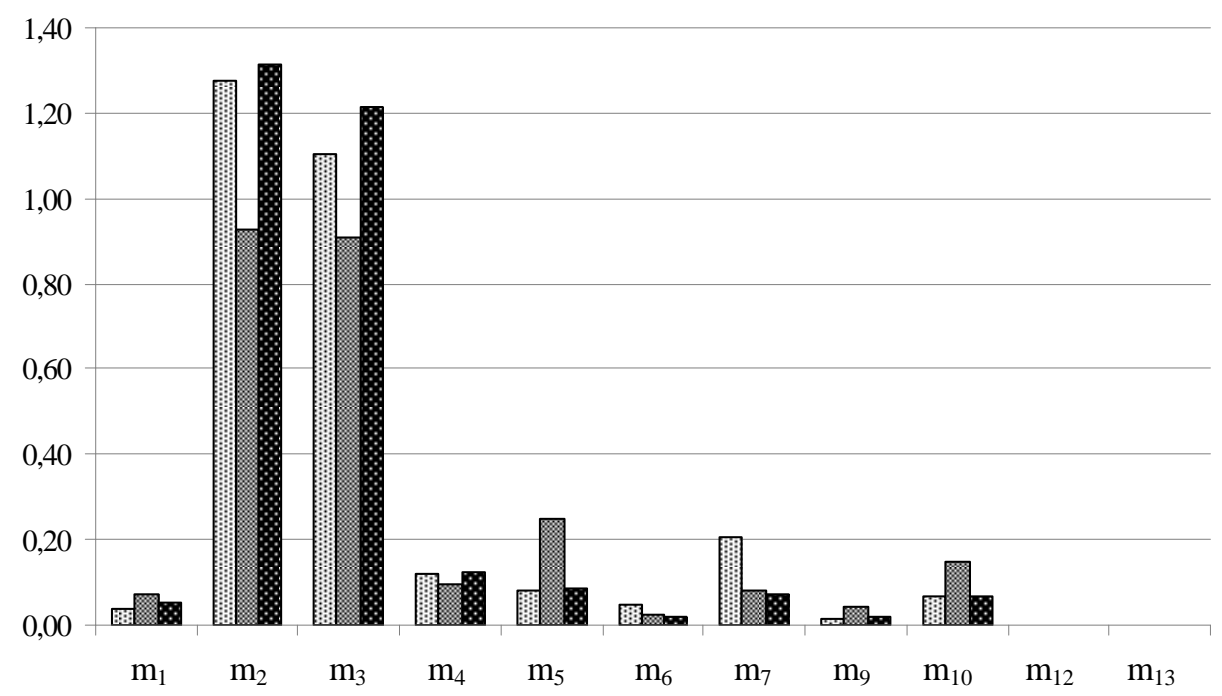

国 3 lata przed upadłością 2 lata przed upadłością rok przed upadłością

* Oznaczenia jak do wykresu 5.6.

Wykres 5.9. Środkowa wartość mierników oceny operacyjnego zagrożenia finansowego w spółkach sektora TSL niezagrożonych upadłością*

Źródło: jak do wykresu 5.2.

W spółkach upadłych wszystkie analizowane kasowe mierniki oceny operacyjnego zagrożenia finansowego wykazywały - począwszy od trzech lat do jednego roku przed upadłością - tendencję malejącą, natomiast rosnącą w przypadku wartości przychodów netto ze sprzedaży usług, towarów i materiałów. Środkowa wartość współczynników eksploatacyjnej rentowności sprzedaży i aktywów ogółem osiągnęła najniższy, a zarazem ujemny poziom na dwa lata przed upadłością. Odmienna sytuacja wystąpiła w przypadku przedsiębiorstw niezagrożonych upadłością, gdzie wyraźnie dostrzegany jest spadek wartości środkowej tych mierników. Najwyższa środkowa wartość przychodów netto ze sprzedaży, jak i współczynnika wydajności pieniężnej sprzedaży oraz aktywów ogółem została zaobserwowana w tej grupie podmiotów gospodarczych w drugim $\mathrm{z}$ analizowanych okresów.

Na podstawie zaprezentowanych wyników badań empirycznych z podstawowego instrumentarium pozwalającego odróżnić podmioty upadłe od niezagrożonych upadłością na 3 lata przez upadłością wykluczony został współczynnik zdolności do obsługi zobowiązań bieżących gotówką osiąganą z działalności operacyjnej $\left(\mathrm{m}_{5}\right)$. 


\subsection{Prognozowanie operacyjnego zagrożenia finansowego przedsiębiorstw sektora TSL przy wykorzystaniu memoriałowych i kasowych mierników oceny ${ }^{46}$}

W celu weryfikacji pojawiających się w literaturze przedmiotu i zaprezentowanych w monografii odmiennych opinii na temat użyteczności informacyjnej przepływów pieniężnych, sformułowane zostały w niniejszym opracowaniu trzy hipotezy badawcze stanowiące, iż:

a) dyskryminacja przebiegu kontynuacji działalności ustugowej przedsiębiorstw sektora TSL wykorzystujaca mierniki kasowe jest jednakowo lub bardziej istotna od dyskryminacji wykonanej jedynie na podstawie mierników memoriałowych,

b) w spótkach sektora TSL modele operacyjnego zagrożenia finansowego wykorzystujace mierniki kasowe wykazuja porównywalna lub wyższa trafność klasyfikacji od modeli uwzględniajacych jedynie mierniki memoriatowe,

c) w spótkach sektora TSL drzewa klasyfikacyjne wykorzystujace mierniki kasowe $w$ ocenie operacyjnego zagrożenia finansowego wykazuja porównywalna lub wyższa trafność klasyfikacji od drzew uwzględniających jedynie mierniki memoriatowe.

Przedstawione $w$ tej części opracowania modele oceny operacyjnego zagrożenia finansowego przedsiębiorstw sektora TSL oparte zostały na danych finansowych na rok, dwa i trzy lata przed upadłością dla spółek upadłych, zaś dla niezagrożonych upadłością - na danych ze sprawozdań finansowych dotyczących jedynie tych lat, które zostały wyselekcjonowane do badañ ${ }^{47}$ (próba analityczna). Do obliczenia analizowanych mierników wykorzystane zostały dane zaczerpnięte z bilansu, rachunku zysków i strat, a także ze sprawozdania z przepływów pieniężnych.

Do analizy dyskryminacyjnej użyty został program Statistica 10 przy wykorzystaniu analizy krokowej postępującej.

\subsubsection{Prognozowanie operacyjnego zagrożenia finansowego na rok przed upadłością przedsiębiorstw sektora TSL}

W wyniku selekcji zmiennych poddanych badaniu, w dalszych rozważaniach uwzględnionych zostało jedynie 7 mierników oceny operacyjnego zagro-

\footnotetext{
${ }^{46}$ Zob. L. Karbownik, The use of accrual-based and cash-based approach in evaluating the operational financial threat of enterprises from the TSL sector-example of application of the discriminant analysis, „Quantitative Methods in Economics” 2013, Vol. XIV, No. 1, SGGW in Warsaw, Warsaw, s. 190-201; L. K a r b ow n i k, Finansowe symptomy operacyjnego zagrożenia finansowego przedsiębiorstw sektora TSL, „Logistyka” 2014, nr 5, CD nr 2, s. 1867-1879.

${ }^{47}$ Model zbilansowany zakłada tak samo liczne grupy podmiotów gospodarczych upadłych, jak i niezagrożonych upadłością (tj. po 5).
} 
żenia finansowego ${ }^{48}$. Sytuacja ta wynikała ze znaczącej zależności między zmiennymi (zob. tab. 5.16), przez co analiza została ograniczona jedynie do badania tych, w których współczynnik korelacji rang Spearmana między nimi osiągnął wartość z przedziału $(-0,8 ; 0,8)$ przy poziomie istotności $0,05^{49}$.

Tabela 5.16. Macierz korelacji rang Spearmana między miernikami oceny operacyjnego zagrożenia finansowego przedsiębiorstw sektora TSL* (rok przed upadłością)

\begin{tabular}{|c|r|r|r|c|c|c|c|c|c|c|c|}
\hline Zmienna & \multicolumn{1}{|c|}{$\mathrm{m}_{1}$} & \multicolumn{1}{|c|}{$\mathrm{m}_{2}$} & \multicolumn{1}{c|}{$\mathrm{m}_{3}$} & $\mathrm{~m}_{4}$ & $\mathrm{~m}_{5}$ & $\mathrm{~m}_{6}$ & $\mathrm{~m}_{7}$ & $\mathrm{~m}_{9}$ & $\mathrm{~m}_{10}$ & $\mathrm{~m}_{12}$ & $\mathrm{~m}_{13}$ \\
\hline \hline $\mathrm{m}_{1}$ & 1,00 & $-0,27$ & $-0,10$ & 0,32 & $-0,44$ & 0,04 & 0,27 & $-0,41$ & $-0,35$ & 0,50 & 0,53 \\
\hline $\mathrm{m}_{2}$ & $-0,27$ & 1,00 & $\mathbf{0 , 9 5}$ & 0,45 & 0,25 & 0,16 & 0,35 & 0,18 & 0,04 & $-0,29$ & 0,02 \\
\hline $\mathrm{m}_{3}$ & $-0,10$ & $\mathbf{0 , 9 5}$ & 1,00 & 0,44 & 0,05 & $-0,02$ & 0,25 & $-0,02$ & $-0,16$ & $-0,22$ & 0,11 \\
\hline $\mathrm{m}_{4}$ & 0,32 & 0,45 & 0,44 & 1,00 & $-0,12$ & 0,52 & $\mathbf{0 , 7 2}$ & $-0,03$ & $-0,15$ & $-0,32$ & 0,48 \\
\hline $\mathrm{m}_{5}$ & $-0,44$ & 0,25 & 0,05 & $-0,12$ & 1,00 & 0,44 & 0,25 & $\mathbf{0 , 9 8}$ & $\mathbf{0 , 9 4}$ & 0,16 & $-0,13$ \\
\hline $\mathrm{m}_{6}$ & 0,04 & 0,16 & $-0,02$ & 0,52 & 0,44 & 1,00 & $\mathbf{0 , 8 5}$ & 0,56 & 0,49 & $-0,28$ & 0,40 \\
\hline $\mathrm{m}_{7}$ & 0,27 & 0,35 & 0,25 & $\mathbf{0 , 7 2}$ & 0,25 & $\mathbf{0 , 8 5}$ & 1,00 & 0,32 & 0,32 & $-0,26$ & 0,62 \\
\hline $\mathrm{m}_{9}$ & $-0,41$ & 0,18 & $-0,02$ & $-0,03$ & $\mathbf{0 , 9 8}$ & 0,56 & 0,32 & 1,00 & $\mathbf{0 , 9 3}$ & 0,10 & $-0,04$ \\
\hline $\mathrm{m}_{10}$ & $-0,35$ & 0,04 & $-0,16$ & $-0,15$ & $\mathbf{0 , 9 4}$ & 0,49 & 0,32 & $\mathbf{0 , 9 3}$ & 1,00 & 0,22 & $-0,01$ \\
\hline $\mathrm{m}_{12}$ & 0,50 & $-0,29$ & $-0,22$ & $-0,32$ & 0,16 & $-0,28$ & $-0,26$ & 0,10 & 0,22 & 1,00 & 0,03 \\
\hline $\mathrm{m}_{13}$ & 0,53 & 0,02 & 0,11 & 0,48 & $-0,13$ & 0,40 & 0,62 & $-0,04$ & $-0,01$ & 0,03 & 1,00 \\
\hline
\end{tabular}

* Pogrubioną czcionką oznaczone zostały wartości współczynników korelacji rang Spearmana istotne dla $\mathrm{p}<0,05$.

Źródło: obliczenia własne na podstawie danych zebranych w Krajowym Rejestrze Sądowym w Warszawie przy wykorzystaniu programu Statistica 10.

Ostatecznie do analizy dyskryminacyjnej zostały zakwalifikowane następujące mierniki: $\mathrm{m}_{1}, \mathrm{~m}_{2}, \mathrm{~m}_{4}, \mathrm{~m}_{5}, \mathrm{~m}_{6}, \mathrm{~m}_{12}$ oraz $\mathrm{m}_{13}$. Przy wykorzystaniu testu Shapiro-Wilka sprawdzono, czy charakteryzują się one rozkładem normalnym. Zgod-

${ }^{48}$ Wśród tych mierników jedynie zmienna $\mathrm{m}_{5}$ zawierała w liczniku informacje zaczerpnięte ze sprawozdania z przepływów pieniężnych.

${ }^{49}$ Do celów opracowania przyjęto następujące założenia:

a) mniej niż 0,2 - to brak związku między badanymi zmiennymi,

b) $0,2-0,4 \quad-$ to zależność jest wyraźna, ale niska,

c) $0,4-0,7 \quad-$ to zależność umiarkowana,

d) $0,7-0,9 \quad-$ to zależność znacząca,

e) powyżej 0,9 - to zależność bardzo silna.

Zob. S. O st a si e wi c z, Z. Ru sn a k, U. Si e d l e cka, Statystyka. Elementy teorii i zadania, Wydawnictwo Akademii Ekonomicznej im. Oskara Langego we Wrocławiu, Wrocław 2003, s. 311. 
nie $\mathrm{z}$ przypuszczeniami $\mathrm{w}$ stosunku do tak małej próby badawczej, zmienne te w większości nie posiadały rozkładu normalnego. Nie spełnione zostało zatem jedno z ważnych (ze statystycznego punktu widzenia) założeń dotyczących analizy dyskryminacyjnej. Należy jednak podkreślić, iż w badaniach ekonomicznych pojawienie się rozkładu normalnego jest rzadkością. W praktyce nie wpływa to jednak na pogorszenie zdolności prognostycznych funkcji dyskryminacyjnej ${ }^{50}$.

Uzyskane wyniki ujawniły (zob. tab. 5.17), iż przeprowadzona analiza dyskryminacyjna była istotną (lamba Wilksa ${ }^{51}=0,24322$, p < 0,0284). Zmienną najbardziej przydatną $\mathrm{w}$ tej analizie przy $\mathrm{p}<0,05$ okazał się być jedynie współczynnik natychmiastowej płynności finansowej ${ }^{52}$. Natomiast na poziomie tendencji ( $\mathrm{tj} . \mathrm{p}<0,1)$ za taką miarę uznać należy współczynnik zdolności do obsługi zobowiązań bieżących gotówką osiąganą z działalności operacyjnej $\left(\mathrm{m}_{5}\right)$.

Tabela 5.17. Podsumowanie funkcji analizy dyskryminacyjnej I dla przedsiębiorstw sektora TSL (rok przed upadłością)

\begin{tabular}{|c|c|c|c|c|}
\hline \multirow{2}{*}{$\mathrm{N}=10$} & \multicolumn{4}{|l|}{$\begin{array}{l}\text { Zmiennych w modelu: 3 } \\
\text { Lrupująca: Y (próba zbilansowana: 2 grupy podmiotów gospodarczych) }\end{array}$} \\
\cline { 2 - 5 } & Lambda Wilksa: ,24322 przybl. $\mathrm{F}(3,6)=6,2229 \mathrm{p}<, 0284$ & \multirow{2}{*}{$\begin{array}{c}\text { F usun. } \\
(1,7)\end{array}$} \\
\hline \hline $\mathbf{m}_{\mathbf{4}}$ & $\mathbf{0 , 8 1 4 4 5 4}$ & $\mathbf{0 , 2 9 8 6 3 3}$ & $\mathbf{1 4 , 0 9 1 5 3}$ & $\mathbf{0 , 0 0 9 4 6 7}$ \\
\hline $\mathrm{m}_{5}$ & 0,424579 & 0,572857 & 4,47382 & 0,078811 \\
\hline $\mathrm{m}_{12}$ & 0,305514 & 0,796112 & 1,53663 & 0,261403 \\
\hline
\end{tabular}

* Pogrubioną czcionką oznaczony został miernik istotny przy $\mathrm{p}<0,05$.

Źródło: obliczenia własne na podstawie danych zebranych w Krajowym Rejestrze Sądowym w Warszawie oraz Centralnego Ośrodka Informacji Gospodarczej Sp. z o.o. przy wykorzystaniu programu Statistica 10.

Na podstawie surowych wartości współczynników funkcji dyskryminacyjnej oszacowany został model 1, który przyjął następującą postać ${ }^{53}$ :

${ }^{50}$ T. Maślanka,op. cit., s. 231.

${ }^{51}$ Statystyka lambda Wilksa jest standardową statystyką stosowaną do wyznaczenia istotności statystycznej mocy dyskryminacyjnej przez aktualnie wybrane zmienne dyskryminacyjne. Jej wartość mieści się w zakresie od 0 (doskonała moc dyskryminacyjna) do 1 (brak mocy dyskryminacyjnej). Zob. A. Stanisz, Przystępny kurs statystyki z zastosowaniem STATISTICA PL na przyktadach medycyny. Tom 3. Analizy wielowymiarowe, StatSoft Polska Sp. z o.o., Kraków 2007, s. 70 i 86.

${ }^{52}$ Siła wpływu tego miernika była jednakże mniejsza niż zmiennej $\mathrm{m}_{5}$, bowiem im zmienna charakteryzuje się wyższą wartością cząstkowej lambdy Wilksa, tym siła wpływu jest mniejsza. Zob. B. Pru sak, op. cit., s. 52.

${ }^{53}$ Wielkością graniczną (punktem granicznym) jest 0 . Wartość powyżej 0 oznacza, iż spółka jest niezagrożona upadłością. 


$$
\mathrm{y}_{1}=-2,3276+29,3662 \mathrm{~m}_{4}+3,0424 \mathrm{~m}_{5}-48,3415 \mathrm{~m}_{12}
$$

Macierz klasyfikacji - zawierająca informacje na temat liczby i odsetka przedsiębiorstw poprawnie sklasyfikowanych w każdej grupie - wskazała, iż wszystkie spółki upadłe zostały poprawnie zaklasyfikowane do wyłonionego rodzaju podmiotów gospodarczych, błędnie zaś jedynie jedna spółka niezagrożona upadłością (zob. tab. 5.18).

Tabela 5.18. Macierz klasyfikacji przedsiębiorstw sektora TSL dla analizy dyskryminacyjnej I (rok przed upadłością)

\begin{tabular}{|l|c|c|c|}
\hline \multirow{2}{*}{$\mathrm{N}=10$} & \multicolumn{3}{|l|}{$\begin{array}{l}\text { Wiersze: obserwowana klasyfikacja } \\
\text { Kolumny: przewidywana klasyfikacja }\end{array}$} \\
\cline { 2 - 4 } & $\begin{array}{c}\text { procent } \\
\text { poprawne }\end{array}$ & $\begin{array}{c}\text { upadłe } \\
\mathrm{p}=0,500\end{array}$ & $\begin{array}{c}\text { niezagrożone } \\
\text { upadłością } \\
\mathrm{p}=0,500\end{array}$ \\
\hline \hline Upadłe & 100,00 & 5 & 0 \\
\hline $\begin{array}{l}\text { Niezagrożone } \\
\text { upadłością }\end{array}$ & 80,00 & 1 & 4 \\
\hline Razem & 90,00 & 6 & 4 \\
\hline
\end{tabular}

Źródło: jak do tab. 5.17.

W toku dalszej analizy utworzone zostały również drzewa klasyfikacyjne za pomocą algorytmu C\&RT, ilustrującego przyporządkowanie badanych jednostek gospodarczych do wcześniej wyłonionych homogenicznych grup podmiotów. Przy tworzeniu drzewa zmienną zależną była zmienna identyfikująca spółki upadłe, jak i niezagrożone upadłością. Zmiennymi - które decydowały o przynależności danego przedsiębiorstwa do jednego z tych dwóch rodzajów podmiotów gospodarczych - były mierniki oceny operacyjnego zagrożenia finansowego zaklasyfikowane do analizy dyskryminacyjnej.

W założeniach wejściowych za regułę podziału została przyjęta miara Giniego, jako kryterium stopu - bezpośrednie zatrzymanie typu FACT, koszty błędnej klasyfikacji uznane zostały za równe, zaś prawdopodobieństwo a priori pojawienia się klas - jako szacowane ${ }^{54}$.

Zasadniczym celem podjętych badań empirycznych było rozpoznanie kluczowych wartości i relacji zachodzących między zmiennymi decydującymi o przynależności spółek sektora TSL do jednej z dwóch grup podmiotów gospodarczych, tj. przedsiębiorstw upadłych, jak i niezagrożonych upadłością. Utworzenie deskryptywnego modelu C\&RT pozwoliło przeto opisać i zaprezentować,

Aby uzyskać wartość funkcji na podstawie której dokonuje się klasyfikacji obiektów (przedsiębiorstw) do określonej grupy - do modelu podstawione zostały wartości surowe, tzn. w żaden sposób nieprzekształcone. Zob. B. Pru s a k, op. cit., s. 51-52.

${ }^{54}$ Zob. http://www.statsoft.pl/textbook/stathome.html. 
które z mierników oceny operacyjnego zagrożenia finansowego odgrywały kluczową rolę w klasyfikacji badanych spółek do jednej z dwóch, wyłonionych homogenicznych grup przedsiębiorstw.

Na początku wszystkie podmioty (10) przypisane zostały do węzła źródłowego oraz tymczasowo sklasyfikowano je jako upadłe jednostki gospodarcze ${ }^{55}$. Utworzone drzewo klasyfikacyjne w wyniku zastosowania algorytmu C\&RT miało 3 węzły końcowe i było głębokie na 2 poziomy (zob. schemat 5.3).

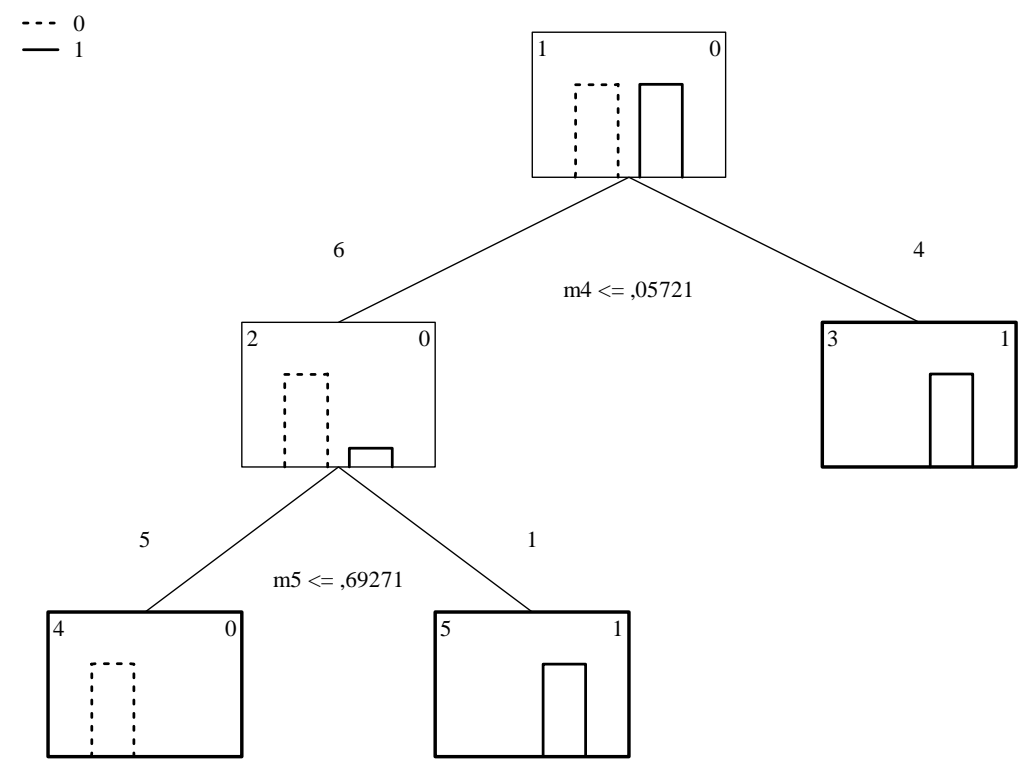

Schemat 5.3. Drzewo podziału przedsiębiorstw sektora TSL na upadłe/niezagrożone upadłością I (dane finansowe na rok przed upadłością)

Źródło: opracowanie własne na podstawie danych zebranych w Krajowym Rejestrze Sądowym w Warszawie oraz Centralnego Ośrodka Informacji Gospodarczej Sp. z o.o. przy wykorzystaniu programu Statistica 10.

${ }^{55} \mathrm{~W}$ każdym kwadracie cyfra umieszczona u góry po lewej stronie oznacza numer węzła.

Liczby znajdujące się nad linami prezentującymi rozgałęzienia oznaczają liczbę spółek sektora TSL, które zakwalifikowane zostały do węzła podrzędnego. Pod każdym węzłem wskazana została zmienna, która posłużyła jako podstawa podziału.

Jeżeli spółka sektora TSL spełniła warunek podziału np. w przypadku węzła pierwszego - współczynnik $\mathrm{m}_{4} \mathrm{w}$ danym przedsiębiorstwie nie był wyższy niż 0,05721 , wówczas zostało ono zakwalifikowane do lewej gałęzi drzewa, a w przeciwnym przypadku - do prawej.

W nazewnictwie liści ma zastosowanie zasada majoryzacji zbiorów, polegająca na przejęciu nazwy/symbolu (w tym przypadku „1 - spółka niezagrożona upadłością” lub „,0 - spółka upadła”) od klasy najliczniej występującej w danym liściu. Zob. M. Ła p c z ý s k i, Drzewa klasyfikacyjne $w$ badaniach satysfakcji i lojalności klientów, [w:] Analiza satysfakcji i lojalności klientów, StatSoft Polska Sp. z o.o., Warszawa-Kraków 2003, s. 99. 
W końcowym podziale analizowanych przedsiębiorstw uzyskano bezbłędną ich klasyfikację (stopa błędu była rzędu 0\%), tzn. wszystkie podmioty gospodarcze zostały poprawnie zakwalifikowane do jednego z dwóch rodzajów podmiotów (tj. upadłych lub niezagrożonych upadłością), co potwierdziła również utworzona macierz klasyfikacji (zob. tab. 5.19).

Tabela 5.19. Macierz klasyfikacji przedsiębiorstw sektora TSL dla drzewa klasyfikacyjnego I (rok przed upadłością)

\begin{tabular}{|l|c|c|c|}
\hline \multirow{2}{*}{$\mathrm{N}=10$} & \multicolumn{3}{|c|}{$\begin{array}{l}\text { Wiersze: przewidywana klasyfikacja } \\
\text { Kolumny: obserwowana klasyfikacja }\end{array}$} \\
\cline { 2 - 4 } & $\begin{array}{c}\text { procent } \\
\text { poprawne }\end{array}$ & upadłe & $\begin{array}{c}\text { niezagrożone } \\
\text { upadłością }\end{array}$ \\
\hline \hline Upadłe & 100,00 & 5 & 0 \\
\hline $\begin{array}{l}\text { Niezagrożone } \\
\text { upadłością }\end{array}$ & 100,00 & 0 & 5 \\
\hline Razem & 100,00 & 5 & 5 \\
\hline
\end{tabular}

Źródło: jak do tab. 5.17.

Każdy model C\&RT można zmienić na zestaw zdań warunkowych typu ,jeżeli .... to...." ${ }^{56}$. Tym samym przyjęta w monografii reguła klasyfikacyjna wyników badań brzmi następująco - w przypadku, gdy w spółce sektora TSL współczynnik natychmiastowej płynności finansowej $\left(\mathrm{m}_{4}\right)$ kształtował się na poziomie nie wyższym niż 0,05721 , a współczynnik zdolności do obsługi zobowiązań bieżących gotówką osiąganą z działalności operacyjnej $\left(\mathrm{m}_{5}\right)$ był równy lub niższy od 0,69271 - to ogłoszona została upadłość danej jednostki gospodarczej (zob. węzeł nr 4). Spółkami spełniającymi ten warunek były: Corrida SA w upadłości likwidacyjnej, AMP Logistyka Sp. z o.o., LOT Ground Services Sp. z o.o. w upadłości likwidacyjnej, EP Services Sp. z o.o. Nowy Przewoźnik Sp. z o.o. w upadłości likwidacyjnej (zob. zał. 8).

$\mathrm{W}$ dalszym etapie badań uwzględnionych zostało jedynie $6 \mathrm{z}$ rozważanych mierników, tj. $\mathrm{m}_{1}, \mathrm{~m}_{2}, \mathrm{~m}_{4}, \mathrm{~m}_{6}, \mathrm{~m}_{12}$ oraz $\mathrm{m}_{13}$. Pomięty został przeto współczynnik zdolności do obsługi zobowiązań bieżących gotówką osiąganą z działalności operacyjnej $\left(\mathrm{m}_{5}\right)^{57}$. Wyniki przeprowadzonych analiz zaprezentowane zostały w tab. 5.20.

${ }^{56}$ „Liczba liści jest zawsze równa liczbie reguł”, [za:] M. Ła a c z y ń s k i, Wptyw aktywności mieszkańców ma poziom życia $w$ gminach woj. matopolskiego, [w:] Statystyka $i$ data mining w badaniach naukowych, StatSoft Polska, Warszawa-Kraków 2005, s. 88.

${ }^{57}$ Pominięty został kasowy miernik oceny operacyjnego zagrożenia finansowego badanych przedsiębiorstw. 
Tabela 5.20. Podsumowanie funkcji analizy dyskryminacyjnej II dla przedsiębiorstw sektora TSL (rok przed upadłością)

\begin{tabular}{|c|c|c|c|c|}
\hline \multirow{2}{*}{$\mathrm{N}=10$} & \multicolumn{3}{|l|}{ Zmiennych w modelu: 2} \\
& \multicolumn{3}{l|}{$\begin{array}{l}\text { Grupująca: Y (próba zbilansowana: } 2 \text { grupy podmiotów gospodarczych) } \\
\text { Lambda Wilksa: ,37476 przybl. F }(2,7)=5,8394 \mathrm{p}<, 0322\end{array}$} \\
\cline { 2 - 5 } & Lambda Wilksa & Cząstk. Wilksa & $\begin{array}{c}\mathrm{F} \text { usun. } \\
(1,7)\end{array}$ & $\mathrm{p}$ \\
\hline \hline $\mathrm{m}_{4}$ & 0,629852 & 0,594994 & 4,764825 & 0,065365 \\
\hline $\mathrm{m}_{2}$ & 0,479323 & 0,781849 & 1,953139 & 0,204946 \\
\hline
\end{tabular}

Źródło: jak do tab. 5.17.

Uzyskane wyniki ujawniły, iż przeprowadzona analiza dyskryminacyjna była istotną przy $\mathrm{p}<0,0322$, a miernikiem najbardziej przydatnym w tejże analizie - choć jedynie na poziomie tendencji - okazał się współczynnik natychmiastowej płynności finansowej ${ }^{58}$. Na podstawie surowych wartości współczynników funkcji dyskryminacyjnej oszacowany został model 1a, który przyjął następującą $\operatorname{postać}^{59}$ :

$$
\mathrm{y}_{1 \mathrm{a}}=2,7243-18,6295 \mathrm{~m}_{4}-1,4773 \mathrm{~m}_{2}
$$

Macierz klasyfikacji wskazała (zob. tab. 5.21), iż wszystkie spółki niezagrożone upadłością zostały poprawnie zaklasyfikowane do wyłonionego rodzaju podmiotów gospodarczych. Do tej grupy została również błędnie sklasyfikowana jedno z upadłych przedsiębiorstw.

Tabela 5.21. Macierz klasyfikacji przedsiębiorstw sektora TSL dla analizy dyskryminacyjnej II (rok przed upadłością)

\begin{tabular}{|l|c|c|c|}
\hline \multirow{2}{*}{$\mathrm{N}=10$} & \multicolumn{3}{|c|}{$\begin{array}{l}\text { Wiersze: obserwowana klasyfikacja } \\
\text { Kolumny: przewidywana klasyfikacja }\end{array}$} \\
\cline { 2 - 4 } & $\begin{array}{c}\text { procent } \\
\text { poprawne }\end{array}$ & $\begin{array}{c}\text { upadłe } \\
\mathrm{p}=0,500\end{array}$ & $\begin{array}{c}\text { niezagrożone } \\
\text { upadłością } \\
\mathrm{p}=0,500\end{array}$ \\
\hline \hline Upadłe & 80,00 & 4 & 1 \\
\hline $\begin{array}{l}\text { Niezagrożone } \\
\text { upadłością }\end{array}$ & 100,00 & 0 & 5 \\
\hline Razem & 90,00 & 4 & 6 \\
\hline
\end{tabular}

Źródło: jak do tab. 5.17.

\footnotetext{
${ }^{58}$ Siła wpływu tego miernika była jednakże mniejsza niż zmiennej $\mathrm{m}_{2}$.

${ }^{59}$ Wielkością graniczną (punktem granicznym) jest 0 .
} 
Utworzone drzewo klasyfikacyjne, w wyniku zastosowania algorytmu C\&RT, miało 3 węzły końcowe i było głębokie na 2 poziomy (zob. schemat 5.4). Podobnie jak w przypadku drzewa klasyfikacyjnego I, w dokonanym podziale przedsiębiorstw sektora TSL uzyskana została bezbłędna klasyfikacja spółek poddanych analizie (zob. tab. 5.22).

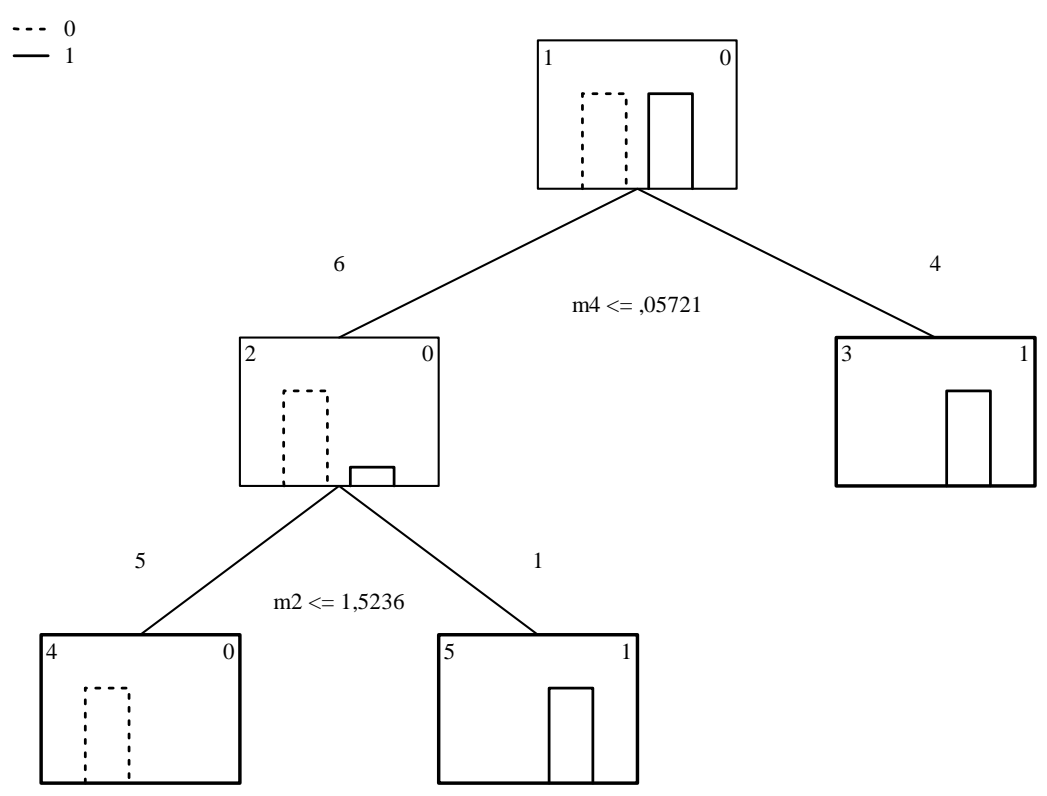

Schemat 5.4. Drzewo podziału przedsiębiorstw sektora TSL na upadłe/niezagrożone upadłością II (dane finansowe na rok przed upadłością)

Źródło: jak do schematu 5.3.

Przykładową regułę klasyfikacyjną można łatwo zapisać w postaci: jeśli przedsiębiorstwo sektora TSL osiągnęło współczynnik natychmiastowej płynności finansowej na poziomie wyższym od 0,05721 , to nie została ogłoszona jego upadłość (węzeł nr 3). Spółkami spełniającymi ten warunek były: M\&M Militzer \& Münch Polska Sp. z o.o., Przedsiębiorstwo Wielobranżowe Podkowa Sp. z o.o., Hellmann Worldwide Logistics Sp. z o.o. oraz CAT Polska Sp. z o.o.

Wyniki badań empirycznych wskazują, iż zastosowanie algorytmu C\&RT przyniosło jednakową - bez względu na rozważany wariant - bezbłędną klasyfikację badanych podmiotów gospodarczych. Oszacowany model 1 wykazał się z kolei lepszą skutecznością w klasyfikacji upadłych spółek sektora TSL, zaś model 1a - przedsiębiorstw niezagrożonych upadłością. Oba zaprezentowane 
modele na rok przed upadłością charakteryzowały się jednakże jednakową (tj. 90\%) ogólną zdolnością predykcyjną. Nieznacznie jednak lepszym okazał się model 1 zawierający współczynnik zdolności do obsługi zobowiązań bieżących gotówką osiąganą $\mathrm{z}$ działalności operacyjnej $\left(\mathrm{m}_{5}\right)$. Dyskryminacja przebiegu kontynuacji działalności usługowej przedsiębiorstw sektora TSL wykorzystująca mierniki kasowe była nieco bardziej istotna w relacji do dyskryminacji wykonanej jedynie na podstawie mierników memoriałowych.

Tabela 5.22. Macierz klasyfikacji przedsiębiorstw sektora TSL dla drzewa klasyfikacyjnego II (rok przed upadłością)

\begin{tabular}{|l|c|c|c|}
\hline \multirow{2}{*}{$\mathrm{N}=10$} & \multicolumn{3}{|c|}{$\begin{array}{l}\text { Wiersze: przewidywana klasyfikacja } \\
\text { Kolumny: obserwowana klasyfikacja }\end{array}$} \\
\cline { 2 - 4 } & $\begin{array}{c}\text { procent } \\
\text { poprawne }\end{array}$ & upadłe & $\begin{array}{c}\text { niezagrożone } \\
\text { upadłością }\end{array}$ \\
\hline \hline Upadłe & 100,00 & 5 & 0 \\
\hline $\begin{array}{l}\text { Niezagrożone } \\
\text { upadłością }\end{array}$ & 100,00 & 0 & 5 \\
\hline Razem & 100,00 & 5 & 5 \\
\hline
\end{tabular}

Źródło: jak do tab. 5.17.

Utworzone reguły ,jeżeli ... to", jak i modele 1 oraz 1a (kanoniczna funkcja dyskryminacyjna) zostały ponadto wykorzystane do przewidywania upadłości spółek sektora TSL z próby walidacyjnej (zob. zał. 9). We wszystkich wariantach uzyskana została identyczna $75 \%$ trafność klasyfikacyji ${ }^{60}$.

\subsubsection{Prognozowanie operacyjnego zagrożenia finansowego na dwa lata przed upadłością przedsiębiorstw sektora TSL}

Wybór mierników dokonany został w analogiczny sposób, jak w sytuacji na rok przed upadłością ${ }^{61}$. Do analizy dyskryminacyjnej zostały zakwalifikowane

${ }^{60}$ Dwie spółki niezagrożone upadłością (DSV Solutions Sp. z o.o. oraz Przedsiębiorstwo Wielobranżowe Podkowa Sp. z o.o.) z próby walidacyjnej:

- prowadziły działalność w sektorze TSL,

- składały sprawozdania do tego samego Krajowego Rejestru Sądowego w Warszawie,

- posiadały porównywalną (w relacji do upadłej spółki) wartość aktywów ogółem w roku, który poddawany był analizie.

Jedna z 4 spółek próby walidacyjnej (tj. DSV Solutions Sp. z o.o.) została błędnie zaklasyfikowana.

${ }^{61}$ Zob. S. Ostasi e wi c z, Z. Ru snak, U. Si ed leck ka, op. cit., s. 311. 
zatem następujące zmienne diagnostyczne: $\mathrm{m}_{1}, \mathrm{~m}_{2}, \mathrm{~m}_{4}, \mathrm{~m}_{5}, \mathrm{~m}_{6}, \mathrm{~m}_{12}$ oraz $\mathrm{m}_{13}$ (zob. tab. 5.23).

Tabela 5.23. Macierz korelacji rang Spearmana między miernikami oceny operacyjnego zagrożenia finansowego przedsiębiorstw sektora TSL* (dwa lata przed upadłością)

\begin{tabular}{|c|c|c|c|c|c|c|c|c|c|c|c|}
\hline Zmienna & $\mathrm{m}_{1}$ & $\mathrm{~m}_{2}$ & $\mathrm{~m}_{3}$ & $\mathrm{~m}_{4}$ & $\mathrm{~m}_{5}$ & $\mathrm{~m}_{6}$ & $\mathrm{~m}_{7}$ & $\mathrm{~m}_{9}$ & $\mathrm{~m}_{10}$ & $\mathrm{~m}_{12}$ & $\mathrm{~m}_{13}$ \\
\hline \hline $\mathrm{m}_{1}$ & 1,00 & $-0,10$ & $-0,15$ & 0,31 & $-0,16$ & $-0,10$ & $-0,16$ & $-0,10$ & $-0,03$ & $\mathbf{0 , 6 8}$ & 0,52 \\
\hline $\mathrm{m}_{2}$ & $-0,10$ & 1,00 & $\mathbf{0 , 9 9}$ & 0,27 & 0,01 & $\mathbf{0 , 6 7}$ & $\mathbf{0 , 8 4}$ & $-0,07$ & 0,10 & $-0,59$ & $-0,52$ \\
\hline $\mathrm{m}_{3}$ & $-0,15$ & $\mathbf{0 , 9 9}$ & 1,00 & 0,28 & $-0,05$ & $\mathbf{0 , 6 5}$ & $\mathbf{0 , 8 3}$ & $-0,13$ & 0,04 & $-0,59$ & $-0,52$ \\
\hline $\mathrm{m}_{4}$ & 0,31 & 0,27 & 0,28 & 1,00 & 0,08 & 0,25 & 0,21 & $-0,05$ & 0,31 & $-0,01$ & 0,06 \\
\hline $\mathrm{m}_{5}$ & $-0,16$ & 0,01 & $-0,05$ & 0,08 & 1,00 & 0,22 & 0,20 & $\mathbf{0 , 9 6}$ & $\mathbf{0 , 9 4}$ & $-0,30$ & $-0,52$ \\
\hline $\mathrm{m}_{6}$ & $-0,10$ & $\mathbf{0 , 6 7}$ & $\mathbf{0 , 6 5}$ & 0,25 & 0,22 & 1,00 & $\mathbf{0 , 9 3}$ & 0,13 & 0,35 & $-0,59$ & $-0,52$ \\
\hline $\mathrm{m}_{7}$ & $-0,16$ & $\mathbf{0 , 8 4}$ & $\mathbf{0 , 8 3}$ & 0,21 & 0,20 & $\mathbf{0 , 9 3}$ & 1,00 & 0,09 & 0,28 & $\mathbf{- 0 , 6 8}$ & $-0,52$ \\
\hline $\mathrm{m}_{9}$ & $-0,10$ & $-0,07$ & $-0,13$ & $-0,05$ & $\mathbf{0 , 9 6}$ & 0,13 & 0,09 & 1,00 & $\mathbf{0 , 8 5}$ & $-0,21$ & $-0,52$ \\
\hline $\mathrm{m}_{10}$ & $-0,03$ & 0,10 & 0,04 & 0,31 & $\mathbf{0 , 9 4}$ & 0,35 & 0,28 & $\mathbf{0 , 8 5}$ & 1,00 & $-0,21$ & $-0,52$ \\
\hline $\mathrm{m}_{12}$ & $\mathbf{0 , 6 8}$ & $-0,59$ & $-0,59$ & $-0,01$ & $-0,30$ & $-0,59$ & $-\mathbf{0 , 6 8}$ & $-0,21$ & $-0,21$ & 1,00 & 0,58 \\
\hline $\mathrm{m}_{13}$ & 0,52 & $-0,52$ & $-0,52$ & 0,06 & $-0,52$ & $-0,52$ & $-0,52$ & $-0,52$ & $-0,52$ & 0,58 & 1,00 \\
\hline
\end{tabular}

* Pogrubioną czcionką oznaczone zostały wartości współczynników korelacji rang Spearmana istotne dla $\mathrm{p}<0,05$.

Źródło: jak do tab. 5.16.

Dyskryminacja była istotną jedynie na poziomie tendencji (zob. tab. 5.24). Ponadto - na podstawie surowych wartości współczynników funkcji dyskryminacyjnej - oszacowany został model 2 , choć żaden z mierników nie okazał się istotnym przy $\mathrm{p}<0,1^{62}$ :

$$
\mathrm{y}_{2}=0,8643-13,8620 \mathrm{~m}_{6}-9,1837 \mathrm{~m}_{4}
$$

Trafność klasyfikacji tego modelu pozostała jednakże na niezmienionym poziomie (tj. 90\% - zob. tab. 5.25) w relacji do modelu 1 i 1a. Macierz klasyfikacji - podobnie jak w modelu 1a - wykazała, iż wszystkie podmioty gospodarcze niezagrożone upadłością zostały poprawnie sklasyfikowane, lecz do tej grupy została również błędnie zaklasyfikowana jedna z upadłych spółek.

\footnotetext{
${ }^{62}$ Wielkością graniczną (punktem granicznym) jest 0.
} 
Tabela 5.24. Podsumowanie funkcji analizy dyskryminacyjnej dla przedsiębiorstw sektora TSL

(2 lata przed upadłością)

\begin{tabular}{|c|c|c|c|c|}
\hline \multirow{2}{*}{$\mathrm{N}=10$} & \multicolumn{4}{l}{$\begin{array}{l}\text { Zmiennych w modelu: } 2 \\
\text { Grupująca: Y (próba zbilansowana: 2 grupy podmiotów gospodarczych) } \\
\text { Lambda Wilksa: ,47489 przybl. F }(2,7)=3,8702 \mathrm{p}<, 0738\end{array}$} \\
\cline { 2 - 5 } & Lambda Wilksa & Cząstk. Wilksa & $\begin{array}{c}\text { F usun. } \\
(1,7)\end{array}$ & $\mathrm{p}$ \\
\hline \hline $\mathrm{m}_{6}$ & 0,653338 & 0,726863 & 2,630432 & 0,148864 \\
\hline $\mathrm{m}_{4}$ & 0,646303 & 0,734775 & 2,526732 & 0,155956 \\
\hline
\end{tabular}

Źródło: jak do tab. 5.17.

Tabela 5.25. Macierz klasyfikacji przedsiębiorstw sektora TSL dla analizy dyskryminacyjnej (2 lata przed upadłością)

\begin{tabular}{|l|c|c|c|}
\hline \multirow{2}{*}{$\mathrm{N}=10$} & \multicolumn{3}{|l|}{$\begin{array}{l}\text { Wiersze: obserwowana klasyfikacja } \\
\text { Kolumny: przewidywana klasyfikacja }\end{array}$} \\
\cline { 2 - 4 } & $\begin{array}{c}\text { procent } \\
\text { poprawne }\end{array}$ & $\begin{array}{c}\text { upadłe } \\
\mathrm{p}=0,500\end{array}$ & $\begin{array}{c}\text { niezagrożone } \\
\text { upadłością } \\
\mathrm{p}=0,500\end{array}$ \\
\hline \hline Upadłe & 80,00 & 4 & 1 \\
\hline $\begin{array}{l}\text { Niezagrożone } \\
\text { upadłością }\end{array}$ & 100,00 & 0 & 5 \\
\hline Razem & 90,00 & 4 & 6 \\
\hline
\end{tabular}

Źródło: jak do tab. 5.17.

Drzewo klasyfikacyjne uzyskane na dwa lata przed upadłością miało 4 węzły końcowe i było głębokie na 2 poziomy (zob. schemat 5.5). W dokonanym podziale podmiotów gospodarczych sektora TSL została uzyskana - podobnie jak poprzednio - bezbłędna klasyfikacja przedsiębiorstw poddanych badaniu (zob. tab. 5.26).

Przykładowa reguła klasyfikacyjna, na podstawie której można dokonać podziału jednostek gospodarczych poddanych badaniu na upadłe lub niezagrożone upadłością, brzmi następująco: jeśli w spółce sektora TSL współczynnik natychmiastowej płynności finansowej $\left(\mathrm{m}_{4}\right)$ kształtował się na poziomie nie wyższym niż 0,08434 , a współczynnik eksploatacyjnej rentowności sprzedaży $\left(\mathrm{m}_{6}\right)$ był wyższy niż 0,04193 , to nie została ogłoszona w stosunku do tej jednostki gospodarczej upadłość (zob. węzeł nr 5). Przedsiębiorstwem spełniającym to kryterium była spółka Mexem Sp. z o.o. (zob. zał. 8). 


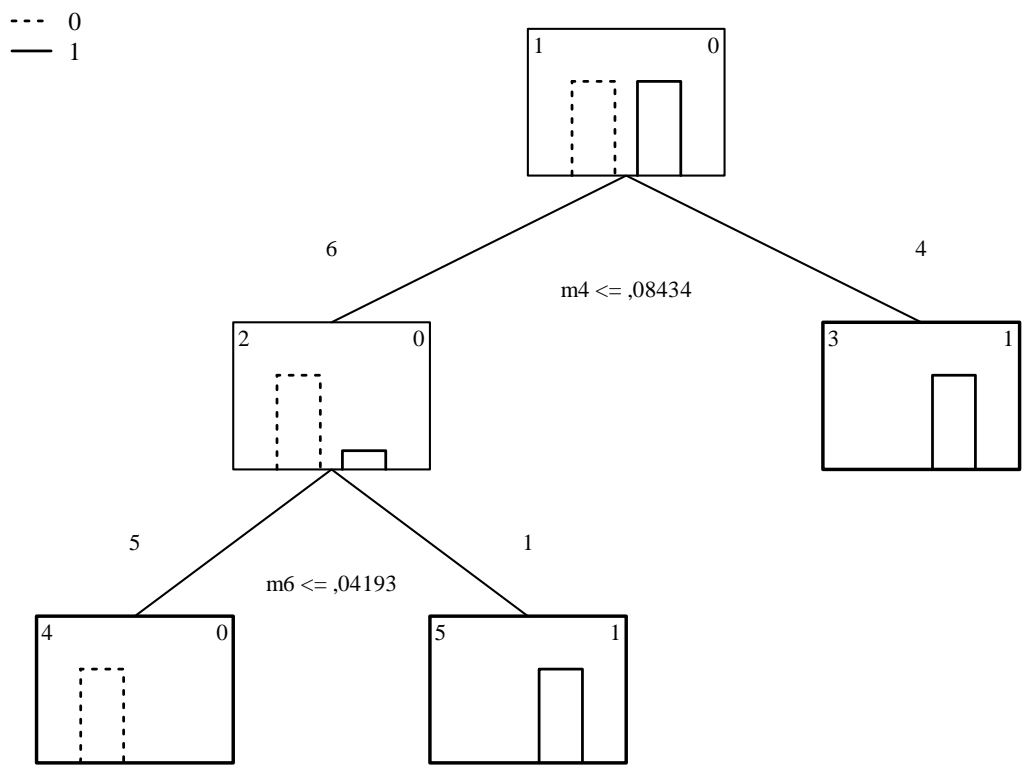

Schemat 5.5. Drzewo podziału przedsiębiorstw sektora TSL na upadłe/niezagrożone upadłością (dane finansowe na 2 lata przed upadłością)

Źródło: jak do schematu 5.3.

Tabela 5.26. Macierz klasyfikacji przedsiębiorstw sektora TSL dla drzewa klasyfikacyjnego (2 lata przed upadłością)

\begin{tabular}{|c|c|c|c|}
\hline \multirow{2}{*}{$\mathrm{N}=10$} & \multicolumn{3}{|c|}{$\begin{array}{l}\text { Wiersze: przewidywana klasyfikacja } \\
\text { Kolumny: obserwowana klasyfikacja }\end{array}$} \\
\hline & $\begin{array}{l}\text { procent } \\
\text { poprawne }\end{array}$ & upadłe & $\begin{array}{c}\text { niezagrożone } \\
\text { upadłością }\end{array}$ \\
\hline Upadłe & 100,00 & 5 & 0 \\
\hline $\begin{array}{l}\text { Niezagrożone } \\
\text { upadłością }\end{array}$ & 100,00 & 0 & 5 \\
\hline Razem & 100,00 & 5 & 5 \\
\hline
\end{tabular}

Źródło: jak do tab. 5.17. 


\subsubsection{Prognozowanie operacyjnego zagrożenia finansowego na trzy lata przed upadłością przedsiębiorstw sektora TSL}

Dla odróżnienia przedsiębiorstw upadłych od jednostek gospodarczych niezagrożonych upadłością zostały wykorzystane następujące mierniki: $\mathrm{m}_{1}, \mathrm{~m}_{2}, \mathrm{~m}_{4}$, $\mathrm{m}_{6}, \mathrm{~m}_{9}, \mathrm{~m}_{12}$ oraz $\mathrm{m}_{13}$ (zob. tab. 5.27) ${ }^{63}$.

Tabela 5.27. Macierz korelacji rang Spearmana między miernikami oceny operacyjnego zagrożenia finansowego przedsiębiorstw sektora TSL* (trzy lata przed upadłością)

\begin{tabular}{|c|c|c|c|c|c|c|c|c|c|c|}
\hline Zmienna & $\mathrm{m}_{1}$ & $\mathrm{~m}_{2}$ & $\mathrm{~m}_{3}$ & $\mathrm{~m}_{4}$ & $\mathrm{~m}_{6}$ & $\mathrm{~m}_{7}$ & $\mathrm{~m}_{9}$ & $\mathrm{~m}_{10}$ & $\mathrm{~m}_{12}$ & $\mathrm{~m}_{13}$ \\
\hline \hline $\mathrm{m}_{1}$ & 1,00 & 0,16 & 0,22 & $-0,32$ & $-0,12$ & $-0,04$ & 0,07 & $-0,07$ & $\mathbf{0 , 6 8}$ & 0,06 \\
\hline $\mathrm{m}_{2}$ & 0,16 & 1,00 & $\mathbf{0 , 9 6}$ & 0,53 & 0,58 & $\mathbf{0 , 6 7}$ & $\mathbf{0 , 6 4}$ & $\mathbf{0 , 6 6}$ & $-0,40$ & $-0,32$ \\
\hline $\mathrm{m}_{3}$ & 0,22 & $\mathbf{0 , 9 6}$ & 1,00 & 0,50 & $\mathbf{0 , 6 6}$ & $\mathbf{0 , 7 8}$ & $\mathbf{0 , 6 5}$ & $\mathbf{0 , 6 7}$ & $-0,40$ & $-0,32$ \\
\hline $\mathrm{m}_{4}$ & $-0,32$ & 0,53 & 0,50 & 1,00 & 0,48 & 0,59 & 0,58 & $\mathbf{0 , 8 1}$ & $-0,59$ & $-0,12$ \\
\hline $\mathrm{m}_{6}$ & $-0,12$ & 0,58 & $\mathbf{0 , 6 6}$ & 0,48 & 1,00 & $\mathbf{0 , 9 5}$ & 0,58 & 0,58 & $-0,59$ & $-0,51$ \\
\hline $\mathrm{m}_{7}$ & $-0,04$ & $\mathbf{0 , 6 7}$ & $\mathbf{0 , 7 8}$ & 0,59 & $\mathbf{0 , 9 5}$ & 1,00 & $\mathbf{0 , 6 7}$ & $\mathbf{0 , 7 1}$ & $-0,59$ & $-0,51$ \\
\hline $\mathrm{m}_{9}$ & 0,07 & $\mathbf{0 , 6 4}$ & $\mathbf{0 , 6 5}$ & 0,58 & 0,58 & $\mathbf{0 , 6 7}$ & 1,00 & $\mathbf{0 , 9 4}$ & $-0,13$ & $-0,21$ \\
\hline $\mathrm{m}_{10}$ & $-0,07$ & $\mathbf{0 , 6 6}$ & $\mathbf{0 , 6 7}$ & $\mathbf{0 , 8 1}$ & 0,58 & $\mathbf{0 , 7 1}$ & $\mathbf{0 , 9 4}$ & 1,00 & $-0,30$ & $-0,15$ \\
\hline $\mathrm{m}_{12}$ & $\mathbf{0 , 6 8}$ & $-0,40$ & $-0,40$ & $-0,59$ & $-0,59$ & $-0,59$ & $-0,13$ & $-0,30$ & 1,00 & 0,50 \\
\hline $\mathrm{m}_{13}$ & 0,06 & $-0,32$ & $-0,32$ & $-0,12$ & $-0,51$ & $-0,51$ & $-0,21$ & $-0,15$ & 0,50 & 1,00 \\
\hline
\end{tabular}

* Pogrubioną czcionką oznaczone zostały wartości współczynników korelacji rang Spearmana istotne dla $\mathrm{p}<0,05$.

Źródło: jak do tab. 5.16.

Otrzymane wyniki pokazały, iż poprowadzona analiza dyskryminacyjna okazała się mało istotną (lamba Wilksa $=0,72141, \mathrm{p}<0,3189$ ), a zmienne $\mathrm{m}_{12}$ $\mathrm{i}_{13}$ istotnymi dopiero przy $\mathrm{p}$ wynoszącym odpowiednio 0,148345 i 0,319862 (zob. tab. 5.28).

Na podstawie surowych wartości współczynników funkcji dyskryminacyjnej oszacowany został model 3, który przyjął następującą postać ${ }^{64}$ :

$$
\mathrm{y}_{3}=-0,123+252,841 \mathrm{~m}_{12}-333,447 \mathrm{~m}_{13}
$$

${ }^{63}$ Zob. S. Ostasiewicz, Z. Ru sn ak, U. Si ed leck ka, op. cit., s. 311.

${ }^{64}$ Wielkością graniczną (punktem granicznym) jest 0. 
Tabela 5.28. Podsumowanie funkcji analizy dyskryminacyjnej dla przedsiębiorstw sektora TSL

(3 lata przed upadłością)

\begin{tabular}{|c|c|c|c|c|}
\hline \multirow{3}{*}{$\mathrm{N}=10$} & \multicolumn{3}{l}{$\begin{array}{l}\text { Zmiennych w modelu: 2 } \\
\text { Grupująca: Y (próba zbilansowana: 2 grupy podmiotów gospodarczych) } \\
\text { Lambda Wilksa: ,72141 przybl. F }(2,7)=1,3516 \mathrm{p}<, 3189\end{array}$} \\
\cline { 2 - 5 } & Lambda Wilksa & Cząstk. Wilksa & $\begin{array}{c}\mathrm{F} \text { usun. } \\
(1,7)\end{array}$ & $\mathrm{p}$ \\
\hline \hline $\mathrm{m}_{12}$ & 0,993308 & 0,726270 & 2,638285 & 0,148345 \\
\hline $\mathrm{m}_{13}$ & 0,839538 & 0,859294 & 1,146220 & 0,319862 \\
\hline
\end{tabular}

Źródło: jak do tab. 5.17.

Ogólna trafność dokonanej klasyfikacji była już niższa niż w modelach 1, 1a i 2, bowiem wynosiła 70\%. Odsetek poprawnie zaklasyfikowanych obserwacji z grupy spółek niezagrożonych upadłością kształtował się na poziomie $100 \%$, zaś spółek upadłych - jedynie 40\% (zob. tab. 5.29).

Tabela 5.29. Macierz klasyfikacji przedsiębiorstw sektora TSL dla analizy dyskryminacyjnej (3 lata przed upadłością)

\begin{tabular}{|l|c|c|c|}
\hline \multirow{2}{*}{$\mathrm{N}=10$} & \multicolumn{3}{|l|}{$\begin{array}{l}\text { Wiersze: obserwowana klasyfikacja } \\
\text { Kolumny: przewidywana klasyfikacja }\end{array}$} \\
\cline { 2 - 4 } & $\begin{array}{c}\text { procent } \\
\text { poprawne }\end{array}$ & $\begin{array}{c}\text { upadłe } \\
\mathrm{p}=0,500\end{array}$ & $\begin{array}{c}\text { niezagrożone } \\
\text { upadłością } \\
\mathrm{p}=0,500\end{array}$ \\
\hline \hline Upadłe & 40,00 & 2 & 3 \\
\hline $\begin{array}{l}\text { Niezagrożone } \\
\text { upadłością }\end{array}$ & 100,00 & 0 & 5 \\
\hline Razem & 70,00 & 2 & 8 \\
\hline
\end{tabular}

Źródło: jak do tab. 5.28.

W kolejnym etapie wyłonione zostały reguły klasyfikacyjne (prezentowane za pomocą drzewa klasyfikacyjnego) przy jednoczesnym wydzieleniu maksymalnie homogenicznych liści z punktu widzenia rozważanej zmiennej zależnej (zob. schemat 5.6). Uzyskana reguła klasyfikacyjna dla tego okresu brzmiała następująco: jeśli współczynnik eksploatacyjnej rentowności sprzedaży był nie wyższy niż 0,04655 , a współczynnik natychmiastowej płynności kształtował się w przedziale $(0,09463 ; 0,25072\rangle$, to spółka nie była zagrożona upadłością. Podmiotami gospodarczymi spełniającym ten warunek były spółki Mostva Sp. z o.o. oraz Przedsiębiorstwo Wielobranżowe Podkowa Sp. z o.o. (zob. zał. 8). 


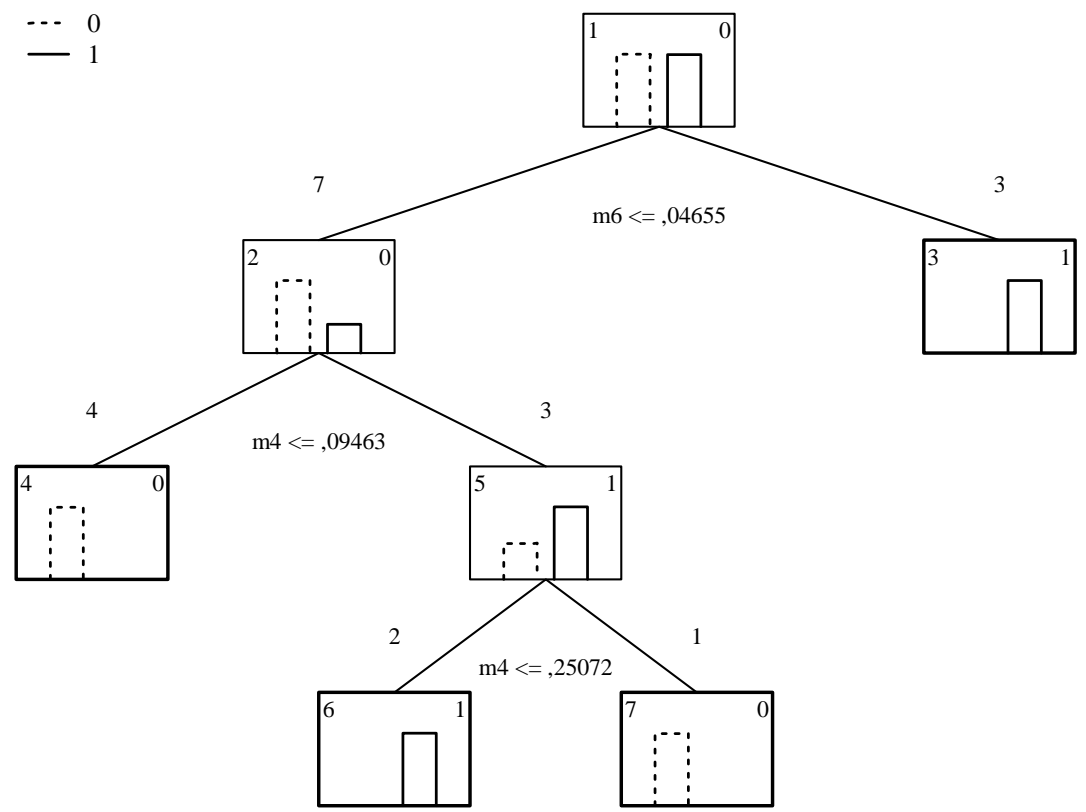

Schemat 5.6. Drzewo podziału przedsiębiorstw sektora TSL na upadłe/niezagrożone upadłością (dane finansowe na 3 lata przed upadłością)

Źródło: jak do schematu 5.3.

Tabela 5.30. Macierz klasyfikacji przedsiębiorstw sektora TSL dla drzewa klasyfikacyjnego (3 lata przed upadłością)

\begin{tabular}{|l|c|c|c|}
\hline \multirow{2}{*}{$\mathrm{N}=10$} & \multicolumn{3}{|c|}{$\begin{array}{l}\text { Wiersze: przewidywana klasyfikacja } \\
\text { Kolumny: obserwowana klasyfikacja }\end{array}$} \\
\cline { 2 - 4 } & $\begin{array}{c}\text { procent } \\
\text { poprawne }\end{array}$ & upadłe & $\begin{array}{c}\text { niezagrożone } \\
\text { upadłością }\end{array}$ \\
\hline \hline Upadłe & 100,00 & 5 & 0 \\
\hline $\begin{array}{l}\text { Niezagrożone } \\
\text { upadłością }\end{array}$ & 100,00 & 0 & 5 \\
\hline Razem & 100,00 & 5 & 5 \\
\hline
\end{tabular}

Źródło: jak do tab. 5.17.

Zaprezentowane modele oceny operacyjnego zagrożenia finansowego wskazują, że na rok i dwa lata przed upadłością każdorazowo został wykorzystany współczynnik natychmiastowej płynności finansowej $\left(\mathrm{m}_{4}\right)$, a na rok i trzy 
lata przed upadłością - współczynnik zabezpieczenia finansowego, którego formuła opiera się na krótkoterminowych rezerwach finansowych z tytułu świadczeń emerytalnych i podobnych $\left(\mathrm{tj} . \mathrm{m}_{12}\right.$ ). Jedynie w pierwszym badanym okresie (tj. na rok przed upadłością) do oszacowanego modelu została włączona również zmienna $\mathrm{m}_{5}$. Zastosowanie $\mathrm{w}$ analizie dyskryminacyjnej tego kasowego miernika oceny operacyjnego zagrożenia finansowego przyczyniło się nieznacznie do zwiększenia poziomu istotności za prezentowanego.

Rezultaty przeprowadzonych badań empirycznych wskazują, iż na rok przed upadłością ${ }^{65}$ w spółkach sektora TSL model operacyjnego zagrożenia finansowego wykorzystujący miernik kasowy wykazał porównywalną trafność klasyfikacji do modelu uwzględniającego jedynie mierniki memoriałowe.

Utworzenie deskryptywnego modelu C\&RT dla każdego analizowanego okresu przyczyniło się natomiast do opisu oraz prezentacji różnych wzorców dotyczących wartości i rodzajów relacji między rozważanymi zmiennymi diagnostycznymi, odgrywającymi zasadniczą rolę w dokonywanej w niniejszym opracowaniu klasyfikacji spółek sektora TSL. Znalezienie istotnych zależności, wzorców i reguł możliwe było przy jednoczesnym wydzieleniu maksymalnie homogenicznych liści z punktu widzenia zmiennej zależnej, którą były dwie grupy przedsiębiorstw, tj. upadłe, jak i niezagrożone upadłością. Na rok, dwa i trzy lata przed upadłością miernikiem wykorzystywanym każdorazowo do tego drzewa był współczynnik natychmiastowej płynności finansowej $\left(\mathrm{m}_{4}\right)$. Zmienna ta - na rok i dwa lata przed upadłością - była kluczową zmienną diagnostyczną, wybraną jako podstawa podziału badanych przedsiębiorstw.

Potwierdzony został zatem prezentowany w literaturze pogląd, iż najważniejszą kategorią zagrożenia finansowego jest płynność finansowa, która jest czynnikiem w decydującym stopniu determinującym upadłość danego podmiotu gospodarczego. Przedsiębiorstwa częściej upadają nie z powodu braku zysku, ale $\mathrm{z}$ powodu braku płynności finansowej ${ }^{66}$.

$\mathrm{Na}$ trzy lata przed upadłością miernikiem stanowiącym podstawę podziału badanych podmiotów gospodarczych stał się współczynnik eksploatacyjnej rentowności sprzedaży $\left(\mathrm{m}_{6}\right)$, który odgrywał również istotną rolę w uzyskanej regule klasyfikacyjnej na dwa lata przed upadłością.

Jedynie na rok przed upadłością w uzyskanej regule klasyfikacyjnej uwzględniony został jeden z kasowych mierników oceny operacyjnego zagrożenia finansowego przedsiębiorstwa, tj. współczynnik zdolności do obsługi zobowiązań bieżących gotówką osiąganą z działalności operacyjnej $\left(\mathrm{m}_{5}\right)$. Reguły klasyfikacyjne utworzone przy wykorzystaniu tej zmiennej diagnostycznej nie

\footnotetext{
${ }^{65} \mathrm{Na}$ dwa i trzy lata przed upadłością ani jeden miernik kasowy nie został bowiem wykorzystany do zaprezentowanej postaci modelu oceny operacyjnego zagrożenia finansowego.

Na dwa i trzy lata przed upadłością niemożliwe zatem stało się dokonanie weryfikacji sformułowanej w niniejszym opracowaniu hipotezy badawczej.

${ }^{66}$ A. Skowronek-Mi elczarek, Controlling, analiza i monitoring $w$ zarzadzaniu przedsiębiorstwem, Centrum Doradztwa i Informacji Difin Sp. z o.o., Warszawa 2007, s. 214.
} 
przyczyniły się do powstania błędu klasyfikacji w przyporządkowaniu badanych spółek do jednej z dwóch - wyłonionych w trakcie analizy - grup podmiotów gospodarczych. Jednocześnie $\mathrm{w}$ przypadku drzewa klasyfikacyjnego uwzględniającego wyłącznie memoriałowe mierniki oceny operacyjnego zagrożenia finansowego nie uległa pogorszeniu trafność klasyfikacyjna tego drzewa. 


\section{ZAKOŃCZENIE}

Bezpieczeństwo finansowe przedsiębiorstwa jest złożoną i wielowymiarową kategorią ekonomiczną, która odnosi się do stanu i procesu kształtowania warunków finansowych, zapewniających przedsiębiorstwu efektywną oraz skuteczną kontynuację działalności i szansę na rozwój. W wymiarze operacyjnym jest ono postrzegane przez pryzmat realizacji efektywnej ekonomicznie i skutecznej kontynuacji działalności przedsiębiorstwa, zdolnej do wykreowania i utrzymania dobrego standingu finansowego. Kształtowanie dobrego standingu finansowego przedsiębiorstwa związane jest bezpośrednio z imperatywem efektywnego łączenia działalności produkcyjnej, marketingowej i kadrowej z działalnością finansową, a także uznania tej ostatniej za wiodącą.

W literaturze nie poświęca się znacznej uwagi operacyjnemu bezpieczeństwu finansowemu przedsiębiorstwa i nie wykorzystuje się jednocześnie memoriałowego oraz kasowego podejścia w jego ocenie.

Istniejące przesłanki jednoczesnego stosowania memoriałowego i kasowego podejścia $\mathrm{w}$ ocenie operacyjnego bezpieczeństwa finansowego przedsiębiorstwa stanowią o stworzeniu bardziej zróżnicowanych, a przez to lepiej dostosowanych instrumentów i sposobów kształtowania przez przedsiębiorstwo warunków efektywnej ekonomicznie kontynuacji działalności.

Wybór oraz konstrukcja memoriałowych i kasowych mierników oceny operacyjnego bezpieczeństwa finansowego przedsiębiorstwa są zdeterminowane zarówno koncepcją zarządzania, jak i warunkami działania podmiotu gospodarczego. Istotną rolę i znaczenie mają także zasady oraz ustawa o rachunkowości, które wzmacniają możliwości ich wykorzystania w zarządzaniu finansowym w przedsiębiorstwie oraz tworzą szanse oszacowania i wykorzystania modelu dyskryminacyjnego dla skuteczniejszego zawiadamiania, a także ostrzegania przed zagrożeniem finansowym.

W rozpatrywanym zbiorze memoriałowych i kasowych mierników oceny operacyjnego bezpieczeństwa finansowego przedsiębiorstwa uwzględnionych zostało 13 mierników oceny, które zostały przyporządkowane do czterech głównych obszarów analizy, a mianowicie: sprzedaży produktów (usług), towarów 
i materiałów, płynności finansowej, rentowności eksploatacyjnej i wydajności pieniężnej, jak i krótkoterminowych rezerw finansowych.

Wyniki przeprowadzonych badań empirycznych w przedsiębiorstwach należących do sektora TSL wskazują na istnienie zróżnicowanych ocen operacyjnego bezpieczeństwa finansowego tych podmiotów gospodarczych z wykorzystaniem memoriałowych i kasowych mierników oceny tego bezpieczeństwa. Tym samym można powiedzieć, że w niniejszej monografii sformułowana teza znalazła swe potwierdzenie.

To zgeneralizowane twierdzenie nie preferuje żadnego z tych podejść, lecz wskazuje na potrzebę ich jednoczesnego stosowania w operacyjnym zarządzaniu przedsiębiorstwem ze względu na ich walory zarówno diagnostyczno-analityczne, jak i predykcyjne.

W zbiorze pozytywnie zweryfikowanych empirycznie hipotez pomocniczych znalazły się następujące stwierdzenia odnoszące się do diagnostycznoanalitycznej warstwy badań:

- Rentowność eksploatacyjna i wydajność pieniężna (gotówkowa) jest tym obszarem kreowania $i$ zapewniania dobrego standingu finansowego przedsiębiorstw sektora TSL, w którym obserwuje się znaczacy spadek wartości memoriałowych i kasowych mierników oceny operacyjnego bezpieczeństwa finansowego (subhipoteza 2.1).

- Znaczaca dywersyfikacja działalności przedsiębiorstw sektora TSL ma miejsce głównie poza sekcja „Transport i gospodarka magazynowa” (subhipoteza 2.3).

- Bieżaca ptynność finansowa jest tym obszarem kreowania i zapewniania dobrego standingu finansowego, w którym obserwuje się najwyższy poziom spreadu pomiędzy memoriałowymi a kasowymi miernikami oceny operacyjnego bezpieczeństwa finansowego (subhipoteza 3.1).

- W przedsiębiorstwach sektora TSL nie wystepuje znaczaca dodatnia zależność korelacyjna pomiędzy memoriatowymi a kasowymi miernikami oceny operacyjnego bezpieczeństwa finansowego (subhipoteza 4.1).

- Rentowność eksploatacyjna i wydajność pieniężna (gotówkowa) jest tym obszarem kreowania i zapewniania dobrego standingu finansowego, w którym obserwuje się najsilniejszy dodatni związek korelacyjny pomiędzy memoriałowymi i kasowymi miernikami oceny operacyjnego bezpieczeństwa finansowego przedsiębiorstw sektora TSL (subhipoteza 4.2).

- Pomiędzy wykazywanq $w$ przedsiębiorstwach sektora TSL liczba grup PKD a memoriałowymi i kasowymi miernikami oceny operacyjnego bezpieczeństwa finansowego wystęuje co najwyżej umiarkowana zależność korelacyjna (subhipoteza 4.3).

- Poziom operacyjnego bezpieczeństwa finansowego spółek sektora TSL ulega obniżeniu w okresie dekoniunktury (subhipoteza 5.1). 
Za pozytywnie zweryfikowane empirycznie hipotezy mieszczące się w warstwie badań predykcyjnych, choć ze względu na swój ,sektorowy” zasięg nie predysponujące do sformułowania zgeneralizowanych wniosków, uznane mogą być następujące twierdzenia:

- Dyskryminacja przebiegu kontynuacji dziatalności ustugowej przedsiębiorstw sektora TSL wykorzystująca mierniki kasowe jest jednakowo lub bardziej istotna od dyskryminacji wykonanej jedynie na podstawie mierników memoriałowych (subhipoteza 6.2).

- W spótkach sektora TSL modele operacyjnego zagrożenia finansowego wykorzystujace mierniki kasowe wykazuja porównywalna lub wyższa trafność klasyfikacji od modeli uwzględniajacych jedynie mierniki memoriatowe (subhipoteza 6.3).

- W spótkach sektora TSL drzewa klasyfikacyjne wykorzystujące mierniki kasowe $w$ ocenie operacyjnego zagrożenia finansowego wykazuja porównywalna lub wyższa trafność klasyfikacji od drzew uwzględniajacych jedynie mierniki memoriałowe (subhipoteza 6.4).

Do negatywnie zweryfikowanych empirycznie subhipotez badawczych należą następujące stwierdzenia:

- Przedsiębiorstwa spedycyjne utrzymuja wyższy poziom operacyjnego bezpieczeństwa finansowego $w$ relacji do pozostatych spótek sektora TSL (subhipoteza 5.2).

- Wzrostowi dywersyfikacji działalności towarzyszy wzrost poziomu operacyjnego bezpieczeństwa finansowego przedsiębiorstw sektora TSL (subhipoteza $5.3)$.

- W przypadku prognozowania zagrożenia upadtościa przedsiębiorstw sektora TSL modele dyskryminacyjne wykorzystujące dane ze sprawozdania z przeptywów pieniężnych wykazuja wyższa zdolność predykcyjna od modeli uwzględniających jedynie dane z bilansu oraz rachunku zysków i strat (subhipoteza 6.1).

W zbiorze weryfikowanych empirycznie subhipotez badawczych znalazły się również twierdzenia, które nie mogły zostać ani jednoznacznie potwierdzone, ani też zanegowane. Ich wartość praktyczna wydaje się być jednakże nie mniejsza od pozostałych hipotez, a są nimi następujące stwierdzenia:

- Przedsiębiorstwa transportowe utrzymuja najczęściej najniższy poziom memoriałowych i kasowych mierników oceny operacyjnego bezpieczeństwa finansowego $w$ relacji do pozostatych spótek sektora TSL (subhipoteza 2.2).

- Poziom spreadu memoriałowych i kasowych mierników oceny operacyjnego bezpieczeństwa finansowego przedsiębiorstw transportowych istotnie różni się od poziomu spreadu mierników w pozostatych spótkach sektora TSL (subhipoteza 3.2).

- Na ksztattowanie się spreadu memoriałowych i kasowych mierników oceny operacyjnego bezpieczeństwa finansowego przedsiębiorstw sektora TSL istotny wptyw wywiera koniunktura gospodarcza na rynku (subhipoteza 3.3). 
Zaprezentowane wyniki badań nad operacyjnym bezpieczeństwem finansowym przedsiębiorstw sektora TSL pozwalają wnioskować o zasadności i potrzebie przeprowadzania dwuwymiarowej - wykorzystującej podejście memoriałowe i kasowe - oceny badanego zjawiska. Takie kompleksowe podejście do analizy oraz diagnostyki (tj. memoriałowe i kasowe) jest podstawą wnikliwej i bardziej obiektywnej jego oceny.

Zaproponowane mierniki oceny operacyjnego bezpieczeństwa finansowego obliczane były na podstawie sprawozdań finansowych badanych podmiotów gospodarczych. Tym samym istniejąca możliwość prowadzenia $\mathrm{w}$ danym przedsiębiorstwie różnej polityki bilansowej, czy też chociażby alternatywnego sposobu ujmowania niektórych zjawisk w rachunkowości oraz przypisywania ich do poszczególnych okresów sprawozdawczych, może wpływać na wiarygodność tychże danych finansowych, a przez to może być istotnym ograniczeniem przeprowadzonych badań i wyprowadzonych na jej podstawie wniosków.

Wyniki te, mimo iż mogą zostać uznane za bogate swym zakresem problemowym i bogactwem zastosowanych metod analizy ekonomicznej, nie tworzą jeszcze wystarczającej podstawy do podjęcia zgeneralizowanej próby ich uogólnienia i nadania im charakteru aplikacyjnego. Są one w swej intencji zorientowane na przedstawienie nowej koncepcji badań z zastosowaniem podejścia memoriałowego i podejścia kasowego, ukierunkowanych na tworzenie warunków wczesnego ostrzegania przedsiębiorstw przed finansowym zagrożeniem kontynuacji i rozwoju ich działalności gospodarczej. Mogą być również punktem odniesienia do dalszych rozważań oraz badań empirycznych z tego zakresu. 


\section{BIBLIOGRAFIA}

Adamik-Citak M., Creative accounting in the era of economic crisis, [w:] W. Wereda, S. S t arnaw ska, Cyclicality, financial safety, and business creativity as the challenges of the modern word, University of Podlasie, Siedlce 2009.

Altman E. I., Financial Ratios. Discriminant Analysis and the Prediction of Corporate Bankruptcy, ,Journal of Finance” 1968, Vol. 23, No. 4.

Anto nowicz P., Metody oceny i prognoza kondycji ekonomiczno-finansowej przedsiębiorstw, Ośrodek Doradztwa i Doskonalenia Kadr Sp. z o.o., Gdańsk 2007.

A n t o no w i z P., Założenia analizy dyskryminacyjnej $w$ konstruowaniu nowych wielowymiarowych modeli klasyfikacyjnych $w$ celu prognozowania upadtości przedsiębiorstw, [w:] A. Ad a m ska, E. M ą c z y ń ska (red.), Upadtości, bankructwa i naprawa przedsiębiorstw. Wybrane zagadnienia, Oficyna Wydawnicza Szkoły Głównej Handlowej w Warszawie, Warszawa 2013.

Ареф’єв В.О., Концептуальні Підходи Щодо Управління Фінансовою Безпекою Підприємства На Стратегічному I Тактичному Рівнях, „Економіка. Економіка підприємства, Бізнесінформ” 2011, № 12 [A refie v V. O., Conceptual Approaches to Enterprise Financial Security Management at Strategic and Tactical Levels, http://www.business-inform.net/thematic-search/?theme=economy-of-enterprise\&lang=en].

B a lt a gi B. H., Econometric Analysis of Panel Data, 3rd Edition, John Wiley \& Sons, 2005.

B a tó g J., Klasyfikacja obiektów w przypadku agregacji danych, [w:] J. Ho ze r (red.), Metody ilościowe w ekonomii, ,Zeszyty Naukowe Uniwersytetu Szczecińskiego nr 365”, Prace Katedry Ekonometrii i Statystyki nr 14, Szczecin 2003.

B e d n ars ki L., Analiza finansowa w przedsiębiorstwie, PWE, Warszawa 1997.

B ed narski L., W a śn i e w ski T. (red.), Analiza finansowa $w$ zarzadzaniu przedsiębiorstwem, t. 1, Fundacja Rozwoju Rachunkowości w Polsce, Warszawa 1996.

Bedyńska S., Brzezicka A. (red.), Statystyczny drogowskaz. Praktyczny poradnik analizy danych w naukach społecznych na przyktadach z psychologii, Wydawnictwo SWPS Academica, Warszawa 2007.

B e rnste in L. A., Wild J. J., Financial statement analysis: Theory, application, and interpretation, 6th ed., The McGraw-Hill Companies, Boston 1998.

B lack A., Wright P., B achman J., W poszukiwaniu wartości dla akcjonariuszy, Oficyna ekonomiczna, Kraków 2000.

B ralc z y k J. (red.), Stownik 100 tysięcy potrzebnych słów, Wydawnictwo Naukowe PWN, Warszawa 2005.

Brdulak H., Polski rynek TSL w $2010 \quad$ r., ostatnia aktualizacja 22.06.2011, http://www.rp.pl/artykul/677116.html.

B u k H., Nowoczesne zarzadzanie finansami. Planowanie i kontrola, Wydawnictwo C. H. Beck, Warszawa 2006. 
B urzykowska M., Duraj J., Controllingowy wymiar oceny płynności finansowej przedsiębiorstwa, Wydawnictwo Uniwersytetu Łódzkiego, Łódź 2009.

C a pi g a M., Grad oń W., S zu st a k G., Sieć bezpieczeństwa finansowego, CeDeWu Sp. z o.o., Warszawa 2010.

Carslaw Ch. A., Mills J. R., Developing Ratios for Effective Cash Flow Statement Analysis, „Journal of Accountancy”, November 1991.

Ca se y C. J., B artczak N. J., Cash Flow: It's Not the Botton Line, „Harvard Business Review” July-August 1984.

Case y C. J., B artczak N. J., Using Operating Cash Flow Data to Predict Financial Distress: Some Extensions, „Journal of Accounting Research” 1985, Vol. 23, No. 1.

Ceny w gospodarce narodowej w 2012 r., Główny Urząd Statystyczny - Departament Handlu i Usług, Urząd Statystyczny w Opolu, Warszawa 2013.

Chupis A., Kashenko K., Financial Security of Agricultural Enterprises, [w:] M. Wasilewski (red.), Ekonomika i organizacja gospodarki żywnościowej, „Zeszyty Naukowe SGGW w Warszawie nr 96", Warszawa 2012.

Ci e si els ki M. (red.), Rynek ustug logistycznych, Difin, Warszawa 2005.

Czubakowska K., Gabrusewicz W., Nowak E., Przychody, koszty, wynik finansowy przedsiębiorstwa, PWE, Warszawa 2009.

Ćwiąkała-Małys A., Aspekty prawnofinansowe sprawozdawczości finansowej, Wydawnictwo Uniwersytetu Wrocławskiego, Wrocław 2000, s. 101, [za:] B. I z y d o r c z y k, T. Ż y zn o w s ki, Sprawozdawczość finansowa jednostek gospodarczych za 1996 r., „Vademecum Rachunkowości”, Difin, Warszawa 1996.

Dane Centralnego Ośrodka Informacji Gospodarczej Sp. z o.o.

Dane Głównego Urzędu Statystycznego w Warszawie.

Dane Info Veriti Polska Sp. z o.o.

Dane Krajowego Rejestru Sądowego w Warszawie.

De Angelo H., De Angelo L., Skinner D. J., Accounting Choice in Troubled Companies, „Journal of Accounting \& Economics” 1994, Vol. 17, Issue 1/2.

De c P., Modele wczesnego ostrzegania przed upadtościa przedsiębiorstw i badania nad ich skutecznościa w Polsce, [w:] E. M ą c z y ń s k a (red.), Bankructwa przedsiębiorstw. Wybrane aspekty instytucjonalne, Szkoła Główna Handlowa w Warszawie - Oficyna Wydawnicza, Warszawa 2008.

DeFond M. L., Jiambalvo J., Debt Covenant Violation and Manipulation of Accruals, „Journal of Accounting and Economics” 1994, Vol. 17, Issue 1/2.

Delaney T., Carlet on R., Cash flow analysis-going beyond the basics, „The RMA Journal” 2008, Vol. 90, Issue 8.

Dharan B. G., Lev B., The Valuation Consequence of Accounting Changes, ,Journal of Accounting, Auditing \& Finance" 1993, Vol. 8, Issue 4.

Doryń W., Franek J., Gaweł A., Lobmayr B., Peterkova J., Prusak B., Stehr Ch., Sobiechowska-Ziegert A., Wasilczuk J., Zięba K., Internationalization, Innovativeness and Growth of Modern Enterprises, ICAN Sp. z o.o. Sp.k., Warszawa 2010.

Dory ń W., Wpływ internacjonalizacji na wyniki ekonomiczne polskich przedsiębiorstw przemystowych, Wydawnictwo Uniwersytetu Łódzkiego, Łódź 2011.

Dor y ń W., Zwiąek pomiędzy wielkościa przedsiębiorstwa i jego aktywnościa eksportowa, [w:] A. M i kuls k a (red.), Zarzadzanie nowoczesnym przedsiębiorstwem: wybrane aspekty, Politechnika Gdańska. Wydział Zarządzania i Ekonomii, Gdańsk 2013.

Dudek E., Analiza wskaźnikowa na podstawie rachunku przeptywów pieniężnych, „Monitor Rachunkowości i Finansów” 2003, nr 6.

Dudek-Szczepankiewicz E. I., Analiza sytuacji finansowej przedsiębiorstwa na bazie sprawozdania z przeptywów pieniężnych, „Monitor Rachunkowości i Finansów” 2004, nr 2.

D un aj B. (red.), Stownik wspótczesnego języka polskiego, t. A-E, Wydawnictwo WILGA, Kraków 2000. 
Duraj A. N., Controlling rezerw w przedsiębiorstwie, [w:] J. D u raj (red.), Controlling w zarzadzaniu przedsiębiorstwem, Wydawnictwo Naukowe NOVUM Sp. z o.o., Płock-Łódź 2003.

Duraj A. N., Gwarancyjna funkcja rezerw finansowych przedsiębiorstwa, [w:] J. D u raj (red.), Prace z zakresu ekonomiki $i$ zarządzania przedsiębiorstwem, „Acta Universitatis Lodziensis", Folia Oeconomica 200, Wydawnictwo Uniwersytetu Łódzkiego, Łódź 2006.

Du raj A. N., Kształtowanie rezerw w przedsiębiorstwie, Wydawnictwo Uniwersytetu Łódzkiego, Łódź 2004.

D u r aj A. N., Nadzór korporacyjny a bezpieczeństwo finansowe przedsiębiorstw, [w:] P. U rb a n e k (red.), Nadzór korporacyjny w warunkach kryzysu gospodarczego, Wydawnictwo Uniwersytetu Łódzkiego, Łódź 2010.

Duraj A. N., O wartości analizy ekonomicznej rezerw przedsiębiorstwa, [w:] J. Du raj (red.), Wartość przedsiębiorstwa $-z$ teorii $i$ praktyki zarzqdzania, Wydawnictwo Naukowe NOVUM Sp. z o.o., Płock-Beijing-Łódź 2004.

Duraj A. N., Rezerwy a strategie finansowe publicznych spótek akcyjnych, Wydawnictwo Uniwersytetu Łódzkiego, Łódź 2008.

Duraj A. N., Rezerwy w sprawozdaniach finansowych przedsiębiorstwa, [w:] J. Du raj (red.), Prace z zakresu ekonomiki $i$ zarządzania przedsiębiorstwem, „Acta Universitatis Lodziensis", Folia Oeconomica 171, Wydawnictwo Uniwersytetu Łódzkiego, Łódź 2004.

Duraj A. N., Ryzyko i rezerwy przedsiębiorstwa, [w:] J. Duraj (red.), Wartość przedsiębiorstwa $-z$ teorii i praktyki zarzadzania, t. IV, Wydawnictwo Naukowe NOVUM Sp. z o.o., Płock-Łódź 2003.

D u raj A. N., Wieloczynnikowa koncepcja modelu bezpieczeństwa finansowego przedsiębiorstwa, [w:] J. Duraj, A. Sajnóg (red.), Ekonomiczne i pozaekonomiczne czynniki zarzadzania wartościa przedsiębiorstwa, Wydawnictwo Uniwersytetu Łódzkiego, Łódź 2013.

D u raj A. N., Wykorzystanie rezerw finansowych w ocenie wyptacalności przedsiębiorstwa, [w:] J. D u r aj (red.), Problemy wspótczesnej analizy ekonomicznej przedsiębiorstwa, Wydawnictwo Uniwersytetu Łódzkiego, Łódź 2007.

D u r a j J., Analiza decyzyjna w przedsiębiorstwie, Polskie Towarzystwo Ekonomiczne w Zielonej Górze, Zielona Góra 1992.

Duraj J., Analiza rozwoju przedsiębiorstwa, [w:] L. B e dnars ki, R. B orowi e cki, J. D u raj, E. Kurtys, T. W a śn i e w ski, B. We rs ty, Analiza ekonomiczna przedsiębiorstwa, Wydawnictwo Akademii Ekonomicznej im. Oskara Langego we Wrocławiu, Wrocław 1996.

D u r aj J., Podstawy ekonomiki przedsiębiorstwa, PWE, Warszawa 2004.

E k şi I. H., Classification of Firm Failure with Classification and Regression Trees, „International Research Journal of Finance and Economics" 2011, Issue 76.

E 1 j a s i a E E., P arte k a W., Przeptywy gotówkowe: ustalanie, planowanie, analiza, zarzadzanie, Ośrodek Doradztwa i Doskonalenia Kadr, Gdańsk 1995.

Encyklopedia PWN - wersja internetowa, http://encyklopedia.pwn.pl/haslo/3928087/kryzys-finansowy.html.

Family financial security, North Central Regional Research Publication nr 131, Special Report 36, Iowa State University of Science and Technology, Iowa 1964.

Fertsch M. (red.), Stownik terminologii logistycznej, Instytut Logistyki i Magazynowania, Poznań 2006.

Figu ra P., Wartości wzorcowe wskaźników finansowych przedsiębiorstw giełdowych, CeDeWu, Warszawa 2012.

Forsythe G., Cash Flow vs. Earnings: Which Is More Meaningful?, September 18, 2006, http://www.schwab.com/public/schwab/research_strategies/market_insight/investing_strategi es/stocks/cash_flow_vs_earnings_which_is_more_meaningful.html.

Fort a M., Rentowność i płynność w ujęciu kasowym i memoriałowym w spótkach z branży spożywczej, [w:] T. D u d y c z, G. O s b e r t-P oc i e ch a (red.), Efektywność - rozważania nad istota i pomiarem, Wydawnictwo Uniwersytetu Ekonomicznego we Wrocławiu, Wrocław 2010. 
Franc-Dąbrowska J., Bezpieczeństwo finansowe a efektywność zaangażowanych kapitatów wtasnych, Roczniki Nauk Rolniczych, seria G, t. 93, z. 1, Warszawa 2006.

Gabru se wi z z W., Analiza finansowa $w$ audycie sprawozdań finansowych, [w:] W. Gabru s e w i c z (red.), Audyt sprawozdań finansowych, PWE, Warszawa 2010.

Gabrusewicz W., Kołaczyk Z., Bilans. Wartość poznawcza i analityczna, Centrum Doradztwa i Informacji Difin Sp. z o.o., Warszawa 2005.

Gabrusewicz W., Remlein M., Sprawozdanie finansowe przedsiębiorstwa: jednostkowe $i$ skonsolidowane, PWE, Warszawa 2011.

Gajdk a J., S to s D., Predicting Corporate Bankruptcy - the Polish Experience, [w:] R. B o r ow i e c k i (red.), Management of Organization During Economic Integration and Globalization, Department of Economic and Organization of Enterprise, Cracow University of Economics, Warsaw-Cracow 2003.

Gajdka J., Stos D., Wykorzystanie analizy dyskryminacyjnej $w$ ocenie kondycji finansowej przedsiębiorstw, [w:] R. B orowi ecki (red.), Restrukturyzacja w procesie przeksztatceń i rozwoju przedsiębiorstw, Wydawnictwo Akademii Ekonomicznej w Krakowie, Kraków 1996.

Gallinger G., Healey P., Liquidity Analysis and Management, Addison-Wesley, Menlo Park 1991.

Geller A. N., He ath L. C., Solvency, Financial Statement and the Importance of Cash-Flow Information, „Cornell Hospitality Quarterly”, November 1981, Vol. 22, No. 3.

Gille spie I., Lew is R., Hamilt on K., Principles of Financial Accounting, Prentice Hall Europe, Hemel Hempstead 1997.

G mytrasiewicz M., Karmańska A., Olchowicz I., Rachunkowość finansowa, Wykład 1, Difin, Warszawa 1996.

Gmytrasiewicz M., Karmańska A., Rachunkowość finansowa, Centrum Doradztwa i Informacji Difin Sp. z o.o., Warszawa 2002.

Go s W., Rachunek przepływów pieniężnych a sterowanie ptynnościa i wypłacalnościa, ,Rachunkowość" 2007, nr 5.

Gottli eb M., Le w c zyń ski W., Cash flows - sprawozdanie z przepływów gotówki: w praktyce USA $i$ w warunkach polskich, Instytut Przedsiębiorczości, Sopot 1993.

Gro m a d a M., Zalety i ograniczenia drzew klasyfikacyjnych. Klasyfikator SLIQ, 2003, multifraktal.net/seminarium/sliq.pdf.

Gru s zc z yń s ki M. (red.), Mikroekonometria. Modele i metody analizy danych indywidualnych, Wolters Kluwer Polska Sp. z o.o., Warszawa 2012.

Grus zc zyń ski M., Empiryczne finanse przedsiębiorstw. Mikroekonomia finansowa, Difin SA \& Marek Gruszczyński, Warszawa 2012.

Grzelak K., Karmańs ka A., Analiza sprawozdania z przeptywów pieniężnych, „Vademecum Przedsiębiorcy i Podatnika" 1996, nr 4.

Had a sik D., Upadtość przedsiębiorstw w Polsce i metody jej prognozowania, „Zeszyty Naukowe - Seria II. Publikacje habilitacyjne" 1998, z. 153.

Ha m rol M. (red.), Analiza finansowa przedsiębiorstwa - ujęcie sytuacyjne, Wydawnictwo Akademii Ekonomicznej w Poznaniu, Poznań 2004.

Hamrol M., Chodakowski J., Prognozowanie zagrożenia finansowego przedsiębiorstwa. Wartość predykcyjna polskich modeli analizy dyskryminacyjnej, [w:] Badania Operacyjne i Decyzje, nr 3, Oficyna Wydawnicza Politechniki Wrocławskiej, Wrocław 2008.

Healy P., The Effect of Bonus Schemes on Accounting Decision, ,Journal of Accounting \& Economics" 1985, Vol. 7.

Hen sher D., J on es S., Mixed logit and error component models of corporate insolvency and bankruptcy risk, [w:] D. He n sher, S. Jon es (ed.), Advances in credit risk modelling and corporate bankruptcy prediction, Cambridge University Press, Cambridge 2008.

Higg in s R. C., Analysis for Financial Management, 5th ed., McGraw-Hill Companies, Boston 1998. 
http://magazyn.wsinf.edu.pl/files/wded/wstep\%20do\%20klasyfikacji\%20danych.pdf.

http://nauka.money.pl/wnioski-o-dofinansowanie/konkurs-39/model-optymalizacji-pakietu-usluglogistycznych-swiadczonych-przez-przedsiebiorstwa-sektora-tsl-trasport-spedycja-logistyka262738.html.

http://www.stat.gov.pl/cps/rde/xbcr/gus/m-uslugi.pdf.

http://www.stat.gov.p1/klasyfikacje/pkd_07/pdf/4_PKD-klucz_2004-2007.pdf.

J a kli k A., Rachunkowość bankowa, Centrum Kreowania Liderów, Skierniewice 1992.

J e r z e mow s k a M., Analiza ekonomiczna w przedsiębiorstwie, PWE, Warszawa 2006.

Jerzemowska M., Przyczynek do historii analizy ekonomicznej, „Zeszyty Teoretyczne Rachunkowości” 2004, nr 20(76), Warszawa.

J erze mowska M., C a m p bell K., Nadzór korporacyjny a zagrożenie przedsiębiorstwa bankructwem, [w:] E. Mąc zyńska (red)., Bankructwa przedsiębiorstw. Wybrane aspekty instytucjonalne, Szkoła Główna Handlowa w Warszawie - Oficyna Wydawnicza, Warszawa 2008.

Jurkowska-Zeidler A., Bezpieczeństwo rynku finansowego w świetle prawa Unii Europejskiej, Wolters Kluwer Polska Sp. z o.o., Warszawa 2008.

J u z zczak-S zu macher G., Makroekonometryczna analiza procesu produkcyjnego, Wydawnictwo Uniwersytetu Łódzkiego, Łódź 1996.

J u s zc zak-S zu macher G., Miary dynamiki, [w:] W. S tarzyń ska (red.), Podstawy statystyki: podręcznik, Centrum Doradztwa i Informacji Difin Sp. z o.o., Warszawa 2004.

K a mi ń s ki R., Polityka bilansowa kształtowania aktywów i pasywów, „Rachunkowość - poradnik praktyczny", kwiecień 2002, nr 4.

Karbownik L., Dyferencjacja rozwoju działalności gospodarczej przedsiębiorstw sektora TSL w Polsce, [w:] J. D u r aj (red.), Prace z zakresu ekonomiki i zarzadzania przedsiębiorstwem, „Acta Universitatis Lodziensis”, Folia Oeconomica 272, Wydawnictwo Uniwersytetu Łódzkiego, Łódź 2012.

Karbownik L., Finansowe symptomy operacyjnego zagrożenia finansowego przedsiębiorstw sektora TSL, ,Logistyka” 2014, nr 5, CD nr 2.

Karbownik L., Kasowe i memoriałowe mierniki oceny bezpieczeństwa finansowego przedsiębiorstwa, [w:] J. D u raj (red.), Instrumenty i sposoby zarzadzania kapitatem przedsiębiorstwa, „Acta Universitatis Lodziensis”, Folia Oeconomica 267, Wydawnictwo Uniwersytetu Łódzkiego, Łódź 2012.

K a rbown i k L., Ocena zdolności predykcyjnej wybranych modeli dyskryminacyjnych w prognozowaniu upadtości przedsiębiorstw sektora TSL, [w:] J. D u raj, A. S ajn ó g (red.), Ekonomiczne i pozaekonomiczne czynniki zarządzania wartościa przedsiębiorstwa, Wydawnictwo Uniwersytetu Łódzkiego, Łódź 2013.

Karbownik L., Pojęcie $i$ obszary kreowania oraz zapewniania bezpieczeństwa finansowego przedsiębiorstwa, [w:] J. D u r a j (red.), Instrumenty i sposoby zarzadzania kapitatem przedsiębiorstwa, ,Acta Universitatis Lodziensis”, Folia Oeconomica 267, Wydawnictwo Uniwersytetu Łódzkiego, Łódź 2012.

Karbownik L., Pomiar i ocena zróżnicowania zakresu działalności gospodarczej przedsiębiorstw sektora TSL, [w:] N. Duraj, A. Pieloch-B abiarz (red.), Przedsiębiorczość, strategie i metody zarzadzania przedsiębiorstwem, Wydawnictwo Uniwersytetu Łódzkiego, Łódź 2014.

Karbownik L., The use of accrual-based and cash-based approach in evaluating the operational financial threat of enterprises from the TSL sector-example of application of the discriminant analysis, „Quantitative Methods in Economics” 2013, Vol. XIV, No. 1, SGGW in Warsaw, Warsaw.

Karbownik L., Zróżnicowanie poziomu operacyjnego bezpieczeństwa finansowego przedsiębiorstw sektora TSL, [w:] J. Du raj (red.), Instrumenty ksztattowania dochodowości i rentowności przedsiębiorstwa, „Acta Universitatis Lodziensis”, Folia Oeconomica 278, Wydawnictwo Uniwersytetu Łódzkiego, Łódź 2013.

Kiziuki e wi c z T., Sprawozdanie z przepływu środków pieniężnych $w$ zarządzaniu firma, Wydawnictwo EKSPERT, Wrocław 1995. 
Koch alsk i C., Budowanie wartości przedsiębiorstwa $w$ oparciu o analizę rentowności sprzedaży, [w:] E. U rb ań c zy k (red.), Strategie wzrostu wartości przedsiębiorstwa. Teoria i praktyka gospodarcza, „Zeszyty Naukowe nr 378”, Prace Instytutu Ekonomiki i Organizacji Przedsiębiorstw nr 43, t. 1, Wydawnictwo Kreos, Szczecin 2004.

Kochalski C., Przydatność standardowej analizy wskaźnikowej przy ocenie wyników działalności spótek giełdowych, [w:] D. Z a r z e c ki (red.), Zarządzanie finansami: mierzenie wyników $i$ wycena przedsiębiorstw, t. 1, Wydawnictwo Uniwersytetu Szczecińskiego, Szczecin 2003.

Kochalski C., Rachunek $i$ analiza kosztów $w$ controllingu operacyjnym i strategicznym. Ocena tradycyjnego podejścia i propozycje zmian, [w:] J. Du raj (red.), Controlling w zarzadzaniu przedsiębiorstwem, Omega Praksis, Łódź 2001.

Ko ch a ls k i C., Syndrom „lasu i drzew” w analizie wskaźnikowej, „Controlling i Rachunkowość Zarządcza" 2008, nr 8.

Kochalski C., The finance-marketing interface, [w:] W. Frąckowiak, C. Kochalski, Modern Managerial Finance. New trends and research areas, Poznań Uniwersity of Economic Press, Poznań 2010.

Kolenda M., Taksonomia numeryczna. Klasyfikacja, porządkowanie i analiza obiektów, Wydawnictwo Akademii Ekonomicznej im. Oskara Langego we Wrocławiu, Wrocław 2006.

Koniunktura w ustugach, Główny Urząd Statystyczny w Warszawie.

Ko rol T., Nowe podejście do analizy wskaźnikowej w przedsiębiorstwie, Wolters Kluwer Polska SA, Warszawa 2013.

Kotler P., Armstrong G., Saunders J., Wong V., Marketing. Podręcznik europejski, PWE, Warszawa 2002.

Kufel T., Ekonometria. Rozwiazywanie problemów z wykorzystaniem programu GRETL, Wydawnictwo Naukowe PWN, Warszawa 2011.

K u s a k A., Ptynność finansowa. Analiza i sterowanie, Wydawnictwo Naukowe Wydziału Zarządzania Uniwersytetu Warszawskiego, Warszawa 2006.

Кузенко Т. Б., Полтинина О. П., Конкретизаиия Угроз Финансовой Безопасности Предприятия, „Економіка Фінансова Стійкість І Безпека, Бізнесінформ” 2011, № 2(1), s. 131-133 [Kuzenko T. B., Poltinina O. P., Concretization of Threats of Financial Security of Enterprise, www.business-inform.net].

Кузенко Т. Б., Усенко К. А., Управление Финансовой Безопасностью Предприятия В Соответствии С Принципами Ее Обеспечения, „Економіка, Фінансова Стійкість І Безпека, Бізнесінформ” 2011, № 2(1), s. 136-138 [K u zenk o T. B., U s enko K. A., Management of Financial Security of Enterprise in Accordance with the Principles of its Control, http://www.business-inform.net/annotated-catalogue/?year=2011\&abstract=2011_ 02_1\&lang=en].

Lach mirowicz M., Rachunek przeptywów pieniężnych w praktyce, CeDeWu Sp. z o.o., Warszawa 2012.

Largay J. A., Stickney C. P., Cash Flows, Ratio Analysis and the W. T. Grant Company Bankruptcy, ,Financial Analysts Journal”, July-August 1980.

Laws on G. H., The Cash Flow Performance of UK Companies, [w:] M. Bromwich, A. Hopwood (eds.), Essays in British Accounting Research, Ch. 4, Pitman Publishing Limited, London 1981.

Lee T. A., Cash Flow Accounting and Corporate Financial Reporting, [w:] M. B ro mwich, A. Hopwood (eds.), Essays in British Accounting Research, Ch. 3, Pitman Publishing Limited, London 1981.

Lee T. A., Cash Flow Accounting, Van Nostrand Reinhold, United Kingdom 1984.

Li T., Hu an g X., A New Concept and Application of Cash Profit, [w:] International Conference on Management and Service Science, Institute of Electrical and Electronic Engineers, September 2009, http://ieeexplore.ieee.org/. 
Li piec-Zajchowska M. (red.), Wspomaganie procesów decyzyjnych, Ekonometria, Warszawa 2003.

Lista 500 największych firm - INE PAN, „Parkiet”, maj 2003.

Ładysz I., Wybrane aspekty zarządzania bezpieczeństwem finansowym i zadtużeniem miasta Wrocławia, [w:] Rocznik Bezpieczeństwa Międzynarodowego, Wydawnictwo Naukowe Dolnośląskiej Szkoły Wyższej, Wrocław 2012.

Łapczyński M., Drzewa klasyfikacyjne w badaniach satysfakcji i lojalności klientów, [w:] Analiza satysfakcji i lojalności klientów, StatSoft Polska Sp. z o.o., Warszawa-Kraków 2003.

Łapczyński M., Wptyw aktywności mieszkańców ma poziom życia $w$ gminach woj. matopolskiego, [w:] Statystyka i data mining w badaniach naukowych, StatSoft Polska, Warszawa -Kraków 2005.

Łun iew sk a M., Ekonometria finansowa. Analiza rynku kapitałowego, Wydawnictwo Naukowe PWN, Warszawa 2008.

Mackevičius J., Senkus K., The System of Formation and Evaluation of the Information of Cash Flows, „Journal of Business, Economics and Management” 2006, Vol. 7, No. 4.

Majka A., Jankowska D., Zastosowanie testu Kruskala-Wallisa jako alternatywy analizy wariancji w badaniach ekonomiczno-spotecznych, [w:] Rola informatyki w naukach ekonomicznych $i$ spotecznych, „Zeszyty Naukowe WSH w Kielcach”, seria 5a, Wydawnictwo Świętokrzyskie Centrum Edukacji na Odległość WSH w Kielcach, Kielce 2007.

Malinowska U., Rogowski W., Rola modeli oceny zagrożenia upadtościa $w$ nowoczesnej analizie finansowej, [w:] M. H a m rol (red.), Analiza finansowa jako narzędzie zarządzania przedsiębiorstwem, Katedra Analizy Finansowej i Strategicznej, Akademia Ekonomiczna w Poznaniu, Poznań 2005.

Mali now sk a U., Wptyw Międzynarodowych Standardów Rachunkowości na walory informacyjne sprawozdań finansowych, [w:] Wspótczesne problemy analizy ekonomicznej, „Prace i Materiały Wydziału Zarządzania Uniwersytetu Gdańskiego 1/2006”, Wydawnictwo Wydziału Zarządzania Uniwersytetu Gdańskiego i Fundacja Rozwoju Uniwersytetu Gdańskiego, Sopot 2006.

Maliń s ki M., Wybrane zagadnienia statystyki matematycznej w EXCELU i pakiecie STATISTICA, Wydawnictwo Politechniki Śląskiej, Gliwice 2010.

Manolas G., Rontos K., S fakian ak is G., V avouras I., The Determinants of the Shadow Economy: The Case of Greece, ,International Journal of Criminology and Sociological Theory", January 2013, Vol. 6, No. 1.

Mańk kow s ki C., Krajowy rynek ustug TSL w warunkach ogólnoświatowego kryzysu gospodarczego i finansowego, „Logistyka” 2010, nr 1.

Marcinkowska M., Ocena działalności instytucji finansowych, Centrum Doradztwa i Informacji Difin Sp. z o.o., Warszawa 2007.

Mare k T., Analiza skupień w badaniach empirycznych. Metody SAHN, Wydawnictwo Naukowe PWN, Warszawa 1989.

Maślanka T., Przepływy pieniężne $w$ zarzadzaniu finansami przedsiębiorstw, Wydawnictwo C. H. Beck, Warszawa 2008.

Matis D., Vladu A. B., Negrea L., Cash-Flow Reporting Between Potential Creative Accounting Techniques And Hedging Opportunities Case Study Romania, „Annales Universitatis Apulensis Series Oeconomica" 2009, Vol. 1, Issue 11.

Matu szc zyk A., Przygladajac się kredytobiorcom, „Bank” 2003, nr 2.

Mączyńska E. (red.), Bankructwa przedsiębiorstw. Wybrane aspekty instytucjonalne, Szkoła Główna Handlowa w Warszawie - Oficyna Wydawnicza, Warszawa 2008.

Mą c z yńs k a E., Globalizacja ryzyka a systemy wczesnego ostrzegania przed upadtościa przedsiębiorstw, [w:] D. A p p e n ze ll e r, Upadtość przedsiębiorstw w Polsce w latach 1990-2003. Teoria i praktyka, „Zeszyty Naukowe” 2004, nr 49, Wydawnictwo Akademii Ekonomicznej w Poznaniu, Poznań 2004. 
Mąc zyńs k a E., Ocena kondycji przedsiębiorstwa (uproszczone metody), „Życie Gospodarcze” 1994, nr 38.

Młodak A., Analiza taksonomiczna w statystyce regionalnej, Centrum Doradztwa i Informacji Difin Sp. z o.o., Warszawa 2006.

Mudie P., Cottam A., Ustugi. Zarzadzanie i marketing, Wydawnictwo Naukowe PWN, Warszawa 1998.

Ne e d le s B. E. Jr., Financial accounting, Houghton Mifflin Company, Boston 1992.

N o w a k E., Analiza sprawozdań finansowych, PWE, Warszawa 2008.

Now orol C., Analiza skupień w badaniach empirycznych. Rozmyte modele hierarchiczne, Wydawnictwo Naukowe PWN, Warszawa 1989.

Olchowicz I., Tła z ała A., Sprawozdawczość finansowa, Difin, Warszawa 2002.

Ostasiewicz S., Rusnak Z., Siedlecka U., Statystyka. Elementy teorii $i$ zadania, Wydawnictwo Akademii Ekonomicznej im. Oskara Langego we Wrocławiu, Wrocław 2003.

P a pi e rn ik - W oj d e r a M., Produktywność jako źródto poprawy rentowności przedsiębiorstwa, [w:] A. S t abryła (red.), Strategie wzrostu produktywności firmy, Wydawnictwo Akademii Ekonomicznej w Krakowie, Kraków 2000.

Pawłowicz L. (red.), Ekonomika przedsiębiorstw: zagadnienia wybrane, ODDK Gdańsk, Gdańsk 2005.

Pen man S. H., Financial Statement Analysis and Security Valuation, McGraw-Hill/Irwin, New York 2001.

P i e r śc i o n e Z Z., Strategie rozwoju firmy, Wydawnictwo Naukowe PWN, Warszawa 1996.

P i otrow s ki K., Bezpieczeństwo finansowe w branży TSL, „Transport i Spedycja” 2011, nr 4.

Płóciennik-Napi e rałow a J., Zasada memoriału, „Rachunkowość” 1999, nr 6.

Pogodzińska M., S ojak S., Wykorzystanie analizy dyskryminacyjnej w przewidywaniu bankructwa przedsiębiorstw, [w:] „Acta Universitatis Nicolai Copernici”, Ekonomia XXV, Zeszyt 299, Toruń 1995.

Polska Klasyfikacja Działalności (PKD) - Załacznik do Rozporzadzenia Rady Ministrów z dnia 24 grudnia 2007 r., DzU 2007, nr 251, poz. 1885: Zasady budowy klasyfikacji.

Polska w Unii Europejskiej - doświadczenia pierwszych miesięcy członkostwa, Urząd Komitetu Integracji Europejskiej - Departament Analiz i Strategii, Warszawa, luty 2005.

Pomykalska B., Pomykalski P., Analiza finansowa przedsiębiorstwa, Wydawnictwo Naukowe PWN, Warszawa 2007.

Pringle J. J., Harris R. S., Essentials of Managerial Finance, Scott, Foresman and Company, Glenview-London 1987.

Prusak B., Nowoczesne metody prognozowania zagrożenia finansowego przedsiębiorstw, Centrum Doradztwa i Informacji Difin Sp. z o.o., Warszawa 2005.

R ac zkow ski K., Bezpieczeństwo finansowe, [w:] J. Płac ze k (red.), Ekonomika bezpieczeństwa państwa w zarysie, Difin, Warszawa 2014.

Raczkowski K., Żukrowska K., Żuber M. (red.), Interdyscyplinarność nauk o bezpieczeństwie, Difin, Warszawa 2013.

Rocznik Statystyczny Rzeczpospolitej Polskiej, Główny Urząd Statystyczny, Warszawa 2007.

Rocznik Statystyczny Rzeczpospolitej Polskiej, Główny Urząd Statystyczny, Warszawa 2008.

Rolbi ecki R., Analiza dyskryminacyjna $w$ ocenie zmian kondycji finansowej przedsiębiorstw transportowych, „Controlling” 2010, nr 8.

R o m a n o w s k M., Planowanie strategiczne w przedsiębiorstwie, PWE, Warszawa 2004.

Rujoub M. A., Cook D. M., Hay L. E., Using Cash Flow Ratio to Predict Business Failure, „Journal of Managerial Issues”, 22 March 1995, Vol. 7, http://www.questia.com/library/1G116838779/using-cash-flow-ratios-to-predict-business-failures.

Rut kow ski A., Zarzadzanie finansami, PWE, Warszawa 2000.

Rybicki P., Jak interpretować rachunek przeptywów pieniężnych, Dodatek do „Controlling i Rachunkowość Zarządcza” 2003, nr 8. 
Sarpong D. (Jr), Winful E. Ch., Ntiamoah J., Determinants of wide interest margins in Ghana: Panel EGLS analysis, „African Journal of Business Management”, September 2013, Vol. 7(35).

Schroeder R. G., Clark M. W., Cathey J. M., Financial Accounting theory and analysis: Text and cases, 9th ed., John Wiley \& Son, New Jersey 2009.

$\mathrm{S} \mathrm{ch}$ w art z K. B., Accounting Changes by Corporations Facing Possible Insolvency, „Journal of Accounting, Auditing \& Finance" 1982, Vol. 6 Issue 1.

S cott S., The Importance of Cash Flow Analysis for Small Businesses, „Commercial Lending Review", March-April 2007.

Sh arm a D. S., I s elin E. R., The Relative Relevance of Cash Flow and Accrual Information for Solvency Assessments: A Multi-Method Approach, ,Journal of Business Finance \& Accounting" 2003, Vol. 30, Issue 7/8.

$\mathrm{Sh}$ arma D. S., Steven son P. A., The Impact of Impending Corporate Failure on the Incidence and Magnitude of Discretionary Accounting Policy Changes, „British Accounting Review" 1997, Vol. 29, No. 2.

$\mathrm{S}$ h ar m a D. S., The Role of Cash Flow Information in Predicting Corporate Failure: The State of the Literature, „Managerial Finance” 2001, Vol. 27, No. 4.

Sh arma D., Predicting Corporate Failure: When Cash Flow Is King, „Journal of Banking and Financial Services", June 2001, http://www.questia.com/library/1G1-76133453/predictingcorporate-failure-when-cash-flow-is-king.

S i e mińska E., Metody pomiaru i oceny kondycji finansowej przedsiębiorstwa, TNOiK - Stowarzyszenie Wyższej Użyteczności DOM ORGANIZATORA, Toruń 2002.

Sierpińska M., Jachna T., Ocena przedsiębiorstwa wedtug standardów światowych, Wydawnictwo Naukowe PWN, Warszawa 2004.

S ierpińska M., Polityka dywidend w spótkach kapitałowych, Wydawnictwo Naukowe PWN, Kraków-Warszawa 1999.

Sierpińska M., W ędzki D., Zarządzanie ptynnościa finansowa w przedsiębiorstwie, Wydawnictwo Naukowe PWN, Warszawa 1997.

S koczylas W., Instrumenty oceny rentowności przedsiębiorstw, [w:] W. S koczylas (red.), S koc zylas W. (red.), Analiza sprawozdawczości finansowej przedsiębiorstwa, Stowarzyszenie Księgowych w Polsce. Zarząd Główny. Centralny Ośrodek Szkolenia Zawodowego, Warszawa 2009.

Skoczylas W., Kierunki analizy przeptywów pieniężnych $w$ przedsiębiorstwie, [w:] W. Ja$\mathrm{n}$ as z (red.), Przedsiębiorstwo w procesie transformacji, ,Zeszyty Naukowe Uniwersytetu Szczecińskiego nr 172”, Prace Instytutu Ekonomiki i Organizacji Przedsiębiorstw nr 34, Szczecin 1996.

Skoczylas W., Nadwyżka pieniężna jako miara efektywności gospodarowania przedsiębiorstwa, [w:] W. J a n a z (red.), Strategie, modele i miary efektywności przedsiębiorstwa, „Zeszyty Naukowe Uniwersytetu Szczecińskiego nr 223”, Prace Instytutu Ekonomiki i Organizacji Przedsiębiorstw nr 36, Szczecin 1998.

S k o c z yl as W., Podejście memoriałowe a podejście kasowe w ocenie dochodowości działalności operacyjnej przedsiębiorstw, [w:] T. Dud ycz, G. O sbert-Poci ech a (red.), Efektywność - rozważania nad istota i pomiarem, Wydawnictwo Uniwersytetu Ekonomicznego we Wrocławiu, Wrocław 2010.

S k o c z yl a W W., Wskaźniki i systemy wskaźników ekonomicznych w pomiarze dokonań przedsiębiorstw, Uniwersytet Szczeciński, Szczecin 2013.

Skoczylas W., Zakres i sposób ustalania wskaźników stosowanych do analizy finansowej przedsiębiorstw, „Rachunkowość - audytor” 2004, nr 1.

$\mathrm{S} k$ ow ron e k-Mi elczarek A., Controlling, analiza $i$ monitoring $w$ zarzadzaniu przedsiębiorstwem, Centrum Doradztwa i Informacji Difin Sp. z o.o., Warszawa 2007.

S ławińska M., Witczak H. (red.), Podstawy metodologiczne prac doktorskich $w$ naukach ekonomicznych, PWE, Warszawa 2008. 
Słownik ekonomiczny i finansowy, Wydawnictwo Książnica, Katowice 1994.

Stownik polszczyzny XVI wieku, t. II, Wrocław-Warszawa-Kraków 1967.

S o b ol E., Stownik języka polskiego, Wydawnictwo Naukowe PWN, Warszawa 2005.

S tan is z A., Przystepny kurs statystyki z zastosowaniem STATISTICA PL na przyktadach medycyny. Tom 3. Analizy wielowymiarowe, StatSoft Polska Sp. z o.o., Kraków 2007.

S te f a ń s k a A., Polskie firmy transportowe coraz bliżej katastrofy, „Rzeczpospolita” 2009, nr 247.

Stępień K., Rentowność a wyptacalność przedsiębiorstw, Centrum Doradztwa i Informacji Difin Sp. z o.o., Warszawa 2008.

S u ch e cka J., W is zn i ew sk a E., Taksonomiczna ocena poziomu realizacji polityki ekologicznej w krajach EU, [w:] M. Z a wa d a (red.), Zastosowanie metod ilościowych w badaniach ekonomiczno-spotecznych, Wydawnictwo Politechniki Częstochowskiej, Częstochowa 2007.

$\mathrm{S}$ we e n e y A. P., Debt Covenant Violations and Managers' accounting responses, „Journal of Accounting \& Economics" 1994, Vol. 17, Issue 3.

S z me re ki et a A., Model rachunkowości w Niemczech a wartość przedsiębiorstwa, [w:] J. D u $\mathrm{raj}$ (red.), Wartość przedsiębiorstwa - z teorii i praktyki zarządzania, Wydawnictwo Naukowe NOVUM Sp. z o.o., Płock-Łódź 2002.

S zopik-Depczyńska K., Korzeniew ic z W., Kapitat ludzki w modelu wartości przedsiębiorstwa, „Studia i Prace Wydziału Nauk Ekonomicznych i Zarządzania nr 24”, Uniwersytet Szczeciński, Szczecin 2011, http://www.wneiz.pl/nauka_wneiz/sip/sip24-2011/SiP-24-12.pdf.

S z r e te r P., Lista obecności w branży transportowej, „Truck \& Business Polska” 2010, nr 3.

S z r e te r P., Niepewność perspektyw rozwoju sprzedaży, „EuroLogistics” 2010, nr 1.

S z r e te r P., Perspektywy rozwoju rynku ustug logistycznych, „EuroLogistics” 2010, nr 6(61).

Śn i że k E., Sprawozdawczość przepływów pieniężnych - krytyczna ocena i propozycja modelu, Wydawnictwo Uniwersytetu Łódzkiego, Łódź 2008.

Śn i eże k E., Akademia Cash Flow - część IX, „Monitor Rachunkowości i Finansów” 2000, nr 1.

Śn i ż̇e k E., Jak czytać cash flow, Fundacja Rozwoju Rachunkowości w Polsce, Warszawa 1997.

Ś ni ė̇e k E., Jak korzystać z rachunku przepływów pieniężnych, „Rachunkowość” 2008, nr 1.

Śnieżek E., Rachunek przeptywów pieniężnych $w$ teorii $i$ praktyce rachunkowości, Fundacja Rozwoju Rachunkowości w Polsce, Warszawa 1994.

Śn ie że k E., Sprawozdawczość przepływów pieniężnych - krytyczna ocena i propozycja modelu, Wydawnictwo Uniwersytetu Łódzkiego, Łódź 2008.

Śn ieżek E., Wi atr M., Praktyczne aspekty sprawozdawczości przeptywów pieniężnych, Wolters Kluwer Polska Sp. z o.o., Warszawa 2011.

Tr a c y J. A., Jak czytać sprawozdania finansowe: dla zarzadzających, przedsiębiorców, bankowców, prawników i inwestorów, Helion, Gliwice 2004.

T u ry n a J., MSR 7 - Rachunek przeptywów pieniężnych, Centrum Doradztwa i Informacji Difin Sp. z o.o., Warszawa 2008, s. 14 i 17, [za:] Międzynarodowe Standardy Sprawozdawczości Finansowej (MSSF) 2007, t. I, Stowarzyszenie Księgowych w Polsce, International Accounting Standards Committee Foundation, Warszawa-Londyn 2007.

T u ry n a J., MSR 7 - Rachunek przepływów pieniężnych, Centrum Doradztwa i Informacji Difin Sp. z o.o., Warszawa 2008.

U rb a n e k P., http://www.wynagrodzenia.pl/wywiady_1.php/wpis.10/drukuj.1.

U rbań c zy k E., Metody ilościowe $w$ analizie finansowej przedsiębiorstwa, Uniwersytet Szczeciński, Szczecin 1998.

Ustawa z dnia 28 lutego 2003 r. Prawo upadtościowe i naprawcze, DzU 2003, nr 60, poz. 535 $\mathrm{z}$ poźn. $\mathrm{zm}$.

Ustawa z dnia 29 września 1994 r. o rachunkowości, DzU 1994, nr 121, poz. 591 z późn. zm.

W a le w s k i P., Integracja i specjalizacja ustug, „Eurologistics” 2009, nr 5.

W a li ńs k a E. (red.), Rachunkowość, Wolters Kluwer Polska Sp. z o.o., Warszawa 2009.

W aśn i e wski T., Analiza sytuacji majątkowej i finansowej przedsiębiorstwa na podstawie pionowej i poziomej oceny aktywów i pasywów bilansu, [w:] L. B e d n a r s ki, R. Bo ro w i e c ki, J. Duraj, E. Kurty s, T. Waśn i e w s ki, B. We rst y, Analiza ekonomiczna przedsiębiorstwa, Wydawnictwo Akademii Ekonomicznej im. Oskara Langego we Wrocławiu, Wrocław 1996. 
W a śn i e w ski T., Sk oczylas W., Cash flow w przedsiębiorstwie. Ustalanie i analiza, Fundacja Rozwoju Rachunkowości w Polsce, Warszawa 1995.

Waśniewski T., Skoczylas W., Jak korzystać ze sprawozdania z przeptywu środków pieniężnych, „Rachunkowość” 1999, nr 12.

W a śn i e w s ki T., S k o c zyl as W., Syntetyczna ocena wyników oraz sytuacji finansowej przedsiębiorstwa, ,Rachunkowość” 1998, nr 4.

Waśnie wski T., S koczyla s W., Teoria i praktyka analizy finansowej $w$ przedsiębiorstwie, Fundacja Rozwoju Rachunkowości w Polsce, Warszawa 2002.

W at s on J., W ells P., The Association Between Various Earnings and Cash Flow Measures of Firm Performance and Stock Returns: Some Australian Evidence, 2005, s. 12, available at SSRN: http://ssrn.com/abstract=815365.

W ą s o w s ki W., Fatszowanie sprawozdań finansowych, „Rachunkowość” 2002, nr 11.

Wąs owski W., Kreatywna rachunkowość, fatszowanie sprawozdań finansowych, Centrum Doradztwa i Informacji Difin Sp. z o.o., Warszawa 2005.

W ęd zk i D., Przeptywy pieniężne w prognozowaniu upadtości przedsiębiorstwa. Przeglad literatury, [w:] Badania operacyjne i decyzje, nr 2, Oficyna Wydawnicza Politechniki Wrocławskiej, Wrocław 2008.

W ęd zki D., Statystyczna weryfikacja istotności przeptywów pieniężnych, „Zeszyty Teoretyczne Rachunkowości” 2003, nr 15(71), Warszawa.

W ęd zki D., Strategie ptynności finansowej przedsiębiorstwa, Oficyna Ekonomiczna, Kraków 2003.

W ojc i echow ski E., Zarys rozwoju rachunkowości w dawnej Polsce, Wydawnictwo Naukowe PWN, Warszawa 1964.

www.klasyfikacje.gofin.pl/pkwiu/1,1,6363,sekcja-h-transport-i-gospodarka-magazynowa.html.

www.stat.gov.pl/klasyfikacje/pkd_07/pdf/zasady_budowy_pkd.pdf.

www.statsoft.pl.

www.statsoft.pl/textbook/.

www.statsoft.pl/textbook/stathome.html.

Wy y ch M., Sprawozdania finansowe jako źródto informacji o przedsiębiorstwie $i$ podstawa podejmowania decyzji, [w:] M. W y p y c h (red.), Finanse przedsiębiorstwa z elementami zarządzania i analizy, Wydawnictwo Absolwent, Łódź 1997.

Załącznik do Rozporządzenia Rady Ministrów z dnia 24 grudnia 2007 r.: Wyjaśnienia PKD 2007, http://www.stat.gov.pl/klasyfikacje/pkd_07/pdf/3_PKD-2007-wyjasnienia.pdf.

З апо ро жцев а Л. А., Финансовая Безопасность Предприятия При Переходе На МСФО, „Проблемы. Мнения. Решения, Международный Бухгалтерский Учет”, сентябрь 2011, № 36(186) [Zaporozhtseva L.A., Financial safety of the enterprise at transition on IFRS, „International accounting”, September 2011, No. 36(186)].

Zgół kowa H. (red.), Praktyczny stownik wspótczesnej polszczyzny, t. 24, Wydawnictwo „KURPISZ”, Poznań 1995.

Zgółkowa H. (red.), Praktyczny słownik wspótczesnej polszczyzny, t. 4, Wydawnictwo „KURPISZ”, Poznań 1995.

$\mathrm{Zu}$ b M., Wptyw poziomu wartości majątku na bezpieczeństwo finansowe wybranych spótdzielni mleczarskich w Polsce, t. XIII, z. 1, Roczniki Naukowe Stowarzyszenia Ekonomistów Rolnictwa i Agrobiznesu, Warszawa-Poznań-Wrocław 2011.

$\mathrm{Zu}$ b M., Wptyw zatrudnienia na rentowność i bezpieczeństwo finansowe wybranych spótdzielni mleczarskich $w$ Polsce, [w:] H. M. S z o e g e (red.), Problemy Rolnictwa Światowego, Zeszyty Naukowe SGGW w Warszawie, Wydawnictwo SGGW, Warszawa 2010.

Zy s iń s k a M., Kierunki rozwoju przedsiębiorstw branży TSL $w$ Polsce w okresie dekoniunktury - wnioski z badań, „Transport Samochodowy” 2010, nr 3. 



\section{SPIS TABEL}

1.1. Słownikowe pojęcie bezpieczeństwa

1.2. Definicje bezpieczeństwa finansowego (przegląd literatury)

1.3. Obszary kreowania i zapewniania bezpieczeństwa finansowego (przegląd literatury)

1.4. Kryteria i mierniki oceny bezpieczeństwa finansowego przedsiębiorstwa w literaturze przedmiotu

1.5. Prezentacja określeń zasady memoriałowej (przegląd literatury) ................... 34

1.6. Przesłanki zastosowania zasady memoriałowej (przegląd literatury) ................ 36

1.7. Prezentacja określeń zasady kasowej (przegląd literatury) ....................... 38

1.8. Przesłanki jednoczesnego stosowania zasady memoriałowej i kasowej (przegląd literatury)

1.9. Wyniki badań empirycznych dotyczących przydatności informacyjnej rachunku przepływów pieniężnych (przegląd literatury)

1.10. Poglądy na temat użyteczności analizy mierników memoriałowych i kasowych dla różnych grup interesariuszy (przegląd literatury)

1.11. Użyteczność analizy operacyjnych przepływów pieniężnych (przegląd literatury)

1.12. Zaproponowany zbiór memoriałowych i kasowych mierników oceny operacyjnego bezpieczeństwa finansowego przedsiębiorstwa

2.1. Zalety i wady liniowej wielowymiarowej analizy dyskryminacyjnej ............... 72

2.2. Zalety i ograniczenia drzew klasyfikacyjnych .............................. 73

2.3. Wybrane obszary i zastosowane mierniki oceny operacyjnego bezpieczeństwa finansowego przedsiębiorstw sektora TSL

2.4. Zestawienie optymalnych wartości mierników oceny operacyjnego bezpieczeństwa finansowego dla badanych przedsiębiorstw sektora TSL (ceny stałe w relacji do 2012 r.)

2.5. Wartości podstawowych statystyk opisowych przychodów netto ze sprzedaży usług, towarów i materiałów w latach 2004-2012 (ceny stałe - dane w zł) .........

2.6. Wartości podstawowych statystyk opisowych współczynnika bieżącej płynności finansowej w latach 2004-2012

2.7. Wartości podstawowych statystyk opisowych współczynnika przyspieszonej płynności finansowej w latach 2004-2012 ....

2.8. Wartości podstawowych statystyk opisowych współczynnika natychmiastowej płynności finansowej w latach 2004-2012 
2.9. Wartość podstawowych statystyk opisowych współczynnika zdolności do obsługi zobowiązań bieżących gotówką osiąganą z działalności operacyjnej w latach 2004-2012

2.10. Wartości podstawowych statystyk opisowych współczynnika eksploatacyjnej rentowności sprzedaży w latach 2004-2012

2.11. Wartości podstawowych statystyk opisowych współczynnika eksploatacyjnej rentowności aktywów ogółem w latach 2004-2012

2.12. Wartości podstawowych statystyk opisowych współczynnika eksploatacyjnej rentowności kapitału własnego w latach 2004-2012 .

2.13. Wartości podstawowych statystyk opisowych współczynnika wydajności pieniężnej (gotówkowej) sprzedaży w latach 2004-2012 .

2.14. Wartości podstawowych statystyk opisowych współczynnika wydajności pieniężnej (gotówkowej) aktywów ogółem w latach 2004-2012

2.15. Wartości podstawowych statystyk opisowych współczynnika wydajności pieniężnej (gotówkowej) kapitału własnego w latach 2004-2012 ....................

2.16. Wartości podstawowych statystyk opisowych współczynnika zabezpieczenia

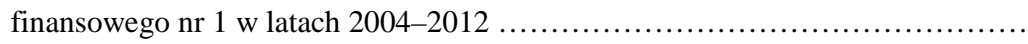

2.17. Wartość podstawowych statystyk opisowych współczynnika zabezpieczenia

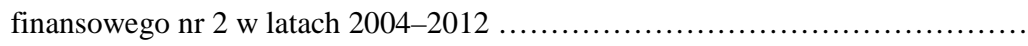

2.18. Tempo zmian średniej i środkowej wartości mierników oceny operacyjnego bezpieczeństwa finansowego spółek sektora TSL między latami 2004-2012 ......

2.19. Istotne różnice między określonymi latami dla wartości mierników oceny operacyjnego bezpieczeństwa finansowego spółek sektora TSL

2.20. Średnia ranga dla istotnie różnych wartości mierników oceny operacyjnego bezpieczeństwa finansowego między określonymi rodzajami działalności (głównymi źródłami przychodu) spółek sektora TSL

2.21. Liczba zidentyfikowanych grup PKD 2007 spółek sektora TSL

2.22. Udział spółek sektora TSL prowadzących działalność w poszczególnych grupach sekcji „Transport i gospodarka magazynowa” w ogólnej liczbie podmiotów poddanych badaniu

3.1. Liczba spółek sektora TSL w których wartość mierników kasowych była wyższa od memoriałowych mierników oceny operacyjnego bezpieczeństwa finansowego przedsiębiorstw

3.2. Liczba spółek sektora TSL w których wartość mierników kasowych była wyższa od memoriałowych mierników oceny operacyjnego bezpieczeństwa finansowego w całym badanym okresie (tj. w latach 2004-2012)

3.3. Średnia dla modułu wartości spreadu między memoriałowymi i kasowymi miernikami oceny operacyjnego bezpieczeństwa finansowego przedsiębiorstw sektora TSL

3.4. Środkowa wartość dla modułu spreadu między memoriałowymi i kasowymi miernikami oceny operacyjnego bezpieczeństwa finansowego przedsiębiorstw sektora TSL 
3.5. Ranking średniej wartości dla modułu spreadu między memoriałowymi i kasowymi miernikami oceny operacyjnego bezpieczeństwa finansowego przedsiębiorstw sektora TSL dla lat 2004-2012

3.6. Maksymalna wartość modułu dla spreadu między memoriałowymi i kasowymi miernikami oceny operacyjnego bezpieczeństwa finansowego przedsiębiorstw sektora TSL

3.7. Poziom istotności różnic między określonymi rodzajami działalności (głównymi źródłami przychodu) dla spreadu memoriałowych i kasowych mierników oceny operacyjnego bezpieczeństwa finansowego przedsiębiorstw sektora TSL (próba niezależna)

3.8. Średnia ranga dla istotnie różnych wartości spreadu mierników oceny operacyjnego bezpieczeństwa finansowego między określonymi rodzajami działalności (głównym źródłem przychodu) spółek sektora TSL (próba niezależna)

3.9. Poziom istotności różnic między określonymi latami dla spreadu memoriałowych i mierników kasowych oceny operacyjnego bezpieczeństwa finansowego spółek sektora TSL (próba zależna)

3.10. Istotne różnice między określonymi latami dla spreadu memoriałowych i kasowych mierników oceny operacyjnego bezpieczeństwa finansowego spółek sektora TSL (analiza POST-HOC)

3.11. Wartości współczynników korelacji rang Spearmana pomiędzy miernikami oceny operacyjnego bezpieczeństwa finansowego przedsiębiorstw sektora TSL w latach 2004-2012

3.12. Ranking wartości współczynników korelacji rang Spearmana między memoriałowymi a kasowymi miernikami w głównych obszarach oceny operacyjnego bezpieczeństwa finansowego przedsiębiorstw sektora TSL w latach 2004-2012...

3.13. Ranking istotnych statystycznie wartości współczynników korelacji rang Spearmana między memoriałowymi a kasowymi miernikami w głównych obszarach oceny operacyjnego bezpieczeństwa finansowego przedsiębiorstw sektora TSL w latach 2004-2012

3.14. Współczynniki korelacji rang Spearmana między memoriałowymi i kasowymi miernikami oceny operacyjnego bezpieczeństwa finansowego a liczbą grup PKD 2007 spółek sektora TSL

3.15. Współczynniki korelacji rang Spearmana między memoriałowymi i kasowymi miernikami oceny operacyjnego bezpieczeństwa finansowego a liczbą grup PKD 2007 w sekcji „Transport i gospodarka magazynowa” spółek sektora TSL

4.1. Mierniki o wysokim współczynniku korelacji rang Spearmana w latach 2004-2012

4.2. Charakter zmiennych diagnostycznych poziomu operacyjnego bezpieczeństwa finansowego

4.3. Wartość syntetycznej miary oceny operacyjnego bezpieczeństwa finansowego przedsiębiorstw sektora TSL w latach 2004-2012 
4.4. Udział procentowy spółek sektora TSL o najwyższej i najniższej wartości syntetycznego miernika oceny operacyjnego bezpieczeństwa finansowego w latach 2004-2012

4.5. Podstawowe statystyki opisowe syntetycznego miernika oceny operacyjnego bezpieczeństwa finansowego przedsiębiorstw sektora TSL w latach 2004-2012...

4.6. Wyniki estymacji modelu objaśniającego poziom bezpieczeństwa finansowego przedsiębiorstw sektora TSL (1)

4.7. Ranking wartości spreadu syntetycznego miernika oceny operacyjnego bezpieczeństwa finansowego przedsiębiorstw sektora TSL w latach 2004-2012 (analiza przestrzenna)

4.8. Średnia i środkowa wartość syntetycznego miernika oceny operacyjnego bezpieczeństwa finansowego spółek sektora TSL za lata 2004-2012

4.9. Ranking spółek sektora TSL według wartości syntetycznego miernika oceny operacyjnego bezpieczeństwa finansowego

4.10. Rodzaj działalności (główne źródło przychodu) spółek sektora TSL o najwyższym poziomie syntetycznego miernika oceny operacyjnego bezpieczeństwa finansowego w latach 2004-2012 .

4.11. Poziom istotności różnicy między określonymi rodzajami działalności (głównymi źródłami przychodu) dla wartości syntetycznego miernika oceny operacyjnego bezpieczeństwa finansowego przedsiębiorstw sektora TSL (próba niezależna) ......

4.12. Średnia ranga dla istotnie różnych wartości syntetycznego miernika oceny operacyjnego bezpieczeństwa finansowego między określonymi rodzajami działalności (głównymi źródłami przychodu) spółek sektora TSL

4.13. Wyniki estymacji modelu objaśniającego poziom bezpieczeństwa finansowego przedsiębiorstw sektora TSL (2)

4.14. Macierz korelacji dla wartości syntetycznego miernika oceny operacyjnego bezpieczeństwa finansowego przedsiębiorstw sektora TSL w latach 2004-2012...

4.15. Podstawowe statystyki opisowe syntetycznego miernika oceny operacyjnego bezpieczeństwa finansowego dla homogenicznych grup przedsiębiorstw sektora TSL w latach 2004-2012

4.16. Poziom istotności różnic między homogenicznymi grupami przedsiębiorstw dla wartości syntetycznego miernika oceny operacyjnego bezpieczeństwa finansowego spółek sektora TSL (próba niezależna)

4.17. Średnia ranga dla istotnie różnych wartości syntetycznego miernika oceny operacyjnego bezpieczeństwa finansowego między homogenicznymi grupami spółek sektora TSL

4.18. Współczynnik korelacji rang Spearmana między liczbą grup PKD 2007 a wartością syntetycznego miernika oceny operacyjnego bezpieczeństwa finansowego przedsiębiorstw sektora TSL

4.19. Współczynnik korelacji rang Spearmana między liczbą grup PKD 2007 w sekcji „Transport i gospodarka magazynowa” a wartością syntetycznego miernika oceny operacyjnego bezpieczeństwa finansowego przedsiębiorstw sektora TSL... 
4.20. Liczba grup PKD 2007 (w tym w sekcji „Transport i gospodarka magazynowa”) dla 5 spółek sektora TSL o najwyższej/najniższej wartości syntetycznego miernika oceny operacyjnego bezpieczeństwa finansowego

4.21. Podstawowe statystyki opisowe liczby grup PKD 2007 dla 5 spółek sektora TSL o najwyższej i najniższej wartości syntetycznego miernika oceny operacyjnego bezpieczeństwa finansowego w latach 2004-2012

4.22. Podstawowe statystyki opisowe liczby grup PKD 2007 w latach 2004-2012 według wyłonionych homogenicznych grup przedsiębiorstw sektora TSL

4.23. Podstawowe statystyki opisowe liczby grup PKD 2007 w sekcji „Transport i gospodarka magazynowa” w latach 2004-2012 według wyłonionych homogenicznych grup przedsiębiorstw sektora TSL

5.1. Modele dyskryminacyjne o najwyższych zdolnościach predykcyjnych dla przedsiębiorstw usługowych

5.2. Modele dyskryminacyjne wykorzystujące dane ze sprawozdania z przepływów pieniężnych

5.3. Zbiorcze zestawienie modeli prognozujących zagrożenie upadłością badanych spółek sektora TSL na rok przed wydaniem sądowego postanowienia o ogłoszeniu upadłości

5.4. Zbiorcze zestawienie modeli prognozujących zagrożenie upadłością badanych spółek sektora TSL na dwa lata przed wydaniem sądowego postanowienia o ogłoszeniu upadłości

5.5. Zbiorcze zestawienie modeli prognozujących zagrożenie upadłością badanych spółek sektora TSL na trzy lata przed wydaniem sądowego postanowienia o ogłoszeniu upadłości

5.6. Trafność klasyfikacji w prognozowaniu zagrożenia upadłości przedsiębiorstw sektora TSL charakteryzująca wybrane funkcje dyskryminacyjne

5.7. Średnie wartości wybranych mierników oceny operacyjnego zagrożenia finansowego w upadłych, jak i niezagrożonych upadłością przedsiębiorstwach sektora TSL (rok przed upadłością)

5.8. Trafność klasyfikacji wybranych mierników oceny operacyjnego zagrożenia finansowego (rok przed upadłością)

5.9. Wartość średnia, odchylenie standardowe, międzygrupowe oraz wewnątrzgrupowe współczynniki zmienności wybranych mierników oceny operacyjnego zagrożenia finansowego (rok przed upadłością)

5.10. Średnie wartości wybranych mierników oceny operacyjnego zagrożenia finansowego w upadłych, jak i niezagrożonych upadłością przedsiębiorstwach sektora TSL (dwa lata przed upadłością)

5.11. Trafność klasyfikacji wybranych mierników oceny operacyjnego zagrożenia finansowego (dwa lata przed upadłością)

5.12. Wartość średnia, odchylenie standardowe, międzygrupowe oraz wewnątrzgrupowe współczynniki zmienności wybranych mierników oceny operacyjnego zagrożenia finansowego (dwa lata przed upadłością) 
5.13. Średnie wartości wybranych mierników oceny operacyjnego zagrożenia finansowego w upadłych, jak i niezagrożonych upadłością przedsiębiorstwach sektora TSL (trzy lata przed upadłością)

5.14. Trafność klasyfikacji wybranych mierników oceny operacyjnego zagrożenia finansowego (trzy lata przed upadłością)

5.15. Wartość średnia, odchylenie standardowe, międzygrupowy oraz wewnątrzgrupowe współczynniki zmienności wybranych mierników oceny operacyjnego zagrożenia finansowego (trzy lata przed upadłością) .....

5.16. Macierz korelacji rang Spearmana między miernikami oceny operacyjnego zagrożenia finansowego przedsiębiorstw sektora TSL (rok przed upadłością) .......

5.17. Podsumowanie funkcji analizy dyskryminacyjnej I dla przedsiębiorstw sektora TSL (rok przed upadłością)

5.18. Macierz klasyfikacji przedsiębiorstw sektora TSL dla analizy dyskryminacyjnej I (rok przed upadłością)

5.19. Macierz klasyfikacji przedsiębiorstw sektora TSL dla drzewa klasyfikacyjnego I (rok przed upadłością)

5.20. Podsumowanie funkcji analizy dyskryminacyjnej II dla przedsiębiorstw sektora TSL (rok przed upadłością)

5.21. Macierz klasyfikacji przedsiębiorstw sektora TSL dla analizy dyskryminacyjnej II (rok przed upadłością)

5.22. Macierz klasyfikacji przedsiębiorstw sektora TSL dla drzewa klasyfikacyjnego II (rok przed upadłością)

5.23. Macierz korelacji rang Spearmana między miernikami oceny operacyjnego zagrożenia finansowego przedsiębiorstw sektora TSL (dwa lata przed upadłością)

5.24. Podsumowanie funkcji analizy dyskryminacyjnej dla przedsiębiorstw sektora TSL (2 lata przed upadłością)

5.25. Macierz klasyfikacji przedsiębiorstw sektora TSL dla analizy dyskryminacyjnej (2 lata przed upadłością)

5.26. Macierz klasyfikacji przedsiębiorstw sektora TSL dla drzewa klasyfikacyjnego (2 lata przed upadłością)

5.27. Macierz korelacji rang Spearmana między miernikami oceny operacyjnego zagrożenia finansowego przedsiębiorstw sektora TSL (trzy lata przed upadłością) .......

5.28. Podsumowanie funkcji analizy dyskryminacyjnej dla przedsiębiorstw sektora TSL (3 lata przed upadłością)

5.29. Macierz klasyfikacji przedsiębiorstw sektora TSL dla analizy dyskryminacyjnej (3 lata przed upadłością)

5.30. Macierz klasyfikacji przedsiębiorstw sektora TSL dla drzewa klasyfikacyjnego (3 lata przed upadłością) 


\section{SPIS WYKRESÓW}

1.1. Bezpieczeństwo a zagrożenie

2.1. Struktura podmiotów gospodarczych z sektora TSL wykazanych w rankingu TOP 500 według poszczególnych KRS

2.2. Struktura podmiotów gospodarczych $\mathrm{z}$ sektora TSL wykazanych w rankingu TOP 500 według głównego źródła przychodów

2.3. Średnia i środkowa wartość przychodów netto ze sprzedaży usług, towarów i materiałów spółek sektora TSL w latach 2004-2012 (ceny stałe - dane w zł) .....

2.4. Średnia ranga dla wartości przychodów netto ze sprzedaży usług, towarów i materiałów w latach 2004-2012 (ceny stałe)

2.5. Średnia i środkowa wartość współczynnika bieżącej płynności finansowej spółek sektora TSL w latach 2004-2012

2.6. Średnia ranga dla wartości współczynnika bieżącej płynności finansowej w latach 2004-2012

2.7. Średnia i środkowa wartość współczynnika przyspieszonej płynności finansowej spółek sektora TSL w latach 2004-2012 .

2.8. Średnia ranga dla wartości współczynnika przyspieszonej płynności finansowej w latach 2004-2012

2.9. Średnia i środkowa wartość współczynnika natychmiastowej płynności finansowej spółek sektora TSL w latach 2004-2012

2.10. Średnia i środkowa wartość współczynnika zdolności do obsługi zobowiązań bieżących gotówką osiąganą z działalności operacyjnej spółek sektora TSL w latach 2004-2012

2.11. Średnia i środkowa wartość współczynnika eksploatacyjnej rentowności sprzedaży spółek sektora TSL w latach 2004-2012

2.12. Średni ranga dla wartości współczynnika eksploatacyjnej rentowności sprzedaży w latach 2004-2012

2.13. Średnia i środkowa wartość współczynnika eksploatacyjnej rentowności aktywów ogółem spółek sektora TSL w latach 2004-2012

2.14. Średnia ranga dla wartości współczynnika eksploatacyjnej rentowności aktywów ogółem w latach 2004-2012

2.15. Średnia i środkowa wartość współczynnika eksploatacyjnej rentowności kapitału własnego spółek sektora TSL w latach 2004-2012

2.16. Średnia ranga dla wartości współczynnika eksploatacyjnej rentowności kapitału własnego w latach 2004-2012 
2.17. Średnia i środkowa wartość współczynnika wydajności pieniężnej (gotówkowej) sprzedaży spółek sektora TSL w latach 2004-2012

2.18. Średnia ranga dla wartości współczynnika wydajności pieniężnej (gotówkowej) sprzedaży w latach 2004-2012

2.19. Średnia i środkowa wartość współczynnika wydajności pieniężnej (gotówkowej) aktywów ogółem spółek sektora TSL w latach 2004-2012

2.20. Średnia ranga dla wartości współczynnika wydajności pieniężnej (gotówkowej) aktywów ogółem w latach 2004-2012

2.21. Średnia i środkowa wartość współczynnika wydajności pieniężnej (gotówkowej) kapitału własnego spółek sektora TSL w latach 2004-2012

2.22. Średnia ranga dla wartości współczynnika wydajności pieniężnej (gotówkowej) kapitału własnego w latach 2004-2012

2.23. Średnia i środkowa wartość współczynnika zabezpieczenia finansowego $\mathrm{nr} 1$ spółek sektora TSL w latach 2004-2012

2.24. Średnia i środkowa wartość współczynnika zabezpieczenia finansowego $\mathrm{nr} 2$ spółek sektora TSL w latach 2004-2012

2.25. Liczba spółek sektora TSL w latach 2004-2012 według ilości grup PKD 2007 ....

2.26. Średnia i środkowa liczba zidentyfikowanych grup PKD 2007 spółek sektora TSL..

2.27. Średnia ranga dla liczby grup PKD 2007 przedsiębiorstw sektora TSL w latach 2004-2012

2.28. Średnia i środkowa liczba zidentyfikowanych grup PKD 2007 w sekcji „Transport i gospodarka magazynowa" spółek sektora TSL

2.29. Tempo zmian (2012/2004) zakresu prowadzonej działalności spółek sektora TSL w sekcji „Transport i gospodarka magazynowa”

2.30. Liczba spółek sektora TSL według najczęściej wykazywanych grup PKD 2007 poza sekcją „Transport i gospodarka magazynowa”

3.1. Wskaźnik ogólnego klimatu koniunktury w sekcji „Transport i gospodarka magazynowa"

3.2. Średnie rangi dla poziomu spreadu współczynnika bieżącej płynności finansowej i współczynnika zdolności do obsługi zobowiązań bieżących gotówką osiąganą z działalności operacyjnej (porównania parami)

3.3. Średnie rangi dla poziomu spreadu współczynnika przyspieszonej płynności finansowej i współczynnika zdolności do obsługi zobowiązań bieżących gotówką osiąganą z działalności operacyjnej (porównania parami)

3.4. Średnie rangi dla poziomu spreadu współczynnika natychmiastowej płynności finansowej i współczynnika zdolności do obsługi zobowiązań bieżących gotówką osiąganą z działalności operacyjnej (porównania parami)

3.5. Średnia oraz środkowa wartość współczynników korelacji rang Spearmana między memoriałowymi i kasowymi miernikami oceny operacyjnego bezpieczeństwa finansowego przedsiębiorstw sektora TSL w latach 2004-2012 
3.6. Średnia oraz środkowa wartość istotnych statystycznie współczynników korelacji rang Spearmana między memoriałowymi i kasowymi miernikami oceny operacyjnego bezpieczeństwa finansowego przedsiębiorstw sektora TSL w latach 2004-2012

3.7. Średni i środkowy poziom korelacji rang Spearmana między memoriałowymi i kasowymi miernikami oceny operacyjnego bezpieczeństwa finansowego a liczbą grup PKD 2007 spółek sektora TSL w latach 2004-2012

3.8. Średni i środkowy poziom korelacji rang Spearmana między memoriałowymi i kasowymi miernikami oceny operacyjnego bezpieczeństwa finansowego a liczbą grup PKD 2007 w sekcji „Transport i gospodarka magazynowa” spółek sektora TSL w latach 2004-2012

4.1. Średnia i środkowa wartość syntetycznego miernika oceny operacyjnego bezpieczeństwa finansowego przedsiębiorstw sektora TSL w latach 2004-2012 .....

4.2. Struktura spółek sektora TSL w latach 2004-2012 według wartości syntetycznej miary oceny operacyjnego bezpieczeństwa finansowego przedsiębiorstw

4.3. Średnia ranga dla wartości syntetycznego miernika oceny operacyjnego bezpieczeństwa finansowego przedsiębiorstw sektora TSL w latach 2004-2012

4.4. Wartość syntetycznej miary oceny operacyjnego bezpieczeństwa finansowego przedsiębiorstw sektora TSL w latach 2004-2012 (analiza przestrzenno-dynamiczna)

4.5. Średnie wartości mierników oceny operacyjnego bezpieczeństwa finansowego spółki DHL Express (Poland) Sp. z o.o. oraz Zakładu Transportu Energetyki „ZTiSZE” Sp. z o.o. dla lat 2004-2012

4.6. Środkowe wartości mierników oceny operacyjnego bezpieczeństwa finansowego spółki DHL Express (Poland) Sp. z o.o. oraz Zakładu Transportu Energetyki „ZTiSZE” Sp. z o.o. dla lat 2004-2012

4.7. Średni poziom operacyjnego bezpieczeństwa finansowego spółek sektora TSL w latach 2004-2012 według głównego źródła przychodu

4.8. Środkowy poziom operacyjnego bezpieczeństwa finansowego spółek sektora TSL w latach 2004-2012 według głównego źródła przychodu

4.9. Wykres odległości wiązania względem etapów wiązania przedsiębiorstw

4.10. Średnia i środkowa wartość syntetycznego miernika oceny operacyjnego bezpieczeństwa finansowego dla jednorodnych grup podmiotów gospodarczych sektora TSL ....

4.11. Średni poziom operacyjnego bezpieczeństwa finansowego w poszczególnych latach poddanych analizie dla homogenicznych grup przedsiębiorstw sektora TSL...

4.12. Rozkład badanych spółek sektora TSL według liczby grup PKD 2007 (liczby grup PKD 2007 w sekcji „Transport i gospodarka magazynowa”) i wartości syntetycznego miernika oceny operacyjnego bezpieczeństwa finansowego w $2004 \mathrm{r}$.

4.13. Rozkład badanych spółek sektora TSL według liczby grup PKD 2007 (liczby grup PKD 2007 w sekcji „Transport i gospodarka magazynowa”) i wartości syntetycznego miernika oceny operacyjnego bezpieczeństwa finansowego w $2005 \mathrm{r}$. 
4.14. Rozkład badanych spółek sektora TSL według liczby grup PKD 2007 (liczby grup PKD 2007 w sekcji „Transport i gospodarka magazynowa) i wartości syntetycznego miernika oceny operacyjnego bezpieczeństwa finansowego w $2006 \mathrm{r}$.

4.15. Rozkład badanych spółek sektora TSL według liczby grup PKD 2007 (liczby grup PKD 2007 w sekcji „Transport i gospodarka magazynowa”) i wartości syntetycznego miernika oceny operacyjnego bezpieczeństwa finansowego w 2007 r.

4.16. Rozkład badanych spółek sektora TSL według liczby grup PKD 2007 (liczby grup PKD 2007 w sekcji „Transport i gospodarka magazynowa”) i wartości syntetycznego miernika oceny operacyjnego bezpieczeństwa finansowego w 2008 r.

4.17. Rozkład badanych spółek sektora TSL według liczby grup PKD 2007 (liczby grup PKD 2007 w sekcji „Transport i gospodarka magazynowa”) i wartości syntetycznego miernika oceny operacyjnego bezpieczeństwa finansowego w 2009 r.

4.18. Rozkład badanych spółek sektora TSL według liczby grup PKD 2007 (liczby grup PKD 2007 w sekcji „Transport i gospodarka magazynowa”) i wartości syntetycznego miernika oceny operacyjnego bezpieczeństwa finansowego w 2010 r.

4.19. Rozkład badanych spółek sektora TSL według liczby grup PKD 2007 (liczby grup PKD 2007 w sekcji „Transport i gospodarka magazynowa”) i wartości syntetycznego miernika oceny operacyjnego bezpieczeństwa finansowego w 2011 r.

4.20. Rozkład badanych spółek sektora TSL według liczby grup PKD 2007 (liczby grup PKD 2007 w sekcji „Transport i gospodarka magazynowa”) i wartości syntetycznego miernika oceny operacyjnego bezpieczeństwa finansowego w 2012 r.

5.1. Porównanie liczby upadłych spółek z sekcji „Transport i gospodarka magazynowa" w województwie mazowieckim z ich liczbą w Polsce w latach 2004-2010 ...

5.2. Średnia wartość mierników oceny operacyjnego zagrożenia finansowego w spółkach niezagrożonych upadłością i upadłych (rok przed upadłością)

5.3. Środkowa wartość mierników oceny operacyjnego zagrożenia finansowego w spółkach niezagrożonych upadłością i upadłych (rok przed upadłością)

5.4. Średnia wartość mierników oceny operacyjnego zagrożenia finansowego w spółkach niezagrożonych upadłością i upadłych (dwa lata przed upadłością) ....

5.5. Środkowa wartość mierników oceny operacyjnego zagrożenia finansowego w spółkach niezagrożonych upadłością i upadłych (dwa lata przed upadłością) ....

5.6. Średnia wartość mierników oceny operacyjnego zagrożenia finansowego w spółkach niezagrożonych upadłością i upadłych (trzy lata przed upadłością) .... 
5.7. Środkowa wartość mierników oceny operacyjnego zagrożenia finansowego w spółkach niezagrożonych upadłością i upadłych (trzy lata przed upadłością) ....

5.8. Środkowa wartość mierników oceny operacyjnego zagrożenia finansowego w upadłych spółkach sektora TSL

5.9. Ś Srodkowa wartość mierników oceny operacyjnego zagrożenia finansowego w spółkach sektora TSL niezagrożonych upadłością 


\section{SPIS SCHEMATÓW}

1.1. Przekształcenie formatu rachunku zysków i strat na potrzeby sprawozdawczości przepływów pieniężnych

2.1. Powiązanie analizy fundamentalnej $\mathrm{z}$ analizą portfelową

2.2. Struktura sekcji „Transport i gospodarka magazynowa”

4.1. Dendogram spółek sektora TSL według wartości syntetycznego miernika oceny operacyjnego bezpieczeństwa finansowego w latach 2004-2012 ....

5.1. Liczba upadłych spółek z sekcji „Transport i gospodarka magazynowa” w Polsce w latach 2004-2012 według województw

5.2. Liczba upadłych spółek z sekcji „Transport i gospodarka magazynowa” w Polsce w latach 2004-2010 według województw

5.3. Drzewo podziału przedsiębiorstw sektora TSL na upadłe/niezagrożone upadłością I (dane finansowe na rok przed upadłością)

5.4. Drzewo podziału przedsiębiorstw sektora TSL na upadłe/niezagrożone upadłością II (dane finansowe na rok przed upadłością)

5.5. Drzewo podziału przedsiębiorstw sektora TSL na upadłe/niezagrożone upadłością (dane finansowe na 2 lata przed upadłością)

5.6. Drzewo podziału przedsiębiorstw sektora TSL na upadłe/niezagrożone upadłością (dane finansowe na 3 lata przed upadłością) 


\section{ZAŁĄCZNIKI}


Załącznik 1

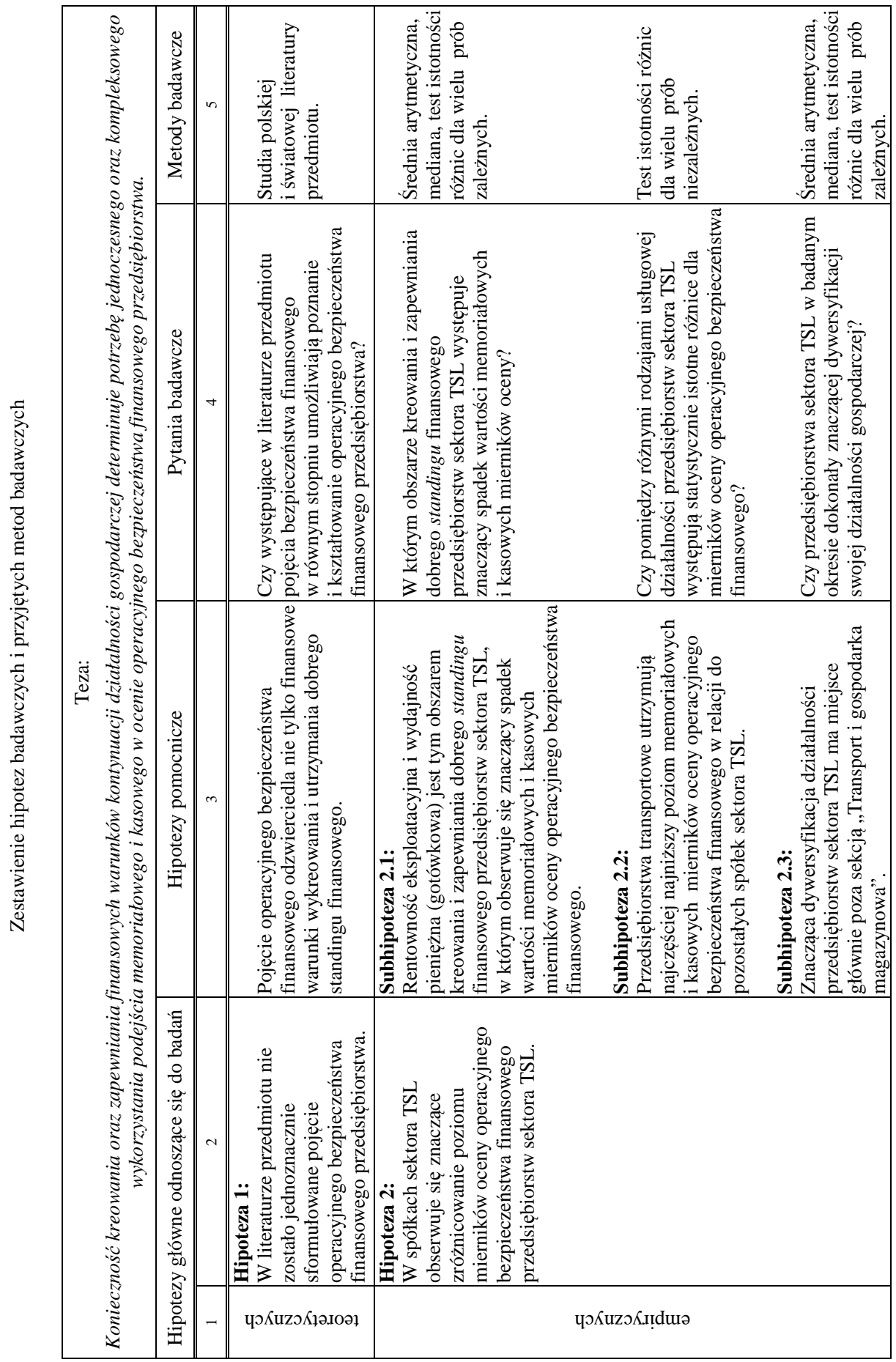




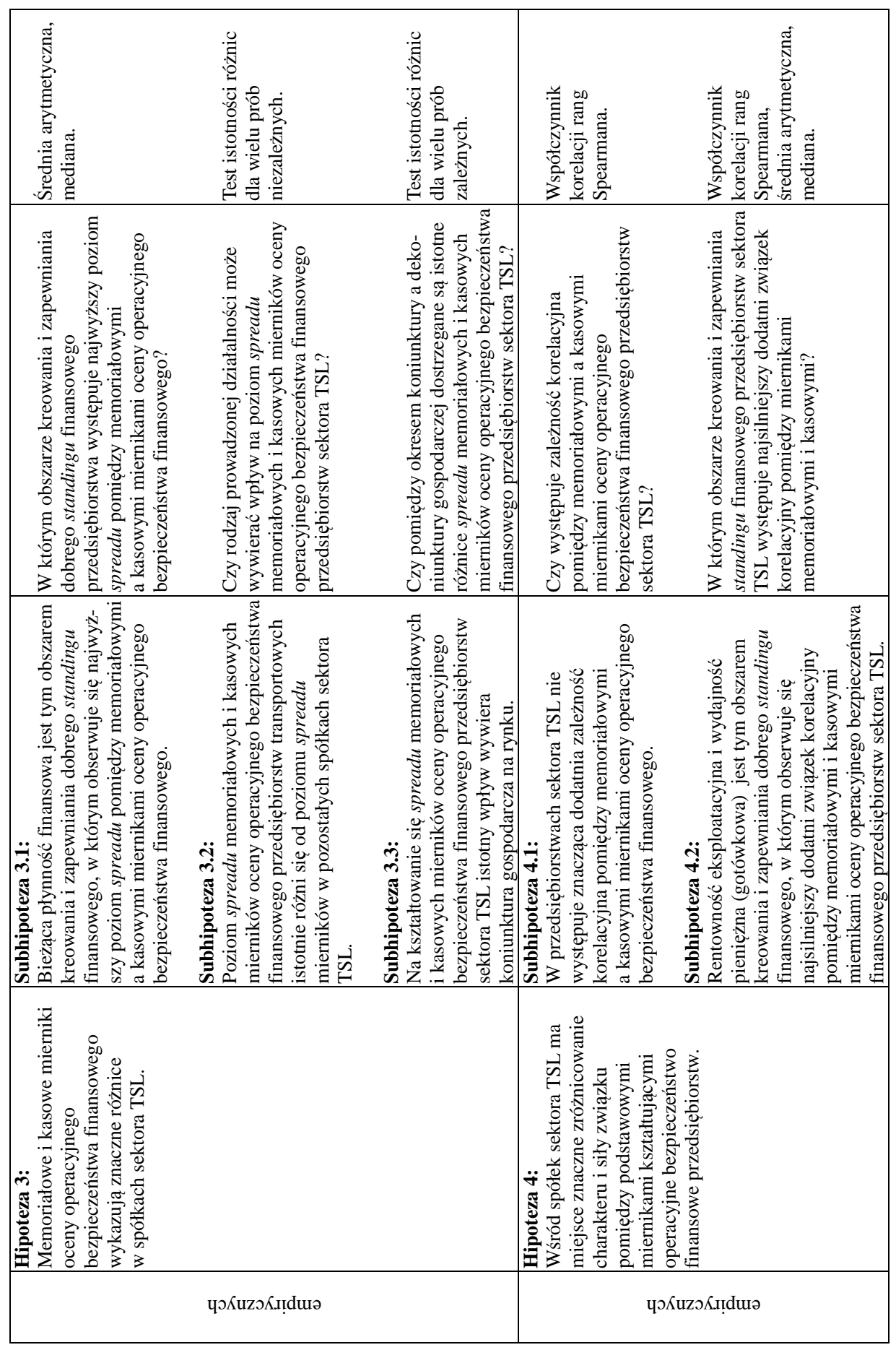




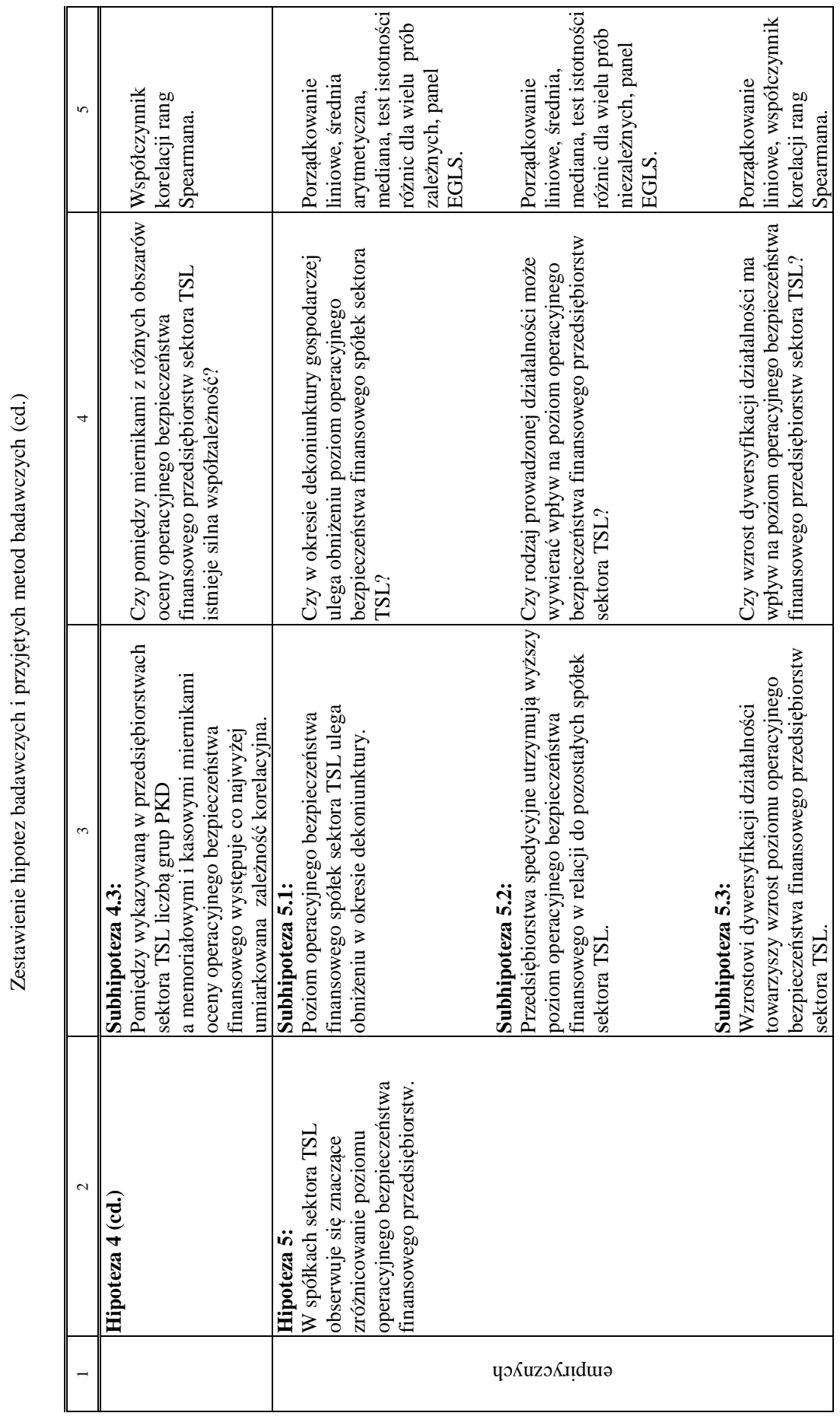




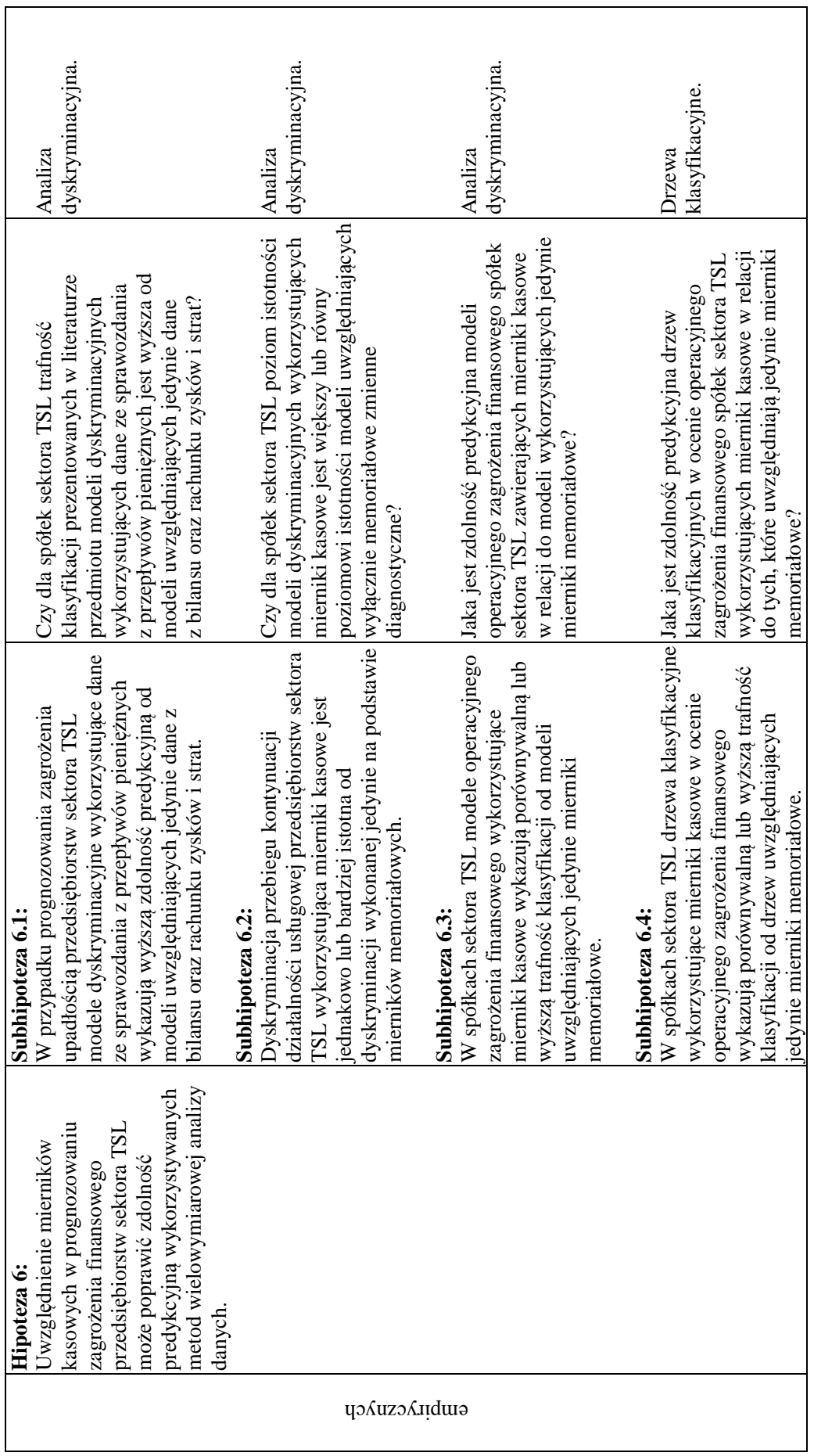




\section{Załącznik 2}

Spółki sektora TSL objęte badaniami empirycznymi ${ }^{\text {(a) }}$

\begin{tabular}{|c|c|c|c|c|}
\hline Lp. & Nazwa & $\begin{array}{c}\text { Data } \\
\text { rejestracji } \\
\text { w Krajowym } \\
\text { Rejestrze } \\
\text { Sądowym }\end{array}$ & Numer KRS & $\begin{array}{l}\text { Główne źródło } \\
\text { przychodów }^{(\mathrm{b})}\end{array}$ \\
\hline 1 & CAT Polska Sp. z o.o. & $2001-06-29$ & 24468 & logistyka \\
\hline 2 & $\begin{array}{l}\text { Neovia Logistics Services Polska } \\
\text { Sp. z o.o. }{ }^{(\mathrm{c})}\end{array}$ & $2001-08-08$ & 34755 & logistyka \\
\hline 3 & CHARTER Sp. z o.o. & $2001-03-22$ & 4003 & transport \\
\hline 4 & DARTOM Sp. z o.o. & $2006-01-09$ & 248708 & transport \\
\hline 5 & DHL Express (Poland) Sp. z o.o. & $2001-10-05$ & 47237 & usługi kurierskie \\
\hline 6 & DIREX Sp. z o.o. & $2001-04-06$ & 6230 & transport \\
\hline 7 & DPD Polska Sp. z o.o. & $2001-07-17$ & 28368 & usługi kurierskie \\
\hline 8 & DSV Road Sp. z o.o. & $2001-05-07$ & 10314 & spedycja \\
\hline 9 & DSV Solutions Sp. z o.o. & $2001-10-09$ & 50920 & logistyka \\
\hline 10 & Fiege Sp. z o.o. & $2002-01-10$ & 80289 & logistyka \\
\hline 11 & GEFCO Polska Sp. z o.o. & $2001-11-22$ & 64862 & logistyka \\
\hline 12 & Go-Trans GmbH Sp. z o.o. $^{(\mathrm{d})}$ & $2003-12-09$ & 181577 & transport \\
\hline 13 & $\begin{array}{l}\text { Hellmann Worldwide Logistics Polska } \\
\text { Sp. z o.o. Sp. Komandytowa }\end{array}$ & $\begin{array}{l}2001-05-25^{(\mathrm{e})} \\
2010-01-05\end{array}$ & $\begin{array}{l}14605^{(\mathrm{e})} \\
344496\end{array}$ & logistyka \\
\hline 14 & M\&M air sea cargo SA ${ }^{(f)}$ & $2002-07-19$ & 123691 & spedycja \\
\hline 15 & Mexem Sp. z o.o. & $2002-07-31$ & 124780 & logistyka \\
\hline 16 & Mostva Sp. z o.o. & $2001-08-10$ & 33437 & transport \\
\hline 17 & PEKAES SA & $2001-06-27$ & 22906 & transport \\
\hline 18 & Polfrost Internationale Spedition Sp. z o.o. & $2002-03-07$ & 97522 & spedycja \\
\hline 19 & Rhenus Logistics $\mathrm{SA}^{(\mathrm{g})}$ & $2001-12-15$ & 71960 & logistyka \\
\hline 20 & Schenker Sp. z o.o. & $2001-09-06$ & 40104 & logistyka \\
\hline 21 & Solid Logistics Sp. z o.o. & $2004-06-04$ & 209516 & spedycja \\
\hline 22 & TARGOR-TRUCK Sp. z o.o. & $2001-12-07$ & 68646 & transport \\
\hline 23 & TNT Express Worldwide (Poland) Sp. z o.o. & $2001-06-05$ & 17387 & usługi kurierskie \\
\hline 24 & TRANS-PETRO-COLOR Sp. z o.o. & $2003-01-17$ & 147805 & transport \\
\hline 25 & UPS Polska Sp. z o.o. & $2001-08-21$ & 36680 & usługi kurierskie \\
\hline 26 & VAN CARGO SA & $2003-09-26$ & 174345 & spedycja \\
\hline 27 & VOS Logistics Polska Sp. z o.o. & $2001-10-18$ & 54495 & transport \\
\hline 28 & $\begin{array}{l}\text { Zakład Transportu Energetyki „ZTiSZE” } \\
\text { Sp. z o.o. }\end{array}$ & $2002-02-01$ & 87332 & transport \\
\hline 29 & ZTE RADOM Sp. z o.o. & $2001-04-24$ & 9241 & transport \\
\hline
\end{tabular}

${ }^{\text {(a) }} \mathrm{W}$ przypadku zmiany nazwy danego podmiotu gospodarczego - użyto nazw przedsiębiorstw wykazanych w sprawozdaniu finansowym na dzień 31 grudnia $2012 \mathrm{r}$.

(b) Rozróżnienie głównego źródła osiąganych przychodów ma znaczenie w dokonywanym w niniejszym opracowaniu porównaniu.

(c) Caterpillar Logistics Services Polska Sp. z o.o. w ranking TOP 500 z 2010 r. (zmiana nazwy w sierpniu 2012 r.).

(d) Go-Trans Sp. z o.o. - w rankingu TOP 500 z $2010 \mathrm{r}$.

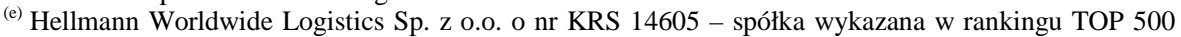
z 2010 r. (data uprawomocnienia wniosku o wykreślenie z rejestru: 2010-02-03).

(f) M\&M air cargo service Polska SA - w rankingu TOP 500 z 2010 r.

(g) Rhenus Contract Logistics SA - w rankingu TOP 500 z 2010 r.

Źródło: opracowanie własne na podstawie danych zebranych w Krajowym Rejestrze Sądowym w Warszawie i P. S z rete r, Lista obecności w branży transportowej, „Truck \& Business Polska” 2010, nr 3, s. 52-69. 


\section{Załącznik 3}

Wartości współczynników korelacji rang Spearmana między miernikami oceny operacyjnego bezpieczeństwa finansowego przedsiębiorstw sektora TSL w 2004 r.*

\begin{tabular}{|c|c|c|c|c|c|c|c|c|c|c|c|c|c|}
\hline Zmienne & $\mathrm{m}_{1}$ & $\mathrm{~m}_{2}$ & $\mathrm{~m}_{3}$ & $\mathrm{~m}_{4}$ & $\mathrm{~m}_{5}$ & $\mathrm{~m}_{6}$ & $\mathrm{~m}_{7}$ & $\mathrm{~m}_{8}$ & $\mathrm{~m}_{9}$ & $\mathrm{~m}_{10}$ & $\mathrm{~m}_{11}$ & $\mathrm{~m}_{12}$ & $\mathrm{~m}_{13}$ \\
\hline \hline $\mathrm{m}_{1}$ & 1,00 & 0,08 & 0,11 & 0,21 & $-0,12$ & 0,08 & $\mathbf{0 , 3 8}$ & 0,34 & $-0,14$ & 0,08 & 0,12 & 0,14 & 0,28 \\
\hline $\mathrm{m}_{2}$ & 0,08 & 1,00 & $\mathbf{0 , 9 9}$ & $\mathbf{0 , 7 9}$ & 0,08 & 0,20 & $\mathbf{0 , 3 8}$ & 0,06 & $-0,18$ & $-0,15$ & $\mathbf{- 0 , 5 7}$ & 0,13 & $-0,12$ \\
\hline $\mathrm{m}_{3}$ & 0,11 & $\mathbf{0 , 9 9}$ & 1,00 & $\mathbf{0 , 8 0}$ & 0,09 & 0,21 & $\mathbf{0 , 3 8}$ & 0,05 & $-0,17$ & $-0,14$ & $\mathbf{- 0 , 5 8}$ & 0,14 & $-0,11$ \\
\hline $\mathrm{m}_{4}$ & 0,21 & $\mathbf{0 , 7 9}$ & $\mathbf{0 , 8 0}$ & 1,00 & 0,32 & 0,19 & 0,23 & $-0,17$ & 0,10 & 0,10 & $-0,36$ & $\mathbf{0 , 4 4}$ & 0,18 \\
\hline $\mathrm{m}_{5}$ & $-0,12$ & 0,08 & 0,09 & 0,32 & 1,00 & $\mathbf{0 , 6 3}$ & 0,04 & $-0,36$ & $\mathbf{0 , 9 0}$ & $\mathbf{0 , 7 1}$ & 0,15 & 0,06 & $-0,14$ \\
\hline $\mathrm{m}_{6}$ & 0,08 & 0,20 & 0,21 & 0,19 & $\mathbf{0 , 6 3}$ & 1,00 & $\mathbf{0 , 5 0}$ & 0,22 & $\mathbf{0 , 6 4}$ & 0,36 & $-0,08$ & $-0,11$ & $-0,18$ \\
\hline $\mathrm{m}_{7}$ & $\mathbf{0 , 3 8}$ & $\mathbf{0 , 3 8}$ & $\mathbf{0 , 3 8}$ & 0,23 & 0,04 & $\mathbf{0 , 5 0}$ & 1,00 & $\mathbf{0 , 7 5}$ & $-0,08$ & 0,31 & $-0,03$ & $-0,35$ & $-0,08$ \\
\hline $\mathrm{m}_{8}$ & 0,34 & 0,06 & 0,05 & $-0,17$ & $-0,36$ & 0,22 & $\mathbf{0 , 7 5}$ & 1,00 & $-0,35$ & 0,00 & 0,25 & $\mathbf{- 0 , 4 3}$ & $-0,13$ \\
\hline $\mathrm{m}_{9}$ & $-0,14$ & $-0,18$ & $-0,17$ & 0,10 & $\mathbf{0 , 9 0}$ & $\mathbf{0 , 6 4}$ & $-0,08$ & $-0,35$ & 1,00 & $\mathbf{0 , 6 4}$ & 0,22 & 0,14 & $-0,13$ \\
\hline $\mathrm{m}_{10}$ & 0,08 & $-0,15$ & $-0,14$ & 0,10 & $\mathbf{0 , 7 1}$ & 0,36 & 0,31 & 0,00 & $\mathbf{0 , 6 4}$ & 1,00 & $\mathbf{0 , 5 2}$ & $-0,16$ & $-0,02$ \\
\hline $\mathrm{m}_{11}$ & 0,12 & $\mathbf{- 0 , 5 7}$ & $\mathbf{- 0 , 5 8}$ & $-0,36$ & 0,15 & $-0,08$ & $-0,03$ & 0,25 & 0,22 & $\mathbf{0 , 5 2}$ & 1,00 & $-0,21$ & 0,14 \\
\hline $\mathrm{m}_{12}$ & 0,14 & 0,13 & 0,14 & $\mathbf{0 , 4 4}$ & 0,06 & $-0,11$ & $-0,35$ & $\mathbf{- 0 , 4 3}$ & 0,14 & $-0,16$ & $-0,21$ & 1,00 & 0,34 \\
\hline $\mathrm{m}_{13}$ & 0,28 & $-0,12$ & $-0,11$ & 0,18 & $-0,14$ & $-0,18$ & $-0,08$ & $-0,13$ & $-0,13$ & $-0,02$ & 0,14 & 0,34 & 1,00 \\
\hline
\end{tabular}

* Pogrubioną czcionką oznaczone zostały wartości współczynników korelacji rang Spearmana istotne dla $\mathrm{p}<0,05$.

Źródło: obliczenia własne na podstawie danych zebranych w Krajowym Rejestrze Sądowym w Warszawie przy wykorzystaniu programu Statistica 10.

Wartości współczynników korelacji rang Spearmana między miernikami oceny operacyjnego bezpieczeństwa finansowego przedsiębiorstw sektora TSL w 2005 r.*

\begin{tabular}{|c|c|c|c|c|c|c|c|c|c|c|c|c|c|}
\hline Zmienne & $\mathrm{m}_{1}$ & $\mathrm{~m}_{2}$ & $\mathrm{~m}_{3}$ & $\mathrm{~m}_{4}$ & $\mathrm{~m}_{5}$ & $\mathrm{~m}_{6}$ & $\mathrm{~m}_{7}$ & $\mathrm{~m}_{8}$ & $\mathrm{~m}_{9}$ & $\mathrm{~m}_{10}$ & $\mathrm{~m}_{11}$ & $\mathrm{~m}_{12}$ & $\mathrm{~m}_{13}$ \\
\hline \hline $\mathrm{m}_{1}$ & 1,00 & $-0,17$ & $-0,12$ & $-0,13$ & $-0,30$ & 0,12 & 0,33 & 0,33 & $-0,29$ & 0,03 & 0,10 & 0,05 & 0,07 \\
\hline $\mathrm{m}_{2}$ & $-0,17$ & 1,00 & $\mathbf{0 , 9 8}$ & $\mathbf{0 , 6 6}$ & 0,29 & $\mathbf{0 , 5 6}$ & $\mathbf{0 , 4 2}$ & 0,24 & 0,02 & 0,16 & $-0,35$ & $\mathbf{0 , 4 1}$ & 0,00 \\
\hline $\mathrm{m}_{3}$ & $-0,12$ & $\mathbf{0 , 9 8}$ & 1,00 & $\mathbf{0 , 6 7}$ & 0,33 & $\mathbf{0 , 5 8}$ & $\mathbf{0 , 3 9}$ & 0,19 & 0,08 & 0,17 & $\mathbf{- 0 , 3 8}$ & $\mathbf{0 , 4 3}$ & $-0,04$ \\
\hline $\mathrm{m}_{4}$ & $-0,13$ & $\mathbf{0 , 6 6}$ & $\mathbf{0 , 6 7}$ & 1,00 & $\mathbf{0 , 6 0}$ & $\mathbf{0 , 4 9}$ & 0,28 & 0,03 & $\mathbf{0 , 4 4}$ & $\mathbf{0 , 5 2}$ & $-0,14$ & 0,36 & 0,07 \\
\hline $\mathrm{m}_{5}$ & $-0,30$ & 0,29 & 0,33 & $\mathbf{0 , 6 0}$ & 1,00 & $\mathbf{0 , 4 5}$ & 0,01 & $-0,18$ & $\mathbf{0 , 9 2}$ & $\mathbf{0 , 7 6}$ & 0,24 & $-0,01$ & $-0,16$ \\
\hline $\mathrm{m}_{6}$ & 0,12 & $\mathbf{0 , 5 6}$ & $\mathbf{0 , 5 8}$ & $\mathbf{0 , 4 9}$ & $\mathbf{0 , 4 5}$ & 1,00 & $\mathbf{0 , 7 7}$ & $\mathbf{0 , 6 2}$ & $\mathbf{0 , 3 8}$ & $\mathbf{0 , 5 1}$ & 0,12 & 0,10 & $-0,01$ \\
\hline $\mathrm{m}_{7}$ & 0,33 & $\mathbf{0 , 4 2}$ & $\mathbf{0 , 3 9}$ & 0,28 & 0,01 & $\mathbf{0 , 7 7}$ & 1,00 & $\mathbf{0 , 9 3}$ & $-0,12$ & 0,36 & 0,25 & $-0,09$ & 0,14 \\
\hline $\mathrm{m}_{8}$ & 0,33 & 0,24 & 0,19 & 0,03 & $-0,18$ & $\mathbf{0 , 6 2}$ & $\mathbf{0 , 9 3}$ & 1,00 & $-0,26$ & 0,20 & 0,32 & $-0,17$ & 0,15 \\
\hline $\mathrm{m}_{9}$ & $-0,29$ & 0,02 & 0,08 & $\mathbf{0 , 4 4}$ & $\mathbf{0 , 9 2}$ & $\mathbf{0 , 3 8}$ & $-0,12$ & $-0,26$ & 1,00 & $\mathbf{0 , 6 5}$ & 0,27 & $-0,05$ & $-0,18$ \\
\hline $\mathrm{m}_{10}$ & 0,03 & 0,16 & 0,17 & $\mathbf{0 , 5 2}$ & $\mathbf{0 , 7 6}$ & $\mathbf{0 , 5 1}$ & 0,36 & 0,20 & $\mathbf{0 , 6 5}$ & 1,00 & $\mathbf{0 , 5 8}$ & $-0,28$ & $-0,17$ \\
\hline $\mathrm{m}_{11}$ & 0,10 & $-0,35$ & $\mathbf{- 0 , 3 8}$ & $-0,14$ & 0,24 & 0,12 & 0,25 & 0,32 & 0,27 & $\mathbf{0 , 5 8}$ & 1,00 & $\mathbf{- 0 , 4 4}$ & $-0,25$ \\
\hline $\mathrm{m}_{12}$ & 0,05 & $\mathbf{0 , 4 1}$ & $\mathbf{0 , 4 3}$ & 0,36 & $-0,01$ & 0,10 & $-0,09$ & $-0,17$ & $-0,05$ & $-0,28$ & $\mathbf{- 0 , 4 4}$ & 1,00 & 0,12 \\
\hline $\mathrm{m}_{13}$ & 0,07 & 0,00 & $-0,04$ & 0,07 & $-0,16$ & $-0,01$ & 0,14 & 0,15 & $-0,18$ & $-0,17$ & $-0,25$ & 0,12 & 1,00 \\
\hline
\end{tabular}

* Oznaczenia jak wyżej.

Źródło: j.w. 
Wartości współczynników korelacji rang Spearmana między miernikami oceny operacyjnego bezpieczeństwa finansowego przedsiębiorstw sektora TSL w 2006 r.*

\begin{tabular}{|c|c|c|c|c|c|c|c|c|c|c|c|c|c|}
\hline Zmienne & $\mathrm{m}_{1}$ & $\mathrm{~m}_{2}$ & $\mathrm{~m}_{3}$ & $\mathrm{~m}_{4}$ & $\mathrm{~m}_{5}$ & $\mathrm{~m}_{6}$ & $\mathrm{~m}_{7}$ & $\mathrm{~m}_{8}$ & $\mathrm{~m}_{9}$ & $\mathrm{~m}_{10}$ & $\mathrm{~m}_{11}$ & $\mathrm{~m}_{12}$ & $\mathrm{~m}_{13}$ \\
\hline \hline $\mathrm{m}_{1}$ & 1,00 & $-0,24$ & $-0,20$ & $-0,08$ & $-0,12$ & 0,08 & 0,36 & 0,34 & $-0,03$ & 0,28 & $\mathbf{0 , 4 4}$ & $-0,04$ & 0,09 \\
\hline $\mathrm{m}_{2}$ & $-0,24$ & 1,00 & $\mathbf{0 , 9 9}$ & $\mathbf{0 , 7 9}$ & 0,29 & 0,32 & 0,29 & 0,13 & 0,18 & 0,20 & $-0,14$ & 0,36 & 0,05 \\
\hline $\mathrm{m}_{3}$ & $-0,20$ & $\mathbf{0 , 9 9}$ & 1,00 & $\mathbf{0 , 7 8}$ & 0,25 & 0,35 & 0,31 & 0,14 & 0,15 & 0,17 & $-0,16$ & 0,35 & 0,03 \\
\hline $\mathrm{m}_{4}$ & $-0,08$ & $\mathbf{0 , 7 9}$ & $\mathbf{0 , 7 8}$ & 1,00 & $\mathbf{0 , 4 8}$ & $\mathbf{0 , 3 7}$ & 0,19 & $-0,08$ & $\mathbf{0 , 4 2}$ & $\mathbf{0 , 3 8}$ & $-0,14$ & 0,32 & 0,11 \\
\hline $\mathrm{m}_{5}$ & $-0,12$ & 0,29 & 0,25 & $\mathbf{0 , 4 8}$ & 1,00 & $\mathbf{0 , 6 0}$ & 0,30 & 0,10 & $\mathbf{0 , 9 6}$ & $\mathbf{0 , 7 8}$ & $\mathbf{0 , 4 0}$ & $-0,25$ & $-0,17$ \\
\hline $\mathrm{m}_{6}$ & 0,08 & 0,32 & 0,35 & $\mathbf{0 , 3 7}$ & $\mathbf{0 , 6 0}$ & 1,00 & $\mathbf{0 , 8 3}$ & $\mathbf{0 , 6 3}$ & $\mathbf{0 , 5 9}$ & $\mathbf{0 , 5 8}$ & 0,22 & $-0,09$ & 0,11 \\
\hline $\mathrm{m}_{7}$ & 0,36 & 0,29 & 0,31 & 0,19 & 0,30 & $\mathbf{0 , 8 3}$ & 1,00 & $\mathbf{0 , 9 0}$ & 0,27 & $\mathbf{0 , 5 5}$ & 0,33 & $-0,01$ & 0,22 \\
\hline $\mathrm{m}_{8}$ & 0,34 & 0,13 & 0,14 & $-0,08$ & 0,10 & $\mathbf{0 , 6 3}$ & $\mathbf{0 , 9 0}$ & 1,00 & 0,08 & $\mathbf{0 , 4 0}$ & $\mathbf{0 , 4 3}$ & $-0,03$ & 0,22 \\
\hline $\mathrm{m}_{9}$ & $-0,03$ & 0,18 & 0,15 & $\mathbf{0 , 4 2}$ & $\mathbf{0 , 9 6}$ & $\mathbf{0 , 5 9}$ & 0,27 & 0,08 & 1,00 & $\mathbf{0 , 7 7}$ & $\mathbf{0 , 4 6}$ & $-0,22$ & $-0,18$ \\
\hline $\mathrm{m}_{10}$ & 0,28 & 0,20 & 0,17 & $\mathbf{0 , 3 8}$ & $\mathbf{0 , 7 8}$ & $\mathbf{0 , 5 8}$ & $\mathbf{0 , 5 5}$ & $\mathbf{0 , 4 0}$ & $\mathbf{0 , 7 7}$ & 1,00 & $\mathbf{0 , 6 8}$ & $-0,17$ & $-0,10$ \\
\hline $\mathrm{m}_{11}$ & $\mathbf{0 , 4 4}$ & $-0,14$ & $-0,16$ & $-0,14$ & $\mathbf{0 , 4 0}$ & 0,22 & 0,33 & $\mathbf{0 , 4 3}$ & $\mathbf{0 , 4 6}$ & $\mathbf{0 , 6 8}$ & 1,00 & $-0,36$ & $-0,17$ \\
\hline $\mathrm{m}_{12}$ & $-0,04$ & 0,36 & 0,35 & 0,32 & $-0,25$ & $-0,09$ & $-0,01$ & $-0,03$ & $-0,22$ & $-0,17$ & $-0,36$ & 1,00 & $\mathbf{0 , 4 2}$ \\
\hline $\mathrm{m}_{13}$ & 0,09 & 0,05 & 0,03 & 0,11 & $-0,17$ & 0,11 & 0,22 & 0,22 & $-0,18$ & $-0,10$ & $-0,17$ & $\mathbf{0 , 4 2}$ & 1,00 \\
\hline
\end{tabular}

* Oznaczenia jak wyżej.

Źródło: j.w.

Wartości współczynników korelacji rang Spearmana między miernikami oceny operacyjnego bezpieczeństwa finansowego przedsiębiorstw sektora TSL w 2007 r.*

\begin{tabular}{|c|c|c|c|c|c|c|c|c|c|c|c|c|c|}
\hline Zmienne & $\mathrm{m}_{1}$ & $\mathrm{~m}_{2}$ & $\mathrm{~m}_{3}$ & $\mathrm{~m}_{4}$ & $\mathrm{~m}_{5}$ & $\mathrm{~m}_{6}$ & $\mathrm{~m}_{7}$ & $\mathrm{~m}_{8}$ & $\mathrm{~m}_{9}$ & $\mathrm{~m}_{10}$ & $\mathrm{~m}_{11}$ & $\mathrm{~m}_{12}$ & $\mathrm{~m}_{13}$ \\
\hline \hline $\mathrm{m}_{1}$ & 1,00 & 0,03 & 0,09 & $-0,15$ & $-0,30$ & 0,05 & $\mathbf{0 , 4 1}$ & 0,31 & $-0,30$ & $-0,16$ & $-0,12$ & 0,17 & $-0,02$ \\
\hline $\mathrm{m}_{2}$ & 0,03 & 1,00 & $\mathbf{0 , 9 8}$ & $\mathbf{0 , 6 7}$ & $-0,08$ & $\mathbf{0 , 4 8}$ & 0,33 & 0,14 & $-0,16$ & $-0,10$ & $\mathbf{- 0 , 3 8}$ & 0,28 & 0,28 \\
\hline $\mathrm{m}_{3}$ & 0,09 & $\mathbf{0 , 9 8}$ & 1,00 & $\mathbf{0 , 6 8}$ & $-0,05$ & $\mathbf{0 , 4 8}$ & 0,36 & 0,17 & $-0,14$ & $-0,07$ & $-0,35$ & 0,23 & 0,20 \\
\hline $\mathrm{m}_{4}$ & $-0,15$ & $\mathbf{0 , 6 7}$ & $\mathbf{0 , 6 8}$ & 1,00 & 0,12 & $\mathbf{0 , 4 2}$ & 0,20 & 0,03 & 0,06 & 0,05 & $-0,19$ & 0,09 & $-0,05$ \\
\hline $\mathrm{m}_{5}$ & $-0,30$ & $-0,08$ & $-0,05$ & 0,12 & 1,00 & 0,33 & 0,04 & 0,01 & $\mathbf{0 , 9 7}$ & $\mathbf{0 , 9 3}$ & $\mathbf{0 , 7 7}$ & $\mathbf{- 0 , 5 6}$ & $\mathbf{- 0 , 3 9}$ \\
\hline $\mathrm{m}_{6}$ & 0,05 & $\mathbf{0 , 4 8}$ & $\mathbf{0 , 4 8}$ & $\mathbf{0 , 4 2}$ & 0,33 & 1,00 & $\mathbf{0 , 7 8}$ & $\mathbf{0 , 6 4}$ & 0,29 & 0,34 & 0,09 & $-0,20$ & 0,08 \\
\hline $\mathrm{m}_{7}$ & $\mathbf{0 , 4 1}$ & 0,33 & 0,36 & 0,20 & 0,04 & $\mathbf{0 , 7 8}$ & 1,00 & $\mathbf{0 , 9 1}$ & $-0,02$ & 0,20 & 0,04 & $-0,10$ & 0,15 \\
\hline $\mathrm{m}_{8}$ & 0,31 & 0,14 & 0,17 & 0,03 & 0,01 & $\mathbf{0 , 6 4}$ & $\mathbf{0 , 9 1}$ & 1,00 & $-0,05$ & 0,16 & 0,18 & $-0,16$ & 0,09 \\
\hline $\mathrm{m}_{9}$ & $-0,30$ & $-0,16$ & $-0,14$ & 0,06 & $\mathbf{0 , 9 7}$ & 0,29 & $-0,02$ & $-0,05$ & 1,00 & $\mathbf{0 , 8 9}$ & $\mathbf{0 , 7 6}$ & $\mathbf{- 0 , 5 5}$ & $\mathbf{- 0 , 4 3}$ \\
\hline $\mathrm{m}_{10}$ & $-0,16$ & $-0,10$ & $-0,07$ & 0,05 & $\mathbf{0 , 9 3}$ & 0,34 & 0,20 & 0,16 & $\mathbf{0 , 8 9}$ & 1,00 & $\mathbf{0 , 8 4}$ & $\mathbf{- 0 , 5 7}$ & $-0,34$ \\
\hline $\mathrm{m}_{11}$ & $-0,12$ & $-\mathbf{0 , 3 8}$ & $-0,35$ & $-0,19$ & $\mathbf{0 , 7 7}$ & 0,09 & 0,04 & 0,18 & $\mathbf{0 , 7 6}$ & $\mathbf{0 , 8 4}$ & 1,00 & $\mathbf{- 0 , 5 6}$ & $\mathbf{- 0 , 4 6}$ \\
\hline $\mathrm{m}_{12}$ & 0,17 & 0,28 & 0,23 & 0,09 & $\mathbf{- 0 , 5 6}$ & $-0,20$ & $-0,10$ & $-0,16$ & $\mathbf{- 0 , 5 5}$ & $\mathbf{- 0 , 5 7}$ & $-\mathbf{0 , 5 6}$ & 1,00 & 0,29 \\
\hline $\mathrm{m}_{13}$ & $-0,02$ & 0,28 & 0,20 & $-0,05$ & $\mathbf{- 0 , 3 9}$ & 0,08 & 0,15 & 0,09 & $\mathbf{- 0 , 4 3}$ & $-0,34$ & $\mathbf{- 0 , 4 6}$ & 0,29 & 1,00 \\
\hline
\end{tabular}

* Oznaczenia jak wyżej.

Źródło: j.w. 
Wartości współczynników korelacji rang Spearmana między miernikami oceny operacyjnego bezpieczeństwa finansowego przedsiębiorstw sektora TSL w 2008 r.*

\begin{tabular}{|c|c|c|c|c|c|c|c|c|c|c|c|c|c|}
\hline Zmienne & $\mathrm{m}_{1}$ & $\mathrm{~m}_{2}$ & $\mathrm{~m}_{3}$ & $\mathrm{~m}_{4}$ & $\mathrm{~m}_{5}$ & $\mathrm{~m}_{6}$ & $\mathrm{~m}_{7}$ & $\mathrm{~m}_{8}$ & $\mathrm{~m}_{9}$ & $\mathrm{~m}_{10}$ & $\mathrm{~m}_{11}$ & $\mathrm{~m}_{12}$ & $\mathrm{~m}_{13}$ \\
\hline \hline $\mathrm{m}_{1}$ & 1,00 & 0,05 & 0,06 & 0,05 & $-0,08$ & 0,36 & $\mathbf{0 , 5 2}$ & $\mathbf{0 , 4 6}$ & $-0,20$ & 0,20 & 0,10 & 0,03 & $-0,08$ \\
\hline $\mathrm{m}_{2}$ & 0,05 & 1,00 & $\mathbf{0 , 9 9}$ & $\mathbf{0 , 7 6}$ & $\mathbf{0 , 4 1}$ & 0,27 & 0,27 & 0,22 & 0,23 & 0,16 & $-0,10$ & 0,21 & 0,19 \\
\hline $\mathrm{m}_{3}$ & 0,06 & $\mathbf{0 , 9 9}$ & 1,00 & $\mathbf{0 , 7 5}$ & $\mathbf{0 , 4 2}$ & 0,27 & 0,28 & 0,22 & 0,23 & 0,18 & $-0,08$ & 0,17 & 0,14 \\
\hline $\mathrm{m}_{4}$ & 0,05 & $\mathbf{0 , 7 6}$ & $\mathbf{0 , 7 5}$ & 1,00 & $\mathbf{0 , 4 1}$ & 0,23 & 0,18 & 0,08 & $\mathbf{0 , 3 8}$ & 0,32 & 0,10 & 0,26 & 0,14 \\
\hline $\mathrm{m}_{5}$ & $-0,08$ & $\mathbf{0 , 4 1}$ & $\mathbf{0 , 4 2}$ & $\mathbf{0 , 4 1}$ & 1,00 & $\mathbf{0 , 3 9}$ & 0,26 & 0,10 & $\mathbf{0 , 8 7}$ & $\mathbf{0 , 7 8}$ & $\mathbf{0 , 5 9}$ & $-0,16$ & 0,22 \\
\hline $\mathrm{m}_{6}$ & 0,36 & 0,27 & 0,27 & 0,23 & $\mathbf{0 , 3 9}$ & 1,00 & $\mathbf{0 , 9 1}$ & $\mathbf{0 , 8 0}$ & 0,34 & $\mathbf{0 , 4 0}$ & 0,23 & $-0,20$ & 0,05 \\
\hline $\mathrm{m}_{7}$ & $\mathbf{0 , 5 2}$ & 0,27 & 0,28 & 0,18 & 0,26 & $\mathbf{0 , 9 1}$ & 1,00 & $\mathbf{0 , 9 5}$ & 0,14 & $\mathbf{0 , 4 3}$ & 0,32 & $-0,10$ & 0,12 \\
\hline $\mathrm{m}_{8}$ & $\mathbf{0 , 4 6}$ & 0,22 & 0,22 & 0,08 & 0,10 & $\mathbf{0 , 8 0}$ & $\mathbf{0 , 9 5}$ & 1,00 & 0,01 & 0,35 & 0,29 & $-0,06$ & 0,18 \\
\hline $\mathrm{m}_{9}$ & $-0,20$ & 0,23 & 0,23 & $\mathbf{0 , 3 8}$ & $\mathbf{0 , 8 7}$ & 0,34 & 0,14 & 0,01 & 1,00 & $\mathbf{0 , 7 4}$ & $\mathbf{0 , 6 0}$ & $-0,16$ & 0,29 \\
\hline $\mathrm{m}_{10}$ & 0,20 & 0,16 & 0,18 & 0,32 & $\mathbf{0 , 7 8}$ & $\mathbf{0 , 4 0}$ & $\mathbf{0 , 4 3}$ & 0,35 & $\mathbf{0 , 7 4}$ & 1,00 & $\mathbf{0 , 8 7}$ & $-0,12$ & $\mathbf{0 , 4 1}$ \\
\hline $\mathrm{m}_{11}$ & 0,10 & $-0,10$ & $-0,08$ & 0,10 & $\mathbf{0 , 5 9}$ & 0,23 & 0,32 & 0,29 & $\mathbf{0 , 6 0}$ & $\mathbf{0 , 8 7}$ & 1,00 & $-0,10$ & $\mathbf{0 , 4 0}$ \\
\hline $\mathrm{m}_{12}$ & 0,03 & 0,21 & 0,17 & 0,26 & $-0,16$ & $-0,20$ & $-0,10$ & $-0,06$ & $-0,16$ & $-0,12$ & $-0,10$ & 1,00 & 0,27 \\
\hline $\mathrm{m}_{13}$ & $-0,08$ & 0,19 & 0,14 & 0,14 & 0,22 & 0,05 & 0,12 & 0,18 & 0,29 & $\mathbf{0 , 4 1}$ & $\mathbf{0 , 4 0}$ & 0,27 & 1,00 \\
\hline
\end{tabular}

* Oznaczenia jak wyżej.

Źródło: j.w.

Wartości współczynników korelacji rang Spearmana między miernikami oceny operacyjnego bezpieczeństwa finansowego przedsiębiorstw sektora TSL w 2009 r.*

\begin{tabular}{|c|c|c|c|c|c|c|c|c|c|c|c|c|c|}
\hline Zmienne & $\mathrm{m}_{1}$ & $\mathrm{~m}_{2}$ & $\mathrm{~m}_{3}$ & $\mathrm{~m}_{4}$ & $\mathrm{~m}_{5}$ & $\mathrm{~m}_{6}$ & $\mathrm{~m}_{7}$ & $\mathrm{~m}_{8}$ & $\mathrm{~m}_{9}$ & $\mathrm{~m}_{10}$ & $\mathrm{~m}_{11}$ & $\mathrm{~m}_{12}$ & $\mathrm{~m}_{13}$ \\
\hline \hline $\mathrm{m}_{1}$ & 1,00 & 0,05 & 0,09 & $-0,10$ & 0,02 & $\mathbf{0 , 4 4}$ & $\mathbf{0 , 6 4}$ & $\mathbf{0 , 6 1}$ & $-0,14$ & 0,24 & 0,16 & 0,26 & 0,15 \\
\hline $\mathrm{m}_{2}$ & 0,05 & 1,00 & $\mathbf{0 , 9 9}$ & $\mathbf{0 , 6 3}$ & 0,36 & 0,23 & 0,27 & 0,12 & 0,13 & 0,07 & $-0,25$ & 0,10 & 0,09 \\
\hline $\mathrm{m}_{3}$ & 0,09 & $\mathbf{0 , 9 9}$ & 1,00 & $\mathbf{0 , 6 0}$ & 0,35 & 0,25 & 0,30 & 0,16 & 0,12 & 0,08 & $-0,25$ & 0,14 & 0,05 \\
\hline $\mathrm{m}_{4}$ & $-0,10$ & $\mathbf{0 , 6 3}$ & $\mathbf{0 , 6 0}$ & 1,00 & $\mathbf{0 , 3 8}$ & 0,07 & 0,01 & $-0,03$ & 0,29 & 0,17 & 0,03 & 0,19 & $-0,07$ \\
\hline $\mathrm{m}_{5}$ & 0,02 & 0,36 & 0,35 & $\mathbf{0 , 3 8}$ & 1,00 & $\mathbf{0 , 4 9}$ & 0,33 & 0,19 & $\mathbf{0 , 9 2}$ & $\mathbf{0 , 7 5}$ & 0,35 & 0,07 & $-0,05$ \\
\hline $\mathrm{m}_{6}$ & $\mathbf{0 , 4 4}$ & 0,23 & 0,25 & 0,07 & $\mathbf{0 , 4 9}$ & 1,00 & $\mathbf{0 , 9 3}$ & $\mathbf{0 , 8 7}$ & 0,36 & $\mathbf{0 , 4 4}$ & 0,22 & 0,00 & 0,07 \\
\hline $\mathrm{m}_{7}$ & $\mathbf{0 , 6 4}$ & 0,27 & 0,30 & 0,01 & 0,33 & $\mathbf{0 , 9 3}$ & 1,00 & $\mathbf{0 , 9 4}$ & 0,17 & $\mathbf{0 , 3 8}$ & 0,20 & 0,10 & 0,21 \\
\hline $\mathrm{m}_{8}$ & $\mathbf{0 , 6 1}$ & 0,12 & 0,16 & $-0,03$ & 0,19 & $\mathbf{0 , 8 7}$ & $\mathbf{0 , 9 4}$ & 1,00 & 0,10 & 0,29 & 0,36 & 0,04 & 0,16 \\
\hline $\mathrm{m}_{9}$ & $-0,14$ & 0,13 & 0,12 & 0,29 & $\mathbf{0 , 9 2}$ & 0,36 & 0,17 & 0,10 & 1,00 & $\mathbf{0 , 7 6}$ & $\mathbf{0 , 4 9}$ & 0,13 & $-0,07$ \\
\hline $\mathrm{m}_{10}$ & 0,24 & 0,07 & 0,08 & 0,17 & $\mathbf{0 , 7 5}$ & $\mathbf{0 , 4 4}$ & $\mathbf{0 , 3 8}$ & 0,29 & $\mathbf{0 , 7 6}$ & 1,00 & $\mathbf{0 , 6 6}$ & 0,32 & 0,03 \\
\hline $\mathrm{m}_{11}$ & 0,16 & $-0,25$ & $-0,25$ & 0,03 & 0,35 & 0,22 & 0,20 & 0,36 & $\mathbf{0 , 4 9}$ & $\mathbf{0 , 6 6}$ & 1,00 & 0,12 & $-0,06$ \\
\hline $\mathrm{m}_{12}$ & 0,26 & 0,10 & 0,14 & 0,19 & 0,07 & 0,00 & 0,10 & 0,04 & 0,13 & 0,32 & 0,12 & 1,00 & 0,32 \\
\hline $\mathrm{m}_{13}$ & 0,15 & 0,09 & 0,05 & $-0,07$ & $-0,05$ & 0,07 & 0,21 & 0,16 & $-0,07$ & 0,03 & $-0,06$ & 0,32 & 1,00 \\
\hline
\end{tabular}

* Oznaczenia jak wyżej.

Źródło: j.w. 
Wartości współczynników korelacji rang Spearmana między miernikami oceny operacyjnego bezpieczeństwa finansowego przedsiębiorstw sektora TSL w 2010 r.*

\begin{tabular}{|c|c|c|c|c|c|c|c|c|c|c|c|c|c|}
\hline Zmienne & $\mathrm{m}_{1}$ & $\mathrm{~m}_{2}$ & $\mathrm{~m}_{3}$ & $\mathrm{~m}_{4}$ & $\mathrm{~m}_{5}$ & $\mathrm{~m}_{6}$ & $\mathrm{~m}_{7}$ & $\mathrm{~m}_{8}$ & $\mathrm{~m}_{9}$ & $\mathrm{~m}_{10}$ & $\mathrm{~m}_{11}$ & $\mathrm{~m}_{12}$ & $\mathrm{~m}_{13}$ \\
\hline \hline $\mathrm{m}_{1}$ & 1,00 & 0,14 & 0,15 & 0,08 & 0,20 & $\mathbf{0 , 5 1}$ & $\mathbf{0 , 6 2}$ & $\mathbf{0 , 6 0}$ & 0,11 & $\mathbf{0 , 4 0}$ & $\mathbf{0 , 4 0}$ & 0,32 & 0,25 \\
\hline $\mathrm{m}_{2}$ & 0,14 & 1,00 & $\mathbf{0 , 9 8}$ & $\mathbf{0 , 7 2}$ & 0,12 & 0,06 & 0,08 & $-0,06$ & 0,00 & $-0,03$ & $-0,15$ & 0,18 & 0,00 \\
\hline $\mathrm{m}_{3}$ & 0,15 & $\mathbf{0 , 9 8}$ & 1,00 & $\mathbf{0 , 7 0}$ & 0,10 & 0,09 & 0,12 & 0,00 & $-0,02$ & $-0,04$ & $-0,16$ & 0,19 & $-0,06$ \\
\hline $\mathrm{m}_{4}$ & 0,08 & $\mathbf{0 , 7 2}$ & $\mathbf{0 , 7 0}$ & 1,00 & 0,29 & 0,01 & $-0,02$ & $-0,12$ & 0,21 & 0,11 & 0,04 & 0,24 & 0,07 \\
\hline $\mathrm{m}_{5}$ & 0,20 & 0,12 & 0,10 & 0,29 & 1,00 & $\mathbf{0 , 4 7}$ & 0,34 & 0,18 & $\mathbf{0 , 9 7}$ & $\mathbf{0 , 8 8}$ & $\mathbf{0 , 7 2}$ & $-0,06$ & $-0,12$ \\
\hline $\mathrm{m}_{6}$ & $\mathbf{0 , 5 1}$ & 0,06 & 0,09 & 0,01 & $\mathbf{0 , 4 7}$ & 1,00 & $\mathbf{0 , 9 1}$ & $\mathbf{0 , 7 9}$ & $\mathbf{0 , 4 4}$ & $\mathbf{0 , 5 4}$ & $\mathbf{0 , 3 9}$ & 0,09 & $-0,05$ \\
\hline $\mathrm{m}_{7}$ & $\mathbf{0 , 6 2}$ & 0,08 & 0,12 & $-0,02$ & 0,34 & $\mathbf{0 , 9 1}$ & 1,00 & $\mathbf{0 , 9 1}$ & 0,26 & $\mathbf{0 , 5 1}$ & $\mathbf{0 , 4 4}$ & 0,06 & $-0,05$ \\
\hline $\mathrm{m}_{8}$ & $\mathbf{0 , 6 0}$ & $-0,06$ & 0,00 & $-0,12$ & 0,18 & $\mathbf{0 , 7 9}$ & $\mathbf{0 , 9 1}$ & 1,00 & 0,11 & $\mathbf{0 , 3 7}$ & $\mathbf{0 , 4 5}$ & 0,12 & 0,03 \\
\hline $\mathrm{m}_{9}$ & 0,11 & 0,00 & $-0,02$ & 0,21 & $\mathbf{0 , 9 7}$ & $\mathbf{0 , 4 4}$ & 0,26 & 0,11 & 1,00 & $\mathbf{0 , 8 6}$ & $\mathbf{0 , 7 0}$ & $-0,09$ & $-0,10$ \\
\hline $\mathrm{m}_{10}$ & $\mathbf{0 , 4 0}$ & $-0,03$ & $-0,04$ & 0,11 & $\mathbf{0 , 8 8}$ & $\mathbf{0 , 5 4}$ & $\mathbf{0 , 5 1}$ & $\mathbf{0 , 3 7}$ & $\mathbf{0 , 8 6}$ & 1,00 & $\mathbf{0 , 9 0}$ & $-0,08$ & 0,01 \\
\hline $\mathrm{m}_{11}$ & $\mathbf{0 , 4 0}$ & $-0,15$ & $-0,16$ & 0,04 & $\mathbf{0 , 7 2}$ & $\mathbf{0 , 3 9}$ & $\mathbf{0 , 4 4}$ & $\mathbf{0 , 4 5}$ & $\mathbf{0 , 7 0}$ & $\mathbf{0 , 9 0}$ & 1,00 & $-0,08$ & 0,13 \\
\hline $\mathrm{m}_{12}$ & 0,32 & 0,18 & 0,19 & 0,24 & $-0,06$ & 0,09 & 0,06 & 0,12 & $-0,09$ & $-0,08$ & $-0,08$ & 1,00 & 0,31 \\
\hline $\mathrm{m}_{13}$ & 0,25 & 0,00 & $-0,06$ & 0,07 & $-0,12$ & $-0,05$ & $-0,05$ & 0,03 & $-0,10$ & 0,01 & 0,13 & 0,31 & 1,00 \\
\hline
\end{tabular}

* Oznaczenia jak wyżej.

Źródło: j.w.

Wartości współczynników korelacji rang Spearmana między miernikami oceny operacyjnego bezpieczeństwa finansowego przedsiębiorstw sektora TSL w 2011 r.*

\begin{tabular}{|c|c|c|c|c|c|c|c|c|c|c|c|c|c|}
\hline Zmienne & $\mathrm{m}_{1}$ & $\mathrm{~m}_{2}$ & $\mathrm{~m}_{3}$ & $\mathrm{~m}_{4}$ & $\mathrm{~m}_{5}$ & $\mathrm{~m}_{6}$ & $\mathrm{~m}_{7}$ & $\mathrm{~m}_{8}$ & $\mathrm{~m}_{9}$ & $\mathrm{~m}_{10}$ & $\mathrm{~m}_{11}$ & $\mathrm{~m}_{12}$ & $\mathrm{~m}_{13}$ \\
\hline \hline $\mathrm{m}_{1}$ & 1,00 & 0,14 & 0,19 & 0,02 & 0,17 & $\mathbf{0 , 7 0}$ & $\mathbf{0 , 7 3}$ & $\mathbf{0 , 6 6}$ & $-0,03$ & $\mathbf{0 , 5 1}$ & $\mathbf{0 , 4 7}$ & 0,29 & 0,33 \\
\hline $\mathrm{m}_{2}$ & 0,14 & 1,00 & $\mathbf{0 , 9 9}$ & $\mathbf{0 , 4 8}$ & $\mathbf{0 , 4 1}$ & 0,15 & 0,23 & 0,16 & 0,24 & 0,04 & $-0,17$ & 0,31 & 0,06 \\
\hline $\mathrm{m}_{3}$ & 0,19 & $\mathbf{0 , 9 9}$ & 1,00 & $\mathbf{0 , 5 2}$ & $\mathbf{0 , 4 2}$ & 0,20 & 0,27 & 0,21 & 0,26 & 0,07 & $-0,15$ & 0,31 & 0,04 \\
\hline $\mathrm{m}_{4}$ & 0,02 & $\mathbf{0 , 4 8}$ & $\mathbf{0 , 5 2}$ & 1,00 & $\mathbf{0 , 5 6}$ & 0,06 & 0,01 & $-0,02$ & $\mathbf{0 , 4 9}$ & 0,25 & 0,07 & $\mathbf{0 , 4 0}$ & 0,14 \\
\hline $\mathrm{m}_{5}$ & 0,17 & $\mathbf{0 , 4 1}$ & $\mathbf{0 , 4 2}$ & $\mathbf{0 , 5 6}$ & 1,00 & $\mathbf{0 , 3 8}$ & 0,27 & 0,13 & $\mathbf{0 , 9 3}$ & $\mathbf{0 , 6 9}$ & $\mathbf{0 , 3 7}$ & 0,23 & $-0,19$ \\
\hline $\mathrm{m}_{6}$ & $\mathbf{0 , 7 0}$ & 0,15 & 0,20 & 0,06 & $\mathbf{0 , 3 8}$ & 1,00 & $\mathbf{0 , 9 5}$ & $\mathbf{0 , 8 7}$ & 0,20 & $\mathbf{0 , 4 9}$ & $\mathbf{0 , 3 9}$ & 0,14 & $-0,05$ \\
\hline $\mathrm{m}_{7}$ & $\mathbf{0 , 7 3}$ & 0,23 & 0,27 & 0,01 & 0,27 & $\mathbf{0 , 9 5}$ & 1,00 & $\mathbf{0 , 9 5}$ & 0,04 & $\mathbf{0 , 4 7}$ & $\mathbf{0 , 4 2}$ & 0,12 & 0,00 \\
\hline $\mathrm{m}_{8}$ & $\mathbf{0 , 6 6}$ & 0,16 & 0,21 & $-0,02$ & 0,13 & $\mathbf{0 , 8 7}$ & $\mathbf{0 , 9 5}$ & 1,00 & $-0,07$ & $\mathbf{0 , 4 0}$ & $\mathbf{0 , 4 5}$ & 0,13 & 0,03 \\
\hline $\mathrm{m}_{9}$ & $-0,03$ & 0,24 & 0,26 & $\mathbf{0 , 4 9}$ & $\mathbf{0 , 9 3}$ & 0,20 & 0,04 & $-0,07$ & 1,00 & $\mathbf{0 , 6 4}$ & $\mathbf{0 , 3 7}$ & 0,12 & $-0,27$ \\
\hline $\mathrm{m}_{10}$ & $\mathbf{0 , 5 1}$ & 0,04 & 0,07 & 0,25 & $\mathbf{0 , 6 9}$ & $\mathbf{0 , 4 9}$ & $\mathbf{0 , 4 7}$ & $\mathbf{0 , 4 0}$ & $\mathbf{0 , 6 4}$ & 1,00 & $\mathbf{0 , 8 6}$ & 0,11 & 0,04 \\
\hline $\mathrm{m}_{11}$ & $\mathbf{0 , 4 7}$ & $-0,17$ & $-0,15$ & 0,07 & $\mathbf{0 , 3 7}$ & $\mathbf{0 , 3 9}$ & $\mathbf{0 , 4 2}$ & $\mathbf{0 , 4 5}$ & $\mathbf{0 , 3 7}$ & $\mathbf{0 , 8 6}$ & 1,00 & 0,09 & 0,08 \\
\hline $\mathrm{m}_{12}$ & 0,29 & 0,31 & 0,31 & $\mathbf{0 , 4 0}$ & 0,23 & 0,14 & 0,12 & 0,13 & 0,12 & 0,11 & 0,09 & 1,00 & $\mathbf{0 , 4 0}$ \\
\hline $\mathrm{m}_{13}$ & 0,33 & 0,06 & 0,04 & 0,14 & $-0,19$ & $-0,05$ & 0,00 & 0,03 & $-0,27$ & 0,04 & 0,08 & $\mathbf{0 , 4 0}$ & 1,00 \\
\hline
\end{tabular}

* Oznaczenia jak wyżej.

Źródło: j.w. 
Wartości współczynników korelacji rang Spearmana między miernikami oceny operacyjnego bezpieczeństwa finansowego przedsiębiorstw sektora TSL w 2012 r.*

\begin{tabular}{|c|c|c|c|c|c|c|c|c|c|c|c|c|c|}
\hline Zmienne & $\mathrm{m}_{1}$ & $\mathrm{~m}_{2}$ & $\mathrm{~m}_{3}$ & $\mathrm{~m}_{4}$ & $\mathrm{~m}_{5}$ & $\mathrm{~m}_{6}$ & $\mathrm{~m}_{7}$ & $\mathrm{~m}_{8}$ & $\mathrm{~m}_{9}$ & $\mathrm{~m}_{10}$ & $\mathrm{~m}_{11}$ & $\mathrm{~m}_{12}$ & $\mathrm{~m}_{13}$ \\
\hline \hline $\mathrm{m}_{1}$ & 1,00 & 0,08 & 0,13 & $-0,01$ & 0,18 & $\mathbf{0 , 4 5}$ & $\mathbf{0 , 6 2}$ & $\mathbf{0 , 5 5}$ & 0,08 & 0,36 & 0,17 & 0,12 & 0,32 \\
\hline $\mathrm{m}_{2}$ & 0,08 & 1,00 & $\mathbf{0 , 9 8}$ & $\mathbf{0 , 6 0}$ & 0,00 & 0,06 & 0,02 & $-0,05$ & $-0,22$ & $-0,06$ & $-0,18$ & 0,18 & $-0,10$ \\
\hline $\mathrm{m}_{3}$ & 0,13 & $\mathbf{0 , 9 8}$ & 1,00 & $\mathbf{0 , 6 2}$ & $-0,05$ & 0,12 & 0,09 & 0,02 & $-0,25$ & $-0,08$ & $-0,22$ & 0,22 & $-0,14$ \\
\hline $\mathrm{m}_{4}$ & $-0,01$ & $\mathbf{0 , 6 0}$ & $\mathbf{0 , 6 2}$ & 1,00 & $-0,08$ & 0,06 & $-0,05$ & $-0,19$ & $-0,22$ & $-0,20$ & $\mathbf{- 0 , 4 2}$ & 0,29 & 0,06 \\
\hline $\mathrm{m}_{5}$ & 0,18 & 0,00 & $-0,05$ & $-0,08$ & 1,00 & 0,31 & 0,28 & 0,18 & $\mathbf{0 , 9 1}$ & $\mathbf{0 , 8 6}$ & $\mathbf{0 , 6 6}$ & $-0,33$ & $-0,14$ \\
\hline $\mathrm{m}_{6}$ & $\mathbf{0 , 4 5}$ & 0,06 & 0,12 & 0,06 & 0,31 & 1,00 & $\mathbf{0 , 9 1}$ & $\mathbf{0 , 8 1}$ & 0,33 & $\mathbf{0 , 4 6}$ & 0,30 & 0,03 & $-0,12$ \\
\hline $\mathrm{m}_{7}$ & $\mathbf{0 , 6 2}$ & 0,02 & 0,09 & $-0,05$ & 0,28 & $\mathbf{0 , 9 1}$ & 1,00 & $\mathbf{0 , 9 4}$ & 0,24 & $\mathbf{0 , 4 8}$ & 0,32 & 0,02 & 0,00 \\
\hline $\mathrm{m}_{8}$ & $\mathbf{0 , 5 5}$ & $-0,05$ & 0,02 & $-0,19$ & 0,18 & $\mathbf{0 , 8 1}$ & $\mathbf{0 , 9 4}$ & 1,00 & 0,15 & $\mathbf{0 , 3 9}$ & 0,33 & 0,00 & $-0,02$ \\
\hline $\mathrm{m}_{9}$ & 0,08 & $-0,22$ & $-0,25$ & $-0,22$ & $\mathbf{0 , 9 1}$ & 0,33 & 0,24 & 0,15 & 1,00 & $\mathbf{0 , 8 3}$ & $\mathbf{0 , 7 0}$ & $-0,29$ & $-0,21$ \\
\hline $\mathrm{m}_{10}$ & 0,36 & $-0,06$ & $-0,08$ & $-0,20$ & $\mathbf{0 , 8 6}$ & $\mathbf{0 , 4 6}$ & $\mathbf{0 , 4 8}$ & $\mathbf{0 , 3 9}$ & $\mathbf{0 , 8 3}$ & 1,00 & $\mathbf{0 , 8 5}$ & $\mathbf{- 0 , 3 8}$ & $-0,06$ \\
\hline $\mathrm{m}_{11}$ & 0,17 & $-0,18$ & $-0,22$ & $\mathbf{- 0 , 4 2}$ & $\mathbf{0 , 6 6}$ & 0,30 & 0,32 & 0,33 & $\mathbf{0 , 7 0}$ & $\mathbf{0 , 8 5}$ & 1,00 & $\mathbf{- 0 , 5 8}$ & $-0,18$ \\
\hline $\mathrm{m}_{12}$ & 0,12 & 0,18 & 0,22 & 0,29 & $-0,33$ & 0,03 & 0,02 & 0,00 & $-0,29$ & $\mathbf{- 0 , 3 8}$ & $\mathbf{- 0 , 5 8}$ & 1,00 & 0,35 \\
\hline $\mathrm{m}_{13}$ & 0,32 & $-0,10$ & $-0,14$ & 0,06 & $-0,14$ & $-0,12$ & 0,00 & $-0,02$ & $-0,21$ & $-0,06$ & $-0,18$ & 0,35 & 1,00 \\
\hline
\end{tabular}

* Oznaczenia jak wyżej.

Źródło: j.w. 


\section{Załącznik 4}

Wartość przychodów netto ze sprzedaży usług, towarów i materiałów dla spółki DHL Express (Poland) Sp. z o.o. oraz Zakładu Transportu Energetyki „ZTiSZE Sp. z o.o.” w relacji do ich wartości optymalnej dla badanych przedsiębiorstw sektora TSL w latach 2004-2012

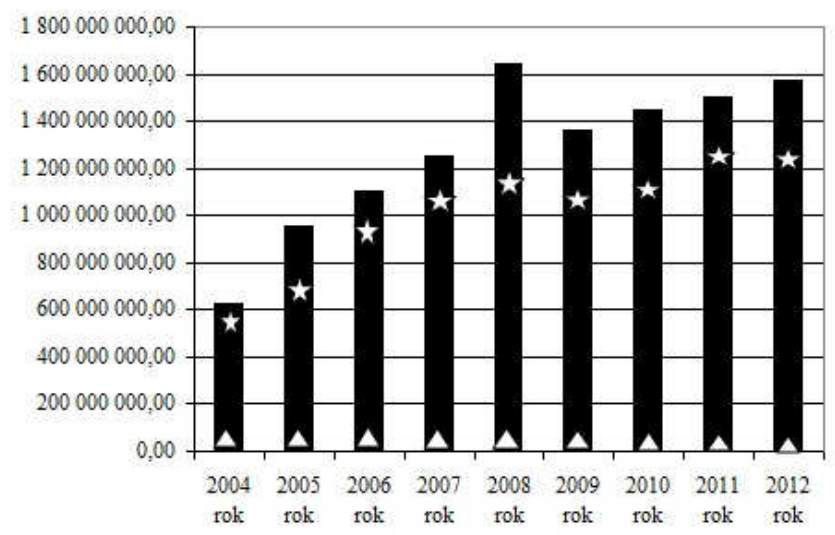

负 DHL Express (Poland) Sp. z o.o.

$\triangle$ Zakład Transportu Energetyki ,ZTiSZE” Sp. z o.o.

Źródło: obliczenia własne na podstawie danych zebranych w Krajowym Rejestrze Sądowym w Warszawie za pomocą programu Microsoft Excel.

Wartość współczynnika bieżącej płynności finansowej dla spółki DHL Express (Poland) Sp. z o.o. oraz Zakładu Transportu Energetyki „ZTiSZE” Sp. z o.o. w relacji do jego wartości optymalnej dla badanych przedsiębiorstw sektora TSL w latach 2004-2012*

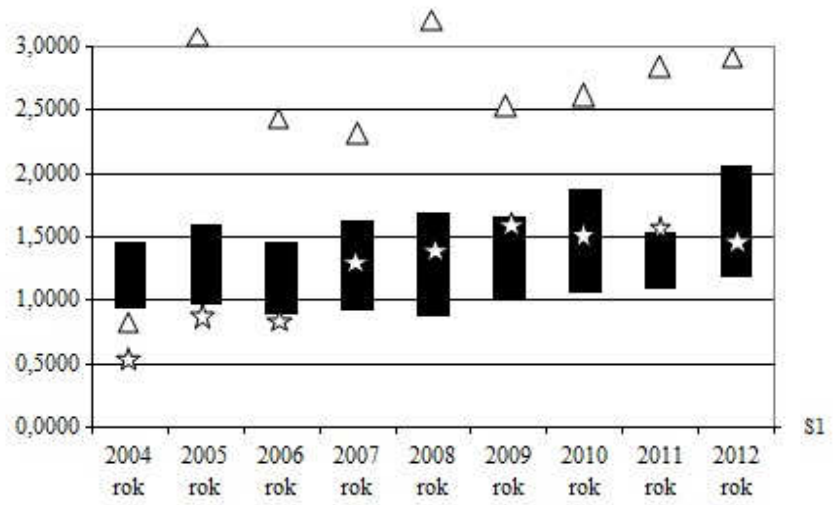

* Oznaczenia jak wyżej.

Źródło: j.w. 
Wartość współczynnika natychmiastowej płynności finansowej dla spółki DHL Express (Poland) Sp. z o.o. oraz Zakładu Transportu Energetyki „ZTiSZE” Sp. z o.o. w relacji do jego wartości optymalnej dla badanych przedsiębiorstw sektora TSL w latach 2004-2012*

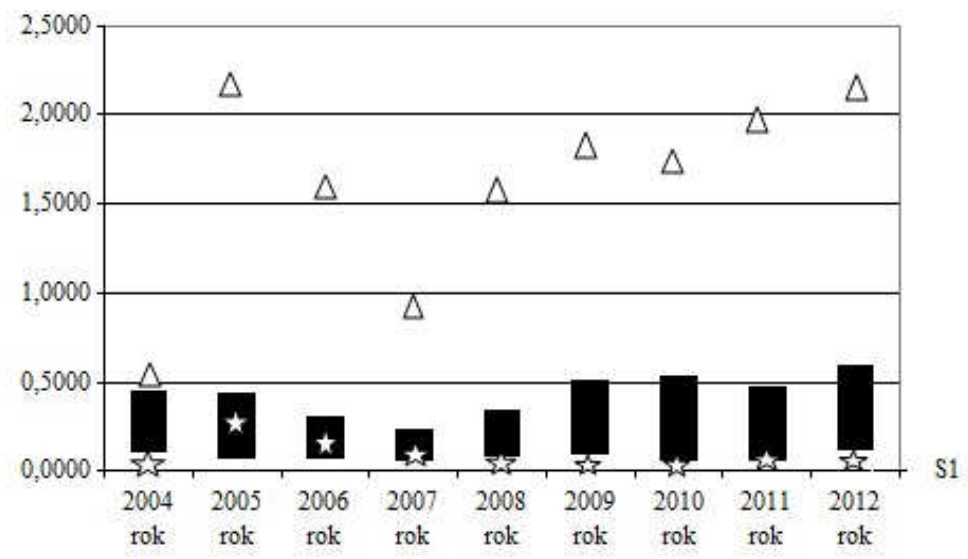

* Oznaczenia jak wyżej.

Źródło: j.w.

Wartość współczynnika zdolności do obsługi zobowiązań bieżących gotówką osiąganą z działalności operacyjnej dla spółki DHL Express (Poland) Sp. z o.o. oraz Zakładu Transportu Energetyki „ZTiSZE” Sp. z o.o. w relacji do jego wartości optymalnej dla badanych przedsiębiorstw sektora TSL w latach 2004-2012*

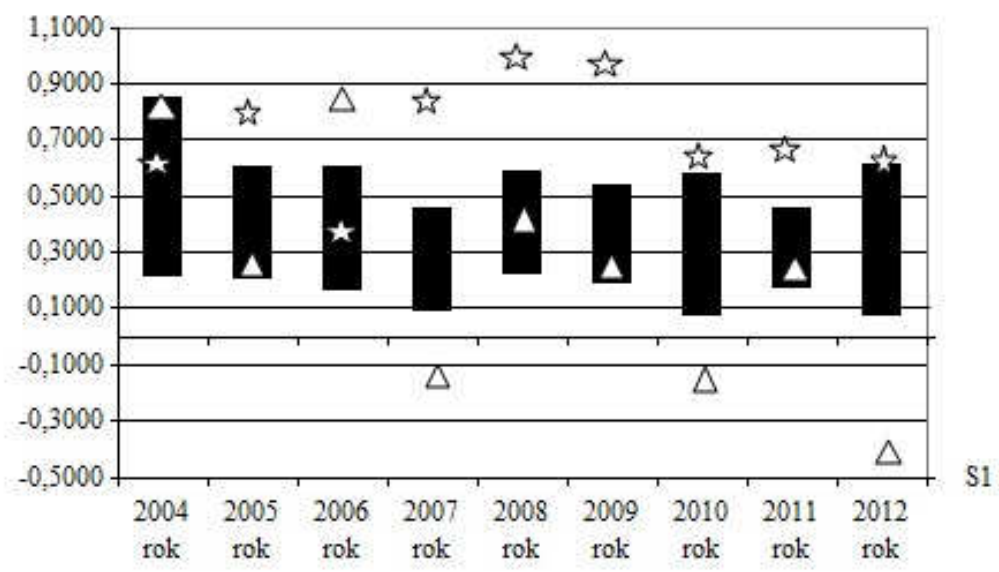

* Oznaczenia jak wyżej.

Źródło: j.w. 
Wartość współczynnika eksploatacyjnej rentowności kapitału własnego dla spółki DHL Express (Poland) Sp. z o.o. oraz Zakładu Transportu Energetyki „ZTiSZE” Sp. z o.o. w relacji do jego wartości optymalnej dla badanych przedsiębiorstw sektora TSL w latach 2004-2012*

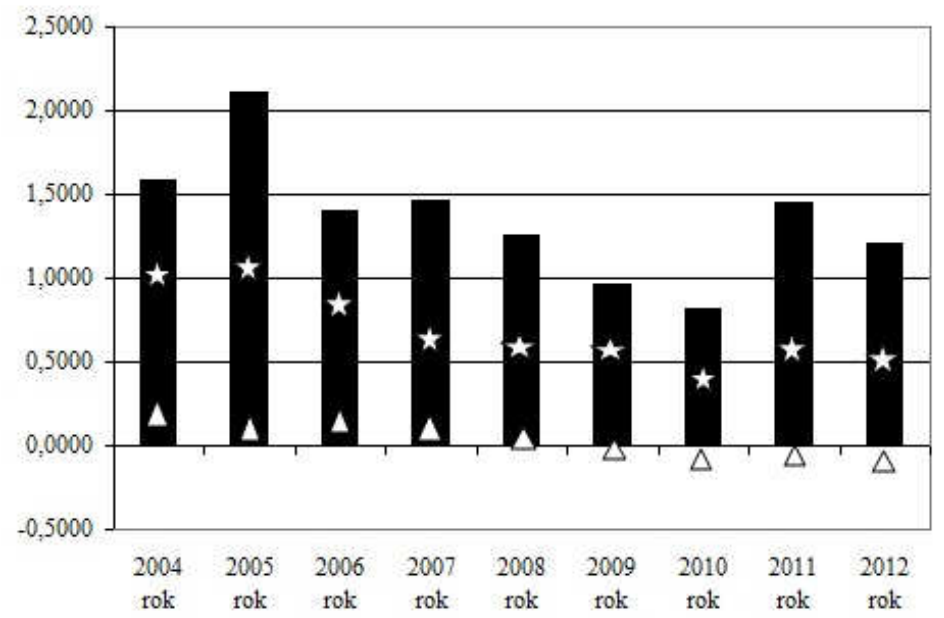

* Oznaczenia jak wyżej.

Źródło: j.w.

Wartość współczynnika wydajności pieniężnej (gotówkowej) kapitału własnego dla spółki DHL Express (Poland) Sp. z o.o. oraz Zakładu Transportu Energetyki ZTiSZE Sp. z o.o. w relacji do jego wartości optymalnej dla badanych przedsiębiorstw sektora TSL w latach 2004-2012*

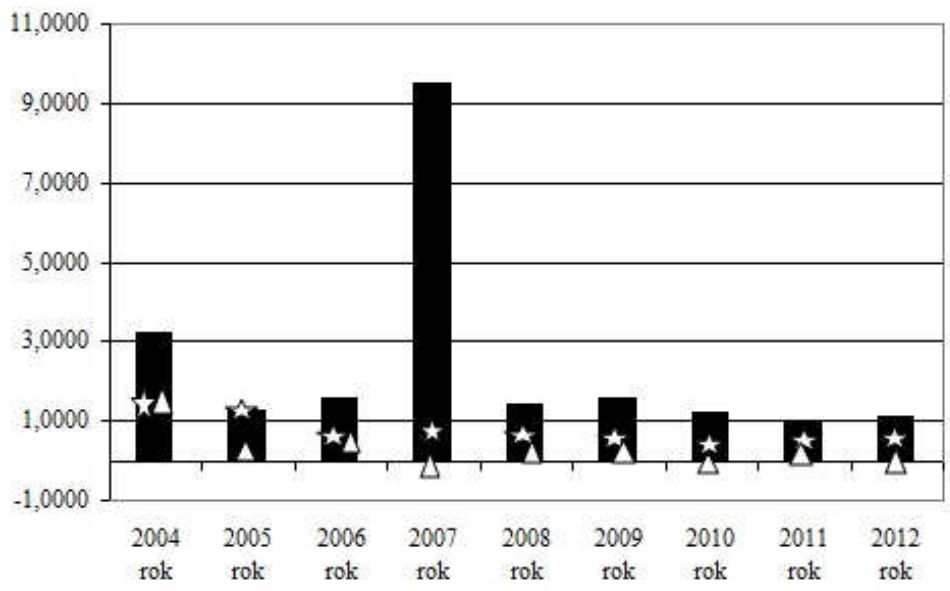

* Oznaczenia jak wyżej.

Źródło: j.w. 
Wartość współczynnika zabezpieczenia finansowego nr 1 dla spółki DHL Express (Poland) Sp. z o.o. oraz Zakładu Transportu Energetyki ZTiSZE Sp. z o.o. w relacji do jego wartości optymalnej dla badanych przedsiębiorstw sektora TSL w latach 2004-2012*

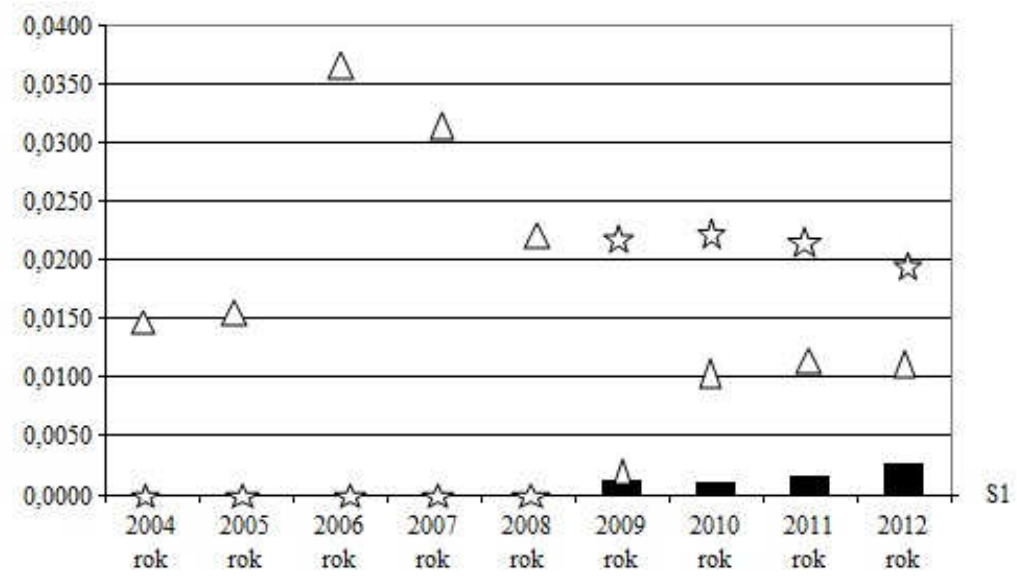

* Oznaczenia jak wyżej.

Źródło: j.w.

Wartość współczynnika zabezpieczenia finansowego nr 2 dla spółki DHL Express (Poland) Sp. z o.o. oraz Zakładu Transportu Energetyki ZTiSZE Sp. z o.o. w relacji do jego wartości optymalnej dla badanych przedsiębiorstw sektora TSL w latach 2004-2012*

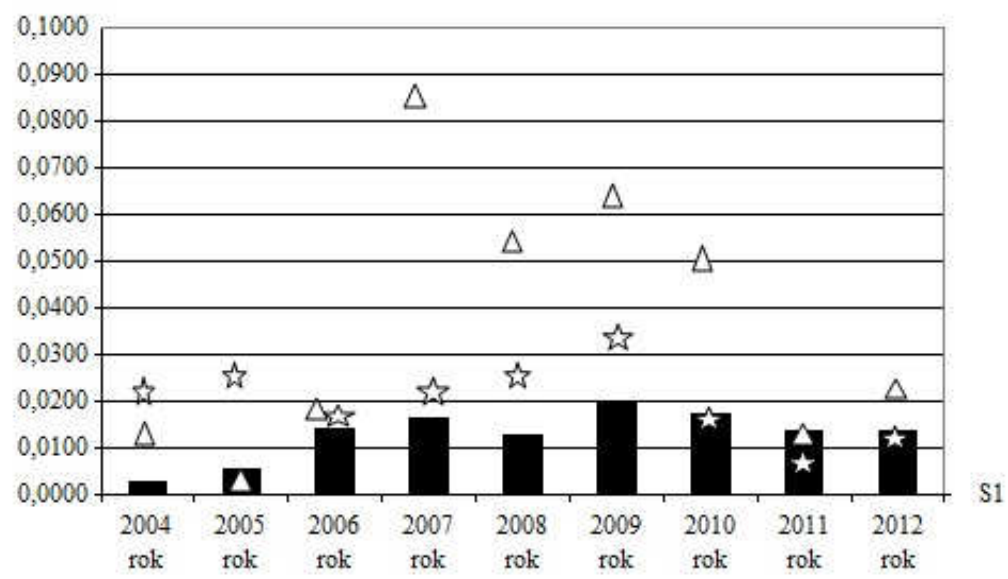

* Oznaczenia jak wyżej.

Źródło: j.w. 
Załącznik 5

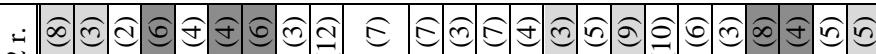

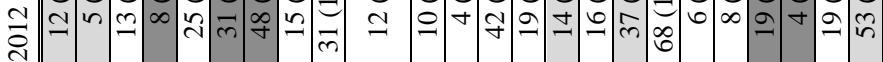

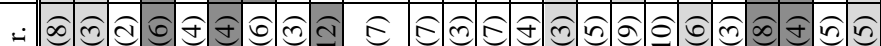

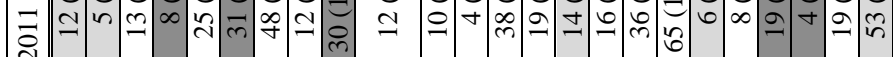

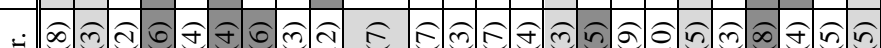
의 $\backsim \infty$ 그

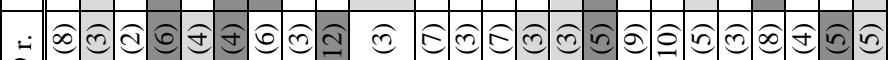

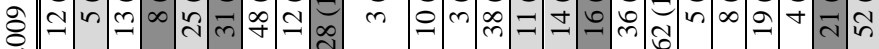

$\operatorname{an} m \infty$ in $\infty$

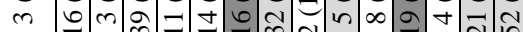

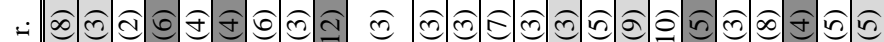

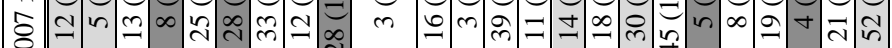

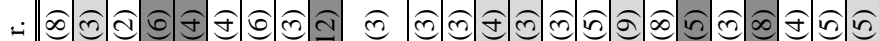

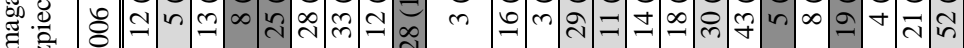

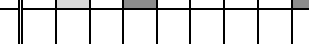

\begin{tabular}{ll|l|l|l|l|l|l|l|l|l}
\hline & & & & & & & & & & \\
\hline
\end{tabular}

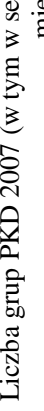

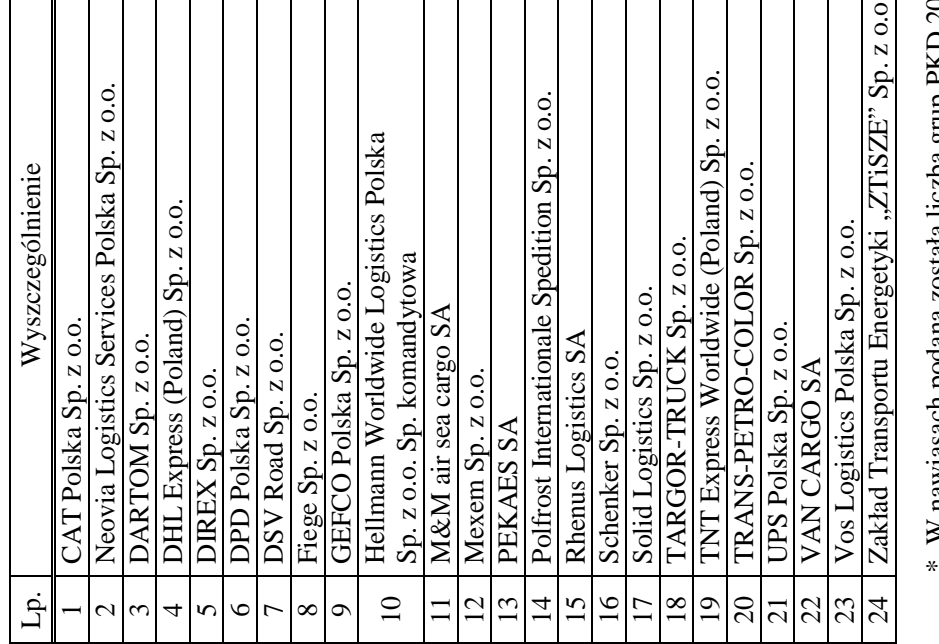




\section{Załącznik 6}

Informacje dotyczące upadłych* spółek sektora TSL w latach 2004-2010

składających sprawozdanie z przepływów pieniężnych

w Krajowym Rejestrze Sądowym w Warszawie ${ }^{(a)}$ (próba analityczna)

\begin{tabular}{|c|c|c|c|c|}
\hline Lp. & Nazwa spółki & $\begin{array}{l}\text { Rodzaj } \\
\text { upadłości }\end{array}$ & $\begin{array}{c}\text { Sprawozdanie } \\
\text { z przepływów } \\
\text { pieniężnych }\end{array}$ & Dominujący PKD 2007 \\
\hline 1 & $\begin{array}{l}\text { Corrida SA } \\
\text { w upadłości } \\
\text { likwidacyjnej }\end{array}$ & $\begin{array}{c}\text { upadłość } \\
\text { obejmująca } \\
\text { likwidację majątku } \\
\text { dłużnika }^{(b)} \\
\end{array}$ & $\begin{array}{l}2002 \mathrm{r} . \\
2003 \mathrm{r} . \\
2004 \mathrm{r}\end{array}$ & $\begin{array}{l}4941 \mathrm{Z} \text { - Transport } \\
\text { drogowy towarów }\end{array}$ \\
\hline 2 & $\begin{array}{l}\text { CMT ARTMEX } \\
\text { Sp. z o.o. }\end{array}$ & $\begin{array}{c}\text { upadłość } \\
\text { obejmująca } \\
\text { likwidację majątku } \\
\text { dłużnika } \\
\end{array}$ & $2004 \mathrm{r}$. & $\begin{array}{l}4941 \mathrm{Z} \text { - Transport } \\
\text { drogowy towarów }\end{array}$ \\
\hline 3 & $\begin{array}{l}\text { AMP Logistyka } \\
\text { Sp. z o.o. }\end{array}$ & $\begin{array}{c}\text { upadłość } \\
\text { z możliwością } \\
\text { zawarcia układu }^{(\mathrm{c})}\end{array}$ & $\begin{array}{l}2002 \mathrm{r} . \\
2003 \mathrm{r} . \\
2004 \mathrm{r} .\end{array}$ & $\begin{array}{l}5210 \text { B - Magazynowanie } \\
\text { i przechowywanie } \\
\text { pozostałych towarów }\end{array}$ \\
\hline 4 & B P FLEET Sp. z o.o. & $\begin{array}{l}\text { oddalenie wniosku } \\
\text { o upadłośćc }\end{array}$ & $2004 \mathrm{r}$. & $\begin{array}{l}4941 \mathrm{Z}-\text { Transport } \\
\text { drogowy towarów }\end{array}$ \\
\hline 5 & $\begin{array}{l}\text { Prima Charter } \\
\text { Sp. z o.o. w upadłości } \\
\text { likwidacyjnej }\end{array}$ & $\begin{array}{c}\text { upadłość } \\
\text { obejmująca } \\
\text { likwidację majątku } \\
\text { dłużnika } \\
\end{array}$ & $2005 \mathrm{r}$. & $\begin{array}{l}5110 \mathrm{Z} \text { - Transport } \\
\text { lotniczy pasażerski }\end{array}$ \\
\hline 6 & $\begin{array}{l}\text { EP Services } \\
\text { Sp. z o.o. }\end{array}$ & $\begin{array}{c}\text { upadłość } \\
\text { obejmująca } \\
\text { likwidację majątku } \\
\text { dłużnika } \\
\end{array}$ & $\begin{array}{l}2005 \mathrm{r} . \\
2006 \mathrm{r} . \\
2007 \mathrm{r} .\end{array}$ & $\begin{array}{l}4941 \mathrm{Z} \text { - Transport } \\
\text { drogowy towarów }\end{array}$ \\
\hline 7 & $\begin{array}{l}\text { LOT Ground Services } \\
\text { Sp. z o.o. } \\
\text { w upadłości } \\
\text { likwidacyjnej }\end{array}$ & $\begin{array}{c}\text { upadłość } \\
\text { obejmująca } \\
\text { likwidację majątku } \\
\text { dłużnika }\end{array}$ & $\begin{array}{l}2005 \mathrm{r} . \\
2006 \mathrm{r} . \\
2007 \mathrm{r} .\end{array}$ & $\begin{array}{l}5223 \mathrm{Z} \text { - Działalność } \\
\text { usługowa wspomagająca } \\
\text { transport lotniczy }\end{array}$ \\
\hline 8 & $\begin{array}{l}\text { Nowy Przewoźnik } \\
\text { Sp. z o.o. w upadłości } \\
\text { likwidacyjnej }\end{array}$ & $\begin{array}{c}\text { upadłość } \\
\text { obejmująca } \\
\text { likwidację majątku } \\
\text { dłużnika }\end{array}$ & $\begin{array}{l}2005 \mathrm{r} . \\
2006 \mathrm{r} . \\
2007 \mathrm{r} .\end{array}$ & $\begin{array}{l}5110 \mathrm{Z} \text { - Transport } \\
\text { lotniczy pasażerski }\end{array}$ \\
\hline 9 & $\begin{array}{l}\text { TX Spedition } \\
\text { Sp. z o.o. w upadłości } \\
\text { likwidacyjnej }\end{array}$ & $\begin{array}{c}\text { upadłość } \\
\text { obejmująca } \\
\text { likwidację majątku } \\
\text { dłużnika }\end{array}$ & $2005 \mathrm{r}$. & $\begin{array}{l}4941 \mathrm{Z} \text { - Transport } \\
\text { drogowy towarów }\end{array}$ \\
\hline 10 & $\begin{array}{l}\text { Polski Express } \\
\text { Sp. z o.o. }\end{array}$ & $\begin{array}{l}\text { oddalenie wniosku } \\
\text { o ogłoszenie } \\
\text { upadłości }\end{array}$ & $2005 \mathrm{r}$. & $\begin{array}{l}4939 \mathrm{Z} \text { - Pozostały } \\
\text { transport lądowy } \\
\text { pasażerski, gdzie indziej } \\
\text { niesklasyfikowany }\end{array}$ \\
\hline
\end{tabular}

* Data postanowienia sądowego. Stan na 8 sierpnia 2012 r.

Uwagi : 
${ }^{\text {(a) }} \mathrm{W}$ tabeli zamieszczono informacje o sporządzaniu sprawozdania z przepływów pieniężnych wyłącznie dotyczącego okresu od roku do 3 lat przez datą upadłości.

(b) Art. 15. Ustawy z dnia 28 lutego 2003 r. Prawo upadtościowe i naprawcze, DzU 2003, nr 60 , poz. 535 z późn. zm. podaje, iż w razie braku podstaw do ogłoszenia upadłości z możliwością zawarcia układu, ogłasza się upadłość obejmującą likwidację majątku dłużnika.

(c) Art. 14. Ustawy z dnia 28 lutego 2003 r. Prawo upadtościowe i naprawcze stanowi, że jeżeli zostanie uprawdopodobnione, że w drodze układu wierzyciele zostaną zaspokojeni w wyższym stopniu, niż zostaliby zaspokojeni po przeprowadzeniu postępowania upadłościowego obejmującego likwidację majątku dłużnika, ogłasza się upadłość dłużnika z możliwością zawarcia układu.

Postępowania upadłościowego z możliwością zawarcia układu nie prowadzi się, gdy z uwagi na dotychczasowe zachowanie się dłużnika nie ma pewności, że układ będzie wykonany, chyba że propozycje układowe przewidują układ likwidacyjny.

(d) Art. 12. Ustawy z dnia 28 lutego 2003 r. Prawo upadłościowe i naprawcze wskazuje, iż Sąd może oddalić wniosek o ogłoszenie upadłości, jeżeli opóźnienie w wykonaniu zobowiązań nie przekracza trzech miesięcy, a suma niewykonanych zobowiązań nie przekracza $10 \%$ wartości bilansowej przedsiębiorstwa dłużnika.

Przepisu tego nie stosuje się, jeżeli niewykonanie zobowiązań ma charakter trwały albo gdy oddalenie wniosku może spowodować pokrzywdzenie wierzycieli.

Oddalając wniosek o ogłoszenie upadłości Sąd - na wniosek dłużnika - może zezwolić na wszczęcie przez dłużnika postępowania naprawczego, jeżeli nie ma przeszkód określonych w art. 492 ust. 3.

Ponadto w art. 13 widnieje informacja, iż Sąd oddali wniosek o ogłoszenie upadłości, jeżeli majątek niewypłacalnego dłużnika nie wystarcza na zaspokojenie kosztów postępowania.

Sąd może oddalić wniosek o ogłoszenie upadłości w razie stwierdzenia, że majątek dłużnika jest obciążony hipoteką, zastawem, zastawem rejestrowym, zastawem skarbowym lub hipoteką morską w takim stopniu, że pozostały jego majątek nie wystarcza na zaspokojenie kosztów postępowania.

Źródło: opracowanie własne na podstawie danych Centralnego Ośrodka Informacji Gospodarczej Sp. z o.o. oraz danych zebranych w Krajowym Rejestrze Sądowym w Warszawie. 


\section{Załącznik 7}

Spółki sektora TSL zakwalifikowane do próby badawczej weryfikującej zdolność predykcyjną wybranych modeli dyskryminacyjnych w prognozowaniu zagrożenia upadłością przedsiębiorstw sektora TSL

\begin{tabular}{|c|c|c|c|c|}
\hline Lp. & \begin{tabular}{|c|} 
Przebieg \\
kontynuacji \\
prowadzonej \\
działalności
\end{tabular} & $\begin{array}{c}\text { Dane na rok przed } \\
\text { upadłością }\end{array}$ & $\begin{array}{c}\text { Dane na } 2 \text { lata przed } \\
\text { upadłością }\end{array}$ & $\begin{array}{c}\text { Dane na } 3 \text { lata przed } \\
\text { upadłością }\end{array}$ \\
\hline 1 & \multirow{6}{*}{ 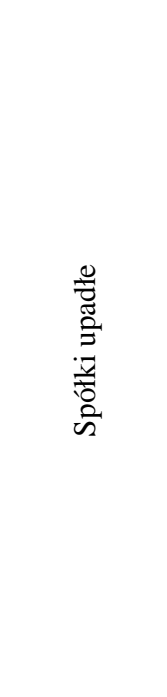 } & $\begin{array}{l}\text { Corrida SA w upadłości } \\
\text { likwidacyjnej }\end{array}$ & $\begin{array}{l}\text { Corrida SA w upadłości } \\
\text { likwidacyjnej }\end{array}$ & $\begin{array}{l}\text { Corrida SA w upadłości } \\
\text { likwidacyjnej }\end{array}$ \\
\hline 2 & & $\begin{array}{l}\text { AMP Logistyka } \\
\text { Sp. z o.o. }\end{array}$ & $\begin{array}{l}\text { AMP Logistyka } \\
\text { Sp. z o.o. }\end{array}$ & $\begin{array}{l}\text { AMP Logistyka } \\
\text { Sp. z o.o. }\end{array}$ \\
\hline 3 & & $\begin{array}{l}\text { LOT Ground Services } \\
\text { Sp. z o.o. w upadłości } \\
\text { likwidacyjnej }\end{array}$ & $\begin{array}{l}\text { LOT Ground Services } \\
\text { Sp. z o.o. w upadłości } \\
\text { likwidacyjnej }\end{array}$ & $\begin{array}{l}\text { LOT Ground Services } \\
\text { Sp. z o.o. w upadłości } \\
\text { likwidacyjnej }\end{array}$ \\
\hline 4 & & EP Services Sp. z o.o. & EP Services Sp. z o.o. & EP Services Sp. z o.o. \\
\hline 5 & & $\begin{array}{l}\text { Nowy Przewoźnik } \\
\text { Sp. z o.o. } \\
\text { w upadłości } \\
\text { likwidacyjnej }\end{array}$ & $\begin{array}{l}\text { Nowy Przewoźnik } \\
\text { Sp. z o.o. } \\
\text { w upadłości } \\
\text { likwidacyjnej }\end{array}$ & $\begin{array}{l}\text { Nowy Przewoźnik } \\
\text { Sp. z o.o. } \\
\text { w upadłości } \\
\text { likwidacyjnej }\end{array}$ \\
\hline 6 & & $\begin{array}{l}\text { Przedsiębiorstwo } \\
\text { Spedycji } \\
\text { Międzynarodowej } \\
\text { C. Hartwig Warszawa SA }\end{array}$ & $\begin{array}{l}\text { Przedsiębiorstwo } \\
\text { Spedycji } \\
\text { Międzynarodowej } \\
\text { C. Hartwig Warszawa SA }\end{array}$ & $\begin{array}{l}\text { Przedsiębiorstwo } \\
\text { Spedycji } \\
\text { Międzynarodowej } \\
\text { C. Hartwig Warszawa SA }\end{array}$ \\
\hline 7 & \multirow{6}{*}{ 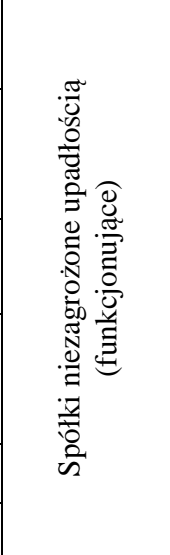 } & $\begin{array}{l}\text { M\&M Militzer \& Münch } \\
\text { Polska Sp. z o.o. }\end{array}$ & $\begin{array}{l}\text { M\&M Militzer \& Münch } \\
\text { Polska Sp. z o.o. }\end{array}$ & $\begin{array}{l}\text { Trans-Petro-Color } \\
\text { Sp. z o.o. }\end{array}$ \\
\hline 8 & & $\begin{array}{l}\text { Przedsiębiorstwo } \\
\text { Wielobranżowe Podkowa } \\
\text { Sp. z o.o. }\end{array}$ & $\begin{array}{l}\text { Polfrost Internationale } \\
\text { Spedition Sp. z o.o. }\end{array}$ & Mostva Sp. z o.o. \\
\hline 9 & & $\begin{array}{l}\text { Hellmann Worldwide } \\
\text { Logistics Sp. z o.o. }\end{array}$ & Mexem Sp. z o.o. & DPD Polska Sp. z o.o. \\
\hline 10 & & $\begin{array}{l}\text { Zasada Logistyka } \\
\text { Sp. z o.o. }\end{array}$ & $\begin{array}{l}\text { M\&M air cargo service } \\
\text { Polska SA }\end{array}$ & $\begin{array}{l}\text { Przedsiębiorstwo } \\
\text { Wielobranżowe Podkowa } \\
\text { Sp. z o.o. }\end{array}$ \\
\hline 11 & & CAT Polska Sp. z o.o. & Charter Sp. z o.o. & VAN Cargo SA \\
\hline 12 & & DSV Solutions Sp. z o.o. & DSV Solutions Sp. z o.o. & Solid Logistics Sp. z o.o. \\
\hline
\end{tabular}

Źródło: opracowanie własne na podstawie danych Centralnego Ośrodka Informacji Gospodarczej Sp. z o.o. oraz danych zebranych w Krajowym Rejestrze Sądowym w Warszawie. 


\section{Załącznik 8}

Spółki sektora TSL zakwalifikowane do analizy dyskryminacyjnej

\begin{tabular}{|c|c|c|c|c|}
\hline Lp. & $\begin{array}{l}\text { Przebieg } \\
\text { kontynuacji } \\
\text { prowadzonej } \\
\text { działalności }\end{array}$ & $\begin{array}{c}\text { Dane na rok przed } \\
\text { upadłością }\end{array}$ & $\begin{array}{c}\text { Dane na } 2 \text { lata przed } \\
\text { upadłością }\end{array}$ & $\begin{array}{c}\text { Dane na } 3 \text { lata przed } \\
\text { upadłością }\end{array}$ \\
\hline 1 & \multirow{5}{*}{ 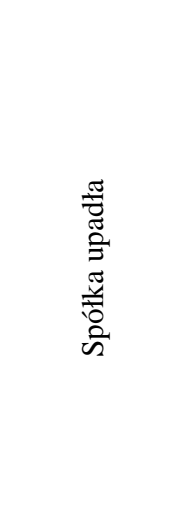 } & $\begin{array}{l}\text { Corrida SA } \\
\text { w upadłości } \\
\text { likwidacyjnej }\end{array}$ & $\begin{array}{l}\text { Corrida SA } \\
\text { w upadłości } \\
\text { likwidacyjnej }\end{array}$ & $\begin{array}{l}\text { Corrida SA } \\
\text { w upadłości } \\
\text { likwidacyjnej }\end{array}$ \\
\hline 2 & & $\begin{array}{l}\text { AMP Logistyka } \\
\text { Sp. z o.o. }\end{array}$ & $\begin{array}{l}\text { AMP Logistyka } \\
\text { Sp. z o.o. }\end{array}$ & $\begin{array}{l}\text { AMP Logistyka } \\
\text { Sp. z o.o. }\end{array}$ \\
\hline 3 & & $\begin{array}{l}\text { LOT Ground Services } \\
\text { Sp. z o.o. w upadłości } \\
\text { likwidacyjnej }\end{array}$ & $\begin{array}{l}\text { LOT Ground Services } \\
\text { Sp. z o.o. w upadłości } \\
\text { likwidacyjnej }\end{array}$ & $\begin{array}{l}\text { LOT Ground Services } \\
\text { Sp. z o.o. w upadłości } \\
\text { likwidacyjnej }\end{array}$ \\
\hline 4 & & EP Services Sp. z o.o. & EP Services Sp. z o.o. & EP Services Sp. z o.o. \\
\hline 5 & & $\begin{array}{l}\text { Nowy Przewoźnik } \\
\text { Sp. z o.o. w upadłości } \\
\text { likwidacyjnej }\end{array}$ & $\begin{array}{l}\text { Nowy Przewoźnik } \\
\text { Sp. z o.o. w upadłości } \\
\text { likwidacyjnej }\end{array}$ & $\begin{array}{l}\text { Nowy Przewoźnik } \\
\text { Sp. z o.o. w upadłości } \\
\text { likwidacyjnej }\end{array}$ \\
\hline 6 & \multirow{5}{*}{ 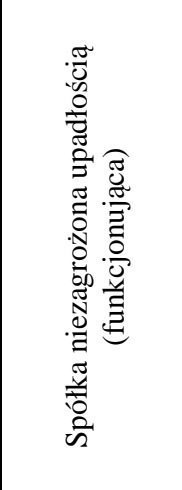 } & $\begin{array}{l}\text { M\&M Militzer \& Münch } \\
\text { Polska Sp. z o.o. }\end{array}$ & $\begin{array}{l}\text { M\&M Militzer \& Münch } \\
\text { Polska Sp. z o.o. }\end{array}$ & $\begin{array}{l}\text { Trans-Petro-Color } \\
\text { Sp. z o.o. }\end{array}$ \\
\hline 7 & & $\begin{array}{l}\text { Przedsiębiorstwo } \\
\text { Wielobranżowe } \\
\text { Podkowa Sp. z o.o. }\end{array}$ & $\begin{array}{l}\text { Polfrost Internationale } \\
\text { Spedition Sp. z o.o. }\end{array}$ & Mostva Sp. z o.o. \\
\hline 8 & & $\begin{array}{l}\text { Hellmann Worldwide } \\
\text { Logistics Sp. z o.o. }\end{array}$ & Mexem Sp. z o.o. & DPD Polska Sp. z o.o. \\
\hline 9 & & $\begin{array}{l}\text { Zasada Logistyka } \\
\text { Sp. z o.o. }\end{array}$ & $\begin{array}{l}\text { M\&M air cargo service } \\
\text { Polska SA }\end{array}$ & $\begin{array}{l}\text { Przedsiębiorstwo } \\
\text { Wielobranżowe } \\
\text { Podkowa Sp. z o.o. }\end{array}$ \\
\hline 10 & & CAT Polska Sp. z o.o. & Charter Sp. z o.o. & VAN Cargo SA \\
\hline
\end{tabular}

Źródło: opracowanie własne na podstawie danych Centralnego Ośrodka Informacji Gospodarczej Sp. z o.o. oraz danych zebranych w Krajowym Rejestrze Sądowym w Warszawie. 


\section{Załącznik 9}

Informacje dotyczące upadłych spółek sektora TSL w latach 2011-2012 składających sprawozdanie z przepływu pieniężnych w Krajowym Rejestrze Sądowym w Warszawie (próba walidacyjna)*

\begin{tabular}{|c|c|c|c|}
\hline Lp. & Nazwa spółki & $\begin{array}{l}\text { Rodzaj } \\
\text { upadłości }\end{array}$ & Dominujący PKD 2007 \\
\hline 1 & $\begin{array}{l}\text { Aviation Asset Management SA } \\
\text { w upadłości likwidacyjnej }\end{array}$ & $\begin{array}{c}\text { upadłość } \\
\text { obejmująca } \\
\text { likwidację } \\
\text { majątku } \\
\text { dłużnika }\end{array}$ & $\begin{array}{l}5110 \mathrm{Z} \text { - Transport lotniczy } \\
\text { pasażerski }\end{array}$ \\
\hline 2 & $\begin{array}{l}\text { Przedsiębiorstwo Spedycji } \\
\text { Międzynarodowej } \\
\text { C. Hartwig Warszawa SA }\end{array}$ & $\begin{array}{c}\text { upadłość } \\
\text { obejmująca } \\
\text { likwidację } \\
\text { majątku } \\
\text { dłużnika }\end{array}$ & $\begin{array}{l}5229 \mathrm{C}-\text { Działalność } \\
\text { pozostałych agencji } \\
\text { transportowych }\end{array}$ \\
\hline
\end{tabular}

* Próba walidacyjna na rok przed upadłością (stan na 8 sierpnia 2012 r.).

Źródło: opracowanie własne na podstawie danych Centralnego Ośrodka Informacji Gospodarczej Sp. z o.o. oraz danych zebranych w Krajowym Rejestrze Sądowym w Warszawie. 